Redakcja

Ryszard F. Sadowski

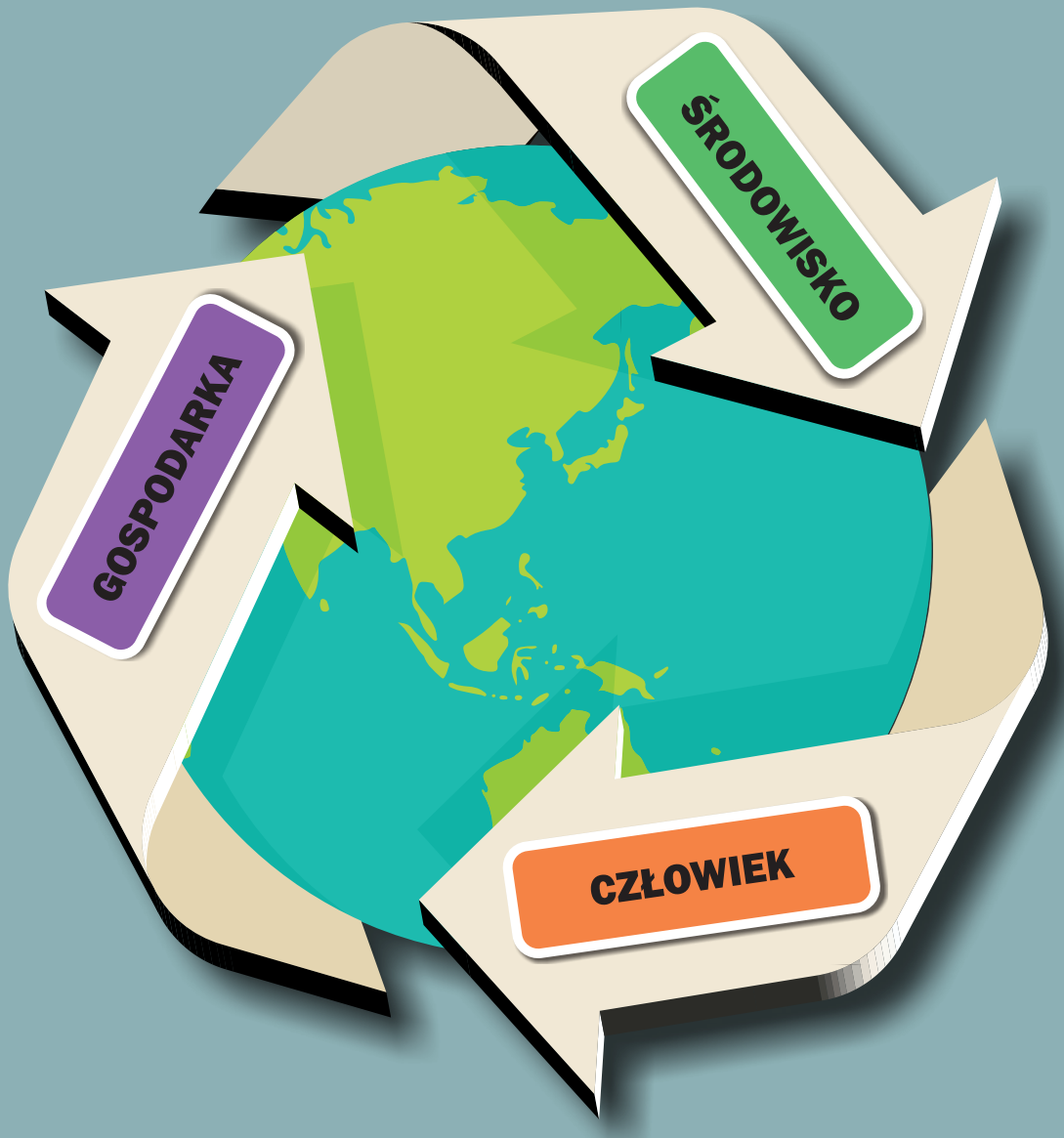

THEORIA I PRAXIS

ZRÓWNOWAŻONEGO ROZWOJU.

30 LAT OD OGLOSZENIA RAPORTU BRUNDTLAND 

Theoria i praxis zrównoważonego rozwoju. 30 lat od ogłoszenia Raportu Brundtland 


\section{MATERIAŁY OGÓLNOPOLSKIEJ KONFERENCJI NAUKOWEJ}

"Theoria i praxis zrównoważonego rozwoju.

30 lat od ogłoszenia Raportu Brundtland"

(Warszawa, UKSW - 20.03.2017 r.)

\section{Komitet Organizacyjny konferencji}

Leszek Drogosz (Miasto Stołeczne Warszawa)

dr Andrzej Kassenberg (Instytut na rzecz Ekorozwoju)

ks. prof. Zbigniew Łepko SDB (Instytut Ekologii i Bioetyki UKSW)

ks. prof. Ryszard F. Sadowski SDB (Instytut Ekologii i Bioetyki UKSW)

dr Wojciech Szymalski (Instytut na rzecz Ekorozwoju)

\section{Rada Programowa konferencji}

prof. Tadeusz Borys (Uniwersytet Ekonomiczny we Wrocławiu)

prof. Helena Ciążela (Akademia Pedagogiki Specjalnej w Warszawie)

prof. Anna Giza-Poleszczuk (Uniwersytet Warszawski)

dr Anna Kalinowska (Uniwersytet Warszawski)

prof. Zbigniew Karaczun (Szkoła Główna Gospodarstwa Wiejskiego w Warszawie)

prof. Elżbieta Mączyńska (Szkoła Główna Handlowa w Warszawie) prof. Maciej Nowicki (Minister Ochrony Środowiska 1991 i 2007-2010) prof. Andrzej Papuziński (Uniwersytet Kazimierza Wielkiego w Bydgoszczy) prof. Włodzimierz Tyburski (Uniwersytet Mikołaja Kopernika w Toruniu)

Towarzystwo Naukowe Franciszka Salezego

ul. Kawęczyńska 53, 03-775 Warszawa

e-mail:tnfs@tnfs.pl

www.tnfs.pl

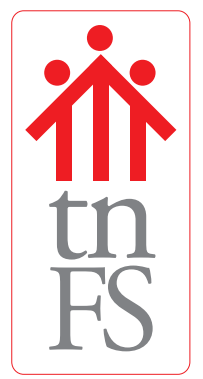




\title{
THEORIA I PRAXIS ZRÓWNOWAŻONEGO ROZWOJU. 30 LAT OD OGLOSZENIA RAPORTU BRUNDTLAND
}

\author{
Redaktorzy \\ Ryszard F. Sadowski SDB \\ Zbigniew Łepko SDB
}

Towarzystwo Naukowe Franciszka Salezego

Warszawa 2017 


\section{Recenzenci}

prof. Tadeusz Borys

prof. Zbigniew Karaczun

\section{Korekta edytorska}

Joanna Wójcik

(C) Copyright by TNFS, Warszawa 2017

\section{Wydawca}

Towarzystwo Naukowe Franciszka Salezego

ul. Kawęczyńska 53, 03-775 Warszawa

e-mail:tnfs@tnfs.pl

www.tnfs.pl

Publikacja wydana przy współpracy

Fundacji Instytut na rzecz Ekorozwoju

ul. Nabielaka 15 lok. 1, 00-743 Warszawa

e-mail: ine@ine-isd.org.pl

www.ine-isd.org.pl

ISBN: 978-83-61451-09-9

eISBN: 978-83-61451-10-5

DOI: https://doi.org/10.21852/tnfs.2017.2

\section{Druk i oprawa}

Poligrafia Salezjańska

30-318 Kraków, ul. Bałuckiego 8, tel./fax (012) 2528500 


\section{Publikację monografii wsparły osoby prywatne i instytucje:}

Andrzej Ancynger

Aleksandra Arcipowska

Wanda Barc

Małgorzata Koziarek

Richard Liroff

Stan Laskowski

Szymon Liszka

Dominik Owczarek

Zygmunt Parczewski

Adam de Sola Pool

Wojciech Suchorzewski

Barbara Szulczewska

Ludwik Tomiałojć

Piotr Tulej

Bank Światowy

Danfoss Poland sp. z o.o.

Edu Tour - Turystyka i Edukacja Klaudia Giordano

Eko Tur Instytut Kształcenia

Fundacja Bank Ochrony Środowiska

Fundacja Green Cross Polska

Fundacja im. Heinricha Bölla

Fundacja na rzecz Energetyki Zrównoważonej

Krajowa Agencja Poszanowania Energii S.A.

Rockwool Polska sp. z o.o. 



\section{SPIS TREŚCI}

\section{CZĘŚĆ WSTĘPNA}

Apel Warszawski o zrównoważony rozwój świata

Gro Harlem Brundtland,

Przesłanie do uczestników konferencji

Adam Hamryszczak,

List do uczestników konferencji

Filip Kochan,

Wystąpienie przedstawiciela Banku Światowego

Andrzej Kassenberg,

Postulat przyspieszenia wdrażania celów i zasad zrównoważonego rozwoju

Zbigniew Łepko,

Wprowadzenie w problematykę konferencji

\section{CZĘ̧́Ć I:}

\section{EWOLUCJA IDEI ZRÓWNOWAŻONEGO ROZWOJU}

Artur Pawłowski,

Rozwój zrównoważony - największe wyzwanie XXI wieku 53

Zbigniew Mirek, Zbigniew Witkowski,

Teoria i praktyka w ochronie przyrody - gdzie szukać zrównoważenia?

Michał Latawiec,

Idea ochrony przyrody a Raport Brundtland

Stefan Konstańczak,

Ekologia versus ideologia. O polskich problemach $\mathrm{z}$ recepcją raportu

Gro Harlem Brundtland 99

Zbigniew M. Karaczun,

Ewolucja idei zrównoważonego rozwoju w Polsce na przykładzie polityki klimatycznej 


\section{CZĘŚĆ II: \\ EPISTEMOLOGICZNE ASPEKTY ZRÓWNOWAŻONEGO ROZWOJU}

Andrzej Papuziński,

Filozofia Raportu Brundtland

Zdzisława Piątek,

Kosmiczne siedlisko ziemskiego życia i problem zrównoważonego

rozwoju

Zbigniew Łepko,

Filozoficzne obrazy przyrody ożywionej a idea zrównoważonego

rozwoju

Ryszard F. Sadowski,

Potencjał religii w zakresie promocji i implementacji

idei zrównoważonego rozwoju 169

\section{CZEŚĆ III:}

\section{AKSJOLOGICZNE ASPEKTY ZRÓWNOWAŻONEGO ROZWOJU}

Krystyna Najder-Stefaniak,

Rozwój zrównoważony i wartości uniwersalne

Włodzimierz Tyburski,

Edukacja etyczna na rzecz zrównoważonego rozwoju 203

Iwona Stachowska,

Postawa samoograniczenia w świetle idei zrównoważonego rozwoju

Małgorzata Gutry-Korycka,

Postulaty zrównoważonego rozwoju ziemi w encyklikach papieskich ..... 229

Ewa Jastrzębska,

CSR jako odpowiedź biznesu na wyzwania rozwoju zrównoważonego

- ewolucja koncepcji 


\section{CZĘŚĆ IV:}

\section{EDUKACYJNE ASPEKTY ZRÓWNOWAŻONEGO ROZWOJU}

Magdalena Kołodziejska, Marta Czerniak-Czyżniak,

Pedagogika na rzecz zrównoważonego rozwoju

Małgorzata Jagodzińska, Elżbieta Buchcic,

Wykorzystanie dorobku Raportu Brundtland w edukacji

dla zrównoważonego rozwoju

Małgorzata Kaniewska, Marcin Klimski,

Edukacja globalna wzmocnieniem procesu budowania solidarnego

i sprawiedliwego świata

Anna Kalinowska,

Dekada ONZ dla Bioróżnorodności 2011-2020 - recepty na zwiększenie świadomości społecznej znaczenia różnorodności biologicznej

dla osiągania Celów Zrównoważonego Rozwoju 2030

Jan Chudzyński,

Podstawy psychologiczne zachowań prośrodowiskowych

Anna Batorczak,

Doskonalenie kompetencji nauczycieli akademickich w zakresie edukacji

dla zrównoważonego rozwoju

Ligia Tuszyńska,

Wczesnoszkolna edukacja zrównoważonego rozwoju w Polsce

i w Norwegii. Analiza porównawcza praktyki pedagogicznej

$\mathrm{w}$ aspekcie przyrodniczym

\section{CZĘŚĆ V:}

\section{INSTRUMENTY ZRÓWNOWAŻONEGO ROZWOJU}

Janusz Radziejowski, Idea zrównoważonego rozwoju w planowaniu przestrzennym 345 
Joanna Godlewska,

Recykling odpadów jako sposób realizacji zasady likwidacji zanieczyszczeń

u źródła w Polsce

Maria Klonowska-Matynia,

Regionalne zróżnicowanie zrównoważonego rozwoju w Polsce.

Analiza przestrzenna

Anna Bernaciak,

Planowanie na rzecz rozwoju zrównoważonego na szczeblu lokalnym w Polsce

- uwarunkowania formalno-prawne 383

Agnieszka Rzeńca, Adam Wojech,

Zrównoważony rozwój miast. Perspektywa władz lokalnych

i mieszkańców - przykład Łodzi

Joanna Fajfer, Paulina Kostrz-Sikora, Bronisława Chechelska-Paliga, Program ochrony środowiska jako narzędzie realizacji idei zrównoważonego rozwoju na terenie miasta Jaworzna

\section{CZEŚŚĆ VI:}

\section{ZRÓWNOWAŻONA GOSPODARKA}

I SPOŁECZEŃSTWO - PODEJŚCIE SEKTOROWE

Jacek Kwiatkowski,

Nowa generacja, nowe potrzeby - miasto reaktywne

versus miasto zrównoważone

Krzysztof Biernat,

Biogospodarka jako zintegrowany sektor przemysłowy Europy

Kamila Radlińska,

Ekonomiczne aspekty budownictwa energooszczędnego

i pasywnego w Polsce

Ewa Matyjaszczyk,

Wdrażanie dyrektywy 2009/128 ustanawiającej ramy wspólnotowego działania na rzecz zrównoważonego stosowania pestycydów w Polsce 469 
Arkadiusz Węglarz,

Polskie budynki spełniające kryteria zrównoważonego rozwoju 481

Mieczysław Reksnis,

Warszawska Polityka Mobilności

\section{CZEŚĆC VII:}

ZRÓWNOWAŻONA GOSPODARKA

\section{SPOŁECZEŃSTWO - PODEJŚCIE HORYZONTALNE}

Urszula Stefanowicz,

Cele ONZ na poziomie lokalnym. Od Agendy 21 po Agendę 2030

- przyjęcie i wdrażanie na poziomie lokalnym celów ONZ

w zakresie zrównoważonego rozwoju

Aleksandra Ciżmowska,

Eliminacja ubóstwa jako nadrzędny cel zrównoważonego rozwoju:

założenia i rzeczywistość

Andrzej Kiepas,

Zrównoważony rozwój w perspektywie „Przemysłu 4.0”

Lech W. Zacher,

Człowiek - środowisko: zderzenia racjonalności, ideologii i interesów

Agnieszka Sobol,

Rola mieszkańców w zrównoważonym rozwoju miast

Agnieszka Jakubowska,

Nierówności w zdrowiu jako wyraz nierówności społecznych:

perspektywa gospodarek UE

Grzegorz Dumieński, Alicja Lisowska, Marta Bedryj, Andrzej Tiukało, Ocena zrównoważenia polityki przeciwpowodziowej państwa $\mathrm{z}$ wykorzystaniem zintegrowanego ryzyka środowiskowego 


\section{CZĘŚĆ VIII:}

\section{ŚRODOWISKO PRZYRODNICZE}

Czesław Wodzikowski,

Program MAB UNESCO jako praktyczna realizacja idei

zrównoważonego rozwoju

Małgorzata Grodzińska-Jurczak,

Czy partycypacja ma sens? Efektywne metody włączania ludzi

w ochronę bioróżnorodności

Małgorzata Falencka-Jabłońska,

Obszary Natura 2000 a rozwój zrównoważony w warunkach polskich

Zbigniew Mirek, Zbigniew Witkowski,

Teoria i praktyka w ochronie przyrody - gdzie szukać kompromisu w sprawie Puszczy Białowieskiej?

Krzysztof Berbeka,

Czy jesteśmy efektywniejsi? Historyczna analiza wykorzystania zasobów wody w Polsce

Ewa Jakusik,

Spodziewane zmiany wysokości fali w południowej części Morza Bałtyckiego w XXI wieku

Anna Latawiec,

Podsumowanie konferencji 663 


\section{CONTENTS}

\section{INTRODUCTORY PART}

The Warsaw Appeal for the Sustainable Development of the World 21

Gro Harlem Brundtland,

Message to Conference Participants

Adam Hamryszczak,

Letter to Conference Participants

Filip Kochan,

Address by the World Bank Representative

Andrzej Kassenberg,

Call to Accelerate the Implementation of the Goals

and Principles for Sustainable Development 35

Zbigniew Łepko,

Introduction to the Conference 45

\section{PART ONE:}

\section{EVOLUTION OF THE IDEA OF SUSTAINABLE DEVELOPMENT}

Artur Pawłowski,

Sustainable Development - the Biggest Challenge for the 21st Century 53

Zbigniew Mirek, Zbigniew Witkowski,

Theory and Practice in Nature Conservation. How to Find Sustainability?

Michał Latawiec,

The Idea of Nature Conservation and the Brundtland Report 85

Stefan Konstańczak,

Ecology versus Ideology. Problems Associated with the Reception of the Gro Harlem Brundtland Report in Poland 
Zbigniew M. Karaczun,

Evolution of the Idea of Sustainable Development in Poland

at the Example of the Climate Policy

PART TWO:

EPISTEMOLOGICAL ASPECTS OF SUSTAINABLE DEVELOPMENT

Andrzej Papuziński,

Brundtland Report Philosophy

Zdzisława Piątek,

Cosmic Habitat of Earthly Life and the Problem

of Sustainable Development

Zbigniew Łepko,

Philosophical Views of Biotic Nature

and The Idea of Sustainable Development

Ryszard F. Sadowski,

The Potential of Religion in the Promotion and Implementation

of the Idea of Sustainable Development

\section{PART THREE:}

\section{AXIOLOGICAL ASPECTS OF SUSTAINABLE DEVELOPMENT}

Krystyna Najder-Stefaniak,

Sustainable Development and Universal Values

Włodzimierz Tyburski,

Ethical Education for Sustainable Development

Iwona Stachowska,

Self-constraint Attitude in the Light of the Idea

of Sustainable Development

Małgorzata Gutry-Korycka,

Call for Sustainable Development of the Earth in Papal Encyclicals 
Ewa Jastrzębska,

CSR as a Business Response to the Challenges of Sustainable

Development - Evolution of the Concept

\section{PART FOUR:}

\section{EDUCATIONAL ASPECTS OF SUSTAINABLE DEVELOPMENT}

Magdalena Kołodziejska, Marta Czerniak-Czyżniak,

Education for Sustainable Development

Małgorzata Jagodzińska, Elżbieta Buchcic,

The Brundtland Report and its Role in Education

for Sustainable Development

Małgorzata Kaniewska, Marcin Klimski,

Global Education in Strengthening the Process of Building

a World of Solidarity and Justice

Anna Kalinowska,

United Nation Decade on Biodiversity 2011-2020 - Recipes for Increasing Social Awareness on the Significance of Biodiversity in Achieving the Sustainable Development Goals 2030 295

Jan Chudzyński,

Psychological Underpinnings of Pro-environmental Behavior

Anna Batorczak, Improving the Competence of Academic Teachers in Education for Sustainable Development

Ligia Tuszyńska, Early Childhood Education for Sustainable Development in Poland and Norway. Comparative Analysis of Pedagogical Practice in Terms of Nature 


\section{PART FIVE:}

\section{INSTRUMENTS OF SUSTAINABLE DEVELOPMENT}

Janusz Radziejowski,

Idea of Sustainable Development in Physical Planning

Joanna Godlewska,

Waste Recycling as a Way of Implementing the Prevention Rule in Poland ... 357

Maria Klonowska-Matynia,

Regional Differentiation of Sustainable Development in Poland.

Spatial Analysis

Anna Bernaciak,

Planning for Sustainable Development at the Local Level in Poland

- the Formal and Legal Conditions

Agnieszka Rzeńca, Adam Wojech,

Sustainable Development of Cities. The Perspective of Local Authorities

and Citizens of Lodz

Joanna Fajfer, Paulina Kostrz-Sikora, Bronisława Chechelska-Paliga, Environmental Program as a Tool for Implementing the Sustainable Development Idea in the City of Jaworzno

\section{PART SIX:}

\section{SUSTAINABLE ECONOMY AND SOCIETY - SECTORAL APPROACH}

Jacek Kwiatkowski,

New Generation, New Needs - Resilient Cities Versus

Sustainable Development Cities

Krzysztof Biernat,

Bioeconomy as an Integrated Industrial Sector of Europe

Kamila Radlińska,

Economic Aspects of Energy-Efficient and Passive Construction in Poland .... 455 
Ewa Matyjaszczyk,

Implementation of Directive 2009/128 Establishing a Framework

for Community Action to Achieve Sustainable Use of Pesticides in Poland 469

Arkadiusz Węglarz,

Polish Buildings Fulfilling the Sustainable Development Criteria

Mieczysław Reksnis,

Warsaw Mobility Policy

495

\section{PART SEVEN:}

SUSTAINABLE ECONOMY AND SOCIETY - HORIZONTAL APPROACH

Urszula Stefanowicz,

UN Goals at the Local Level. From Agenda 21 to Agenda 2030 -

Adopting and Implementing the UN Sustainable Development

Goals at the Local Level

Aleksandra Ciżmowska,

Poverty Elimination as the Superior Goal of Sustainable Development:

Facts and Assumptions

Andrzej Kiepas,

Sustainable Development in the Perspective of "Industry 4.0"

Lech W. Zacher,

Man - Environment: Clashes of Rationalities, Ideologies and Interests ..... 547

Agnieszka Sobol,

The Role of Citizens in Sustainable Development of Cities

Agnieszka Jakubowska,

Inequalities in Health as an Expression of Social Inequality:

Prospects for the EU Economies

Grzegorz Dumieński, Alicja Lisowska, Marta Bedryj, Andrzej Tiukało, Assessment of the State's Sustainable Flood Policy Based on the Integrated Environmental Risk 


\section{PART EIGHT:}

\section{NATURAL ENVIRONMENT}

Czesław Wodzikowski,

UNESCO MAB Program as a Practical Realization of the Idea of Sustainable Development

Małgorzata Grodzińska-Jurczak,

Does Participation Matter? Effective Tools on Engaging People

into Biodiversity Governance

Małgorzata Falencka-Jabłońska,

Sustainable Development and the Natura 2000 Areas in Poland

Zbigniew Mirek, Zbigniew Witkowski,

Theory and Practice in Nature Conservation.

How to Find a Compromise on the Białowieża Forest?

Krzysztof Berbeka,

Are we Being Effective? Historical Analysis

of Water Resources Consumption in Poland

Ewa Jakusik,

Expected Changes in Wave Height in the Southern Part of the Baltic Sea in the XXI Century

Anna Latawiec,

Conclusion of the Conference 663 
CZĘŚ́C WSTĘPNA 



\section{APEL WARSZAWSKI o zrównoważony rozwój świata}

Zebrani w dniu 20 marca 2017 r. na konferencji poświęconej teorii i praktyce zrównoważonego rozwoju z okazji 30. rocznicy ogłoszenia Raportu Brundtland, zabieramy głos w imieniu reprezentowanych przez nas środowisk intelektualistów, przedsiębiorców, organizacji pozarządowych, administracji rządowej i samorządowej, mediów oraz uczniów i studentów. Świadomi wyzwań, przed którymi staje dziś ludzkość, jesteśmy przekonani o konieczności połączenia wysiłków wszystkich ludzi dobrej woli na rzecz zrównoważonego rozwoju świata - bezpiecznego miejsca życia obecnych i przyszłych pokoleń. Jesteśmy ponadto przekonani, że tylko trafne teorie kryzysu środowiskowego pozwolą wypracować adekwatne do zagrożeń praktyczne strategie ich przezwyciężenia. Warunkiem powodzenia tego przedsięwzięcia jest więc konsekwentne współdziałanie wyznaczone odpowiedziami na pytania: gdzie jesteśmy?, co nam zagraża?, jak przezwyciężyć niekorzystne megatrendy? i jaka w tym kontekście jest sytuacja Polski?

\section{Gdzie jesteśmy?}

Trzydziestoletni wpływ Raportu Brundtland na kierunek rozwoju świata można oceniać dwojako: $z$ jednej strony obserwuje się coraz szersze zainteresowanie problematyką zrównoważonego rozwoju, $z$ drugiej zaś niepokojący wzrost zagrożeń środowiska oraz ładu społecznego i gospodarczego. Optymizmem napawa ogłoszenie przez ONZ Celów zrównoważonego rozwoju przyjętych 25 września 2015 r., które powinny być osiągnięte do roku 2030. Niepokojem natomiast napawa coraz szybsze wyczerpywanie się zasobów naturalnych, utrata różnorodności biologicznej, niezrównoważona konsumpcja napędzana przez gospodarkę linearną, nasilające się emisje i koncentracje zanieczyszczeń, powiększające się obszary ubóstwa, ograniczanie roli społeczności lokalnych oraz przybierająca na sile skala uchodźctwa. 


\section{Co nam zagraża?}

Analiza aktualnych megatrendów pozwala określić kierunek, w którym podąża świat konfrontowany $\mathrm{z}$ narastającymi wyzwaniami. $\mathrm{Na}$ szczególną uwagę w tym względzie zasługują: pogłębiające się rozbieżności struktur wiekowych populacji regionów świata, narastająca urbanizacja świata, podatność na choroby i ryzyko pandemii, coraz szybsze zmiany technologiczne o rozbieżnych konsekwencjach, pogłębiająca się wielobiegunowość świata, zaostrzenie konkurencji o zasoby, rosnąca presja na ekosystemy, coraz groźniejsze skutki zmiany klimatu oraz zwiększające się zanieczyszczenie środowiska.

\section{Jak przezwyciężyć niekorzystne megatrendy?}

Warunkiem przezwyciężenia niekorzystnych megatrendów jest stworzenie takiej wizji rozwoju cywilizacji w XXI wieku, która uwzględniałaby przede wszystkim:

a) wdrożenie cyrkulacyjnej gospodarki umiaru;

b) wprowadzenie takiego dostępu do dóbr, który wszystkim ludziom umożliwi godziwe warunki życia;

c) wypracowanie efektywnej społecznie, ekonomicznie i przyrodniczo alokacji środków;

d) promocję partycypacyjnego sposobu podejmowania decyzji, który uwzględnia zaangażowanie przedsiębiorstw i społeczeństwa obywatelskiego;

e) propagowanie jakości życia obecnego i przyszłych pokoleń opartego na jasno określonych, nieegocentrycznych systemach wartości;

f) udostępnienie edukacji wszystkim obywatelom przez całe życie. 


\section{Sytuacja Polski}

Dokonana w 1989 r. transformacja ustrojowa pozytywnie wpłynęła na podejście Polski do zrównoważonego rozwoju. Wprowadzenie gospodarki rynkowej z jednej strony przyczyniło się do efektywniejszego wykorzystania zasobów naturalnych i energii oraz spowodowało zmniejszenie zanieczyszczeń środowiska; z drugiej zaś, przynajmniej w początkowym okresie, zaostrzyło napięcia społeczne ze względu na utrzymujące się bezrobocie oraz poszerzenie się skali ubóstwa. Budowa systemu demokratycznego ukazała jednocześnie konieczność rozwoju społeczeństwa obywatelskiego, które może spożytkować pozytywny wpływ zmian środowiskowych i zniwelować negatywny wpływ przemian społecznych. Ujawnione $\mathrm{w}$ tym zakresie pozytywne tendencje w rozwoju Polski zostały wzmocnione dzięki akcesowi do Unii Europejskiej w 2004 r. i pozyskanym z niej środkom finansowym. Dzięki temu wydatkowano znaczne nakłady na ochronę środowiska, przyczyniając się do poprawy jego stanu.

Przemianom społecznym w Polsce towarzyszyły równoległe przemiany gospodarcze, które spowodowały wzrost poziomu życia dużej części społeczeństwa, co doprowadziło do wzrostu konsumpcji, wzrostu śladu ekologicznego i produkcji odpadów. Ponadto środowisko przyrodnicze i zdrowie ludzi zostały narażone na niebezpieczeństwo zanieczyszczeń chemicznych, spowodowanych rozproszoną presją na środowisko i brakiem dostatecznej świadomości ekologicznej. Zmiana tego niekorzystnego kierunku wymaga konsekwentnego wprowadzania elementów tzw. zielonej gospodarki, którą charakteryzuje: rozwój energetyki odnawialnej, poprawa efektywności zasobowej i energetycznej, rozwój ekologicznych gospodarstw i przetwórstwa żywności, dowartościowanie transportu szynowego, publicznego i niezmotoryzowanego, rozwój ekoturystyki oraz ekoinnowacji.

W tej sytuacji strategia rozwoju Polski wymaga wypracowania i wdrażania takich działań, które zgodnie z art. 5 Konstytucji RP umożliwią realizację zrównoważonego rozwoju opartego na równoprawnym traktowaniu trzech kapitałów: społecznego, gospodarczego i przyrodniczego. To zaś oznacza między innymi: 
a) w sferze społecznej:

$\checkmark$ wzmocnienie kapitału społecznego jako kapitału wzajemnego zaufania;

$\checkmark$ zabezpieczenie jakości życia obecnego i przyszłych pokoleń;

$\checkmark$ konsekwentne respektowanie zasady subsydiarności i partycypacji na wszystkich szczeblach struktury społecznej;

$\checkmark$ prowadzenie systematycznej edukacji społeczeństwa na rzecz zrównoważonego rozwoju;

b) w sferze gospodarczej:

$\checkmark$ przechodzenie od nieefektywnej gospodarki linearnej do cyrkulacyjnej gospodarki umiaru;

$\checkmark$ kreowanie zrównoważonej konsumpcji podkreślającej znaczenie dóbr niematerialnych;

$\checkmark$ dążenie do wzrostu produktywności zasobów i poprawy efektywności ich użytkowania;

$\checkmark$ wdrażanie nowej generacji innowacyjności promującej rozwiązania inteligentne;

$\checkmark$ uwzględnianie w rachunku ekonomicznym kosztów społecznych i wartości usług ekosystemowych;

c) w sferze przyrodniczej:

$\checkmark$ planowanie tempa wykorzystania zasobów, zwłaszcza nieodnawialnych, jako przejaw sprawiedliwości międzypokoleniowej;

$\checkmark$ wyznaczenie i przestrzeganie limitów zanieczyszczeń;

$\checkmark$ wzmocnienie infrastruktury przyrodniczej kraju i ochrony różnorodności biologicznej wraz z troską o zachowanie funkcji (usług) ekosystemów;

$\checkmark$ tworzenie ładu przestrzennego.

Sygnatariusze niniejszego Apelu zachęcają do podjęcia debaty obywatelskiej nad praktycznymi sposobami wprowadzenia w życie zawartego w nim przesłania oraz do upowszechniania jego treści w różnych środowiskach. 


\section{Przesłanie Gro Harlem Brundtland do uczestników konferencji „Theoria i praxis zrównoważonego rozwoju. 30 lat od ogłoszenia Raportu Brundtland" (Warszawa, UKSW - 20.03.2017 r.)}

Chciałabym przeprosić, że nie mogę osobiście brać udziału w tym doniosłym zgromadzeniu w Warszawie, którego celem jest podkreślenie wagi, scharakteryzowanie, analiza i wsparcie zrównoważonego rozwoju.

Wzajemne powiązania pomiędzy globalnymi systemami - myślenie w skali ogólnoświatowej - stanowią jeden z nadrzędnych tematów, którymi zajmuję się w mojej pracy zawodowej. Wiele osób oraz założeń ideowych ukształtowało moją osobowość, tok myślenia i działania. Jednak koncepcją, do której zawsze powracam, jest potrzeba holistycznego podejścia do społeczeństwa, kultur, gospodarki i środowiska.

Uważam, że właśnie dzięki takiemu spojrzeniu na świat ponad 30 lat temu zostałam powołana przez Sekretarza Generalnego Organizacji Narodów Zjednoczonych, Javiera Péreza de Cuéllara, do utworzenia i poprowadzenia niezależnej komisji, której celem było podjęcie próby zmierzenia się z głównymi wyzwaniami ogólnoświatowymi, tj. zagrożeniem dla środowiska i zasobów naturalnych, rosnącą presją związaną z liczebnością populacji, a także ubóstwem i brakiem rozwoju. Po raz pierwszy podjęliśmy się oceny kluczowych wyzwań nie w sposób odosobniony, lecz z holistycznego punktu widzenia.

W raporcie Komisji pt. Nasza wspólna przyszłość ostrzegaliśmy, że globalne zjawiska, które już są zauważalne, w tym zmiany klimatyczne, pustynnienie, degradacja lasów, niedobory wody, zmniejszająca się bioróżnorodność i wzrastające uzależnienie od „brudnych” i niebezpiecznych źródeł energii, stanowią poważne zagrożenie dla pomyślności i bezpieczeństwa przyszłych pokoleń, a tym samym dla zrównoważonego rozwoju, który zdefiniowaliśmy jako „proces mający na celu zaspokojenie aspiracji rozwojowych obecnego pokolenia w sposób umożliwiający realizację tych samych dążeń pokoleniom następnym". 
Od tego czasu w wielu dziedzinach poczyniono pewne postępy. Znacznie więcej dzieci, w tym także dziewcząt, otrzymuje wykształcenie. Oczekiwana długość życia uległa poprawie, a umieralność wśród dzieci spadła. Podczas gdy w przeszłości obserwowano wzrost liczby osób cierpiących głód, od kilku lat ich liczba systematycznie spada. Po wielu latach ciężkiej pracy, w 2015 roku zawarliśmy międzynarodowe porozumienie w sprawie zmian klimatycznych.

Dla wielu osób obecne czasy to jednak okres wielkiej niepewności. Decyzje, które podejmujemy teraz, będą mieć wpływ na rozwój przez następne dziesięciolecia. Praca na rzecz zrównoważonej przyszłości trwa!

Życzę Państwu owocnej konferencji oraz konstruktywnego zaangażowania w stawianie czoła wyzwaniom, które są przed nami.

Gro Harlem Brundtland 


\section{List skierowany do uczestników konferencji „Theoria i praxis zrównoważonego rozwoju” przez Adama Hamryszczaka, podsekretarza stanu w Ministerstwie Rozwoju}

Szanowni Państwo,

Uprzejmie dziękuję za zaproszenie na dzisiejszą konferencję, której tematyka wpisuje się we wdrażaną obecnie Strategię na Rzecz Odpowiedzialnego Rozwoju. Niestety ze względu na bieżące obowiązki nie mogłem pojawić się na konferencji osobiście.

Stoimy przed ogromnymi wyzwaniami dla trwałego i zrównoważonego rozwoju. Wymagają one wypracowania nowego podejścia, zintegrowanych rozwiązań, nowego modelu rozwoju. Pozwolę sobie wyrazić głębokie przekonanie, że Strategia na Rzecz Odpowiedzialnego Rozwoju przyjęta przez Radę Ministrów 14 lutego br. odzwierciedla potrzeby rozwojowe postrzegane $\mathrm{w}$ ramach powyższego paradygmatu.

Zdecydowanie opowiadamy się w niej za koncepcją odpowiedzialnego rozwoju i zwiększeniem poczucia tożsamości instytucji państwa w kształtowaniu procesów gospodarczych, społecznych i terytorialnych, przy zachowaniu konstytucyjnego modelu społecznej gospodarki rynkowej.

Odpowiedzialny rozwój to rozwój z myślą o przyszłych pokoleniach, bez umniejszania ich szans. Istotne jest tym samym odpowiednie kształtowanie relacji pomiędzy konkurencyjnością gospodarki, dbałością o środowisko oraz jakością życia. Takie postrzeganie odpowiedzialnego rozwoju stanowi odzwierciedlenie koncepcji rozwoju zrównoważonego w rozumieniu rozpowszechnionym przed 30. laty dzięki raportowi Światowej Komisji Gro Harlem Brundtland do spraw Środowiska i Rozwoju. Raport ten, noszący jakże znamienny tytuł Nasza wspólna przyszłość (Our Common Future), stanowił impuls dla kolejnych przełomowych działań na rzecz zrównoważonego rozwoju. Chciałbym tu wspomnieć o takich wydarzeniach jak Szczyt Ziemi w 1992 r. oraz będący jego pokłosiem dokument Agenda 21, a także Deklaracja Milenijna Narodów Zjednoczonych i Milenijne Cele Rozwoju, zastąpione w 2015 r. przez Cele zrównoważonego rozwoju (Sustainable Development Goals). 
Odpowiedzialny rozwój to przede wszystkim takie planowanie i realizacja działań rozwojowych, by ich efekt, w perspektywie kilkunastu lub nawet kilkudziesięciu lat, sprzyjał powiększaniu i polepszaniu kapitału ludzkiego, umożliwiał rozwój obywateli i samorealizację w warunkach społecznych, gospodarczych i środowiskowych nie gorszych od występujących obecnie. To również znajdowanie takich rozwiązań, które pozwalają na aktywne włączenie w procesy rozwojowe wszystkich grup społecznych, dając im jednocześnie możliwość czerpania korzyści ze wzrostu gospodarczego.

Taka koncepcja odpowiedzialnego rozwoju, na podstawie której Polska określiła swój nowy model rozwoju, jest spójna z niezwykle ambitną wizją ukierunkowaną na zmiany, wizją świata wolnego od ubóstwa, w której każdy człowiek ma możliwość rozwoju. Na takiej właśnie wizji opierają się Cele zrównoważonego rozwoju, które społeczność międzynarodowa przyjęła wraz z Agendą 2030 ONZ na rzecz zrównoważonego rozwoju we wrześniu 2015 roku.

W przyjętej przez Rząd Strategii na Rzecz Odpowiedzialnego Rozwoju stawiamy człowieka w centrum bezpośredniego zainteresowania, podporządkowując działania w sferze gospodarczej osiąganiu celów związanych z poziomem i jakością życia obywateli. Oczekiwanym efektem takiego podejścia będzie ograniczenie wykluczenia społecznego, ubóstwa, wszelkiego rodzaju nierówności społecznych, a także budowa silniejszego kapitału społecznego i zwiększenie jego roli w rozwoju.

Ze względu na swoją rolę i przypisane jej zadanie, Strategia sanowi instrument elastycznego zarządzania głównymi procesami rozwojowymi w kraju, a jej realizacja będzie wspierać wdrażanie przez Polskę Agendy 2030.

Kończąc moje wystąpienie, chciałbym podkreślić, że celem głównym działań rozwojowych zaplanowanych w Strategii na Rzecz Odpowiedzialnego Rozwoju jest stworzenie warunków dla wzrostu dochodów mieszkańców Polski przy jednoczesnym wzroście spójności w wymiarze społecznym, ekonomicznym, środowiskowym i terytorialnym. Oznacza to, że pomyślna realizacja Strategii przełoży się na wzrost zamożności Polaków oraz zmniejszenie liczby osób zagrożonych ubóstwem i wykluczeniem społecznym, podczas gdy w sferze in- 
stytucjonalnej sprawi ona, że państwo stanie się bardziej przyjazne dla obywateli i przedsiębiorców.

Reasumując, Strategia na Rzecz Odpowiedzialnego Rozwoju jest odpowiedzią na stojące przed Polską wyzwania XXI w. Wierzę, że jej realizacja przyczyni się do uzyskania trwałego, społecznie i terytorialnie zrównoważonego rozwoju gospodarczego, który doprowadzi do wzrostu dobrobytu polskich rodzin. 



\section{Wystąpienie Filipa Kochana, przedstawiciela Banku Światowego, podczas sesji plenarnej otwierającej konferencję „Theoria i praxis zrównoważonego rozwoju. 30 lat od ogłoszenia Raportu Brundtland"}

Bez mądrej i skutecznej polityki rozwoju 100 milionów ludzi na świecie może popaść $\mathrm{w}$ ubóstwo $\mathrm{z}$ powodu zmian klimatu.

Jak większość z Państwa tu zgromadzonych zapewne wie, Bank Światowy jest międzynarodową instytucją finansową, której misją jest ograniczanie ubóstwa i wspieranie zrównoważonego rozwoju. Chciałbym chwilę zatrzymać się na słowie „zrównoważony”. Kiedy zaczynałem pracę w Banku w 2015 roku, jedną z pierwszych trudności, jakie napotkałem, było właściwe przetłumaczenie misji naszej instytucji, którą po angielsku jest: ending poverty and boosting shared prosperity. Tak zwane twin goals Banku Światowego - bliźniacze cele. Ending poverty to oczywiście ograniczanie ubóstwa. Boosting shared prosperity to?... No właśnie. Pojawiały się próby typu wspieranie wspólnego dobrobytu, popieranie dzielonej pomyślności - coś tu nie gra, prawda? Uznaliśmy, że najlepiej po polsku brzmi wspieranie zrównoważonego rozwoju. No tak, ale zrównoważony rozwój zawiera po polsku konotacje środowiskowe i ekologiczne. A nam przecież chodzi o wspieranie takiego rozwoju gospodarki, z którego owoców czerpałyby jak najszersze grupy społeczne...

Okazuje się jednak, że języki polski jest bardziej zaawansowany od angielskiego, można powiedzieć wyprzedził język angielski, ponieważ, na podstawie naszych najnowszych badań i analiz, ochrona środowiska czy ograniczanie skutków zmian klimatu ma szczególne znaczenie właśnie dla najuboższych, najgorzej sytuowanych. W polskim słowie „zrównoważony” zawiera się i zazębia zarówno dbałość o klimat, jak i o rozwój gospodarczy. Mam wrażenie, że nigdy wcześniej nie patrzono tak na klimat. Od kilku lat klimat na stałe wpisał się do agendy nie tylko światowych przywódców politycznych, naukowych czy religijnych, ale także coraz częściej zajmują się nim ministrowie finansów, ministrowie gospodarki czy instytucje takie jak nasza kojarzone ze światem finansów. 
Bez mądrej i skutecznej polityki rozwoju 100 milionów ludzi na świecie może popaść $\mathrm{w}$ ubóstwo $\mathrm{z}$ powodu zmian klimatu - to wniosek $\mathrm{z}$ raportu Banku Światowego na temat zrównoważonego rozwoju opublikowanego w ubiegłym roku.

Naszym zdaniem, choć skutki zmian klimatycznych są oczywiście odczuwalne przez wszystkich, to najbardziej zagrożone są najbiedniejsze kraje i najbiedniejsze społeczeństwa. Pozwolę sobie wyjaśnić, dlaczego tak uważamy?

Po pierwsze, dochody najbiedniejszych ludzi są najsilniej uzależnione od rolnictwa. Najbiedniejsi są też najbardziej wrażliwi na nagłe wzrosty cen żywności. Niektóre modele ekonometryczne pokazują, że zmiana klimatu może obniżyć światowe plony o 5 procent do roku 2030 i aż o 30 procent do roku 2080, przy uwzględnieniu pewnych działań adaptacyjnych człowieka, takich jak lepsze nawadnianie, nowoczesne środki ochrony roślin. Spodziewany spadek plonów może się zaś przyczynić do wzrostu cen produktów rolnych, produktów spożywczych, co w konsekwencji może wepchnąć pewną grupę konsumentów w ubóstwo. Mieliśmy z takim zjawiskiem do czynienia na przykład w latach 2010-2011, kiedy w wyniku nagłego wzrostu cen żywności 44 miliony ludzi popadło na świecie w biedę. Problem dotyczy nie tylko konsumentów, ale również producentów. W Ugandzie, na przykład, niespełna 10 lat temu spadek dostępności wody o 10 procent obniżył dochody rolników o 15 procent, a najbiedniejszych rolników o niemal 20 procent. A więc jeszcze raz: dochody najbiedniejszych ludzi są najsilniej uzależnione od rolnictwa, które z kolei jest najbardziej wrażliwą na zmiany klimatyczne dziedziną gospodarki.

Po drugie, najbiedniejsi są bardziej narażeni na klęski żywiołowe i nietypowe zjawiska pogodowe. Ekstremalnie wysokie temperatury w Europie w 2003 roku, w wyniku których zmarło ponad 70 tysięcy ludzi, pod koniec tego wieku będą typowymi temperaturami w lecie. Okres suszy może się wydłużyć o 20 procent w większości krajów świata do 2080 roku, zaś w 2030 roku liczba osób narażonych na ryzyko powodzi może wzrosnąć o ponad 10 procent. Choć na takie czy inne klęski żywiołowe narażeni są wszyscy, bogaci i biedni, to badania pokazują, że to głównie ludzie biedniejsi zamieszkują tereny najbardziej narażone na ryzyko pogodowe, gdyż tereny te są po prostu tańsze, ponieważ łatwiej dostępne.

Po trzecie z kolei, najbiedniejsi czy najsłabsi, na przykład dzieci, są najbardziej narażeni na choroby, które rodzą się w wyniku zmian kli- 
matycznych, takie jak np. malaria. Okazuje się, że nawet niewielki wzrost średnich temperatur może mieć znaczny wpływ na przenoszenie tej choroby. Ocieplenie klimatu o 2 stopnie Celsjusza może zwiększyć grono potencjalnych chorych na malarię o 5 procent, czyli o ponad 150 milionów osób. Wskaźniki te są jeszcze bardziej znaczące na przykład na kontynencie afrykańskim.

Po czwarte wreszcie, na zmiany klimatu najbardziej narażeni są najbiedniejsi, ponieważ otrzymują oni zwykle mniejsze wsparcie od rodziny i przyjaciól, a także znacznie rzadziej mogą korzystać z instrumentów finansowych czy ubezpieczeniowych, aby zabezpieczyć się przed ryzykiem związanym z konsekwencjami zmiany klimatu.

Reasumując, słowo „zrównoważony” w języku polskim doskonale oddaje bieżące trendy w światowej polityce rozwoju, ponieważ opisuje działania na rzecz wspierania najuboższych grup społecznych, a także walkę z konsekwencjami zmian klimatu. W Banku Światowym uważamy, że te kwestie są coraz bardziej ze sobą powiązane i od siebie zależne.

Na koniec chciałbym podkreślić, że Bank Światowy jest instytucją, która podejmuje zdecydowane działania na rzecz ochrony klimatu na całym świecie, uważając właśnie, że zagadnienie to jest ściśle powiązane z obroną interesów najuboższych i wpieraniem światowego rozwoju. Przejawia się to na przykład w niefinansowaniu przez Bank Światowy projektów opartych na energetyce węglowej. Na całym świecie wspieramy z kolei inwestycje w odnawialne źródła energii, inteligentne i przyjazne środowisku rolnictwo, a także zwiększamy dostępność narzędzi monitorujących i oceniających ryzyko klimatyczne szczególnie w najbiedniejszych krajach. Ogłoszony przez nas niedawno Plan Działania na Rzecz Klimatu jeszcze silniej podkreślił nasze plany zwiększenia finansowania na rzecz ochrony klimatu o jedną trzecią do potencjalnej kwoty nawet 29 miliardów dolarów rocznie.

Tym optymistycznym akcentem chciałbym zakończyć swoje wystąpienie. Przepraszam, jeśli rozczarowałem Państwa i nie skupiłem swojej uwagi na kwestiach lokalnych, polskich, które pewnie większość tutaj zgromadzonych interesują najbardziej. Bank Światowy ma jednak globalny mandat i dlatego uznałem, że warto dodać nieco międzynarodowego kontekstu. 

Andrzej Kassenberg

Instytut na rzecz Ekorozwoju

a.kassenberg@ine-isd.org.pl

\section{Postulat przyspieszenia wdrażania celów i zasad zrównoważonego rozwoju ${ }^{1}$}

\section{ŚWIAT}

Minione 30 lat od słynnego raport można oceniać dwojako. Z jednej strony coraz szersze jest zainteresowanie problematyką zrównoważonego rozwoju, czego dowodem jest ogłoszenie w zeszłym roku przez Organizację Narodów Zjednoczonych 17 Celów Zrównoważonego Rozwoju, które społeczność międzynarodowa zamierza osiągnąć do roku 2030. $\mathrm{Z}$ drugiej jednak bardzo niepokojące są trendy co do:

wyczerpywania się, zwłaszcza nieodnawialnych, zasobów naturalnych, w tym utraty różnorodności biologicznej i usług ekosystemów; poszerzającej się niezrównoważonej, przede wszystkim materialnej, konsumpcji napędzanej przez gospodarkę linearną (pobierz ze środowiska - zużyj - wyrzuć);

istnienia nadal wielu groźnych dla zdrowia, gospodarki i przyrody zanieczyszczeń, co w konsekwencji może prowadzić do załamania się przyrodniczych systemów podtrzymujących życie na Ziemi (np. zmiany klimatu); znacznych obszarów nędzy i biedy przy ogromnej koncentracji bogactwa w posiadaniu małej grupy osób;

ograniczania woli społeczności lokalnych co do podejmowania istotnych dla nich decyzji i szerzącej się na szeroką skalę korupcji;

* powiększającej się skali uchodźctwa czy to z powodu wojen i konfliktów, czy też ze względu na pogarszające się warunki do uzyskania minimum warunków do egzystencji w wyniku zmian klimatu, braku dostępu do wody, braku żywności i ubóstwa energetycznego.

\footnotetext{
${ }^{1}$ Niniejszy artykuł stanowił podstawę do przygotowania Apelu Warszawskiego o zrównoważony rozwój świata, który został przyjęty przez uczestników konferencji „Theoria i praxis zrównoważonego rozwoju" zorganizowanej w dniu 20 marca 2017 z okazji 30-leciea ogłoszenia Raportu Brundtland Nasza wspólna przyszłość.
} 
W okresie 1970-2012 wg WWF globalne populacje ryb, ptaków, ssaków, płazów i gadów spadły o 58 procent. Mimo tego, że w ciągu ostatnich 30 lat udało się znacznie zmniejszyć rozmiary skrajnego ubóstwa, to według Banku Światowego 1,2 miliarda ludzi na świecie (tj. ponad $17 \%$ ziemskiej populacji) żyje za mniej niż 1,25 dolara dziennie. Według Oxfam International dysproporcje majątkowe są większe niż kiedykolwiek, gdyż biedniejsza połowa ludzkości ma tyle majątku, co ośmiu najbogatszych ludzi świata. Nadal, według Międzynarodowej Agencji Energii, 1,2 miliarda ludzi nie ma dostępu do energii elektrycznej. Obecnie konsumujemy 1,6 razy więcej zasobów, niż wynosi potencjał biologiczny Ziemi do ich odtwarzania. Granica odnawialności została przekroczona 40 lat temu. Globalne wykorzystanie zasobów materialnych od 1900 roku wzrosło dziesięciokrotnie, a liczba ludność wzrosła 4,2 razy.

Analiza megatrendów pozwala nam określić, w jakim kierunku idzie świat i jakie stoją przed nami wyzwania. Europejska Agencja Środowiska zidentyfikowała 11 megatrendów. Biorąc je pod uwagę, jak również wiele innych opracowań, można je zarysować w następujący sposób:

Pogłębiająca się rozbieżność trendów dotyczących światowej populacji - wg ONZ w roku 2050 liczba ludności może osiągnąć 9,7 mld, a w roku 2100 przekroczyć 11 mld. To przekłada się na zwiększenie liczebności dostępnej na rynku siły roboczej oraz, co także kluczowe, liczby konsumentów. Obecnie obserwowane trendy są rozbieżne. Rosnące i młodsze populacje w krajach rozwijających się, globalny wzrost zamożnej klasy średniej i starzenie się społeczeństw w krajach rozwiniętych będą miały wpływ na ruchy migracyjne, tworząc mieszankę korzyści i zagrożeń, zarówno w regionach rozwiniętych, jak i rozwijających się.

W stronę bardziej zurbanizowanego świata - obecnie ponad 1/2 ludności świata mieszka na obszarach miejskich, a do 2050 roku udział ten ma zwiększyć się do 2/3. Przy odpowiednich inwestycjach ciągła urbanizacja może pobudzać tworzenie innowacyjnych rozwiązań problemów społecznych i dotyczących środowiska, ale 
może również prowadzić do zwiększonego wykorzystania zasobów i zanieczyszczenia oraz pogłębiania się biedy (wzrost slumsów).

Zmieniające się obciążenie chorobami i ryzyko pandemii - około $25 \%$ chorób i zgonów można przypisać czynnikom środowiskowym, a w 2050 roku zanieczyszczenie powietrza ma się stać główną przyczyną przedwczesnej umieralności. Światowe Forum Ekonomiczne szacuje, że między 2010 a 2030 leczenie przewlekłych chorób będzie globalnie kosztować 47 bilionów USD.

Coraz szybsze zmiany technologiczne. Nowe technologie radykalnie zmieniają świat, w szczególności w dziedzinie nano- i biotechnologii oraz technologii informacyjnych i komunikacyjnych. $\mathrm{Z}$ jednej strony stwarzają one możliwości zmniejszenia wpływu ludzi na środowisko i zwiększenia bezpieczeństwa zasobów, z drugiej jednak związane są z zagrożeniami i niepewnością. Następować będą dalsze zmiany w sposobie pracy, ale prawdziwa rewolucja może nastąpić ok. 2020 roku, kiedy to na rynku pracy $1 / 2$ pracowników będzie z pokolenia, które urodziło się i dorastało razem $\mathrm{z}$ technologiami cyfrowymi. W ciągu najbliższych 20 lat w wyniku automatyzacji w gospodarkach rozwiniętych może zniknąć blisko połowa obecnych zawodów.

Coraz bardziej wielobiegunowy świat. Stały wzrost gospodarczy? Większość prognoz przewiduje w nadchodzących dekadach kontynuację ekspansji gospodarczej na świecie wraz z towarzyszącą intensyfikacją konsumpcji i wykorzystania zasobów, w szczególności w Azji i Ameryce Łacińskiej. Obecnie obserwuje się znaczące przesunięcia w hierarchii gospodarczej; na pierwszy plan wychodzą przede wszystkim państwa azjatyckie, co wpływa na globalne współzależności i handel. Na kontynencie azjatyckim w 2030 roku ma mieszkać 66\% światowej klasy średniej, odpowiedzialnej za 59\% światowej konsumpcji klasy średniej. Dla porównania warto wspomnieć, że w 2009 roku było to odpowiednio $28 \%$ i $23 \%$. 


\section{Zaostrzenie światowej konkurencji o zasoby i rosnąca presja na} ekosystemy. Globalne wykorzystanie zasobów materialnych do 2030 roku może się podwoić. Do wzrostu przyczynia się rozwój przemysłu i zmieniające się wzorce konsumpcji. Skala wzrostu zapotrzebowania na nie może wywołać ograniczenia dostępności wielu krytycznie ważnych zasobów i spowodować poważne szkody w środowisku. Nierównomierne rozmieszczenie geograficzne zasobów może dodatkowo wywołać skoki cen, odbić się na standardzie życia, a nawet przyczynić się do konfliktów geopolitycznych. Urbanizacja świata i rosnąca liczba mieszkańców globu oznacza zwiększone zapotrzebowanie na surowce i zasoby naturalne. Według prognoz, do 2030 roku globalne zapotrzebowanie na energię i żywność ma się zwiększyć o $50 \%$, zaś na wodę o $40 \%$. Z dostępem do wody problem może mieć aż połowa światowej populacji. Zmniejszenie się dostępności wody może też obniżyć plony zbóż nawet o 30\%.

Coraz poważniejsze skutki zmiany klimatu. Pod koniec XXI wieku (2081-2100), oczekuje się, że jeśli emisje gazów cieplarnianych będą nadal rosły tak jak w ostatnich dekadach, to średnia temperatura powierzchni planety wzrośnie o $3,3-5,5^{\circ} \mathrm{C}$ w porównaniu do okresu odniesienia (1880-1910). Przewiduje się, że postępująca zmiana klimatu spowoduje poważne skutki zarówno dla ekosystemów, jak i społeczeństw (m.in. w zakresie dostępu do żywności, częstości występowania susz i ekstremalnych warunków pogodowych), a także gospodarki.

Zwiększające się zanieczyszczenie środowiska. Zanieczyszczenia pochodzą z trzech głównych obszarów działalności: spalania paliw kopalnych (przede wszystkim przez energetykę, przemysł i transport), stosowania nawozów sztucznych i pestycydów w rolnictwie oraz rosnącego wykorzystania chemikaliów. Ze wzrostem emisji zanieczyszczeń wiąże się przekroczenie granic planetarnych takich jak utrata różnorodności biologicznej, zaburzenia w obiegu związków azotu oraz zmiana klimatu.

Warunkiem przezwyciężenia niekorzystnych megatrendów jest stworzenie takiej wizji rozwoju cywilizacji w perspektywie II połowy XXI, 
która oznacza położenie nacisku przede wszystkim na uznanie fizycznej skończoności ekosystemu kuli ziemskiej, zarówno co do zasobów nieodnawialnych, jak i odnawialnych (granice odnawialności), do stwierdzenia ograniczonej pojemności środowiska (kontrola odprowadzania zanieczyszczeń) oraz konieczności zachowania usług ekosystemów. Aby chronić Ziemię i ludzką cywilizację, niezbędne staje się wypracowanie nowego podejścia do rozwoju gospodarczego; ów nowy ład można nazwać cywilizacją/gospodarką umiaru. Wyraża się on przede wszystkim w stabilnym poziomie zużycia zasobów, co przekłada się na skalę konsumpcji. Innymi słowy, gospodarkę umiaru wyznacza sześć kluczowych elementów (Enough is Enough 2010):

a) zrównoważone podejście, czyli gospodarka o ustabilizowanej wielkości w ramach limitu wyznaczonego przez dostępne zasoby i zdolność do odprowadzania zanieczyszczeń;

b) wprowadzenie sprawiedliwego podziału dóbr, który wszystkim ludziom umożliwi godziwe warunki życia;

c) wypracowanie efektywnej społecznie i ekologicznie alokacji środków dla różnych przejawów aktywności, tak aby wykorzystać odpowiednio gospodarkę rynkową, uwzględniając jej zalety i niedoskonałości (koszty zewnętrzne);

d) promocja partycypacyjnego sposobu podejmowania decyzji, który uwzględnia zaangażowanie przedsiębiorstw i społeczeństwa obywatelskiego;

e) propagowanie wysokiej jakości życia obecnego i przyszłych pokoleń opartej na jasno określonych wartościach;

f) udostępnienie edukacji wszystkim obywatelom przez całe życie.

Krytycznym element cywilizacji umiaru jest odejście od gospodarki linearnej na korzyść gospodarki zamkniętego obiegu, czyli takiej, która pozwala zachować możliwie jak najdłużej wartość dodaną produktów i wyeliminować odpady. System pozwala na ich ponowne wielokrotne wykorzystanie w sposób produktywny, tworząc w ten sposób kolejne wartości. Wymaga to zmian w każdym ogniwie łańcucha wartości. Zamknięty obieg to takie podejście, przy którym już na eta- 
pie projektowania zapewnia się utrzymanie produktów, komponentów i materiałów w najwyższym stopniu użyteczności i ich wartości, w każdym momencie cyklu. Zmiany następują kolejno: od fazy projektowania do nowych modeli biznesowych i rynkowych; od nowych sposobów przekształcania odpadów w zasoby do nowych zachowań konsumentów. Oznacza to zasadniczą zmianę systemową oraz wprowadzenie rozwiązań innowacyjnych nie tylko w technologiach, ale również w zarządzaniu, organizacji społeczeństwa, metodach finansowania i w polityce.

W gospodarce zamkniętego obiegu istnieje ostre rozróżnienie pomiędzy konsumpcją a użytkowaniem zasobów. Wynika z tego zasadnicza zmiana polegająca na tym, że wytwórca czy sprzedawca zachowuje prawo własności do swojego produktu tam, gdzie jest to możliwe. Działa on jako dostawca usługi (czyli satysfakcji z korzystania z produktu) klientowi, przy czym nie chodzi tu o jednorazowe skonsumowanie. Ta zasadnicza zmiana ma istotne implikacje dla skutecznych i wydajnych systemów odbioru produktów, a także dla rozprzestrzeniania się produktowych oraz biznesowych modeli zachowań oraz praktyk. System stymuluje wytwarzanie coraz bardziej wytrzymałych produktów, łatwych do demontażu czy naprawy (remontu). Jednocześnie tam, gdzie jest to zasadne, prowadzi do zmiany: $\mathrm{z}$ kupowania produktu na uzyskanie usługi zapewniającej taką samą satysfakcję jak posiadanie produktu. Wg Waltera Stahela, pioniera gospodarki zamkniętego obiegu, obowiązujący model linearny spowodował odwrót od usługi na rzecz kupna produktu, co prowadzi do marnotrawstwa. Dzisiaj gospodarka zamkniętego obiegu staje się synonimem dobrego gospodarowania zasobami i inteligentnego zarządzania.

Wysoka jakość życia w cywilizacji umiaru oznacza dostęp do żywności, czystej wody, urządzeń sanitarnych oraz usług zdrowotnych, a przede wszystkim zmniejszenie śmiertelności, zwłaszcza u dzieci, a także długowieczność oraz programy zdrowotne ukierunkowane na zdrowie reprodukcyjne kobiet. Wszystko to odgrywa kluczową rolę $\mathrm{w}$ rozwiązywaniu problemów demograficznych i związanego $\mathrm{z}$ nimi kryzysu migracyjnego. W związku z tym, że ludność będzie w zdecydowanej większości mieszkać w miastach, stawać się będą one zwarte, 
najbardziej efektywne i zrównoważone środowiskowo, w celu zapewnienia dobrobytu rosnącej populacji. Inteligentne planowanie zapewnia efektywne wykorzystanie przestrzeni miejskiej.

Coraz bardziej ograniczone możliwości rządów wobec coraz poważniejszych długoterminowych wyzwań globalnych, przed którymi stoja społeczeństwa, wymaga przyjęcia dodatkowych dróg podejmowania decyzji i zwiększenia zaangażowania przedsiębiorstw i społeczeństwa obywatelskiego. Zmiany te są konieczne, ale powodują również obawy dotyczące koordynacji, efektywności i odpowiedzialności.

\section{POLSKA}

W ciągu ostatnich ponad 25 lat w Polsce nastąpiły zasadnicze zmiany w podejściu do ochrony środowiska i zrównoważonego rozwoju. Dokonana transformacja ustrojowa pod koniec lat 80. i na początku lat 90. oraz akces do UE wyraźnie zaznaczyły swoje piętno. Przede wszystkim wprowadzenie gospodarki rynkowej i bankructwo lub ograniczenie produkcji wielu zakładów przemysłowych, w tym uciążliwych, przyczyniło się do poprawy wykorzystania zasobów i energii oraz spowodowało zmniejszenie odprowadzania wielu zanieczyszczeń do środowiska, a w konsekwencji - do poprawy stanu środowiska. Jednocześnie oznaczało to zaistnienie poważnych problemów społecznych, takich jak wysokie bezrobocie czy nadal szeroka skala biedy i ubóstwa. Przykładowo skala ubóstwa energetycznego sięga co najmniej dziesięciu procent społeczeństwa.

Budowa systemu demokratycznego stworzyła możliwość rozwoju społeczeństwa obywatelskiego. Jednak kapitał społeczny jest w Polsce słabo rozwinięty. Polska posiada jedno z ostatnich miejsce wśród społeczeństw europejskich co do poziomu zaufania do siebie nawzajem i do instytucji publicznych, podobnie jest $\mathrm{z}$ angażowaniem się $\mathrm{w}$ wybory, jak i podejmowaniem wspólnych działań dla ogólnego dobra.

Jednocześnie warto zaznaczyć, że własnym wysiłkiem, wspomaganym środkami z UE, dokonano znacznego postępu w wyposażeniu kraju w infrastrukturę ochrony środowiska i to zarówno komunalną jak i przemysłową. To także przyczyniło się i przyczynia do poprawy stanu środowiska. Podjęto działania dotyczące rozszerzenia obszarów objętych ochroną przyrody i bioróżnorodności przyrodniczej, zwłaszcza w zakresie euro- 
pejskiej sieci Natura 2000. Jednak postęp, mimo że znaczny, ciągle jest niewystarczający, części zaniedbań nie udało się jeszcze usunąć i tak:

- bogaty i znaczny kapitał przyrodniczy, zwłaszcza różnorodności biologicznej, ulega deprecjacji;

- mimo znacznych wysiłków, nadal występuje znaczne zacofanie w wyposażeniu w infrastrukturę ochrony środowiska;

- poprawa jakości środowiska postępuje, choć wolno, a w obszarach zurbanizowanych znacząco pogarsza się jakość powietrza atmosferycznego (tzw. smog) w wyniku niskiej emisji - szacuje się, że przyczynia się to do 45.000 przedwczesnych zgonów;

- następuje wzrost efektywności wykorzystania zasobów przy nadal niskiej ich produktywności, a także istotnego zacofania w gospodarce odpadami.

Jednocześnie pojawiły się nowe zagrożenia i to o nieznanej do tej pory skali. W szczególności dotyczy to negatywnego oddziaływania transportu drogowego przy jednoczesnym spadku znaczenia transportu publicznego i kolejowego. Stworzone po zmianach możliwości rozwoju konsumpcji, zwłaszcza materialnej, spowodowały, że ślad ekologiczny, którego wartość znacznie spadła bezpośrednio po zmianach, teraz zaczyna powoli rosnąć. Odbija się to także na gospodarce odpadami. Rozwój infrastruktury drogowej i urbanizacji, często niekontrolowanej i prowadzącej do rozprzestrzeniania się miast, odbił swoje piętno na obszarach cennych przyrodniczo, uszczuplając je. Warte podkreślenia jest zagrożenie substancjami chemicznymi oraz wynikająca ze słabej kontroli presja na środowisko i zdrowie ludzi małej i średniej przedsiębiorczości.

Zbyt wolno wprowadzane są elementy zielonej gospodarki. Takie jak: rozwój energetyki odnawialnej, poprawa efektywności zasobowej i energetycznej, rozwój ekologicznych gospodarstw i przetwórstwa żywności, próby powstrzymania upadku transportu publicznego oraz rozwój ekoturystyki. Ciągle wyzwaniem jest szybszy rozwój ekoinnowacji.

Zmiana kierunku rozwoju Polski wymaga wypracowania i wdrażania takich działań, które zgodnie z art. 5 Konstytucji RP umożliwią realizację zrównoważonego rozwoju opartego na równoprawnym traktowaniu trzech kapitałów: gospodarczego, społecznego i przyrodniczego, co oznacza: 
a) w sferze społecznej:

$\checkmark$ zasadnicze wzmocnienie kapitału społecznego, zaufania między ludźmi jako motoru napędowego zmian w kierunku społeczeństwa zrównoważonego rozwoju;

$\checkmark$ postawienie w strategii rozwoju kraju na jakość życia bieżącego pokolenia, jak i pokoleń po nim następujących, przy równoprawnym ich traktowaniu;

$\checkmark$ szerokie stosowanie zasady subsydiarności i partycypacji społecznej w rozwiązywaniu problemów rozwoju na wszystkich szczeblach: od lokalnego po międzynarodowy;

$\checkmark$ prowadzenia systematycznej edukacji społeczeństwa na rzecz zrównoważonego rozwoju;

b) w sferze gospodarczej:

$\checkmark$ przechodzenie od nieefektywnej gospodarki linearnej do cyrkulacyjnej gospodarki umiaru;

$\checkmark$ kreowanie zrównoważonej konsumpcji, podkreślającej znaczenie dóbr niematerialnych;

$\checkmark$ dążenie do wzrostu produktywności zasobów i poprawy efektywności ich użytkowania;

$\checkmark$ wdrażanie nowej generacji innowacyjności promującej rozwiązania inteligentne;

$\checkmark$ uwzględnianie w rachunku ekonomicznym kosztów społecznych i wartości usług ekosystemowych;

c) w sferze przyrodniczej:

$\checkmark$ planowanie tempa wykorzystania zasobów, zwłaszcza nieodnawialnych, jako przejaw sprawiedliwości międzypokoleniowej;

$\checkmark$ wyznaczenie i przestrzeganie limitów zanieczyszczeń;

$\checkmark$ zasadnicze wzmocnienie infrastruktury przyrodniczej kraju i ochrony różnorodności biologicznej wraz z dbaniem o zachowanie funkcji (usług) ekosystemów,

$\checkmark$ tworzenie ładu przestrzennego. 
Przekonanie polskich elit i społeczeństwa do korzyści wynikających z wyzwań, jakie stawia zrównoważony rozwój, nie jest zadaniem łatwym, $z$ uwagi na specyfikę przyjętego modelu gospodarczego, opartego na coraz bardziej intensywnym użytkowaniu zasobów (praca, kapitał, surowce naturalne, energia), oraz ze względu na budowanie społeczeństwa nadkonsumpcyjnego przy deprecjacji kapitału przyrodniczego. Wszelkie działania zmierzające do wdrażania nowego kierunku „zielonej” transformacji natrafiają na opór. Jednak przestawienie gospodarki i społeczeństwa na nowe tory przynosi i będzie przynosić wymierne korzyści, które zrekompensują koszty transformacji. Oznaczają one bowiem kształtowanie świadomego współczesnych wyzwań społeczeństwa, tworzenie wysokiej jakości życia, w tym poprawy zdrowia obywateli dzisiaj i jutro, a także kreowanie innowacyjnej, inteligentnej gospodarki w ramach wyznaczonych przez dostępne zasoby oraz możliwości odprowadzania zanieczyszczeń tak, aby przyrodnicze systemy podtrzymujące życie na Ziemi, a przede wszystkim usługi ekosystemów, mogły sprawnie funkcjonować.

\section{Bibliografia:}

Enough is Enough: Ideas for a sustainable economy in a world of finite resources. The report of the Steady State Economy Conference, red. Dan W. O’Neill, Rob Dietz i Nigel Jones. 2010. Leeds, UK: Center for the Advancement of the Steady State Economy and Economic Justice for All. 
Zbigniew Łepko

Uniwersytet Kard. Stefana Wyszyńskiego - Instytut Ekologii i Bioetyki

z.lepko@uksw.edu.pl

\section{Wprowadzenie w problematykę konferencji pt. „Theoria i praxis idei zrównoważonego rozwoju”}

Zakres problematyki naszej konferencji wyznacza wprost jej tytuł: "Theoria i praxis idei zrównoważonego rozwoju. 30 lat od Raportu Gro Harlem Brundtland”. Proponując taki tytuł, pomysłodawcy i organizatorzy konferencji chcą zarówno odnotować ogromnie ważne wydarzenie dla całej ludzkości, jakie wyznaczył dokładnie 30 lat temu (20.03.1987) Raport Gro Harlem Brundtland pt. Nasza wspólna przyszłość, jak i skoncentrować uwagę na wywołanej ideą zrównoważonego rozwoju w dyskusji nad nieoczywistą relacją praktyki do zawartej w niej teorii. Pomysłodawcy i organizatorzy konferencji odwołują się przy tym

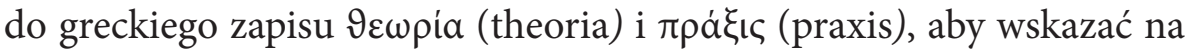
starożytne ustalenia odnośnie do relacji obu tych kategorii.

Choć zdecydowana większość uczestników dzisiejszej konferencji doskonale zna problematykę idei zrównoważonego rozwoju, to jednak referat wprowadzający musi, przynajmniej pokrótce, przypomnieć podstawowe informacje z tego zakresu. Należy zatem przypomnieć, że termin „zrównoważony rozwój” pochodzi z raportu Światowej Komisji ds. Środowiska i Rozwoju (World Commission on Environment and Development) z 1987 r. Nasza wspólna przyszłość (Our Common Future). Według niego rozwój zrównoważony oznacza taki rozwój, „,który zaspokaja potrzeby obecne, nie pozbawiając przyszłych pokoleń możliwości zaspokojenia ich potrzeb" (ŚKŚR 1991, 67). Jak widać, źródło idei zrównoważonego rozwoju tkwi w pojęciu „zrównoważoności” (trwałości, Nachhaltigkeit, sustainability), które po raz pierwszy pojawiło się w języku niemieckim i odnosiło się do XVIII-wiecznej gospodarki leśnej. Po raz pierwszy użył go w 1713 roku Hans Carl von Carlowitz w pracy Die Sylvicultura oeconomica oder Haußwirthliche Nachricht und Naturmäßige Anweisung zur Wilden Baum-Zucht (Carlowitz 1713/2013, Buch I, Kapitel 7, \$20). Pierwotnie oznaczało więc ono sposób gospodarowania 
lasem, polegający na tym, że wycina się tylko tyle drzew, ile może w to miejsce urosnąć, tak by las nigdy nie został zlikwidowany, lecz mógł się zawsze odbudować (Wey 1982, 157). Koncepcja zrównoważonego rozwoju na początku XIX wieku była propagowana przez wszystkie niemieckie Wyższe Szkoły Leśnicze. Dzięki temu, że niemieckie leśnictwo cieszyło się wówczas dużym uznaniem na całym świecie, pojęcie to zostało przejęte przez liczne środowiska naukowe w innych krajach.

W początkach drugiej połowy XX wieku zostało ono użyte w odniesieniu do szeroko rozumianej gospodarki. Dzisiaj z reguły rozciąga się je na społeczne, ekonomiczne i ekologiczne aspekty organizacji i funkcjonowania społeczeństw ludzkich. Tym samym jest ono uznawane za oficjalny termin w debatach naukowych i politycznych. Przyjmuje się, że w dzisiejszym znaczeniu zaczęło ono funkcjonować od początku lat osiemdziesiątych XX wieku, czyli wraz z publikacją World Conservation Strategy (WCS 1980).

Pomijając wcześniejsze zastosowania tego terminu, trzeba stwierdzić, że dzisiejsze jego znaczenie rozumiane jest właśnie zgodnie z przesłaniem Raportu Brundtland z roku 1987. W pewnym sensie wyraża ono formułę dyplomatycznego kompromisu między koniecznością ochrony środowiska a koniecznością rozwoju cywilizacyjnego, czyli wzrostu gospodarczego, zwłaszcza krajów półkuli południowej. Od tego czasu termin ten ogromnie zyskał na popularności i znalazł różne zastosowania w debacie politycznej, w badaniach naukowych, przedsięwzięciach gospodarczych i inicjatywach obywatelskich.

Istotny wpływ na rozumienie tego pojęcia miał Szczyt Ziemi w Rio de Janeiro w roku 1992. Prowadzony wówczas dyskurs akcentował przede wszystkim technokratyczny charakter zawartej w nim koncepcji. Oznaczało to, że zalecane wówczas próby rozwiązania kwestii ekologicznej odwoływały się do technologii albo innych typów racjonalności naukowej. Tym samym komponent społeczny w porównaniu z Raportem Brundtland został niejako przesunięty na drugi plan. Wtedy też wyraźnie pojawił się problem praktycznego spożytkowania dobrej teorii zawartej w idei zrównoważonego rozwoju.

Od Szczytu Ziemi w Johannesburgu (2002 r.) zaczęto stawiać akcent na metody osiągania celów zrównoważonego rozwoju. W ślad za tym na znaczeniu przybierał problem trudności zastosowania teorii w praktyce. 
Wtedy też wskazano na konieczność edukacyjnego wzmocnienia konceptów zrównoważonego rozwoju. Dlatego z początkiem roku 2005 ONZ zorganizowała dekadę kształcenia na rzecz zrównoważonego rozwoju. Celem tego przedsięwzięcia była popularyzacja tej idei poprzez edukację środowiskową i edukację globalną. Zrodzone wówczas liczne inicjatywy $\mathrm{w}$ tym względzie zmierzały do wypracowania metod przekształcania celów zrównoważonego rozwoju w strategie zrównoważonego rozwoju.

W ślad za tym zaczęto mówić o zrównoważonym rozwoju jako regulatywnym modelu działań i zaczęto poszukiwać możliwości wkomponowania sfery praxis $\mathrm{w}$ procesy zarządzania zrównoważonym rozwojem. Właśnie te tendencje pomysłodawcy dzisiejszej konferencji uznają za ważny przyczynek do dyskusji nad zagadnieniem relacji praktyki do teorii. Ten pomysł wzmacnia obserwacja, że niektórym próbom wiązania praktyki z teorią zrównoważonego rozwoju towarzyszą zbyt wielkie oczekiwania. W niektórych przypadkach traktują one mianowicie ideę zrównoważonego rozwoju jako podstawę tworzenia algorytmu działań niezawodnie zabezpieczających przyszłość życia na Ziemi. Niejako w reakcji na te zbyt optymistyczne oczekiwania należy zauważyć, że idea zrównoważonego rozwoju posiada charakter heurystyczny. Tę opinię można wesprzeć rozważaniami Hansa-Georga Gadamera, zgodnie z którymi można przyjąć, że idea „zrównoważonego rozwoju” stanowi pewien rodzaj inspiracji do działań na rzecz przetrwania obecnego i przyszłych pokoleń. W tym sensie skłania do pogłębionej refleksji nad właściwą dla tego przypadku relacją praktyki do teorii. Gadamer podpowiada, że dobrym dla niej punktem odniesienia może być zreflektowane przez filozofie starożytnej Grecji odniesienie praxis do theoria. Greckiej tradycji myślenia europejskiego możemy zaufać przede wszystkim dlatego, że stworzona przez nią nauka podporządkowuje się warunkom ludzkiego świata przeżywanego i jego naczelnemu pojęciu, jakim jest „przyroda” (physis) (Gadamer 1988, 226).

Kluczowym zagadnieniem $\mathrm{w}$ tych rozważaniach jest więc idea filozofii praktycznej i samo pojęcie praxis, w jego znaczeniu podstawowym, czyli niezafałszowanym przez zależność od tego, co znamy dziś pod nazwą nauki stosowanej. Gadamer pyta więc, czym jest praxis i co to znaczy praxis. Odpowiedzi zaś szuka u Arystotelesa i przypomina, że „poję- 
cie «praxis» kształtuje się u Arystotelesa w relacji do ducha umiejętności wytwórczych. Arystoteles wprowadza bowiem rozróżnienie między techne - wiedzą, która kieruje zdolnością wytwarzania, a phronesis wiedzą, która kieruje praktyką. Rozróżnienie to nie oznacza rozdziału, ale pewien porządek, mianowicie podporządkowanie sfery techne i jej możliwości sferze phronesis i jej praktyce" (Gadamer 1988, 226-227) .

Oznacza to, że w zarejestrowanej w pojęciu „rozwój zrównoważony” informacji, nagromadzonej między innymi w wyniku ludzkiego doświadczenia zaburzeń funkcjonowania ekosystemów Ziemi, zawiera się zachęta do działania według reguł właściwych praxis zreflektowanej przez starożytnych mędrców. Praxis nie jest bowiem działaniem według ściśle ustalonych reguł, jak dzieje się to w przypadku stosowania wiedzy, lecz stanowi wyraz pierwotnego usytuowania człowieka $\mathrm{w}$ jego środowisku przyrodniczym i społecznym. To zaś poszerza perspektywę rozważań i pozwala stwierdzić, że pojęcie „rozwój zrównoważony” nie tylko przekazuje informację o zagrożeniu środowiska życia, lecz także mobilizuje do współdziałania ludzi ze względu na związane $\mathrm{z}$ nim wyzwania. W tym spojrzeniu na praxis zawiera się bowiem pierwotna więź tych wszystkich, którzy żyją we wspólnocie losu i działania. Ostatecznie można więc powiedzieć, że uwzględniająca mądrość starożytną refleksja nad kształtem praxis, jaki wyłania się z pojęcia „rozwój zrównoważony”, prowadzi do wniosku, iż kształt ten ujawnia zarówno aspekty praktyczno-techniczne, jak i praktyczno-moralne. Oznacza to dalej, że zapośredniczona techniką relacja człowieka do właściwego mu środowiska życia zawsze uwarunkowana jest moralnością człowieka i zasobami jego wyposażenia technicznego. Kierowany do człowieka apel, zawarty w pojęciu „rozwój zrównoważony”, ma więc na celu podporządkowanie technicznej działalności człowieka jego moralności (Łepko 2003, 66-67). Zadanie nasze „polega na tym, mówi Gadamer, by włączyć teoretyczne poznanie i techniczne możliwości człowieka do jego praxis i tej praxis je podporządkować, a nie na tym, by przekształcać własny świat przeżywany, który jest światem praxis, w teoretycznie uzasadnioną konstrukcje techniczną" (Gadamer 1988, 227).

Tak myśląc, poprzez dzisiejszą konferencję pragniemy potwierdzić heurystyczny charakter idei zrównoważonego rozwoju, zgodnie z którą utrzymanie standardu życia obecnych pokoleń nie powinno koli- 
dować z długotrwałym bezpieczeństwem przyrody i w tym sensie nie powinno zagrażać bezpieczeństwu pokoleń przyszłych. Pragniemy zarazem pokazać, że tak rozumiany rozwój zrównoważony rodzi problemy, których adekwatne rozpoznanie wymaga współpracy przedstawicieli coraz większej ilości dyscyplin naukowych. Problemy te stanowią wyzwanie nie tylko dla specjalistów różnych nauk przyrodniczych czy technicznych, ale także dla antropologów, politologów, socjologów, psychologów, prawników, filozofów i teologów. Zdobyte w tym względzie doświadczenia kilku ostatnich dziesięcioleci pozwalają stwierdzić, że liczba dyscyplin naukowych zaangażowanych w przezwyciężenie kryzysu współczesnej cywilizacji stanowi rzeczywistą miarę jego złożoności (Łepko 2008, 7-8). I choć dzisiaj trudno wyrokować co do efektywności współdziałania tak różnych dyscyplin ludzkiej wiedzy, to jednak z pewnością wiadomo, że istnienia Ziemi - naszego wspólnego domu - nie zabezpieczy się jedynie środkami technicznymi. Sądzimy, że dobrą ilustracją takiego myślenia jest projekt badawczy leżący u podstaw programów realizowanych w Instytucie Ekologii i Bioetyki na Wydziale Filozofii Chrześcijańskiej UKSW (Kureethadam, Łepko i Sadowski 2016, 18-19). Należy ponadto podkreślić, że twórczym dopełnieniem i rozwinięciem realizacji tych programów jest rozległa działalność Instytutu na Rzecz Ekorozwoju oraz liczne inicjatywy podejmowane przez Biuro Infrastruktury m.st. Warszawy. Zaangażowanie Instytutu Ekologii i Bioetyki UKSW, Instytutu na Rzecz Ekorozwoju oraz Biura Infrastruktury m.st. Warszawy w organizację konferencji "Theoria i praxis zrównoważonego rozwoju” dobrze oddaje zawarte w jej tytule napięcie między teorią i praktyką zrównoważonego rozwoju.

\section{Bibliografia:}

Carlowitz, Hans Carl von. 1713/2013. Die Sylvicultura oeconomica oder Haußwirthliche Nachricht und Naturmäßige Anweisung zur Wilden Baum-Zucht, red. Joachim Hamberger. München 2013: Oekom Verlag.

Gadamer, Hans Georg. 1988. Obywatele dwóch światów. W: Człowiek w nauce współczesnej. Rozmowy w Castel Gandolfo - 1983, red. Krzysztof Michalski, 215-230. Paris: Editions du Dialogue. Seciete d'Editions Internationales. 
Kureethadam, Joshtrom I., Zbigniew Łepko i Ryszard F. Sadowski 2016. Introduction: Anthropological Perspective on the Recovery of Oikos. W: Return to The OIKOS. Ways to Recover Our Common Home, red. Joshtrom I. Kureethadam, Zbigniew Łepko i Ryszard F. Sadowski, 13-25. Rome: LAS.

Łepko, Zbigniew. 2003. Antropologia kryzysu ekologicznego w świetle wspótczesnej literatury niemieckiej. Warszawa: Wydawnictwo UKSW.

Łepko, Zbigniew. 2008. Foreword. W: A Holistic Approach to Environment Conservation, red. Ryszard F. Sadowski i Jacek Tomczyk, 7-9. Warszawa: Wydawnictwo UKSW.

Wey, Klaus-Georg. 1982. Umweltpolitik in Deutschland: kurze Geschichte des Umweltschutzes in Deutschland seit 1900. Opladen: Westdeutscher Verlag.

ŚKŚR (Światowa Komisja ds. Środowiska i Rozwoju). 1991. Nasza wspólna przyszłość, tłum. Urszula Grzelońska i Ewa Kolanowska. Warszawa: Państwowe Wydawnictwo Ekonomiczne. 


\section{CZĘŚĆ I \\ EWOLUCJA IDEI ZRÓWNOWAŻONEGO ROZWOJU}



Artur Pawłowski

Politechnika Lubelska - Wydział Inżynierii Środowiska a.pawlowski@pollub.pl

\section{Rozwój zrównoważony - największe wyzwanie XXI wieku}

\section{Wprowadzenie}

Wiek XX miał bez wątpienia przełomowy charakter w dziejach ludzkości, chociażby z uwagi na imponujący postęp technologiczny i medyczny, który wtedy się dokonał. Zarazem doświadczyliśmy dwóch wojen światowych i ogromnej degradacji środowiska. Co więcej, po raz pierwszy w historii człowiek posiadł technologie umożliwiające zniszczenie całej planety. Te wyzwania stały się przedmiotem analizy Światowej Komisji ds. Środowiska i Rozwoju, powołanej przez ONZ w 1983 r. Po 4 latach opublikowano raport Nasza wspólna przyszłość (zwany także Raportem Brundtland, od nazwiska przewodniczącej komisji Gro Harlem Brundtland).

\section{Raport Nasza wspólna przyszłość}

Jego istotną częścią była próba podsumowania sukcesów i porażek człowieka w XX w., w oparciu o którą usiłowano zarysować wizję dalszego rozwoju ludzkości. Wśród kluczowych kwestii wskazano na: stabilizację liczebności populacji ludzkiej, zabezpieczenie żywności dla człowieka, powstrzymanie utraty gatunków i zasobów genetycznych, w szczególności odnośnie do lasów tropikalnych, zaopatrzenie w energię, zrównoważony przemysł i prawidłowy rozwój obszarów miejskich.

Wśród głównych zagrożeń wymieniono: spadek ilości obszarów nadających się pod uprawy rolnicze (główne przyczyny: erozja gleb i pustynnienie), nadmierny wyręb lasów, szczególnie w Ameryce Południowej i Azji, nadmierne spalanie paliw kopalnych i związane z tym zanieczyszczenia atmosfery ( $w$ aspekcie globalnym prowadzą one do nadmiernego efektu cieplarnianego, a regionalnie do powstawania kwaśnych deszczy, stanowiących zagrożenie nie tylko dla organizmów żywych, ale także dla zabytkowych obiektów kulturowych) i zależność przemysłu od surowców naturalnych. 
Bezpośrednio w odniesieniu do człowieka zwrócono także uwagę na (ŚKŚR 1991):

$\checkmark$ wzrost liczby głodujących;

$\checkmark$ wzrost liczby analfabetów;

$\checkmark$ wzrost liczby ludności nie mającej dostępu do czystej wody;

$\checkmark$ wzrost liczby ludności nie mającej zdrowego i bezpiecznego mieszkania;

$\checkmark$ wzrost liczby ludności nie mającej opału;

$\checkmark$ zwiększanie się rozpiętości między narodami bogatymi i biednymi;

$\checkmark$ wyścig zbrojeń.

Dostrzeżono również sukcesy (ŚKŚR 1991):

$\checkmark$ spadek umieralności niemowląt;

$\checkmark$ przedłużenie przeciętnego wieku życia;

$\checkmark$ wzrost liczby dorosłych, którzy potrafią czytać i pisać;

$\checkmark$ wzrost odsetka dzieci uczęszczających do szkół;

$\checkmark$ szybszy wzrost globalnej produkcji żywności niż liczby ludności.

Przedstawiony bilans sukcesów i porażek wypadł niejednoznacznie. W dyskusji duży nacisk położono na - często lekceważone - potrzeby krajów biednych. Zauważono, że mimo różnorodnych programów pomocowych, przepaść pomiędzy krajami bogatymi i biednymi nie tylko się nie zmniejsza, ale coraz bardziej się pogłębia. Wyrazem tego jest fakt, że choć wzrasta ilość ludzi potrafiących czytać i pisać, to zarazem także nadal przybywa analfabetów. Ponadto podkreślono, że kwestie ekonomiczne są ściśle związane $\mathrm{z}$ uwarunkowaniami środowiskowymi. Jest to relacja dwustronna. Rozwój ekonomiczny wywiera negatywny wpływ na środowisko (choćby w aspekcie zużywania surowców), a zarazem degradacja środowiska może ograniczać rozwój ekonomiczny. We współczesnym świecie - jak dobitnie w komentarzu z ramienia OECD podkreślał Donald J. Johnston - „środowisko nie jest sferą niezależną od ludzkich działań, ambicji i potrzeb” (Johnston 2002). Współczesne sytuacje kryzysowe (w aspekcie środowiskowym, rozwojowym, rolniczym, społecznym czy energetycznym) także nie są od siebie niezależne. To jest jeden kryzys 
globalny odnoszący się do podejścia człowieka wobec środowiska, którego nie da się już rozwiązać w ramach jurysdykcji poszczególnych krajów.

Drogą do rozwiązania naszkicowanych powyżej przenikających się problemów miała być koncepcja rozwoju zrównoważonego. Sam termin nie był nowy, użyto go uprzednio m.in. w Światowej Strategii Ochrony Przyrody z 1980 r., jednak raport z 1987 r. nadał mu nowe znaczenie. Mimo kilku zbliżonych propozycji i określeń, to właśnie raport Nasza wspólna przyszłość okazał się mieć charakter przełomowy. Jego wielkim osiągnięciem było powszechne przyjęcie koncepcji rozwoju zrównoważonego w sferze naukowej, politycznej, a także wśród szerokich kręgów światowej opinii publicznej.

\section{Problematyka rozwoju zrównoważonego}

We wspominanym raporcie za zrównoważony uznano taki typ rozwoju, „który gwarantuje zaspokojenie potrzeb obecnych pokoleń, nie zagrażając zdolności przyszłych pokoleń do zaspokajania własnych potrzeb" (ŚKŚR 1991). Proponowana definicja (zwana zasadą rozwoju zrównoważonego) otrzymała wymiar normatywny i do niej nawiązywały wszystkie przyszłe strategie rozwojowe.

W następnych latach powstało wiele kolejnych definicji rozwoju zrównoważonego. W swojej monografii Rozwój zrównoważony - idea, filozofia, praktyka (2008) podaję $50 \mathrm{z}$ nich. To istotny problem metodologiczny: jak prowadzić dyskusję wokół koncepcji, która jest tak różnorodnie definiowana? Odpowiedź jest jednak bardzo prosta: definicji jest wiele, ale powszechnie przyjęta jest tylko jedna - to definicja pochodząca z omawianego raportu Nasza wspólna przyszłość. To właśnie to określenie znajdziemy w dokumentach Organizacji Narodów Zjednoczonych, Unii Europejskiej, a w Polsce nawet w obowiązującej konstytucji.

W ramach tak rozumianego rozwoju zrównoważonego wskazuje się na dwa podstawowe paradygmaty: sprawiedliwości wewnątrz- i międzypokoleniowej. Powinniśmy więc tak korzystać ze środowiska i z dostępnych zasobów surowców, aby były one dostępne także dla przyszłych pokoleń. W szczegółowej dyskusji wskazuje się na trzy główne obszary problematyczne, ściśle ze sobą powiązane: środowiskowy, ekonomiczny i społeczny. 
W szczególny sposób podkreślić trzeba ten ostatni, bowiem tak jak degradacji może ulegać środowisko przyrodnicze, tak też może jej ulegać środowisko społeczne. Jest to nie tylko kwestia relacji międzyludzkich, ale także rzeczywistej utraty zasobów społecznych i kulturowych. Wystarczy wspomnieć, że choć obecnie w użyciu jest ok. 6,5 tys. języków, jednak do końca obecnego wieku przetrwa co najwyżej $10 \%$ z nich. Już dziś 80\% mieszkańców Ziemi posługuje się zaledwie 83 językami, a 3500 kolejnych kultywuje zaledwie 0,2\% ludzkości (Burda 2014).

Triada środowisko - ekonomia - społeczeństwo powinna być oparta na refleksji filozoficznej. Etyczne uzasadnienie dla zrównoważonego rozwoju to „fundament” całej dyskusji. Szczególnie wyraźne jest to w wymiarze indywidualnym. To wszak zupełnie odmienna sytuacja, gdy człowiek podejmuje dane działania tylko dlatego, że tak nakazuje mu prawo, niż gdy jest osobiście przekonany, że tak właśnie należy czynić1.

Należy jeszcze podkreślić, że rozwój zrównoważony nie jest tylko nowym programem ochrony środowiska (termin ekorozwój ma znacznie węższe znaczenie), nie jest też kolejnym programem rozwoju ekonomicznego (jest nową alternatywą dla dominującego nadal paradygmatu wzrostu gospodarczego). To próba sformułowania programu integrującego różnorodne płaszczyzny ludzkiego działania, często uprzednio rozpatrywane oddzielnie. Zakres proponowanych zmian jest bardzo szeroki i w przyjmowanych strategiach daleko wykracza poza zagadnienia zasygnalizowane w raporcie Nasza wspólna przyszłość. Koniecznie odwołać się tu trzeba do pierwszej (i do dziś podstawowej) strategii Agenda 21 przyjętej w 1992 r. podczas Szczytu Ziemi w Rio de Janeiro, stanowiącej w swej istocie zupełnie nową wizję relacji pomiędzy człowiekiem a środowiskiem. Dlatego uzasadniony wydaje się postulat, według którego rozwój zrównoważony, w przypadku rzeczywistego wpro-

\footnotetext{
${ }^{1} \mathrm{~W}$ swoich pracach proponuję rozszerzony model rozwoju zrównoważonego, który składa się z trzech poziomów i 3 płaszczyzn. Poziom I to płaszczyzna etyczna. Poziom II tworzą płaszczyzny ekologiczna, społeczna i ekonomiczna. Poziom III natomiast to płaszczyzny techniczna, prawna i polityczna. Tradycyjna dyskusja wokół rozwoju zrównoważonego koncentruje się na poziomie drugim. Bez zakorzenienia w etyce (poziom pierwszy) będzie ona jednak niepełna. Natomiast bez poziomu trzeciego naszej uwadze mogą umknąć konkretne rozwiązania praktyczne. Podkreślić należy, że wymienione płaszczyzny, mimo hierarchicznej struktury, przenikają się, przez co często nie sposób wskazać na problemy charakterystyczne tylko dla jednej $\mathrm{z}$ nich.
} 
wadzenia w życie, stanie się rewolucją porównywalną do dotychczas wymienianych w dziejach ludzkości momentów przełomowych, często określanych także jako rewolucja rolnicza, naukowa, przemysłowa (Pawłowski 2009) ${ }^{2}$.

\section{Rozwój zrównoważony jako droga ku przyszłości}

Koncepcja rozwoju zrównoważonego została sformułowana w 1987 r. Obecne mija więc dokładnie 30 lat od tego momentu, a zarazem 25 od przygotowania pierwszej strategii Agenda 21. Co w tym czasie udało się osiągnąć?

Ocenę utrudnia dość ograniczony horyzont czasowy. Ponadto niewiele możemy powiedzieć o przyszłości, w każdej chwili mogą pojawić się czynniki całkowicie zmieniające dotychczasowy punkt widzenia. Tak jak atak terrorystyczny na Nowy Jork z 11 września 2001 r. rozwiał iluzję bezpieczeństwa współczesnego świata, tak też doświadczyć możemy niespodziewanych katastrof ekologicznych spowodowanych zanieczyszczaniem środowiska przez człowieka (np. w aspekcie gwałtownych zmian klimatycznych). Równie dobrze możemy stać się świadkami nowych przełomowych odkryć naukowych i technicznych, np. odnoszących się nowych, wydajnych źródeł energii.

Przewodnicząca komisji ONZ przygotowującej raport Nasza wspólna przyszłość, Gro Harlem Brundtland, kilka lat temu w wywiadzie udzielonym sieci The Baltic University, a poświęconym ocenie poziomu wdrożenia zrównoważonego rozwoju, powiedziała, że „odnotowaliśmy znaczący postęp w wielu kwestiach, pewien postęp w innych, a w niektórych obszarach nic się niestety nie zmieniło. Podkreślić jednak należy,

\footnotetext{
${ }^{2}$ Nie brak też głosów, że mamy obecnie do czynienia z rewolucją informatyczną, związaną z powszechnym wykorzystywaniem Internetu, która ma być następnym krokiem po rewolucji przemysłowej (Haliniak 2004). Faktycznie, Internet to niezwykła platforma pozwalająca zdobywać i upowszechniać informacje istotne, przyczyniające się do rozwoju społeczeństwa informatycznego (Wątroba 2002). Zarazem technologia ta wydaje się zmierzać w kierunku ślepego zaułka. W 2007 r. aż 95\% wiadomości mailowych otrzymywanych przez użytkowników poczty elektronicznej to był tzw. spam, a więc materiały niechciane, zawierające nachalne reklamy (jak podał „PC World Komputer” w numerze 2/2008 - jeszcze w 2001 r. takich przesyłek było tylko $5 \%)$. Poza tym Internet nie zmienił stosunku człowieka do przyrody, a pod wpływem coraz doskonalszych sposobów komunikowania się ludzie nie zmniejszyli swojej presji na środowisko. Technologie informatyczne są po prostu narzędziem, które może zostać wykorzystane w rewolucji o ogólniejszym charakterze.
} 
że w wielu kwestiach postęp jest widoczny. Przykładem może być Protokół Montrealski, stanowiący przełom w międzynarodowej współpracy dla zwalczania dziury ozonowej. Pokazuje on bowiem, że w ważnych sprawach osiągnięcie globalnego porozumienia jest możliwe” (Brundtland 1997).

Co jeszcze należy umieścić po stronie pozytywów?

Wydaje się, że po pierwsze upowszechnienie samej koncepcji rozwoju zrównoważonego. W historii ludzkości było wiele bardzo interesujących idei, które nie zostały zaakceptowane. Raport Nasza wspólna przyszłość spotkał się jednak z ogromnym odzewem. Dzięki niemu rozwój zrównoważony stał się przedmiotem dyskusji podczas Szczytów Ziemi w Rio de Janeiro (dwukrotnie: 1992 i 2012) oraz Johannesburgu (2002). Dziś ta idea zajmuje centralne miejsce we wszystkich strategiach rozwojowych i to na różnych poziomach (od ustaleń międzynarodowych po regionalne i lokalne).

Wiele zmieniło się także w sektorze energetycznym. W skali całego świata zauważalny jest spadek wykorzystywania paliw kopalnych jako nośników energii na rzecz rozwoju odnawialnych źródeł energii i rozwiązań hybrydowych. W szczególny sposób wyróżnić tu należy postawę Unii Europejskiej i wdrożonej w niej strategii „3 x 20 do roku 2020 r." (UE 2008), w ramach której zakłada się: zwiększenie o $20 \%$ efektywności wykorzystywania energii, zmniejszenie o $20 \%$ emisji gazów cieplarnianych i osiągnięcie $20 \%$ udziału odnawialnych źródeł energii w ogólnym bilansie energetycznym. Konsekwentnie w okresie od 1987 r. do dziś bardzo wyraźnie rozwinęły się technologie przyjazne środowisku.

W aspekcie społecznym nie udało się wprawdzie wyeliminować większości problemów widocznych w 1987 r., jednak wiele inicjatyw zmierza właśnie w tym kierunku. Warto ponownie odwołać się do Unii Europejskiej, tym razem w kontekście strategii „Europa 2020” (UE 2010). Wśród najważniejszych celów, które powinny zostać 
osiągnięte, wskazuje się na równość i spójność społeczną. Oznacza to konieczność budowania demokratycznego, bezpiecznego i sprawiedliwego społeczeństwa, respektującego podstawowe prawa człowieka i różnorodność kultur. Ważna jest także walka z wykluczeniem. Ujmując inaczej, celem jest zbudowanie społeczeństwa równych możliwości, zapewniającego wysokie standardy życia i pełne zatrudnienie w całej Unii Europejskiej.

Wśród najważniejszych problemów, których nie udało się od czasu publikacji raportu Nasza wspólna przyszłość rozwiązać, należy wskazać na:

$\checkmark$ Postępujące zmiany klimatyczne. Światowa polityka koncentruje się głównie na zmniejszeniu emisji $\mathrm{CO}_{2}$, ale nawet $\mathrm{w}$ tym zakresie nie jest w pełni skuteczna. Ponadto bagatelizuje się wpływ innych gazów cieplarnianych, takich jak metan, freony, ozon czy tlenki azotu. Co więcej, gdy w 2013 r. odkryto nowy gaz cieplarniany PFTBA (perfluorotributyloamina), którego potencjał w kontekście globalnego ocieplania jest aż 7 tys. razy większy niż w przypadku ditlenku węgla (Times 2013), nie podjęto żadnych działań zaradczych.

Postępująca degradacja biosfery i dalsze nadmierne zużywanie surowców naturalnych (i to nie tylko nośników energii). Zakres ludzkiej ingerencji w biosferę osiągnął już tak wysoki poziom, że niektórzy naukowcy postulują, aby uznać, że mamy obecnie do czynienia $\mathrm{z}$ zupełnie nowym etapem $\mathrm{w}$ dziejach naszej planety, który powinien zostać nazwany antropocenem (Steffen et al. 2015). Fatalną praktyką jest zachęcanie konsumentów do częstego kupowania coraz to nowych wersji popularnych urządzeń, takich jak np. telefony komórkowe. W rezultacie zasoby wielu pierwiastków są już praktycznie na wyczerpaniu. Przykładowo: światowe zasoby Indu będą dostępne jeszcze tylko przez ok. 10 lat. Tymczasem, jak wskazuje Thomas Graedel z Yale Uniwersytetu, „komputer zbudowany bez Indu miałby osiągi maszyny z lat 80" (Graedel i Klee 2002). Należy dodać, że nadmierne zużywanie surowców nie jest zjawiskiem odnoszącym się do wszystkich obszarów świata w jednakowy sposób. Na Północy 
mieszka ledwie 1/5 ludzkości, ale zużywa ona 70\% dostępnej energii, $75 \%$ metali i 85\% drewna. Zasoby te w zatrważającym stopniu są marnotrawione: amerykańskie szacunki wskazują, że 93\% surowców zużywanych w USA „nie jest przetwarzanych w towary handlowe. Poza tym $80 \%$ zasobów wyrobów gotowych wyrzucanych jest już po jednorazowym użyciu, a pozostałe nie są tak trwałe, jak powinny być" (Weizsacker et al. 1997). Do urządzeń wprowadza się nawet specjalne oprogramowanie, które ma wykazać szybsze zużycie. Podkreślić należy, że większość tych traconych surowców znajduje się na Południu, a ich pozyskiwanie jest przyczyną istotnej degradacji środowiska biedniejszych krajów.

Kryzys społeczny. W skali całego świata obszary biedy nie kurczą się, a nieustannie zwiększają. Pomiędzy 1973 a 1998 r. poziom konsumpcji w przeciętnym afrykańskim gospodarstwie domowym nie tylko nie zwiększył się, ale zmniejszył i to aż o 20\% (Clark 2007). Obecnie ponad miliard ludzi dysponuje dochodem nieprzekraczającym jednego dolara na dzień, a prawie trzy miliardy nie zarabiają więcej niż 2 dolary (Wise 2001). W krajach rozwijających się ok. 1 mld ludzi jest niedożywionych, każdego dnia umiera z głodu 25 tys. ludzi. Nadal $20 \%$ ludzkości cierpi na brak wody pitnej, a 40\% na brak urządzeń sanitarnych i elektrycznych (Steffen et al. 2015).

$\checkmark$ Dysproporcje pomiędzy bogatymi a biednymi uległy pogłębieniu wraz z postępowaniem procesów globalizacyjnych. Duże globalne korporacje przybrały charakter ponadnarodowy (postnarodowy, a poniekąd także antynarodowy), przez co osłabiły rolę, którą do tej pory odgrywały poszczególne państwa. Jeżeli przyjęte $\mathrm{w}$ danym kraju czy grupie krajów (nawet na poziomie UE) rozwiązania i strategie (płaszczyzny polityczna i prawna) są z ich punktu widzenia niekorzystne, to część aktywności przeniosą na teren innych państw, gdzie takie działania mogą być dopuszczalne (Ikerd 2005). Globalny charakter przyjęły także rynki finansowe. Związana jest $\mathrm{z}$ tym istotna przemiana: jeszcze niedawno kapitalizm opierał się na realnej produkcji towarów i usług. Dziś dominują spekulacje, które prowadzą do przejmowania ogrom- 
nych sum pieniędzy bez wytwarzania jakiejkolwiek wartości dodanej. Przykładowo, w 2010 r. wartość zawieranych codziennie transakcji finansowych sięgała 4 trylionów dolarów. Jednakże aż 98\% z nich nie było związanych z produkcją, ale ze spekulacjami finansowymi - to fortuny tworzone $z$ niczego (Lietaer et al. 2012).

Wzrost ilości konfliktów zbrojnych. Po działaniach wojennych w krajach arabskich, prowadzonych przez koalicję pod wodzą USA, kraje te zostały zrujnowane, zapanował chaos i zwiększył się poziom biedy. Zbiegło się to w czasie $\mathrm{z}$ wyżem demograficznym: na $900 \mathrm{mln}$ dzieci w krajach biednych przypada tylko 30 milionów ich rówieśników w krajach Europy i Ameryki. Brak możliwości zdobycia pracy i bieda skłaniają młodych ludzi ku radykalnemu islamowi i jest przyczyną niezwykle groźnego dla światowego pokoju tzw. Państwa Islamskiego.

Brak wspólnego stanowiska opinii międzynarodowej wobec nowych zjawisk, takich jak uchodźcy. W tak wielkiej masie ludzi przybywającej do Europy nie ma realnej możliwości ich weryfikacji, bez wątpienia jednak jest wśród nich wielu bojowników Państwa Islamskiego. Warto zaznaczyć, że to właśnie z tych przyczyn bogate kraje muzułmańskie, takie jak Arabia Saudyjska, nie przyjmują uchodźców, choć przecież ci też są muzułmanami. Niezbędne jest tu międzynarodowe porozumienie i podjęcie wspólnych działań (USA, Unia Europejska, Rosja), które pozwoliłyby wygasić istniejące konflikty zbrojne, w szczególności w Syrii. To jedyny sposób na powstrzymanie fali uchodźców.

Istnienie powyższych realnych wyzwań nie oznacza, że jesteśmy wobec nich bezsilni. Problemy zostały rozpoznane, teraz należy je rozwiązać.

\section{Podsumowanie}

Podejmując działania wobec wyzwań XXI w., musimy pamiętać o lekcjach z przeszłości - wiele cywilizacji przed nami upadło. Arnold Toybnee twierdził, że działo się tak z dwóch przyczyn: zbyt dużej koncentracji dóbr w rękach nielicznych oraz bierności elit, które nie reagowały na zmieniającą się sytuację aż do momentu, gdy nie było już od- 
wrotu (Toynbee 1929 i 1960). Jared Diamond (2008) dodaje zagrożenia wynikające $z$ degradacji środowiska. Wszystkie te trzy zjawiska obserwujemy we współczesnym zglobalizowanym świecie.

Przyszłość nie jest jednak jeszcze przesądzona. Wśród ważnych dokumentów podejmujących to zagadnienie w sposób szczególny należy wyróżnić encyklikę papieża Franciszka Laudato Si' (2015). Praktycznie w całości odnosi się ona do kwestii zagrożonego prawidłowego rozwoju człowieka. Ojciec Święty apeluje, byśmy - niezależnie od skali zagrożeń, których jesteśmy świadkami - pamiętali, że „wszystko może się zmienić", a istotną rolę w tej przemianie odegrać ma konsekwentne wdrażanie rozwoju zrównoważonego. Potężne korporacje reprezentują globalizację egoistyczną. Niezbędne jest wspieranie innej formy globalizacji, zwanej globalizacją inkluzywną, ekohumanistyczną, opartej na zasadzie dobra wspólnego (Annan 1997). Tylko wtedy rozwój zrównoważony stanie się rzeczywistością - dla dobra tak obecnych, jak i przyszłych pokoleń.

\section{Bibliografia:}

Annan, Kofi. 1997. Renewing the United Nations: A Programme for Reform. Nowy Jork: UNICEF.

Bruntdland, Gro Harlem. 1997. Interview for the Baltic University Network, Uppsala: Baltic University.

Burda, Katarzyna. 2014. Ginące języki. Newsweek, 2.12.2014.

Clark, Garrette. 2007. Evolution of the Global Sustainable Consumption and Production Policy and the United Nations Environment Programme's (UNEP) Supporting Activities. Journal of Cleaner Production, 15(6), 492-498.

Diamond, Jared. 2008. Collapse: How Societies Choose to Fail or Succeed. New York: Viking.

Franciszek. 2015. Encyklika "Laudato Si”".

Graedel, Thomas E. i Robert J. Klee. 2002. Getting Serious about Sustainability. Environmental Science \& Technology, 36(4), 523-529.

Haliniak, Marek. 2004. Zrównoważony rozwój a społeczeństwo informatyczne. W: Filozoficzne, społeczne i ekonomiczne uwarunkowania 
zrównoważonego rozwoju, red. Artur Pawłowski, 169-188. Lublin: Komitet Inżynierii Środowiska.

Ikerd, John E. 2005. Sustainable Capitalism a Matter of Common Sense. Bloomfield: Kumarin Press Inc.

Johnson, Donald J. 2002. Sustainable Development: Our Common Future. OECD Observer, 233(8). Dostęp: 20.02.2017. http://oecdobserver.org/news/archivestory.php/aid/780/Sustainable_development:_ Our_common_future.html.

Lietaer, Bernard et al. 2012. Money and Sustainablity. The Missing Link. Devon: Triarchy.

Pawłowski, Artur. 2008. Rozwój zrównoważony - idea, filozofia, praktyka. Lublin: Komitet Inżynierii Środowiska.

Pawłowski, Artur. 2009. The Sustainable Development Revolution. Problemy Ekorozwoju/ Problems of Sustainable Development, 4(1), 65-76.

Steffen, Will et al. 2015. The Trajectory of the Antrhopocene: The Great Acceleration. The Anthropocene Review, 2(1), 81-95.

ŚKŚR (Światowa Komisja ds. Środowiska i Rozwoju). 1991. Nasza wspólna przyszłość, tłum. Urszula Grzelońska i Ewa Kolanowska. Warszawa: Państwowe Wydawnictwo Ekonomiczne.

Times Live. 2013. Canadian researchers discover new greenhouse gas. Times, 11.12.2013.

Toynbee, Arnolod J. 1939, 1960. A Study of History. Oxford: Oxford University Press.

Unia Europejska. 2008. Pakiet energetyczno-klimatyczny. Bruksela: UE.

Unia Europejska. 2010. Europe 2020: A European Strategy for Smart, Sustainable, and Inclusive Growth. Bruksela: UE.

Wątroba, Wiesław. 2002. Społeczeństwo informacji w globalizacyjnym kontekście. W: Kapitał ludzki w procesie globalizacji a $w$ zrównoważonym rozwoju, red. Franciszek Piontek, 130-142. Wisła: Akademia Techniczno-Humanistyczna w Bielsku-Białej, Wyższa Szkoła Ekonomii i Administracji w Bytomiu. 
Weizsäcker, Ernst von, Amory B. Lovins i Hunter L. Lovins. 1997. Factor Four: Doubling Wealth, Halving Resource Use - The New Report to the Club of Rome. London: Earthscan.

Wise, Timothy A. 2001. Global Perspectives: The North/South Imbalance. Overview essay. W: A Survey of Sustainable Development. Social and Economic Dimensions. Frontier Issues in Economic Thought, red. Jonathan M. Harris et al., 79-90. Waszyngton-Covelo-Londyn: Island Press. 
Zbigniew Mirek

Instytut Botaniki im. W. Szafera Polskiej Akademii Nauk

z.mirek@botany.pl

Zbigniew Witkowski

Podhalańska Państwowa Wyższa Szkoła Zawodowa w Nowym Targu

zbigniew.witkowski@onet.eu

\section{Teoria i praktyka w ochronie przyrody - gdzie szukać zrównoważenia?}

\section{Wprowadzenie}

Rozwój naszej cywilizacji w ostatnich kilkudziesięciu latach został poddany narastającej krytyce (Meadows et al. 1973), a jej efektem było ukształtowanie się koncepcji rozwoju zrównoważonego. Wdrażanie tej koncepcji stało się jedną z dominujących sił kierunkowych (driving force) rozwiniętych ekonomicznie demokratycznych społeczeństw, a sama teoria rozwoju zrównoważonego stała się paradygmatem nauki i praktyki w takich dziedzinach jak nauki ekonomiczne, nauki społeczne i nauki środowiskowe. Zgodnie z nim wzrost ekonomiczny ma być związany ze wzrostem dobrostanu społeczeństw, sprawiedliwości wewnątrz- i międzypokoleniowej, a w dziedzinie środowiska służyć przynajmniej zachowaniu istniejących składowych środowiska (Ryc. 1.)

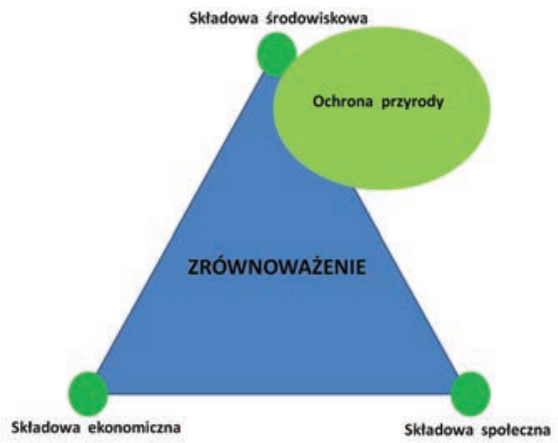

Ryc. 1. Trzy składowe rozwoju zrównoważonego. Rozwój taki zachodzi jedynie wówczas, kiedy jego składowe są zharmonizowane. Ochrona przyrody jest elementem składowej środowiskowej (opracowanie własne). 
Rozwój zrównoważony osiągnął najwyższy priorytet w polskim prawodawstwie. Jest wymieniany wśród zasad ustrojowych państwa, jako zasada najwyższej rangi (art. 5 Konstytucji RP) i zdefiniowany w art. 3 Ustawy Prawo Ochrony Środowiska z dnia 27 kwietnia 2001: „Zrównoważony rozwój to taki rozwój społeczno-gospodarczy, w którym następuje proces integrowania działań politycznych, gospodarczych i społecznych, z zachowaniem równowagi przyrodniczej oraz trwałości podstawowych procesów przyrodniczych, w celu zagwarantowania możliwości zaspokajania podstawowych potrzeb poszczególnych społeczności lub obywateli zarówno współczesnego pokolenia, jak i przyszłych pokoleń".

Jednym $\mathrm{z}$ istotnych elementów problematyki środowiskowej rozwoju zrównoważonego jest ochrona przyrody. Wśród 27 zasad przyjętych w trakcie obrad Szczytu Ziemi w Rio de Janeiro w 1992 r. dwie dotyczą ochrony zasobów przyrodniczych:

- niezbywalne prawo człowieka do korzystania ze środowiska i jego zasobów; ochrona środowiska dla przyszłych pokoleń;

- obowiązek ochrony ekosystemów i różnorodności biologicznej przez każde państwo.

Konwencje międzynarodowe, encykliki i wystąpienia papieskie (Franciszek 2015) w sprawach środowiska, a także dokumenty unijne i polskie prawodawstwo (Ustawa z dnia 16 kwietnia 2004 r. o ochronie przyrody. Dz.U. $2004 \mathrm{nr} 92$ poz. 880) nakierowane są na cele praktyczne skierowane głównie do ludzkości i podnoszenia jakości naszego środowiska. Tymczasem ugruntowana koncepcja ideologiczna ochrony przyrody (Soulé 1985), przekonania większości przyrodników i organizacji pozarządowych (Witkowska i Witkowski) skłaniają się ku tradycyjnemu przekonaniu, że „prawdziwa” ochrona wymaga odseparowania obiektu chronionego od działalności gospodarczej człowieka. Stanowiska takie są zarzewiem konfliktu, którego strony, stojąc na odległych pozycjach ideologicznych, nie mogą porozumieć się w kwestii realizacji celów praktycznych. Przejawem takiego konfliktu jest między innymi spór o sposób ochrony Puszczy Białowieskiej (Bobiec et al. 2016; Weiner 2016). 
Celem naszym jest prezentacja trzech głównych i aktualnych obecnie podejść $\mathrm{w}$ teorii ochrony przyrody $\mathrm{z}$ uwzględnieniem dwóch przeciwstawnych stanowisk reprezentowanych przez Michaela Soulé i Petera Kareiva oraz trzeciego, w pewnym sensie integrującego logikę tamtych dwu (Mirek 1991, 1997, 2000a, 2000b, 2000c, 2001). Artykuł opiera się na kilku modułach:

1. W pierwszym zwracamy uwagę na najważniejsze kryterium rozwoju zrównoważonego, którym powinno być poszanowanie bioróżnorodności (Mirek 2001). Międzynarodowa Konwencja o Bioróżnorodności, która także odwołuje się do kategorii rozwoju zrównoważonego, stawia przed nasze oczy bioróżnorodność, nie tylko jako paradygmat ochrony przyrody, ale też jako taką czyni ją (nolens volens) miernikiem owego zrównoważenia (Mirek 2001, 2002a, 2000b), które obejmuje relacje: człowiek - przyroda, człowiek - człowiek poprzez przyrodę (zarówno wewnątrzpokoleniowo, jak i międzypokoleniowo).

2. Rozważamy, w kontekście przywołanego powyżej kryterium, trzy różne modele relacji człowiek - przyroda rozpiętej pomiędzy ekonomiczną eksploatacją (użytkowaniem) a ochroną przyrody.

3. Pokazujemy, jak owe trzy modele uzależnione są od postrzegania człowieka i przyrody w kontekście relacji Bóg - człowiek - przyroda. Dwa pierwsze próbują się obejść bez odniesienia relacji człowiek przyroda do autorytetu Boga; trzeci, oparty na tradycji chrześcijańskiej stanowiącej korzenie kultury zachodniej, sięga do wszystkich trzech składowych relacji.

\section{Dlaczego chronimy przyrodę?}

\section{Koncepcja biocentryczna M. Soulé}

Idea ochrony przyrody i związane z nią działania praktyczne mają już ponad 150 lat. Tymczasem dziedzina ta jako nowoczesna dyscyplina naukowa powstała stosunkowo niedawno. Dopiero powstanie w $1980 \mathrm{r}$. Światowej Strategii Ochrony Przyrody (IUCN-UNEP-WWF 1980) i opublikowanie opiniotwórczego podręcznika przez Soulé i Wilcoxa (Conservation biology: An evolutionary-ecological perspective 1980), spowodowało gwałtowny rozwój tej dyscypliny naukowej, a włączenie 
do jej problematyki zagadnień genetyki populacyjnej doprowadziło do powstania wielu wysoko impaktowych czasopism takich jak Biological Conservation w Europie i Conservation Biology w USA.

Okazało się niebawem, że rozumiemy ochronę przyrody bardzo różnie, co jest stałym powodem konfliktów, w tym także dzisiejszego konfliktu o Puszczę Białowieską. Otóż w ochronie przyrody lansowane są dwie istotnie różniące się między sobą koncepcje ideowe. Autorem pierwszej z nich był wybitny amerykański biolog Michael Soulé, który opublikował $\mathrm{w}$ BioScience słynny manifest pt. What is conservation biology. W artykule tym podał zasady funkcjonalne ochrony przyrody i jej podstawy normatywne (etyczne). Nowo powstałą dziedzinę wiedzy (CB - conservation biology) opisał jako „dyscyplinę kryzysową", naukę, która ratuje przyrodę, podobnie jak biologia raka ratuje życie ludzi. Dziedzina ta, w odróżnieniu od innych gałęzi biologii jest nauką holistyczną, a badacze według autora manifestu powinni kierować się następującymi zasadami funkcjonalnymi:

1. Większość gatunków to "producenci” zjawisk i procesów ewolucyjnych. Postulat ten przyjmuje, że systemy naturalne, ustabilizowane, będą działały inaczej od tych, które są pod wpływem działań człowieka. Kolejnym funkcjonalnym postulatem jest zwrócenie uwagi na skalę procesów.

2. W wielu ekologicznych procesach (być może wszystkich) występuja zjawiska progowe, poniżej lub powyżej których może dojść do naglych chaotycznych zmian lub zatrzymania dotychczasowych procesów. Dzieje się tak wówczas, kiedy system jest zbyt mały lub zbyt duży. Innymi słowy, procesy ekologiczne mieszczą się w średnim przedziale skali procesów w czasie i przestrzeni. Takich zjawisk i procesów nie obserwujemy w zbyt dużych lub zbyt starych systemach ekologicznych. Powodzie czy wybuchy wulkanów nie należą do sfery zjawisk ekologicznych. Podobnie w zbyt małych przestrzennie fragmentach ekosystemu niektóre zjawiska (np. sukcesji) mogą ulec zahamowaniu.

\section{Genetyczne i demograficzne procesy mają próg, poniżej którego zjawiska} i procesy losowe przeważają nad deterministycznymi i adaptacyjnymi. Wynika z tego postulat funkcjonalny, że prawdopodobieństwo przeżycia populacji zależy od jej rozmiarów. 
4. Rezerwaty przyrody sa $w$ chronicznym stanie nierównowagi (zagrożenia) w przypadku gatunków rzadkich i gatunków o dużych rozmiarach ciała. Dotyczy to szczególnie niewielkich wysp (środowiskowych), gdzie - jak w przypadku rezerwatów - zbyt małe populacje wielu gatunków muszą być sztucznie zasilane z powodu zagrożenia ekstynkcją (Conservation biology: An evolutionary-ecological perspective 1980).

Idee prezentowane przez Soulé wyrażają się explicité w jego postulatach normatywnych. Autor mówi o wartościach, przy czym opiera się o dorobek głębokiej ekologii (ekozofii) A. Naessa.

\section{Oto 4 postulaty etyczne M. Soulé:}

\section{Różnorodność organizmów jest dobra (dobrem).}

Jeżeli przyjmujemy ten postulat, staje się on częścią naszej filozofii. Konsekwencją tego postulatu jest stwierdzenie, że ekstynkcja gatunku i populacji jest złem. Postulat ten nie dotyczy naturalnych ekstynkcji, które w skali życia człowieka są niezwykle rzadkie.

\section{Ekologiczna złożoność jest dobrem.}

Ten postulat odnosi się do złożoności ekosystemu i komplikacji procesów ekologicznych. Autor wyraźnie odróżnia złożoność systemów ekologicznych tworzonych przez człowieka, np. w miastach, od postulowanej złożoności ekosystemów naturalnych.

\section{Ewolucja jest dobrem.}

Jeżeli zakładamy, że życie jest dobrem, to jak możemy zachować neutralność wobec procesów ewolucji? Jedynym sposobem na wsparcie tego postulatu jest, według autora, zachowanie naturalnych procesów ewolucyjnych w tak wielu siedliskach, jak to jest możliwe.

4. Różnorodność biologiczna ma swoją wartość wewnętrzna, niezależnie od jej wartości użytkowej.

Ten postulat normatywny należy uznać za podstawowy. Tu właśnie autor pokazuje, czym różni się podejście ideowe do ochrony przyrody od spojrzenia utylitarnego. W tym względzie nawiązuje, nieświa- 
domie zresztą (podobnie jak i Naess), do wcześniejszej o parędziesiąt lat konstatacji Jana Gwalberta Pawlikowskiego (1938).

\section{Koncepcja antropocentryczna P. Kareiva i M. Marvier}

Mimo wielu oznak, że ludzkość idzie w innym kierunku i poprzez koncepcję rozwoju zrównoważonego narzuca niejako nadrzędność rozwiązań utylitarnych nad ideowymi także w ochronie przyrody, dopiero w 2012 roku ukazała się, również w BioScience, polemika z koncepcjami M. Soulé. Autorami tej koncepcji byli nie mniej wybitni naukowcy P. Kareiva i M. Marvier, którzy manifest nazwali What is conservation science?

Współcześnie człowiek dominuje w środowisku i nie da się oddzielić dobra innych gatunków od dobra człowieka - deklarują autorzy. Conservation Science (CS) zajmuje się nie tyko bioróżnorodnością i dynamiką układów przyrodniczych, ale też dynamiką społeczną i wzajemnym odnoszeniem się obu systemów i procesów. Nauka ta jest nadal dyscypliną kryzysową (jak u Soulé), ale opiera się na lepszym rozeznaniu rzeczywistości i wynikającym z postępu technologii nagromadzeniu dotychczasowej wiedzy. Dzięki tej wiedzy planowanie działań ochroniarskich jest oparte o wybór celu i strategii działań.

Podstawowym błędem biocentrycznej koncepcji Soulé było uproszczenie dotyczące roli ludzi w odniesieniu do bioróżnorodności. Zdecydowana większość naszej populacji, według niego, to ludzie zagrażający przyrodzie, nikła mniejszość, głównie „zachodni” biolodzy, stara się chronić i zapobiegać szkodom. Autorzy CS widzą to znacznie szerzej. Po pierwsze ochrona jest ekspresją wartości wyznawanych przez ludzi. Ludzkie stanowiska i racje są nakierowane na kształtowanie świata dla przyszłych pokoleń. Z punktu widzenia psychologii i etyki, rozpoznanie ludzkich działań i postaw w odniesieniu do przyrody ma kluczowe znaczenie dla jej ochrony. Jest to jednak wymiar do dziś skrajnie zaniedbany w CB.

Po drugie, różnorodność nie jest jedynym celem działań ochroniarskich. Ludzkie życie i utrzymanie (środki do życia) też są z tymi działaniami powiązane. Autorzy wskazują przypadki, kiedy działania ochroniarskie naruszają warunki ekonomiczne i dobrostan ludzi, a tworzenie obszarów chronionych powoduje pogorszenie ich sytuacji społecznej i ekonomicznej. Oczywiście większość populacji ludzkiej korzysta z po- 
wstania obszarów chronionych, ale są także i tacy, którzy ewidentnie tracą. Stąd relacje i powiązania między społecznościami lokalnymi a zarządzającymi obszarami chronionymi wymagają większej uwagi w tworzeniu i gospodarowaniu na tych obszarach. Idea CB eksponująca przede wszystkim ochronę przyrody prowadzi do złej diagnozy i w konsekwencji do niewłaściwych, konfliktowych rozwiązań. Współczesna CS musi, obok nauk biologicznych, korzystać także z wiedzy społecznej, zarządzania biznesowego, antropologii, polityki i wielu innych dziedzin wiedzy humanistycznej.

Dla rodzącej się dyscypliny CB Soulé wskazał 4 główne postulaty funkcjonalne, które nie straciły na aktualności, mimo iż degradacja obszarów i gatunków chronionych ma miejsce na całym świecie. Według autorów nowej strategii (CS) jedynym sposobem poprawy sytuacji jest wprowadzenie lokalnych społeczności do strategii ochrony i szersze objęcie uwagą obszarów leżących poza terenem chronionym. Odnosząc się do koncepcji Soulé, autorzy (Kareiva i Marvier 2012) CS pokazują, jak istotnie zmienił się kontekst środowiskowy, społeczny i gospodarczy, w którym obecnie operuje ochrona przyrody.

W ciągu jednej generacji ludzka populacja wzrosła o 40\% (od 1985). Znaczna część tego wzrostu odbywała się na obszarach o wysokiej bioróżnorodności. Już tylko ten fakt pokazuje, jak trudno będzie pogodzić potrzeby rosnącej populacji z potrzebą ochrony bioróżnorodności. W tym 25-leciu (od 1985) wzrosła znacząco konsumpcja energii, wzrosła też koncentracja dwutlenku węgla w atmosferze, co przełożyło się na ok. $0,5^{\circ} \mathrm{C}$ wzrostu średniej temperatury na planecie. W tym czasie wzrosła też powierzchnia przekształconych ekosystemów. Obecnie ponad $40 \%$ to ekosystemy pastwisk i upraw związanych z wyżywieniem ludzi.

W tym czasie zaszły też pozytywne zmiany. Od 1985 powierzchnia chroniona wzrosła z $6,5 \mathrm{mln} \mathrm{km}^{2}$ do ponad $16 \mathrm{mln} \mathrm{km}^{2}$. W tym samym czasie morskie obszary chronione wzrosły z mniej niż $1 \mathrm{mln} \mathrm{km}^{2}$ do ponad $8,1 \mathrm{~km}^{2}$. To prawdziwy sukces, ale wzrost powierzchni chronionej sam w sobie nie zapewni odwrócenia negatywnych tendencji w degradacji bioróżnorodności w obliczu wzrastającej presji człowieka, tym bardziej, że społeczeństwa i politycy odwracają się od wsparcia ochrony bioróżnorodności. Jak wykazały badania Instytutu Gallupa, jeszcze w 1984 r. większość respondentów wybierała priorytet środowiska nad 
ekonomią. W 2004 r. znacznie podniósł się wskaźnik poparcia dla ekonomii (1984 - 61\% za ochroną środowiska kosztem ekonomii, w 2011 deklarowało tak tylko 26\%).

Kolejnym problemem jest zmiana zachowań dzieci i młodzieży, z których większość żyje już w miastach. Osoby te mają mniejszy kontakt z przyrodą, a dodatkowym czynnikiem oddalającym młodzież od przyrody jest atrakcyjność Internetu i gier komputerowych. Zmniejszenie zainteresowana dzieci i młodzieży przyrodą powoduje mniejszy nacisk na liczbę wydawnictw zajmujących się tym zagadnieniem.

W dyskusji z koncepcją Soulé, Kareiva i Marvier proponują własne postulaty, które należy traktować raczej jako wskazania dla praktyki działań w ochronie przyrody niż ogólne wytyczne o charakterze normatywnym.

1. Nie ma obecnie naturalnych systemów. Badania planety wykazały, że nie ma takiego miejsca, gdzie nie udokumentowano naszej obecności. Obecny okres dziejów Ziemi nazwany został antropocenem (Stoner i Melathopoulos 2015), gdzie nasze działania w wielu sferach środowiska przewyższają działania wszystkich innych gatunków. Oczywiście w historii ludzie mieli także zadziwiająco duży wpływ na środowisko i przyrodę, jednak obecnie jest on najsilniejszy i niesie z sobą wielkie konsekwencje, stąd nie może już być ignorowany w ochronie przyrody.

2. Zachodnia cywilizacja zaproponowała obszary chronione wolne od wpływu człowieka, z których mieszkańców po prostu wysiedlano i wykluczano z procesów decyzyjnych. Decyzje te okazały się społecznie niesprawiedliwe i naukowo błędne. Chociaż obszary te spełniają swoją rolę, jednak przyszłość ochrony należy do obszarów użytkowanych przez człowieka. Wobec zmian klimatu i inwazji gatunków introdukowanych, także te naturalne obszary wymagają interwencji dla utrzymania istniejącego systemu lub założonych celów ochrony.

3. Los człowieka i dzikiej przyrody jest powiązany i zależy od tych samych czynników, takich jak czyste powietrze, czysta woda oraz zasoby żywności i schronienie. Wiele czynników szkodzących dobrostanowi człowieka szkodzi także dzikiej przyrodzie.

4. Ekosystemy, od których zależy nasza woda, żywność i lekarstwa, to 
także te ekosystemy, w których żyją inne gatunki. Ochrona przyrody to $\mathrm{z}$ jednej strony ochrona wartości wewnętrznej systemów biologicznych, $\mathrm{z}$ drugiej jednak - także ochrona tych wartości, które podtrzymują nasze życie i dobrostan. Populacja ludzka, podobnie jak cała przyroda, znajduje się na znacznie podwyższonym poziomie ryzyka.

5. Przyroda jest zadziwiająco odporna. Jednak nie oznacza to, że ekosystem się odtworzy bez usunięcia presji człowieka ani też że wszystkie ekosystemy są równie odporne.

6. Dzisiaj nie można już dłużej rozpowszechniać hasła „myśl lokalnie - działaj globalnie", bo nasze wysiłki lokalne w ochronie przyrody mogą być zniweczone przez globalne trendy, takie jak zmiany klimatu, zanieczyszczenia, wycinanie lasów pod uprawy czy międzynarodowy handel i jego wpływ na rozprzestrzenianie się gatunków inwazyjnych, czy też polowania w Afryce i zapotrzebowanie na rogi nosorożca w Chinach. Dlatego też ochroniarze powinni być równie silnie zainteresowani postanowieniami Światowej Organizacji Handlu (WTO), jak i stanowieniem nowych obszarów chronionych.

Kareiva i Marvier odchodzą od formułowania postulatów normatywnych. Dążą do pokazania tych działań, które ich zdaniem pozwolą na osiągnięcie sukcesu w ochronie przyrody.

1. Ochrona przyrody musi być wprowadzana w krajobrazie zmienionym przez człowieka. Pragnienie osiągnięcia sukcesu w naturalnych ekosystemach staje się coraz bardziej nierealistyczne. Obecnie mamy do czynienia ze stale przekształcanymi ekosystemami i krajobrazami (zmiany klimatu, obce gatunki itp.) Ochroniarze muszą zrozumieć, że ludzie są częścią systemów biologicznych i mogą żyć też w dzikich puszczach. W takich miejscach ochrona powinna obejmować zarówno ludzi jak i bioróżnorodność. Lokalne społeczności starają się chronić dobra, które użytkują, co jest korzystne dla strategii CS. Ochrona potrzebuje komplementarnych strategii łączących ochronę ekosystemów i gatunków z zabezpieczeniem potrzeb ludzi, którzy tam żyją, zbierają plony i polują. 
2. Ochrona przyrody osiągnie długotrwały sukces tylko wówczas, kiedy społeczeństwa wesprą cele ochrony. Eksperci i praktycy działający w ochronie przyrody powinni wyjść poza swoje tradycyjne działania i zainteresować się też rozwojem ekonomicznym, ubóstwem, brakiem pracy i prawami środowiskowymi.

3. Eksperci i praktycy ochrony przyrody muszą współpracować z wielkimi korporacjami. Niewielka liczba korporacji ma ogromne możliwości pozyskiwania zasobów, produkcji żywności, przekształcania krajobrazu itp. Korporacje to „kluczowe gatunki” w globalnym ekosystemie. Celem współpracy z korporacjami jest poprawa ich dotychczasowych działań i przyzwyczajeń.

4. Tylko wspólne działania ochroniarskie i ekonomiczne pozwalają odnieść sukces. Nauka zajmująca się ochroną przyrody powinna rozwijać to zagadnienie.

5. Ostatecznie w działaniach na rzecz ochrony przyrody nie powinno się nadużywać zaufania, szczególnie w odniesieniu do lokalnych społeczności. Te ostatnie w obliczu surowych zakazów i braku środków ekonomicznych stają się bezradne wobec decyzji polityków. Ludzie mają prawo decydowania o swoim losie, podobnie jak powinni decydować o przestrzeni i wodzie, od których zależą. To jest nie tylko słuszne moralnie, ale też przyniesie lepszy efekt ochroniarski niż decyzje odgórne bez oglądania się na lokalnych mieszkańców.

Ochrona przyrody jest reaktywna, defensywna i jej zadaniem jest zmniejszanie ubytków różnorodności i utrzymania jej taką, jaka kiedyś była. Ochrona pociąga za sobą wielki projekt odtwarzania, a ich (Kareiva i Marvier) ambicją jest tworzenie tak wielu obszarów chronionych, jak to jest możliwe. Ich wizja ochrony to osiąganie równowagi między rozwojem człowieka a ochroną bioróżnorodności.

Współcześnie zatem musimy łączyć w ochronie przyrody postulaty koncepcji biocentrycznej, gdzie celem działań jest utrzymanie warunków do realizacji wartości wewnętrznych gatunków i ekosystemów, ze 
stanowiskiem antropocentrycznym, gdzie realizacja potrzeb wewnętrznych ekosystemów i gatunków odbywa się niejako „przy okazji” realizacji potrzeb naszej ludzkiej populacji. Biosfera jest jedna, potrzeby w znacznym stopniu spotykają się. W praktyce jednak potrzeby naszej populacji są zaspokajane kosztem potrzeb innych gatunków. Mimo szybkiego wzrostu powierzchni obszarów chronionych na Ziemi, proces przyspieszonego wymierania gatunków i degradacji struktury biologicznej systemów żywych nadal postępuje. Co prawda, widzimy już objawy spowalniania tego procesu, jednak daleko jeszcze do tego, aby uznać, iż przyroda żywa znajduje się w dynamicznej równowadze.

\section{Koncepcja teocentryczna}

Trzecia koncepcja, która pozwala zbudować platformę konsyliacyjną dla obu wymienionych wyżej skrajnych podejść, zbudowana jest na obiektywnej prawdzie dwu ksiąg: Księgi Natury i Księgi Pisma. Jest to prawda ukazująca realizm relacji, jakie panują w trójkącie Bóg - człowiek - przyroda. Co istotne, są to relacje zwrotne i wewnętrznie niesprzeczne. Centralną wartością tych relacji jest szeroko rozumiane życie (zarówno człowieka, jak i przyrody) i jego obiektywne dobro (jego dobro-byt).

W przeciwieństwie do obu poprzednich, skrajnych koncepcji, jednej antropo-, a drugiej biocentrycznej, ta jest w pewnym sensie, antropoi biocentryczna równocześnie. Będąc ze swej istoty teocentryczna, ukazuje jednak wyraźnie, że ów teocentryzm uwzględnia najlepiej rozumiany interes człowieka, co czyni tę koncepcję sui generis antropocentryczną. Analogicznie, uwzględnia ona także autentyczne dobro pozostałych form życia, co czyni ją na swój sposób biocentryczną. Można bowiem powiedzieć, że Bóg w swoim stwórczym zamyśle „od początku” (Rdz 1; J 1) miał na uwadze prawdziwe dobro wszystkich bytów, wszystkich form życia, jakie powołał do istnienia, a więc i dobro człowieka, i dobro przyrody. Wzywając człowieka do panowania nad resztą stworzenia (Rdz 1), Bóg rozumiał jednak owo panowanie, w przeciwieństwie do niektórych scjentystycznych egzegetów (White 1967), jako służbę „W sprawiedliwości i prawości serca" (Mdr 9,1-5); rozumiał je przede wszystkim jako troskę o dzieło stworzenia powierzone odtąd pieczy człowieka mającego uczestniczyć w kontynuacji stwórczego zamysłu Boga - nie w bezwzględnej eksploatacji Ziemi. Istotą tego panowania od strony pozytywnej jest zatem 
miłość, tożsama z autentyczną troską o obiektywne dobro każdego bytu.

Równocześnie, ów stosunek miłości człowieka do reszty stworzenia jest warunkiem sine qua non i niejako tożsamym z troską człowieka o wewnętrzny stan ludzkiego serca oraz o jego zewnętrzne przejawy wyrażone w czynach. Tak rozumiana relacja - ze względu na istniejące więzi miedzy człowiekiem a jego środowiskiem przyrodniczym, stanowiącym dlań obiektywne dobro, jest także od innej strony - dobrem człowieka, zarówno w sensie bezpośrednim (chroni stan jego serca środowisko wewnętrzne), jak i pośrednim (chroni środowisko przyrodnicze, w którym człowiek żyje i którego część stanowi). Tak ujęta relacja człowieka do stworzenia buduje także, pośrednio, kształt relacji między człowiekiem a człowiekiem (via środowisko) oraz między człowiekiem a Bogiem (via środowisko).

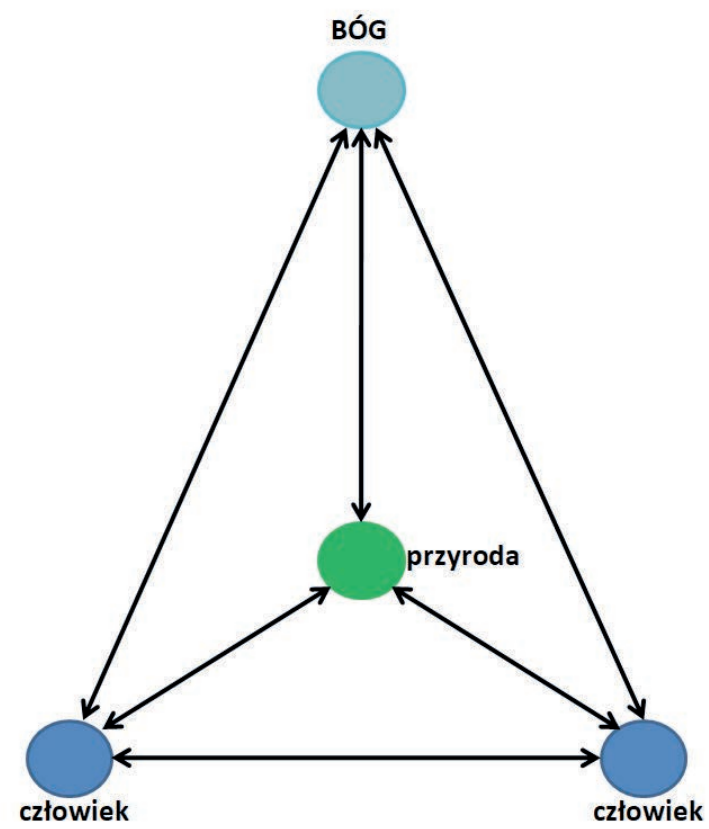

Ryc. 2. Relacja człowiek - środowisko przyrodnicze odniesiona do chrześcijańskiego pojęcia Boga-Stwórcy. 
Ze względu na ich charakter wertykalny (odniesienie do Boga) relacje, o których mowa (ryc. 2), są niesterowalne zewnętrznie poprzez nakazy i zakazy formalno-prawne, mechanizmy ekonomiczne czy struktury organizacyjne. Są one bardzo ważną, co prawda, ale zawsze tylko pomocą $\mathrm{w}$ tworzeniu tego typu relacji. Istotowo bowiem relacje te domagają się uwewnętrznionego, niejako na poziomie serca/sumienia, systemu wartości harmonizujących - w ramach dobra wspólnego - autentyczne dobro wszystkich trzech „uczestników” owej relacji (Bóg - człowiek - przyroda).

Na wagę tego uwewnętrznienia wartości (w procesie formacji sumienia) zwrócił uwagę jeszcze w połowie lat 70. ubiegłego wieku montrealski zespół GAMMA (Zieliński 2008) w swojej koncepcji wzrostu zerowego - poprzedniczce koncepcji rozwoju zrównoważonego. Zwracał na to uwagę już parędziesiąt lat wcześniej Jan Gwalbert Pawlikowski, który pisał: „(...) idea ochrony przyrody ma z etyką dużo podobieństw (...). Nie jest to gałąź wiedzy albo rzecz zawodu, ale jest to norma postępowania, która powinna być normą ogólną (...)" i jako taka „do każdej potrawy (czyt. każdej ludzkiej działalności) dodaną być powinna”; „(...) rozszerza ona pojęcia obowiązku i odpowiedzialności, tudzież uczucie solidarności i miłości także poza sferę stosunków z ludźmi, na całe - jak je nazywa A. Mickiewicz - «królestwo nieme»" (Pawlikowski 1938).

Francuski ekolog i ornitolog Jean Dorst (1924-2001), komentując współczesne nadzieje na uratowanie przyrody przy pomocy środków technicznych czy regulacji prawnych, również podkreślał wagę tego uwewnętrznienia: „Niech się nikomu nie zdaje, że dla zachowania ludzkości wystarczy walczyć z zanieczyszczeniami, lepiej gospodarować zasobami Ziemi i powstrzymać mnożenie się szkodliwych obszarów działalności ludzkiej! Kiedy choroba tkwi w sercu pacjenta, lekarz nie uleczy go nakładając na rany maści, które w takiej chwili pełniłyby tylko funkcję placebo”. I dodawał: „Przyczyny naszych nieszczęść tkwią w naszych duszach. I tam też znajdują się powody nadziei, że staniemy się wreszcie prawdziwymi ludźmi”. Dorst w ten, może nie najbardziej precyzyjny sposób, mówi, że źródłem kryzysu środowiskowego jest kryzys etyczny, a problem tkwi na poziomie ludzkiego sumienia (tu ogólnie określanego mianem duszy). „Proces uczłowieczenia może posuwać się dalej tylko pod warunkiem, że poczujemy się w pełni solidarni ze światem żywym, 
z tą ziemią" (Dorst 1979). Podobnie widział przyczyny obecnego kryzysu środowiskowego Th. S. Derr (1974) „nauka i technika nie zdołają sprostać temu wyzwaniu [którym jest przezwyciężenie obecnego kryzysu ekologicznego], a rozwiązań trzeba szukać w sferze moralności i teologii”.

Z końcem lat 40. ubiegłego stulecia, także Aldo Leopold przenosił istotę zagrożenia na poziom sumienia, które nie bez powodu nazywał sumieniem ekologicznym (Aleksandrowicz 1979). Etyczny wymiar problemów związanych z zagrożeniami środowiska papież Jan Paweł II ujął bardzo lapidarnie: „kryzys ekologiczny jest przede wszystkim kryzysem moralnym" (Jan Paweł II 1989); wskazał tym samym na pierwotne przyczyny i źródło kryzysu. Kościół katolicki wielokrotnie, od początku lat 70. ubiegłego wieku, zabierał głos w sprawie kryzysu ekologicznego, o czym wspomina papież Franciszek w punktach 4-6 swojej najnowszej encykliki Laudato Si'. W tym ostatnim dokumencie Papież - wzorem swych poprzedników - z mocą podkreśla, że degradacja środowiska przyrodniczego ma swe pierwotne przyczyny w degradacji etycznej i kulturowej człowieka. Omawiana koncepcja teocentryczna, zbudowana na myśli chrześcijańskiej, stanowi - jeśli nie w praktyce, to z pewnością w warstwie ideowej - rdzeń zachodniej cywilizacji. Odwołuje się ona do cnoty umiarkowania, zbudowanej w istocie na właściwie rozumianej miłości wpisanej w wolę Boga. Wzorem dla człowieka, w jego relacji ze światem, jest relacja Boga do człowieka i Boga do reszty stworzenia. Wydobądźmy zatem podstawowe rysy tej relacji:

1. Przyroda jest stworzeniem - własnością Boga-Stwórcy, przedmiotem Jego miłości wpisanym w szerszy sens stworzenia; zarazem elementem odkupienia wpisanego w ów stwórczy zamysł.

2. Przyroda oddana jest panowaniu człowieka wezwanego przez samego Boga, by w Jego imieniu „rządy sprawował” nad całością stworzenia, uczestnicząc w stwórczym zamyśle Stwórcy. Charakterystyki tego panowania są znane: człowiek ma to czynić zgodnie z zamysłem, a więc i wolą Boga.

3. Miarą relacji człowieka do stworzenia jest zatem miłość do Boga i szacunek wobec Jego zamierzeń. Jeśli tak, to dobro człowieka wpi- 
sane jest w podwójnym, bezpośrednim i pośrednim, sensie w autentyczne dobro stworzenia. Panowanie zatem człowieka, które to dobro narusza, godzi (bezpośrednio i pośrednio) w panującego. Owo zrównoważenie w relacji człowiek - przyroda, eksploatacja - ochrona, opisane jest relacją miłości, a więc autentycznym dobrem każdego (Boga, człowieka i przyrody); dobrem indywidualnym harmonijnie połączonym z kategorią dobra wspólnego.

\section{Uwagi końcowe i wnioski}

1. Koncepcja rozwoju zrównoważonego zakłada, że ochrona przyrody jest składową elementu środowiskowego. Koncepcja ta w odniesieniu do biosfery eksponuje stanowisko antropocentryczne, czyli ochronę życia na Ziemi dla podtrzymania i poprawy dobrostanu populacji ludzkiej. Ochrona pozostałych form życia, aczkolwiek bardzo wyraźnie zaznaczona, uwzględniana jest jednak przede wszystkim ze względu na dobrostan środowiska jako całości, w tym dobro samego człowieka, a nie jako wartość sama w sobie. Stąd podejście takie może być traktowane jako „umiarkowany antropocentryzm”.

2. We współczesnej ochronie przyrody antropocentryczna koncepcja jest nadal silnie kontestowana, zwłaszcza przez przyrodników. Twórca koncepcji biocentrycznej M. Soulé pisze, iż „Różnorodność biologiczna ma swoją wartość wewnętrzną, niezależnie od jej wartości użytkowej”. Dlatego zagrożone gatunki i ekosystemy powinniśmy chronić bez oglądania się na potrzeby człowieka, a nawet niekiedy eliminując ludzi z obszarów poddanych ochronie. Tych ważnych konstatacji dotyczących sfery wartości nie odnosi jednak do żadnych systemów filozoficznych, etycznych czy religijnych.

3. Koncepcja przeciwstawna, antropocentryczna, zaprezentowana przez P. Kareiva i M. Marvier, wskazuje, że skuteczna ochrona przyrody powinna polegać na ochronie dóbr i usług świadczonych nam przez gatunki i ekosystemy ziemskiej biosfery. Chroniąc nasze potrzeby, chronimy także potrzeby innych gatunków. W ochronie przyrody nie można już pomijać potrzeb człowieka, a tym bardziej wysiedlać 
lokalnych mieszkańców z obszarów poddanych ochronie. Autorzy ci sugerują też podjęcie przez przyrodników współpracy z dużymi korporacjami, zamiast podejmowania walki z nimi. Także i ta koncepcja nie jest oparta na żadnym stabilnym i spójnym systemie wartości.

4. Jeżeli poważnie potraktować tę trzecią koncepcję odwołującą się do kulturowych podstaw zachodniej cywilizacji i uwzględnić konstatacje obiektywnych ekspertyz (zespół GAMMA), to trzeba zauważyć, że zdefiniowany w naszej Konstytucji i przez nią wymagany rozwój zrównoważony staje się postulatem nierealnym do osiągnięcia w praktyce. Zbliżenie bowiem do tego, wyznaczonego przez miłość, wspólnego dobra wpisanego w tak ujmowany rozwój zrównoważony nie jest na miarę człowieka (Homo sapiens) definiowanego jako byt wyłącznie biologiczny i behawioralny. Ono - skoro przychodzi poprzez sumienie - jest wyzwaniem na miarę Imago Dei. Ten wszakże model (ryc. 2) jest obecnie eliminowany konsekwentnie zarówno przez prawodawstwo jak i edukację czy formację duchową z przestrzeni życia publicznego w Europie (w szczególności Zachodniej). Księga Pisma nie zostawia złudzeń co do tego, na ile możliwe jest przywrócenie, w warunkach doczesności, autentycznego wzrostu zerowego opartego na miłości, sprawiedliwości wewnątrz- i międzypokoleniowej (warunek sine qua non rozwoju zrównoważonego). O realnych możliwościach tworzenia owego modelu najlepiej mówią światowe trendy cywilizacyjne, obserwowane od tamtego czasu, tzn. lat siedemdziesiątych ubiegłego stulecia. Także politycy nadal nie mówią każdego dnia o niczym innym, jak tylko o rosnącym wskaźniku wzrostu gospodarczego w miejsce tzw. wzrostu zerowego jako o rzeczy najważniejszej pod słońcem. Do realizacji takiego priorytetu nie jest potrzebny Imago Dei; wręcz przeciwnie, najlepiej służy mu lansowany, behawioralnie opisany Homo sapiens ubrany w strój idioty konsumpcyjnego. Wystarczy także zapytać, co od czasu prac zespołu GAMMA (1976) i Raportu Brundtland oraz podpisania Konwencji o Bioróżnorodności (1992) stało się w przestrzeni publicznej z kluczowymi miernikami rozwoju zrównoważonego: bioróżnorodnością i sumieniem. Odpowiedź narzuca się sama, skoro 
wiemy, w jakim tempie nadal przebiega ekstynkcja gatunków oraz jak dalece relatywizowana jest przestrzeń fundamentalnych wartości budujących w szerszej przestrzeni publicznej dobro wspólne.

5. Światowy spór dotyczący ideowych pryncypiów ochrony przyrody od dawna powraca w Polsce przy różnych okazjach. Ostatnio jednak rozgorzał ze zdwojoną siłą na kanwie dyskusji (często bardziej politycznych niż merytorycznych) dotyczących zakresu ochrony przyrody w gospodarczej części Puszczy Białowieskiej. Tę kwestię rozważamy w odrębnym tekście (Mirek i Witkowski 2017), odwołując się do analizowanych powyżej podejść do ochrony przyrody oraz do koncepcji rezerwatu biosfery - modelowego rozwiązania ochrony obszarowej wypracowanego w ramach rozwoju zrównoważonego.

\section{Bibliografia:}

Aleksandrowicz, Julian. 1979. Sumienie ekologiczne. Warszawa: Wiedza Powszechna.

Bibliografia Puszczy Białowieskiej. Dostęp: 20.01.2017. http://bpn.com. pl/index.php?option=com_content\&task=view\&id=101\&Itemid=177.

Bobiec, Andrzej et al. 2016. Dlaczego martwe świerki sa potrzebne w Puszczy Białowieskiej. Dostęp: 10.09.2016. http://kochampuszcze.pl/ PuszczaBialowieska_list_Naukowcow.pdf.

Conservation biology: An evolutionary-ecological perspective, red. Michael E. Soulé i Bruce A. Wilcox. 1980. Sunderland: Sinauer Assoc.

Derr, Thomas S. 1974. Ecologie et libération humaine. Genève: Labor et Fides.

Dorst, Jean. 1979. Siła życia, tłum. Wiktor Dłuski. Warszawa: Wyd. PIW.

DYREKTYWA RADY 79/409/EWG z dnia 2 kwietnia 1979 roku w sprawie ochrony dzikich ptaków (ze zmianami). Dostęp: 30.12.2016. http:// www.natura2000.org/wp-content/uploads/2015/02/dyrektywa_ptasia.pdf.

DYREKTYWA RADY 92/43/EWG z dnia 21 maja 1992 r. w sprawie ochrony siedlisk przyrodniczych oraz dzikiej fauny i flory. Dostęp: 30.12.2016. http://natura2000.gdos.gov.pl/uploads/download/633. 
Franciszek. 2015. Encyklika "Laudato Si".

IUCN-UNEP-WWF. 1980. World Conservation Strategy. Gland (Switzerland).

Jan Paweł II. 1989. Orędzie na XXIII Światowy Dzień Pokoju „Pokój $z$ Bogiem Stwórca, pokój z calym stworzeniem".

Kareiva, Peter i Michelle M. Marvier. 2012. What is Conservation Science? BioScience, 62(11), 962-969.

Kareiva, Peter i Michelle M. Marvier. 2013. Shared conservation goals but differing views on how to most effectively achieve resulta: A response from Kareiva and Marvier. BioScience, 63, 242-243.

Kloor, Keith. 2015. The Battle for the Soul of Conservation Science. Issues in science and technology, 31(2), 74-79.

Konstytucja RP .1997. Dostęp: 30.12.2016. http://www.sejm.gov.pl/ prawo/konst/polski/kon1.htm

Meadows, Donella H. et al. 1973. Granice wzrostu, tłum. Wiesława Raczkowska i Stanisław Raczkowski. Warszawa: Państwowe Wydawnictwo Ekonomiczne.

Ministerstwo Środowiska. Konwencja o Różnorodności Biologicznej. Dostęp: 03.01.2017. http://biodiv.gdos.gov.pl/convention/text-convention.

Mirek, Zbigniew. 1991. Bóg - człowiek - przyroda. Horyzonty Wiary, 13, 51-66.

Mirek, Zbigniew. 1997. W kręgu kultury i natury - geneza ideologii ochrony przyrody i turystyki u Jana Gwalberta Pawlikowskiego. W: Kultura a natura, red. Zbigniew Mirek i Zbigniew Krzan, 31-37. Kraków-Zakopane: Wyd. TPN.

Mirek, Zbigniew. 2000a. Duchowy wymiar relacji człowiek - przyroda. W: Przyroda - nauka - kultura. Humanistyczny kontekst nauk przyrodniczych u progu XXI wieku, red. Bogdan Zemanek, 107-127. Kraków: Instytut Botaniki PAN.

Mirek, Zbigniew. 2000b. Ekoteologia i ekoetyka - geneza, źródła i kierunki refleksji chrześcijańskiej. W: Między niebem a ziemią. Ku ety- 
ce ekologicznej, red. Anna Dyduch-Falniowska et al., 85-110. Kraków: Instytut Ochrony Przyrody PAN.

Mirek, Zbigniew. 2000c. Powołani do panowania. W: Mówić o Stwórcy i przyrodzie. Przewodnik edukacyjny, red. Anna Dyduch-Falniowska et al., 93-97. Kraków: Instytut Ochrony Przyrody PAN, Instytut Studiów Franciszkańskich.

Mirek, Zbigniew. 2001. Co to jest ekorozwój? W: Mówić o przyrodzie. Zintegrowana wizja przyrody, red. Anna Dyduch-Falniowska et al., 145180. Kraków: Instytut Ochrony Przyrody PAN, Instytut Studiów Franciszkańskich, Instytut Botaniki PAN.

Mirek, Zbigniew. 2002a. Zintegrowana wizja ochrony przyrody. W: Mówić o ochronie przyrody. Zintegrowana wizja ochrony przyrody, red. Monika Grzegorczyk et al., 9-15. Kraków: Instytut Ochrony Przyrody PAN, Instytut Botaniki PAN, Instytut Studiów Franciszkańskich.

Mirek, Zbigniew. 2002b. Krajobraz kulturowy jako środowisko życia. W: Mówić o ochronie przyrody. Zintegrowana wizja ochrony przyrody, red. Monika Grzegorczyk et al., 199-215. Kraków: Instytut Ochrony Przyrody PAN, Instytut Botaniki PAN, Instytut Studiów Franciszkańskich.

Mirek, Zbigniew i Zbigniew Witkowski. 2017. Teoria i praktyka w ochronie przyrody - gdzie szukać kompromisu w sprawie Puszczy Białowieskiej? W: Theoria i praxis zrównoważonego rozwoju, red. Ryszard F. Sadowski, Zbigniew Łepko, s. 609, Warszawa: TNFS.

Naess, Arne. 2003. Ecology, Community and Lifestyle: Outline of an Ecosophy. Cambridge: Cambridge University Press.

Pawlikowski, Jan Gwalbert. 1938. O lice Ziemi. Warszawa: PROP.

Raport U'Thanta przedstawiony na sesji Zgromadzenia Ogólnego w dniu 26 maja 1969 przez Sekretarza Generalnego ONZ U Thanta, zatytułowany „Człowiek i jego środowisko” (ang. The problems of human environment) wyrażony w rezolucji nr 2390.

Soulé, Michael E. 1985. What is conservation biology? BioScience, 35, 727-734. 
Stoner, Alexander M. i Andony Melathopoulos. 2015. Freedom in the Anthropocene: Twentieth-Century Helplessness in the Face of Climate Change. Berlin: Springer.

UNEP. 2016. UNEP Frontiers 2016 Report: Emerging Issues of Environmental Concern. United Nations Environment Programme, Nairobi.

Ustawa z dnia 16 kwietnia 2004 r. o ochronie przyrody. Dz.U. 2004 nr 92 poz. 880 .

Weiner, January. 2016. Po co nam puszcze. Tygodnik Powszechny, 27 (3 lipca).

White, Lynn. 1967. The historical roots of our ecological crisis. Science, 155(3767 - Mar 10, 1967), 1203-1207.

Witkowska, Katarzyna i Zbigniew Witkowski. Konsolidacja ekologicznych organizacji pozarzadowych na przykładzie sporu o Puszczę Biatowieska, ss. 12 (archiwum autora).

Zasady ogólnych praw i obowiązków Deklaracja z Rio de Janeiro w sprawie środowiska i rozwoju. Europa-Universität Viadrina, Frankfurt (Oder). 2002. Dostęp 03.01.2017. http://voelkerrecht.euv-frankfurt-o.de.

Zieliński, Paweł. 2008. Zespół GAMMA - Raport. W: Encyklopedia pedagogiczna XXI wieku, t. 7, red. T. Pilch, 891-899. Warszawa: Wydawnictwo Akademickie Żak. 
Michał Latawiec

Uniwersytet Kard. Stefana Wyszyńskiego w Warszawie - Wydział Filozofii Chrześcijańskiej m.latawiec@uksw.edu.pl

\section{Idea ochrony przyrody a Raport Brundtland}

\section{Wstęp}

Ochrona przyrody jest istotnym elementem szeroko rozumianego zrównoważonego rozwoju ${ }^{1}$. Dlatego warto zastanowić się, w jaki sposób Raport Brundtland wpłynął na dzisiejsze do niej podejście. Pierwsza część artykułu poświęcona jest prezentacji ochrony przyrody jako idei, która w polskich warunkach kształtowała się na przełomie XIX i XX w. W drugiej części przedstawione zostaną najważniejsze elementy Raportu Brundtland w kontekście przyrodniczym. Ostatni punkt artykułu to wskazanie wpływu raportu Nasza wspólna przyszłość na dzisiejszą ideę ochrony przyrody.

\section{Ochrona przyrody jako idea}

Ochronę przyrody rozumieć można przynajmniej na trzy sposoby: jako ideę, aktywne działanie oraz prężnie rozwijającą się naukę. Poprzestając na pierwszym $z$ nich, uznajemy, że ochrona przyrody jest rozumiana jako idea, która ulega ciągłej ewolucji. Aby lepiej zrozumieć zmiany w niej zachodzące, wyodrębnia się okresy odzwierciedlające te zmiany.

Pierwszy typ podziałów odnosi się do charakteru samej idei. Wśród wielu propozycji w ramach tego typu wyróżnić możemy:

\footnotetext{
${ }^{1}$ W Raporcie Brundtland zamiast jednoznacznej definicji zrównoważonego rozwoju odnajdujemy ogólne założenie nowego paradygmatu rozwoju jako „rozwoju, który zaspokaja potrzeby obecne, nie pozbawiając przyszłych pokoleń możliwości zaspokojenia ich potrzeb" (ŚKŚR 1991, 67). Termin «zrównoważony rozwój» obecny jest również w polskich aktach prawnych, w tym także w Konstytucji. Definicja zawarta w ustawie Prawo ochrony środowiska jest rozbudowana i uszczegółowiona. Ustawodawca przez zrównoważony rozwój rozumie „taki rozwój społeczno-gospodarczy, w którym następuje proces integrowania działań politycznych, gospodarczych i społecznych, z zachowaniem równowagi przyrodniczej oraz trwałości podstawowych procesów przyrodniczych, w celu zagwarantowania możliwości zaspokajania podstawowych potrzeb poszczególnych społeczności lub obywateli zarówno współczesnego pokolenia, jak i przyszłych pokoleń" (Dz.U.2001.62.627, 3).
} 
- okres amatorski, konserwatorski, biocenotyczny (Wodziczko 1936);

- okres konserwatorski, biocenotyczny, planistyczny (Wodziczko 1948; Szczęsny 1971) ${ }^{2}$;

- profil ochrony konserwatorskiej, krajobrazowej, różnorodności biologicznej (Radziejowski 2011).

Drugi typ podziałów odnosi się do ram czasowych. Proponuje się dwa takie podziały:

- do pierwszej wojny światowej, okres międzywojenny, czas po II wojnie światowej (Wnuk 2010);

- początki państwa polskiego i I Rzeczypospolitej, okres zaborów, okres II Rzeczypospolitej, okres PRL, okres III Rzeczypospolitej (Symonides 2007, Łapiński i Abdurakhmanov 2007).

Miom zdaniem, należy przyjąć trzy profile rozwoju idei ochrony przyrody uwzględniające charakter zachodzących zmian począwszy od XX w. Zmiany o charakterze progresywnym są widoczne w trzech elementach idei: przedmiocie, metodzie i celu. Proponowanymi przeze mnie profilami są kolejno okresy: ochrony oblicza Ziemi, ochrony zasobów, ochrony zrównoważonego rozwoju.

W okresie ochrony oblicza Ziemi sposoby i cele jej ochrony zależały od formy, w jakiej znajdowała się przyroda. Dla przyrody 'pierwotnej', kształtowane były dwie formy ochrony: rezerwatu i parku narodowego. Ich celem, oprócz zachowania przyrody dla przyszłych pokoleń, było umożliwienie kontaktu z prawdziwą przyrodą. Natomiast celem ochrony w przypadku przyrody przekształconej przez kulturę było zachowanie resztek przyrody pierwotnej tak, aby uratować je przed interesami gospodarczymi. Drugim zaś celem - sztuczne kierowanie rozwojem przyrody traktowanej nieużytkowo.

Na początku XX w. przyrodnicy próbowali określić relację zachodzącą między ochroną przyrody a techniką. Można odnieść wrażenie, że ochrona surowców niezbędnych w procesach technicznych nie była klu-

\footnotetext{
${ }^{2}$ Ta propozycja jest często spotykana. Dlatego warto zwrócić uwagę na różnice w uzasadnieniach tego podziału.
} 
czowym problemem w kwestii ochrony oblicza Ziemi (Jasieński 1932). Mając na uwadze, że bez techniki zaspokojenie potrzeb ludzkości będzie niemożliwe, przyrodnicy wskazywali jedynie, iż nie można eksploatować surowców na terenach natury pierwotnej.

Postulaty głoszone przez zwolenników ochrony przyrody spotykały się często z brakiem zrozumienia. Pojawiły się nieporozumienia, np. pogląd, że ochrona przyrody ma na celu powstrzymać postęp cywilizacyjny (Brunicki 1911). Jak wskazywał Pawlikowski, najczęściej konflikty między zwolennikami i przeciwnikami ochrony przyrody występowały wskutek nadawania innych wartości tym samym elementom przyrodniczym (Pawlikowski 1932).

Utrzymanie profilu ochrony oblicza Ziemi było trudnym zadaniem, ponieważ bywał on utożsamiany z ochroną przyrody przed człowiekiem, ewidencjonowaniem i wyłączaniem wybranych elementów przyrody. Równie ważnym aspektem było nierespektowanie ówczesnego nowoczesnego prawa (Bartkowski 1975). Ograniczenie idei do tworzenia parków narodowych odbiło się na innych działaniach, np. nie rozwijała się ochrona gatunkowa. Odbywało się to kosztem zaniechania wprowadzenia w życie pozostałych postulatów. Powstał dysonans między hasłami, przyjętymi aktami prawnymi a konkretnymi działaniami.

Kształtowanie się nowego profilu ochrony zasobów zbiegło się z powojenną potrzebą zmiany dotychczasowych zadań stawianych przed ochroną przyrody. Główną tego przyczyną była konieczność odbudowy kraju po wojnie i dążenie do szybkiego rozwoju gospodarczego. Przyrodę zaczęto postrzegać przez pryzmat zasobów, a jej ochronę w dwóch aspektach ochrony zasobów wyczerpywalnych oraz ochrony zasobów naturalnych.

Motywy gospodarcze tej ochrony miały odpowiadać zasadom racjonalnego wykorzystania sił produkcyjnych przyrody i być zgodne z założeniami gospodarki planowej (Szczęsny 1971). Potrzeba ochrony obszarów została dodatkowo uzasadniona. Dostrzeżono wartość prowadzonych badań naukowych, bowiem nie wszystkie cele można było zrealizować w warunkach laboratoryjnych. Dostrzeżono korzyści gospodarcze, a ponadto sama ochrona przyrody nabrała charakteru naukowego. Warto przypomnieć o propozycji nowej nauki - sozologii, obejmującej zagadnienia ochrony przyrody i jej zasobów (Goetel 1966). 
Na zniekształcony obraz tej idei wpłynęły potrzeby odbudowy kraju i postępujący rozwój cywilizacyjny. Planistyczna idea ochrony przyrody została odczytana i zastąpiona przez planową gospodarkę ukierunkowaną na zysk. Dla osiągnięcia zamierzonych celów i planów gospodarczych usprawiedliwiano w ten sposób ingerencję w przyrodę.

W profilu zrównoważonego rozwoju ochrona przyrody stała się problemem ogólnoświatowym. W literaturze pojawiło się wiele opracowań opisujących skutki rozwoju cywilizacyjnego (Raport Sekretarza Generalnego ONZ 1969; Leńkowa 1961; Carson 1962). Poszukiwano sposobu na pogodzenie dalszego rozwoju społeczno-gospodarczego z wymogami ochrony środowiska przyrodniczego, a także na poprawę warunków życia człowieka. Konsekwencją raportu U Thanta było zwrócenie uwagi na przekraczane środowiskowe progi, tworzące naturalne bariery rozwoju. W konsekwencji w systemie prawnym zaczęto określać normy dotyczące jakości środowiska. Zwrócono również uwagę na konieczność ochrony dużych obszarów Ziemi oraz na koncepcję korytarzy ekologicznych (Liro 1998; Wolfram 2010). Interesujący jest też program Natura 2000, realizowany na obszarze Wspólnoty Europejskiej, którego celem jest ochrona cennych gatunków i siedlisk przyrodniczych.

Obecne wyzwania zaczęto realizować $\mathrm{z}$ wykorzystaniem narzędzi ekonomicznych, gospodarczych i politycznych. Podejście to odzwierciedlone zostało w przyjętej polityce ekologicznej z $1991 \mathrm{r}$. Miało ono cztery główne cele: bezpieczne dla zdrowia ludzkiego środowisko; równowagę ekologiczną w podstawowych ekosystemach; niezbędne warunki odnowy sił człowieka oraz możliwości dalszego rozwoju gospodarczego (Kozłowski 2000). Z perspektywy czasu można stwierdzić, że mimo opracowania wielu planów i strategii, problemem stała się w dużym stopniu realizacja założonych celów (Stanowisko w sprawie kryzysu 2007). Przyjęta zasada „zrównoważonego rozwoju” została wpisana do wielu dokumentów, jednak jej istota zagubiła się w zapisach urzędowych. „Stosunkowo prosta zasada zrównoważonego rozwoju prowadzi do formułowania skomplikowanych strategii działania (...). Strategie te nie zawsze udaje się wprowadzić w życie, a niektóre $z$ tych wprowadzonych nie funkcjonują właściwie" (Pawłowski 2006, 31). 


\section{2. Środowisko przyrodnicze w Raporcie Nasza wspólna przyszlość}

Ochrona przyrody nie jest nadrzędnym celem Raportu Nasza wspólna przyszłość, szczególnie jeśli chodzi o zachowanie w niezmienionej formie wszystkich elementów przyrodniczych. Istotnym przesłaniem Raportu jest twierdzenie, że ochrona gatunków i ekosystemów jest warunkiem koniecznym dla zrównoważonego rozwoju (ŚKŚR 1991, 218). Przyroda jest ważnym elementem rozwoju gospodarczego i wzrostu, które „powodują oczywiście zmiany w ekosystemie fizycznym. Żaden ekosystem nie musi pozostać w całości nienaruszony" (ŚKŚR 1991, 70). Postulowany zrównoważony rozwój nie miał oznaczać stałego stanu harmonii - „raczej proces zmian, w którym wykorzystywanie zasobów, kierunki inwestowania, kierunki rozwoju techniki i zmiany instytucjonalne pozostają w zgodzie z przyszłymi i bieżącymi potrzebami” (ŚKŚR 1991, 27). Mimo świadomości, iż część gatunków wyginie, wskazano, że powinniśmy zabezpieczyć wszystkie gatunki „w stopniu, jaki jest możliwy z technicznego, ekonomicznego i politycznego punktu widzenia" (ŚKŚR 1991, 197). Należy zatem ustalić priorytety $\mathrm{w}$ ochronie przyrody. W przypadku gatunków, ochronie powinny podlegać nie tylko dziko występujące rośliny i zwierzęta czy też gatunki uprawne i hodowlane - ważne dla ludzkiego dobrobytu. Ochronie powinny podlegać również gatunki utrzymujące ekosystemy w zdrowym i produktywnym stanie (ŚKŚR 1991, 197).

Autorzy Raportu nie umniejszają roli parków narodowych jako formy ochrony przyrody. Jednak, ich zdaniem, tradycyjne podejście do tych terenów jako do obszaru odizolowanego również od spraw społecznych jest niewystarczające. W ramach zmiany sposobu kształtowania i zarządzania obszarami chronionymi przedstawiono hasło parks for development, „bo i tak parki służą podwójnemu celowi: ochronie siedlisk gatunków i jednocześnie procesom rozwoju" (ŚKŚR 1991, 209). Przewidywanie i zapobieganie negatywnym skutkom rozwoju na takich terenach miałoby przynieść większe korzyści również w ochronie gatunkowej. „Zmiana struktury gospodarki i sposobu wykorzystywania ziemi wydaje się najlepszym długookresowym podejściem, zapewniającym przetrwanie gatunków żyjących w stanie naturalnym i ich ekosystemów" (ŚKŚR 1991, 206). Tu rysuje się nowe podejście do gatunków i ekosystemów wyrażające się w zasadzie „przewidywać i zapobiegać”. 
Niezależnie od tego, w Raporcie odczytać możemy konieczność zwiększenia obszarów chronionych, „których świat będzie potrzebował w przyszłości" (ŚKŚR 1991, 34). To jednak wiąże się z koniecznością zwiększenia kosztów takiej ochrony, zarówno bezpośrednich, jak i tych wynikających z częściowej rezygnacji z rozwoju. Pamiętajmy, iż nawet tworzenie najbardziej efektywnie zarządzanych obszarów chronionych nie jest wystarczającym rozwiązaniem i nie spowolni wymierania gatunków (ŚKŚR 1991, 200), jeśli problemy środowiskowe pozostaną nierozwiązane na terenach sąsiadujących.

W Raporcie Nasza wspólna przyszłość środowisko przyrodnicze jest ujmowane przez pryzmat zasobów, w tym także dzikiej przyrody. Dzięki takiemu ujęciu przyrody można było połączyć aspekty przyrodnicze z rozwojem ekonomicznym. Dało to możliwość podkreślenia istotnej wagi tych komponentów w ekonomicznym aspekcie rozwoju. Komponenty przyrodnicze i ekonomiczne są ze sobą wielorako powiązane na wielu poziomach, „stają się układem przyczyn i skutków, nie mającym początku ani końca" (ŚKŚR 1991, 22). W ten sposób zasoby przyrodnicze będą determinować rozwój i dlatego należy je chronić.

Różnorodność gatunków i siedlisk jest konieczna dla poprawnie funkcjonującego ekosystemu. Niektóre zasoby są jednak eksploatowane ze stanu dzikiego. Tymczasem dla zapewnienia stałych zysków dorównujących popytowi, należałoby rozpocząć produkcję w kontrolowanych warunkach (ŚKŚR 1991, 86). Powinny np. być tworzone stawy dla gatunków ryb hodowlanych czy też plantacje lasów gospodarczych. Takie działania miałyby zapewnić ochronę dzikiej przyrody ${ }^{3}$.

Główną racją ochrony bogactwa przyrodniczego w kontekście rozwoju ekonomicznego jest potencjalna wartość tkwiąca w różnorodności genetycznej. „Materiał genetyczny zawarty w gatunkach dziko żyjących przynosi gospodarce światowej miliony dolarów rocznie w postaci ulepszonych odmian zbóż, nowych leków i surowców dla przemysłu" (ŚKŚR 1991, 33). Zatem w sporach o ochronę gatunków argumenty ekonomiczne o znaczących zyskach z takich działań są coraz skuteczniejsze. Walor użytkowy przyrody nie jest jedyny. Autorzy raportu wskazują również na aspekty „moralne, etyczne, kulturowe, estetyczne i czysto naukowe

${ }^{3}$ Zagrożeniem mogą być konsekwencje wprowadzenia upraw monokulturowych. 
przemawiające za zachowaniem naturalnych form życia" (ŚKŚR 1991, 33). Racji tych nie można jednak przełożyć na wymiar finansowy. Potrzeba ochrony różnorodności gatunkowej jest też uzasadniona w inny sposób. „Ginięcie gatunków roślin i zwierząt ogranicza liczbę możliwości wyboru dla przyszłych pokoleń. Tak więc stabilność rozwoju [zrównoważony rozwój - M.L.] wymaga zachowania gatunków roślin i zwierząt i ich ochrony" (ŚKŚR 1991, 210).

W raporcie dobrze ukazany został problem konfliktu interesów. Często $\mathrm{z}$ ochroną przyrody wygrywają krótkookresowe interesy gospodarcze. Zbyt rzadko myśli się o długookresowym zrównoważonym rozwoju i przyszłych potencjalnych korzyściach. W celu ochrony różnorodności genetycznej postuluje się przedstawienie ochrony gatunkowej i ekosystemów jako atrakcyjnej z punktu widzenia krótko i długo okresowego (ŚKŚR 1991, 210). Ponadto, problemy dotyczące gatunków są częściej rozpatrywane w kategoriach naukowych i ochrony niż jako istotne problemy gospodarcze. Stąd wyprowadzono wniosek, że pomija się aspekt polityczny (ŚKŚR 1991, 212). „Sprawą o podstawowym znaczeniu jest umieszczenie problemu ginących gatunków i zagrożonych ekosystemów w programach politycznych jako głównej kwestii dotyczącej zasobów" (ŚKŚR 1991, 213).

Kolejnym ważnym zagadnieniem jest zanikanie odmian $\mathrm{w}$ ramach poszczególnych gatunków. Dlatego w naszych działaniach „powinniśmy rozróżniać ginięcie gatunków od ginięcia nośników genów” (ŚKŚR 1991, 197). Chodzi np. o ryż i kukurydzę̧, których pula genowa obecnie jest tylko częścią tego, co występowało jeszcze kilkadziesiąt lat temu. Procesy ewolucji stwarzają problemy ochrony genetycznej, dlatego rządy „muszą działać selektywnie i decydować, ochrona których nośników genów zasługuje na angażowanie środków publicznych" (ŚKŚR 1991, 197).

\section{Konsekwencje Raportu Brundtland}

Raport Nasza wspólna przyszłość ukazał się, gdy problemy związane $\mathrm{z}$ degradacją środowiska przyrodniczego zostały już dostrzeżone. Zagadnienia te były podejmowane $\mathrm{z}$ różnych perspektyw $\mathrm{w}$ literaturze zarówno naukowej, jak i popularnonaukowej. $\mathrm{Z}$ tej racji na arenie

\footnotetext{
${ }^{4}$ Warto pamiętać, że rośliny te jako gatunki nie były i nie są zagrożone.
} 
międzynarodowej podjętych zostało wiele inicjatyw. Należy zwrócić uwagę choćby na: raport sekretarza ONZ U Tanta z 1969 r.; Deklarację Sztokholmską z 1972 r.; raporty Klubu Rzymskiego Granice Wzrostu z 1972 oraz Ludzkość w punkcie zwrotnym z 1974 r. W tych dokumentach przedstawiano znaczenie aspektów przyrodniczych i ich wpływ na różne obszary życia społecznego. Pojawiły się odwołania do praw i obowiązków społeczeństwa względem środowiska przyrodniczego.

Raport wpłynął na świadomość społeczną. M.in. ugruntował współczesne podejście do ochrony przyrody. Dlatego też strategia zrównoważonego rozwoju, której celem jest - w szerokim znaczeniu - osiągnięcie harmonii między ludźmi oraz ludzkością a przyrodą (ŚKŚR 1991, 94), powinna być szansą dla chronionej przyrody. W Raporcie sformułowano ogólne założenie zrównoważonego rozwoju, czyli „rozwoju, który zaspokaja potrzeby obecne, nie pozbawiając przyszłych pokoleń możliwości zaspokojenia ich potrzeb" (ŚKŚR 1991, 67). Założenia zrównoważonego rozwoju przedstawione w Raporcie Brundtland stały się inspiracją dla filozoficznych analiz relacji człowieka ze środowiskiem przyrodniczym ${ }^{5}$.

I tak, ważnym wkładem Raportu do idei ochrony przyrody jest próba zmiany postaw społecznych. „Pożyczamy kapitał środowiskowy od przyszłych pokoleń, nie mając zamiaru ani możliwości spłacenia zaciągniętego długu. Przyszłe pokolenia będą mogły przeklinać nas za marnotrawstwo, ale nie będą mogły nigdy wyegzekwować od nas naszych długów. Postępujemy tak, jak postępujemy, ponieważ możemy sobie na to pozwolić; przyszłe pokolenia nie mają głosu, nie mają też siły politycznej ani finansowej i nie są w stanie zakwestionować naszych decyzji” (ŚKŚR 1991, 26). Jest to wskazanie, iż do kwestii ochronny przyrody można włączyć dyskusję podjętą z punktu widzenia filozofii i etyki. Postulowana zbiorowa odpowiedzialność w kwestii ochrony naszego środowiska przyrodniczego nie jest równoznaczna $\mathrm{z}$ rezygnacją poszczególnych państw z suwerenności w gospodarowaniu zasobami. Odpowiedzialność ta ma polegać na pomocy w ochronie zasobów, tak aby poszczególne państwa nie były skazane tylko na własne siły (ŚKŚR 1991, 213).

\footnotetext{
${ }^{5}$ Polska debata filozoficzna o stosunku człowieka do przyrody jest coraz „donioślejsza”. Warto pamiętać o dorobku i spuściźnie VI Polskiego Zjazdu Filozoficznego w Toruniu (1995).
} 
Po drugie, Raport potwierdza słuszność nowatorskiego podejścia wskazującego na związki zachodzące między ochroną przyrody a rozwojem społeczno-gospodarczym. Zawarte są w nim przykłady urzeczywistnienia założeń zrównoważonego rozwoju. Dla przykładu, w Światowej Karcie Przyrody, jak pisze Kozłowski, „określono obowiązki dotyczące badania procesów naturalnych, ekosystemów i gatunków (...), a tym samym zapewnienia niezbędnych warunków do życia człowieka i dalszego jego rozwoju. Określone zostały zasady oraz obowiązki współczesnego człowieka wobec przyrody" (Kozłowski 1991, 7). Istotny był również Światowy Kongres Parków Narodowych w Bali z 1982 r., odbywający się pod hasłem „Parki Narodowe i obszary chronione jako wsparcie dla rozwoju społeczno-ekonomicznego". W deklaracji kończącej kongresu potwierdzono istotną rolę obszarów chronionych w realizacji założeń zrównoważonego rozwoju (The Bali Declaration 1983).

Inne realizacje dotyczące niektórych tez ogłoszonych w Raporcie możemy odnaleźć również $\mathrm{w}$ polskim prawie. W ustawie o ochronie i kształtowaniu środowiska z 1980 r., w art. 1, czytamy, że ochrona i racjonalne kształtowanie środowiska zmierza do zapewnienia obecnemu i przyszłym pokoleniom korzystnych warunków życia oraz realizacji prawa do korzystania z zasobów środowiska i zachowania jego wartości. Zauważmy, że zarówno w tej ustawie, jak i późniejszej Prawo ochrony środowiska z 2001 r., środowisko przyrodnicze jest postrzegane jako zasoby. Dla ich ochrony w polskim prawie przyjęte zostały ustawy szczegółowe: Prawo wodne; Prawo geologiczne; ustawa o lasach; ustawa o ochronie przyrody. W tym przypadku ujęcie poszczególnych elementów składowych środowiska przez pryzmat zasobów - przyjęte w Raporcie - ugruntowało się także w polskim prawie.

W Polsce przyjęto wiele dokumentów, które nawiązywały do Raportu. Wymienić można np. Strategię ochrony żywych zasobów przyrody $w$ Polsce, w której odnajdziemy stwierdzenie, że „ochrona nie może się ograniczać tylko do samej kategorii żywych zasobów przyrody. Musi ona również objąć procesy i zjawiska przyrody nieożywionej warunkujące życie organizmów, a także nawiązywać do programu działań gospodarczych zmierzających do stworzenia zrównoważonego ekologicznie rozwoju kraju. (...) Raport ten pod tytułem Nasza wspólna przyszłość 
dotyczący strategii ochrony środowiska na kuli ziemskiej powodzenie działań na rzecz ochrony warunkuje koniecznością wykazania ekonomicznych korzyści z niej płynących" (Ryszkowski i Bałazy 1991, 8). Propozycję łączenia ochrony przyrody i rozwoju gospodarczego odnaleźć można również w dokumencie Krajowa strategia ochrony i umiarkowanego użytkowania różnorodności biologicznej. W tekście przyjętym przez Ministerstwo Środowiska czytamy, że „Zgodnie z koncepcją rozwoju zrównoważonego, ochrona różnorodności biologicznej jest warunkiem koniecznym dalszego rozwoju gospodarczego kraju, a działania w tym zakresie muszą być zintegrowane z polityką społeczno-gospodarczą" (Krajowa strategia ochrony 2003, 8).

Najważniejszą próbą realizacji nowej wizji rozwoju przedstawionej w Raporcie była przyjęta przez rząd polski w 1991 r. polityka ekologiczna Zapisano wówczas, że „polityka ekorozwoju [zrównoważonego rozwoju - M.L.] to z jednej strony nadanie rozwojowi konsumpcji i produkcji oraz rozwojowi cywilizacyjnemu kierunku zachowującego w sposób trwały walory i zasoby środowiska, $z$ drugiej zaś czynna ochrona środowiska przyrodniczego. Oba kierunki polityki ekorozwoju są w Polsce aktualne" (Uchwała Sejmu Rzeczypospolitej Polskiej 1991). Kozłowski, podczas konferencji UNCED w Rio de Janeiro 5 czerwca 1992 r., zaprezentował ten dokument, mówiąc, że „Traktuje on ochronę środowiska jako sprawę o najwyższej randze na równi $\mathrm{z}$ rozwojem gospodarczym i postępem cywilizacyjnym. W ślad za tym następuje odejście od filozofii wzrostu gospodarczego za wszelką cenę na rzecz poprawy jakości życia i kształtowania bezpieczeństwa ekologicznego mieszkańców naszego kraju w połączeniu z dbałością o stan środowiska przyrodniczego" (Kozłowski 1993, 17). Choć dokument ten był wówczas nowatorski, to zastrzeżenia budził sposób realizacji założonych celów. Obecnie zaś w Polsce nie ma przyjętej aktualnej polityki ekologicznej państwa.

Przez trzydzieści lat, które upłynęły od momentu ogłoszenia Raportu, możemy wskazać na wiele inicjatyw, które miały być odpowiedzią na jego postulaty. M.in. przyjętych zostało wiele ważnych konwencji międzynarodowych, jak np.: Konwencja o różnorodności biologicznej z Rio de Janeiro (9.05.1992); Protokół z Kioto (11.12.1997); Konwencja o dostępie do informacji, udziale społeczeństwa w podejmowaniu decyzji 
oraz dostępie do sprawiedliwości w sprawach dotyczących środowiska z Aarhus (25.06.1998); Konwencja w sprawie trwałych zanieczyszczeń organicznych z Sztokholmu (22.05.2001); Ramowa Konwencja o ochronie i zrównoważonym rozwoju Karpat z Kijowa (22.05.2003).

Najlepszym przykładem powiązania spraw ochrony z rozwojem jest program Natura 2000. Proces inwestycyjny na terenach nim objętych jest realizowany $z$ uwzględnieniem aspektów przyrodniczych (Latawiec 2011). Dzięki sposobowi zarządzania obszarami tak chronionymi można stwierdzić, że jest to podejście, które może być dobrym narzędziem realizującym część postanowień Raportu.

\section{Zakończenie}

Warto podkreślić, że w Polsce temat ochrony przyrody jest obecny od dawna. Raport Brundtland wpisał się w historię idei. Po jego ogłoszeniu dostrzeżono konkretne aspekty dotyczące tej ochrony. Wzmocniony został nowoczesny sposób myślenia o celach i sposobach współczesnej ochrony przyrody. Sformułowano podstawy do rozwijania i urzeczywistniania zasady zrównoważonego rozwoju. Ochrona przyrody może być traktowana jako narzędzie prowadzące do zrównoważonego rozwoju. W Raporcie Brundtland wskazano, iż możliwe jest pogodzenie - zdawałoby się odmiennych - celów rozwoju gospodarczego, społecznego i przyrodniczego.

Ponadto tekst Raportu jest inspiracją do filozoficznej debaty nad ideą ochrony przyrody, miejscem i rolą człowieka w tej ochronie. Można $\mathrm{w}$ nim odczytać antropocentryczne nastawienie związane $\mathrm{z}$ próbą powiązania narzędzi ekonomicznych, gospodarczych, politycznych z realizacją tej idei oraz podkreśleniem miejsca człowieka w przyrodzie.

Choć postulaty zawarte w Raporcie są słuszne, to ich realizacja natrafia na szereg trudności. Problemem nie są założenia zrównoważonego rozwoju, lecz jego realizacja. Z jednej strony, stale jeszcze ujawniają się braki w uświadomieniu społeczeństwa o konsekwencjach ignorowania idei ochrony przyrody, z drugiej zaś - opieszałość w tworzeniu stosownych ustaw i zarządzeń. Dlatego to od nas zależy, czy uda się urzeczywistnić założenia Raportu. Należy dołożyć starań, aby nie zatracić istoty „zrównoważonego rozwoju”. W konsekwencji nie można dopuścić, by postulaty idei ochrony przyrody zostały ponownie wypaczone. 


\section{Bibliografia:}

Bartkowski, Tadeusz. 1975. Ochrona zasobów przyrody i zagospodarowanie środowiska geograficznego. Warszawa-Poznań: PWN.

Brunicki, Julian. 1911. W sprawie ochrony zabytków przyrody. Sylwan, 29(3), 132-139.

Carson, Rachel. 1962. Silent Spring. Boston: Houghton Mifflin.

Dz.U.2001.62.627. Prawo ochrony środowiska, tekst ujednolicony.

Goetel, Walery. 1966. Sozologia - nauka o ochronie przyrody i jej zasobów. Kosmos ser A, 15(5), 473-482.

Jasieński, Henryk. 1932. Stosunek techniki do przyrody. W: Skarby przyrody i ich ochrona, red. Władysław Szafer, 50-64. Warszawa: PROP.

Kozłowski, Stefan. 1993. Rio. Szczyt Ziemi. Początek ery ekologicznej. Łódź: Akapit Press.

Kozłowski, Stefan. 2000. Ekorozwój - wyzwanie XXI wieku. Warszawa: PWN.

Kozłowski, Stefan. 1991. Gospodarka a środowisko przyrodnicze. Warszawa: PWN.

Krajowa strategia ochrony i umiarkowanego użytkowania różnorodności biologicznej wraz z programem działań. 2003. Warszawa: Ministerstwo Środowiska.

Latawiec, Michał. 2011. Analiza historyczna ustawowych form ochrony przyrody w Polsce. Warszawa: UKSW.

Leńkowa, Antonina. 1961. Oskalpowana Ziemia. Kraków: PAN.

Liro, Anna. 1998. Strategia wdrażania krajowej sieci ekologicznej ECONET-Polska. Warszawa: Fundacja IUCN.

Łapiński, Jacek i Gajirbeg Abdurakhmanov. 2007. Rozwój myśli ekologicznej w Polsce i w Rosji - wybrane aspekty. Lublin: KUL.

Pawlikowski, Jan Gwalbert. 1932. Ogólny rzut oka na istotę ochrony przyrody, jej znaczenie, zadania i sposoby realizacji. W: Skarby przyrody i ich ochrona, red. Władysław Szafer, 1-15. Warszawa: PROP. 
Pawłowski, Artur. 2006. Wielowymiarowość rozwoju zrównoważonego. Problemy ekorozwoju, 1, 23-32.

Raport Sekretarza Generalnego ONZ U Thanta z dnia 26.V.1969 r. „Człowiek i jego środowisko”. 1969. Biuletyn Polskiego Komitetu do Spraw UNESCO, Nr specjalny.

Radziejowski, Janusz. 2011. Obszary chronionej przyrody. Historia, stan obecny, wyzwania przyszłości. Warszawa: Wszechnica Polska.

Ryszkowski, Lech i Stanisław Bałazy. 1991. Strategia ochrony żywych zasobów przyrody w Polsce. Poznań: ZBŚRiL PAN.

Stanowisko $w$ sprawie kryzysu w ochronie przyrody w Polsce. 2007. Warszawa: PROP.

Symonides, Ewa. 2007. Ochrona przyrody. Warszawa: WUW.

Szczęsny, Tadeusz. 1971. Ochrona przyrody i krajobrazu. Warszawa: PWN.

ŚKŚR (Światowa Komisja ds. Środowiska i Rozwoju). 1991. Nasza wspólna przyszłość, tłum. Urszula Grzelońska i Ewa Kolanowska. Warszawa: Państwowe Wydawnictwo Ekonomiczne.

The Bali Declaration. 1983. Environmental Conservation, 10(1), 73. DOI: $10.1017 /$ S0376892900011978.

Uchwała Sejmu Rzeczypospolitej Polskiej z dnia 10 maja 1991 r. w sprawie polityki ekologicznej. M.P.1991.18.118.

Wnuk, Zygmunt. 2010. Ekologia i ochrona środowiska. Wybrane zagadnienia. Rzeszów: WURz.

Wodziczko, Adam. 1948. Na straży przyrody. Widomości i wskazania $z$ dziedziny ochrony przyrody. Kraków: PROP.

Wodziczko, Adam. 1936. Ochrona przyrody w Wielkopolsce. Poznań.

Wolfram, Krzysztof. 2010. Historyczny i współczesny wymiar Zielonych Płuc Polski. Dostęp: 10.02.2017. http://www.fzpp.ehost.pl/assets/files/historyczny\%20I\%20wspolczesny\%20wymiar\%20zpp.pdf. 

Stefan Konstańczak

Uniwersytet Zielonogórski - Wydział Humanistyczny

s.konstanczak@ifil.uz.zgora.pl

\section{Ekologia versus ideologia. $O$ polskich problemach $\mathrm{z}$ recepcją raportu Gro Harlem Brundtland}

\section{Wstęp}

Konieczność podejmowania działań na rzecz ochrony środowiska dziś jest tak oczywista, że nikt nawet nie próbuje jej zakwestionować. Praktycznie w każdym programie dowolnego ugrupowania politycznego znajdują się obietnice podjęcia zakrojonych na mniejszą lub większą skalę przedsięwzięć w tym zakresie. Choć ich realizacja jest bardzo kosztowna, to niewiele jest ekip rządzących, które $\mathrm{z}$ takich obietnic się nie wywiązują. Niemniej jednak 40 lat temu w Polsce sytuacja była diametralnie inna, gdyż świadomość ekologiczna społeczeństwa dopiero się kształtowała, a poczucie zagrożenia stanem środowiska naturalnego było relatywnie niewielkie. Uwieńczenie procesu uwrażliwiania społeczeństwa wiązać należy dopiero z powstaniem w 1990 r. Instytutu na rzecz Ekorozwoju, którego raporty odegrały ogromną rolę w ukształtowaniu świadomości ekologicznej społeczeństwa polskiego.

Problematyka ochrony środowiska jeszcze w latach 70. nie była przedmiotem większego zainteresowania polityków, którzy zostawili ten problem ciałom społecznym w rodzaju Ligi Ochrony Przyrody (LOP) oraz Państwowej Komisji Ochrony Przyrody (PKOP). Inaczej mówiąc, problemy ochrony przyrody pozostawiono w gestii ekspertów, których wspomagali entuzjaści ekologii. Polskę na arenie międzynarodowej również reprezentowali specjaliści, co zaowocowało pozytywną oceną działań na rzecz ochrony środowiska podejmowanych w naszym kraju. Dzięki zabiegom LOP i PKOP w czerwcu 1966 r. został też uchwalony pierwszy w Polsce akt prawny w dziedzinie ochrony środowiska Ustawa o ochronie powietrza atmosferycznego przed zanieczyszczeniem (Ustawa 1966, poz. 87).

W Polsce do roku 1989 wolna prasa w zasadzie nie istniała, a gazety miały nie tylko ściśle reglamentowany dostęp do informacji, ale także ograniczoną możliwość publikowania treści. Monopol informacyjny, 
gwarantowany sprawnie funkcjonującymi instytucjami cenzury, posiadała tylko władza polityczna. $Z$ różnych przyczyn nie była ona zainteresowana udostępnianiem społeczeństwu informacji na temat stanu środowiska naturalnego. Z chwilą rozpoczęcia intensywnego programu industrializacji państwa władze polityczne nie były w ogóle zainteresowane upowszechnianiem informacji na temat negatywnych skutków z nim związanych. Głoszone wówczas hasło jedności moralno-politycznej narodu nie dopuszczało możliwości powstania jakiegokolwiek wyłomu, a świadomość istnienia problemów ekologicznych musiałaby taką jedność zakwestionować.

$\mathrm{Na}$ podstawie analizy informacji prasowych $\mathrm{z}$ tego okresu można przyjąć, że momentem przełomowym dla ukształtowania się świadomości ekologicznej społeczeństwa polskiego był proces związany z powstawaniem ogólnoświatowych regulacji dotyczących podejmowania działań na rzecz ochrony środowiska, w tym także prowadzenia instytucjonalnej edukacji w tym zakresie. Momentem kulminacyjnym tego procesu było w przekonaniu autora opublikowanie w 1987 r. Raportu Brundtland. To zaiste fascynujące zadanie, aby zrekonstruować i uporządkować w racjonalny ciąg proces przeobrażeń świadomości społecznej, która, jak należy sądzić, ostatecznie doprowadziła do transformacji systemowej w Polsce. Ekologia jak i sozologia odegrały w tym procesie ważną rolę, gdyż z dyscyplin akademickich niezauważalnie stały się częścią codzienności, wraz z nadziejami i lękami, które towarzyszą nam wszystkim do dziś.

\section{Na drodze ku wielkiej przemianie}

Prześledzenie wszystkich czynników, które spowodowały zmianę istniejącego i niekorzystnego stanu rzeczy, nie jest możliwe w krótkim wystąpieniu konferencyjnym. Niemniej jednak można prześledzić niektóre $\mathrm{z}$ tych uwarunkowań na podstawie lektury prasy codziennej i periodycznej, jaka się w tym czasie ukazywała w Polsce. Swoistym papierkiem lakmusowym tych zmian były treści, jakie zaczęły się pojawiać na łamach najważniejszych czasopism tego okresu, czyli w oficjalnym organie partii rządzącej „Trybunie Ludu” oraz w dzienniku „Rzeczpospolita” stanowiącym formalnie organ rządu ówczesnej PRL. Przyspieszona in- 
dustrializacja kraju w latach 70. spowodowała lawinowe narastanie problemów ekologicznych związanych zwłaszcza z rozbudową przemysłu chemicznego oraz wydobywczego. Polska stała się na przykład jednym z największych światowych producentów siarki, którą wydobywano na sposób rabunkowy tak długo, że nawet dziś miejsca te są prawdziwą ekologiczną pustynią. Ochrona ze strony ciał społecznych przestała zatem już wystarczać. Nie mogły one nawet dotrzeć do głównego nurtu przekazu informacji, który całkowicie zdominowała „propaganda sukcesu". Nie było w niej miejsca na jakiekolwiek opisy negatywnych skutków rozwoju przemysłu. Ekologom ówczesnym nie ułatwiał też zadania znikomy nakład wydawanych przez nich czasopism. Specjalistyczne periodyki „Chrońmy Przyrodę Ojczystą” jak i krakowska „Aura”, choć redagowane były na wysokim poziomie, to jednak docierały tylko do specjalistów. To paradoksalne, ale z dzisiejszej perspektywy problemy ochrony środowiska w naszym kraju były przedmiotem większej troski sąsiadów niż samych Polaków.

Problemy ochrony środowiska nie stanowily zatem wówczas przedmiotu większego zainteresowania nie tylko władz politycznych, ale nawet społeczeństwa. Nie znaczy to oczywiście, że nikt w naszym kraju nie dostrzegał istniejących problemów ekologicznych, jednak możliwość rozpowszechniania wiadomości na ten temat poza oficjalnymi kanałami informacyjnymi praktycznie nie istniała. Wszechwładna cenzura dbała o to, aby żadna informacja o zagrożeniach nie dostała się do publicznej wiadomości. Sytuację zmienia dopiero zapoczątkowany w latach 70 . proces odprężenia międzynarodowego, którego kulminacją było podpisanie przez szefów 35 państw aktu końcowego Konferencji Bezpieczeństwa i Współpracy w Europie. Dokument podpisany w Helsinkach 1 sierpnia 1975 miał dla kwestii upublicznienia informacji na ten temat znaczenie przełomowe. Określał bowiem nie tylko zasady postępowania w polityce międzynarodowej, ale także we wszystkich kwestiach, które dotyczyły spraw wykraczających poza kompetencje jednego państwa. Problemy ekologiczne, jako nieuznające żadnych granic ustanowionych przez człowieka, z oczywistych względów zyskały taki status.

Sam fakt, że ustalenia tzw. drugiego koszyka KBWE zostały w całości opublikowane w Polsce dopiero 5 lat po ich podpisaniu świadczy o tym, 
że były one niewygodne dla władzy. Wraz z opublikowaniem tych dokumentów rozpoczęła się jednak w Polsce nowa epoka w kwestiach ochrony środowiska naturalnego, a jej początkiem było uchwalenie w $1980 \mathrm{r}$. nowej ustawy o ochronie i kształtowaniu środowiska, która tym razem nie poprzestała na samych deklaracjach, ale powołała do życia Państwową Inspekcję Ochrony Środowiska (PIOŚ) kompetencyjnie podlegającą ministrowi ochrony środowiska, zasobów naturalnych i leśnictwa (Ustawa 1980, poz. 6).

Trudno dziś mieć pewność, ale niewątpliwie konieczność uwzględniania wymogów ekologicznych musiała zahamować dotychczasowy, nieskrępowany żadnymi ograniczeniami ekologicznymi, proces uprzemysłowienia kraju. Wydaje się także, że obciążenia budżetu związane z koniecznością zmniejszania uciążliwości dla środowiska już istniejących zakładów przemysłowych były jednym z czynników powodujących narastanie od połowy lat 70. kryzysu ekonomicznego w Polsce. Wiele ówczesnych decyzji nakładających na zakłady pracy dodatkowe obciążenia finansowe na rzecz środowiska naturalnego napotykały opór ze strony zarówno ich kierownictwa jak i załóg. Musiało to uświadomić ówczesnej władzy konieczność zdobycia społecznego poparcia dla tego typu działań. Nieoczekiwanym efektem tego typu zabiegów były bowiem zorganizowane lokalne protesty, które ze względu na cel ekologiczny nie mogły być zażegnywane środkami siłowymi, a zasięg ich społecznego oddziaływania był bardzo szeroki.

\section{Ekologiczne przyśpieszenie}

Początek lat 80. nie przyniósł radykalnych zmian w działaniach na rzecz ochrony środowiska. Polska przeżywała w tym okresie wyjątkowo burzliwy okres, który był następstwem powstania „Solidarności” i zapoczątkowanych procesów modernizacji społeczeństwa. Wraz z transmisją w stronę społeczeństwa danych o gospodarce, ujawnione zostały także niektóre dane na temat stanu środowiska naturalnego. Należy sądzić, że dopiero od tego momentu weszły one na stałe do publicznej debaty. Świadectwem tego typu przemian było powstanie w Krakowie jeszcze w $1980 \mathrm{r}$. Polskiego Klubu Ekologicznego, pierwszej niezależnej organizacji monitorującej stan środowiska naturalnego w Polsce. Nic zatem dziwne- 
go, że później przy Komitecie Obywatelskim „Solidarności” rozpoczęła funkcjonować komisja ochrony środowiska i zasobów naturalnych, której przewodniczył Stefan Kozłowski (1928-2007). Ten dyskurs społeczny obejmujący również kwestie ochrony środowiska został gwałtownie przerwany przez wprowadzenie 13 grudnia 1981 r. stanu wojennego. Kwestie ekologiczne znowu przestały być priorytetem dla władz. Jedną z niewielu możliwości podtrzymywania międzynarodowej współpracy stanowiła wówczas jednak właśnie płaszczyzna ekologiczna. Zapewniało to udział polskich ekspertów w pracach powołanej w 1983 r. World Commission on Environment and Development, zwanej także Komisją Brundtland, a także umożliwiało - wprawdzie skromny - udział naszych polityków w życiu społeczności międzynarodowej.

O tym, że problemy ekologiczne były ściśle związane z politycznymi najlepiej, przekonuje wiedeńska deklaracja z 11 czerwca 1983 r. poświęcona polityce ochrony przyrody i ochronie środowiska w Europie. W pkt. 2 tej deklaracji odwoływano się do ustaleń KBWE oraz do Światowej Karty Przyrody, a także do Światowej Strategii Ochrony Przyrody. W dokumencie wyrażono także zaniepokojenie zaniedbaniami w tej kwestii, obligując zarazem państwa europejskie do wzmożenia wysiłków w tej dziedzinie (Stawiński 1985, 56-57). Mizeria ekonomiczna ówczesnej Polski czyniła z naszego kraju jeden z głównych obiektów krytyki za zaniedbania w tym względzie. Nic zatem dziwnego, że oficjalna propaganda starała się wykazać, że Polska jednak nie zasługuje na taką krytykę, gdyż kwestie dotyczące ochrony środowiska są przedmiotem zainteresowania najwyższych władz. Ponieważ władzę w Polsce sprawowali wówczas wojskowi, dbali również o proekologiczny wizerunek swej instytucji. Wojsko zresztą było wówczas stosunkowo często przywoływane w publikacjach prasowych jako przykład różnego rodzaju inicjatyw proekologicznych i podejmowanych działań na rzecz poprawy stanu środowiska naturalnego (Reperowicz 1984, 3; Na odsiecz 1987, 2; Wojsko 1987, 1-2). Zapewne miało to na celu poprawienie wizerunku tej instytucji nadszarpniętego po wprowadzeniu stanu wojennego.

Również partia komunistyczna starała się nadążać z duchem czasu i w KW PZPR powstała specjalna Komisja ds. Zdrowia Ludności i Środowiska. Odbywała ona wyjazdowe posiedzenia w regionach, w których 
stan środowiska naturalnego budził największe obawy (Sprawy 1984, 1). Miało to przekonać opinię publiczną, że sprawy ochrony środowiska naturalnego stanowią jeden z zasadniczych kierunków zainteresowania partii rządzącej. Najwyższy formalnie organ władzy, jakim była ówczesna Rada Państwa, także starał się wykazać swoją aktywnością w sferze ochrony przyrody. W tym celu utworzono specjalną Komisję do spraw Ochrony Środowiska, która zainaugurowała swoją działalność 12 stycznia 1987 r. (Strategia 1987, 1). Przewodniczącym Komisji został zastępca przewodniczącego Rady Państwa, co miało zapewne pokazać, że do tej działalności przywiązuje się wielką wagę. Nie zmieniło to jednak w niczym faktu, że ówczesne organy samorządu terytorialnego do czasu publikacji Raportu Brundtland miały bardzo ograniczone możliwości wykazania się swoją aktywnością na rzecz ochrony środowiska naturalnego. Sytuacja zmienia się na korzyść dopiero od drugiej połowy 1987 r. (Gospodarność 1987, 1; Forowicz 1987b, 3).

Przedstawiciele polskich władz odpowiedzialni za stan środowiska naturalnego chętnie wypowiadali się w środkach masowego przekazu na temat własnej aktywności zmierzającej do poprawy istniejącego stanu. W myśl tych wypowiedzi Polska była jednym z głównych inicjatorów międzynarodowych regulacji dotyczących poprawy środowiska naturalnego. Chętnie też za przyczynę niezadowalającego stanu środowiska w naszym kraju obwiniali ograniczenia w przepływie nowoczesnych technologii lub jej zbyt wysokie koszty (Pisarewicz 1985, 3; Podwysocki 1987, 4). Aby społeczeństwo nie odnosiło wrażenia, że tego typu ograniczenia hamują działania zmierzające do poprawy stanu środowiska naturalnego, popularyzowano osiągnięcia rodzimej myśli technicznej. Miało to przy okazji także wykazywać nieskuteczność restrykcji wprowadzonych po 1981 r. przez państwa Zachodu (Wynalazki 1987, 4; Czystej wody 1987, 3; Nowoczesne 1987, 4).

Nie brakowało również pozytywnych przykładów zmian powodowanych przez nowe ustawodawstwo proekologiczne. Rzecz jasna znajdowało to od razu swój wyraz na łamach prasy (Wrzask 1987, 7). Zgodnie z ustaleniami z Helsinek, w Polsce rozpoczęto także prace nad programami edukacji ekologicznej dzieci i młodzieży (Panek 1985, 3). W tym przypadku władze oświatowe nadążały za trendami ogólnoświatowymi. 
W prasie centralnej zaczęły się ponadto ukazywać informacje na temat lokalnych inicjatyw społecznych zmierzających do poprawy stanu środowiska naturalnego. Już nie tylko władze polityczne i administracyjne wykazywały troskę o kondycję przyrody, ale i sami mieszkańcy. Zmiana taka dokonała się zapewne z powodu znaczącego wzrostu znaczenia ruchów ekologicznych na Zachodzie. W ten sposób zamierzano wykazać, że również w naszym kraju jest podobnie. Jedną z pierwszych tego rodzaju inicjatyw społecznych, która przybrała formy instytucjonalne był Społeczny Komitet Ochrony Jezior Mazurskich powstały w czerwcu 1984 r. O politycznym usytuowaniu tej inicjatywy świadczy jednak jego związek z legitymizującym ówczesną władzę tzw. Patriotycznym Ruchem Odrodzenia Narodowego (PRON), który objął patronat nad komitetem (Zagórska 1985, 3). Z niejasnych dziś względów, to właśnie PRON stał się wkrótce najważniejszym animatorem społecznych działań proekologicznych w Polsce. Możliwe, że była to także próba na dowartościowanie tego ruchu w oczach społeczeństwa, które traktowało go z wyraźną rezerwą. Formalnie był on jednak oddolną inicjatywą społeczną, i to zapewne zaważyło o takim kierunku jego zaangażowania, i od drugiej połowy 1985 r. to właśnie ta organizacja cieszyła się w czasopismach centralnych wyraźnymi preferencjami w kwestii własnych proekologicznych inicjatyw.

Niekiedy piętnowanie sprawców zagrożeń ekologicznych przybierało zgoła groteskowy wymiar, tak jak podniesiony 21.12.1984 r. przez „Trybunę Ludu" problem bankructwa Wojewódzkiego Przedsiębiorstwa Wodociągów i Kanalizacji w Kielcach, które powinno upaść z powodu przewidzianego ustawą obligatoryjnego nałożenia przez wojewodę kar za zanieczyszczenie środowiska. Pikanterii sprawie dodał fakt, że dziennikarze nie zbadali dokładnie sprawy, gdyż budowa potrzebnej oczyszczalni ścisków leżała w gestii tego samego wojewody, a nie karanego przedsiębiorstwa. Istniała zatem wówczas ograniczona wolność słowa, przynajmniej w kwestiach, których nie uznawano za priorytetowe. Co ciekawe redakcja gazety zamieściła nawet replikę czytelnika na ten tekst, co wcześniej w zasadzie się nie zdarzało (Rawicki 1985, 9).

$\mathrm{Na}$ łamach prasy lokalnej, a nawet centralnej, zaczęto niebawem publikować także sprawozdania $\mathrm{z}$ konfliktów dotyczących protestów 
społecznych związanych $\mathrm{z}$ funkcjonowaniem uciążliwych dla środowiska i mieszkańców zakładów przemysłowych. Dotyczyło to przede wszystkim Celwiskozy w Kotlinie Jeleniogórskiej oraz Huty Siechnica pod Wrocławiem. Ważną rolę w mobilizowaniu społeczności lokalnych odgrywał w tych przypadkach Polski Klub Ekologiczny.

\section{Ekologia jako instrument walki ideologicznej}

Zapewne ryzykowne jest stwierdzenie, że rywalizacja pomiędzy Wschodem a Zachodem toczyła się również na płaszczyźnie ekologicznej. Bogatsi sąsiedzi nie szczędzili bowiem słów krytyki pod adresem krajów tzw. realnego socjalizmu za zaniedbania $w$ tej dziedzinie. $Z$ racji słabej kondycji ekonomicznej Wschodu rywalizacja ta została podjęta, ale na poziomie teoretycznym. W polskiej prasie eksponowano przerysowany obraz problemów w sferze ochrony środowiska, jakie zdarzały się za linią Łaby. Takie zdarzenie miało np. miejsce 17 stycznia $1985 \mathrm{r}$. w Zagłębiu Ruhry, gdzie ogłoszono „alarm smogowy” i wprowadzono szereg obostrzeń prawnych mających ograniczyć niekorzystne skutki tego zjawiska. Korespondent „Trybuny” z satysfakcją podkreślał bezsilność lokalnych władz, które muszą czekać na sprzyjające prądy atmosferyczne, aby pozbyć się problemu (Drecki 1985, 7). W komentarzach redakcyjnych starano się wówczas poróżnić ze sobą państwa Zachodu, tak jak w przypadku rozpowszechniania informacji, że zanieczyszczenia atmosferyczne znad Zagłębia Ruhry są przyczyną kwaśnych deszczów nad Skandynawią (Siedlecki 1985, 5).

Krytyka sięgała także Stanów Zjednoczonych. Eksponowano dane z raportów przygotowywanych przez tamtejsze różne gremia, które wykazywały zaniedbania w sferze ochrony środowiska i ostrzegały przed ich możliwymi skutkami (Skażenie 1985, 6). W kontekście współczesnego zmotoryzowania Polski i niekorzystnych skutków ekologicznych z tym związanych nieco humorystycznie brzmią przytyki ówczesnych dziennikarzy pod adresem USA. Samochód jawił się tam jako największy truciciel środowiska, który z tego powodu jest sprawcą wielu chorób i zgonów obywateli (Siedlecki 1983, 8). Na łamach prasy polskiej publikowano także sprawozdania z procesów sądowych wytaczanych poszczególnym zakładom przemysłowym za zaniedbania $\mathrm{w}$ kwestii zabezpieczania śro- 
dowiska przed negatywnymi skutkami stosowanych technologii (Największy truciciel 1985, 7). Z takich informacji łatwo można było wyciągnąć wnioski, że dbałość o przyrodę w USA niczym istotnym się nie różni od tej, jaką wykazują polskie władze. Polscy politycy długo nie zapominali także o restrykcjach ekonomicznych wobec Polski nałożonych przez Stany Zjednoczone po wprowadzeniu stanu wojennego. Nagle usytuowano je w ekologicznym kontekście, co zapewne miało pozbawić je w oczach społeczeństwa uzasadnienia politycznego.

Wiele miejsca w polskiej prasie centralnej poświęcono też zajęciu przez francuskie jednostki specjalne statku Greenpeace „Rainbow Warrior", który płynął na francuska Polinezję, aby uniemożliwić dokonanie próby z bronią jądrową. Akcja ta była bez ogródek nazywana „zbrodniczą operacją", a w przekazach prasowych wątki ekologiczne zlały się w jedno z „walką o pokój”" (Jaworski 1985, 7).

W świetle polskich publikacji prasowych z okresu poprzedzającego opublikowanie Raportu Brundtland można odnieść wrażenie, że ochrona środowiska stanowiła przedmiot nieustannego zainteresowania zarówno władz administracyjnych jak i politycznych, a wspierało je w tym nieomal całe społeczeństwo. Przekonywano w nich, że cały Sejm z troską zajmował się doskonaleniem istniejącego prawodawstwa, uchwalał programy ochrony środowiska naturalnego na kolejne lata, a także podjąı specjalną uchwałę $w$ sprawie ochrony środowiska naturalnego w naszym kraju (Ochrona środowiska 1987, 1)1. Posłowie ponadto starali się w jakimś stopniu uzgodnić ze sobą nieskoordynowane dotąd działania różnych instytucji państwowych oraz ciał aspołecznych. Na początku 1987 r. sprawy ochrony środowiska stały się dzięki temu przedmiotem obrad Rady Społeczno-Gospodarczej przy sejmie PRL IX kadencji (Wszyscy musimy chronić środowisko 1987, 1). Jednym z efektów tych spotkań i narad były propozycje nowego ustawodawstwa, które by łączyło interesy środowiska z interesami producentów (Jastrzębski 1987, 6). Była to odpowiedź na krytykę polskich działań na rzecz środowiska naturalnego podejmowaną przez sąsiednie państwa. Zmuszała ona do działań nie tylko propagandowych, ale przede wszystkim praktycznych.

\footnotetext{
${ }^{1}$ Treści uchwały oraz wszystkich wystąpień, a także sprawozdanie z przebiegu dyskusji poselskiej zamieściła „Rzeczpospolita” w numerze 26 z 1987 (s. 4-5).
} 
O zakresie aktywności państwa w rozwiązywaniu problemów ekologicznych miała świadczyć kompleksowość podejmowanych działań, które łączyły środki administracyjne z zaangażowaniem społecznym (Forowicz 1987a, 3). Zapewne wiązało się to ze świadomością, że Raport Brundtland niebawem zostanie opublikowany.

Moment opublikowania Raportu był trudnym wyzwaniem dla socjalistycznej władzy. Nie mogła odrzucić postulatów i elementów krytycznych, jakie zawierał, gdyż oznaczałoby to, że władze zajmują stanowisko lekceważące zagrożenia dla zdrowia i życia obywateli. Z punktu widzenia materializmu historycznego problemy ekologiczne w ogóle nie powinny przecież powstać. Raport Brundtland wykazał także, że przyczyną kryzysu ekologicznego są sami ludzie, a więc podważał bezpośrednio sztandarową tezę materializmu historycznego, że baza kształtuje nadbudowę, a zatem świadomość ludzka ulega zmianom wraz z dokonującym się postępem cywilizacyjnym. Co prawda erozja marksizmu była już wówczas faktem, ale po publikacji Raportu niewątpliwie uległa przyśpieszeniu. Ideologia zatem ostatecznie przegrała z ekologią i mamy szczęście, że tak się stało.

\section{Zakończenie}

Czy można dziś uznać moment opublikowania Raportu za przełomowy w historii świata? Czy zasadne jest dzielenie dziejów na przed i po jego opublikowaniu? Politolodzy i historycy zazwyczaj piszą historię datami wielkich wojen lub nadzwyczajnych zdarzeń, które wpłynęły na świadomość społeczeństw światowych. Nikomu zaś nie przyjdzie nawet na myśl, aby tę historię pisać od momentu opublikowania teorii względności lub odkrycia Kopernika. Może nadszedł czas, aby zmienić myślenie, gdyż przecież dopiero potraktowanie świata jako dobra wspólnego, co przypieczętował właśnie Raport i sam proces jego powstawania, doprowadziło do zażegnania groźby większej, jaką była możliwość atomowej apokalipsy. Co prawda, trudno przypisywać takie znaczenie jednostkowemu wydarzeniu, ale wpisywało się ono w pewien ciąg zdarzeń, który ustalił ostatecznie nowy porządek świata. Ten porządek nie jest przecież idealny, bo nierozwiązanym problemem są nowe wędrówki ludów, które jawią się nam jako zagrożenie na miarę kryzysu 
ekologicznego w sensie ideowym opanowanego właśnie przez postulaty Raportu oraz ich późniejszą realizację.

Gdy opublikowano Raport Brundtland, w Polsce nikt jeszcze go tak nie nazywał. W pewnym sensie został on zignorowany ${ }^{2}$. Bliższe informacje na jego temat były dostępne wyłącznie specjalistom. Wedle wielu był to kolejny raport o stanie świata, jakich wcześniej opublikowano już wiele. Raport z 1987 r. przeczy jednak takiemu podejściu, gdyż jest ofertą, z której mogą skorzystać wszyscy na miarę swoich możliwości. Każdy może być też beneficjentem programu, ale każdy ma też związane z tym obowiązki.

Minione 30 lat, które upłynęły od opublikowania Raportu Brundtland, nie przyniosły radykalnej poprawy istniejącego stanu, a więc nie zostały wyeliminowane zagrożenia ekologiczne, a być może nawet ich przez ten czas przybyło. Cechą charakterystyczną tych lat była jednak zmiana patrzenia na naszą planetę, którą zaczęto traktować jako wspólne dobro. Ewolucja stanowiska władz polskich wobec istniejących zagrożeń środowiska naturalnego jest tego najlepszym dowodem. Potraktowanie problemu jako jeszcze jednej płaszczyzny rywalizacji ideologicznej musiało jednak skutkować niepotrzebną stratą czasu i rozproszeniem środków. To paradoksalne, ale tej walki nie można było wygrać. Przegrana w niej oznaczała nie tylko uwrażliwienie społeczeństwa na problemy ekologiczne, ale także zmusiła władze do wzmożonych wysiłków dla poprawy kondycji środowiska. To nie przypadek, że protesty społeczne spowodowały zaniechanie kontynuowania budowy elektrowni jądrowej w Żarnowcu. Publikacja Raportu Brundtland była zatem ogniwem procesu, w którym dochodziło do przeobrażenia europejskiej sceny politycznej. Te zmiany były nieuchronne w tym sensie, że nie istniały już żadne możliwości powstrzymania tego procesu. Można stąd wysunąć wniosek, że podłoża procesów polskiej modernizacji należy doszukiwać się także na płaszczyźnie ekologicznej. Ostatecznym wygranym jest i było polskie społeczeństwo, które wówczas dopiero zyskiwało świadomość ekologiczną. Dziś żyjemy już w całkowicie innych realiach, nie odczuwamy bezpośrednio skutków kryzysu ekologicznego,

\footnotetext{
${ }^{2}$ W języku polskim Raport został opublikowany dopiero w 1991 r. Dla przykładu raport o stanie świata pod redakcją L. Browna z 1984 r. w tym samym wydawnictwie ukazał się dużo szybciej, bo już w 1986 r.
} 
a walka o czyste środowisko toczy się w znacznie subtelniejszych formach. W tej kwestii możemy być wzorem dla krajów, które w tej walce sytuują się na poziomie, jaki Polska zajmowała w połowie lat 80 . Mamy z tej racji zarówno prawo jak i obowiązek egzekwowania od nich co najmniej takiego samego zaangażowania w kwestiach usuwania zagrożeń ekologicznych, jakie podejmowano wówczas w naszym kraju. Okazuje się bowiem, że presja zewnętrzna może być znacznie skuteczniejsza od wewnętrznej. Przekonuje nas o tym nasza własna historia.

\section{Bibliografia:}

Czystej wody nie zabraknie. 1987. Rzeczpospolita, 12, 3.

Drecki, Ryszard. 1985. Katastrofa w Zagłębiu Ruhry. Trybuna Ludu, 16, 7.

Forowicz, Krystyna. 1987a. Przyroda zyskuje sprzymierzeńców. Rzeczpospolita, 144, 3.

Forowicz, Krystyna. 1987b. Rady narodowe i środowisko. Chronić z własnej woli. Rzeczpospolita, 98, 3.

Gospodarność, czystość, ochrona środowiska. 1987. Rzeczpospolita, 97, 1 i 4.

Jastrzębski, Bronisław. 1987. Ochrona gruntów rolnych a ochrona środowiska. Rzeczpospolita, 65, 6; 70, 8.

Jaworski, Marek. 1985. Socjaliści potępiają zamach na statek „Greenpeace". Trybuna Ludu,196, 7.

Na odsiecz przyrodzie: wojsko i ochrona środowiska. 1987. Trybuna Ludu, 34, 2.

Największy truciciel na ławie oskarżonych. 1985. Trybuna Ludu, 196, 7.

Nowoczesne agregaty i oczyszczalnie. 1987. Rzeczpospolita, 23, 4.

Ochrona środowiska jest konstytucyjnym obowiązkiem. 1987. Trybuna Ludu, 28, 1 i 3.

Panek, Krystyna. 1985. Ekologia w tornistrze. Trybuna Ludu, 252, 3.

Pisarewicz, Gennadiusz. 1985. Środowisko nie zna granic (wywiad z ministrem-kierownikiem Urzędu Ochrony Środowiska i Gospodarki Wodnej prof. Stefanem Jarzębskim). Trybuna Ludu, 241, 3. 
Podwysocki, Tadeusz. 1987. Przede wszystkim monitoring. Rzeczpospolita, 38, 4.

Rawicki Jan.1985. Ochrona środowiska - przyczyną bankructwa? Trybuna Ludu, 27, 9.

Reperowicz, Stanisław. 1984. Wojsko w czołówce: Ochrona środowiska - wspólny obowiązek. Trybuna Ludu, 234, 3.

Siedlecki, Zbigniew. 1985. Polewanie kwasem. Trybuna Ludu, 28, 5.

Siedlecki, Zbigniew. 1983. Trująca ignorancja. Trybuna Ludu, 160, 8.

Skażenie środowiska w USA. Alarmujące dane. 1985. Trybuna Ludu, 177, 6.

Sprawy ochrony środowiska. Wyjazdowe posiedzenie Komisji KC PZPR ds. Zdrowia Ludności i Środowiska. 1984. Trybuna Ludu, 251, 1 i 3.

Stawiński, Wiesław. 1985. Wiedeńska deklaracja uchwalona w dniu 11 czerwca 1983 r. na Międzynarodowym Sympozjum poświęconym rozwojowi polityki ochrony przyrody i ochronie środowiska w Europie oraz wychowaniu i nauczaniu w tym zakresie. Chrońmy Przyrodę Ojczystą, 1, 56-59.

Strategia ekologiczna. Niezbędne czyste powietrze i woda. Inauguracyjne posiedzenie Komisji ds. Ochrony Środowiska Rady Państwa. 1987. Rzeczpospolita, 11, 1 i 5.

ŚKŚR (Światowa Komisja ds. Środowiska i Rozwoju). 1991. Nasza wspólna przyszłość, tłum. Urszula Grzelońska i Ewa Kolanowska. Warszawa: Państwowe Wydawnictwo Ekonomiczne.

Ustawa z dnia 21 kwietnia o ochronie powietrza atmosferycznego przed zanieczyszczeniem. 1966. Dziennik Ustaw, 14, poz. 87.

Ustawa z dnia 31 stycznia 1980 r. o ochronie i kształtowaniu środowiska. 1980. Dziennik Ustaw, 3, poz. 6.

Wojsko w trosce o środowisko. Konkretne badania. 1987. Rzeczpospolita, 33, 1-2.

Wrzask, Władysław. 1987. Truciciele zbudują oczyszczalnię. Trybuna Ludu, 94, 7. 
Wszyscy musimy chronić środowisko. Rządowe przedsięwzięcia w ocenie Rady Społeczno-Gospodarczej. 1987. Rzeczpospolita, 18, 1 i 5.

Wynalazki ratują przyrodę. 1987. Rzeczpospolita, 4, 5.

Zagórska, Alicja. 1985. Społeczne inicjatywy w ochronie mazurskich jezior. Trybuna Ludu, 79, 3. 
Zbigniew M. Karaczun

Szkoła Główna Gospodarstwa Wiejskiego w Warszawie - Katedra Ochrony Środowiska zbigniew_karaczun@sggw.pl

\section{Ewolucja idei zrównoważonego rozwoju w Polsce na przykładzie polityki klimatycznej}

\section{Wstęp}

Polityka klimatyczna wyrosła z podobnego pnia co idea zrównoważonego rozwoju. Jej początki sięgają tego samego okresu, kiedy to uznano, że podejmowane decyzje muszą uwzględniać interes przyszłych pokoleń Od początku budziła liczne kontrowersje. Sceptycy nie uznają wyników badań naukowych wskazujących na wpływ człowieka na klimat (Wang i Oppenheimer 2005, 4) lub twierdzą, że działania nie są potrzebne, bo system klimatyczny jest samoregulujący się i mechanizmy naturalne zapewnią przywrócenie równowagi. Sceptyków nie przekonuje nawet ujawnianie fałszerstw przeciwników polityki klimatycznej (Costella 2010, 12). W ostatnich latach równie silnie atakowane są propozycje działań na rzecz zrównoważonego rozwoju i ochrony środowiska (Mastalerz).

Zdaniem autora nie jest to przypadkowe. Polityka klimatyczna jest $\mathrm{w}$ istocie polityką zrównoważonego rozwoju. Postuluje korzystanie z zasobów odnawialnych i wzrost efektywności wykorzystania nieodnawialnych. W większym stopniu służy bezpieczeństwu przyszłych pokoleń niż obecnej generacji. Chociaż bowiem niekorzystne efekty zmian klimatu manifestuje się już obecnie, to znaczące, negatywne skutki wystąpią w drugiej połowie obecnego stulecia. Dlatego niezbędne jest dostosowanie wielkości presji na klimat do nieprzekraczalnych barier wyznaczanych przez stabilność systemu klimatycznego.

Celem niniejszego artykułu jest autorska analiza ewolucji podejścia do zrównoważonego rozwoju na przykładzie polskiej polityki klimatycznej od 1988 roku do roku 2016 i próba identyfikacji uwarunkowań, które decydowały i decydują o kształcie tej polityki. 


\section{Ewolucja polskiej polityki klimatycznej}

\section{Początki i kształtowanie się polskiej polityki klimatycznej. Lata 1991-2003}

W proces transformacji Polska wkroczyła $\mathrm{z}$ bardzo zdegradowanym i zanieczyszczonym środowiskiem i z silnym ruchem ekologicznym. $\mathrm{Z}$ tych powodów poprawa stanu środowiska stała się jednym $\mathrm{z}$ priorytetów nowych władz. Chociaż dominowała potrzeba rozwiązywania spraw bezpośrednio zagrażających zdrowiu i życiu Polaków, to już w I Polityce Ekologicznej Polski (MOŚiZN 1991, 7), przyjętej w 1991 roku, dostrzeżono konieczność ochrony klimatu - ograniczania emisji gazów cieplarnianych adekwatnie do porozumień międzynarodowych ${ }^{1}$. Dzięki temu Polska wzięła aktywny udział w negocjacjach Konwencji Klimatycznej i stosunkowo szybko ją ratyfikowała (w 1994 roku).

Lata 90. XX w. to okres rozwoju polityki klimatycznej, w tym okresie Polska podpisała Protokół z Kioto i rozpoczęła tworzenie zaplecza eksperckiego: powstały m.in. Ośrodek Ochrony Klimatu (przekształcony w Biuro Wykonawcze Konwencji Klimatycznej) i Krajowe Centrum Inwentaryzacji Emisji (które stało się zalążkiem KOBIZE). Wdrażano instrumenty wspierające redukcję emisji nakierowanych m.in. na zwiększanie efektywności energetycznej. Działania te przyniosły oczekiwane efekty, w latach 1991-2003 emisja GHG w Polsce zmniejszyła się o ponad $50 \mathrm{Gg} \mathrm{CO}_{2 \mathrm{eq}}$ (KOBIZE 2016, 27). To okres, w którym waga zrównoważonego rozwoju była znaczna, czego dowodem jest jego uwzględnienie, jako podstawy działań w zakresie ochrony środowiska, w art. 5 przyjętej w 1997 roku Konstytucji RP.

Symbolicznym zakończeniem tego okresu była ratyfikacja Protokołu z Kioto (w 2002 roku) oraz przyjęcie przez Radę Ministrów w październiku 2003 roku dokumentu: Polityka Klimatyczna Polski. Strategie redukcji emisji gazów cieplarnianych w Polsce do roku 2020 (MŚ 2003). Dzięki współpracy organizacji ekologicznych z resortem środowiska przy tworzeniu Polityki Klimatycznej oparto ten dokument na idei zrównoważonego rozwoju, a w celach ochrony klimatu dostrzeżono szansę: „celem polityki klimatycznej jest włączenie się Polski do wysiłków

1 Warto odnotować, że Ramowa Konwencja NZ w sprawie Zmiany Klimatu podpisana została dopiero rok później. 
społeczności międzynarodowej na rzecz ochrony klimatu globalnego poprzez wdrażanie zasad zrównoważonego rozwoju (...) w sposób zapewniający osiągnięcie maksymalnych, długoterminowych korzyści gospodarczych, społecznych i politycznych" (MŚ 2003, 13). Umożliwiło to przyjęcie ambitnego celu: "Jak wykazały analizy i badania (...) redukcję około 30\% emisji gazów cieplarnianych (względem roku bazowego 1988) osiąga się bez wdrażania dodatkowej polityki klimatycznej do roku 2010. Dlatego też celem ilościowym prezentowanej polityki klimatycznej jest pogłębienie skali redukcji emisji gazów cieplarnianych do poziomu 40\% do roku 2020" (MŚ 2003, 14).

Analizując pierwszy okres kształtowania się polskiej polityki klimatycznej, można stwierdzić, że cele tej polityki nie budziły wówczas zasadniczych kontrowersji. W dużym stopniu było to spowodowane poważnym traktowaniem paradygmatu zrównoważonego rozwoju i przyjęciem, że wzrost społeczno-gospodarczy nie może odbywać się kosztem środowiska przyrodniczego. Szczególnie wyraźne było to w pierwszej połowie lat 90., gdy pomimo rosnącego bezrobocia akceptowano zamykanie i ograniczanie produkcji zakładów wywierających nadmierną presję na środowisko. W drugiej połowie tej dekady zaczęło jednak dominować zmęczenie procesem transformacji, rozpoczęto wówczas przeciwstawiać cele zrównoważonego rozwoju bieżącym potrzebom. Na początku XXI wieku przedłużająca się transformacja doprowadziła do zawężenia horyzontu czasowego podejmowanych decyzji politycznych, a rosnąca rywalizacja polityczna jeszcze bardziej spolaryzowała stanowiska wobec potrzeby i możliwości wdrażania w Polsce zasad zrównoważonego rozwoju. W ten sposób ujawniła się cecha systemu demokratycznego niekorzystna dla ekorozwoju -- dominacja politycznych, krótkookresowych interesów, nad długookresowymi korzyściami społecznymi i przyrodniczymi (Kozłowski 2000, 77). Niekorzystnie wpłynęło to także na politykę klimatyczną.

\section{Europeizacja polskiej polityki klimatycznej. Lata 2004-2014}

Wkrótce po przyjęciu Polityki Klimatycznej okazało się, że brak jest woli politycznej dla wdrażania jej celów. Było to spowodowane pogłębiającym się sceptycyzmem wobec zrównoważonego rozwoju i chęcią utrzymania gospodarczego status quo - obrony polskich przedsiębiorstw 
przed konkurencją z innych krajów unijnych. Polityka klimatyczna stała się także zakładnikiem coraz brutalniejszej rywalizacji politycznej.

Dostosowanie się Polski do wymagań środowiskowych Unii Europejskiej wymagało gigantycznego wysiłku: legislacyjnego, organizacyjnego i finansowego. Szacowano, że koszt wdrożenia nowych wymagań wyniesie od 80 do niemal 160 miliardów zł (Indra 2000, 38). W rzeczywistości, koszty te okazały się jeszcze wyższe, tylko na wdrożenie wymagań Dyrektywy Rady 91/271/EWG dotyczącej oczyszczania ścieków komunalnych wydano ponad 56 miliardów zł (Brodziński 2015, 4). Stało się to powodem negowania potrzeby i sensowności działań na rzecz ochrony środowiska. Ponieważ w 2003 roku UE przyjęła dyrektywę 2003/87/WE ustanawiającą europejski system handlu uprawnieniami do emisji gazów cieplarnianych (EU ETS), krytyka dotknęła także politykę klimatyczną.

Pierwszy konflikt wokół polityki klimatycznej wybuchł pod koniec 2004 roku, kiedy Ministerstwo Środowiska zatwierdziło projekt I Krajowego Planu Rozdziału Uprawnień do Emisji (I KPRU), przyznając krajowym podmiotom objętym EU ETS ponad 286 mln uprawnień rocznie, podczas gdy ich średnioroczna emisja w latach 1999-2002 wynosiła 219,8 mln $\mathrm{Mg} \mathrm{CO}_{2}$ (MŚ 2004, 27). Komisja Europejska uznała to za nieuprawnioną pomoc publiczną i w marcu 2005 roku podjęła decyzję o zmniejszeniu liczby uprawnień dla Polski o niemal $50 \mathrm{mln} \mathrm{Mg}$ (do $239 \mathrm{Mg} \mathrm{CO}_{2} /$ rok). Opóźnienie przyjęcia I KPRU spowodowało, że polskie przedsiębiorstwa nie sprzedawały nadwyżki uprawnień, gdy ich ceny były najwyższe (Karaczun 2010,114).

Proces tworzenia I KPRU doprowadził do istotnej zmiany w podejściu do idei zrównoważonego rozwoju i ochrony klimatu. Podczas gdy punktem wyjścia Polityki Klimatycznej Polski była chęć budowy bezpieczeństwa ekologicznego dla przyszłych pokoleń, to w I KPRU uznano, że potrzeba ochrony klimatu nie może stanowić ograniczenia dla wzrostu gospodarczego. Resort środowiska nawet nie podjął próby wprowadzenia regulacji, które wymuszałyby niskoemisyjną transformację polskiej energetyki. Zamiast tego zredefiniowano pojęcie zrównoważonego rozwoju, uznając jedynie, że jest to równoważenie potrzeb społecznych, gospodarczych i przyrodniczych. W podejściu tym traciła na znaczeniu konieczność utrzymania stabilności systemu przyrodniczego, rozumia- 
na jako potrzeba dostosowania zakresu korzystania ze środowiska do jego pojemności ekologicznej. Przestawał się liczyć interes przyszłych generacji, dominujące znaczenie miał interes bieżący i wzrost gospodarczy. Umożliwiło to uniknięcie zmian w energetyce węglowej.

Z nową siłą konflikt wybuchł, gdy Komisja Europejska zaproponowała sposób rozdziału uprawnień na emisję po 2012 roku - tzw. I Pakiet energetyczno-klimatyczny UE. Pakiet w imieniu Polski podpisał w marcu 2007 roku prezydent Lech Kaczyński. Nie wzbudziło to zainteresowania, nie przeprowadzono debaty, brak było reakcji biznesu. Resort środowiska zlekceważył prowadzone od marca 2007 roku negocjacje dotyczące instrumentarium Pakietu. Dlatego też Polska nie wpłynęła na kształt tworzonych regulacji, refleksja, że mogą one mieć znaczący wpływ na gospodarkę przyszła dopiero w 2008 roku, kiedy opublikowany został tzw. Raport 2030 (EnergSys 2008). Dokument, opracowany na zlecenie Polskiego Komitetu Energii Elektrycznej, prognozował, że wdrożenie celów Pakietu spowoduje wzrost cen energii o 100\%, wzrost bezrobocia, gwałtowne załamanie rozwoju gospodarczego i spadek PKB. Pomimo tego, że zawierał on nieścisłości i uproszczenia (IBnGR 2008), a rzeczywistość nie potwierdziła katastrofalnych prognoz, Raport 2030 trwale wpłynął na sposób podejścia w Polsce do polityki klimatycznej. Ugruntował przekonanie dużej części polityków, że cele UE są zbyt restrykcyjne, nie uwzględniają specyfiki i uzależnienia Polski od węgla. Pozwoliło to głosić tezę, że ochrona klimatu nie jest polityką zrównoważonego rozwoju, a stała się „religią klimatyczną” (Nowa religia klimatyczna 2011). Z takiej pozycji możliwa i dopuszczalna stała się krytyka Ojca Świętego Franciszka za jego progresywne podejście do kwestii klimatycznych w encyklice Laudato Si' (PrisonPlanet.com 2015).

Spowodowało to osamotnienie Polski w ramach Unii. Nie potrafiąc zdefiniować swoich interesów inaczej niż przez obronę węglowej energetyki i przedstawić alternatywnej propozycji, której wdrożenie nie naruszałoby funkcjonowania wspólnego rynku i nie redukowało ambicji klimatycznych UE, polscy negocjatorzy trzykrotnie musieli zgłosić weto wobec planów Komisji Europejskiej dotyczących rozwoju polityki klimatycznej. Brakowało zrozumienia, że ochrona klimatu stała się integralnym elementem całościowej polityki Unii w zakresie rozwoju, a przepisy jej dotyczące muszą mieć szeroki i jednolity charakter. Sze- 
roki, bo redukcja emisji wymagana jest w każdym sektorze gospodarki i większości dziedzin życia człowieka. Jednolity, bo - wpływając na konkurencyjność podmiotów gospodarczych - normy prawne muszą mieć jednolity charakter we wszystkich krajach Unii. Zabrakło też refleksji moralnej i etycznej wskazującej na odpowiedzialność krajowej polityki wobec społeczeństw najbardziej zagrożonych skutkami zmian klimatu i wobec przyszłych pokoleń.

Próby blokowania rozwoju europejskiej polityki klimatycznej okazały się nieskuteczne. Komisja Europejska proponowała inne sposoby wdrażania zawetowanych rozwiązań, pracowała także nad nowymi celami. 22 stycznia 2014 roku przedstawiła założenia Pakietu energetyczno-klimatycznego 2030: 40\% redukcja emisji gazów cieplarnianych oraz zwiększenie udziału energii ze źródeł odnawialnych w energii finalnej do $27 \%$. Prezentując te cele, przewodniczący Komisji Europejskiej odwołał się do ekorozwojowych korzeni polityki klimatycznej: „Działania na rzecz ochrony klimatu są kluczowe dla przyszłości naszej planety, podczas gdy polityka energetyczna jest kluczowa dla naszej konkurencyjności" (Barroso 2014, 3).

Choć nie brakowało wówczas w Polsce bardzo krytycznych ocen tej propozycji i jej wpływu na krajową gospodarkę (wPolityce.pl 2015), to tym razem rząd postanowił podejść do problemu konstruktywnie. Rozpoczęto analizy wpływu podwyższenia celów klimatyczno-energetycznych na stan polskiej gospodarki oraz możliwości zastosowania mechanizmów kompensujących wysokie koszty redukcji emisji. Powołano Centrum Analiz Klimatycznych - forum współpracy Ministerstwa Gospodarki, Środowiska i Finansów z Bankiem Światowym, na poziomie wiceministrów gospodarki, środowiska, spraw zagranicznych, finansów, skarbu państwa, infrastruktury i rozwoju oraz rolnictwa i rozwoju wsi stworzono nieformalny zespół, którego celem było zapewnienie pełnej koordynacji stanowisk poszczególnych resortów wobec propozycji UE (Tomczykiewicz 2014). Prace te pozwoliły na określenie zakresu kompromisu, a w efekcie na poparcie przez Polskę celów Pakietu energetyczno-klimatycznego 2030. 


\section{Polityka klimatyczna po 2015 roku}

Zaakceptowanie celów Pakietu 2030 niosło nadzieję, że krajowa polityka klimatyczna ponownie oprze się na idei zrównoważonego rozwoju. Byłoby to racjonalne, dzięki temu mogłaby się ona stać bodźcem wspierającym rozwój w Polsce innowacyjnych sektorów gospodarki i społeczeństwa wiedzy oraz zmniejszającym presję gospodarki na środowisko. Dzięki funduszom UE możliwa stała się niskoemisyjna modernizacja energetyki i gospodarki. Posiadając znakomicie rozwinięty rynek technologii IT i telekomunikacyjnych, Polska mogła stać się istotnym dostawcą rozwiązań niskoemisyjnych. Nadzieję na zmianę wzmacniało poparcie przez Polskę stanowiska negocjacyjnego UE na Konferencję Stron Konwencji Klimatycznej w Paryżu w grudniu 2015 roku (COP21) i podpisanie Porozumienia Paryskiego wynegocjowanego w trakcie tej Konferencji.

Nie jest jednak przesądzone, że szansa zostanie wykorzystana. Za sukces polskiej delegacji w trakcie COP21 uznano bowiem nie osiągnięcie porozumienia, ale zamianę w jego tekście pojęcia „dekarbonizacja” na „neutralność klimatyczną" (BiznesAlert.pl 2015). Od tej chwili Ministerstwo Środowiska konsekwentnie przeciwstawia europejską politykę klimatyczną zobowiązaniom międzynarodowym. W wydanym w 2017 roku komunikacie stwierdzono m.in. „przyjęty w roku 2008 pakiet klimatyczno-energetyczny, nastawiony jedynie na dekarbonizację atmosfery poprzez redukcję emisji CO2 w wybranych działach produkcji (...) był sprzeczny z ideą Konwencji klimatycznej i protokołem $z$ Kioto. Blokował polskie zasoby energetyczne w postaci wegla (...) i uzależniał Polske od obcych źródeł energii i obcych technologii" (mos.gov.pl 2017).

Tak silne przeciwstawienie polityki unijnej, nastawionej na redukcję emisji gazów cieplarnianych i odchodzenie od paliw kopalnych, działaniom międzynarodowym, które w opinii resortu środowiska tego nie wymagają, może świadczyć o powrocie do traktowania zrównoważonego rozwoju w sposób zawężający. Dlatego niepokojącym sygnałem, zdającym się potwierdzać tezę o malejącej wadze idei zrównoważonego rozwoju w decyzjach politycznych i gospodarczych, jest wycofanie się obecnego rządu z rozwoju energetyki prosumenckiej, zablokowanie rozwoju energetyki wiatrowej i zawieszenie prac nad Narodowym Programem Rozwoju Gospodarki Niskoemisyjnej (MG 2015). 


\section{Podsumowanie}

Polska jest krajem sukcesu klimatycznego. Po 1989 roku emisja gazów cieplarnianych zmniejszyła się o około 30\%, a dochód narodowy wzrósł ponad dwukrotnie. Przyjmując, że polityka klimatyczna jest w praktyce polityką zrównoważonego rozwoju, można by uznać, że nasz kraj rozwijał się w sposób zrównoważony. Jak wykazano w artykule jest to jednak obraz zbyt uproszczony. Podejście do zrównoważonego rozwoju na przestrzeni ostatniego ćwierćwiecza przeszło w Polsce znaczącą ewolucję. I niestety, nie była to ewolucja w dobrą stronę.

$\mathrm{W}$ pierwszych latach procesu transformacji gospodarczej działania na rzecz ochrony środowiska traktowane były jako niezbędny element modernizacji gospodarki i długofalowej, strategicznej wizji. Zrównoważony rozwój stał się podstawą polskiej polityki ekologicznej i zasadą konstytucyjną.

Podejście to zaczęło się zmieniać pod koniec lat 90., a po wejściu Polski do UE waga problematyki przyrodniczej ulegała znaczącemu ograniczaniu. Decyzje polityczne i gospodarcze miały przynosić korzyści krótkookresowe, a nie tworzyć bezpieczeństwo dla przyszłych pokoleń. Ochrona środowiska zaczęła być postrzegana jako bariera, a nie podstawa dla rozwoju społeczno-gospodarczego. Przykładami tego mogą być spór wokół przyjęcia Pakietu energetyczno-klimatycznego 2020 czy konflikt wokół budowy obwodnicy Augustowa i ochrony Doliny Rospudy.

Ewolucja pojęcia zrównoważonego rozwoju jest o tyle zaskakująca, że początek lat 90. to okres transformacji - politycznej i gospodarczej - a więc sytuacji, w której preferowane jest podejmowanie decyzji krótkookresowych. Jak się wydaje, progresywne podejście do zrównoważonego było wówczas możliwe dzięki niższemu upolitycznieniem życia społecznego. Dzięki temu rządzące na początku lat 90. ekipy starały się stworzyć trwały fundament rozwoju, skupiając się na konsekwentnym wdrażaniu długookresowej wizji, w mniejszym stopniu troszcząc się o realizację krótkookresowego interesu politycznego. Politycy zarządzający tymi zmianami ponieśli za to wysoką cenę, większość z nich po przegranych wyborach znikła $z$ życia politycznego. Ich miejsce zajęły nowe partie, które znacznie więcej uwagi zwracają na zapewnienie sobie reelekcji niż na realizację celów długookresowych. Skróciło to perspektywę podejmowanych decyzji do 4 lat, a interes przyszłych pokoleń przegrał z krótkoterminowym interesem wyborców. 
Ofiarą tej zmiany stała się także polityka klimatyczna. Gdy walka polityczna zaostrzyła się, potrzeba ochrony klimatu w interesie bezpieczeństwa kolejnych generacji przegrała z potrzebą uzyskania poparcia dobrze zorganizowanego lobby górniczego, związków zawodowych i pracowników sektora energetycznego. Interes społeczny (utrzymanie miejsc pracy w górnictwie węglowym) i gospodarczy (niedokonywanie modernizacji sektora energetycznego) przeważył nad potrzebą ochrony środowiska. Można więc postawić tezę, że polska polityka klimatyczna nie jest obecnie polityką zrównoważonego rozwoju.

Po przystąpieniu do UE jedynym środowiskiem, które konsekwentnie domagało się wdrażania polityki klimatycznej zgodnie z zasadami zrównoważonego rozwoju, były organizacje pozarządowe. Niestety, pomimo ich wysiłków, w publicznej debacie kwestia ochrony klimatu praktycznie nie istnieje. Podobnie jest z pojęciem „rozwój zrównoważony”. Powoduje to, że krótkookresowe interesy gospodarcze i polityczne dominują nad potrzebą utrzymania stabilności systemu ekologicznego. Jest to niebezpieczne, nie tylko dlatego, że zatrzymanie zmiany klimatu wymaga odrzucenia paradygmatu priorytetu wzrostu gospodarczego nad celami środowiskowymi i oparcia rozwoju na rozwiązaniach niskoemisyjnych czy dlatego, że - opierając swój rozwój na paliwach kopalnych - Polska może pozostać na obrzeżu głównego nurtu globalnej gospodarki. Głównym zagrożeniem jest pogorszenie jakości życia w naszym kraju. Już dziś zanieczyszczenie powietrza powoduje rocznie przedwczesną śmierć ok. 50 tys. mieszkańców naszego kraju (EEA 2016, 60). Odrzucenie potrzeby działań na rzecz ochrony klimatu w interesie nie tylko obecnego, ale także przyszłych pokoleń i utrzymywanie niezreformowanej polskiej energetyki, będzie ten problem jeszcze bardziej pogłębiać.

\section{Bibliografia:}

Barroso, Jose. 2014. Statement by President Barroso on the 2030 Energy and Climate Framework. Press conference with Commissioners Oettinger and Hedegaard. Brussels, 22 January 2014. Dostęp: 18.01.2017. http://europa.eu/rapid/press-release_SPEECH-14-50_en.htm.

BiznesAlert.pl. 2015. Szydło: Polska odniosła sukces w Paryżu. Dostęp: 13.12.2017. http://biznesalert.pl/szydlo-polska-odniosla-sukces-w-paryzu/. 
Brodziński, Sławomir. 2015. Odpowiedź Podsekretarza Stanu w Ministerstwie Srodowiska, Głównego Geologa Kraju, Sławomira Brodzińskiego na interpelację posła Macieja Orzechowskiego w sprawie wdrożenia przepisów dyrektywy dotyczącej oczyszczania ścieków komunalnych 22.05.2015.

EEA. 2016. Air quality in Europe. Luxembourg: Publications Office of the European Union.

EnergSys. 2008. Wpływ proponowanych regulacji unijnych $w$ zakresie wprowadzenia europejskiej strategii rozwoju energetyki wolnej od emisji CO2 na bezpieczeństwo energetyczne Polski, a w szczególności możliwości odbudowy mocy wytwórczych wykorzystujacych paliwa kopalne oraz poziom cen energii elektrycznej. Warszawa: EnergSys Sp. z o.o.

IBnGR. 2008. Ewaluacja RAPORTU 2030. „Wpływ proponowanych regulacji unijnych $w$ zakresie wprowadzania europejskich strategii rozwoju energetyki wolnej od emisji CO2 na bezpieczeństwo energetyczne Polski, a w szczególności możliwości odbudowy mocy wytwórczych wykorzystujacych paliwa kopalne oraz poziom cen energii elektrycznej”. Warszawa: Instytut Badań nad Gospodarką Rynkową.

Indra, Sebastian. 2000. Negocjacje akcesyjne w obszarze „środowisko naturalne”. W: Materiały sympozjum Warsztaty 2000 nt. „Zagrożenia naturalne w górnictwie" (Ustroń Śl., 29-31maja 2000 Polska Akademia Nauk), red. Elżbieta Pilecka, 37-43. Ustroń Śl.: Instytut Gospodarki Surowcami Mineralnymi i Energią, Wyższy Urząd Górniczy.

Karaczun, Zbigniew. 2010. Ewolucja polityki klimatycznej Polski w latach 1988-2010. W: Zmiany klimatu a społeczeństwo, red. Leszek Karski i Irena Grochowska, 105-121. Warszawa: Wyd. C.H. Beck.

KOBIZE. 2016. Krajowy raport inwentaryzacyjny 2016. Inwentaryzacja gazów cieplarnianych w Polsce dla lat 1988-2014. Raport wykonany na potrzeby Ramowej konwencji Narodów Zjednoczonych w sprawie zmian klimatu oraz Protokołu z Kioto. Warszawa: Wyd. IOŚ-KOBIZE.

Kozłowski, Stefan. 2000. Ekorozwój. Wyzwanie XXI wieku. Warszawa: PWN.

Mastalerz, Przemysław. [brw]. Dwie przeciwko milionom, czyli krótkie argumenty przeciwko szkodliwym mitom ekologicznym. Dostęp: 6.02.2017. http://www.chemia.org/id21.html. 
MG. 2015. Projekt dokumentu: Narodowy Program Rozwoju Gospodarki Niskoemisyjnej. Projekt przyjęty Kierownictwo Ministerstwa Gospodarki $w$ dniu 4 sierpnia 2015. Warszawa: MG.

Mos.gov.pl. 2017. Przegląd resortu środowiska 6.02.2017. Dostęp: 13.02.2017. https://www.mos.gov.pl/aktualnosci/szczegoly/news/przeglad-resortu-srodowiska/.

MOŚiZN. 1991. I Polityka Ekologiczna Państwa. Warszawa: Ministerstwo Ochrony Środowiska i Zasobów Naturalnych.

MŚ. 2003. Polityka Klimatyczna Polski. Strategie redukcji emisji gazów cieplarnianych $w$ Polsce do 2020 roku. Dokument przyjęty przez Radę Ministrów w dniu 4 października 2003 r. Warszawa: Ministerstwo Środowiska.

MŚ. 2004. I Krajowy Plan Rozdziału Uprawnień do Emisji. Warszawa: Ministerstwo Środowiska.

Nowa religia klimatyczna. Wywiad $z$ Jarosławem Grzesikiem, przewodniczącym delegacji Solidarności na szczycie klimatycznym w Durbanie 28.12.2011. 2011. Dostęp: 12.02.2017. http://www.mpolska24.pl/ post/3807/nowa-religia-klimatyczna.

PrisonPlanet.com. 2015. Zielone szaleństwo owładnęło Watykanem. Papież wzywa do utworzenia Nowego Porządku Świata. Dostęp: 12.02.2017. http://www.prisonplanet.pl/polityka/zielone_szalestwo,p590985101.

The Climategate e-mails, red. John Costella. 2010. Melbourne: The Lavoisier Group.

Tomczykiewicz, Tomasz. 2014. Odpowiedź Tomasza Tomczykiewicza sekretarza stanu w Ministerstwie Gospodarki na interpelacje posłów Piotra Chmielowskiego i Adama Kępińskiego w sprawie formułowania celów polityki energetycznej Polski do 2030 r. (Warszawa, dnia 24 marca 2014). Dostęp: 28.12.2016. http://www.sejm.gov.pl/Sejm7.nsf/InterpelacjaTresc.xsp?key=306446D1.

Wang, James i Michael Oppenheimer. 2005. The Latest Myths and Facts on Global Warming. New York: Defense Fund. 
WPolityce.pl. 2015. Pakiet klimatyczny zagrożeniem dla Polski. Do 2030 roku będziemy musieli zamknać wszystkie elektrownie węglowe. Dostęp: 23.01.2017. http://wpolityce.pl/gospodarka/230556pakiet-klimatyczny-zagrozeniem-dla-polski-do-2030-roku-bedziemymusieli-zamknac-wszystkie-elektrownie-weglowe. 


\section{CZĘŚĆ II \\ EPISTEMOLOGICZNE ASPEKTY ZRÓWNOWAŻONEGO ROZWOJU}



Andrzej Papuziński

Uniwersytet Kazimierza Wielkiego w Bydgoszczy

papuzin@ukw.edu.pl

\section{Filozofia Raportu Brundtland}

\section{Wstęp}

Raport Brundtland (Raport Komisji Brundtland; dalej: Raport) to potoczna nazwa raportu pt. Nasza wspólna przyszłość, opracowanego przez Światową Komisję do spraw Środowiska i Rozwoju (dalej: Komisja), którą kierowała norweska polityk Gro Harlem Brundtland. Komisja została powołana przez Zgromadzenie Ogólne Narodów Zjednoczonych rezolucją 38/161 przyjętą na 38. sesji jesienią $1983 \mathrm{r}$. Utworzono ją w celu przygotowania długookresowej strategii nieprzerwanego rozwoju dotyczącej środowiska oraz zaproponowania sposobów rozszerzenia współpracy międzynarodowej w zakresie środowiska na inne sfery, z uwzględnieniem zależności, które łączą środowisko, zasoby, ludzi i rozwój. Przygotowanie tej strategii - znanej dziś jako strategia zrównoważonego rozwoju - zajęło Komisji cztery lata. Wyniki zostały ogłoszone 20 marca 1987 r. W ciągu trzydziestu lat od ogłoszenia Raportu zrównoważony rozwój (dalej: ZR) stał się ważną częścią polityki światowej, procesów integracji międzynarodowej (np. traktaty Unii Europejskiej), stosunków bi- i multilateralnych sąsiadujących ze sobą krajów oraz polityki wewnętrznej wielu państw.

\section{Spór o sens ZR}

Mimo szerokiego uznania, program ZR bywa przedmiotem kontestacji. Włodzimierz Tyburski zwraca uwagę na to, że wywołuje on „także krytyczne odniesienia wśród badaczy kwestionujących samą ideę lub podważających przynajmniej niektóre jej założenia” (Tyburski 2011, 15).W skazuje na trzy nurty tej krytyki. Jeden jest wyrazem reakcji zwolenników modeli wzrostu gospodarczego, przeciwko którym idea ZR została skierowana. Dla obrońców status quo idea ZR posuwa się za daleko w sprawach, które wymagają ich zdaniem niewielkich korekt. Na przekór temu, drugi nurt krytyki dotyczy nadmiernie zachowawczej 
specyfiki kierunków działań wskazywanych przez tę ideę. Trzeci podnosi sprawę arbitralnego charakteru wpisanych w nią celów.

Chociaż wymienione nurty krytyki idei ZR tępią ostrza ocen w ogniu sprzecznych zarzutów, nie powinno się nad nimi przechodzić do porządku dziennego. Wielość istniejących obecnie koncepcji i teorii, na które została rozpisana wyjściowa idea $\mathrm{ZR}$, a także różnice, jakie między nimi zachodzą, pozwalają przypuszczać, że każda z tych krytyk znajduje potwierdzenie. Różnorodność możliwych interpretacji idei jest ceną, która nieubłaganie towarzyszy procesowi obiektywizacji idei na drodze przechodzenia od tego, co jednostkowe i wewnętrzne, do tego, co powszechne i zewnętrzne. Mechanizm mnożenia tych interpretacji można opisać, traktując jako punkt wyjścia heglowski wywód na temat obiektywizacji idei (Hegel 1994, 47-48, 52, 64, 455, 488). Idea jest totalnością myśli, w jej naturze leży rozwój, poprzez który ujmuje siebie i na końcu procesu społecznej obiektywizacji staje się tym, czym jest od początku sama w sobie. W momencie narodzin jest zaprzeczeniem bytu społecznego. Dlatego jej treść jest jednocześnie abstrakcyjna i konkretna. Musi być uboga pod względem formy, ale jako jedność odróżnionych określeń negacji tego, co w świecie społecznym istnieje, pozostaje konkretem sama w sobie. Jak wywodził Georg W. F. Hegel, człowiek „myśli myśl”: idea wyrażona w mowie staje się „czymś” dla człowieka tylko pod tym warunkiem, że „uprzedmiotowi się” w jego świadomości, stając się w ten sposób przedmiotem jego myślenia. Tak jak twórca idei, również jej odbiorca „zapośrednicza” swoje myślenie, czyli odnosi je do przedmiotu, który staje się treścią tego myślenia. Wychodząc poza heglowski styl wypowiedzi, należy zauważyć, że owym przedmiotem jest taki zobiektywizowany społeczny konstrukt świadomości zbiorowej, jak problem społeczny, który nurtuje odbiorcę idei. Jest to ten sam problem społeczny, który jest istotny dla twórcy idei, ale już np. wdziany nie z tej samej strony, pod innym kątem lub nie z taką samą jak dla niego wagą. Obiektywizująca się idea jest zestawiana lub nawet zderzana z różnymi aspektami, stronami i poziomami problemu społecznego, którego dotyczy. Przedstawiony mechanizm jest mechanizmem konkretyzacji treści idei w świadomości jej odbiorcy w formie jednego z właściwych jej określeń. Uruchamia się w chwili, w której idea przekracza próg subiek- 
tywnych zamysłów jej twórcy i staje się własnością publiczną. W fazie kulminacyjnej jego działania partykularne określenia wpadają w dialektyczny wir dyskusji, który je porywa i wplata w krąg syntetyzującego ujęcia akceptowalnego rozwiązania problemu. W rezultacie wszystkie określenia idei powracają do pierwotnej jedności, w której byt jest już jednak tożsamy z pojęciem, na gruncie rozumnej organizacji życia społecznego i politycznego. Są oczekiwaną i ostateczną postacią działania mechanizmu uprzedmiotawiania idei.

Może się to wydać zaskakujące, ale stanowisko Hegla znajduje potwierdzenie w ramach fenomenologicznej teorii intencjonalności poznania. Podkreślana przez Edmunda Husserla aktywność świadomości w stosunku do przedmiotu myślenia od innej strony prowadzi do opisu tego samego różnicującego mechanizmu obiektywizacji idei. Charakterystyka intencjonalności wskazuje, że nadawanie znaczenia, analogizujące unaocznianie itd. są takimi typami „przeżyć intencjonalnych, które mogą być przyporządkowane każdemu dowolnie pomyślanemu przedmiotowi (...) i różnicują się w całej swej budowie noetyczno-noematycznej, gdy tylko uszczegółowienia doznaje utrzymywana w nieokreśloności ogólność przedmiotu intencjonalnego" (Husserl 1982, 73-74) ${ }^{1}$.

Ze względu na nieuniknione następstwa procesu obiektywizacji idei w sferze publicznej, oceny i dyskusje na temat idei ZR są permanentnie narażone na uleganie Baconowskim złudzeniom jaskini i rynku. Wyniki mogą być zniekształcone tak przez tradycję, doświadczenia historyczne i przesądy cechujące środowiska, z których pochodzą uczestnicy debaty, jak przez odmienne znaczenia nadawane w związku $\mathrm{z}$ tym przez nich kluczowym pojęciom języka polemiki. Michael R. Redclift podniósł tę sprawę już jakieś dziesięć lat temu: „Od czasów pionierskich rozważań Komisji Brundtland, wyrażenie «zrównoważony rozwój» było stosowane na różne sposoby, w zależności czy używano go w kontekście akademickim, planowania, biznesu czy polityki środowiskowej. W wyniku tego, w ciągu ostatnich dwudziestu lat mogliśmy spotkać się z kilkoma dyskusjami na temat zrównoważonego rozwoju, z których część wzajemnie się wyklucza” (Redclift 2009, 34).

\footnotetext{
${ }^{1}$ Noeza to akt świadomościowy, a noemat to przedmiot owego aktu świadomości.
} 
W innym kontekście na omawiany tu problem zwrócił uwagę Michael Walzer, postulując potrzebę rozróżnienia thin and thick ethics, etyki „rzadkiej” i „gęstej”, nienasyconej i nasyconej treścią. Pojęcia moralne - twierdzi amerykański filozof - „mają swoje minimalne i maksymalne znaczenia. Zazwyczaj umiemy podać ich rozmyte i gęste wyjaśnienia i te dwa sposoby rozumienia są odpowiednie w różnych kontekstach, służą innym celom" (Walzer 2012, 16).Chociaż pomiędzy nimi nie zachodzi sprzeczność, jako że „minimalistyczne znaczenia są zakorzenione w maksymalistycznej moralności" (Walzer 2012, 16), w omawianym przypadku rozbieżności pojawiają się na etapie przejścia od minimalistycznej w istocie idei ZR do maksymalistycznych interpretacji tej idei, zapisanych w koncepcjach i teoriach ZR. Wtedy dochodzą bowiem do głosu takie czy inne okoliczności społeczne i historyczne.

Przedstawiony wywód na temat rozbieżności w interpretacji idei sustainable development $\mathrm{i}$ ich przyczyn prowadzi do wniosku w kwestii właściwego poziomu analizy koncepcji i teorii będących jej rozwinięciem. Mówi on o tym, że istotną sprawą $\mathrm{w}$ dyskusji na temat ZR jest zejście $\mathrm{z}$ debatą do możliwie najniższego poziomu dyskursu, na którym będzie się miało na względzie wytwór pracy identyfikowalnego autora. Powyższy wniosek stanowi uzasadnienie próby opisania filozofii ZR zaprezentowanej tylko w jednym opracowaniu, wspomnianym Raporcie Brundtland.

\section{Filozoficzny poziom dyskursu na temat ZR}

Za Oksfordzkim słownikiem filozoficznym wieloznaczne pojęcie dyskursu można zdefiniować jako zespół norm rządzących strumieniem mowy na temat danego przedmiotu wypowiedzi, tj. rządzących jego wytworami, jak np. narracja lub argument (Blackbourn 1997, 96). Jednym $z$ rodzajów tak rozumianego dyskursu jest dyskurs filozoficzny, prowadzony na gruncie przyjętych w nim założeń.

Niezależnie od różnic, jakie występują między pracami poświęconymi założeniom ZR, łączy je myśl o istnieniu filozofii ZR. Ich autorzy wspólnie przyjmują, jak to ujmuje Zbigniew Hull, że na filozofię ZR składają się „idee wiodące i naczelne wartości programów czy polityk rozwoju zrównoważonego - świadomie bądź implicite (najczęściej) założone, przekonania ontologiczne, aksjologiczne i historiozoficzne 
determinujące sposób jego rozumienia i wyznaczające jego cele" (Hull 2003, 17). Zdaniem Hulla można ją zrekonstruować, stawiając pytania, które dotyczą założeń na temat: sposobu pojmowania przyrody i miejsca zajmowanego w niej przez człowieka; rozumienia człowieka i tworzonego przezeń świata społecznego; prezentowanego sposobu myślenia o interakcjach i związkach człowieka z przyrodą; uznawanych i postulowanych wartości oraz celów życiowych ludzi i roztaczanych wizji rozwoju społeczno-gospodarczego; sposobu pojmowania gospodarki oraz roli technologii w określaniu relacji człowieka $\mathrm{z}$ biosferą (Hull 2011, 70-71). Same założenia muszą natomiast dotyczyć szeroko rozumianej problematyki filozoficznej, tak jak jest ona rozdzielona między różne działy filozofii.

Autorzy, którzy przyjmują tezę o istnieniu filozofii ZR w przedstawionym sensie, zgadzają się również z twierdzeniem mówiącym o istnieniu teorii ZR, nawet gdy nie stosują tej kategorii. Przedstawiona teza $\mathrm{w}$ kwestii teoretycznego poziomu dyskursu na temat ZR w filozofii ZR jest uzasadniona przez funkcje, jakie pełnią przyjęte $w$ niej założenia. Mianowicie, są one czymś więcej niż tylko podstawą innych twierdzeń jako ich konieczne warunki, ponieważ są także normami, które decydują o ładzie panującym w ich obrębie. Pozwalają więc nie tylko na uzasadnienie danego konkretnego twierdzenia, ale ponadto prowadzą do wyznaczenia jego miejsca w strukturze pozostałych tez, składających się razem na dane stanowisko. Tym samym spełniają warunki minimalne, jakie John Rawls nałożył na teorię, wyraźnie odróżniając to, co jest teorią, od tego, co jest tylko koncepcją lub zaledwie ideą. Zdaniem Rawlsa, idea jest jedynie ogólnym przekonaniem o możliwościach (lub naturalnych koniecznościach, zgodnie z koncepcją uprawnień naturalnych) życia człowieka, występującym w formie poglądu na temat właściwego kierunku i słusznego celu ludzkiego życia. Mając na uwadze dyskurs, można na tej podstawie powiedzieć, że normy przynależne do tego poziomu dyskursu ogólnie wskazują kierunek działania skoncentrowanego na celu. Natomiast koncepcja to - według amerykańskiego filozofa - zbiór powiązanych ze sobą zasad określających (konkretyzujących) ideę. Z punktu widzenia dyskursu znaczy to tyle, że na tym kolejnym poziomie dyskursu dochodzą normy uwzględniające 
zasady sposobów osiągnięcia celu. Dołączenie do dyskursu przesłanek, które uzasadniają owe zasady oraz wyznaczają ich wagi w sytuacjach konfliktu, przenosi go na poziom teorii. Teoria jest więc koncepcją wzbogaconą o opis roli jej własnych zasad w określaniu tego, co ukazuje idea leżąca u podłoża owej koncepcji. Jako najwyższa forma dyskursu, zawiera normy mówiące nie tylko o tym, do jakich zasad należy się odwołać, aby osiągnąć cel, ale też dlaczego należy się posłużyć właśnie takimi, a nie innymi zasadami i dlaczego jednym $\mathrm{z}$ nich przysługuje pierwszeństwo przed innymi w danej sytuacji, do określonego momentu czy miejsca (Rawls, 2009, 38-42).

W literaturze przedmiotu niejednokrotnie pojawia się teza, że o ZR należy mówić, poczynając od Konferencji Sztokholmskiej z 1972 r. Jeśli przyjąć ją za dobrą monetę, to tylko pod tym warunkiem, że wykorzystując Rawlsowskie rozróżnienia - będzie się miało na uwadze jeszcze podówczas mglistą ideę ochrony zasobów naturalnych dla przyszłych pokoleń. Bo pierwsza teoria ZR została przedstawiona dopiero w Raporcie. Na kartach tego długiego, w wydaniu polskim liczącego blisko pięćset stron, dokumentu zostały przedstawione liczne zasady ZR, dzięki którym idea ZR przekształca się w koncepcję. Na ogół mają kształt reguł praktycznego działania w sferze stosunków międzynarodowych oraz pracy rządów i są skierowane na rozwiązanie uwzględnionych w dokumencie problemów globalnych w imię trwałości rozwoju społecznego i wzrostu gospodarczego oraz ochrony środowiska. Są to reguły nakładające obowiązki prima facie ${ }^{2}$.W śród norm wymienionych $\mathrm{w}$ omawianym raporcie odrębna specyfika wyróżnia tzw. zasadę ZR. Jest to zasada sprawiedliwości wewnątrz- i międzypokoleniowej. To za sprawą tej reguły koncepcja ZR z Raportu awansuje do rangi teorii. Zasada sprawiedliwości odgrywa najważniejszą rolę w dziele określania wagi pozostałych zasad i nadawaniu im rang. Zgodnie $\mathrm{z}$ wpisanymi w tę zasadę normami dyskursu, w działaniach na rzecz ZR najwyższą wagę należy przywiązywać do takiego zaspokojenia potrzeb i słusznych aspiracji współcześnie żyjących ludzi, aby przyszłe pokolenia miały w tym względzie podobne możliwości.

${ }^{2}$ Obowiązek prima facie ma moc wiążącą pod warunkiem, że nie występują silniejsze moralne względy, które go zawieszają. 
O sposobie ich pojmowania, zwłaszcza potrzeb podstawowych, decyduje specyficzna mieszanka zasad sprawiedliwości, przede wszystkim zasady „Każdemu według potrzeb”, „Każdemu według jego zasług” i „Każdemu według jego stanu posiadania” (Acker-Widmaier 1999, 70). Kolejna norma wskazuje na pierwszeństwo starań o zaspokojenie potrzeb podstawowych przed troską o realizację pozostałych potrzeb i preferencji. Trzecia wskazuje na konieczność objęcia szczególną opieką ludzi biednych na świecie. Czwarta, zdecydowanie realistyczna, obliguje do uwzględnienia ograniczeń, jakie na możliwości zaspokojenia potrzeb bieżących i przyszłych są narzucane przez dzisiejszy stan techniki, organizację społeczeństw oraz możliwości biosfery w sferze absorbowania skutków działalności człowieka (ŚKŚR 1991, 27, 67). Piąta norma stanowi o tym, że każdy rząa (państwo) musi dostosować strategie i programy ZR do własnych warunków i potrzeb. Szósta, ściśle związana z poprzednią, zawiera regułę subsydiarności. Inne normy mają charakter szczegółowych wniosków, które zostały wyprowadzone $z$ informacji statystycznych na temat zniszczenia środowiska, nierównego rozkładu bogactwa na świecie, zadłużenia krajów rozwijających się, wzrostu liczby ludności w XX stuleciu i przewidywań w tym zakresie, migracji ze wsi do miast, wyczerpywania zasobów itd.

Powyższe uwagi prowadzą do wniosku, że sprawiedliwość jest najważniejszą normą filozoficznego dyskursu Raportu na temat ZR. Jest kardynalnym warunkiem tego rozwoju i głównym założeniem leżącym u podstaw wielu propozycji wdrażania go w życie, z którymi wystąpiła Komisja. Żaden adekwatny opis filozofii ZR Raportu nie może abstrahować od tego zagadnienia. Mając na względzie różne koncepcje i teorie ZR, należy przyjąć, że problem sprawiedliwości jest linią oddzielającą adekwatne próby rozwinięcia idei sustainable development od prób nadużywających tej nazwy. Jak trafnie zauważa Eugeniusz Kośmicki, ZR jest upolitycznioną odpowiedzią na ograniczenia consensusu sztokholmskiego z 1972 r., który zatopił kwestie sprawiedliwego globalnego rozwoju w toni rokowań na temat ochrony środowiska (Kośmicki 2007, 195-196). 


\section{Sprawiedliwość jako główne normatywne założenie Raportu ${ }^{3}$}

Ograniczony charakter dóbr, którymi dysponuje ludzkość, jest największą przeszkodą na drodze do równości wszystkich ludzi. Nierówny dostęp ludzi do zasobów został uznany w Raporcie za jedno z głównych źródeł zagrożeń dla niezakłóconego korzystania z zasobów (ŚKŚR 1991, 130) i przyczynę niesprawiedliwości w stosunkach międzynarodowych oraz między różnymi grupami ludzi. Sprawiedliwość jest najważniejszym jawnym założeniem teleologicznym tego dokumentu.

Co się rozumie w Raporcie przez sprawiedliwość? Zgodnie z elementarnym sensem tego pojęcia, sprawiedliwość występuje w Raporcie zarówno na płaszczyźnie rozważań o charakterze aksjologicznym, jak i deontologicznym. W pierwszym znaczeniu jest ważną wartością społeczną i polityczną, w drugim - kluczową kategorią normatywną. Innymi słowy, mówi o tym, co jest pożądane, oraz o tym, co jest obowiązkiem. Więcej trudności sprawia identyfikacja podejścia Komisji do tych

\footnotetext{
${ }^{3}$ Filozoficzne założenia teorii ZR już niejednokrotnie były przedmiotem uwagi polskich filozofów. Spośród publikacji na ten temat należy wyróżnić artykuł Leszka Gawora pt. Filozofia zrównoważonego rozwoju - preliminaria, który dotyczy wprost tego zagadnienia. Gawor szczegółowo przedstawił szereg tez filozoficznych wpisanych w różne dokumenty polityczne i opracowania na temat ZR, które - jak słusznie twierdzi - dają podstawy do mówienia o filozofii ZR. Inne teksty o filozofii ZR poruszają zagadnienie filozoficznych założeń teorii ZR pośrednio. Ich autorzy - Tadeusz Borys, Zbigniew Hull, Dariusz Liszewski, Zdzisława Piątek, Barbara Piontek, Adam Płachciak, Antoni Skowroński, Włodzimierz Tyburski, Włodzimierz Zięba oraz piszący te słowa - podejmowali kwestię filozoficznych założeń teorii ZR w bardzo różnych kontekstach. Niejednokrotnie chodzi o pewien projekt. W takim wypadku założenia były rekonstruowane na podstawie celów, jakie zostały wpisane w ten czy inny autorski koncept ZR. Siłą rzeczy przedmiotem uwagi były tylko założenia jednego typu, mianowicie takie, które składają się na wartości ZR. Opracowania tego rodzaju cechowało dążenie do możliwie pełnego określenia przesłanek aksjologicznych. Z kolei w studiach o charakterze opisowym i rekonstrukcyjnym problem założeń teorii ZR był postrzegany przez pryzmat różnych pierwszoplanowych zagadnień. Najczęściej chodziło o łady ZR i edukację. Pierwsze podejście prowadzi do koncentracji uwagi na założeniach leżących u podstaw społecznych, ekonomicznych lub środowiskowych aspektów teorii ZR. Drugie - do formułowania zbiorów wartości zgodnych z danym, historycznie i światopoglądowo określonym, systemem edukacyjnym i do przyjmowania założeń o charakterze pragmatycznym, mających wpływ na powodzenie działań wychowawczych. Niezależnie od tego, do której z wymienionych grup należą, publikacje te cechowało dążenie do syntezy, do zsumowania i łącznego przedstawienia założeń filozoficznych ZR wydobytych z różnych źródeł. Do tej pory brakuje publikacji spełniających postulat sformułowany za zakończenie pierwszego paragrafu tego artykułu, w których celowo założonym przedmiotem opisu i analizy byłyby filozoficzne założenia teorii ZR wpisanie w taki, a nie inny konkretny dokument, dające możliwość porównania i konfrontacji z filozofiami ZR opartymi na innych założeniach lub stosujących inne miary wag tych samych przesłanek.
} 
spraw. Ze względu na sposób postawienia zagadnienia sprawiedliwości w pismach Platona i Arystotelesa należy ono dzisiaj do dwóch odrębnych dyscyplin filozoficznych. Choć w obu przez sprawiedliwość rozumie się równe czy też bezstronne traktowanie ludzi, związane ze stosowaniem jednakowych kryteriów oceny potrzeb lub szans jednostek, to w jednym wypadku jest uznawana za cechę jednostki ludzkiej, natomiast w drugim - za właściwość systemu społecznego. Przekonanie, że trzeba mówić o dwóch filozoficznych teoriach sprawiedliwości, etycznej i właściwej dla filozofii polityki, utrwaliło się ostatecznie za sprawą Immanuela Kanta w XVIII stuleciu. Do której z nich należy zaliczyć uwagi na temat sprawiedliwości zawarte w Raporcie? Trudno odpowiedzieć na to pytanie w sposób jednoznaczny. Nacisk położony przez Komisję na aspekt naturalnej równości ludzi, edukacyjne cele Raportu oraz podjęta za ich sprawą próba kształtowania światowej opinii publicznej przez ukazywanie różnych form ludzkiego cierpienia, którego można by było uniknąć, wskazują, że omawiany dokument jest licznymi nićmi połączony z etyką - ma na celu kształtowanie ludzkich sumień, postaw i indywidualnej odpowiedzialności (Hahn 2009, 14; ŚKŚR 1991, 46). Ostrożne lawirowanie Komisji między różnymi prawami i wolnościami politycznymi oraz prawami ekonomicznymi, społecznymi i kulturalnymi, z których wyprowadza się wnioski pod adresem rządów państw i zrębów właściwego ładu międzynarodowego, pokazuje jednak coś innego, odsłaniając wielorakie parantele tekstu dokumentu z filozofią polityki.

W filozofii polityki sprawiedliwość jest widziana przez pryzmat sprawiedliwości dystrybutywnej. Tematyka sprawiedliwości obejmuje $\mathrm{w}$ niej podział różnych dóbr o charakterze publicznym, jak np. bogactwo, urzędy i honory, wykształcenie. Otóż szereg z nich stanowi oś tematów rozpatrywanych w Raporcie. Komisja postawiła sobie bowiem za cel ustalenie „nowego etapu współpracy międzynarodowej opartej na przesłance, że każda istota ludzka, żyjąca obecnie i pojawiająca się w przyszłości, ma prawo do przyzwoitego życia” (ŚKŚR 1991, 65). Obok wspomnianego powyżej nierównego dostępu do władzy politycznej, także ubóstwo i inne przejawy nierówności ekonomicznych zostały przez nią uznane za przyczynę szeregu problemów związanych z wyczerpywaniem zasobów i zagrożeniem dla środowiska (ŚKŚR 1991, 50, 
71). Natomiast niezdolność do dostrzegania wspólnego interesu w ZR została potraktowana jako wynik „lekceważenia sprawiedliwości społecznej i ekonomicznej w stosunkach wewnątrz krajów i między krajami” (ŚKŚR 1991, 74). Wskazany wątek sprawiedliwości społecznej jeszcze bardziej przemawia na rzecz interpretacji Raportu w kategoriach filozofii polityki, co podkreślają np. autorzy opracowania Nachhaltige Entwicklung integrativ betrachtet (Kopfmüller et al. 2001, 135). Przyjęcie przez Komisję założenia mówiącego o konieczności pójścia w ZR drogą sprawiedliwości społecznej prowadzi do wniosku, że sprawiedliwość jest na kartach Raportu rozumiana przede wszystkim jako taka organizacja systemu ekonomicznego, w którym zapewnia się równy dostęp do podstawowych dóbr dla wszystkich jego podmiotów, zarówno indywidualnych, jak i zbiorowych. Podmiotem indywidualnym jest jednostka ludzka. W Raporcie jednak o wiele częściej występuje podmiot zbiorowy: kobiety, dzieci, rdzenni mieszkańcy, ubodzy, ogromna liczba ludzi w krajach rozwijających się, społeczeństwa zorganizowane w państwo. Wbrew liberalistycznym interpretacjom problemu sprawiedliwości, w których kwestionuje się sensowność kategorii sprawiedliwość społeczna, w Raporcie dochodzi do głosu arystotelesowska tradycja, zgodnie z którą sprawiedliwość i sprawiedliwość społeczna są dwiema stronami jednego problemu, którym jest realizacja podstawowego dobra. Tym dobrem jest oczywiście samodoskonalenie się człowieka czy też rozwój człowieczeństwa w człowieku. Na gruncie Raportu to dobro zostało ukryte pod postacią wartości spełnienia aspiracji człowieka do lepszego życia (ŚKŚR 1991, 68).

Co jest do tego potrzebne? Za autorami Raportu można odpowiedzieć: zaspokojenie potrzeb, a dokładnie - zgodnie z brzmieniem zasady ZR - „rozwój, który zaspokaja potrzeby obecne, nie pozbawiając przyszłych pokoleń możliwości zaspokojenia ich potrzeb" (ŚKŚR 1991, 67). Potrzeby to kolejna kategoria wymagająca interpretacji, obudowana ogromną literaturą. Mając na względzie dyskutowane przez filozofów i naukowców sprawy, trudno nie postawić pytań o rodzaj i listę potrzeb, wymagany poziom ich zaspokojenia oraz główny podmiot, którego potrzeby są przedmiotem troski? Co do ostatniej sprawy zasada ZR nie pozostawia żadnych wątpliwości. Chodzi w niej przede wszystkim o po- 
trzeby ludzi biednych na świecie. Z kolei poziom zaspokojenia - jak wskazano powyżej - jest z jednej strony limitowany wielkością zasobów Ziemi i względami ochrony środowiska, natomiast z drugiej - ograniczeniami, jakie stan techniki i organizacji społeczeństwa narzuca na zdolność środowiska w tym względzie. Nie może się wznieść ponad ekologiczne możliwości świata, co znaczy, że nie wchodzi tu w grę równanie poziomu zaspokojenia potrzeb materialnych do poziomu społeczeństw konsumpcyjnych (ŚKŚR 1991, 34). Koncentracja uwagi na zagadnieniu niebezpiecznie malejących zasobów i ochronie środowiska przyrodniczego może prowadzić do mylnego wniosku, że w Raporcie chodzi wyłącznie o propagowanie zadania zaspokojenia potrzeb materialnych, zwłaszcza potrzeb podstawowych. W rzeczywistości jest inaczej. Chociaż często pojawia się w nim wątek zaspokojenia podstawowych potrzeb człowieka, to równie nieodzowne okazuje się zaspokojenie uzasadnionych aspiracji do poprawy poziomu życia. Lista podstawowych potrzeb materialnych wymienianych w omawianym dokumencie jest krótka, dotyczy żywności, ubrania, mieszkania i pracy. Listy uzasadnionych aspiracji w nim brak. Można ją jednak sporządzić na podstawie uwag porozrzucanych w różnych częściach opracowania: równość ludzi niezależnie od koloru skóry, równouprawnienie płci, bycie niewykorzystywanym przez innych, udział we władzy, dostęp do wykształcenia przynajmniej na elementarnym poziomie i najlepiej zawodowego, możliwość korzystania z zasadniczych usług medycznych. Żadna z tych list z pewnością nie jest pełna, ponieważ możliwe katalogi są otwarte na to wszystko, co w konkretnych społeczeństwach sprzyja poczuciu jednostki szacunku do samego siebie. Komisja przyjęła słuszne założenie o społecznym i kulturowym charakterze odczuwanych potrzeb.

Przyjęcie tej przesłanki wykracza poza konsekwencje w zakresie omawianych powyżej ustaleń na temat poziomu zaspokojenia potrzeb. Przedstawione założenie włącza Raport w dyskusję, która niedługo po jego opublikowaniu, już po zburzeniu muru berlińskiego, a więc w zupełnie nowych warunkach, rozgorzała pomiędzy protagonistami paradygmatu jednopoziomowej a zwolennikami paradygmatu wielopoziomowej sprawiedliwości globalnej, tj. przedstawicielami - jak to nazywa Marta Soniewicka - kosmopolityzmu i partykularyzmu (Soniewicka 
2010, 103-105). Zgodnie z pierwszym podejściem sprawiedliwość nakłada obowiązek jednakowego traktowania wszystkich ludzi na świecie. Drugie dopuszcza do głosu poczucie bliskości ludzi, odróżniając obowiązki wobec własnego narodu i reszty ludzkości. Przesłanka o społecznym i kulturowym sposobie odczuwania potrzeb wzbrania przed akceptacją skrajnie egalitarnego dążenia do zapewnienia każdemu człowiekowi tego samego i w takim samym wymiarze, natomiast skłania do działania na rzecz takich samych celów $\mathrm{z}$ uwzględnieniem odmiennych tradycji i kultury. Sprawiedliwość społeczna znajduje w Raporcie wyraz jako postulat zagwarantowania wszystkim ludziom równych możliwości do czynienia sensownego użytku z ich wolności, do zapewnienia człowiekowi niezbędnych warunków dla swobodnego kształtowania samego siebie, do podejmowania satysfakcjonujących działań, dzięki którym można być tym, kim się chce zostać. Przesłanka o społecznym i kulturowym sposobie odczuwania potrzeb wiele wobec tego mówi o stosunku członków Komisji do wspólnot narodowych ukonstytuowanych w państwa. Ponieważ wszystkie te sposoby odczuwania potrzeb są związane $\mathrm{z}$ kształtowaniem osobowości $\mathrm{w}$ innych warunkach, każdy z nich odpowiada za odrębny typ tożsamości jednostki. Odmienne narodowe doświadczenia przeszłości, wartości i przeżycia w inny sposób kształtują tożsamość członków konkretnych narodów i w ten sposób nadają znaczenie moralne takim tworom społecznym, jak państwo narodowe. Uznanie moralnego wymiaru państwa narodowego pociąga za sobą usprawiedliwienie zróżnicowania na „swoich” i „resztę”. Skłonność Komisji do posługiwania się zasadą subsydiarności w zakresie wypracowywania i realizacji przez każdy kraj własnego modelu ZR, dopasowanego do lokalnych warunków (ŚKŚR 1991, 65), wskazuje także na znaczenie przypisywane w Raporcie roli kooperacji wewnątrznarodowej w procesie wytwarzania wspólnego bogactwa, będącej clou argumentacji na rzecz uznania moralnego znaczenia państwa narodowego. W efekcie trzeba stwierdzić, że w Raporcie dochodzą do głosu przesłanki paradygmatu wielopoziomowej, tj. partykularnej sprawiedliwości globalnej. Wracając do podziału filozoficznych ujęć problemu sprawiedliwości między etykę i filozofię polityki, trzeba na wszelki wypadek postawić kropkę nad „i” i stwierdzić w tym miejscu wyraźnie, że paradygmat 
wielopoziomowej sprawiedliwości globalnej nadaje ton wyłącznie tym partiom Raportu, w których mowa o zapewnieniu sprawiedliwości społecznej na świecie poprzez usunięcie źródeł niesprawiedliwości, jakie tkwią $\mathrm{w}$ relacjach politycznych. W innych słychać wyraźnie echa ujęć etycznych, według których wszyscy ludzie są równi wobec cierpienia i zasługują na taką samą troskę.

\section{Zakończenie}

$\mathrm{Na}$ koniec garść wniosków na temat przesłania Raportu, dalszych działań w zakresie rekonstrukcji filozoficznych założeń tego dokumentu i służącej temu metody.

Wracając do przedstawionych na wstępie krytycznych ocen programu ZR, można stwierdzić, że Komisja dążyła do wypracowania jak najbardziej realistycznej strategii przemian globalnych o charakterze gospodarczym, społecznym i w zakresie ochrony środowiska. Raport ogranicza postulaty dotyczące obowiązków podmiotów stosunków międzynarodowych do tego, co niezbędnie konieczne, i pozostawia im tyle wolności, ile jest tylko możliwe.

Przedstawione założenie Raportu na temat sprawiedliwości jest najważniejszą przesłanką tego dokumentu. Otwiera długą listę założeń, które wymagają rekonstrukcji i charakterystyki w świetle różnych stanowisk, tradycji i ujęć filozoficznych. Dalsze badania filozofii Raportu powinny objąć je wszystkie. W warstwie założeń metafizycznych, teoriopoznawczych i metodologicznych Raportu na pierwszy plan wysuwają się takie przesłanki, jak: holizm, determinizm, empiryzm genetyczny, krytyczny realizm, monizm i naturalizm metafizyczny. Podstawowe założenie historiozoficzne odwołuje się do ideału postępu. W grupie przesłanek antropologicznych istotną rolę odgrywa antropocentryzm (w wersji umiarkowanej), przekonania o racjonalności bytu ludzkiego, dysponowaniu przez człowieka wolną wolą, posiadaniu przez niego sumienia. Podstawowe założenia z zakresu etyki i filozofii politycznej dotyczą sprawiedliwości, odpowiedzialności, globalizmu, dobra wspólnego, kosmopolityzmu, egalitaryzmu i równości. Przesłanki aksjologiczne pozostają ukryte w sferze założeń metafizycznych, antropologicznych, historiozoficznych, etycznych i należących do filozofii polityki, dlatego 
nie zostały osobno ujęte. Niewykluczone, że dokładniejsza analiza odsłoni jeszcze jakieś inne założenia, nieuwzględnione w tym miejscu.

Dla uzyskania wyników istotnych pod względem poznawczym i praktycznym duże znaczenie ma droga, po której będzie się posuwać rekonstrukcja założeń filozofii Raportu. W jakim kierunku poprowadzić badania przesłanek dokumentu, który jest przede wszystkim globalną strategią działania? A dokładniej mówiąc, z którym Zgromadzenie Ogólne Narodów Zjednoczonych związało nadzieję na długookresowe strategie nieprzerwanego rozwoju dotyczące środowiska i rozszerzenie współpracy międzynarodowej w zakresie środowiska na inne sfery, z uwzględnieniem zależności, które łączą środowisko, zasoby, ludzi i rozwój (ŚKŚR 1991, 9)? Heglowski wywód w sprawie obiektywizacji świadomości prowadzi do wniosku, że zamiast spłaszczać filozoficzne dyskusje w sprawie ZR do wypranego z treści consensusu filozoficznego, lepiej jest zrozumieć specyfikę każdego stanowiska $\mathrm{z}$ osobna $\mathrm{w}$ jego niezgodności $\mathrm{z}$ innymi i wpleść je wszystkie w krąg dyskusji sprawdzającej wartość obowiązujących w nich założeń. Wartość przyjętych założeń można wtedy wypróbowywać - jak radzi Charles Taylor (Taylor 2010, 104) - w kontekście ich konsekwencji dla jakości życia osobistego i społecznego. Istotnym argumentem w dyskusji na temat strategii ZR jest więc znajomość realnego i potencjalnego wpływu następstw przyjętych założeń filozoficznych na zdolność zamieszkujących glob zbiorowości - różniących się pod względem bogactwa, potrzeb i stylów życia - do realizacji podstawowych funkcji społecznych. Innymi słowy, należy je jak najdokładniej zoperacjonalizować, np. w stylu propozycji operacjonalizacji paradygmatu ZR, z którą wystąpił Tadeusz Borys. Zasadnicze punkty tego projektu dotyczą operacjonalizacji prawnej, diagnostycznej i planistycznej, aksjologicznej, pomiarowej oraz dziedzinowej, czyli sektorowej (Borys 2010, 35-36).

\section{Bibliografia:}

Acker-Widmaier, Gerald. 1999. Intertemporale Gerechtigkeit und nachhaltiges Wirtschaften. Zur normatives Begründung eines Leitbildes. Marburg: Metropolis.

Blackburn, Simon. 1997. Oksfordzki słownik filozoficzny, tłum. Jan Woleński. Warszawa: Książka i Wiedza. 
Borys, Tadeusz. 2010. Zrównoważony rozwój jako wyzwanie edukacyjne. W: Edukacja dla zrównoważonego rozwoju, t. 1, red. Tadeusz Borys, 25-40. Białystok-Wrocław: Fundacja Ekonomistów Środowiska i Zasobów Naturalnych.

Hahn, Henning. 2009. Globale Gerechtigkeit. Eine philosophische Einführung. Frankfurt am Mein: Campus Verlag GmbH.

Hegel, Georg W. F. 1994. Wykłady z historii filozofii, tłum. Adam Węgrzecki i Florian Ś. Nowicki. Warszawa: Wydawnictwo Naukowe PWN.

Hull, Zbigniew. 2003. Filozofia zrównoważonego rozwoju. W: Filozoficzne i społeczne uwarunkowania zrównoważonego rozwoju, red. Artur Pawłowski, 15-25. Lublin: Komitet Inżynierii Środowiska PAN, Monografie nr 16.

Hull, Zbigniew. 2011. Wprowadzenie do filozofii zrównoważonego rozwoju. W: Zasady ksztattowania postaw sprzyjajacych wdrażaniu zrównoważonego rozwoju, red. Włodzimierz Tyburski, 33-83. Toruń: Wydawnictwo Uniwersytetu Mikołaja Kopernika.

Husserl, Edmund. 1982. Medytacje kartezjańskie. Wprowadzenie do fenomenologii, tłum. Andrzej Wajs i Andrzej Półtawski. Warszawa: PWN.

Kopfmüller, Jürgen et al. 2001. Nachhaltige Entwicklung integrativ betrachtet. Konstitutive Elemente, Regeln, Indikatoren. Berlin: Edition Sigma.

Kośmicki, Eugeniusz. 2007. Geneza koncepcji trwałego i zrównoważonego rozwoju. W: Uwarunkowania i mechanizmy zrównoważonego rozwoju. Materialy VI Międzynarodowej Konferencji Naukowej-Bialystok-Tallin, 2-5 lipca 2007, 187-201. Białystok: Wydawnictwo Wyższej Szkoły Ekonomicznej w Białymstoku.

Rawls, John. 2009. Teoria sprawiedliwości, tłum. Maciej Panufnik, Adam Romaniuk i Jarosław Pasek. Warszawa: Wydawnictwo Naukowe PWN.

Redclift, Michael R. 2009. Rozwój zrównoważony (1987-2005) oksymoron czasu dorastania. Problemy Ekorozwoju / Problems of Sustainable Development, 4(1), 33-50. 
Soniewicka, Marta. 2010. Granice sprawiedliwości. Sprawiedliwość ponad granicami. Warszawa: Oficyna a Wolters Kluwer business.

ŚKŚR (Światowa Komisja ds. Środowiska i Rozwoju). 1991. Nasza wspólna przyszłość, tłum. Urszula Grzelońska i Ewa Kolanowska. Warszawa: Państwowe Wydawnictwo Ekonomiczne.

Taylor, Charles. 2010. Nowoczesne imaginaria społeczne, tłum. Adam Puchejda i Karolina Szymaniak. Kraków: Wydawnictwo Znak.

Tyburski, Włodzimierz. 2011. Zasady kształtowania postaw sprzyjających wdrażaniu zrównoważonego rozwoju. Toruń: Wydawnictwo Naukowe Uniwersytetu Mikołaja Kopernika.

Walzer, Michael. 2012. Moralne maksimum, moralne minimum, tłum. Joanna Erbel. Warszawa: Wydawnictwo Krytyki Politycznej. 
Zdzisława Piątek

Uniwersytet Jagielloński - Instytut Filozofii

zdzislawa.piatek33@gmail.com

\section{Kosmiczne siedlisko ziemskiego życia i problem zrównoważonego rozwoju}

\section{Wstęp}

Przedmiotem moich rozważań będzie analiza i uzasadnienie twierdzenia, że realizacja postulatów zawartych w raporcie Nasza wspólna przyszłość zależy nie tylko od zrównoważonego rozwoju ludzkiego świata we wspólnocie biosfery, ale także od warunków panujących w kosmicznym środowisku zamieszkiwanej przez nas planety. Sądzę bowiem, że głównym celem zawartym w tej deklaracji jest stworzenie warunków umożliwiających trwanie ziemskiego życia (w tym trwanie gatunku ludzkiego) w ewolucyjnej skali czasu. Przedmiotem deklaracji jest nasza wspólna przyszłość w naszym wspólnym domu, zlokalizowanym w kosmicznym środowisku życia.

W szerokiej perspektywie ekologia - rozumiana jako nauka o siedlisku (oikos) ziemskiego życia - obejmuje także środowisko kosmiczne i dlatego kosmologia oraz astrofizyka stają się częścią ekologii. Niektórzy nawet twierdzą, że „kosmologia jest najwspanialszą nauką o środowisku naturalnym" (Rees 2001, 187). Zajmując wszechświatowy punkt widzenia, działamy i poznajemy w taki sposób, jakbyśmy byli mieszkańcami Wszechświata. Warto jednak podkreślić, że do wszechświatowej świadomości musimy dojrzewać stopniowo, gdyż wymaga ona radykalnej zmiany naszych potocznych intuicji, a zwłaszcza zmiany skali czasu i przestrzeni. W tej nowej perspektywie gatunek ludzki jest zaledwie niewielką częścią planetarnej wspólnoty życia i uczestniczy w niewyobrażalnie rozległym procesie ewolucji kosmicznej. Rozważę więc po kolei: 1. wpływ kosmicznego środowiska na powstanie, trwanie i rozwój ziemskiego życia; 2. strategie zrównoważonego rozwoju jako program, który pośrednio umożliwi ewakuację gatunku ludzkiego $\mathrm{w}$ inne rejony galaktyki wtedy, kiedy życie na Ziemi stanie się niemożliwe; 3. nowe spojrzenie na wartość cywilizacji technicznej i na rolę gatunku ludzkiego w ewolucji życia. 
W konfrontacji z ekologią uwzględniającą kosmiczne środowisko życia, tradycyjna ekologia badająca jedynie jego lokalne, ziemskie środowisko jest tak samo ograniczona jak astronomia geocentryczna w konfrontacji $z$ astronomią heliocentryczną. Druga istotna zmiana związana z kosmicznym punktem widzenia to możliwość zmiany ewaluacji kultur. W ciągu ostatnich lat wielkim osiągnięciem w badaniach antropologicznych było twierdzenie, że nie ma kultur wyższych i niższych, gdyż różne systemy kulturowe mają taką samą wartość jako sposoby organizacji ludzkiego życia. One są po prostu inne, a inny nie znaczy gorszy ani lepszy. Ta sama zasada odniesiona do wartościowania gatunków uczestniczących w ewolucji ziemskiego życia skłania do akceptacji biocentryzmu. Jednakże nowa, kosmiczna perspektywa dostarcza dobrych racji do uzasadnienia wyróżnionej pozycji zarówno gatunku ludzkiego jak i cywilizacji technicznej.

\section{Kosmiczne środowisko ziemskiego życia}

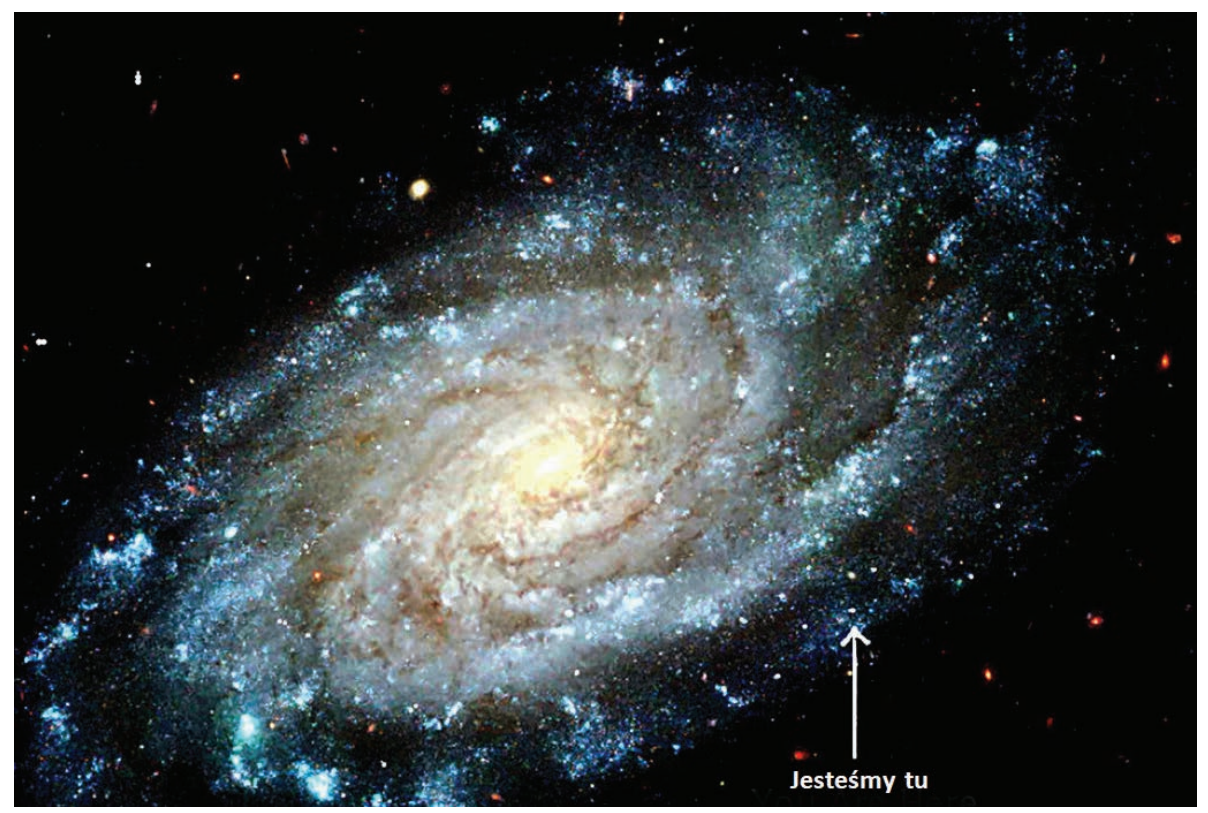

Rysunek 1. Położenie Układu Słonecznego w Galaktyce Drogi Mlecznej. Źródło: http://www.poorwilliam.net/pix/you_are_here.jpg 
Rozpoznanie, że środowiskiem ziemskiego życia jest kosmos, radykalnie zmienia naukę o środowisku, wymaga bowiem nie tylko nowego sposobu myślenia o naszych związkach z Wszechświatem, nowej skali czasu i przestrzeni, ale także zmiany intuicji związanych z poczuciem odpowiedzialności. Nie chodzi o to, żeby się poczuwać do odpowiedzialności za zdarzenia, które zachodzą w kosmosie i na które nie mamy żadnego wpływu, lecz o odpowiedzialność za nasze działania, których skutki są odległe w czasie i mają wpływ na przebieg ziemskiej ewolucji. Intensywne badania kosmosu w ciągu ostatniego stulecia wskazują, że kosmos jest niewyobrażalnie wielki, dynamiczny i ewoluuje, działając swoim rytmem w kosmicznej skali czasu. We Wszechświecie ${ }^{4}$ nic nie jest trwałe, a równowaga sił jest niezwykle krucha, gdyż występują w nim na przemian procesy tworzenia i destrukcji. Kosmiczny recykling polega na tym, że gwiazdy rodzą się w mgławicach pyłu oraz gazu i umierają w wybuchach supernowych, wyrzucających w przestrzeń masy pyłu i gazu oraz ogromne ilości energii w postaci promieniowania gamma. Mimo że dynamika kosmicznych przemian dokonuje się w dużej skali czasu, to jednak ich rozpoznanie i obserwacja uzasadniają twierdzenie, że warunki sprzyjające ewolucji ziemskiego życia i ziemskiej cywilizacji nie będą trwały wiecznie.

Ze względu na zadaną objętość tego artykułu, skupię się na zwróceniu uwagi jedynie na niektóre warunki w kosmicznej ekosferze, które miały wpływ na powstanie środowiska ziemskiego życia, umożliwiają jego trwanie i prawdopodobnie doprowadzą do tego, że życie na Ziemi stanie się niemożliwe. Mimo że we Wszechświecie działają siły, których nie możemy kontrolować, to jednak możemy rozpoznać niezwykły ciąg wydarzeń, które doprowadziły do powstania Układu Słonecznego w bezpiecznej strefie naszej galaktyki, a następnie do usytuowania Ziemi w optymalnej odległości od Słońca. Mówiąc o optymalnym usytuowaniu Ziemi w Układzie Słonecznym, mam na myśli warunki sprzyjające powstaniu i ewolucji życia. Jest ich wiele, między innymi takie jak: wspomniana już optymalna odległość Ziemi od Słońca, która umożliwia istnienie wody w stanie ciekłym, oraz orbita Ziemi (zbliżona

\footnotetext{
${ }^{4}$ Pojęć „Wszechświat” i „kosmos” będę używała zamiennie, Wszechświat to nazwa indywidualna wszystkiego, co istnieje, a kosmos to zbiór wszystkich obiektów i procesów tworzących Wszechświat.
} 
do kolistej) sprawiająca, że nie ma dużych wahań temperatury spowodowanych porami roku, a obecność Księżyca stabilizuje tę orbitę i wywołuje pływy, które powodują mieszanie wód w oceanach. Z kolei pole magnetyczne Ziemi osłania powierzchnię przed szkodliwym promieniowaniem kosmicznym oraz wiatrami słonecznymi, a bliskość Jowisza (planety 10 razy większej, o silnej grawitacji) działa jak tarcza obronna przed asteroidami, kometami i innymi obiektami z kosmosu, które po uderzeniu w powierzchnię naszej planety mogłyby zniszczyć ziemskie życie. Jednakże, mimo tych sprzyjających warunków i tarczy ochronnej Jowisza, wielkie katastrofy wydarzyły się już dwukrotnie w ciągu historii ziemskiego życia i za każdym razem doprowadziły do wyginięcia $2 / 3$ gatunków, które wtedy żyły.

Do sprzyjających warunków należy także i to, że Słońce, w porównaniu z innymi gwiazdami tego typu, jest stabilne i stanowi źródło życiodajnej energii, która związana w procesach fotosyntezy napędza kanały metaboliczne w całej biosferze. Słońce to olbrzymi reaktor termojądrowy, w którym „spala się” wodór i powstaje hel plus energia, która dociera do Ziemi jako promieniowanie świetlne. Astrofizycy wyliczyli, że zapasy słonecznego paliwa wyczerpią się za około 5 miliardów lat, a po jego wyczerpaniu Ziemia stanie się pustkowiem nienadającym się do życia. Jest to prognoza dobrze uzasadniona, której nie można lekceważyć, mimo że jest odległa w czasie. Ewolucja gwiazd podobnych do Słońca pozwala astrofizykom przewidywać, że po wyczerpaniu zapasów wodoru Słońce zacznie spalać hel i będzie wtedy powstawał węgiel oraz tlen, a w następnej fazie ewolucji tej gwiazdy fuzja jądrowa węgla i tlenu będzie prowadziła do powstania atomów żelaza, a to oznacza zapaść/implozję gwiazdy. W rezultacie tych reakcji jądro Słońca będzie się kurczyło, a jego korona będzie się rozrastać. Słońce przemieni się w czerwonego olbrzyma, stanie się 20 do 30 razy większe i pochłonie najpierw Merkurego, potem Wenus, a następnie Ziemię (jeżeli wcześniej, w miarę słabnącej grawitacji nie ucieknie ona w otchłań kosmosu). W następnej, końcowej fazie ewolucji Słońce przemieni się w białego karła. Na etapie czerwonego olbrzyma temperatura na Ziemi wzrośnie (do 1000 stopni C), oceany wyparują i nie będzie na niej warunków do życia. Żeby ziemskie życie mogło przetrwać, ludzkość będzie musiała się ewakuować w inne 
przyjazne miejsca w Drodze Mlecznej. Opisany scenariusz ewolucji Układu Słonecznego to nie jest opowieść science fiction, lecz dobrze rozpoznany fakt z dziedziny astrofizyki. W Drodze Mlecznej są miliardy gwiazd podobnych do Słońca i w pobliżu nich astronomowie (posługując się analizą spektroskopową) poszukują planet posiadających warunki zbliżone do warunków panujących na Ziemi. Istnieje bogata literatura poświęcona poszukiwaniom pozaziemskiego życia, a zwłaszcza pozaziemskich inteligentnych form życia (Wabble 2007).

Słońce przestanie być życiodajne za około dwa miliardy lat i tyle mamy czasu, aby stworzyć cywilizację umożliwiającą ewakuację w inne rejony galaktyki. Astrofizycy uzbrojeni w potężne teleskopy poszukują więc w Drodze Mlecznej światów przyjaznych dla życia, czyli planet położonych w pobliżu stabilnych gwiazd i posiadających ślady węgla, tlenu oraz wody. Niemal co tydzień odkrywają jakąś planetę, ale większość z nich to "piekielne planety” wrogie życiu, gdyż panuje na nich bardzo wysoka temperatura, szaleją burze i występują inne niesprzyjające warunki. Jednakże w naszej galaktyce znajdują także "bliźniacze Ziemie”, na których panują warunki zbliżone do ziemskich. Ale wszystkie miejsca, zarówno sprzyjające jak i niesprzyjające życiu, znajdują się bardzo daleko od Układu Słonecznego. Dlatego też gatunek ludzki ma około półtora miliarda lat na wypracowanie takiego poziomu cywilizacji technicznej, który umożliwi znalezienie pozaziemskich środowisk sprzyjających życiu i kolonizację kosmosu. W tym celu ekologia o wymiarze kosmicznym bada warunki, które umożliwią zadomowienie gatunku ludzkiego we Wszechświecie, a strategia zrównoważonego rozwoju zawarta w deklaracji Nasza wspólna przyszłość określa warunki, które muszą być spełnione po to, aby mogła się rozwinąć cywilizacja otwarta na kosmiczne uwarunkowania. Już obecnie są podejmowane próby stworzenia systemów chroniących Ziemię przed niektórymi zagrożeniami z kosmosu. Należy do nich monitorowanie przez NASA przestrzeni okołoziemskiej w celu wykrywania groźnych asteroid (większych niż kilku metrów) oraz różne propozycje zapobiegania ich zderzeniu z powierzchnią Ziemi.

Na marginesie pragnę zauważyć, że do niedawna nie wiedzieliśmy prawie nic o naszych związkach z kosmosem. W kosmologii Arystotelesa 
sfera niebieska, czyli niebo gwiaździste nad nami, było siedzibą bogów i było odseparowane od niedoskonałej sfery podksiężycowej. W centrum tej sfery, stanowiącej jednocześnie centrum Wszechświata, znajdowała się Ziemia i tylko w sferze podksiężycowej obowiązywały prawa fizyki. Uznawano, że nie ma żadnego oddziaływania między tymi heterogenicznymi sferami, stąd brał się trwający przez wieki spór o pochodzenie meteorów: wszak z Nieba nic nie mogło spaść, zwłaszcza kamienie.

To astrofizyka „odczarowała Niebo gwiaździste nad nami” i rozpoznała lokalizację Ziemi w kosmicznej ekosferze. Z badań kosmologicznych wywodzi się zarysowana powyżej narastająca świadomość uwarunkowań ziemskiego życia ze strony kosmicznego środowiska i odkrycie, że w sensie dosłownym ludzie i pozostałe istoty żywe są dziećmi Wszechświata. Jesteśmy dziećmi Wszechświata, gdyż zarówno Ziemia, jak i nasze organizmy są zbudowane z pyłu gwiezdnego zawierającego pierwiastki, które powstały w jądrach gwiazd supernowych. Okazuje się, że we wczesnym etapie ewolucji kosmosu, kiedy nie było jeszcze gwiazd ani światła, tylko wysokoenergetyczna plazma, powstały lekkie pierwiastki, czyli wodór, a potem hel, i to one stanowią większość materii we Wszechświecie. Teoria Wielkiego Wybuchu opisująca narodziny Wszechświata (Singh 2007) przyjmuje, że fuzja jądrowa, czyli synteza wszystkich ciężkich pierwiastków znanych z tablicy Mendelejewa, dokonuje się w jądrach gwiazd supernowych, gdyż to dopiero w nich zaistniały warunki potrzebne do zachodzenia tego procesu. Warunki, o których mowa, to bardzo wysokie temperatury i bardzo wysokie ciśnienie, których nie było w „ciemnym wieku kosmosu”, kiedy powstały atomy wodoru oraz helu, a nie było jeszcze gwiazd. Kosmiczne „reaktory termojądrowe”, czyli supernowe, to eksplodujące gwiazdy o masie przekraczającej setki tysięcy razy masę Słońca. W momencie spektakularnych eksplozji wyrzucają one w przestrzeń kosmosu ogromne ilości energii $\mathrm{w}$ postaci promieniowania gamma oraz obłoki zawierające wszystkie ciężkie pierwiastki syntetyzowane $\mathrm{w}$ jądrze. W tym kosmicznym recyklingu powstają mgławice pyłu i gazu, z którego następnie tworzą się nowe gwiazdy, planety i my - ludzie.

W moich rozważaniach dotyczących ewolucji Wszechświata akceptuję postulat obiektywności w rozumieniu J. Monoda, nie zakładam więc 
działania zasady antropicznej, a to znaczy, że - podobnie jak w rozumieniu przebiegu ziemskiej ewolucji - nie zakładam działania zasady celowej. Wszechświat nie powstał dla nas i nie dba o to, co się z nami stanie, dlatego w pewnym sensie i w określonym zakresie nasza przyszłość jest w naszych rękach. Skoro we Wszechświecie powstały inteligentne istoty, które są w stanie zrozumieć prawa rządzące światem i mogą rozmyślać o swoim pochodzeniu, to mogą także (w pewnym zakresie) kształtować swoją przyszłość.

\section{Zrównoważony rozwój jako mechanizm umożliwiający zado-} mowienie ziemskiego życia i gatunku ludzkiego we Wszechświecie

Rozpoznanie (na gruncie nowej ekologii), że Wszechświat to bardzo niebezpieczne miejsce, i w związku $\mathrm{z}$ tym ziemskie środowisko nie zawsze będzie sprzyjało ewolucji życia, skłania inteligentne i odpowiedzialne istoty ludzkie do działania na rzecz stworzenia cywilizacji zaawansowanej technicznie, która - w momencie zagrożenia - umożliwiłaby ewakuację w inne przyjazne rejony galaktyki. Po to, żeby ludzie mogli stworzyć taką cywilizację, potrzebny jest odpowiednio długi okres. Zrównoważony rozwój (będę używała skróconej nazwy ZR) ma umożliwić jego zdobycie. Tak więc idea trwałego samopodtrzymującego się rozwoju, ma zapewnić ewolucyjną przyszłość gatunku ludzkiego rozumianą jako ciągłość trwania ludzkości we wspólnocie ziemskiej biosfery, a potem jej rozproszenie i ewolucję w innych zakątkach Wszechświata. Zatem w perspektywie kosmicznej ZR ma umożliwić naszym potomkom zbudowanie „kosmicznej Arki Noego”.

Nie wnikając w szczegółowe dyskusje związane z różnymi sposobami rozumienia ZR, można przyjąć, że odnosi się on do procesów uzgadniania ładu gospodarczego, społecznego i środowiskowego, z tym wszakże, że w nowej perspektywie środowisko obejmuje także wymiar kosmiczny. Różnorodne strategie ZR to działania zmierzające do zbudowania cywilizacji globalnej, w której zasada ochrony środowiska będzie stanowiła podstawową zasadę organizacji społeczeństw, a to z kolei oznacza wkroczenie problemów ekologicznych do polityki. „Zielona” polityka wymaga, żeby ludzie nauczyli się nowych sposobów współdziałania w zabieganiu o ochronę środowiska w skali międzynarodowej. W ten 
sposób narodziły się ogólnoświatowe formy współdziałania, tzw. Szczyty Ziemi, na których są uzgadniane postulaty ograniczenia emisji dwutlenku węgla, konwencje o ochronie bioróżnorodności, nakaz stosowania technologii przyjaznych środowisku czy dyrektywa nakazująca wykorzystywanie odnawialnych źródeł energii oraz wiele innych cennych inicjatyw mających na celu dostosowanie funkcjonowania antroposfery do wydolności przyrodniczego środowiska. Są to wielkie wyzwania pod adresem cywilizacji, która w swoim dotychczasowym rozwoju była nastawiona na nieograniczoną eksploatację zasobów surowcowych bez uwzględniania kosztów środowiskowych. W rezultacie tej krótkowzrocznej, rabunkowej polityki środowiskowej ewolucja ziemskiego życia okazuje się zagrożona nie tyle przez odległe w czasie czynniki kosmiczne, takie jak wspomniane powyżej wyczerpanie energii słonecznej czy wybuch supernowej, lecz przez destrukcyjne działania ludzi uzbrojonych w niezwykle skuteczne narzędzia rabowania zasobów środowiska.

Kryzys środowiskowy został rozpoznany w Raporcie o Stanie Świata ogłoszonym przez U Thanta na forum ONZ w roku 1969 pod znamiennym tytułem Człowiek $i$ jego środowisko. Jako jedną z głównych przyczyn rozpoznanego kryzysu wskazano w nim rozwój cywilizacji technicznej, która umożliwiła niezwykle szybkie (wykładnicze) tempo wzrostu gospodarczego i nadmierną eksploatację środowiska nastawioną na doraźne korzyści. Idea ZR, która pojawiła się w Raporcie Gro Harlem Brundtland ogłoszonym w roku 1987, stanowi projekt nowej, proekologicznej cywilizacji, która ma na celu zahamowanie narastającego kryzysu i przeciwdziałanie samozagładzie, między innymi poprzez ograniczenie rozwoju cywilizacji technicznej i powrót do natury. Śledząc dyskusje w kwestii kryzysu środowiskowego i ZR, można odnieść wrażenie, że postęp techniczny jest wykorzystywany głównie do niszczenia środowiska. Liczne organizacje „Zielonych” krytykują rozwój cywilizacji zaawansowanych technologicznie i zwracają uwagę na to, że dają one ludziom wielką moc przekształcania środowiska, która nie jest jednocześnie sprzężona $\mathrm{z}$ możliwością przewidywania dalekosiężnych skutków tego działania i panowania nad nimi. Do tego nurtu należy filozofia Henryka Skolimowskiego (1999), jednego z twórców ekofilozofii, który, oceniając negatywnie cywilizację techniczną, uważa ją za wymysł 
Szatana dany ludziom po to, żeby dokonali samozagłady. Natomiast Vaclav Klaus (2008) głosi pogląd przeciwstawny i traktuje postulaty ekologów dotyczące zahamowania rozwoju cywilizacji technicznej jako przejaw histerii „społeczeństwa opętanego ekologią”. Klaus twierdzi, że de facto postulaty ekologów stanowią zamach na ludzką wolność i są nawoływaniem do powrotu do stanu barbarzyństwa. W kontekście tych sporów warto zauważyć, że już od czasów Arystotelesa było wiadomo, iż technika ma charakter ambiwalentny i może być wykorzystana zarówno do nieodpowiedzialnego niszczenia środowiska, które może grozić samozagładą gatunku, jak i do rozpoznania zagrożeń oraz do przywrócenia równowagi w środowisku. A także, jak powyżej argumentowałam, zaawansowana technika może umożliwić ewakuację gatunku ludzkiego wraz z częścią biosfery w inne rejony galaktyki wtedy, kiedy Ziemia przestanie być planetą przyjazną życiu. Tak więc cywilizacja techniczna rozważana w kontekście nowej ekologii, w której środowiskiem ziemskiego życia jest kosmos, nabiera walorów pozytywnych, bo tylko ona umożliwia kontynuację ziemskiego życia w środowisku pozaziemskim. Jeżeli dostrzeżemy, że istotnym elementem ZR zawartym w Raporcie Brundtland jest postulat solidarności międzypokoleniowej, który nakazuje dbanie o interesy przyszłych pokoleń, to można zasadnie twierdzić, że podstawowy interes naszych potomków (możliwość życia, także w środowisku pozaziemskim) jest zbieżny z działaniem na rzecz rozwoju zaawansowanej techniki. Z kolei ewoluowalność ziemskiego życia określa tę otwartą możliwość trwania życia w kosmicznym środowisku i koresponduje z imperatywem Hansa Jonasa (1996, 38), który nakazuje: „Postępuj zawsze tak, aby skutki twojego działania dały się pogodzić z ciągłością trwania autentycznego życia ludzkiego". Sądzę, że twierdzenie o ambiwalentnym charakterze techniki jest dobrze uzasadnione, gdyż - rozwijając technikę - ludzie nie tylko niszczą środowisko, ale także potrafią je chronić i utrzymać w stanie równowagi, zapewniając nakazaną imperatywem „ciągłość trwania autentycznego życia ludzkiego”.

Warto podkreślić, że nie każde przekształcenie środowiska jest jego degradacją. Być może, dzięki postępom w dziedzinie inżynierii genetycznej, będziemy mogli kierować ewolucją naszych ciał i kolonizować planety posiadające nieco inne warunki środowiskowe. Jest wielu ko- 
smologów i astrofizyków, którzy twierdzą, że powinniśmy przygotować się do kolonizacji kosmosu, budując - w różnych rejonach Układu Słonecznego - przejściowe bazy potrzebne jako pozaziemskie punkty startowe. Już obecnie są podejmowane działania zmierzające w tym kierunku, są to międzynarodowe stacje orbitalne czy budowane na pustyni eksperymentalne bazy typu biosfera 2000, a także programy poszukiwania cywilizacji pozaziemskich SETI.

\section{Wartość cywilizacji technicznej}

Różne strategie ZR zostały wprowadzone po to, żeby przeciwdziałać negatywnym skutkom "gwałtu zadawanego naturze”, czyli nadmiernej eksploatacji środowiska, która narasta wraz z rozwojem cywilizacji technicznej. Jak już zauważyłam, w tradycyjnej ekologii ZR jest mechanizmem, który ma umożliwić trwałą, samopodtrzymującą się kohabitację gatunku ludzkiego z biosferą. Ma więc zapewnić funkcjonowanie biosfery i trwanie ziemskiego życia tak długo, jak długo Ziemia będzie miejscem umożliwiającym życie. Natomiast ZR rozpatrywany w kontekście ekologii o wymiarze kosmicznym ma dodatkowo zapewnić wysoki poziom rozwoju zaawansowanej cywilizacji naukowo-technicznej umożliwiającej nie tylko badanie kosmicznego środowiska życia, ale także kolonizację kosmosu oraz trwanie życia w kosmicznym środowisku. Na podkreślenie zasługuje fakt, że ZR - rozpatrywany jako mechanizm trwania gatunku ludzkiego w kosmicznym środowisku - prowadzi do zmiany wartościowania systemów kulturowych. Następuje dowartościowanie cywilizacji naukowo-technicznej ze względu na to, że tylko ona - w przeciwieństwie do kultur plemiennych - stwarza otwarte możliwości trwania ziemskiego życia w środowisku pozaziemskim. O ile - w świetle ZR odnoszonego do ziemskiego środowiska - kultury plemienne mają wysoką wartość jako strategie utrzymywania środowiskowej równowagi, to w odniesieniu do warunków kosmicznych ich wartość jest znikoma. W etyce środowiskowej podkreśla się środowiskową mądrość Aborygenów, Buszmenów, Indian czy Eskimosów, zwracając uwagę na to, że ich systemy kulturowe są dostosowane do wydolności środowiska, ponieważ nie budują oni stałych siedzib, nie prowadzą hodowli zwierząt ani uprawy roli, żyją, kultywując tradycję przekazaną 
przez przodków, i właściwie wykorzystują środowisko podobnie jak słonie, lwy czy niedźwiedzie. Ale też ich ewolucyjna przyszłość jest równie zagrożona jak przyszłość słoni (Diamond 2005).

Nowa ekologia o wymiarze kosmicznym w pewnym sensie rewaloryzuje antropocentryzm, gdyż spośród gatunków żyjących tu na Ziemi tylko ludzie rozwijają cywilizację umożliwiającą ewakuację życia w kosmos, kiedy zajdzie taka potrzeba. W nowej perspektywie gatunek ludzki nie tylko na powrót zajmuje swoją wyróżnioną pozycję pośród innych gatunków, ale ma także do spełnienia zbawczą misję w stosunku do możliwości trwania ziemskiego życia. Warto zauważyć, że kosmiczna ekologia docenia cywilizację techniczną za to wszystko, za co ekofilozofia krytykowała ją w ramach pojęciowych ZR rozpatrywanych w odniesieniu do ewolucji biosfery.

\section{Zakończenie}

Podsumowując moje rozważania, pragnę zwrócić uwagę na dwa istotne fakty. Pierwszy to ten, że ewolucyjna wiedza o mechanizmach ziemskiego życia w istotny sposób zmieniła spojrzenie na relacje gatunku ludzkiego z innymi gatunkami uczestniczącymi w ewolucji biosfery, a drugim równie ważnym faktem jest zwrócenie uwagi na to, że wiedza o ewolucji Wszechświata dostarczona przez kosmologię i astrofizykę radykalnie zmieniła spojrzenie na relacje gatunku ludzkiego z Wszechświatem. My także, razem z planetą, którą zamieszkujemy, jesteśmy uczestnikami tych kosmicznych przemian, a nie tylko biernymi obserwatorami Nieba gwiaździstego nad nami. Natomiast obie dziedziny wiedzy, które się na siebie nakładają i funkcjonują jak palimpsest, zmieniają zarówno wartościowanie cywilizacji technicznej, jak i rolę gatunku ludzkiego w ewolucji. Warto zauważyć, że antropocentryzm, o którym mowa w kosmicznej ekologii, ma inną naturę i różni się od tradycyjnego antropocentryzmu, jednakże rozwinięcie tego tematu wymaga odrębnych rozważań. Różnica polega na tym, że, umieszczając inteligentne istoty ludzkie $\mathrm{w}$ domniemanym zbiorze inteligentnych istot we Wszechświecie, nie wiemy, jak w tej konfrontacji wypadniemy. Nie wiemy, jakie miejsce przypadnie nam w udziale, kiedy spotkamy „braci w rozumie” i staniemy się członkami galaktycznej społeczności. 


\section{Bibliografia:}

Diamond, Jared. 2005. Upadek. Dlaczego niektóre społeczeństwa upadły, a innym się udało, tłum. Jacek Lang et al. Warszawa: Prószyński i S-ka.

Jonas, Hans. 1996. Zasada odpowiedzialności. Etyka dla cywilizacji technicznej, tłum. Marek Klimowicz i Tomasz Kowalski. Kraków: Wydawnictwo Platan.

Klaus, Vaclav. 2008. Błękitna planeta w zielonych okowach. Co jest zagrożone: klimat czy wolność, tłum. Zbigniew Krzysztyniak. Warszawa: Przedsiębiorstwo Wydawnictwo „Rzeczpospolita” S.A.

Rees, Martin. 2001. Nasz kosmiczny dom, tłum. Piotr Rączka. Warszawa: Prószyński i S-ka.

Singh, Simon. 2007. Wielki wybuch, narodziny wszechświata, tłum. Jan Koźlarczyk. Warszawa: Wydawnictwo Albatros.

Skolimowski, Henryk. 1999. Wizje nowego millenium. Kraków: Wydawnictwo EJB.

Wabble, Tobias D. 2007. Życie we wszechświecie. Stanowiska przyrodoznawstwa, filozofii i teologii, tłum. Bogdan Baran. Warszawa: PIW. 
Zbigniew Łepko

Uniwersytet Kard. Stefana Wyszyńskiego w Warszawie - Instytut Ekologii i Bioetyki z.lepko@uksw.edu.pl

\section{Filozoficzne obrazy przyrody ożywionej a idea zrównoważonego rozwoju}

\section{Wprowadzenie}

Poszukiwanie proporcjonalnej równowagi między cywilizacyjnymi aspiracjami człowieka a długotrwałym bezpieczeństwem przyrody domaga się namysłu nad obrazami obu członów tej relacji. Choć w niniejszym opracowaniu docenia się wagę obrazów człowieka w tym zakresie, to jednak uwagę poznawczą koncentruje się na obrazach przyrody ożywionej. Wśród nich na szczególną uwagę zasługują konfrontowane ze sobą w literaturze: obraz fizjocentryczny i obraz fizjologiczny. Najbardziej reprezentatywne dla zwolenników pierwszego obrazu jest stanowisko Hansa Jonasa $(1979 ; 1983 ; 1990)$, dla zwolenników drugiego obrazu zaś stanowisko Lothara Schäfera (1987, 15-37; 1993).

Jonas ukazuje przyrodę jako przestrzeń, która warunkuje istnienie różnych, ale zarazem równowartościowych podmiotów życia. Taka przyroda stanowi pewną całość, która poddana jest powszechnym prawom. Jonas przeciwstawia ją antropocentrycznym obrazom przyrody. Jego zdaniem antropocentryzm stoi w sprzeczności z naturalnym dążeniem człowieka do ochrony samego siebie. Istnienie człowieka może bowiem zabezpieczyć jedynie respekt wobec przyrody ze względu na naturalnie przynależną jej wartość i godność. Biologicznie spokrewniony z przyrodą człowiek zobowiązany jest do dochowania jej wierności, czego najwyższym wyrazem jest wierność swojej własnej egzystencji.

Schäfer postuluje fizjologiczny obraz przyrody i utożsamia go $\mathrm{z}$ obrazem umiarkowanie antropocentrycznym. Ukazuje on przyrodę jako pewną całość, która sprzyja, bądź nie sprzyja fenomenowi życia, wielorako zapodmiotowanemu. Fizjologiczne ujęcie przyrody wskazuje więc na związek człowieka z przyrodą, wyrażający się w fizjologicznych procesach wymiany między organizmem a jego środowiskiem. Funkcjonalna sprawność fizjologii ludzkiego ciała stanowi bowiem miernik 
funkcjonalnej sprawności metabolizmu przyrody. Oznacza to, że dobre samopoczucie i zdrowie fizyczne człowieka stanowią najbardziej miarodajne wskaźniki korzystnych warunków środowiska naturalnego. Z tego punktu widzenia ochrona przyrody swój najpełniejszy wyraz znajduje w ochronie człowieka.

Niniejszy tekst nie poprzestaje na konfrontacji prezentowanych obrazów przyrody ożywionej, lecz podejmuje próbę wyznaczenia minimalnych warunków współpracy ich reprezentantów na rzecz równoważenia cywilizacyjnych aspiracji obecnego pokolenia ludzkości z aspiracjami pokoleń przyszłych. Oba obrazy przyrody w sobie właściwy sposób sprzyjają bowiem zerwaniu z iluzjami nowożytnego przyrodoznawstwa, że przyroda jest obszarem bezgranicznym, a jej zasoby są niewyczerpywalne. Oba obrazy we właściwy sobie sposób przyczyniają się też do kształtowania postawy człowieka przyjaznego światu i budowy świata przyjaznego człowiekowi (Łepko 1999, 279).

\section{Fizjocentryczny obraz przyrody ożywionej}

W punkcie wyjścia prac nad fizjocentrycznym obrazem przyrody Jonas stawia tezę o utrwalonym w kulturze europejskiej antropocentrycznym usprawiedliwieniu dominacji człowieka nad przyrodą. Choć dostrzega on wiele postaci antropocentryzmu, to jednak jego głównych źródeł upatruje w nowożytnej absolutyzacji światopoglądu przyrodoznawczego. Dominującym motywem tego światopoglądu jest dążenie do poznania świata w oderwaniu od aksjologii. Na tej podstawie Jonas twierdzi, że metodologiczne izolowanie w czasach nowożytnych nauk przyrodniczych od wartościowania przerodziło się w tezę ontologiczną. Utrzymuje ona, że przyroda, zarówno jako habitat, jak i przedmiot badań, jest aksjologicznie neutralna. W tej aksjologiczno-ontologicznej tezie Jonas dostrzega główną przyczynę techniczno-technologicznego władztwa człowieka nad przyrodą (Jonas 1983, 7-9).

Rozpoznanie związku przyczynowego między obrazem przyrody neutralnej aksjologicznie a absolutną władzą człowieka nad przyrodą skłania Jonasa do podjęcia próby ustalenia relacji człowieka do przyrody z fizjocentrycznego punktu widzenia. Zakłada on, że podmiotowa godność i prawo do respektu przysługują całej przyrodzie ożywio- 
nej. Konsekwentnie też mówi o takiej relacji człowieka do przyrody, która wyraża się w odpowiedzialności za przyrodę. Ten problem, jego zdaniem, musi stać się priorytetową sprawą filozofii współczesnej. Podejmuje więc próbę filozoficznego usprawiedliwienia normatywnego rozumienia przyrody, które postuluje tworzenie norm postępowania człowieka względem przyrody na podstawie teorii przyrody (Jonas 1979, 91-93).

Komentatorzy twórczości Jonasa warunkują powodzenie tego zadania przyjęciem założenia, że przyroda jest „nie tylko przyrodą”. Oprócz tego wszystkiego, co stanowi o jej „przyrodniczości”, na co wskazują jej składowe ilościowe, przedstawia ona bowiem właściwą sobie wartość i godność. Tym samym przyroda jako taka zobowiązuje człowieka najpierw do tworzenia etyki odpowiedzialności i następnie do odpowiedzialnego względem niej postępowania (Wetz 1994, 134-135). Jonas funduje taką etykę właśnie z odwołaniem się do ontologicznej struktury bytu-przyrody. Przeciwstawia się tym samym dwóm najbardziej rozpowszechnionym i bronionym, jak podkreśla, dogmatom naszych czasów: pierwszy głosi, że nie istnieje żadna prawda metafizyczna, drugi zaś utrzymuje, że nie można wnioskować o powinności z samego faktu istnienia (Jonas 1979, 92).

Pierwszy z tych dogmatów ogranicza zakres aktualnie wartościowej wiedzy do obszaru przyrodoznawstwa, które stroni od wartości i sensu. Nie dysponuje więc ono możliwością zakwestionowania ani ważności tej problematyki, ani, tym bardziej, obiektywnego istnienia wartości. Dla Jonasa oznacza to, że przyrodoznawstwo nie wypowiada całej prawdy o przyrodzie. Nie można więc z góry wykluczyć możliwości tworzenia etyki z odwołaniem się do metafizyki przyrody (Jonas 1979, 92).

Ta możliwość zaś kwestionowana jest przez stanowisko wyrażone drugim dogmatem, zgodnie z którym z faktycznego stanu rzeczy, czyli z jakiegoś ,„jest”, nie można wyprowadzić normy, czyli ustalić „jak być powinno". Nieuwzględnienie tego stanowiska prowadzi bowiem do błędu, który George Edward Moore (Moore 1903) nazwał „błędem naturalistycznym", a który dzisiaj rozumiany jest zgodnie ze znaczeniem nadanym mu przez Davida Hume’a (Hume 1978). Według niego wartości nie są właściwościami rzeczy i deskryptywnie określonych stanów rzeczy, 
lecz projekcjami potrzeb i oczekiwań człowieka względem rzeczy i faktycznych stanów rzeczy. Otóż dokładnie ten pogląd krytykuje Jonas, przekonany że wartości i godność stanowią naturalne atrybuty przyrody. Ich istnienie nie jest zależne wyłącznie od intencjonalnych aktów wartościującego podmiotu, który dokonuje ich projekcji na przedmioty (rzeczy), jak gdyby nie przynależały one do rzeczy-w-sobie.

Wartości przynależne rzeczom-w-sobie nie narzucają się podmiotowi poznającemu z oczywistą koniecznością. Trzeba je zatem rozpoznać na drodze refleksji filozoficznej, posiłkowanej sprawnością intelektu kontemplatywnego. W ten sposób zdaje się Jonas wyrażać postulat władzy nad naukową potęgą człowieka wobec przyrody, czyli zerwania z tradycją poznawczą, tworzoną w zależności od „wyhodowanego przez nowożytną naukę intelektu agresywnego i manipulacyjnego" (Jonas 1979, 251). Jonasa postulat władzy nad naukową potęgą człowieka wobec przyrody może być zatem rozumiany jako apel do poznawczych możliwości człowieka, wciąż jeszcze zdolnego do czerpania z zasobów swojego wyposażenia moralnego, stanowiącego ostatnią bodaj instancję, do której apelować jeszcze warto (Jonas 1979, 251). Z tym przeświadczeniem Jonas przedstawia do refleksji obraz przyrody wartościowej i sensownej. Prezentuje mianowicie teleologiczną wykładnię przyrody w aspekcie całościowo rozumianej orientacji przyrody na cel, przejawiającej się w dążeniu do coraz wyższych poziomów organizacji życia oraz $\mathrm{w}$ aspekcie osobniczo manifestowanej tendencji poszczególnego organizmu do bycia swoim własnym celem (Jonas 1979, 143 i 157; Jonas 1973).

Pierwszy aspekt prezentowanej przez Jonasa teleologicznej interpretacji przyrody wskazuje na jej wewnętrzną dynamikę w dążeniu do coraz wyższych poziomów organizacji, a więc przyrody zorientowanej na cel, w dążeniu do którego wykorzystuje ona każdą sprzyjającą ku temu okazję. Ze względu na możliwość wystąpienia w przyrodzie okoliczności wyznaczających początek nowych, poprzednio nieznanych celów, Jonas skłonny jest raczej mówić o dyspozycji do osiągania celu niż o ukierunkowaniu na cel. Ta dyspozycja nie jest wyrazem jakiegoś uświadomionego „chcenia”, nie stanowi więc funkcji jakiegoś rozumu tkwiącego wewnątrz świata, ani też działania Boga umieszczonego poza światem. Jest ona raczej wyrazem koncentracji sił przyrody na fenome- 
nie życia. Zgodnie z tym ujęciem fenomen życia stanowi zasadę porządkującą skomplikowane procesy funkcjonowania całej przyrody ożywionej (Jonas 1979, 155-157).

Wskazywana w tej koncepcji koncentracja sił przyrody na zjawisku życia najpełniejszy wyraz znajduje w osobniczo manifestowanej tendencji poszczególnego organizmu do bycia swoim własnym celem. Ujawnia się w ten sposób drugi aspekt prezentowanej przez Jonasa teleologicznej interpretacji przyrody. W dążeniu do celu bowiem byt czyni się wartym własnego wysiłku, coraz bardziej wzmacniając tę wartość przez stawanie się swoim własnym celem. W tym sensie każda czująca i dążąca do przetrwania istota żywa wypowiada "tak” wobec życia jako dobitne "nie” wobec niebytu. Dlatego też „sam fakt, że byt nie jest obojętny względem siebie samego, czyni z jego odmienności od niebytu podstawową wartość wszystkich wartości, pierwsze «tak» w ogóle" (Jonas 1979, 155). Rozwijając tę myśl, można powiedzieć, że wszystko, co żyje, jest wartościowe, ponieważ tak „chce” przyroda. Ona też stanowi dla Jonasa wzór i zarazem podstawę uzasadnienia ludzkiej powinności szacunku i czci względem wszystkich istot żywych. Respektowanie tej powinności zależy zaś od samego człowieka, gdyż „tylko on sam może być odpowiedzialny” (Jonas 1979, 185). Tylko on bowiem jest w stanie rozpoznać niezbywalną wartość przyrody i w ślad za tym wziąć za nią odpowiedzialność. Stąd wynika zadanie sprzyjania poznawczym i moralnym uzdolnieniom człowieka, w oparciu o które swoim odniesieniom do przyrody może on nadać perspektywę przyszłości. Może on mianowicie przewidywać dalekosiężne skutki swoich działań w przyrodzie i związaną z tymi działaniami sytuację ekologiczną przyszłych pokoleń ludzkich.

Jonas postuluje wobec tego kształtowanie ekologicznej wrażliwości i związanych z nią postaw ludzkich w ramach tzw. "heurystyki lęku”, której zadanie polega właśnie na wzbudzaniu wyobrażenia przyszłych zdarzeń jako odległych w czasie skutków obecnego oddziaływania ludzi na przyrodę (Jonas 1979, 63-65). Trzeba mianowicie wyostrzyć świadomość w tym zakresie i techniczne zaangażowanie człowieka w przyrodzie wiązać z naukowymi prognozami, uwzględniającymi dalekosiężne skutki tego zaangażowania. Jonas proponuje $\mathrm{w}$ tym przypadku unaocznienie długofalowych skutków technicznej działalności człowieka poprzez 
wspierane metodami naukowymi hipotetyczne ich przewidywania. Całość zbudowanej w ten sposób strategii przedsięwzięć proekologicznych nazywa zaś „futurologią porównawczą” (Jonas 1979, 62). W ten sposób chce przed współczesnym człowiekiem uwiarygodnić apokaliptyczną wizję jego przyszłości i wskazać na jej zależność od zjawisk wywołanych jego aktualną działalnością w przyrodzie. Efektem takiej pedagogicznej strategii miałoby być najpierw zrodzone w człowieku uczucie lęku, wyostrzające zmysł obserwacji i dostrzegania zjawisk kryzysowych w przyrodzie poddanej techniczno-technologicznej potędze człowieka, a następnie poczucie odpowiedzialności i gotowość do odpowiedzialności za przyrodę. Zgodnie $\mathrm{z}$ tym ujęciem tylko uczucie wsparte intelektem jest w stanie motywować i kierować odpowiedzialnym działaniem człowieka. Dlatego też opracowania koncepcji Jonasa podkreślają, że postulat „heurystyki lęku” stanowi konieczne ogniwo łączące teorię z praktyką odpowiedzialności człowieka za los nadchodzących pokoleń ludzkich (Wille 1996, 258-262).

Wskazanie na gotowość do podjęcia przez człowieka odpowiedzialności jest istotnym elementem postulowanej przez Jonasa ontologicznej etyki odpowiedzialności. Zdaniem znawców przedmiotu (Wetz 1994, 115-120) Jonas wykorzystuje w tym względzie dorobek Maxa Webera, który jako pierwszy wprowadził kategorię odpowiedzialności do dyskusji etycznych. W krytycznej analizie praktycznej filozofii Kanta Weber odróżnił etykę usposobienia moralnego, czyli etykę intencji, od etyki odpowiedzialności i podkreślał, że jakość ludzkich działań powinna wynikać nie tylko $\mathrm{z}$ etyki usposobienia moralnego, lecz również z uwzględnienia prawdopodobnych skutków tych działań. Gdy jednak Weber w swoich rozważaniach uwzględnia jedynie świat aktualnych odniesień międzyludzkich, Jonas bierze pod uwagę odniesienie człowieka do całości przyrody ożywionej i do przyszłych pokoleń ludzkich. Konsekwentnie też z przyrody i przyszłych pokoleń ludzkich czyni instancję, przed którą człowiek ponosi odpowiedzialność. Utożsamia więc to, za co człowiek jest odpowiedzialny, z tym, przed czym jest on odpowiedzialny: przed przyrodą człowiek jest odpowiedzialny za jej ochronę i pielęgnację. W tej koncepcji racja zobowiązująca człowieka do odpowiedzialnego postępowania względem przyrody wynika z samej przyrody (Jonas 1979, 157). 
Zróżnicowanych wzorców odpowiedzialności człowieka Jonas nie ogranicza do relacji międzyludzkich, lecz rozciąga je także na relacje człowieka z całą biosferą. Odkąd bowiem „człowiek stał się niebezpieczny nie tylko dla siebie, lecz i dla całej biosfery, spadła na nas swego rodzaju odpowiedzialność metafizyczna, wykraczająca ponad interes własny" (Jonas 1979, 246). Takie stanowisko uzasadnia wspólnota losu człowieka i przyrody, rozumianej jako miejsce zamieszkania istoty ludzkiej w najbardziej wzniosłym sensie tego słowa. Stąd wniosek Jonasa, że naturalne zobowiązanie człowieka do szacunku wobec przyrody można ostatecznie podporządkować odpowiedzialności wobec samego człowieka, bez groźby popadnięcia w wąski, antropocentryczny punkt widzenia (Jonas 1979, 246). Antropocentryczne podejście do przyrody, tradycyjnie wykładane jako podporządkowanie przyrody arbitralnie ustalanym potrzebom człowieka, faktycznie jest zgubne dla samego człowieka. W najlepszym przypadku prowadzi ono bowiem do dehumanizacji człowieka, czyli atrofii jego istoty. Wysoce prawdopodobnym jego następstwem może zaś stać się biologiczne unicestwienie ludzkiej egzystencji, nawet w wymiarze całego gatunku Homo sapiens. W tym sensie antropocentryzm stoi w sprzeczności z naturalnym dążeniem człowieka do ochrony samego siebie. W tym też sensie istnienie człowieka może zabezpieczyć jedynie respekt wobec przyrody ze względu na przynależną jej wartość i godność. Biologicznie spokrewniony z przyrodą człowiek zobowiązany jest do dochowania jej wierności, a najwyższym tego wyrazem jest wierność swojej własnej egzystencji. Z perspektywy doświadczenia własnej egzystencji człowiek jest w stanie adekwatnie ocenić wartość przyrody i uznać naturalny charakter swojego zobowiązania do odpowiedzialności za jej przetrwanie (Jonas 1979, 246).

\section{Fizjologiczny obraz przyrody ożywionej}

Postulat fizjologicznego obrazu przyrody stanowi krytyczną reakcję na prezentowane przez Jonasa filozoficzne uzasadnienie konieczności zmiany postępowania człowieka względem przyrody. Zdaniem Schäfera przyjęta przez Jonasa fizjocentryczna perspektywa tego uzasadnienia ściąga na siebie zarzut naturalizmu i anachronizmu. Zarzut naturalizmu odnosi się do tej części koncepcji Jonasa, w której zaleca on przyjęcie normatywnego pojęcia przyrody. Zarzut anachronizmu dotyczy zaś teleolo- 
gicznej prezentacji przyrody jako wartościowej przez dążenie do celów wyznaczanych różnorodnymi formami życia (Schäfer 1987, 22-25).

Krytyka stanowiska Jonasa podkreśla, że dokonana przez niego teleologiczna interpretacja przyrody jest anachroniczna w odniesieniu do wymagań epoki podarwinowskiej i do wyzwań, jakie niesie ze sobą dzisiejsze doświadczenie kryzysu ekologicznego. Ostatecznie podjętą przez Jonasa próbę fizjocentrycznego uzasadnienia etyki odpowiedzialności Schäfer uznaje za nieudaną. Nie umożliwia ona ponadto przezwyciężenia antropocentryzmu, wikłając się w jego nowe odmiany, ukryte niejako w pojmowaniu człowieka przez samego siebie jako najbardziej warty osiągnięcia cel w przyrodzie (Schäfer 1993, 152-173).

Zdaniem Schäfera trudności w urealnieniu koncepcji Jonasa zwiększa ponadto obecne w niej utożsamienie powszechnego antropocentryzmu z egoistyczną postawą człowieka. Historia kultury nowożytnej pokazuje, że utożsamienie takie jest nieuprawnione. Postulowane od początków europejskiej nowożytności metodyczne wykorzystywanie przyrody w celu zwiększenia materialnego dobrobytu ludzkości znalazło bowiem praktyczny wyraz jedynie w egoistycznym dążeniu krajów wysoko rozwiniętych do pomnażania swojego dobrobytu kosztem pozostałej części ludzkości. To zjawisko znajduje proporcjonalne urzeczywistnienie także w strukturze społeczeństw krajów wysoko uprzemysłowionych.

Choć Schäfer nie ma prostej recepty na skuteczne przeciwdziałanie praktykom wykorzystania przyrody, to jednak pewne nadzieje w tym względzie wiąże z obecną $\mathrm{w}$ filozofii podmiotu zasadą równości i solidarności międzyludzkiej, nie zaś z działaniami podejmowanymi w imię przyrody (Schäfer 1987, 26). Dlatego też konsekwentnie orientuje się na antropocentryzm etyki tradycyjnej, zgodnie z którym odpowiedzialność za przyrodę stanowi część zobowiązań wobec człowieka. Są to więc zobowiązania wobec dzisiejszych i nadchodzących pokoleń ludzkich. Oznacza to, że odpowiedzialność człowieka za przyrodę może się pojawić tylko jako część odpowiedzialności człowieka za człowieka (Schäfer 1993, 165). Tym samym wypowiada Schäfer główną tezę pozytywnego wykładu własnej koncepcji etyki ekologicznej, fundowanej na antropologicznej zasadzie racjonalnej i moralnej autonomii człowieka względem przyrody. Zgodnie z tym podejściem tworzenie etyki odpo- 
wiedzialności nie tylko nie wymaga odrzucenia antropocentryzmu, lecz nawet wyraźnie go zakłada. Dopiero bowiem w perspektywie antropocentrycznej, uwyraźniającej autonomię człowieka, ujawnia się problem jego odpowiedzialności względem przyrody.

Tak pojmowany antropocentryzm nie jest tożsamy z egoizmem człowieka. Nie wskazuje więc na radykalną opozycję człowieka względem środowiska naturalnego, lecz stanowi podstawę teorii, zgodnie z którą korzystanie przez człowieka z zasobów przyrody podporządkowane jest specyficznie ludzkim uzdolnieniom poznawczym, szczególnie zaś jego moralności (Schäfer 1987, 26). Jakkolwiek bowiem człowiek zdany jest na korzystanie z zasobów przyrody, to jednak konieczność tę musi wiązać $\mathrm{z}$ racjonalnie rozpoznanymi i moralnie szacowanymi granicami wzrostu dobrobytu materialnego. Chodzi więc o to, aby wzrost gospodarczy i wzrost dobrobytu materialnego nie był dla człowieka celem samym w sobie. Oznacza to, że człowiek tylko wtedy jest uprawniony do zaspokajania swoich potrzeb dobrami przyrody, gdy potrzeby te potrafi należycie oszacować. Pociąga to za sobą konieczność prewencyjnego stylu zachowania się człowieka wobec przyrody (Schäfer 1987, 26).

Działania zmierzające do zaspokojenia potrzeb człowieka dobrami przyrody muszą być zatem powiązane z moralnością człowieka. Ta zaś uwzględnia nie tylko materialne i biologiczne powodzenie człowieka, lecz również utrzymanie i wzrost humanistycznej jakości jego życia. Kryzys, w którym tkwimy, jest bowiem kryzysem nasycenia w zakresie aktualnie dominujących dóbr materialnych. I jest to stan właściwy dla egoistycznej relacji człowieka wobec przyrody pozaludzkiej. Dążenie do podniesienia humanistycznej jakości życia człowieka ze względu na relację do przyrody pozaludzkiej powinno zatem wyrażać się w dążeniu do utrwalania priorytetu dóbr niematerialnych i społecznych. Wtedy też relacja człowieka wobec przyrody pozaludzkiej może wyrazić się różnymi odmianami współistnienia (Scherhorn 1997, 162-251). W ten sposób biologiczny wykład ekologii człowieka wzbogacają aspekty humanistyczne, wskazujące na potrzebę prewencyjnych odniesień człowieka wobec przyrody ze względu na wymóg wyrażanych jednostkowo dobrych stosunków międzyludzkich i pokojowo utrwalonej sytuacji międzynarodowej. Zgodnie z tym wykładem jakość relacji międzyludzkich stanowi pochodną jakości odniesień człowieka wobec przyrody pozaludzkiej. 
Przyjęte przez Schäfera uzasadnienie odpowiedzialności człowieka za przyrodę antropocentryzmem etyki tradycyjnej konsekwentnie prowadzi do przyjęcia fizjologicznej koncepcji przyrody. Zrywa ona z podtrzymywanym przez zwolenników fizjocentryzmu rozumieniem przyrody jako pewnej całości poddanej powszechnym prawom. Rozumie zaś przyrodę jako pewną całość, która sprzyja, bądź nie sprzyja fenomenowi życia. Fizjologiczne ujęcie przyrody wskazuje więc na związek człowieka z przyrodą, wyrażający się w fizjologicznych procesach wymiany między organizmem a jego otoczeniem. Zdaniem Schäfera nie implikuje ono ani archaicznego hasła „z powrotem do natury”, ani też odrzucenia uwarunkowanej techniką obecności człowieka w środowisku naturalnym, lecz podporządkowuje ją zasadom moralno-praktycznym, obejmującym odpowiedzialność za fizyczne zdrowie i biologiczne życie człowieka. Formułowane zaś w jej ramach zdania normatywne nie ściągają na siebie podejrzeń o naturalizm. Zawarta w nich powinność nie wynika bowiem z normatywnego odwołania się człowieka do przyrody, lecz z obowiązków, które człowiek ma wobec samego siebie, w szczególności zaś z obowiązku troski o swoje zdrowie fizyczne (Schäfer 1993, 206-210). Funkcjonalna sprawność fizjologii ludzkiego ciała stanowi bowiem miernik funkcjonalnej sprawności metabolizmu przyrody. Oznacza to, że dobre samopoczucie i fizyczne zdrowie człowieka stanowią najbardziej miarodajne wskaźniki korzystnych warunków ludzkiego środowiska naturalnego.

Fizjologiczna koncepcja przyrody wskazuje ponadto na nowe doświadczenie podstawowe, które można opisać jako powrót do światopoglądu skończoności. Nieskończone uniwersum nowożytnego przyrodoznawstwa stworzyło iluzję, że przyroda jest obszarem bezgranicznym, a jej zasoby są niewyczerpywalne. Faktycznie zaś jest tak, że przyroda, jako nasz habitat i miejsce realnych oddziaływań, ma ściśle zakreślone granice, a procesy wymiany między organizmem i środowiskiem są bardziej gęste, bezpośrednie i ściślejsze niż do niedawna sądzono. Jest więc jasne, że skutki kryzysu ekologicznego szybko dosięgają człowieka w fizjologicznym obiegu życia przyrody. Dlatego też pytania o odpowiedzialność człowieka za przyrodę zmierzają do ochrony organizmów żywych w przekonaniu, że w istocie rzeczy najpełniejszy swój wyraz znaj- 
duje ona w ochronie samego człowieka. Człowiek jako organizm żywy stanowi bowiem część metabolizmu przyrody (Schäfer 1993, 223-237).

Wskazanie na fizjologiczne doświadczenie metabolizmu przyrody umożliwia ekologiczne wartościowanie sposobów i zakresów technicznych ingerencji człowieka w przyrodę. Zgodnie z tym ujęciem odpowiedzialność człowieka nie odnosi się do przyrody jako takiej, lecz do następstw jego działań w przyrodzie. Oznacza to, że odpowiedzialność nie wyraża jedynie pewnego typu relacji człowieka do przyrody, lecz wprost nakłada na niego powinność kultywowania przyrody. Dlatego też główne zadanie filozofii współczesnej należy wiązać z poszukiwaniem kryteriów ekologicznego wartościowania techniki. Przy jej pomocy można bowiem podążać za przeświadczeniem, że koniecznym warunkiem efektywnego korzystania z przyrody jest jej ochrona. Według tej koncepcji technika spełnia rolę pośredniczącą $\mathrm{w}$ spełnianiu przez człowieka kultywacyjnej funkcji wobec samego siebie i przyrody. Technika stanowi tutaj istotne dopełnienie relacji człowieka do przyrody. Gdy więc zwolennicy fizjocentryzmu w technice upatrują zagrożenie dla przyrody, Schäfer dostrzega techniczne możliwości jej kultywowania. Pod warunkiem wszakże, iż zastosowanie techniki będzie się odbywać w perspektywie jej ekotechnicznego uzupełnienia (Ropohl 1985, 28 -30 i 111-134). Dlatego też Schäfer, w odróżnieniu od Jonasa, szansy dla ludzkości nie upatruje w postulacie nowej etyki ekologicznej, lecz w postulacie alternatywnych form techniki wartościowanej ekologicznie. Tym samym dostrzega możliwość dochowania wierności nowożytnemu projektowi korzystania z przyrody bez niebezpieczeństwa popadnięcia w błędy popełnione na etapie naiwnej jego realizacji (Schäfer 1993, 267).

Refleksja nad relacją człowieka do przyrody nie musi więc uwzględniać normatywnego charakteru przyrody, lecz ekologiczne wartościowanie sposobów kultywowania przyrody. Ono też zakłada uznanie przyrody za środek w odniesieniu do celu, jakim jest człowiek. Konsekwentnie też pojęcie kultury Schäfer wiąże nierozdzielnie ze stanowiskiem antropocentrycznym i twierdzi, że „kto domaga się odrzucenia antropocentryzmu, odrzuca tym samym zadanie kultywowania przyrody" (Schäfer 1987, 27-28). Właściwe rozumienie tezy o człowieku jako celu przyrody domaga się jej wzbogacenia o tezę o człowieku jako 
istocie zdolnej do wartościowania w zakresie doboru środków sprzyjających kultywowaniu przyrody. Związek obu tych tez ujmuje Schäfer zgodnie ze stanowiskiem Immanuela Kanta wyrażonym w Krytyce władzy sądzenia (Kant 1964, 414-431). Według tego ujęcia człowiek tylko wtedy może być postrzegany jako ostateczny cel przyrody, gdy sam dysponuje możliwością ustalania celów. Ponieważ człowiek może ustalać cele jedynie w obszarze działań obyczajowo-praktycznych, jego pozycja władcy przyrody nie jest związana z możliwością dysponowania określonymi środkami technicznymi, lecz z moralnością. Pozycja ta przysługuje człowiekowi nie dlatego, że ma on władzę podporządkowania sobie przyrody ze względu na arbitralnie ustalane cele, lecz tylko dlatego, że zgodnie z moralnością może on traktować przyrodę jako środek do osiągania określonych celów. Relacja człowieka do przyrody jest więc podporządkowana moralności człowieka, który dzięki temu sam stanowi zasadę odpowiedzialnego podejścia do kryzysu ekologicznego (Schäfer 1987, 28).

\section{Podsumowanie}

Choć przywołane tutaj obrazy przyrody stanowią wynik różnych perspektyw poznawczych, to jednak w równym stopniu sprzyjają zerwaniu z iluzjami nowożytnego przyrodoznawstwa, że przyroda jest obszarem bezgranicznym, a jej zasoby są niewyczerpywalne. Oba obrazy w równym stopniu też przyczyniają się do kształtowania postaw człowieka przyjaznego światu i budowy świata przyjaznego człowiekowi. Można więc je potraktować jako w równym stopniu ważne przyczynki do wiązania zawartej w idei zrównoważonego rozwoju dobrej teorii z próbami jej praktycznego zastosowania. W tym sensie stanowiska filozoficzne wyrażone przywołanymi tutaj obrazami przyrody o tyle przyczyniają się do prac nad rozwiązaniem kwestii ekologicznej, o ile wykazują metodologiczną odrębność od nauk przyrodniczych. $Z$ tej racji dzisiaj mówi się o nowej filozofii przyrody, której specyfika nie polega jedynie na adekwatnym metodologicznie orzekaniu o przyrodzie, lecz także na kształtowaniu relacji człowieka do przyrody i relacji człowieka do samego siebie, w tym mianowicie sensie, w jakim sam człowiek jest także przyrodą (Böhme 1989, 7-12). To zaś pokazuje, że prezentowane obra- 
zy przyrody ożywionej nawiązują do tego nurtu poszukiwań filozoficznych, który uwzględnia aktywną obecność człowieka w przyrodzie. Jest to więc jedna $\mathrm{z}$ odmian filozofii praktycznej, którą konstytuuje poszukiwanie prawdy ludzkiego działania w świecie. Akcentując biologiczny związek człowieka $\mathrm{z}$ naturalnym środowiskiem jego życia, filozofia ta wskazuje na charakterystyczną dla człowieka możliwość wzbogacenia tego związku przez odpowiedzialność. Zgodnie z tą koncepcją człowiek jest w sobie właściwy sposób reprezentatywny dla swojego środowiska życia: przynależy do niego i zarazem jest w stanie dystansować się wobec niego. Ta zdolność człowieka wyraża się zaś w różnych typach relacji człowieka do środowiska: może on traktować środowisko instrumentalnie, ale może też brać za nie odpowiedzialność (Łepko 2014, 61-70). W tym sensie jest on jednym ze źródeł zagrożeń ekologicznych i zarazem nadzieją na ich przezwyciężenie. Rzecz w tym, aby zbudować stabilną zasadę tej nadziei, czyli zasadę odpowiedzialności człowieka za swoje środowisko życia. Prezentowana powyżej konfrontacja filozoficznych obrazów przyrody ożywionej stanowi ważny przyczynek do prac nad taką zasadą (Meyer-Abich 1997, 154-162).

\section{Bibliografia:}

Böhme, Gernot. 1989. Einleitung. Einer neuen Naturphilosophie den Boden bereiten. W: Klassiker der Naturphilosophie. Von den Vorsokratikern bis zur Kopenhagener Schule, red. Gernot Böhme, 7-12. München: C. H. Beck.

Hume, David. 1978. Treatise of Human Nature. Oxford: University Press.

Jonas, Hans. 1973. Organismus und Freiheit. Ansätze zu einer philosophischen Biologie. Göttingen: Vandenhoeck\& Ruprecht.

Jonas, Hans. 1979. Das Prinzip Verantwortung. Versuch einer Ethik für die technologische Zivilisation. Frankfurt am Main: Suhrkamp.

Jonas, Hans. 1983. Forschung und Verantwortung. Aulavorträge. St. Gallen: Hochschule St. Gallen für Wirtschafts- und Sozialwissenschaften.

Kant, Immanuel. 1964. Krytyka władzy sądzenia, tłum. Jerzy Gałecki. Warszawa: PWN. 
Łepko, Zbigniew. 1999. W sprawie antropologicznych aspektów ekofilozofii. W: Ochrona środowiska w filozofii i teologii, red. Józef M. Dołęga i Jacek W. Czartoszewski, 265-280. Warszawa: Wydawnictwo Akademii Teologii Katolickiej.

Łepko, Zbigniew. 2014. Die anthropologischen Aspekte der Umweltkrise. Seminare. Poszukiwania naukowe, 35(2), 61-70.

Meyer-Abich, Klaus Michael. 1997. Mit-Wissenschaft: Erkenntnisideal einer Wissenschaft. W: Vom Baum der Erkenntnis zum Baum des Lebens. Ganzheitliches Denken der Natur in Wissenschaft und Wirtschaft, red. Klaus M. Meyer-Abich, 19-162. München: C. H. Beck.

Moore, George Edward.1903. Principia Ethica. Cambridge: At the University Press.

Ropohl, Günter. 1985. Die unvollkommene Technik. Frankfurt am Main: Suhrkamp.

Schäfer, Lothar. 1987. Selbstbestimmung und Naturverhältnis des Menschen W: Über Natur. Philosophische Beiträge zum Naturverständnis, red. Otto Schwemmer, 15-36. Frankfurt am Main: Vittorio Klostermann.

Schäfer, Lothar. 1993. Das Bacon-Projekt. Von der Erkenntnis, Nutzung und Schonung der Natur. Frankfurt am Main: Suhrkamp.

Scherhorn, Gerhard. 1997. Das Ganze der Güter. W: Vom Baum der Erkenntnis zum Baum des Lebens. Ganzheitliches Denken der Natur in Wissenschaft und Wirtschaft, red. Klaus M. Meyer-Abich, 162-251. München: C. H. Beck.

Wetz, Franz Josef.1994. Hans Jonas zur Einführung. Hamburg: Junius Verlag.

Wille, Bernd. 1996. Ontologie und Ethik bei Hans Jonas. Dettelbach: Röll Verlag. 
Ryszard F. Sadowski

Uniwersytet Kard. Stefana Wyszyńskiego w Warszawie - Instytut Ekologii i Bioetyki r.sadowski@uksw.edu.pl

\section{Potencjał religii w zakresie promocji i implementacji idei zrównoważonego rozwoju}

\section{Wprowadzenie}

Wbrew wciąż utrzymującemu się stereotypowi na temat winy religii w kwestiach środowiskowych należy stwierdzić, że religie mają znaczący udział zarówno w rozpoznawaniu kryzysu środowiskowego, jak i w działaniach na rzecz jego przezwyciężania. Wzmożone zainteresowanie zagadnieniami środowiskowymi ze strony intelektualistów identyfikujących się z różnymi tradycjami religijnymi zauważa się już w latach 50. XX wieku, dokumentują to liczne opracowania (Sheldon 1992; Fowler 1995; Bakken, Engel i Engel 1995). Religie od początku uczestniczyły więc w identyfikacji współczesnych zagrożeń ekologicznych, a od kilku dekad aktywnie angażują się w walkę z kryzysem środowiskowym, m.in. poprzez wspieranie idei zrównoważonego rozwoju.

Przełomowym momentem w dyskusji nad rolą religii w tzw. kwestii ekologicznej było opublikowanie przez Lynna T. Whitea artykułu pt. The Historical Roots of Our Ecologic Crisis (1967). Zdaniem White’a winę za zaistnienie współczesnego kryzysu środowiskowego ponosi judeochrześcijańska tradycja religijna. Upowszechniając biblijne opowiadanie o stworzeniu świata, ukształtowała bowiem wśród swoich wyznawców przekonanie o dominującej roli człowieka względem stworzeń i o jego nieograniczonym prawie do dowolnego dysponowania i przekształcania przyrody dla swoich potrzeb. Artykuł White’a stał się katalizatorem, który zainicjował ożywioną dyskusję nad rolą chrześcijaństwa w sprawstwie kryzysu środowiskowego (Sponsel 2016). Dyskusja ta trwa do dziś. Zaś teza o ekologicznej winie chrześcijaństwa weszła do literatury przedmiotu jako Lynn White thesis (Whitney 2013).

Zainicjowana przez White’a dyskusja doprowadziła do dogłębnych i interdyscyplinarnych badań nad rolą chrześcijaństwa w kwestii ekologicznej. Opinie uczonych są w tym względzie podzielone. Na obecnym 
etapie tego sporu argumenty przeciwników poglądów White’a zdają się przeważać. Współczesne badania nie tylko bowiem przeczą jego interpretacji tekstów biblijnych, ale wręcz wskazują na ich ekologiczny potencjał (Sadowski 2015, 83-95 i 268-287).

Debata sprowokowana przez Whitéa z czasem przestała dotyczyć jedynie tradycji judeochrześcijańskiej. Zaczęto stawiać także pytania o to, jak inne tradycje religijne kształtują relacje swych wyznawców do środowiska. Dobrym przykładem rozszerzenia zakresu tej dyskusji są badania prowadzone przez M. E. Tucker i J. A. Grima, którzy w latach 1996-1998 zorganizowali na Uniwersytecie Harvarda cykl konferencji poświęconych stosunkowi największych światowych religii do środowiska naturalnego. Owocem tych konferencji jest seria wydawnicza Religions of the World and Ecology. Rozpoczęte w ten sposób poszukiwania naukowe okazały się na tyle obiecujące, że powstała grupa uczonych, którzy postanowili je kontynuować. Inicjatywa ta przyjęła nazwę Forum on Religion and Ecology (FORE) (Taylor 2016, 293).

Z czasem spór o rolę chrześcijaństwa w kwestii ekologicznej przybrał postać sporu o rolę religii w tej kwestii. Linia podziału przebiega obecnie pomiędzy skupionymi wokół FORE zwolennikami tzw. greening of religion hypothesis oraz między zwolennikami koncepcji dark green religion. Pierwsi stoją na stanowisku, że tradycyjne religie są krytycznie ważnym partnerem w budowaniu zrównoważonego świata (Taylor 2016, 296). Drudzy zaś twierdzą, że wyznawcy rodzącej się biocentrycznej dark green religion opartej na naukowej kosmologii i przekonaniu o pokrewieństwie wszystkich istot żywych wykazują znacznie więcej rewerencji wobec przyrody niż przedstawiciele tradycyjnych religii (Taylor 2011, 259).

Pomijając szczegółowe badania na temat tego, która religia i w jakim zakresie wpływa na rzecz zrównoważonego rozwoju świata, opracowanie to stawia sobie za cel wskazanie potencjału religii w promocji i implementacji idei zrównoważonego rozwoju. Wydaje się bowiem, że poprzez ukazanie religijnych inspiracji tej idei oraz zaangażowanie liderów religijnych we współpracę z naukowcami, politykami i działaczami ekologicznymi religie mogą istotnie wesprzeć implementację idei zrównoważonego rozwoju nie tylko na poziomie globalnym, regionalnym 
czy krajowym, ale przede wszystkim - lokalnym i indywidualnym. Ze względu na ograniczoną objętość niniejszego opracowania autor skoncentruje się na ukazaniu wpływu religii na środowiskowy aspekt idei zrównoważonego rozwoju, pozostawiając ukazanie wpływu religii na ekonomiczny, społeczny i instytucjonalno-polityczny aspekt tej idei do późniejszego opracowania.

\section{Religijne inspiracje idei zrównoważonego rozwoju}

Idea zrównoważonego rozwoju odwołuje się do koncepcji umiaru i wstrzemięźliwości, które są obecne w myśli europejskiej od tysiącleci. Licznych przykładów na potwierdzenie tej tezy dostarcza zarówno filozofia grecka, jak i literatura rzymska. Dzięki ich obecności możliwe było wypracowanie w kulturze Zachodu zasady „złotego środka” (łac. aurea mediocritas) oraz pochwały umiaru i harmonii, które stanowiły podstawę kultury antycznej (Sadowski 2011, 71-72; Sadowski 2016a). Ważną rolę w kształtowaniu „kultury umiaru” odegrały i odgrywają do dziś religie. Wpisują się w to zarówno monoteistyczne tradycje religijne dominujące w Europie, jak i politeistyczne religie azjatyckie.

Dobrą ilustracją wkładu tych ostatnich w promowanie „kultury umiaru" są pisma buddyjskie. Zachęcają one bowiem do wybierania pośredniej drogi (sanskr. madhyamā-pratipad) i odradzają wszelkie skrajności, zarówno nadmiar, jak i niedostatek. Ponieważ tylko umiarkowane życie, jak nauczał Budda, gwarantuje osiągnięcie pełni człowieczeństwa (Gross 1997, 298-299; Lang 2004).

W tradycji hinduistycznej jest natomiast obecna idea dobra wspólnego (sanskr. savra-bhūta-hitā), która zobowiązuje wyznawców tej religii m.in. do troski o przyrodę. Postawy takie wspiera zasada sarvakalyānkari-karma, która zachęca do podejmowania działań na rzecz dobra wspólnego i troski o innych (Dwivedi 2000, 12-13). Ponadto tradycja hinduistyczna wspiera sprawiedliwość międzypokoleniową, będącą istotnym elementem idei zrównoważonego rozwoju. Przyczynia się do tego koncepcja karmy, w myśl której każdy intencjonalny czyn pociąga za sobą trwałe, choć nie zawsze od razu zauważalne konsekwencje (karma-phala). Dotyczy to także czynów, które bezpośrednio lub pośrednio wpływają na przyrodę. Rozpoczętej karmy nie może zatrzymać 
nawet śmierć osoby, która ją zainicjowała. Karma dosięga bowiem tę osobę w kolejnym jej wcieleniu. Wydaje się, że można tu mówić o swoiście rozumianym religijno-kulturowym zabezpieczeniu przed krótkowzrocznym i nieodpowiedzialnym sposobem postępowania człowieka względem przyrody (Sadowski 2011, 68-69).

Największy wkład w budowę cywilizacji umiarkowania i wypracowanie podstaw dla współczesnej idei zrównoważonego rozwoju wniosły jednak religie monoteistyczne. Tradycja judaistyczna jednoznacznie pochwala umiarkowanie i wstrzemięźliwość, gani zaś wszelką przesadę. Potwierdzają to liczne fragmenty Starego Testamentu (Prz 30,1-9; Mdr 8,7; Syr 37,31). Biblia nie pozostawia też wątpliwości, że świat został stworzony przez Boga jako dobry i to On jest jego jedynym właścicielem (Ps 24,1; 1Krn 29,11-12). Człowiek zaś jest jedynie dzierżawcą, który może używać świata dla własnych potrzeb na warunkach wyznaczonych mu przez Stwórcę (Kpł 25,23). Księga Rodzaju wyraźnie wskazuje na obowiązki człowieka względem stworzenia symbolizowanego przez ogród Eden. Zadaniem człowieka jest jego uprawianie i doglądanie $(\mathrm{Rdz} 2,15)$. Lingwistyczna analiza tego tekstu wyraźnie wskazuje, że to człowiek jest na usługach Edenu, nie zaś Eden na usługach człowieka. Zadaniem człowieka jest więc służyć, strzec i chronić przyrodę (Pardee 2013, 127; Sadowski 2015, 91-95).

Dobrą ilustracją wstrzemięźliwego korzystania z zasobów środowiskowych i podejmowania decyzji z uwzględnieniem interesów przyszłych pokoleń był wprowadzony przez rabinów zakaz zwiększania liczebności stad krótko po powstaniu Bark Kochby (132-135 AD), które przyczyniło się do poważnej degradacji izraelskich pastwisk (Tirosh-Samuelson 2006, 45). Innym przykładem wskazującym na odpowiedzialność człowieka za przyrodę w tradycji rabinistycznej jest komentarz do Księgi Rodzaju zawarty w midraszu Kohelet Rabbah, który stwierdza: „Gdy Bóg stworzył pierwszego człowieka, pokazał mu wszystkie drzewa ogrodu Eden i rzekł mu: «Zobacz moje dzieła, jakże są piękne i godne czci. Wszystko, co stworzyłem, stworzyłem dla ciebie. Bądź jednak ostrożny, nie zmarnuj i nie zniszcz mojego świata, bo jeśli to zrobisz, nie będzie nikogo oprócz ciebie, by go naprawić»" (Sadowski 2016a, 305).

Chrześcijaństwo, nawiązując do starotestamentalnej tradycji, także podkreśla wartość wstrzemięźliwości i umiarkowania. Potwierdza to 
Nowy Testament, w którym często występują takie określenia, jak skromność, prostota, umiarkowanie, powściągliwość czy wstrzemięźliwość (Dz 24,25; Tt 2,11-12). Ponadto tradycja chrześcijańska głosi, że rozwój człowieka nie może ograniczać się jedynie do wymiaru horyzontalnego (dobra doczesne), lecz musi on obejmować także wymiar wertykalny (dobra duchowe i kulturowe). Chrześcijaństwo występuje w ten sposób przeciw nadmiernemu konsumpcjonizmowi (Mt 16,26; Mt 19,23-24; 1J 3,17), a przez to wychodzi naprzeciw idei zrównoważonego rozwoju.

Ojcowie Kościoła i późniejsi pisarze chrześcijańscy wielokrotnie podkreślali znaczenie troski o stworzenie i konieczność roztropnego korzystania z jego zasobów. Potwierdzenie tej tezy znajduje się w licznych pismach Grzegorza Wielkiego, Minicjusza Feliksa, Tertuliana, Laktancjusza, Arnobiusza Starszego, Ireneusza z Lyonu, Bazylego Wielkiego, Grzegorza Wielkiego, Grzegorza z Nyssy, Augustyna z Hippony i wielu innych (Sadowski 2015, 96-101). Znaczący wpływ na kształtowanie odpowiedzialnego stosunku do przyrody wywarły także późniejsze nurty duchowości chrześcijańskiej. Szczególnie interesujące wydają się w tym względzie modele relacji do przyrody określane jako:

1. Celtycki ożywiający model relacji do przyrody, traktujący przyrodę jako miejsce doświadczania Boga;

2. Benedyktyński opiekuńczy model relacji do przyrody, wskazujący na odpowiedzialność człowieka za przetwarzanie świata powierzonego mu przez Stwórcę;

3. Hildegardy z Bingen oblubieńczy model relacji do przyrody, zwracający uwagę na konieczność przywracania harmonijnych relacji między człowiekiem, światem i Stwórcą, który, zaślubiając Matkę Ziemię, napełnia całe stworzenie życiodajną siłą viriditas;

4. Franciszka z Asyżu braterski model relacji do przyrody, akcentujący pokrewieństwo człowieka i bytów pozaludzkich, które pozwala człowiekowi ustanawiać partnerskie relacje ze wszystkimi członkami ziemskiej wspólnoty życia (Sadowski 2017). 
Chrześcijańskie inspiracje idei zrównoważonego rozwoju można także dostrzec w aksjologicznych podstawach tej idei. Jej nieustanne dopracowywanie skłania do wyrażenia jej aksjologicznych podstaw. Tylko wskazanie tych podstaw explicite daje bowiem nadzieję na spójność tej wciąż ewoluującej idei oraz na skuteczność jej implementacji. Do zasad fundujących idę zrównoważonego rozwoju zalicza się zwykle: zasadę umiarkowania, zasadę złotego środka, zasadę sprawiedliwości, zasadę dobra wspólnego, a także zasadę pokoju, zasadę solidarności, zasadę wolności, zasadę prawdy i zasadę miłości. Większość tych zasad jest mocno zakotwiczona w tradycji chrześcijańskiej, czego wyrazem jest społeczne nauczanie Kościoła katolickiego (Dołęga i Sadowski 2009, 14-17 i 22-33).

Pewnych inspiracji idei zrównoważonego rozwoju można doszukiwać się także w tradycji muzułmańskiej. Koran jednoznacznie potępia bowiem marnotrawstwo i nadmierną konsumpcję (VI, 31) oraz zachęca do umiaru (XIII, 8; XV, 21). Dobrą tego ilustracją jest zdanie przypisywane Mahometowi: „Żyj na tym świecie tak, jakbyś miał żyć na nim wiecznie, ale żyj dla przyszłego świata tak, jak byś miał umrzeć jutro" (Foltz 2006, 211).

Wydaje się więc, że idea zrównoważonego rozwoju przynajmniej wlatentnej formie była wyraźnie obecna w kulturze Zachodu oraz w pewnym zakresie także w kulturach kształtowanych przez religie Wschodu. Chociaż trudno określić, na ile poszczególne tradycje religijne dostarczyły inspiracji dla idei zrównoważonego rozwoju, nie sposób jednak odmówić im wpływu na takie ukształtowanie kultury, które umożliwiło wypracowanie tej idei w dobie współczesnego kryzysu środowiskowego.

\section{Religia i nauka wspólnie na rzecz zrównoważonego rozwoju}

Debata zainicjowana przez Whitea na temat roli religii w sprawstwie i przezwyciężaniu kryzysu środowiskowego spowodowała, że wokół FORE zgromadziło się liczne środowisko uczonych reprezentujących bardzo różnorodne dyscypliny naukowe i utożsamiających się z różnymi tradycjami religijnymi. To reprezentatywne gremium zapoczątkowało nowy etap refleksji nad zagadnieniami ze styku religii i środowiska. W wyniku ożywionej współpracy uczestników FORE podjęto próbę wyłonienia nowej gałęzi wiedzy określanej jako religion and ecology 
(Tucker 2002, 11; Monserud 2002). W celu upowszechniania wyników prowadzonych w tym zakresie badań w 1997 r. powstało czasopismo „World Views: Global Religions, Culture, and Ecology”, zaś w 1999 r. powołano do życia kolejne czasopismo o podobnym profilu tematycznym „Worldviews: Environment, Culture, Religion”. Następnie założono International Society for the Study of Religion, Nature and Culture (2005). Bezpośrednim skutkiem aktywności tego towarzystwa naukowego są liczne publikacje, m.in. The Encyclopedia of Religion and Nature (Sadowski 2009a, 216-217).

Ważnym etapem kształtowania się nowej gałęzi wiedzy było wprowadzenie do kształcenia na poziomie uniwersyteckim przedmiotu pod nazwą religion and ecology. Dzięki staraniom M. E. Tucker i J. A. Grima na Yale University zapoczątkowano międzywydziałowy kierunek studiów magisterskich o nazwie Yale Religion and Ecology Program. Podobne kierunki powstały też na innych zachodnich uczelniach. Kolejnym etapem rozwoju badań nad zagadnieniami ze styku religii i ekologii było otwarcie na University of Florida w 2001 r. specjalności studiów doktoranckich pt. religion and ecology (Sadowski 2009a, 217-218).

Zwieńczeniem wysiłków wielu uczonych zaangażowanych w badania nad związkiem religii i ekologii było dookreślenie rodzącej się dyscypliny, którą scharakteryzowano następująco: Religion and ecology ma charakter interdyscyplinarny, obejmuje m.in. studia środowiskowe, geografię, historię, antropologię, socjologię i politologię. Odpowiada zarówno na zagadnienia historyczne, jak i współczesne, w celu zrozumienia relacji między człowiekiem, Ziemią, Wszechświatem i rzeczywistością sacrum. Religion and ecology bada takie zagadnienia, jak twórcza i destrukcyjna dynamika przyrody; boska obecność w przyrodzie; celowość przyrody i wszechświata; sposoby i zakres wzajemnego oddziaływania środowiska przyrodniczego i kultury; symboliczny wyraz przyrody w mitach i rytuałach religijnych oraz rozumienie ekologii w tradycyjnych praktykach rolniczych, handlowych, rybackich i myśliwskich. Ponadto religion and ecology analizuje sposoby wyrażania przez wspólnoty religijne stosunku do właściwego im środowiska życia. W skrócie religion and ecology można określić jako nowy paradygmat poznawczy złożonych i różnorodnych systemów relacji człowiek - Ziemia obecnych w różnych religiach (Tucker i Grim 2001, 14-17; Sadowski 2009a, 218). 
Zaangażowanie uczonych reprezentujących różne dyscypliny naukowe i tradycje religijne przyczyniło się do ożywienia dialogu środowisk religijnych, uczonych zajmujących się kryzysem środowiskowym, polityków oraz działaczy ekologicznych. Wypracowanie naukowych podstaw motywowanej religijnie troski o przyrodę pozwoliło tym środowiskom wkroczyć na zupełnie nowy poziom dialogu. Naukowa refleksja nad poszczególnymi tradycjami religijnymi ukazała ich ekologiczny potencjał i przyczyniła się do postrzegania religii jako ważnych partnerów w budowie zrównoważonego świata. Zmianę mentalności w postrzeganiu religii u osób zaangażowanych w promocję i wdrażanie idei zrównoważonego rozwoju dobrze ilustruje książka Gary’ego Gardnera pt. Inspiring Progress. Religions' Contribiutions to Sustainable Development, w której akcentuje on rolę religii w ukazywaniu płaszczyzny etycznej, niezbędnej do skutecznego wdrażania zrównoważonego rozwoju (Gardner 2006). Gardner tezę tę zasygnalizował już kilka lat wcześniej w opublikowanym przez Worldwatch Institute Raporcie o stanie świata 2003. W rozdziale pt. Engaging Religion in the Quest for a Sustainable World wskazuje on na pięć kluczowych atutów religii, ze względu na które należy zachęcać religie do zaangażowania się w budowę zrównoważonego świata. Do atutów tych zalicza:

\footnotetext{
$\checkmark$ zdolność kształtowania kosmologicznych obrazów świata;

$\checkmark$ autorytet moralny;

$\checkmark$ wielką liczbę wyznawców;

$\checkmark$ znaczące środki ekonomiczne;

$\checkmark$ wspólnototwórczy potencjał religii (Gardner 2003, 154).
}

Zaś Paula J. Posas, badając możliwe korzyści z zaangażowania religii w walkę ze zmianami klimatycznymi, wskazuje, że ekologiczny potencjał religii ma swoje źródło w:

$\checkmark$ tradycyjnych i unikalnych funkcjach religii w społeczeństwie;

$\checkmark$ nauczaniu etycznym;

$\checkmark$ zasięgu i wpływach;

$\checkmark$ zdolności inspirowania swoich wyznawców do podjęcia działań (Posas 2007, 38; Sadowski 2013b, 84). 
Artur Pawłowski podkreśla natomiast wpływ religii na kształtowanie postawy umiaru u swych wyznawców, szczególnie przez wskazywanie etycznego wymiaru ich czynów. Jego zdaniem, warunkiem skutecznej implementacji idei zrównoważonego rozwoju jest hierarchizacja jej płaszczyzn z jednoczesnym wskazaniem fundamentalnej roli płaszczyzny etycznej (Pawłowski 2008, 109-111).

Dostrzeżenie w religiach ważnego partnera w budowie zrównoważonego świata ukazało, że religie mogą wspomóc uczonych, polityków i działaczy ekologicznych nie tylko na polu naukowej refleksji, ale także w praktycznych działaniach na rzecz walki z kryzysem środowiskowym. Zapoczątkowało to różne formy współpracy i zaangażowania środowisk religijnych w ochronę homeostazy naszej planety.

Bezpośrednim efektem zmiany $\mathrm{w}$ postrzeganiu roli religii $\mathrm{w}$ kwestii ekologicznej były zachęty uczonych do zaangażowania się religii w troskę o środowisko. W odpowiedzi na te propozycje zwierzchnicy poszczególnych religii zaczęli podejmować indywidualne i wspólne inicjatywy w formie orędzi, lobbingu i ukazywania moralnego wymiaru kryzysu ekologicznego, zachęcając swych wiernych do podejmowania bezpośrednich działań na rzecz budowy zrównoważonego świata.

Współautor książki Granice wzrostu - Jørgen Randers - był jednym z pierwszych uczonych, którzy dostrzegli rolę, jaką religie mogą odegrać w walce z kryzysem środowiskowym. Już w 1972 r. stwierdził: „prawdopodobnie jedynie religia dysponuje siłą moralną zdolną do wprowadzenia koniecznych zmian" (Randers 1972, 32). Ważnym krokiem na drodze do rozwoju dialogu uczonych i przywódców religijnych na rzecz budowy zrównoważonego świata był apel międzynarodowej grupy wybitnych uczonych, którzy zwrócili się do liderów religijnych zebranych w ramach Global Forum of Spiritual and Parlamentary Leaders. W apelu tym uczeni stwierdzili: „Problemy tak wielkiej wagi, i rozwiązania domagające się tak szerokiej perspektywy, od początku muszą być rozpatrywane zarówno w wymiarze religijnym, jak i naukowym. Świadomi naszej wspólnej odpowiedzialności, my naukowcy - którzy przez długi już czas jesteśmy zaangażowani w walkę z kryzysem ekologicznym z mocą apelujemy do światowej wspólnoty ludzi wierzących, by w słowach i czynach z maksymalnym zaangażowaniem podjęli działania 
w celu ochrony środowiska naturalnego naszej planety" (Sagan 1990, 615; Sadowski 2013b, 85-86).

W odpowiedzi przywódcy religijni stwierdzili: „jako przedstawiciele różnych religii akceptujemy profetyczną odpowiedzialność przekazania milionom naszych wyznawców pełnej wiedzy, we wszystkich jej wymiarach, na temat wyzwań ekologicznych, przed jakimi dziś stajemy. (...) Osiągnęliśmy porozumienie na najwyższym poziomie przywództwa wśród szerokiego spectrum tradycji religijnych, że kwestia ochrony środowiska musi mieć pierwszorzędną wagę dla wszystkich wierzących. Odpowiedź na kryzys ekologiczny może i musi przekroczyć granice religii i polityki” (NRPE 2003, 118-119).

Do środowiskowego dialogu uczonych i liderów religijnych dołączyli także politycy, którzy również rozpoznali znaczenie zaangażowania religii w zrównoważony rozwój świata. Od kilku dekad przedstawiciele religii są więc zapraszani na szczyty klimatyczne i spotkania, podczas których podejmowane są ważne decyzje na temat kryzysu środowiskowego. Dobrą ilustracją zmiany nastawienia polityków do religii na gruncie współpracy na rzecz wdrażania zrównoważonego rozwoju jest powołanie do życia w lutym 2016 r. w Berlinie International Partnership on Religion and Sustainable Development (PaRD). Organizacja ta gromadzi podmioty rządowe i pozarządowe, $w$ tym organizacje religijne i świeckie, które łączy przekonanie o ważności wartości religijnych dla osiągnięcia Celów Zrównoważonego Rozwoju 2030 (PaRD 2017). Innym przykładem docenienia przez polityków roli religii we wdrażaniu zrównoważonego rozwoju była konferencja naukowa pt. Religion \& Sustainable Development: Building Partnerships to End Extreme Poverty (New York, 12.06.2015). Współorganizatorami tej konferencji były następujace instytucje: World Bank Group, German Federal Ministry for Economic Cooperation and Development, U.S. Agency for International Development, UK Department For International Development, GHR Foundation, World Vision oraz Joint Learning Initiative on Faith and Local Communities (The World Bank 2015).

Obecnie w dialog na temat zrównoważonego rozwoju świata zaangażowani są specjaliści z niemal wszystkich obszarów nauki. Uczestniczą w nim przedstawiciele nauk humanistycznych, społecznych, ścisłych, 
przyrodniczych, technicznych oraz rolniczych, leśnych i weterynaryjnych. Do grona uczonych dołączyli także politycy, przedstawiciele organizacji pozarządowych, ruchów ekologicznych oraz artyści i liderzy religijni. Udział tych ostatnich w dialogu na rzecz ochrony naszej planety jest obserwowany już od dawna (Tucker 2003, 43-44). Zaangażowanie liderów religijnych $\mathrm{w}$ walkę $\mathrm{z}$ kryzysem środowiskowym jest dziś czymś oczywistym. Przywódcy największych religii świata coraz częściej wypowiadają się na ten temat. Do szczególnie aktywnych w tym względzie należy prawosławny patriarcha Konstantynopola Bartłomiej I oraz papieże Jan Paweł II, Benedykt XVI i Franciszek. Ten ostatni, ogłaszając w 2015 r. encyklikę Laudato Si', zainicjował wielką mobilizację wyznawców różnych religii na całym świecie w kontekście szczytu klimatycznego w Paryżu COP-21 (Sadowski 2016b).

\section{Religia na rzecz implementacji idei zrównoważonego rozwoju}

Literatura przedmiotu dostarcza licznych wypowiedzi liderów religijnych na tematy związane ze zrównoważonym rozwojem. W kontekście promocji idei zrównoważonego rozwoju warto jednak zwrócić uwage na stosunkowo mało znane przemówienie Jana Pawła II do członków Papieskiej Akademii Nauk, w którym dokonuje on refleksji nad niebezpieczeństwami zagrażającymi całej planecie oraz możliwymi kierunkami działań, które pozwoliłyby uchronić świat przed zniszczeniem (John Paul II 1999).

Niezwykle ważne wydaje się także przesłanie Jana Pawła II zawarte w orędziu wygłoszonym 1.01.1990 r. z okazji Światowego Dnia Pokoju. „Dziś kwestia ekologiczna nabrała tak poważnych rozmiarów, że odwołuje się do odpowiedzialności właściwie wszystkich ludzi. Złożoność jej aspektów... wskazuje na potrzebę zjednoczenia wysiłków w celu ustalenia konkretnych obowiązków i zadań, jakie należą do jednostek, narodów, państw i całej międzynarodowej wspólnoty” (Jan Paweł II 1990, 15).

Wiele wskazuje na to, że zaangażowanie liderów wielu wspólnot chrześcijańskich przyczyniło się do powstania licznych organizacji ekologicznych o religijnej proweniencji. Organizacje te są swoistym fenomenem. Ich członkowie angażują się bowiem w ochronę przyrody głównie z pobudek religijnych. Zjawisko to obserwowane jest we wszystkich 
największych religiach świata. Najwięcej takich organizacji powstało jednak na gruncie chrześcijańskim. Znaczna część tych organizacji ma charakter międzywyznaniowy, a nawet międzyreligijny. Powstawanie organizacji ekologicznych o religijnej proweniencji odnotowuje się już w latach 80. XX w., proces ten nasilił się jeszcze w dwóch kolejnych dekadach. Zauważa się także powstawanie organizacji, które wprawdzie nie mają charakteru religijnego, lecz za cel stawiają sobie pomoc religiom w zdynamizowaniu ich działań na rzecz budowy zrównoważonego świata (Allison 2007; Sadowski 2013b, 87; Sadowski 2009b, 157-159).

Wśród działań środowisk religijnych na rzecz troski o naszą planetę można wyróżnić:

$\checkmark$ wywieranie presji na polityków w celu podejmowania bardziej zdecydowanych działań na rzecz ochrony przyrody;

$\checkmark$ działania mające na celu wdrażanie nowoczesnych technologii przyjaznych środowisku;

$\checkmark$ projekty polegające na zalesianiu i rekultywacji terenów zagrożonych pustynnieniem;

$\checkmark$ kampanie medialne nastawione na zmianę przyzwyczajeń konsumenckich;

$\checkmark$ kampanie na rzecz edukacji ekologicznej;

$\checkmark$ nauczanie, które wskazuje wiernym, że relacja człowieka do przyrody ma wymiar moralny;

$\checkmark$ modlitwę za stworzenie oraz formowanie wiernych do „nawrócenia ekologicznego" (Sadowski 2009b, 150-152).

Wiele spośród tych działań zostało opisanych w literaturze przedmiotu. Działalność polskich organizacji ekologicznych o religijnej proweniencji na rzecz wdrażania rozwoju zrównoważonego nie jest jeszcze rzetelnie zbadana i opisana. Ukazały się jednak już pierwsze opracowania na ten temat (Sadowski 2009b; Sadowski 2013b, 89-92; Sadowski 2013a).

Wiele inicjatyw na rzecz wdrażania idei zrównoważonego rozwoju prezentuje Raport o stanie świata 2003. Podkreśla on wkład religii w odchodzenie od obsesyjnej konsumpcji, jaką w dużej mierze charakteryzują się społeczeństwa państw rozwiniętych (Gardner 2003, 160 i 167-171). Najnowsze badania wskazują zaś, że działania środowisk re- 
ligijnych na rzecz wdrażania zrównoważonego rozwoju są niezbędnym warunkiem do walki ze zmianami klimatu. Sigurd Bergmann podaje liczne przykłady religijnych inicjatyw na rzecz ochrony klimatu. Religie współpracują na tym polu m.in. z takimi organizacjami jak WWF, International Consultancy on Religion, Education and Culture oraz Alliance of Religion and Conservation. Pokazuje on też liczne inicjatywy klimatyczne Światowej Rady Kościołów, European Christian Environmental Network i projekty realizowane przez organizacje muzułmańskie, buddyjskie oraz religie pierwotne (Bergmann 2015, 389-392).

$\mathrm{Na}$ podkreślenie zasługuje wielka mobilizacja katolików na całym świecie, którzy zainspirowani zapowiedzią ogłoszenia encykliki Laudato Si’ założyli Światowy Ruch Katolików na rzecz Ochrony Klimatu (Global Catholic Climate Movement - GCCM). Organizacja ta zrzesza osoby indywidualne i organizacje katolickie z całego świata, które zajmują się walką z kryzysem klimatycznym. GCCM stawia sobie za cel mobilizację środowisk katolickich zachęconych przez papieża Franciszka do działań na rzecz ochrony klimatu. Z inicjatywy GCCM zebrano 907048 podpisów pod petycją, która została przekazana sygnatariuszom szczytu klimatycznego w Paryżu (GCCM 2015). Troska o zmniejszenie emisji $\mathrm{CO}_{2}$ jest głównym celem działalności Catholic Climate Covenant (CCC), do której przynależy ponad 17 tys. amerykańskich parafii katolickich i wiele milionów katolików. Do największych sukcesów CCC należy zaliczyć takie projekty klimatyczne jak: St. Francis Pledge; Creation Care Teams; Feast of St. Francis; Advocacy; Catholic Climate Ambassadors (CCC 2017). Panoramę zaangażowania środowisk religijnych w walkę ze zmianami klimatycznymi prezentuje raport Religious Organizations Taking Action on Climate Change, który wymienia liczne działania podejmowane z pobudek religijnych na rzecz ochrony klimatu (Allison 2007).

Analizując działalność religii na rzecz zrównoważonego rozwoju świata, Ian Barbour zwraca uwagę, że istnieje kilka ważnych powodów, dla których religie chętnie wpisują się w tego typu inicjatywy. Zdaniem Barboura, przesądza o tym pokrewieństwo wielu doktryn religijnych i koncepcji zrównoważonego rozwoju w ujmowaniu takich zagadnień jak: 1) długoterminowa, globalna wizja świata; 2) szacunek dla wszystkich form życia oraz 3) troska związana ze wzrostem populacji. Wska- 
zuje on także na zagadnienia, które są specyficzne dla niektórych religii: 1) zaangażowanie na rzecz sprawiedliwości społecznej; 2) realistyczną wizję ludzkiej natury; 3) postawę pokory oraz 4) wizję szczęśliwego życia, które nie opiera się na konsumpcji (Barbour 2000, 388-399). Wszystkie wymienione powyżej argumenty pozwalają prognozować, że zaangażowanie religii w zrównoważony rozwój świata będzie nadal rosło, a religie staną się jeszcze ważniejszymi partnerami w tym procesie.

\section{Zakończenie}

Wydaje się, że obecnie niewiele jest już osób, które negują zasadność angażowania się religii w budowanie zrównoważonego świata. Przyczyniło się do tego wiele ekologicznych inicjatyw podejmowanych przez środowiska religijne, które z pobudek duchowych czynnie angażują się $\mathrm{w}$ walkę $\mathrm{z}$ kryzysem środowiskowym. Inicjatywy te przyjmują różne formy:

$\checkmark$ wystąpienia liderów religijnych na rzecz ochrony środowiska;

$\checkmark$ czynny udział w Szczytach Ziemi oraz innych ważnych wydarzeniach, podczas których podejmowane są decyzje w sprawie tzw. kwestii ekologicznej;

$\checkmark$ wywieranie presji na polityków, by podejmowali bardziej zdecydowane działania na rzecz troski o kondycję naszej planety;

$\checkmark$ kampanie społeczne wskazujące na moralny wymiar stosunku człowieka do przyrody;

$\checkmark$ działalność na rzecz edukacji ekologicznej;

$\checkmark$ propagowanie takiego modelu rozwoju człowieka, który nie ogranicza się jedynie do rozwoju horyzontalnego (sfery ekonomicznej), ale akcentuje rozwój wertykalny (sfera duchowo-kulturowa);

$\checkmark$ stowarzyszanie się osób w organizacjach ekologicznych, w których wiodącą motywacją działań na rzecz ochrony przyrody są przekonania religijne;

$\checkmark$ podejmowanie przez te organizacje konkretnych działań na rzecz ochrony przyrody;

$\checkmark$ duchowe formowanie wiernych do „nawrócenia ekologicznego";

$\checkmark$ modlitwa za stworzenie. 
Trudno jest jednoznacznie wskazać zakres pozytywnego wkładu środowisk religijnych $\mathrm{w}$ troskę o kondycję naszej planety i budowanie zrównoważonego świata. Nie sposób też ocenić, która tradycja religijna i w jakim zakresie najbardziej sprzyja strategii zrównoważonego rozwoju. Jedną z nielicznych prób oszacowania takiego wpływu są badania socjologiczne przeprowadzone w USA na temat przekonań Amerykanów w sprawie zmian klimatycznych. Badania te przeprowadzono w kontekście ogłoszenia przez papieża Franciszka encykliki Laudato Si' (24.05.2015) oraz jego wypowiedzi na temat zmian klimatycznych podczas spotkania z prezydentem Obamą i przemówienia podczas sesji plenarnej ONZ we wrześniu 2015 roku. Badania obejmowały dwie serie sondaży, które przeprowadzono na przełomie lutego i marca 2015, tj. przed ogłoszeniem encykliki, oraz na przełomie września i października - tuż po zakończeniu wizyty papieża w USA. Wyniki tych badań opublikowano w raporcie The Francis Effect: How Pope Francis Changed the Conversation about Global Warming. Raport nie pozostawia wątpliwości w sprawie wpływu papieża na przekonania Amerykanów. Zmiana ich przekonań na temat kwestii klimatycznej była bowiem na tyle istotna, że określono ją „efektem Franciszka” (Maibach et al. 2015, 1).

Ważnym atutem religii w zakresie promocji i implementacji idei zrównoważonego rozwoju jest uświadomienie wyznawcom, że idea ta jest głęboko zakorzeniona w doktrynach ich religii poprzez jej zgodność z takimi koncepcjami, jak umiarkowanie, wstrzemięźliwość, nadany przez Stwórcę obowiązek troski o stworzenie i bliźnich, prymat „być” nad „mieć”, myślenie w perspektywie dalekosiężnej... Wydaje się jednak, że ten ekologiczny atut religii jest wciąż niezauważany, a co za tym idzie - niewystarczająco wykorzystywany. Idea zrównoważonego rozwoju jest bowiem często postrzegana przez społeczeństwa jako obca, zewnętrzna, narzucona, co w konsekwencji prowadzi do jej realizacji w możliwie najmniejszym stopniu. Ukazanie tej idei jako głęboko zakorzenionej $w$ tradycję religijną i kulturę danej społeczności daje nadzieję na postrzeganie jej jako swojej, rodzimej i własnej, co wpłynie - jak można przypuszczać - na skuteczniejszą jej implementację, szczególnie na poziomie lokalnym $\mathrm{i}$ indywidualnym.

Pomimo laicyzacji, jakiej w dużej mierze ulega współczesna cywilizacja zachodnia, rola religii jest wciąż znacząca. Badania przeprowadzone 
w latach 2006-2008 w 143 krajach świata na temat wpływu przekonań religijnych na codzienne decyzje wiernych wskazują, że znaczna większość ludzkiej populacji, podejmując swe wybory, uwzględnia normy religijne (Sadowski 2013b, 82-83). Daje to podstawy do ekologicznej przemiany mentalności ludzkości, która zaowocuje prośrodowiskowymi postawami. $\mathrm{Z}$ dużą dozą pewności można więc stwierdzić, że rola religii jako ważnego partnera $\mathrm{w}$ walce $\mathrm{z}$ kryzysem ekologicznym i promocji idei zrównoważonego rozwoju będzie wciąż rosła. Oczywiste jest, że same religie nie są w stanie zrealizować tych zadań, coraz bardziej oczywiste jest jednak, że bez nich nie uda się tego zrobić (Tucker i Grim 1997, xvii).

\section{Bibliografia:}

Allison, Elizabeth. 2007. Religious Organizations Taking Action on Climate Change. Dostęp: 1.03.2017. http://fore.yale.edu/files/ReligiousOrganizations-Taking-Action-on-Climate-Change.pdf.

Bakken, Peter W., Joan G. Engel i J. Ronald Engel. 1995. Ecology, Justice, and Christian Faith: A Critical Guide to the Literature. Westport, Conn.: Greenwood Press.

Barbour, Ian G. 2000. Scientifc and Religious Perspectives on Sustainability. W: Christianity and Ecology, red. Dieter T. Hessel i Rosemary R. Ruether, 385-399. Cambridge: Harvard University Press.

Bergmann, Sigurd. 2015. Sustainable Development, Climate Change and Religion. W: The Routledge Handbook of Religions and Global Development, red. Emma Tomalin, 389-404. London: Routledge.

CCC. 2017. Catholic Climate Covenant. Dostęp: 1.03.2017. www.catholicclimatecovenant.org.

Dołęga, Józef M. i Ryszard F. Sadowski. 2009. Funding principles of sustainable development. W: A Humanist Approach to Sustainable Development, red. Zbigniew Łepko i Ryszard F. Sadowski, 13-38. Warszawa: Wydawnictwo UKSW.

Dwivedi, Onkar P. 2000. Dharmic Ecology. W: Hinduism and Ecology. The Intersection of Earth, Sky, and Water, red. Cristopher K. Chapple i Mary E. Tucker, 3-22. Cambridge: Harvard University Press. 
Foltz, Richard C. 2006. Islam. W: The Oxford Handbook of Religion and Ecology, red. Roger S. Gottlieb, 207-219. Oxford: Oxford University Press.

Fowler, Robert B. 1995. The Greening of Protestant Thought. Chapel Hill, N.C.: University of North Carolina Press.

Gardner, Gary. 2003. Engaging Religion in the Quest for a Sustainable World. W: State of the World 2003. A Worldwatch Institute Report on Progress Toward a Sustainable Society, 150-175. New York-London: WW Norton \& Company.

Gardner, Gary. 2006. Inspiring Progress. Religions' Contributions to Sustainable Development. New York-London: WW Norton \& Company.

GCCM. 2015. Światowy Ruch Katolików na rzecz Ochrony Klimatu. Dostęp: 1.03.2017. https://catholicclimatemovement.global/pl/.

Gross, Rita M. 1997. Buddhist Resources for Issues of Population, Consumption, and the Environment. W: Buddhism and Ecology. The Interconnection of Dharma and Deeds, red. Mary E. Tucker i Duncan R. Williams, 291-311. Cambridge: Harvard University Press.

Jan Paweł II. 1990. Orędzie na XXIII Światowy Dzień Pokoju (Watykan, 1.01.1990). Dostęp: 1.03.2017. http://papiez.wiara.pl/doc/378717. Pokoj-z-Bogiem-Stworca-pokoj-z-calym-stworzeniem-1990.

John Paul II. 1999. Address to the Participants in a Study Week Organized by the Pontifical Academy of Sciences (Vatican, 12.03.1999). Dostęp: 20.02.2017. http://w2.vatican.va/content/john-paul-ii/en/speeches/1999/ march/documents/hf_jp-ii_spe_19990312_acd-sciences.html.

Lang, Karen. 2004. Madhyamaka School. W: Encyclopedia of Buddhism, red. Robert E. Buswell, t. 2, 479-485. New York: Macmillan.

Maibach, Edward et al. 2015. The Francis Effect: How Pope Francis Changed the Conversation about Global Warming. Fairfax: George Mason University and Yale University. Dostęp: 1.03.2017. http://environment. yale.edu/climate-communication-OFF/files/The_Francis_Effect.pdf.

Monserud, Bruce. 2002. Religion and Ecology: Visions or an Emerging Academic Field Consultation Report. Worldviews: Environment Culture Religion, 6(1), 81-93. 
NRPE (National Religious Partnership for the Environment). 2003. The Joint Appeal in Religion and Science: Statement by Religious Leaders at The Summit on Environment. W: Worldly Wonder. Religions Enter Their Ecological Phase, red. Mary E. Tucker, 116-123. Chicago-La Salle: Open Court.

PaRD. 2017. Mission Statement. Dostęp: 1.03.2017. http://www.partner-religion-development.org/about/mission-statement/.

Pardee, Cambry. 2013. Making Earth Heaven: Ecological Implications of Genesis 1-3. Leaven, 21(3), 125-128.

Pawłowski, Artur. 2008. Rozwój zrównoważony - idea, filozofia, praktyka. Lublin: Komitet Inżynierii Środowiska PAN.

Posas, Paula J. 2007. Roles of religion and ethics in addressing climate change. Ethics in Science and Environmental Politics, 7, 31-49.

Randers, Jørgen. 1972. Ethical Limitations and Human Responsibility. W: To Create a Different Future: Religious Hope and Technological Planning, red. Kenneth L. Vaux, 28-39. New York: Friendship Press.

Sadowski, Ryszard F. 2009a. „Religion and Ecology” - nowy paradygmat poznawczy. Studia Ecologiae et Bioethicae, (7)1, 213-220.

Sadowski, Ryszard F. 2009b. The role of religion in the world and in Poland in the formulation and implementation of the Sustainable Development Strategy. W: A Humanist Approach to Sustainable Development, red. Zbigniew Łepko i Ryszard Sadowski, 139-168. Warszawa: Wydawnictwo UKSW.

Sadowski, Ryszard F. 2011. Religia i kultura klasyczna u podstaw idei zrównoważonego rozwoju. Seminare, (30)2, 65-79.

Sadowski, Ryszard F. 2013a. Aktualizacja ekologicznego potencjału religii w ochronie ekosystemów leśnych. Studia Ecologiae et Bioethicae, (11)1, 7-27.

Sadowski, Ryszard F. 2013b. Religijne źródła troski o stan środowiska przyrodniczego. Seminare, 33, 81-93.

Sadowski, Ryszard F. 2015. Filozoficzny spór o rolę chrześcijaństwa $w$ kwestii ekologicznej. Warszawa: TNFS.

Sadowski, Ryszard F. 2016a. Historical Inspirations of the Principle of Sustainable Development. W: Return to the Oikos. Ways to Recover 
our Common Home, red. Joshtrom I. Kureethadam, Zbigniew Łepko i Ryszard F. Sadowski, 296-311. Rome: LAS.

Sadowski, Ryszard F. 2016b. Teoretyczne i praktyczne zaangażowanie różnych tradycji religijnych w kwestię klimatyczną. Studia Ecologiae et Bioethicae, (14)3, 89-112.

Sadowski, Ryszard F. 2017. Resources within Spiritual and Mystical Christian Traditions for the Care of Earth - our Common Home. W: Alliance for the Care of Our Common Home: Taking Forward Laudato si', red. Joshtrom I. Kureethadam, w druku. Rome: LAS.

Sagan, Carl. 1990. Guest Comment: Preserving and cherishing the Earth - an appeal for joint commitment in science and religion. American Journal of Physics, (58)7, 615-617.

Sheldon, Joseph K. 1992. Rediscovery of Creation: A Bibliographical Study of the Church's Response to the Environmental Crisis. Metuchen: American Theological Library Association.

Sponsel, Leslie. 2016. Lynn White Jr., One Catalyst in the Historical Development of Spiritual Ecology. W: Religion and Ecological Crisis: The "Lynn White Thesis" at Fifty, red. Todd LeVasseur i Anna Peterson, 89103. London: Routledge.

Taylor, Bron. 2010. Dark Green Religion: Nature Spirituality and the Planetary Future. Berkeley: University of California Press.

Taylor, Bron. 2011. Editor's Introduction: Toward a Robust Scientific Investigation of the 'Religion' Variable in the Quest for Sustainability. Journal for the Study of Religion, Nature and Culture, 5(3), 253-262.

Taylor, Bron. 2016. The Greening of Religion Hypothesis (Part One): From Lynn White, Jr and Claims That Religions Can Promote Environmentally Destructive Attitudes and Behaviors to Assertions They Are Becoming Environmentally Friendly. Journal for the Study of Religion, Nature and Culture, 10(3), 268-305.

The World Bank. 2015. Global Conference on Religion and Sustainable Development: Strengthening Partnerships to End Extreme Poverty. Dostęp: 1.03.2017. http://www.worldbank.org/en/news/press-release/2015/07/12/global-conference-religion-sustainable-development. 
Tirosh-Samuelson, Hava. 2006. Judaism. W: The Oxford Handbook of Religion and Ecology, red. Roger S. Gottlieb, 45-64. Oxford: Oxford University Press.

Tucker, Mary E. 2002. Worldly Wonder: Religions Enter Their Ecological Phase. Religion East \& West, (2), 1-31.

Tucker, Mary E. i John A. Grim. 1997. The Nature of the Environmental Crisis. W: Buddhism and Ecology. The Interconnection of Dharma and Deeds, red. Mary E. Tucker i Duncan R. Williams, xv-xxxi. Cambridge: Harvard University Press.

Tucker, Mary E. i John A. Grim. 2001. Introduction: The Emerging Alliance of World Religions and Ecology. Daedalus, (130)4, 1-22.

White, Lynn T. 1967. The Historical Roots of Our Ecologic Crisis. Science, 155(3767), 1203-1207.

Whitney, Elspeth. 2013. The Lynn White Thesis. Reception and Legacy. Environmental Ethics, 35(3), 313-331. 


\section{CZĘŚ́C III AKSJOLOGICZNE ASPEKTY ZRÓWNOWAŻONEGO ROZWOJU}



Krystyna Najder-Stefaniak

Szkoła Główna Gospodarstwa Wiejskiego w Warszawie - Wydział Nauk Społecznych krystyna_najder_stefaniak@sggw.pl

\section{Rozwój zrównoważony i wartości uniwersalne}

\section{Wprowadzenie}

Teoria i praktyka zrównoważonego rozwoju jest dziś tematem wielu konferencji i prac naukowych. Pojęcie „rozwój zrównoważony”, pojawiło się w refleksji dotyczącej kryzysu przemysłu wydobywczego, wprowadzone w 1713 roku przez Hansa Carla von Carlowitza jako idea zrównoważonej gospodarki leśnej. Powróciło do debaty publicznej w latach siedemdziesiątych dwudziestego wieku w nowym szerokim znaczeniu przekraczającym sferę leśnictwa.

W 1975 roku Rada Zarządzająca UNEP zaproponowała definicję sustainable development, która mówi, że „jest to taki przebieg nieuchronnego rozwoju gospodarczego, który nie naruszałby w sposób istotny i nieodwracalny środowiska życia człowieka, nie doprowadziłby do degradacji biosfery, który godziłby prawa przyrody, ekonomiki i kultury”. Zawarte w tej definicji sformułowania pozwalają wnioskować, że jej autorzy zakładają nieuchronność rozwoju gospodarczego i dostrzegają problem zagrożeń wynikających z tego rozwoju. Mają świadomość tego, że może on być osiągany kosztem zniszczeń w obszarze kultury i przyrody.

W 1987 roku, w Raporcie Organizacji Narodów Zjednoczonych noszącym tytuł Nasza wspólna przyszłość (nazywanym też Raportem Brundtland - od nazwiska przewodniczącej grupy roboczej, pani Gro Haarlem Brundtland) zaproponowano definicję, która brzmi: „Rozwój zrównoważony jest to rozwój, który zapewnia zaspokojenie potrzeb obecnych pokoleń, nie przekreślając możliwości zaspokojenia potrzeb pokoleń następnych".

Zauważmy, że w zdegradowanym środowisku człowiek nie ma warunków, by w pełni aktualizować swoją potencjalność, czyli realizować siebie. Paradoksalnie rozwój cywilizacyjny może więc zagrażać człowiekowi. Jeśli chcemy poradzić sobie z takim zagrożeniem, powinniśmy, jak podpowiada Albert Schweitzer, dbać o to, by poziom kultury nie 
był niższy niż poziom cywilizacji technicznej i by nie doprowadzić do pojawienia się człowieka neoprymitywnego, czyli człowieka, który kulturowo nie dorasta do poziomu cywilizacji technicznej, jaką dysponuje. Rozwój zrównoważony powinien więc dotyczyć relacji między wszystkimi wymiarami świata człowieka a także relacji między wymiarami samego człowieka: kulturowym, cywilizacyjnym i biologicznym.

Pojęcia są zawsze jakimś projektem rozumienia rzeczywistości i magazynem wiedzy nagromadzonej $\mathrm{w}$ nich przez lata, a czasem wieki. Czerpiąc z tego magazynu wiedzy i doświadczeń, jakich dostarcza aktualnie nasze otoczenie, możemy doprowadzić do synergii, której efektem będzie twórcze rozbudowanie pojęcia. Pojęcie może mieć „moc stwórczą", jeśli implikuje nowy sposób myślenia. Ten nowy sposób myślenia pozwala nie tylko inaczej rozumieć, ale też inaczej organizować działania. Pojęciom należy więc przyglądać się nie tylko z perspektywy praw$d y$, ale i z perspektywy dobra.

W perspektywie agatologicznej rozwój zrównoważony można widzieć jako:
$\checkmark$ zadanie do zrealizowania;
$\checkmark$ rezultat czynienia dobra;
$\checkmark$ środek do osiągnięcia wartości;
$\checkmark$ kryterium poprawności działania.

W każdym z wymienionych sposobów widzenia rozwoju zrównoważonego postrzegany jest on jako wartościowy. Ceni się go za to, że pozwala nie destrukcyjnie, lecz twórczo zmieniać rzeczywistość. Jest ceniony także dlatego, że dzięki niemu aktywność człowieka nie zamyka się w określonym systemie praktyki, ale przekracza jej granice i ożywia systemy bycia, pozwalając im trwać.

Aktywność ukierunkowywana jest zawsze przez wartości. Wartości partykularne porządkują aktywność w określonym systemie bycia i wydają się być gwarancją trwania tego systemu. Wartości uniwersalne dają szansę na taki związek z rzeczywistością, który nie zamyka aktywności w określonym systemie praktyki. Wartości uniwersalne są ważne dla trwania każdego systemu aktywności. Poza tym stanowią punkt od- 
niesienia, gdy trzeba twórczo przekroczyć uwarunkowania systemów, w których realizujemy naszą aktywność. Są usprawiedliwieniem oraz punktem odniesienia dla twórczego działania i myślenia. Aktywność skutkująca rozwojem zrównoważonym musi być porządkowana nie przez wartości partykularne, lecz przez wartości uniwersalne. $Z$ tego, że aktywności skutkująca rozwojem zrównoważonym ma związek z wartościami uniwersalnymi, wynika, dlaczego staje się on przedmiotem debaty publicznej, gdy problemem jest kryzys wymagający twórczego wydostania się z pułapek teraźniejszości.

\section{Pojęcie rozwoju zrównoważonego}

Pojęcie „rozwój zrównoważony”, jak każde pojęcie, jest projektem rozumienia rzeczywistości i magazynem wiedzy. Wypełnia się treścią, ulegając promieniowaniu kontekstów, w jakich jest używane. Dziś jest odpowiedzią na dostrzegane we współczesnym świecie przez teoretyków i praktyków problemy związane $\mathrm{z}$ funkcjonowaniem systemów przyrodniczych, kulturowych i gospodarczych, a także odpowiedzią na możliwości zrozumienia, jakie daje myślenie porządkowane przez metaforę ekosystemu.

Pojęcie rozwoju zrównoważonego współbrzmi z pojęciem życia ogniskującym, jak zauważył Georg Simmel (Simmel 2007, 57), od XX wieku myślenie w kulturze europejskiej. Gdy o zależnościach zaczynamy myśleć w schemacie relacji ekosystemowej, zauważamy, że rozwój zrównoważony gwarantuje życie systemów.

Dzisiejsze pojęcie rozwoju zrównoważonego ma korzenie w idei zrównoważonej gospodarki leśnej. Hans Carl von Carlowitz obserwował kryzys przemysłu wydobywczego spowodowany brakiem drewna, którego nie były w stanie dostarczać lasy zniszczone przez dziesięciolecia wycinania drzew bez wysiłków na rzecz uzupełniania drzewostanu. Trudna sytuacja zainspirowała go do zaproponowania idei zrównoważonego rozwoju. Pojawiła się ona w jego książce Sylvicultura Oeconomica, oder haußwirthliche Nachricht und Naturmäßige Anweisung zur Wilden Baum-Zucht uznanej za pierwszy kompleksowy traktat o leśnictwie. Carlowitz wprowadził pojęcie „zrównoważenie” (niem. Nachhaltigkeit), nazywając nim taki rodzaj gospodarki leśnej, która powoduje, że las może się re- 
generować, że w miejsce drzew wyciętych mają szansę wyrosnąć nowe, tak by las nie został zlikwidowany. Uznanie, jakim cieszyło się leśnictwo niemieckie na początku XIX wieku, spowodowało, że pojęcie „zrównoważenie" zostało przejęte przez naukowców z innych krajów.

Immanuel Kant zainspirował filozofów do rozważań na temat relacji między pojęciami i rzeczywistością realną. W efekcie tych rozważań mamy przekonanie, że język nie jest tworem wtórnym względem rzeczywistości, nie powiela jej, nie proponuje pojęć, które są jej symbolicznym odpowiednikiem, lecz porządkuje nasze myślenie i nasze rozumienie rzeczywistości. Pojęcia, którymi się posługujemy, sugerują wnioski i decyzje, a w konsekwencji mają wpływ na nasze działania oraz poprzez nie na kształt człowieczego świata. Są ważne z perspektywy etyki i jednocześnie kształtowane przez kontekst teorii i praktyki oferowany przez system rozumienia i system działania, które czasem należy twórczo przekroczyć.

Kontekst proponowany przez paradygmat myślenia, w którym ważne jest pojęcie synergii i pojęcie ekosystemu, komplikuje aksjologiczny aspekt nowożytnego pojęcia rozwoju. W tym nowym kontekście potrzebne jest określenie „zrównoważony”, które sprawia, że rozwój przestaje zagrażać przypadkowością i bezwzględnością zmian. „Rozwój zrównoważony” jest tak jak kiedyś „rozwój” pojęciem wartościującym. Pojęcie rozwoju zrównoważonego można też przeciwstawić współczesnej radykalnej nieciągłości, o której czytamy w książce Manuela Castellsa zatytułowanej Społeczeństwo sieci (The Rise of the Network Society) (Castells 2007).

Najbardziej obszerne określenie rozwoju zrównoważonego znajdujemy w opracowaniu pt. 27 Zasad Zrównoważonego Rozwoju w Deklaracji $z$ Rio podpisanej na Konferencji Narodów Zjednoczonych „Środowisko i Rozwój”. Jest to 27 zasad, których należy przestrzegać, by przyczyniać się do realizowania rozwoju zrównoważonego. Zasady te są dobrze wpisane w aktualną sytuację na świecie. Z perspektywy prakseologii można je uznać za użyteczne wskazówki.

W oparciu o pojęcie „zrównoważonego rozwoju” (Sustainable Development/Le Development Durable) zdefiniowane w raporcie Światowej Komisji Środowiska i Rozwoju ONZ, który ukazał się w 1987 roku, wypracowano doktrynę rozwoju zrównoważonego. Jest to doktryna ekonomii politycznej. Postuluje się w niej rezygnację z „żelaznej 
reguły ekonomii” Thomasa Malthusa (1766-1834)1 i przyjęcie nowych zasad gospodarowania, z uwzględnieniem tego, że cywilizacja osiągnęła poziom dobrobytu możliwy do utrzymania, pod warunkiem odpowiedniego gospodarowania. To odpowiednie gospodarowanie wymaga opracowania modelu, który gwarantowałby właściwe relacje pomiędzy wzrostem gospodarczym i dbałością o szeroko rozumiane środowisko, a więc nie tylko środowisko przyrodnicze, ale także to wytworzone przez człowieka. Realizacja takiego modelu musiałaby skutkować podwyższeniem poziomu jakości życia (w tym także życia człowieka). W doktrynie zrównoważonego rozwoju ważne staje się pojęcie sprawiedliwości społecznej i teoria dobra publicznego oraz perspektywa sozoekonomii.

W badaniach dotyczących rozwoju zrównoważonego przeważają te dotyczące wymiaru cywilizacyjnego i biologicznego. Bardzo potrzebne są poświęcone rozwojowi zrównoważonemu opracowania mieszczące się w obszarze filozofii i aksjologii. Zastanawiając się nad istotą zrównoważonego rozwoju, należy pamiętać o spostrzeżeniu Alberta Schweitzera, który zwrócił uwagę na to, że brak równowagi między rozwojem cywilizacji technicznej i rozwojem kultury jest źródłem różnorakich zagrożeń, jakim musi przeciwstawić się współczesny człowiek. Nasuwa się wniosek, że człowiek powinien rozwijać się w sposób zrównoważony we wszystkich swoich wymiarach: kulturowym, cywilizacyjnym i biologicznym.

U podstaw rozumienia są założenia ontologiczne, epistemologiczne i antropologiczne, ale także doświadczenia związane $\mathrm{z}$ „odpowiadaniem” rzeczywistości na naszą aktywność. Umiejętność odczytywania i analizowania tych odpowiedzi daje szansę na zdystansowanie się od obowiązujących paradygmatów aktywności poznawczej i praktycznej. Efektem aktywności poznawczej są teorie wyjaśniające zależności, zjawiska i wydarzenia, tłumaczące ich podstawy, czyli obowiązujące we wszechświecie prawa. Efektem aktywności praktycznej realizowanej w oparciu o teorie jest tworzony przez człowieka świat. Teorie stanowią rzeczywistość wirtualną. Budowany przez człowieka ludzki świat jest rzeczywistością realną.

\footnotetext{
${ }^{1}$ Żelazna reguła Thomasa Malthusa brzmi: „Wzrost dobrobytu powoduje wyższą rozrodczość człowieka, ta z kolei powoduje nadmiar rąk do pracy, co obniża płace, poziom życia i w konsekwencji przyrost naturalny".
} 
Zderzenie teorii z rzeczywistością realną może skutkować zmianą paradygmatu aktywności poznawczej. Taka zmiana paradygmatu dzieje się aktualnie. Inspirowana jest przez biologów zajmujących się badaniem ekosystemów i przez fizyków kwantowych. Biolodzy mają wpływ na zmianę stereotypu nowożytnego myślenia o zależnościach w liniowym schemacie podmiot $\rightarrow$ przedmiot na myślenie o zależnościach w schemacie relacji ekosystemowej. Doświadczenia fizyków w przestrzeni aktywności poznawczej spowodowały, że o poznawaniu przestajemy myśleć w platońskiej metaforze widzenia i zastępujemy ją metaforą dotyku. Metafora widzenia, porządkując myślenie o poznawaniu, sugerowała, że aktywność poznawcza nie zmienia tego, co jest jej przedmiotem. Od naszego „patrzenia” nie zmienia się to, na co patrzymy. Poznawanie polega na „oglądaniu” tego, co jest niezależne od aktywności poznawczej. Nowa metafora porządkująca myślenie o poznawaniu sprawia, że poznawanie zaczynamy rozumieć jako aktywność powodującą pojawienie się odpowiedzi na „dotknięcie” rzeczywistości. Efektem tak rozumianej aktywności poznawczej jest to, co pojawia się w procesie poznawania. By zaakceptować takie rozumienie procesu poznawania, musimy zmienić wyobrażenie bytu. Musimy go postrzegać nie jako zbiór elementów, lecz jako potencjalność do zaktualizowania. Zmiany podstawowych założeń i schematów porządkujących myślenie skutkują zmianą paradygmatów aktywności poznawczej i praktycznej, a w konsekwencji nowym rozumieniem rzeczywistości i nowym systemem jej funkcjonowania nowym światem człowieka.

W myśleniu ekosystemowym rozwój zrównoważony to rozwój oparty na zmianach, które umożliwiają życie systemów, w jakich zachodzą. Rozwój zrównoważony zaczynamy postrzegać jako otwarty system bycia. Rozwój taki dzieje się w czasie trójwymiarowym, mającym wymiar przeszłości, teraźniejszości i przyszłości. Teraźniejszość zawiera ślady i tropy. Ślady otwierają na to, co było, i pomagają czerpać z przeszłości. Tropy otwierają na możliwą przyszłość wynikającą z tego, co aktualnie obecne. W projektowaniu rozwoju zrównoważonego powinniśmy uwzględniać pełną obecność, czyli także zawarte w niej ślady i tropy. Ślady i tropy inspirują do twórczej aktywności, do realizowania twórczych zmian, ponieważ: 
$\checkmark$ łączą teraźniejszość z przeszłością i przyszłością;

$\checkmark$ mają charakter otwarty - nigdy nie są ściśle określone;

$\checkmark$ umożliwiają twórcze przekroczenie teraźniejszości.

Rozwój zrównoważony jest efektem aktywności człowieka. Aktywność ukierunkowują wartości. Bardzo potrzebna jest aksjologiczna refleksja dotycząca rozwoju zrównoważonego. Jego fundamentem wydają się być wartości uniwersalne.

\section{Specyfika wartości uniwersalnych}

W postmodernistycznej refleksji uniwersalność wartości niepokoi jak każda stałość i wszystko, co może podporządkowywać sobie i utrwalać aktywność człowieka i bytowanie bytu. Lękowi przed stałością towarzyszy tu tęsknota za jakąś pozostającą w metaforze słyszenia „estetyką znikania”. Ta tęsknota współbrzmi z rezygnacją z klasycznej perspektywy prawdy i uniwersalności wartości.

Bez klasycznej perspektywy prawdy rzeczywistość staje się pozytywnym uniwersum faktów, które nie musi być prawdziwe. Znika nie tylko rozróżnienie na fałsz i prawdę, ale także rozróżnienie na to, co pozorne i realne. Człowiek będący autorem takiego świata bez transcendencji i prawdy usiłuje ocalić życie rzeczywistości, sięgając po ciągłe jej zaprzeczanie. W rezultacie myśli, wartościuje i działa w perspektywie doraźności. Doraźność wydaje się być gwarantem różnorodności, uniwersalność jej zaprzeczeniem.

Jak rozumieć uniwersalność wartości, żeby nie wykluczała ona różnorodności wartościowania? Uniwersalizm nie musi kojarzyć się z jednakowością i ujednoliceniem, nie musi wiązać się z niwelacją różnicy. Jeśli zrezygnujemy z aksjologicznego idealizmu subiektywnego, to uniwersalnymi wartościami nie musimy nazywać tych wartości, które są akceptowane przez wszystkich. Możemy uznać za wartości uniwersalne takie, które są jednakowo ważne dla różnorakich systemów bycia.

Poszukiwaniem zrozumienia wartości zajmują się teoretycy w obszarze aksjologii. Powstała ona na przełomie XIX i XX wieku jako samodzielna dyscyplina filozoficzna, a nazwę swoją zawdzięcza Paulowi Lapie (1867-1927) i Edwardowi von Hartmannowi (1842-1906). Lapie 
wprowadził to pojęcie w swojej wydanej w 1902 roku pracy zatytułowanej Logique de la volante. E. Hartmann swoje wydane w roku 1908 dzieło zatytułował Grundniss der Axiologie oder Wertwägslehre.

Problematykę aksjologiczną znajdujemy już w filozofiach starożytnych greków, ale pojęcie wartości pojawiło się w dyskursie filozoficznym jako przedmiot refleksji filozoficznej dopiero w latach sześćdziesiątych XIX wieku dzięki uważanemu za prekursora aksjologii i twórcę filozofii wartości, niemieckiemu filozofowi i logikowi Rudolfowi Hermanowi Lotze. Punktem wyjścia swoich rozważań uczynił on podkreśloną przez Kanta różnicę między bytem (tym, co jest) a powinnością (tym, co być powinno), punktem dojścia tych rozważań stało się stwierdzenie, że wartości nie są faktyczne jak rzeczy, które zawierają „treść” i „istnienie”, lecz są normatywne, zawierają „treść” i „obowiązywalność”. Zdaniem Lotzego wartości stanowią odrębną dziedzinę, która jest poza empirią. Uważał, że nauce o bycie, rozumianym jako byt przyrodniczy, powinna towarzyszyć nauka o wartościach, które czynią byt sensownym.

Lotze wyraźnie oddzielił rzeczy i wartości. Tym drugim przypisał walor obowiązywania i umieścił je w sferze powinności. Spostrzeżenie, że wartości mają obowiązywalność, inspiruje do postawienia pytania, z czego wynika obowiązywalność wartości, i może być punktem wyjścia do pojawienia się wątpliwości, czy istnieją wartości uniwersalne. Sformułowanie pozytywnej odpowiedzi na to pytanie utrudnia zarówno modernistyczny jak i postmodernistyczny paradygmat myślenia. Efektem pierwszego było przekonanie o końcu kultury, wartości i sensu świata. W drugim uniwersalność wartości niepokoi jak każda stałość i wszystko, co może podporządkowywać sobie i utrwalać aktywność człowieka i bytowanie bytu.

Nowożytny paradygmat myślenia porządkowanego przez metaforę maszyny i liniowy, jednokierunkowy schemat relacji podmiot $\rightarrow$ przedmiot nie sprzyjał znalezieniu odpowiedzi na to pytanie i zrozumieniu specyfiki wartości. W rezultacie oczywiste były stwierdzenia o trudnej definiowalności wartości. Władysław Tatarkiewicz pisał, że „zdefiniowanie wartości jest trudne, jeśli w ogóle jest możliwe. Wyraz ten bowiem zdaje się oznaczać swoiste, proste, nierozkładalne zjawisko, ein Urphänomen jak mówią Niemcy. (...) To, co wygląda na definicje «war- 
tości», jest raczej zastąpieniem wyrazu przez inny wyraz mniej więcej to samo znaczący, na przykład «dobro». Albo jest omówieniem" (Tatarkiewicz 1978, 62).

Sprzyja zrozumieniu specyfiki wartości, które „mają treść i obowiązywalność”, porządek narzucany myśleniu przez metaforę ekosystemu. W paradygmacie ekosystemowego myślenia wartości przestają być czymś uprzedmiotowionym, nie istnieją jak rzeczy czy idee, lecz implikują ważność. Czym są? Może - jak proponuje w swej pracy Miraże świadomości estetycznej Jan Kurowicki - „momentem struktury praktyki” (Kurowicki 1982), a może „atraktorem” przyciągającym trajektorie aktywności w systemach bycia?

Klasyczne teorie aksjologiczne współbrzmią z metafizyką obecności. Jeśli zrezygnujemy z metafizyki obecności, zastępując ją metafizyką potencjalności, to znaczy nie będziemy myśleć o bycie jako o czymś, co jest, lecz jako o czymś, co aktualizuje jakieś swoje możliwości zaistnienia, to możemy postrzegać wartość jako atraktor. Ukierunkowuje ona aktywność, ale nie narzuca jej sztywnego schematu realizowania.

Wartości ukierunkowują działania ludzi, ale są też w pewnym sensie konsekwencją działań, ponieważ mają obowiązywalność w systemach aktywności inicjowanych i realizowanych przez człowieka. Porządkują te systemy i wydają się być gwarancją ich trwania. Czy wynika z tego, że możemy mówić wyłącznie o wartościach partykularnych, wyznaczonych przez określony kontekst praktyki i przestających być wartościami poza tym kontekstem? Są takie, które można nazwać partykularnymi, i takie, które potrafią porządkować działania człowieka w różniących się systemach działań. Tak jakby proponowane były z poziomu metapraktyki. Wartości uniwersalne to wartości istotne dla każdego systemu bycia, niezależnie od tego, czy ludzie w tych systemach zdają sobie z tego sprawę, czy nie. Ich realizowanie jest niezbędne, by system mógł trwać. Ponadto umożliwiają zdystansowanie się do wartości partykularnych i są gwarancją bezpieczeństwa rozumianego jako możliwość przeciwstawienia się zagrożeniom. Dzięki nim możliwa jest twórcza aktywność, solidarność, transgresja i rozwój zrównoważony.

Przykładem wartości uniwersalnych jest triada: prawda, dobro, piękno. Kryterium uniwersalności prawdy, dobra i piękna nie jest powszech- 
ność ich doświadczania czy uznawania, lecz powszechność obowiązywania. Nie tracą ważności nawet wtedy, gdy nie są doceniane i realizowane. Uniwersalność prawdy, dobra i piękna polega na tym, że są to wartości niezbędne dla trwania każdej kultury i każdego systemu aktywności.

Zauważmy, że prawda, dobro i piękno nie muszą szukać uzasadnienia w określonych systemach bycia. Uzasadniają nawzajem swoje znaczenie. Prawda jest cenna, bo umożliwia realizowanie dobra. Realizując dobro, odkrywamy prawdę. Piękno zyskuje znaczenie w kontekście prawdy i dobra, ponieważ daje szansę wydostania się poza granice, jakie nakreśliliśmy w wyniku aktywności poznawczej i praktycznej, sprawia, że granice te są zawsze tymczasowe (Najder-Stefaniak 2013).

Każda z wartości składających się na triadę ma swoją specyfikę niepozwalającą na wzajemną zastępowalność. Jednocześnie trudno znaleźć uzasadnienie dla uniwersalności każdej z tych wartości oddzielnie. Oddzielnie mogą być wartościami partykularnymi. Wyznaczone są wtedy przez funkcjonalne zależności w określonych systemach aktywności. Zebrane w triadę zaczynają wyznaczać same siebie, nie muszą już wynikać z systemów znaczeń narzucanych przez zintegrowane w określonej praktyce działania i stają się uniwersalne.

Pożyteczne jest, by człowiek realizował się w miarę równomiernie we wszystkich przestrzeniach platońskiej triady. Znaczące zaburzenie tej równomierności owocuje patologią. Zamknięcie w przestrzeni estetycznej jest niebezpieczne, bo likwiduje poczucie odpowiedzialności, ale zrezygnowanie z tej przestrzeni jest też niebezpieczne - pozbawia źródła „życia” przestrzeń poznawczą i moralną, uniemożliwia twórcze myślenie i twórcze działanie. Dopiero połączenie trzech obszarów aktywności zakreślonych przez triadę umożliwia realizowanie powołania człowieka do twórczości, ułatwia wyzwolenie się z mocy partykularnych prawd i partykularnych wartości. Jeśli człowiek ma realizować swoją aktywnością rozwój zrównoważony, powinien być przygotowany do swobodnego poruszania się zarówno w przestrzeni prawdy, dobra jak i piękna.

\section{Wartości uniwersalne jako fundament rozwoju zrównoważonego}

Wychodząc poza nowożytny schemat postrzegania relacji, odkrywamy, że wartości nie są ani cechą przedmiotów, ani subiektywnym wy- 
tworem człowieka, ani obiektywnymi bytami idealnymi. Zauważmy, że poza wartościami, które nie istnieją, lecz mają ważność, mamy jeszcze to, co istnieje i uważane jest za wartościowe. Co pozwala rzeczom, zjawiskom, wydarzeniom i czynom uzyskiwać wymiar wartościowości? Stają się one wartościowe, gdy służą realizowaniu wartości. Pozytywnie wartościowany rozwój zrównoważony służy realizowaniu wartości uniwersalnych i możliwy jest dzięki realizowaniu wartości uniwersalnych.

Wartości uniwersalne są proponowane jakby z poziomu metapraktyki. Dają szansę na taki związek z rzeczywistością, który nie zamyka aktywności w określonym systemie bycia, nie ogranicza aktywności przez partykularne cele. Wartości uniwersalne są ważne nie tylko dla trwania każdego systemu aktywności, ale także dlatego, że stanowią punkt odniesienia, gdy trzeba twórczo przekroczyć uwarunkowania systemów bycia, w których realizujemy naszą aktywność. Są usprawiedliwieniem oraz punktem odniesienia dla twórczego działania i myślenia. Pomagają człowiekowi przeciwstawiać się zagrożeniom i pokonywać kryzysy.

Wiodącym pojęciem starożytnej etyki była „troska”. Jak zauważa Foucault, ta etyczna troska jest obowiązkiem i jednocześnie rodzajem „techniki” życia łączącej perspektywę prawdy i dobra, techniki, której efektem jest „rozwój sztuki istnienia” (Foucault 1995, 601). Fundamentem rozwoju zrównoważonego są uniwersalne wartości: Prawda, Dobro i Piękno.

\section{Podsumowanie}

System postrzegany w schemacie relacji podmiot $\rightarrow$ przedmiot może kojarzyć się z podporządkowaniem, zniewalaniem i przemocą. W schemacie podmiot $\rightarrow$ przedmiot funkcjonuje system totalitarny. W schemacie ekosystemu funkcjonują systemy, o których można powiedzieć, że są żywe. Te interakcyjne, otwarte, względnie izolowane systemy pomagają człowiekowi realizować jedność różnorodności.

Jeśli uznamy, że dla każdego systemu bycia, dla którego gwarantem życia i trwania jest ludzkie działanie, ważne jest, by człowiek realizował nastawienie poznawcze, praktyczne i estetyczne, to musimy też przyjąć, że prawda, dobro i piękno jako wartości puentujące te trzy rodzaje nastawienia człowieka są wartościami uniwersalnymi. Przeciwstawiając postmodernistycznej doraźności twórcze trwanie oferowane przez kulturę 
ekologiczną, odkrywamy znaczenie współkonstytuujących się: prawdy, dobra i piękna, ich związek z rozwojem zrównoważonym i rolę rozwoju zrównoważonego dla życia tworzonych przez człowieka światów.

\section{Bibliografia:}

Castells, Manuel. 2007. Społeczeństwo sieci, tłum. Kamila Pawluś, Mirosława Marody, Janusz Stawiński i Sebastian Szymański. Warszawa: PWN.

Foucault, Michael. 1995. Historia seksualności, tłum. Bogdan Banasiak, Tadeusz Komendant i Krzysztof Matuszewski. Warszawa: Czytelnik.

Kurowicki, Jan. 1982. Miraże świadomości estetycznej. Miejsce kategorii estetycznych w materializmie historycznym. Warszawa: Książka i Wiedza.

Najder-Stefaniak, Krystyna. 2013. The Value of Beauty in the Perspective of Eco-Systemic Thinking. Dialogue and Universalism, 23(4), 141-149. DOI: 10.5840/du201323454.

Simmel, Georg. 2007. Filozofia kultury. Wybór esejów, tłum. Wojciech Kunicki. Kraków: Wydawnictwo UJ.

Tatarkiewicz, Władysław. 1978. Parerga. Warszawa: PWN.

Tyburski, Włodzimierz. 2013. Dyscypliny humanistyczne i ekologia. Toruń: Wydawnictwo UMK. 
Włodzimierz Tyburski

Akademia Pedagogiki Specjalnej im. Marii Grzegorzewskiej - Instytut Filozofii i Socjologii wlodzimierz.tyburski@umk.pl

\section{Edukacja etyczna na rzecz zrównoważonego rozwoju}

Nie ulega wątpliwości, że trudna i skompilowana sytuacja, w jakiej znalazła się współczesna cywilizacja, stawia przed edukacją, tj. nauczaniem i wychowaniem, ogromne wyzwania. Wymaga ona zrozumienia potrzeby respektowania ograniczeń nałożonych na rozwój społeczny i gospodarczy, mobilizacji do obronnych działań na rzecz środowiska przyrodniczego i nade wszystko głębokiej przemiany mentalnej jednostki i całych zbiorowości, spotęgowania wieloaspektowych, mądrych, konsekwentnych i wychowawczych działań na różnych poziomach i o różnym charakterze. Twórcy programu trwałego i zrównoważonego rozwoju konsekwentnie stawiają zagadnienie edukacji w rzędzie zadań priorytetowych. Wszystkie formułowane dokumenty programowe jednoznacznie wskazują na potrzebę wypracowania strategii działań edukacyjnych na rzecz trwałego i zrównoważonego rozwoju, nakierowanego na kształtowanie nowego myślenia o świecie przyrody, kultury ekologicznej, wzorców życia indywidualnego i społecznego, pożądanych systemów wartości, idei sprawiedliwości społecznej i solidaryzmu międzypokoleniowego. Zadaniu temu towarzyszy przekonanie, że rzetelna praca edukacyjna w swym wymiarze praktycznym nabiera szczególnego znaczenia, ponieważ najlepiej nawet opracowane teorie i programy pozostają tylko teoriami i programami, jeśli nie uda się im wpływać na kształtowanie świadomości społecznej, kształtować konkretnych indywidualnych oraz zbiorowych postaw i zachowań, gdy formułowane na ich gruncie systemy wartości nie są rozpoznawalne, akceptowane i realizowane przez konkretnych ludzi.

W pracach edukacyjnych na rzecz zrównoważonego rozwoju szczególnie istotne zadania stają przed etyką środowiskową. Poddaje ona krytycznej ocenie wyłącznie instrumentalny i utylitarny stosunek człowieka do świata przyrody, a jednocześnie dąży do ujawniania tych wartości, norm i zasad, które stoją na straży ochrony i zachowania życia istot ludzkich 
i pozaludzkich oraz całych ekosystemów. To refleksja z zakresu etyki środowiskowej wypracowuje aksjologię zrównoważonego rozwoju. Wskazując na rolę wartości i norm moralnych jako czynnika regulującego nasze stosunki z przyrodniczym środowiskiem, zmierza do objęcia reglamentacją moralną niezwykle bogaty obszar relacji człowieka z przyrodą. Wpisując do świadomości społecznej katalog określonych wartości norm regulujących stosunki człowieka $\mathrm{z}$ jego środowiskiem, etyka ta pragnie wpływać na motywacje, kształtować postawy i zachowania, aby ograniczyć, minimalizować przejawy zła zadawanego przyrodzie.

Podkreślmy zatem: naczelnym celem etyki środowiskowej jest aktywne wspieranie tych wszystkich wysiłków, których głównym zadaniem jest: a) obrona świata przyrody przed ludzką agresją i działaniami destrukcyjnymi; b) obrona samego człowieka jako jednostki i gatunku przed, powodowanymi przez niego samego, negatywnymi skutkami płynącymi z zanieczyszczonego i zdegradowanego środowiska.

Etyka środowiskowa, kreując kulturę ekologiczną jednostki i społeczeństwa, jest doniosłą i integralną częścią składową edukacji dla zrównoważonego rozwoju. Wypracowuje aksjologię zrównoważonego rozwoju, proponując zestaw uniwersalnych wartości takich jak: życie, zdrowie, sprawiedliwość, które mają tę zaletę, że gotów jest je zaakceptować każdy nieomal człowiek, i dlatego można wokół nich jednoczyć ludzi w skali całego nieomal globu. Te wartości należy wpisać w projekt zrównoważonego rozwoju za pośrednictwem odpowiednich mechanizmów społeczno-gospodarczych i przez skuteczną edukację mobilizować ludzi do wcielania ich w życie. Konstruując model aksjologicznych preferencji w relacjach człowieka ze środowiskiem oraz ukazując ich imperatywne odpowiedniki, w postaci zasad i norm, etyka ta pragnie wpisać je w praktykę życia i działania. Słusznie zatem przypomina się, że bez etyki środowiskowej nie byłoby koncepcji zrównoważonego rozwoju, co więcej, taki rozwój zawsze będzie się do etyki środowiskowej odwoływał. W swych wysiłkach na rzecz edukacji ekologicznej - pojmowanej jako ważna i integralna część edukacji na rzecz zrównoważonego rozwoju - etyka środowiskowa dąży do tego, aby świadomość kryzysu ekologicznego znalazła wsparcie w świadomości moralnych powinności człowieka wobec przyrody. Zaś w życiu społecznym i ekonomicznym etyka ta zmierza do tego, aby świadomość tych powinności została wple- 
ciona w reguły działania społecznego, politycznego i gospodarczego. Filozofia i etyka środowiskowa zaangażowane na rzecz zrównoważonego rozwoju, przybliżając świadomości współczesnych myślenie integralne i pojęcie ładu, pragną eliminować zasadnicze sprzeczności między człowiekiem a jego środowiskiem społecznym, gospodarczym i przyrodniczym, a jednocześnie zachęcają do działań mających na celu integrowanie i harmonizowanie poczynań gospodarczych, społecznych i politycznych z zachowaniem trwałości oraz równowagi świata przyrody.

Przy czym, wskazać tu koniecznie należy na fakt, że owocność i efektywność działań na rzecz zrównoważonego rozwoju wymaga uprzedniego zaakceptowania kilku podstawowych postulatów formułowanych we wszystkich nieomal dokumentach poświęconych tej problematyce, także na konferencjach i sympozjach. Należy do nich:

1. umieszczenie edukacji na pierwszym miejscu w realizacji polityki proekologicznej państwa;

2. uznanie przez czynniki decyzyjne różnych szczebli faktu, iż edukacja jest podstawowym warunkiem kształtowania ładu środowiskowego;

3. wykorzystanie wartości etycznych, kulturowych bliskich danemu społeczeństwu w pracy edukacyjnej na rzecz ładu środowiskowego jako integralnej i fundamentalnej części składowej zrównoważonego rozwoju;

4. uznanie edukacji jako istotnego warunku zmiany modelu konsumpcyjnego i stowarzyszonych z nim stylów życia;

5. włączanie edukacji ekologicznej do programów edukacyjnych i traktowanie edukacji ekologicznej jako integralnej części edukacji ogólnej;

6. zwiększenie dostępu społeczeństwa do informacji o stanie środowiska i postępach edukacji na rzecz środowiska.

Sądzę, że w realizacji tak postawionych zadań szczególnie doniosłe znaczenie spełniać może i powinna, obok filozofii ekologicznej, etyka środowiskowa. Dyscypliny te nie tylko postulują obronę i wspieranie wszyst- 
kich ważnych struktur biosfery, ale przede wszystkim ukierunkowują proces edukacji na kreowanie takiego sposobu myślenia, które cechuje:

a) nastawienie holistyczne i systemowe w pojmowaniu biosfery i roli człowieka (społeczeństwa) w biosferze oraz stowarzyszone $\mathrm{z}$ nimi przekonanie, iż człowiek jest integralną częścią przyrody i nie może być oddzielony od przyrody i rządzących nią praw;

b) zdolność kojarzenia i integrowania wiedzy pochodzącej z różnych dziedzin nauki i praktyki sprzyjająca konstruowaniu spójnego systemu w sferze teorii i działania;

c) pogląd, iż człowiek, wykorzystując dobra i siły natury, może kontrolować przyrodę, ale powinien to czynić bezpiecznie tylko w ramach jej praw;

d) uznanie, iż jeśli świat przyrody ma być podstawą życia jednostki i społeczeństwa, to jego zdolności do samoodnowienia muszą być utrzymane;

e) postulat, aby w stosunkach człowieka z przyrodą postawa walki i dominacji ustąpiła postawie pojednania, opiekuństwa, partnerstwa;

f) przekonanie, że ludzkie myślenie jest „programowo aksjologiczne”, zorientowane określonym systemem wartości, regułami i wskazaniami, który to fakt respektować powinna zorientowania na rzecz kształtowania ładu środowiskowego edukacja.

Powyżej przedstawione, o bardzo ogólnym charakterze, przekonania, wypełnione konkretną treścią, stanowić powinny filozoficzną podstawę relacji świata ludzkiego i przyrodniczego, w ich wymiarze indywidualnym, społecznym, gospodarczym, politycznym i ekologicznym. Powinny także stanowić najbardziej wyjściową, elementarną podstawę pracy edukacyjno-wychowawczej na rzecz utrzymania bądź odbudowy ładu środowiskowego.

Jeśli zatem uznany - co raczej nie powinno budzić wątpliwości - że w pracy edukacyjnej na rzecz zrównoważonego rozwoju niezwykle pomocny okazuje się dorobek filozofii ekologicznej i etyki środowiskowej, to przypomnijmy, że dyscypliny te wyrosły z zainteresowań środowiskiem i troski związanej z jej nieustannie pogarszającym się stanem. 
Proponują one przede wszystkim radykalną zmianę stosunku człowieka do jego naturalnego otoczenia. Akcentują potrzebę stałego poszerzania wiedzy przyrodniczej o relacjach zachodzących w środowisku między działającym człowiekiem a przyrodą, ale także odwoływania się do szeroko pojętego świata wartości, uczuć i motywacji, w zgodzie z przekonaniem, że wiedza ekologiczna powinna być wsparta o te zagadnienia, które odnoszą się do moralnych, także estetycznych odniesień człowieka do jego przyrodniczego otoczenia. Współoddziaływanie poznania (wiedzy) i aksjologii skutkować może pożądanymi rezultatami w sferze praktycznego czynu i działania.

Dlatego praca edukacyjna na rzecz kształtowania ładu środowiskowego powinna obejmować trzy zasadnicze poziomy: a) kognitywny; b) emocjonalno-wolitywny; c) behawioralny.

Pierwszy (poziom kognitywny) związany jest z przekazywaniem rzetelnej wiedzy przyrodniczej, ale także z prezentacją i uzasadnieniem wartości ekoetycznych i ich imperatywnych odpowiedników. Idzie tu o budowanie systemowej edukacji, a więc takiej naukowej wiedzy systemowej na temat środowiska, która daje szansę na prawidłowe zarządzanie nim, a wzbogacona poprzez system wartości i ich imperatywne odpowiedniki stwarza możliwość zbudowania prawidłowego układu harmonii między naturą i człowiekiem. Warunkiem niezbędnym dla edukacji na rzecz ładu środowiskowej jest akceptacja podejścia holistycznego. Programy nakierowane na analizę zjawisk w skali mereologicznej i rezygnujące bądź niedoceniające holistycznego podejścia do edukacji środowiskowej, w istocie okazują się mało efektywne i nie prowadzą do zrozumienia i przyswojenia podstawowych zjawisk przyczynowo-skutkowych dokonujących się w środowisku przyrodniczym oraz wzajemnych oddziaływań świata ludzkiego i przyrodniczego. Nie mniej istotną częścią składową edukacji na poziomie kognitywnym jest poznawcze rozpoznanie tych wartości i ich imperatywnych odpowiedników, które wyznaczają aksjologiczny (etyczny, estetyczny) wymiar relacji człowieka $\mathrm{z}$ jego przyrodniczym otoczeniem. Wielce pomocna $\mathrm{w}$ tym dziele jest etyka środowiskowa, która dąży do wypracowania aksjologicznych preferencji między człowiekiem a środowiskiem. Wartości spełniałyby rolę kryteriów regulujących owe relacje, byłyby drogowskazem działań 
oraz podstawą konstruowania norm, reguł postępowania. Oczekuje się także, że wartości tonowałyby możliwe konflikty między działającym człowiekiem a przyrodą oraz sprzyjałyby dokonywaniu takich wyborów, które nie naruszałyby ładu środowiskowego w sytuacji, gdy człowiek przystosowuje świat przyrody do swych potrzeb. Spełniając taką rolę, wartości stają się nieomal strażnikami dóbr natury. Równie ważnym elementem edukacji ekologicznej jest poznanie tych norm zasad i powinności, które służą utrzymaniu ładu środowiskowego. Przybierają one postać zarówno ogólnych wskazań regulujących kontakty człowieka z przyrodą, jak i szczegółowych zaleceń, które wskazują, co należy czynić, aby zachować życie, zdrowie, wartości estetyczne przyrody i równowagę ekologiczną - niezbędne wyznaczniki ładu środowiskowego.

Drugi poziom edukacji ekologicznej (emocjonalno-wolitywny) skupia uwagę na pobudzaniu i kształtowaniu wrażliwości moralnej na problemy świata przyrody. Każda mądra praca edukacyjno-wychowawcza odwołuje się zatem do sfery uczuć, woli i motywacji, upatrując w niej realną siłę zachęcająca do działań na rzecz realizacji określonych wartości. Takimi wartościami są dobro przyrody i ład środowiskowy. Tu także, obok budowania wrażliwości moralnej na problemy przyrodniczego otoczenia, jest miejsce na kształtowanie wrażliwości estetycznej na piękno świata przyrody. Uczyć zatem należy zarówno myślenia ekologicznego jak i wrażliwości ekologicznej, dobrych, emocjonalnych odniesień do przyrody tak, aby człowiek - jak powiada pedagogia normatywna Rudolfa Steinera - czuł się członkiem wszechświata, zaś jako istota ludzka miał poczucie odpowiedzialności za wszystko, co się dzieje.

Trzeci poziom edukacji (behawioralny) kształtuje konkretne postawy i zachowania, mobilizuje do aktywnego, czynnego przeciwstawiania się szkodliwym, zakłócającym ład środowiskowy działaniom i procesom. Przebudowa świadomości w duchu świadomości ekologicznej to niezwykle doniosłe, ale przecież nie jedyne zadanie edukacji środowiskowej. Nie wystarczy ograniczyć się do przekazywania określonego kwantum wiedzy i systemu wartości. Wiemy przecież, że wiedza jest ważnym, ale niewystarczającym warunkiem tego, aby ludzie zajmowali praktyczne i odpowiedzialne postawy wobec pojawiających się zagrożeń. Dobrze rozumieli to już starożytni myśliciele (stoicy), gdy mówili: „wiem, co dobre, ale robię inaczej”. Odnosząc tę myśl do interesującego 
nas zagadnienia, moglibyśmy powiedzieć: wiem, co jest niekorzystne dla środowiska i utrzymania jego ładu, ale nie jest regułą, iż podejmuję działania mające na celu praktyczne przeciwstawianie się tej sytuacji. Zatem celem edukacji na rzecz ładu środowiskowego na poziomie behawioralnym jest kształtowanie postawy aktywnie, praktycznie określającej się wobec konkretnych faktów i wydarzeń. Idzie o to, aby propagowane przez edukację ekologiczną idee były akceptowane, uznawane i - co szczególnie ważne - realizowane.

Podkreślmy zatem, iż szeroko rozumianym celem edukacji ekologicznej jest nie tylko wyposażenie człowieka w określoną wiedzę o funkcjonowaniu środowiska (określony zespół informacji powiązanych w system przyczynowo-skutkowy), w system wartości i ich imperatywne odpowiedniki, ale także kształtowanie postawy manifestującej się w konkretnych działaniach i poczynaniach. Z kolei zadaniem edukacji ekologicznej na poziomie szkoleniowym i realizacyjnym jest wypracowanie konkretnych środków, metod i programów wdrażających ogólnie sformułowane $\mathrm{w}$ powyższej wypowiedzi propozycje i idee w praktyke kształceniowo-wychowawczą.

Jest więc oczywiste, że etyka środowiskowa wraz z filozofią środowiskową wnoszą szczególnie doniosły i wartościowy wkład do teorii i praktyki zrównoważonego rozwoju. Dają podwaliny teoretyczne samej koncepcji oraz podstawy aksjologiczne. Etyka środowiskowa ofiarowuje wypracowany na swym gruncie system wartości, który można ująć z perspektywy dwóch wzajemnie uzupełniających się podejść. Jedno wskazuje cel, mówi, czego warto chcieć, pragnąć, do czego warto dążyć, co ma stanowić najbardziej elementarne i uniwersalne zadanie działalności proekologicznej człowieka w jej związkach z życiem społecznym i gospodarczym. Z takiego punktu widzenia do zasadniczych wartości wpisujących się $\mathrm{w}$ ideę zrównoważonego rozwoju, a propagowanych przez etykę środowiskową, należy między innymi: życie, zdrowie, sprawiedliwość. Idzie tu o oczywisty postulat szacunku dla życia człowieka, a także ochrony innych form życia, akcentowanie ewidentnej zależności między stanem zdrowia człowieka a dobrym stanem jego przyrodniczego otoczenia, także ładem społecznym i gospodarczym oraz działaniem na rzecz budowania i zachowania sprawiedliwości wewnątrzpokoleniowej, jak i międzypokoleniowej. Drugie podejście wskazuje drogę do 
celu. Mówi, jak należy postępować, aby życie, zdrowie i sprawiedliwość nie pozostawały pustymi słowami, aby chroniły i wzbogacały człowieka, harmonizowały jego stosunki ze światem przyrody i uzasadniały racjonalną formę rozwoju społecznego i ekonomicznego. $\mathrm{Z}$ takiego punktu widzenia do głównych wartości koncepcji zrównoważonego rozwoju zaliczyć należy: odpowiedzialność, powściągliwość - umiarkowanie, wspólnotowość, solidarność. Działalność charakteryzująca się poczuciem odpowiedzialności, gospodarka ograniczająca wybujałe apetyty konsumpcyjne i opowiadająca się za powściągliwością w korzystaniu z dóbr przyrody, także myślenie akcentujące wspólnotowe pomosty świata ludzkiego i przyrodniczego, służą ochronie najbardziej konstytutywnych dla egzystencji świata przyrody i człowieka wartości, jakimi są życie, zdrowie i sprawiedliwość. Zauważmy, że edukacja na rzecz zrównoważonego rozwoju, podobnie jak edukacja ekologiczna, przybiera postać edukacji formalnej i nieformalnej. Ich powodzenie wzrasta, jeśli jest profesjonalnie prowadzona promocja idei zrównoważonego rozwoju. Praca edukacyjna powinna być zróżnicowana w zależności od możliwości odbiorców i winna przebiegać na trzech zasadniczych poziomach kształcenia: obywatelskim, decydenckim i eksperckim. Sądzimy, że edukacja na rzecz zrównoważonego rozwoju powinna być składową i integralną częścią wykształcenia każdego nieomal członka społeczności. Idzie w sumie o to, aby każdy z nas był bardziej niż dotychczas świadomy problemów i treści związanych z koncepcją zrównoważonego rozwoju i zarazem dostrzegał osobiste możliwości kreatywnego jej wspierania.

Finalizując niniejsze rozważania, przywołajmy jeszcze raz myśl już wcześniej sformułowaną. Akcentuje ona zwłaszcza to przekonanie, że w działaniach na rzecz edukacji ekologicznej, pojmowanej jako ważna część składowa edukacji na rzecz zrównoważonego rozwoju, etyka środowiskowa dąży do tego, aby świadomość postępującej destrukcji środowiska, i w jej efekcie kryzysu ekologicznego, znalazła przeciwwagę w moralnych powinnościach człowieka wobec przyrody. Natomiast w życiu społecznym i gospodarczym - do tego, aby świadomość tych powinności została wpleciona $\mathrm{w}$ reguły i mechanizmy działania społecznego, politycznego i gospodarczego. 


\section{Bibliografia:}

Bonenberg, Marek M. 1992. Etyka środowiskowa: założenia i kierunki. Kraków: Wydawnictwo Uniwersytetu Jagiellońskiego.

Ciążela, Helena. 2005. Edukacja wobec etycznego wymiaru idei rozwoju trwałego i zrównoważonego. Prakseologia, 145, 171-182.

Edukacja dla zrównoważonego rozwoju, t. 1-4, red. Tadeusz Borys. 2010. Białystok-Wrocław: Wydawnictwo Ekonomia i Środowisko.

Etyka środowiskowa. Teoretyczne i praktyczne implikacje, red. Włodzimierz Tyburski. 1998. Toruń: Top Kurier.

Hull, Zbigniew. 1996. Aksjologia ekonomii a ekologia. W: Ekonomia, ekologia, etyka, red. Włodzimierz Tyburski, 13-23. Toruń: Top Kurier.

Kiepas, Andrzej. 2006. Etyka jako czynnik ekorozwoju w nauce i technice. Problemy Ekorozwoju, 1(2), 77-86.

Papuziński, Andrzej. 1998. Edukacja ekologiczna a etyka środowiskowa w świetle dyskusji na temat racjonalności pedagogiki. W: Etyka środowiskowa. Teoretyczne i praktyczne implikacje, red. Włodzimierz Tyburski, 48-67. Torun: Top Kurier.

Pawłowski, Artur. 2008. Rozwój zrównoważony - idea, filozofia, przyroda. Lublin: Komitet Inżynierii Środowiskowej PAN.

Piątek, Zdzisława. 1998. Etyka środowiskowa. Nowe spojrzenie na miejsce człowieka $w$ przyrodzie. Kraków: Wydawnictwo Uniwersytetu Jagiellońskiego.

Skolimowski, Henryk. 1991. Eco-philosophy. Designing New Tactics for Living. Boston-London: Marion Boyars.

Tyburski, Włodzimierz. 2013. Dyscypliny humanistyczne i ekologia. Toruń: Wydawnictwo Naukowe Uniwersytetu Mikołaja Kopernika.

Zasady kształtowania postaw sprzyjających wdrażaniu zrównoważonego rozwoju, red. Włodzimierz Tyburski. 2011. Toruń: Wydawnictwo Naukowe Uniwersytetu Mikołaja Kopernika. 

Iwona Stachowska

Akademia Pedagogiki Specjalnej im. Marii Grzegorzewskiej - Instytut Filozofii i Socjologii istachowska@aps.edu.pl

\section{Postawa samoograniczenia w świetle idei zrównoważonego rozwoju}

Nie ten jest biedny, kto posiada mało,

lecz ten, kto pragnie więcej.

Seneka

Aby żyć lepiej, trzeba odtąd produkować

i konsumować inaczej, czynić lepiej

i więcej, posiadając mniej.

Andre Gorz

\section{Wstęp}

"Jak to się dzieje, że posiadając tak wiele, ciągle pragniemy więcej?" (Jackson 2015, 28). „Co zrobić, żeby chcieć mniej?” (Krall 2016 [1968]). Chociaż pytania te dzieli od siebie niemal pół wieku, poruszone w nich problemy nie straciły na wadze i pozostają aktualnymi zagadnieniami dotyczącymi conditio humana.

Źródeł owych pytań, mających filozoficzno-etyczne zaplecze, a odnoszących się do umiejętności dokonania słusznego wyboru czy kwestii dobrego życia, należy upatrywać w starożytnej myśli Zachodu i Wschodu. Wystarczy przywołać starogrecką maksymę „Nic w nadmiarze”, jej rzymski odpowiednik w postaci wezwania ne quid nimis, stoicką autarkię i apatię, dalekowschodnią koncepcję umiarkowania obecną w taoizmie czy japońską regułę taro wo shiru.

Współcześnie wątki te przeżywają renesans za sprawą coraz powszechniejszego rozczarowania i przesytu dominującymi standardami konsumpcji. Ich krytyka widoczna jest między innymi w dyskusjach toczących się wokół alternatywnych modeli zachowań konsumenckich, takich jak „alternatywny hedonizm” (Kate Soper), „dobrowolna prostota” (Duane Elgin), „downshifting” (Julien Schore), „minimalizm” (Leo Babauta), czy oddolnych ruchach, takich jak „Slow Life”, "Slow Food”, „Slow Fashion”, „Fair Trade”. 
Wspólnym pierwiastkiem łączącym wspomniane wyżej podejścia jest $\mathrm{z}$ jednej strony dążenie do zrównoważenia konsumpcji, produkcji oraz życia w zgodzie $\mathrm{z}$ koncepcją zrównoważonego rozwoju, zaś z drugiej promowanie postawy samoograniczenia jako elementu warunkującego świadome i rozsądne zaspokajanie potrzeb oraz odpowiedzialne korzystanie z dóbr.

W artykule zostaną ze sobą zderzone główne założenia idei zrównoważonego rozwoju z ideą samoograniczenia. Przyjęcie tej perspektywy rozważań umożliwi pokazanie leżących u ich podstaw wspólnych założeń, jak również pozwoli wskazać różnice i zaakcentować podstawowe trudności, które, jak się wydaje, niełatwo będzie wyeliminować.

\section{Zrównoważony rozwój i ograniczenie in genere}

Idea zrównoważonego rozwoju pojawiła się jako jedna z odpowiedzi na dylemat dotyczący wzrostu, wobec którego zostaliśmy postawieni. Jest to wybór między kontynuacją niezrównoważonego wzrostu, okupionego rosnącym zużyciem zasobów, kosztami środowiskowymi oraz narastającymi nierównościami społecznymi, a niepewnym postwzrostem czy odejściem od wzrostu (Jackson 2015, 91).

W dwóch kluczowych dla kształtowania się formuły zrównoważonego rozwoju dokumentach: pierwszym raporcie Klubu Rzymskiego Granice wzrostu (Meadows et al. 1973) oraz w raporcie komisji Brundtland Nasza wspólna przyszłość (ŚKŚR 1991), znajdziemy bezpośrednie nawiązania do ograniczenia. W pierwszym pojawia się ono jako gospodarczy postulat „zerowego wzrostu” wyznaczający pożądany kierunek zmiany rozwoju gospodarczego. W drugim odnajdziemy je w definicji zrównoważonego rozwoju jako jedno z budujących je pojęć. Zrównoważony rozwój został bowiem zdefiniowany jako taki, który gwarantuje zaspokojenie potrzeb obecnych pokoleń, nie ograniczając przyszłym pokoleniom możliwości zaspokojenia ich potrzeb (ŚKŚR 1991, 67). Obranie tej ścieżki rozwoju ma skutkować odejściem od destrukcyjnego modelu cywilizacji w kierunku modelu zrównoważonego, respektującego w równym stopniu wymiar ekonomiczny oraz czynniki społeczne i środowiskowe.

Jeśli zgodnie z założeniami zrównoważonego rozwoju przyjmiemy, że rozwój gospodarczy powinien uwzględniać zarówno regułę społecznej 
sprawiedliwości jak i bariery ekologiczne, to wyrównanie dysproporcji społecznych czy zmniejszenie antropopresji pociąga za sobą ograniczenie skali produkcji oraz konsumpcji, które nie mogą rosnąć w nieskończoność (Kronenberg i Iida 2011, 69). Dlatego mówi się o ilościowym ograniczeniu czasu pracy, liczby nabywanych towarów, a także zmniejszeniu emisji zanieczyszczeń, redukcji zużycia zasobów naturalnych czy ograniczeniu produkcji odpadów (Latouche 2009; Jackson 2015). Pojawiają się również, biorące pod uwagę owe ilościowe ograniczenia, ponadnarodowe projekty gospodarki umiaru czy polityki niskoemisyjnej (Jackson 2015; Kołodko 2014; Stern 2010).

Wśród czynników sprzyjających wdrażaniu zrównoważonego rozwoju znaczącą rolę odgrywają także próby zmiany dominujących w kulturze zachodniej wzorców konsumpcji, postaw, zachowań, systemów wartości i ocen, które kierują naszą uwagę w stronę jakościowego ujęcia ograniczenia. Wykraczające poza ilościowe kryteria ekonomiczne ograniczenie jakościowe jawi się jako sytuacja ludzkiego wyboru, celowe pomniejszenie, a precyzyjniej - samoograniczenie. Argumentuje się przy tym, że kształtowanie postawy samoograniczenia ma na poziomie jednostkowym poprawić jakość życia poprzez rozsądne zaspokajanie potrzeb, zaś na poziomie globalnym prowadzić do wypracowania ładu w dziedzinie konsumpcji oraz ograniczyć nasz zgubny wpływ na środowisko (Jackson 2005). Samoograniczenie rozważane w ramach zrównoważonego rozwoju dotyczyłoby zatem nowego kierunku filozofii konsumenckiej oznaczającej konkretny rodzaj nastawienia do świata oraz szczególny styl życia związany z ideałami „dobrowolnej prostoty”, „prostego życia”, minimalizmu czy „zrównoważonej konsumpcji”.

Zrównoważona konsumpcja, jak podkreśla Włodzimierz Tyburski, „wpisuje się w założenia zrównoważonego rozwoju i ma na uwadze respektowanie wymogów związanych z jego realizacją" (Tyburski 2011, 143). W ten sposób została ona ujęta w międzynarodowych dokumentach i raportach (OECD 1998, UNEP 2001). Tim Jackson zauważa jednak, że nie jest jasne, co rzeczywiście rozumiemy przez zrównoważoną konsumpcję, gdyż pod wspomnianym hasłem kryją się różne strategie działania, od zmniejszenia konsumpcji począwszy, a na zarządzaniu chciwością skończywszy (Jackson 2005, 20). 
Podobne semantyczne nieostrości pojawiają się w przypadku samoograniczenia, które jest terminem wieloznacznym, definiowanym nieco odmiennie w zależności od epoki, miejsca występowania, kultury czy zakresu przedmiotowego, którego dotyczy. Przyjrzyjmy się zatem bliżej jego współczesnym implikacjom.

\section{Różne oblicza samoograniczenia}

Samoograniczenie jest rozumiane jako dobrowolny akt rezygnacji z dóbr, które posiadamy bądź też do których posiadania dążymy. Posiłkując się analizami Henryka Elzenberga dotyczącymi „wyrzeczenia”, można pokusić się o przeprowadzenie szkicowej typologizacji i dokonać rozróżnienia na samoograniczenie zewnętrzne oraz wewnętrzne (Elzenberg 2012 [1925], 145-174). Pierwsze zakłada rezygnację z posiadania lub dążenia do posiadania określonych dóbr, a więc jest działaniem skutkującym zmianą $\mathrm{w}$ świecie zewnętrznym, np. zmniejszenie ilości nabywanych towarów bądź ograniczenie spożycia substancji szkodliwych. Z kolei drugie ma charakter jakościowy i polega na zmianie nastawienia podmiotu względem danej rzeczy, a dokładnie oparcie się swemu pożądaniu w określonym zakresie. Może nim być np. gotowość do ograniczenia samej chęci posiadania dóbr materialnych lub przezwyciężenie nałogu. W praktyce zazwyczaj samoograniczenie wewnętrzne idzie w parze z zewnętrznym. Jednak, jak pokazuje Elzenberg, nie zawsze mamy do czynienia z ich współwystępowaniem: „Mogę się dobrowolnie wyzbyć przedmiotu, którego nie przestaję pożądać (...): to będzie wyrzeczenie czysto zewnętrzne. I na odwrót: mogę przestać pożądać, nie przestając dążyć, przestać być przywiązanym, nie przestając posiadać (...) będzie to wyrzeczenie czysto wewnętrzne" (Elzenberg 2012 [1925], 152).

To z pozoru oczywiste rozróżnienie ma daleko idące konsekwencje, zwłaszcza jeśli osadzimy je w kontekście ograniczenia konsumpcji. Próba zmiany zachowań i wzorców zaspokajania potrzeb może bowiem przybrać formę pozorną i powierzchowną, ograniczoną wylącznie do ilościowych oraz krótkotrwałych zmian. Piewca idei „dobrowolnej prostoty" Duane Elgin określa takie działania mianem kosmetycznych strategii maskujących, które nie mają wpływu na zmianę wiodących tren- 
dów, a jedynie poprawiają nasze samopoczucie i dają fałszywe poczucie bezpieczeństwa: „Nakładamy zieloną szminkę na nasze niezrównoważone życie, aby nadać mu wygląd zdrowego i szczęśliwego" (Elgin 2010, 7). Tego rodzaju powierzchowność widoczna jest między innymi w bezrefleksyjnym podążaniu za modą na produkty sygnowane przymiotnikami „zielony”, „ekologiczny”, „slow” czy w szalonym pędzie do oczyszczania pola $\mathrm{z}$ dóbr materialnych, tylko po to, by zrobić miejsce na kolejne (Bauman 2015, 43; Popkiewicz 2012, 454-455). Autorzy skupieni wokół zagadnienia zrównoważonej konsumpcji dostrzegają, iż tego typu podejście nie ma nic wspólnego z klasycznym rozumieniem samoograniczenia i nie prowadzi do wypracowania trwałych nawyków oraz postaw.

Niewystarczalność samoograniczenia zewnętrznego doskonale zilustrował Richard Gregg, przytaczając odpowiedź Mahatmy Gandhiego na jego uwagę, iż łatwo mu zrezygnować $\mathrm{z}$ większości rzeczy poza książkami: „Więc nie rezygnuj z nich. Tak długo, jak czerpiesz wewnętrzny spokój i komfort z posiadania pewnych rzeczy, powinieneś je zatrzymać. Jeśli zrezygnujesz $\mathrm{z}$ nich $\mathrm{w}$ akcie poświęcenia lub z poczucia obowiązku, będziesz chciał je odzyskać. Zrezygnuj z nich jedynie wtedy, jeśli pragniesz innych tak bardzo, że te wcześniejsze przestają być dla ciebie atrakcyjne lub wówczas, gdy zaczynają kolidować z tym czego bardziej pożądasz" (Gregg 1936, 12).

Cenna uwaga Gandhiego prowadzi nas w stronę głębokiego i świadomego samoograniczenia, czyli trwałej dyspozycji, która łączy w sobie zarówno wymiar wewnętrzny jak i zewnętrzny. Błędne byłoby bowiem twierdzenie, że wystarczy poprzestać na ograniczeniu wewnętrznym (Elzenberg 2012 [1925], 155). Podobnie jak jego zewnętrzny odpowiednik i ono może okazać się zwodnicze, gdyż wiąże się z ryzykiem odrodzenia chęci posiadania i wbrew pierwotnym oczekiwaniom może prowadzić do niezrównoważonych zachowań konsumenckich.

Istotną kwestię stanowi wskazanie racji przemawiających za przyjęciem postawy samoograniczenia, czyli dookreślenie, po co mielibyśmy się ograniczać. Co pragniemy przez akt samoograniczenia osiągnąć, a czego pragniemy uniknąć? Innymi słowy: w jakim celu i dlaczego należy podjąć ten wysiłek?

Jak zauważa Elzenberg każdy rodzaj wyrzeczenia jest motywowany przesłankami o charakterze aksjologicznym i ma swoje uzasadnienie 
w sądach o wartościach (Elzenberg 2012 [1925], 157). U źródeł wszelkiego wartościowania, zdaniem toruńskiego filozofa, leży racja logiczna przyznająca samoograniczeniu wartość dodatnią, a tym samym oceniająca je jako coś dobrego. Jednak przyznanie samoograniczeniu wartości pozytywnej nie wystarczy, trzeba bowiem dookreślić, że jest ono lepsze niż to, czego się wyzbywamy bądź z czego rezygnujemy lub też że jest wartościowe ze względu na swoje skutki. Za Elzenbergiem jedno z nich określimy jako samoograniczenie z konieczności wyboru, a kolejne jako samoograniczenie dla celów pozytywnych (Elzenberg 2012 [1925], 159163). Pierwsze ma charakter powszechny i towarzyszy nam w codziennych sytuacjach. Natomiast drugie afirmuje sam akt samoograniczenia i traktuje je jako środek do osiągnięcia zamierzonego celu. Zdaniem autora Etyki wyrzeczenia ten rodzaj etycznej gimnastyki nie jest powszechnie występującą dyspozycją.

Dostosowując refleksję na temat samoograniczenia do dzisiejszych wymagań oraz aktualnych wyzwań społecznych, ekonomicznych, przyrodniczych czy moralnych, zauważymy, że pod hasłem live better by consuming less ukrywa się szeroki wachlarz powodów, dla których warto się ograniczyć. Elgin wymienia wśród nich między innymi: poprawę jakości życia; rozwój osobisty; równowagę między rozwojem wewnętrznym i zewnętrznym, pracą a życiem prywatnym, najbliższymi a wspólnotą; bardziej harmonijne relacje $\mathrm{z}$ przyrodą; promowanie sprawiedliwości i równości, zwiększenie zasobów dostępnych dla przyszłych pokoleń; ochronę gatunków zagrożonych wyginięciem; reagowanie na globalne niedobory wody, ropy i innych istotnych zasobów naturalnych (Elgin 2010, 4). Upraszczając, można powiedzieć, że amerykański badacz, podobnie jak inni zwolennicy zrównoważonej konsumpcji, wskazuje trzy drogi wyznaczające przestrzeń wartości, ku którym zmierzamy, kierując się samoograniczeniem. Są to: dobro własne, dobro gatunku ludzkiego lub dobro przyrody (Elgin 2010; Jackson 2005; Kronenberg i Iida 2011).

Wśród wiodących strategii działania najsilniej za przyjęciem postawy samoograniczenia przemawiają pobudki psychologiczne. Jak wynika $\mathrm{z}$ analiz psychologów społecznych oraz ekonomistów, potrzeba zmiany zakresu i standardów konsumpcji rodzi się wraz z dostrzeżeniem dysproporcji pomiędzy materialnym statusem a jakością życia. 
Wbrew dominującym w społeczeństwach zachodnich standardom, które zachęcają, by definiować swoją pozycję społeczną i określać życiowe cele $\mathrm{w}$ kategoriach posiadania, osobisty dobrostan wykracza poza materialne przyjemności. Jackson definiuje go w następujący sposób: „Dobrobyt przekracza troski materialne. Tkwi w jakości naszego życia oraz w zdrowiu i szczęściu naszych rodzin. Jest obecny w sile naszych relacji i zaufaniu, które pokładamy we wspólnocie. Świadczy o nim nasza satysfakcja z pracy oraz poczucie wspólnego sensu i celu" (Jackson 2015, 42). Co więcej, strategia maksymalizowania materialistycznych potrzeb nie dość, że nie ma przełożenia na poprawę jakości życia, to dodatkowo generuje psychologiczne cierpienie, wiąże się z poczuciem żalu, niezadowoleniem wywołanym nadmiarem ofert i koniecznością dokonania wyboru spośród nich, lękiem przed niedostatkiem dóbr, a także obawą przed porównaniami społecznymi oraz potrzebą uznania (Kasser 2002; Schwartz 2015).

Można odnieść wrażenie, że, odwołując się do psychologicznych analiz ludzkich potrzeb i pytając o dobro ludzkiego życia, w gruncie rzeczy nie wychodzimy poza antropocentryzm w jego skrajnej indywidualistyczno-egoistycznej wersji (Papuziński 2013, 14-20). Jacek Jaśtal, odwołując się do poglądów Johna O’Neilla, podkreśla, że nawet próby poszerzenia pojęcia wspólnoty moralnej czy pogłębione ujęcie ludzkich potrzeb wskazujące, że ich: „pełna realizacja możliwa jest jedynie w jakiejś łączności ze środowiskiem naturalnym traktowanym jako coś więcej niż źródło doraźnych korzyści” (Jaśtal 2006, 46), nie przełamują antropocentryzmu, nie odchodzimy bowiem od ludzkiego sposobu patrzenia na kwestie środowiskowe (Jaśtal 2006, 49). Zauważa jednak, że przywołane strategie stanowią łagodniejszą wersję antropocentryzmu, bo chociaż wiążą motywacje do zachowań proekologicznych z charakterystycznymi dla człowieka stanami emocjonalnymi i potrzebami, to nie zakładają wyłącznie instrumentalnego stosunku do przyrody (Jaśtal 2006, 46). Jak wyjaśnia Andrzej Papuziński, w takich przypadkach chodzi o umiarkowany antropocentryzm, który proponuje ograniczenie konsumpcji i zakłada „równowagę między wzrostem gospodarczym a stanem ekosystemów w celu zapewnienia społeczeństwu wysokiej jakości życia, rozumianej nie tylko w kategoriach ekonomicznych, ale 
i społecznych, humanistycznych" (Papuziński 2013, 14). Wizja dobrobytu oparta na samoograniczeniu ma zatem gwarantować podwójne korzyści: satysfakcjonujące, a zarazem zrównoważone ekologicznie życie (Jackson 2005, 25). Nawet wówczas, gdy - jak zauważają Kronenberg i Iida - zwolennicy alternatywnych strategii zachowań konsumenckich w pierwszej kolejności odwołują się do psychologicznych potrzeb człowieka, a dopiero potem do kwestii zrównoważenia czy ochrony środowiska (Kronenberg i Iida 2011, 70).

Podsumowując ten etap rozważań, należałoby zatem doprecyzować, że samoograniczenie to dobrowolny, przemyślany oraz zamierzony akt rezygnacji z niektórych dóbr materialnych oraz z zaspokojenia niektórych potrzeb i zwrot w kierunku wartości wewnętrznych, wpływający na poprawę jakości życia oraz jego zrównoważenie w wymiarze jednostkowym (troska o siebie), wspólnotowym czy gatunkowym (troska o aktualny i przyszły dobrostan ludzi) lub przyrodniczym (troska o środowisko naturalne).

\section{Samoograniczenie wobec problematyki zrównoważonego rozwoju: zależności, różnice, wyzwania}

Umieszczenie refleksji na temat samoograniczenia w kontekście zmiany myślenia o konsumpcji pozwala dostrzec, w jak istotny sposób może ono wspierać i promować program zrównoważonego rozwoju. Obie idee są zbieżne aksjologicznie i zorientowane na takie wartości jak: poprawa jakości życia, sprawiedliwość, wolność, odpowiedzialność i dążą do zmiany stanu wiedzy, mentalności, wzorców konsumpcji, oferując wizję zaspokajania potrzeb w sposób bardziej zrównoważony. Wbrew wiodącym tendencjom wskazują, że rozwój w ramach ograniczeń jest nie tylko realną możliwością, ale koniecznością (Jackson 2015, 183). Jednak na drodze do ich realizacji pojawiają się trudne do usunięcia przeszkody.

Jak zauważają Kronenber i Iida, jednym z głównych problemów podejmowanych w dyskusjach nad zrównoważonym rozwojem, a tym samym także nad samoograniczeniem, jest problem skali (Kronenberg i Iida 2011, 69). Jego rozpoznanie leży u podstaw pracy Ernsta F. Schumachera Małe jest piękne, w której czytamy: „Nie ma jednej odpowiedzi na pyta- 
nie o właściwą skalę. Do różnych rzeczy człowiek potrzebuje rozmaitych struktur - małych i dużych, zamkniętych i otwartych. (...) Tak więc skala zależy od tego, co chcemy zrobić" (Schumacher 1981, 80-81).

W przypadku samoograniczenia problem skali kieruje naszą uwagę w stronę konkretnych pytań: jakie potrzeby i pragnienia mamy ograniczać oraz w jakiej mierze? Zarówno zrównoważony rozwój, jak i zrównoważona konsumpcja czy odwołujące się do samoograniczenia ruchy „dobrowolnej prostoty”, „minimalizmu” czy „downshiftingu” nie sugerują ograniczenia wszelkich ludzkich potrzeb i pragnień. Dążąc do zmiany nawyków konsumpcyjnych, proponują minimalizm tudzież zrównoważenie $\mathrm{w}$ zakresie zaspokajania potrzeb materialnych, zużycia zasobów naturalnych, produkcji odpadów i zanieczyszczeń, a w zamian oferują maksymalizm na polu potrzeb pozamaterialnych, rozwoju wewnętrznego, szacunku, poczucia identyfikacji ze wspólnotą oraz z przyrodą. Jednak dookreślenie, iż chodzi o minimalizm w zakresie dążenia do posiadania dóbr materialnych, niewiele jeszcze wnosi do dyskusji na temat ograniczenia konsumpcji. Istotną kwestią jest bowiem doprecyzowanie, gdzie miałyby przebiegać granice owego samoograniczenia, o jakiej skali mowa? Ważniejsza od tego, co konsumować, jest zatem decyzja, jak konsumować, w jaki sposób i w jakim zakresie zaspokajać ludzkie potrzeby przez dobra naturalne i sztuczne (Kronenberg i Iida 2011, 70).

Kwestia ustalenia zakresu samoograniczenia okazuje się być nieostra. Tak jak w przypadku zrównoważonego rozwoju nie ma zgodności co do rozumienia skali zrównoważenia (Hull 2005, 59), analogicznie trudno znaleźć jedną miarę dla samoograniczenia. Elgin opowiada się za restrykcyjnym ograniczeniem posiadania (2010). Serge Latouche, zwolennik kultury ograniczenia i propagator ruchu „odejścia-od-wzrostu”, przekonuje, by konsumować mniej (Latouche 2009, 37). Natomiast Jackson proponuje, by skoncentrować swoje wysiłki na tym, by nie konsumować więcej (Jackson 2011). Jak widać, horyzont samoograniczenia rozciąga się od wersji rygorystycznej (wyrzeczenie, asceza) do wersji łagodniejszej (umiarkowanie, powściągliwość). Ostatecznie jednak nadal nie wiadomo, gdzie wyznaczyć granicę ograniczenia konsumpcji. Wobec zróżnicowania stanowisk i niejednoznaczności skali może warto, idąc za przykładem Jacka Hołówki (Hołówka 1994, 391-392), odwrócić perspektywę patrze- 
nia na problem skali i zamiast szukać zewnętrznie określonych kryteriów, wyznaczonych chociażby na drodze instytucjonalnych ustaleń o charakterze międzynarodowym, zwrócić się w stronę podmiotu moralnego, który powinien dobrowolnie i świadomie postanowić, jak daleko gotowy jest ograniczyć własne potrzeby konsumpcyjne ze względu na dobro innych ludzi oraz natury, tak obecnie jak i w przyszłości.

Kłopoty z wyznaczeniem skali obnażyły kolejną trudność z samoograniczeniem rozumianym jako jedno z założeń nowego, zrównoważonego paradygmatu rozwoju. Skoro skłonność do samoograniczenia stanowi dobrowolną i indywidualną decyzję podmiotu moralnego, wydaje się, iż nie da się, na drodze narzucanych z zewnątrz instytucjonalnych ustaleń, np. przepisów prawa, wyegzekwować świadomego i długofalowego samoograniczenia w korzystaniu $\mathrm{z}$ dóbr oraz zaspokajaniu potrzeb konsumpcyjnych przez jednostkę. Nie oznacza to jednak, że nie należy podejmować jakichkolwiek wysiłków w celu zmiany postaw i zachowań konsumentów w życiu codziennym. Wprawdzie samoograniczenia nie można narzucić, ale można je kształtować, zwiększając poziom wiedzy na temat ekologicznych i społecznych współzależności oraz konsekwencji podejmowanych przez konsumentów decyzji. W tym sensie, kształtowanie etycznej postawy samoograniczenia idzie $\mathrm{w}$ parze $\mathrm{z}$ edukacja na rzecz zrównoważonego rozwoju, gdyż tak jak ona ma prowadzić do wygenerowania świadomych, proekologicznych i prozrównoważonych zachowań konsumenckich.

Edukacja mająca na celu zmianę wzorców konsumpcji i produkcji jest istotna, gdyż ma głębokie konsekwencje dla całego systemu społeczno-ekonomiczno-przyrodniczego. Jak twierdzi Jackson, większość konsumentów nie postrzega siebie jako konsumentów zasobów naturalnych i nie jest świadoma, że swoimi codziennymi wyborami może przyczyniać się do pogłębiania kryzysu ekologicznego (Jackson 2005, 25). Dlatego uważa on, że jeśli konsumenci zostaną rzetelnie poinformowani i zrozumieją wpływ swoich wyborów na środowisko, będą bardziej skłonni brać pod uwagę te czynniki przy podejmowaniu kolejnych decyzji, a tym samym będą gotowi na to, aby ograniczyć chęć posiadania.

Obok wypracowanych na niwie międzynarodowej rozwiązań edukacyjno-politycznych, mających na celu miedzy innymi zmianę nawy- 
ków konsumpcyjnych, założenia te starają się wdrożyć w życie oddolne ruchy społeczne obejmujące konsumentów, jak i producentów, takie jak „,,Slow Life”, „Slow Food”, „Slow Fashion” czy „Fair Trade”. Promując model sprawiedliwego, humanitarnego i zrównoważonego ekologicznie procesu wytwarzania, nabywania i konsumowania produktów, dostarczają zarazem informacji na temat: gdzie, przez kogo, w jakich warunkach i w jaki sposób produkuje się poszczególne towary, podając chociażby dane dotyczące ich „plecaka ekologicznego". Pomimo niewystarczalności owych oddolnych działań, warto dostrzec, że przyczyniają się one do zmiany myślenia o sposobach zaspokajania potrzeb, tym bardziej, że odbijają się szerokim echem w mediach masowych, stanowiąc przeciwwagę dla wciąż obecnych w głównym nurcie irracjonalnych, niezrównoważonych wzorców konsumpcji (Kronennerg i Iida 2011, 68, 72). Małgorzata Kowalewska zauważa, że inicjatywy te stały się w dość krótkim czasie rozpoznawalne w skali globalnej i przyczyniły się do promowania idei zrównoważonego rozwoju również wśród osób niezaangażowanych wcześniej w działania proekologiczne (Kowalewska 2016, 184).

Przynależność do społeczności „świadomych konsumentów” stała się dzisiaj modna. Trudno oszacować, jak długofalowy będzie ów trend i czy przełoży się na trwałe zmiany nawyków i zachowań, czy ograniczy wyłącznie do chwilowego samoograniczenia zewnętrznego, nośnych medialnie haseł i sloganów, ale trudno przejść obojętnie wobec faktu, że obecnie angażuje pewną grupę klientów i producentów w etyczną konsumpcję.

Zauważmy jednak, że samoograniczenie jako dobrowolny akt rezygnacji z dóbr materialnych realizuje się przede wszystkim na poziomie działań jednostkowych czy oddolnych inicjatyw, które zakładają drobne korekty w konsumpcyjnym modelu życia. Tymczasem warunkiem zmiany obecnego trendu są również działania odgórne: zmiana prawodawstwa, wypracowanie długofalowych, ponadnarodowych rozwiązań politycznych czy solidarnych, wspólnie zaplanowanych wysiłków społecznych. Jackson przekonuje, że naiwnością byłoby sądzić, że indywidualne wysiłki na rzecz upraszczania życia, zrównoważenia konsumpcji, samoograniczenia wystarczą (Jackson 2005, 19). Jak pisze: „zmiana społecznej logiki konsumpcji nie może zostać zredukowana do sfery indywidualnego wyboru. Mimo rosnącego pragnienia zmiany, prawie niemożliwe jest, by ludzie po prostu mogli wybrać zrównoważony styl 
życia, niezależnie od tego, jak bardzo tego chcą. (...) Szanse rozpropagowania takich zachowań w społeczeństwie są znikome bez zmian w strukturze społecznej" (Jackson 2015, 188-189). W podobnym duchu wypowiadał się wiele lat wcześniej Hans Jonas, przestrzegając, że ówczesny destrukcyjny trend rozwoju cywilizacji „wymaga zmiany naszych nawyków konsumpcyjnych, a więc i stylu życia nas wszystkich, i co za tym idzie zmiany w całym układzie gospodarczym, który tym nawykom służy i z którego żyje" (cyt. za Tyburski 2011, 140).

Aktualność podjętych przez Jonasa problemów skłania do refleksji, iż trudno kreślić korzystny scenariusz dla implementacji samoograniczenia. Optymizmem nie napawa również fakt niepowodzeń wdrażania założeń zrównoważonego rozwoju, chociażby fiasko polityki niskoemisyjnej czy ciągle stosowany mechanizm przerzucania skutków dzisiejszej konsumpcji na przyszłe pokolenia. Przyjęcie postawy samoograniczenia wymaga zakwestionowania dotychczasowych sposobów postępowania, zmiany stylu życia, wiąże się także z transformacją gospodarczą. Są to niechętnie ponoszone indywidualne oraz ponadindywidualne koszty, które trzeba jednak brać pod uwagę, rozważając możliwości i przeszkody do jego realizacji.

\section{Zakończenie}

Podsumowując podjęte wątki, ograniczmy się do dwóch ogólnych stwierdzeń dotyczących samoograniczenia oraz zrównoważonego rozwoju. Po pierwsze podkreślmy, że samoograniczenie w zaspokajaniu potrzeb oraz korzystaniu $\mathrm{z}$ dóbr jest jedną z centralnych kategorii zrównoważonego rozwoju, wspierającą zmianę myślenia o konsumpcji. Jako takie ma prowadzić do umiarkowanej i rozsądnej realizacji ludzkich celów, mając na uwadze nie tylko dobro własne, ale dobro obecnych i przyszłych pokoleń, jak również troskę o środowisko naturalne.

$\mathrm{Z}$ kolei drugi wniosek dotyczy utrudnień związanych z kształtowaniem postawy samoograniczenia w duchu idei zrównoważonego rozwoju. Przeszkody te mają przeważnie charakter teoretyczny, ale ich skutki odczuwane są na poziomie praktycznym. Są to: problemy z zakresem przedmiotowym samoograniczenia oraz z jego skalą, czyli z doprecyzowaniem, jakie pragnienia i potrzeby mamy ograniczać oraz w jakiej mierze, a także problem pogodzenia wpisanej w samoograniczenie 
wolności wyboru z narzucanymi z zewnątrz ustaleniami, przepisami, normami pojawiającymi się $\mathrm{w}$ dokumentach oraz raportach $\mathrm{z}$ zakresu zrównoważonego rozwoju.

Zasygnalizowane obszary problemowe nie mają jednak zniechęcać, lecz pokazać, że wykształcenie skłonności do samoograniczenia, które stanowi jeden $\mathrm{z}$ warunków przełożenia idei zrównoważonego rozwoju na praktykę społeczną, winno dokonywać się na drodze odpowiednich procesów wychowawczych, co wpisuje postawę samoograniczenia w ramy edukacji dla zrównoważonego rozwoju.

\section{Bibliografia:}

Bauman, Zygmunt. 2015. O przemijaniu trwania. W: Śmieć w kulturze, red. Katarzyna Kuligowska i Cezary Obracht-Prondzyński, 35-47. Gdańsk: Wydawnictwo Naukowe Katedra.

Elgin, Duane. 2010. Voluntary simplicity. Dostęp: 22.02.2017. http:// duaneelgin.com/wp-content/uploads/2010/12/voluntary-simplicity-Chapter-One.pdf.

Elzenberg, Henryk. 2012 [1925]. Wartość i człowiek. Toruń: Wydawnictwo Naukowe Uniwersytetu Mikołaja Kopernika.

Gregg, Richard. 1936. The Value of Voluntary Simplicity. Dostęp: 22.02.2017. http://www.duaneelgin.com/wp-content/uploads/2010/11/ the_value_of_voluntary_simplicity.pdf.

Hołówka, Jacek. 1994. O pomocy w potrzebie. W: O wartościach, normach i problemach moralnych, red. Magdalena Środa, 379-392. Warszawa: PWN.

Hull, Zbigniew. 2005. Filozofie zrównoważonego rozwoju. W: Zrównoważony rozwój. Od utopii do praw człowieka, red. Andrzej Papuziński, 52-63. Bydgoszcz: Oficyna Wydawnicza Branta.

Jackson, Tim. 2005. Live Better by Consuming Less? Is There a "Double Dividend" in Sustainable Consumption. Journal of Industrial Ecology, 9, 19-36.

Jackson, Tim. 2011. Żelazna klatka konsumpcjonizmu. Dostęp: 22.02.2017. http://www.instytutobywatelski.pl/2687/lupa-instytutu/zelazna-klatka-konsumpcjonizmu. 
Jackson, Tim. 2015. Dobrobyt bez wzrostu. Ekonomia dla planety o ograniczonych możliwościach, tłum. Marcin Polakowski. Toruń: Wydawnictwo Naukowe Uniwersytetu Mikołaja Kopernika.

Jaśtal, Jacek. 2006. Etyka cnót wobec wyzwań etyki środowiskowej: spór o granice naturalistycznego dyskursu etycznego. Diametros, 9, 34-50.

Kasser, Tim. 2002. The high price of materializm. Cambridge: MIT Press.

Kołodko, Grzegorz. 2014. Nowy Pragmatyzm, czyli ekonomia i polityka dla przyszłości. Ekonomista, 2, 161-180.

Kowalewska, Małgorzata. 2016. Etyka na talerzu. Idea zrównoważonego rozwoju we współczesnych praktykach konsumenckich. W: Etyka o wspótczesności. Wspótczesność w etyce, red. Dorota Sepczyńska, Marek Jawor i Andrzej Stoiński, 173-186. Olsztyn: Wydawnictwo UWM.

Krall, Hanna. 2016 [1968]. Było dużo niepokoju. Dostęp: 22.04.2016. http://www.polskieradio.pl/9/874/Artykul/1489430,Hanna-Krall-bylo-duzo-niepokoju.

Kronenberg, Jakub i Natsuyo Iida. 2011. Simple Living and Sustainable Consumption. Problemy Ekorozwoju, 6(2), 67-74.

Latouche, Serge. 2009. Farewell to Growth. Cambridge: Polity Press.

Meadows, Donella et al. 1973. Granice wzrostu, tłum. Wiesława Rączkowska et al. Warszawa: PWE.

OECD. 1998. Towards sustainable consumption patterns: A progress report on member country initiatives. Paris: OECD.

Papuziński, Andrzej. 2013. Aksjologia zrównoważonego rozwoju: próba typologizacji. Problemy Ekorozwoju, 8(1), 5-25.

Popkiewicz, Marcin. 2012. Świat na rozdrożu. Katowice: Wydawnictwo Sonia Draga.

Schumacher, Ernst. 1981. Małe jest piękne, tłum. Ewa Szymańska. Warszawa: PIW.

Schwartz, Barry. 2015. Paradoks wyboru. Dlaczego więcej oznacza mniej, tłum. Marcin Walczyński. Warszawa: PWN. 
Stern, Nicholas. 2010. Globalny ład, tłum. Anna Orzechowska-Barcz. Warszawa: Wydawnictwo Krytyki Politycznej.

ŚKŚR (Światowa Komisja ds. Środowiska i Rozwoju). 1991. Nasza wspólna przyszłość, tłum. Urszula Grzelońska i Ewa Kolanowska. Warszawa: Państwowe Wydawnictwo Ekonomiczne.

Tyburski, Włodzimierz. 2011. Etyka środowiskowa i jej wkład w budowanie świadomości sprzyjającej wdrażaniu idei zrównoważonego rozwoju. W: Zasady kształtowania postaw sprzyjających wdrażaniu zrównoważonego rozwoju, red. Włodzimierz Tyburski, 85-157. Torun: Wydawnictwo Naukowe Uniwersytetu Mikołaja Kopernika.

UNEP. 2001. Consumption opportunities: Strategies for change. Paris: UNEP. 

Małgorzata Gutry-Korycka

Uniwersytet Warszawski - Wydział Geografii i Studiów Regionalnych msgutryk@uw.edu.pl

\section{Postulaty zrównoważonego rozwoju Ziemi w encyklikach papieskich}

\section{Wstęp}

Trzy ostatnie pontyfikaty papieży: Jana Pawła II, Benedykta XVI i Franciszka, obejmujące lata 1978-2017, a więc okres blisko 40 lat życia Kościoła, obfitowały w encykliki (w sumie opracowano ich w tym czasie aż 20), co ilustruje rys. 1. Skierowane były do wiernych, którzy znajdowali w nich nie tylko przesłanie społecznej nauki Kościoła, lecz także odniesienia do współczesnych zmian egzystencjalnych, uwarunkowanych przyrodniczo i gospodarczo. Zwykle wyrażały troskę o człowieka, a niektóre $z$ nich także o przyrodę.

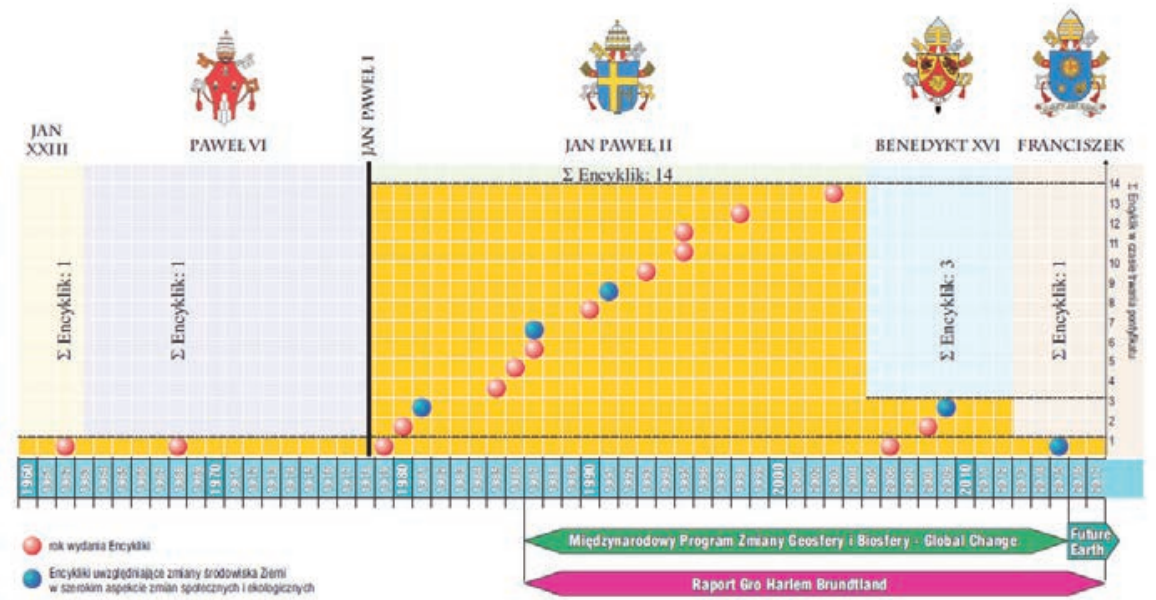

Rys. 1. Encykliki uwzględniające zmiany środowiska Ziemi w szerokim aspekcie zmian społecznych i ekologicznych na tle encyklik ogłoszonych w latach 1978-2015 (zestawienie własne wg różnych źródeł). 
Celem niniejszego artykułu jest przegląd i charakterystyka encyklik od końca lat 70. ubiegłego wieku do 2016 r., które - obok Raportu Gro Harlem Brundtland oraz powstających programów światowych (m.in. International Geosphere-Biosphere Programme - Global Change, obecnie Future Earth System) - stanowią ważne ogniwo aktualnych wskazań kierunku rozwoju gospodarczego i społecznego świata z głęboką refleksją i troską o jego przyszłość (IGBP 2016). Niektóre aspekty wpisujące się w tę tematykę zostały poruszone również na kilku konferencjach międzynarodowych i krajowych, między innymi w Krakowie (Gutry-Korycka 2016).

Publikacja Raportu Brundtland z 1987 r. nieprzypadkowo zbiegła się z wprowadzeniem doktryny ekonomicznej zakładającej jakość życia na poziomie idei zrównoważonego rozwoju cywilizacyjnego. Za jej podstawę przyjęto bowiem raport Nasza wspólna przyszłość, który stał się ważną inspiracją do badań naukowych nad wywołanymi ociepleniem klimatu globalnymi zmianami środowiska biotycznego i abiotycznego Ziemi. Wiele lat później A. Kukliński (2009) ujął kształtowanie się porządku globalnego w model trójkąta trwałego rozwoju, określającego integrację trzech elementów: wzrostu gospodarczego, postępu społecznego oraz perspektywy zmian ekologicznych. Przy czym kluczową rolę, jak wskazał T. Żylicz (2004), w rozumieniu idei zrównoważonego rozwoju odegrała idea ograniczonych możliwości zaspokajania potrzeb przyszłych pokoleń, zwłaszcza społeczeństw najuboższych. Ograniczenia te są realizowane $\mathrm{w}$ wyniku wymuszonych na środowisku przyrodniczym przez stan techniki, organizacji i własności społecznej możliwości zaspokojenia potrzeb obecnych i przyszłych pokoleń.

W ślad za Raportem Brundtland wzrosło zainteresowanie znaczeniem problematyki globalnych zmian na arenie międzynarodowej. Przewodnią rolę naukową w tym zakresie przejęła ICSU (International Council of Sciences Union) Rada Unii Naukowych, pod auspicjami której utworzono niezależny program międzynarodowy IGBP - Global Change z sekretariatem w Sztokholmie. Należy ponadto nadmienić, że państwa skandynawskie (Heurling 1988), wniosły znaczący wkład organizacyjny i merytoryczny w ukształtowanie ram programu, dbając o jego realizację całościową i cząstkową (NRC 1998). W końcu 
2015 r. nastąpiło przekształcenie tego programu w Światowy Program Future Earth System, rozumiany jako synteza rozwoju naszego globu, czyli podsumowanie wiedzy teoretycznej i empirycznej dotyczącej Ziemi.

Wiele organizacji światowych, takich jak ONZ, FAO, WMO, WHO, UNESCO, Bank Światowy i Komisja Brundtland, przystąpiło do konstrukcji fundamentu naukowego (teoretyczno-empirycznego) w celu oceny zmian, ich przyczyn, skutków oraz następstw środowiskowych i społecznych powiązanych ze strategią oraz adaptacją w różnej skali - od globalnej poprzez regionalną do lokalnej. Biorąc za podstawę i wykorzystując dotychczasowy dorobek nauki (poglądy i projekcje na przyszłość), wkład organizacyjny oraz polityczno-społeczny ludzkości, wymienieni trzej papieże poprzez encykliki włączyli się do dialogu z wiernymi na różnym poziomie intelektualnym, politycznym i społecznym.

\section{Encykliki Ojca Świętego Jana Pawła II}

Jan Paweł II w swych encyklikach poświęcił wiele miejsca problematyce bezpośrednich i pośrednich oddziaływań człowieka na środowisko przyrodnicze Ziemi i wskazał na ich niepokojące konsekwencje zapowiadające nieodwracalne kataklizmy.

W pierwszej encyklice Redemptor hominis Jan Paweł II odwołuje się do nauczania swoich poprzedników, szczególnie zaś Jana XXIII i jego encykliki Pacem in terris, a także Populorum progressio Pawła VI. Jan Paweł II dostrzegł w nich mocny akcent postawiony na społecznych problemach świata współczesnego i odwołał się do nadziei na rozwój cywilizacyjny ludzkości wyrównujący opóźnienia ekonomiczne biednych krajów półkuli południowej względem bogatych krajów półkuli północnej. Należy przy tym zauważyć, że terminologia geograficzna, jakiej Jan Pawła II używa w encyklice Redemptor hominis, odwołuje się do umownej granicy między bogactwem a ubóstwem, przebiegającej wewnątrz tych samych społeczeństw, zarówno wysoko rozwiniętych, jak też dopiero wkraczających na drogę rozwoju.

Papież zauważa, że widzialna „natura”, którą Grecy, w celu uporządkowania świata, nazywali „Kosmosem”, obejmowała ożywione i nieoży- 
wione jego składniki naturalne: rośliny, zwierzęta, skały, które nie mogły być wykorzystywane w sposób dowolny, lecz jedynie w celu zaspokojenia określonych potrzeb gospodarczych. Wykorzystanie zasobów naturalnych, zwłaszcza nieodnawialnych, powinno być ograniczane ze względu na zabezpieczenie życia przyszłych pokoleń. Równocześnie papież odnosi się do zjawiska obniżającej się jakości życia w strefach uprzemysłowionych, niosących poważne konsekwencje dla zdrowia i życia ludności.

W encyklice Laborem exercens Jan Paweł II nawiązuje do 90. rocznicy przedstawionej przez papieża Leona XIII w 1891 r. encykliki Rerum novarum i odnosi się do „własności prywatnej i powszechnego przeznaczenia dóbr". Na nowo odczytuje nauczanie Kościoła o prawie do posiadania własności. Wskazuje przy tym na powszechne przeznaczenie dóbr i na znaczenie ich przepływu w procesach zaspokajania potrzeb człowieka. W tym kontekście odwołuje się do zamierzeń Stwórcy, który stworzył Ziemię, a na niej człowieka, zaś człowiekowi dał ją w posiadanie, aby swoją pracą czynił ją sobie poddaną i cieszył się jej owocami. To zaś uzasadnia powszechne przeznaczenie dóbr Ziemi; przy czym Jan Paweł II dostrzega, że praca ludzka i Ziemia to czynniki współdziałające ze sobą.

Jan Paweł II w encyklikach niejednokrotnie podejmuje kwestię ekologiczną, opisującą relację człowiek - przyroda, ze szczególnym uwzględnieniem ilościowej i jakościowej degradacji środowiska ludzkiego habitatu. W tym kontekście papież uzasadnia fundamentalne znaczenie rodziny, czyli środowiska naturalnego każdego człowieka, stanowiącego główną kategorię ekologii ludzkiej. Papież wskazuje też na doniosłe znaczenie takiego obowiązku państwa, jak obrona i zabezpieczenie dóbr zbiorowych, czyli środowiska przyrodniczego i środowiska ludzkiego. Zdaniem papieża tej ochrony dóbr nie zapewni się za pomocą wyłącznie mechanizmów rynkowych i obrony dóbr zbiorowych.

\section{Encyklika Ojca Świętego Benedykta XVI}

Najobszerniejsza z trzech encyklik Ojca Świętego Benedykta XVI „Caritas in veritate” o integralnym rozwoju ludzkim w miłości i prawdzie powstała w 2009 r. Jest ona skierowana zarówno do wiernych, jak i wszystkich ludzi dobrej woli; składa się z sześciu głównych części (Benedykt XVI 2009): 
$\checkmark$ Przesłanie Populorum progressio (O rozwoju powszechnym),

$\checkmark$ Rozwój ludzki w naszych czasach,

$\checkmark$ Braterstwo, rozwój ekonomiczny i społeczeństwo obywatelskie,

$\checkmark$ Rozwój ludów, prawa i obowiązki, środowisko,

$\checkmark$ Współpraca rodziny ludzkiej,

$\checkmark$ Rozwój narodów a technika.

Z punktu widzenia tytułu niniejszego opracowania na szczególną uwagę zasługuje czwarta część encykliki Rozwój ludów, prawa i obowiąz$k i$, środowisko. Benedykt XVI nawiązuje w niej do kierunków rozwoju ekonomicznego, głównie zaś do przedsiębiorczości w układzie międzynarodowym i funduszowym. Temat rozwoju gospodarczego papież łączy ze stosunkiem człowieka do środowiska naturalnego, coraz mniej zasobnego, a więc coraz słabiej zabezpieczającego pomyślne trwanie przyszłych pokoleń. Zdaniem papieża człowiek traktuje bowiem środowisko z punktu widzenia kulturowego oraz prawnego. W związku z tym projekty zrównoważonego rozwoju ludzkości nie mogą ignorować następnych pokoleń; powinny charakteryzować się stabilnością i sprawiedliwością międzypokoleniową i brać pod uwagę liczne dziedziny, m.in. ekologię, prawo, ekonomię, politykę i kulturę.

W encyklice Caritas in veritate Benedykt XVI uwzględnia środowisko przyrodnicze z punktu widzenia zasobów energetycznych, zwłaszcza obejmujących surowce i źródła nieodnawialne. W tym kontekście zwraca uwagę na nowe, alternatywne źródła i technologie. Dotyczy to szczególnie krajów ubogich, szybko eksploatujących, sprzedających własne zasoby i surowce energetyczne. Zdaniem papieża potrzebna jest zatem planowa, przemyślana redystrybucja źródeł energetycznych. W ślad za tym papież apeluje o nowy styl życia, o ugodę społeczną oraz zawieranie umów międzynarodowych regulujących sytuację w regionach „zapalnych", których liczba bardzo szybko wzrasta. Benedykt XVI odwołuje się do idei zrównoważonego rozwoju środowiska przyrodniczego i danych w zakresie zmian klimatu. 


\section{Encyklika Ojca Świętego Franciszka}

Encyklika papieża Franciszka Laudato Si. W trosce o wspólny dom (2015) składa się z sześciu głównych rozdziałów:

$\checkmark$ Co się dzieje w naszym domu?

$\checkmark$ Ewangelia stworzenia;

$\checkmark$ Ludzki pierwiastek kryzysu ekologicznego;

$\checkmark$ Ekologia integralna;

$\checkmark$ Wytyczne i działania;

$\checkmark$ Edukacja ekologiczna i duchowość przyrody.

W encyklice Ojciec Święty Franciszek, tak jak i jego poprzednicy, odniósł się do współczesnych problemów i zmian nurtujących świat, zwracając szczególną uwagę na konieczność ochrony klimatu Ziemi, zmniejszenia zanieczyszczenia powietrza, wód lądowych i oceanicznych, co prowadzi do postępującej utraty różnorodności biologicznej ekosystemów wodnych i śródlądowych. Poruszył problem sprawiedliwego odniesienia społeczeństw do odnawialnych i nieodnawialnych bogactw naturalnych oraz źródeł energii, nawiązując równocześnie do międzynarodowej współpracy w zakresie ochrony przyrody w układzie regionalnym.

W encyklice Laudato Si' Franciszek dokonał wnikliwej analizy współczesnego kryzysu ekologicznego, wskazując jego przyczyny i negatywne konsekwencje. Proponuje skuteczne rozwiązywanie wymienionych problemów przez wspólne działania, większą solidarność społeczną w relacjach do krajów ubogich i nawołuje do zmiany przyzwyczajeń i nawyków co do ograniczonego korzystania z zasobów przyrody. Wysunięte postulaty zmierzają prosto do zwiększenia wysiłków na rzecz powstrzymania i ograniczenia zmian klimatu prowadzących do globalnego ocieplenia. Nie ignorując zmian klimatycznych stwierdzonych na Ziemi, przedstawia głęboki związek przyczynowo-skutkowy pomiędzy obecną sytuacją ekonomiczną na globie ziemskim a olbrzymimi różnicami społecznymi. W trosce o nasz wspólny dom (Ziemię), z charakterystyczną dla niego wrażliwością, prostotą i wnikliwością analizuje procesy, zjawiska i interakcje globalne, szukając zrozumienia obiektywnych przyczyn, aby przedstawić najlepsze i najbardziej skuteczne rozwiązania pragmatyczne. Proponuje podejście do tych problemów według kryte- 
riów tzw. ekologii integralnej, szczególne ważnej dla człowieka żyjącego w coraz bardziej zglobalizowanym świecie.

Encyklika papieża Franciszka istotnie wzbogaca globalną dyskusję na temat środowiska przyrodniczego Ziemi, ze szczególnym uwzględnieniem znaczenia odnawialnych i nieodnawialnych dóbr powszechnych - powietrza, wody, gleby i biosfery. Papież wskazuje, że sytuacja ekologiczna i ekonomiczna pozostają w ścisłym związku ze zmianami globalnymi klimatu, a te decydują o zmianach hydrologicznych, geomorfologicznych, glebowych itd. Papież Franciszek przytacza przesłanki naukowe, wskazujące na konieczność ochrony Ziemi - naszego wspólnego domu - w trosce o ludzkość, która nie może odstąpić od zrównoważonego rozwoju. $\mathrm{Z}$ tej racji dokonuje przeglądu głównych przyczyn i skutków obecnego kryzysu ekologicznego, nakreślając kierunki dialogu i działań w przyszłości, podejmowanych z myślą o wypracowaniu właściwych strategii działania.

Problematyka zasobów wodnych Ziemi, zawarta w punkcie drugim rozdziału pierwszego, została omówiona na tle zasobności horyzontów wodonośnych, rzek i jezior, pod kątem źródeł zaopatrzenia ludności w wodę. Odpowiednia ilość i jakość dostępnej wody pitnej na Ziemi jest zagadnieniem kluczowym dla ludzkości, przyrody i rozwoju, zwłaszcza w obszarach suchych i półsuchych Afryki, Azji i Australii, także w niektórych regionach śródziemnomorskich i w Kalifornii (Gromiec 2015). Znaczenie wody wynika $\mathrm{z}$ faktu jej niezbędności do życia człowieka oraz życia całej przyrody ożywionej, a także uwarunkowania nią płynnego rozwoju gospodarki.

\section{Zakończenie}

Przytoczone encykliki są donośnym głosem Kościoła katolickiego, skierowanym nie tylko do wiernych katolików, ale także do całej ludzkości. W tym sensie stanowią ważną inspirację do głębokich przemyśleń, działań oraz do studiów i projektów interdyscyplinarnych, a nawet transdyscyplinarnych. Mimo różnie rozkładanych akcentów, we wskazanych tutaj encyklikach widać duże podobieństwo w zakresie oceny problemów i kierunków ich rozwiązywania w ramach polemiki światowej. Myśli w nich zawarte w znacznej mierze potwierdzają słuszność stanowisk w odnośnych kwestiach środowiskowych, prezentowanych 
na forum ONZ i innych organizacji międzynarodowych, z troską o człowieka i jego dobro wspólne.

Podobieństwo wskazanych encyklik wyraża się także w uwzględnianiu aktualnego stanu wiedzy, zarówno z zakresu nauk geograficznych, jak też społecznych, biologicznych i medycznych. Wymienieni papieże wiedzę z różnych dziedzin wykorzystują jak barometr ogólnoświatowej atmosfery społeczno-polityczno-gospodarczej. Swoje stanowisko $\mathrm{w}$ tych kwestiach niejako uzgadniają $\mathrm{z}$ danymi ekonomii, techniki, medycyny czy biologii.

Różnice zarysowują się w sposobie akcentowania problemów oraz w szczegółowości interpretacji procesów degradacyjnych, niebezpieczeństw nieodwracalności zagrożeń ochrony bogactw przyrody, a także w zakresie przestrzegania zasad ograniczenia przeciwdziałaniu słabej odnawialności. Wszystkie encykliki „nawołują” człowieka do działań na rzecz zatrzymania procesów, które zmniejszają szansę pomyślnego życia nadchodzących pokoleń.

Przedstawione encykliki trzech papieży odwołują się do świadomości, sprawiedliwości i empatii społecznej w kontekście dostępu do dóbr i zasobów odnawialnych i nieodnawialnych Ziemi. Koniecznym tego warunkiem są próby wdrażania idei zrównoważonego rozwoju ludzkości.

Encykliki te jednakowo wyraźnie akcentują rangę kwestii środowiskowej, społecznej, gospodarczej i politycznej. Wszystkie one bowiem dotyczą przyrody, wykorzystania energii i surowców. Nabierają one szczególnego znaczenia ze względu na obserwowane zmiany klimatu, zanieczyszczenia wody i zubożenia różnorodności przyrody. Nagłośniane społecznie problemy, dotykające zmian globalnych, mogą stanowić inspirację także do badań naukowych i przedsięwzięć gospodarczych. Z pewnością warto je przestudiować $z$ uwagą i poznać ich głęboki sens etyczno-moralny. W tym sensie encyklika Laudato Si' jest zdecydowanym krokiem w kierunku zatrzymania negatywnych problemów zintegrowanych (Tarnowski i Skowrońska 2016).

Wskazywani tu papieże Jan Paweł II, Benedykt XVI i Franciszek wybiegają swym nauczeniem w przyszłość i wskazują celowość konkretnych działań gospodarczych, społecznych i politycznych oraz sugerują konkretne rozwiązania mające na celu podniesienie świadomości eko- 
logicznej, wprowadzenie sprawiedliwości, równości społecznej i empatii. Widać więc, że zawarte w encyklikach nauczanie papieży wpisuje się w ideę zrównoważonego rozwoju Ziemi, naszego wspólnego domu.

\section{Bibliografia:}

Benedykt XVI. 2009. Encyklika "Caritas in veritate” o integralnym rozwoju ludzkim w miłości i prawdzie.

Franciszek. 2015. Encyklika „Laudato Si””.

Gromiec, Marek. 2015. Kwestia wody na tle problemów ekologicznych świata w encyklice Laudator Si'. Gospodarka Wodna, 10, 281-282.

Gutry-Korycka, Małgorzata. 2016. The management of the global's resources in the light of recent Pape Encyclicas. Papers on Global Change IGBP, (23), 103-110. DOI:10.1515/igbp-2016-0008.

Heurling, Bo et al. 1988. Swedish Perspectives on Human Response to Global Change. Stockholm: Swedish Council for Planning and Coordination of Research National Resources.

IGBP (International Geosphere-Biosphere Programme). 2016. Annual Report 2014/15. Stockholm: Borgs Grafiska. Dostęp: 20.02.2017. http:// www.igbp.net/download/18.950c2fa1495db7081e25bf/1433835587044/ IGBP-AR_2014-web.pdf.

Jan Paweł II. 1996. Encykliki Ojca Świętego Jana Pawła II. Kraków: Wydawnictwo Znak.

Kukliński, Antoni. 2009. Procesy tworzenia i destrukcji porządku globalnego. W: Polska transformacja i jej przyszłość, red. Elżbieta Mączyńska, 210-220. Warszawa: PTE.

NRC (National Research Council (U.S.)). 1998. Overview, Global Environmental Change: Research Pathways for the Next Decade. Washington, D.C.: National Academy Press.

Tarnowski, Karol i Małgorzata Skowrońska. 2016. Przewrót franciszkański. Gazeta Wyborcza, 30-31.12.2016, 16.

Żylicz, Tomasz. 2004. Ekonomia środowiska i zasobów naturalnych. Warszawa: Polskie Wydawnictwo Ekonomiczne. 

Ewa Jastrzębska

Szkoła Główna Handlowa w Warszawie - Kolegium Ekonomiczno-Społeczne ewa.jastrzebska@sgh.waw.pl

\section{CSR jako odpowiedź biznesu na wyzwania rozwoju zrównoważonego - ewolucja koncepcji}

\section{Wstęp}

Koncepcja rozwoju zrównoważonego ex definitione wymaga zaangażowania biznesu w jej realizację. Pogłębione przez globalizację zagrożenia ogólnoświatowe (m.in. zmiany klimatyczne, degradacja środowiska, w tym utrata bioróżnorodności, nierówności dochodowe i rosnąca grupa prekariuszy, ubóstwo czy głód, o którym dramatycznie pisał Martin Caparrós), a także rosnąca rola biznesu we współczesnym świecie powodują nasilanie się oczekiwań społecznych, by przedsiębiorstwa ponosiły odpowiedzialność adekwatną do tej roli (bo noblesse oblige). Odpowiedzią przedsiębiorstw na te wyzwania jest koncepcja społecznej odpowiedzialności biznesu (corporate social responsibility, CSR), która cieszy się coraz większą popularnością, ale i spotyka z permanentną, choć opartą na różnych przesłankach, krytyką.

Celem artykułu jest zaprezentowanie ewolucji koncepcji CSR, zarówno w ujęciu sposobów jej definiowania, jak i powstających w tym obszarze inicjatyw (w tym ich częstych rewizji), a także pojawiających się koncepcji pokrewnych. Tak sformułowany cel przełożył się na przyjęte metody badawcze (krytyczna analiza desk i web research).

\section{Geneza CSR}

Koncepcja CSR ma korzenie pragmatyczne, jednak do jej powstania przyczyniły się w dużej mierze także koncepcje teoretyczne. Kluczowy w tym zakresie był rozwój etyki biznesu oraz teorii interesariuszy, a przede wszystkim paradygmatu rozwoju zrównoważonego.

Etyka biznesu jako dziedzina nauki narodziła się w Stanach Zjednoczonych - za jej początek można uznać opublikowanie w 1926 r. w No- 
wym Jorku przez Everetta W. Lorda książki The fundamentals of business ethics. O rozwoju etyki biznesu możemy jednak mówić dopiero od lat 60. $\mathrm{XX}$ w., zaś prawdziwy wzrost jej popularności nastąpił od lat 80 . XX w. w związku z coraz liczniejszymi skandalami korporacyjnymi oraz pojawieniem się ruchów ekologicznych i konsumenckich. To na gruncie etyki biznesu rozpoczęła się dyskusja, czy przedsiębiorstwo może być podmiotem odpowiedzialności moralnej i czy w swojej działalności powinno się kierować jakimiś wartościami. CSR wychodzi z założenia, że tak i odpowiada na pytanie, jak należy to robić.

Pierwsze założenia teorii interesariuszy sformułował E. Merrick Dodd (1932), stwierdzając, że firma nie tylko ma obowiązki wobec społeczeństwa, ale przedsiębiorcy powinni dobrowolnie i bez czekania na przymus prawny zarządzać $\mathrm{w}$ taki sposób, aby te obowiązki spełniać. Samo pojęcie interesariusza zawdzięczamy Stanford Research Institute, który w 1963 r. wprowadził termin stakeholder jako grę słów nawiązującą do terminu stockholder (akcjonariusz) czy shareholder (udziałowiec), definiując zarazem interesariuszy jako wszystkich tych, bez których żadna organizacja nie mogłaby funkcjonować (Freeman 1984, 31). Jednak pierwsze ugruntowane w teorii zarządzania podejście do koncepcji interesariuszy zaprezentował R. Edward Freeman (1984) w publikacji Strategic management: a stakeholder approach. Przedstawił w niej nie tylko nową definicję interesariuszy (to każda grupa lub jednostka, na którą wpływa lub która może mieć wpływ na osiąganie celów przedsiębiorstwa), lecz także zaproponował ramy analizy interesariuszy, których punktem wyjścia jest mapa interesariuszy. Jego zdaniem zdolność firmy do zarządzania relacjami z interesariuszami ściśle zależy właśnie od analizy mapy interesariuszy. Freeman zaprezentował zatem usystematyzowane podejście do zarządzania, w którym bierze się pod uwagę otoczenie zewnętrzne firmy, a nie wyłącznie jej akcjonariuszy.

Najistotniejsza dla rozwoju CSR była jednak koncepcja rozwoju zrównoważonego (sustainable development). W sposób kompleksowy została ona zaprezentowana w Raporcie Brundtland Nasza wspólna przyszłość z 1987 r., a szerszej społeczności globalnej przedstawiono ją podczas II Konferencji ONZ w Rio de Janeiro w 1992 r. Wówczas uznano, że rozwój zrównoważony to taki „rozwój, który zaspokaja potrzeby 
obecne, nie pozbawiając przyszłych pokoleń możliwości zaspokojenia ich potrzeb" (ŚKŚR 1991, 67). Koncepcja ta na początku była interpretowana przede wszystkim w kategoriach ekorozwoju, czyli poszanowania środowiska przyrodniczego. Jednak bardzo szybko uświadomiono sobie istnienie współzależności pomiędzy zagrożeniami ekologicznymi a problemami społecznymi i gospodarczymi i zaczęto podkreślać, że rozwój zrównoważony to taki rozwój społeczno-gospodarczy, który jest zgodny z wymaganiami ochrony środowiska przyrodniczego, zatem oznacza dążenie do równowagi między trzema filarami: ekonomicznym, społecznym i środowiskowym. Już w Raporcie Brundtland zawarto apel do wszystkich przedsiębiorstw, zauważając, że biznes ma ogromne możliwości wprowadzenia daleko idących zmian w modelu rozwoju świata i podkreślając zarazem konieczność współpracy międzysektorowej na rzecz rozwoju zrównoważonego (UN 1987; ŚKŚR 1991).

Początkowo pojęć rozwoju zrównoważonego i CSR używano zamiennie, jednak w opublikowanej w 2010 r. normie ISO 26000 ostatecznie doprecyzowano, że społeczna odpowiedzialność skupia się na organizacji i dotyczy jej odpowiedzialności wobec społeczeństwa i środowiska, a nadrzędnym celem tej koncepcji jest maksymalizowanie wkładu przedsiębiorstwa w rozwój zrównoważony. Norma podkreśliła także, że celem rozwoju zrównoważonego jest zapewnienie globalnemu społeczeństwu stabilnych i trwałych warunków istnienia, nie zaś stabilności i trwałości konkretnej organizacji (PKN 2012, 21). Koncepcja społecznej odpowiedzialności jest zatem odpowiedzią biznesu na wyzwania rozwoju zrównoważonego, operacjonalizacją tego paradygmatu w wymiarze lokalnym.

\section{Definiowanie CSR}

Ewolucję CSR można dostrzec już w zmianie brzmienia samego terminu - stosowany nadal przez Komisję Europejską termin corporate social responsibility (którego oficjalne tłumaczenie w Polsce brzmi „społeczna odpowiedzialność przedsiębiorstw”) został w międzynarodowej normie ISO 26000 zastąpiony terminem social responsibility (społeczna odpowiedzialność) dla podkreślenia, że CSR dotyczy nie tylko korporacji transnarodowych czy nawet mikro, małych i średnich przedsię- 
biorstw, lecz wszystkich organizacji, w tym niebiznesowych. Warto także zauważyć, że OECD zamiast terminu CSR stosuje pojęcie responsible business conduct - RBC (odpowiedzialne postępowanie biznesowe, odpowiedzialne prowadzenie biznesu), a od $2016 \mathrm{r}$. w dokumentach UE, OECD, ONZ, MOP zaczęto stosować podwójny zapis CSR/RBC.

Choć wiele jest ujęć ewolucji CSR, to w większości podejść uznaje się, że początkowo koncepcja ta była interpretowana przede wszystkim w kategoriach filantropii, rozszerzającej się stopniowo do corporate community involvement (zaangażowania społecznego, czyli działań na rzecz społeczności lokalnej i społeczeństwa), by wreszcie, po etapie instytucjonalizacji (standaryzacji) CSR, przekształcić się w strategiczny CSR - wpisywanie koncepcji rozwoju zrównoważonego w filozofię i strategię firmy. Część autorów uznaje, że po okresie filantropijnym należy wyróżnić etap środowiskowy, ale większość jest jednak zdania, że ten nurt rozwijał się równolegle wraz z rozwojem koncepcji rozwoju zrównoważonego, interpretowanej początkowo przede wszystkim właśnie w kategoriach ekorozwoju.

Najpełniej ewolucję CSR można dostrzec, śledząc sposób, w jaki definiowano tę koncepcję. Chociaż począ̧tków społecznej odpowiedzialności biznesu można doszukać się już w książce Ewangelia bogactwa (The Gospel of Wealth) Andrew Carnegie z 1889 r. (w której przedstawił dwie zasady prowadzenia działalności gospodarczej - miłosierdzia i powierniczości), to pierwszą próbę definicyjnego ujęcia CSR przypisuje się Howardowi R. Bowenowi $(1953,6)$, który uznał, że jest to „obowiązek przedsiębiorców do prowadzenia takich polityk, podejmowania takich decyzji oraz realizowania takich działań, które są zbieżne z celami i wartościami społeczeństwa". Istotną rolę w rozwoju CSR odegrała definicja S. Prakasha Sethi (1975), który - rozważając wymiary społecznej aktywności przedsiębiorstw - wprowadził rozróżnienie pomiędzy społecznym obowiązkiem (social obligation) wynikającym z uwarunkowań prawnych, społeczną odpowiedzialnością (social responsibility), polegającą na dostosowaniu do oczekiwań społecznych, a społeczną wrażliwością (social responsiveness) wiążącą się z odpowiadaniem na potrzeby społeczeństwa. Kolejnym istotnym wkładem w rozwój CSR była zaprezentowana w 1979 r. piramida odpowiedzialności Archiego B. Carrolla (1991), w ramach której wyróżnił on cztery wymiary odpowiedzialności 
przedsiębiorstwa: ekonomiczny, prawny (przestrzeganie prawa), etyczny (działanie $\mathrm{w}$ duchu prawa i powyżej jego wymogów) oraz dobrowolny, filantropijny (zaangażowanie społeczne). A. B. Carroll uznał, że u podstaw społecznej odpowiedzialności leży odpowiedzialność ekonomiczna, zakładająca, że przedsiębiorstwo powinno przede wszystkim przynosić zyski (model after profit obligation) ${ }^{1}$.

Biorąc pod uwagę, że - chociaż CSR narodził się w Stanach Zjednoczonych i tam powstały pierwsze prace $\mathrm{z}$ tego zakresu - koncepcja ta najpełniej wdrażana jest w Europie, warto przypomnieć, jak była początkowo w UE rozumiana. Pierwszą próbę zdefiniowania tej koncepcji podjęto w 2001 r. w Zielonej Księdze, w której uznano, że CSR to koncepcja, w ramach której przedsiębiorstwa dobrowolnie uwzględniają kwestie społeczne i ekologiczne w swojej działalności biznesowej oraz w relacjach z interesariuszami (European Commission 2001, 6). Obecnie obowiązującą unijną definicję CSR zaprezentowano na rys. 1.

Choć w ciągu kilkudziesięciu lat historii CSR pojawiło się wiele prób ujęcia tej koncepcji ${ }^{2}$, żadna z nich nie została uznana za kompleksową, obejmującą wszystkie obszary i aspekty społecznej odpowiedzialności. Poszczególne definicje zwracały bowiem uwagę na różne wymiary CSR, np. społeczny, środowiskowy, ekonomiczny, interesariuszy, dobrowolny. Jak wynika $\mathrm{z}$ analizy definicji CSR, także niecytowanych, na przestrzeni lat zmieniało się rozumienie tej koncepcji (od polityki do odpowiedzialności za wpływ), podejście do niej (od obowiązku do dobrowolności, ale związanej z zobowiązaniem do kontynuowania raz podjętych działań, od reakcji do odpowiadania) oraz jej zakres (od zaangażowania społecznego do rozwoju zrównoważonego, od dostosowania do oczekiwań społecznych do wychodzenia naprzeciw oczekiwaniom wszystkich interesariuszy). Wydaje się, że dopiero definicja zawarta w normie ISO 26000, będącej międzynarodowym konsensusem (co potwierdza np. fakt, że została zaimplementowana w dokumentach UE), zyskała powszechne uznanie.

Wybrane, najczęściej przytaczane współcześnie definicje CSR zaprezentowano na rys. 1.

\footnotetext{
${ }^{1}$ Warto podkreślić, że w opozycji do tej koncepcji pozostają modele before profit obligation, w których uznaje się pierwszeństwo wartości moralnych przed innymi wartościami.

${ }^{2}$ Szeroki przegląd definicji CSR zawiera m.in. Carroll 2008 oraz Dahlsrud 2008.
} 
ISO 26000

- odpowiedzialność organizacji za wpływ jej decyzji i działań na społeczeństwo i środowisko, poprzez przejrzyste i etyczne zachowanie, które: przyczynia się do zrównoważonego rozwoju, włączając w to zdrowie i dobrobyt społeczeństwa; uwzględnia oczekiwania interesariuszy; jest zgodne $\mathrm{z}$ mającym zastosowanie prawem i spójne $\mathrm{z}$ międzynarodowymi normami zachowania; jest wprowadzone $\mathrm{w}$ całej organizacji i praktykowane w jej działaniach $\mathrm{w}$ obrębie jej sfery wpływów (2010)

Odnowiona strategia UE 2011-14 odpowiedzialności spolecznej przedsiębiorstw

- odpowiedzialność przedsiębiorstw za ich wpływ na społeczeństwo (2011)

\section{OECD}

- wnoszenie pozytywnego wkładu do gospodarczych, środowiskowych i społecznych postępów na rzecz osiągnięcia rozwoju zrównoważonego a także unikanie, zapobieganie lub łagodzenie negatywnych skutków bezpośrednio powiązanych z działaniami, produktami i usługami oraz relacjami biznesowymi (2015)

- przede wszystkim zgodność z prawem, w tym dotyczącym praw człowieka, ochrony środowiska, stosunków pracy, rozliczalności finansowej, nawet jeśli jest niewystarczająco egzekwowane, oraz odpowiadanie na oczekiwania społeczne zgłaszane np. przez organizacje pozarządowe, społeczności lokalne, związki zawodowe, za pośrednictwem mediów (2017)

Rys. 1. Wybrane definicje CSR. Źródło: opracowanie własne na podstawie: OECD 2017; OECD 2015, 75; PKN 2012, 16; Komisja Europejska 2011.

\section{Inicjatywy CSR}

Jak ewoluował CSR (zwłaszcza rozumienie i zakres tej koncepcji), można także prześledzić, analizując pojawiające się $\mathrm{w}$ tym obszarze inicjatywy (normy, standardy, wytyczne) oraz stopień ich rewizji. Inicjatywy służą doprecyzowaniu wymagań w zakresie społecznej odpowiedzialności, ułatwieniu wdrażania CSR na poziomie strategicznym i operacyjnym, umożliwieniu sprawdzenia zgodności postępowania organizacji z CSR oraz komunikowaniu interesariuszom społecznej odpowiedzialności organizacji.

W toku dialogu $\mathrm{z}$ interesariuszami inicjatywy CSR ewoluowały w odpowiedzi na zmieniające się interpretowanie samej koncepcji i wyzwania pojawiające się w otoczeniu, a także w związku z samodoskonaleniem inicjatyw. W kolejnych rewizjach uwypuklano te elementy, które nie były wcześniej wystarczająco artykułowane, przez co je niesłusznie pomijano (jak np. kwestie zrównoważonego zarządzania łańcuchem dostaw czy praw człowieka w kontekście problemu współczesnego niewolnictwa i wydłużających się dzięki globalizacji łańcuchów wartości), 
wprowadzano wymóg angażowania interesariuszy (co jest istotą CSR), udoskonalano inicjatywy, dodając rozwiązania umożliwiające weryfikację stopnia ich wdrożenia (w odpowiedzi na jedynie deklaratywne wdrażanie inicjatyw przez organizacje), a także wskazywano, w jakich punktach inicjatywy są kompatybilne ze sobą nawzajem (by zwiększyć zainteresowanie nimi oraz zmniejszyć zdezorientowanie i zagubienie organizacji mnogością inicjatyw).

Choć w przypadku poszczególnych inicjatyw można wskazać ich funkcję wiodącą - główne przeznaczenie (np. wskazywanie sposobów postępowania w zakresie CSR w przypadku ISO 26000 lub określanie wymogów systemów zarządzania i certyfikacji w przypadku SA 8000), to w toku ewolucji klasyfikacja taka przestała być zasadna, gdyż inicjatywy zmierzają w kierunku coraz większej kompleksowości (np. dodając nowe obszary zainteresowania, nowe wymogi, odwołując się do siebie nawzajem, wprowadzając narzędzia weryfikacji).

Porównanie wybranych, najbardziej znanych inicjatyw CSR pod kątem ich zakresu, roku powstania, instytucji opracowującej oraz częstości i zakresu dotychczasowych rewizji zaprezentowano na rys. 2.

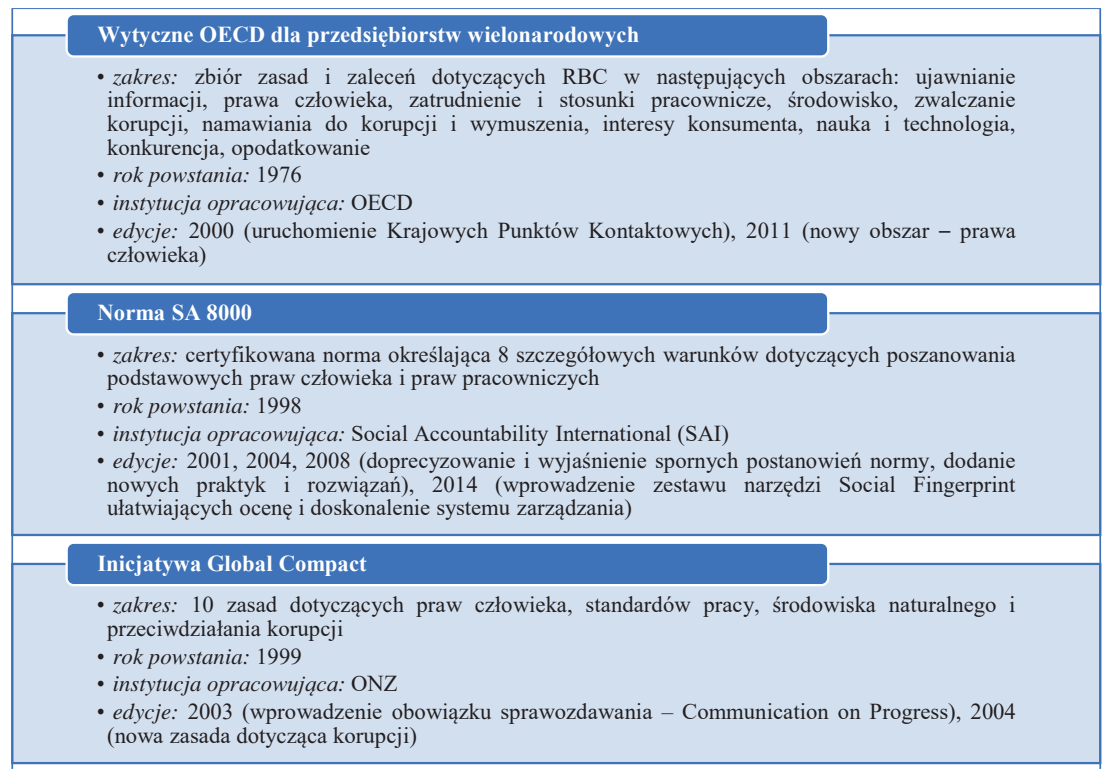




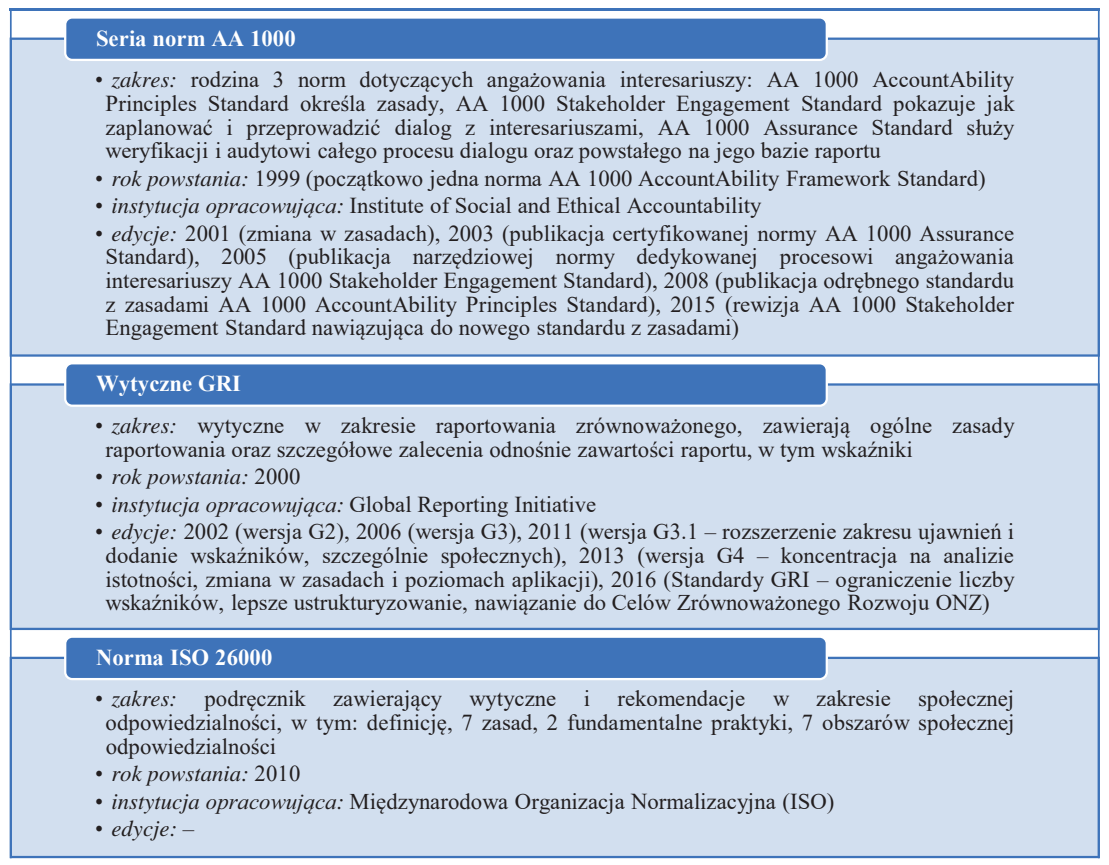

Rys. 2. Porównanie wybranych inicjatyw CSR. Źródło: opracowanie własne na podstawie informacji dostępnych na stronach internetowych poszczególnych inicjatyw.

\section{Koncepcje pokrewne}

Wieloznaczność pojęcia, brak precyzyjnej definicji, ciągła ewolucja CSR, a także wielość początkowo konkurencyjnych wobec siebie inicjatyw CSR sprawiły, że powstało wiele koncepcji pokrewnych, doprecyzowujących czy uwypuklających różne aspekty tej idei ${ }^{3}$. Nowe propozycje dotyczyły zmian całej koncepcji CSR bądź jej kluczowych elementów, a wyrażane były także poprzez propozycje odmiennego rozwinięcia nazwy (np. corporate social responsiveness dla podkreślenia proaktywnego charakteru CSR). Z jednej strony pojawiające się koncepcje pokrewne potęgowały zamęt interpretacyjny wokół idei społecznej odpowiedzialności biznesu i jej krytykę (raczej niepotrzebnie wprowadzając nową retorykę, zamiast powodować głębokie zmiany w myśleniu o strategicznym zarządzaniu relacjami z interesariusza-

\footnotetext{
${ }^{3}$ Wayne Visser, Dirk Matten, Manfred Pohl i Nick Tolhurst wymieniają ich ponad100 (Visser et al. 2010).
} 
mi), z drugiej zaś - były jednak kolejnym głosem w dyskusji na rzecz odejścia od Friedmanowskiego poglądu, że the social responsibility of business is to increase its profits (społeczną odpowiedzialnością biznesu jest pomnażanie zysków) (Friedman 1970). Granice pomiędzy CSR a koncepcjami pokrewnymi są płynne, często występują one synonimicznie, czasami jednak pojawiają się sprzeczne interpretacje nawet w podejściu do danej koncepcji. Zestawienie wybranych, najbardziej znanych koncepcji pokrewnych do CSR (charakterystyka, rok powstania i autor) zaprezentowano na rys. 3.

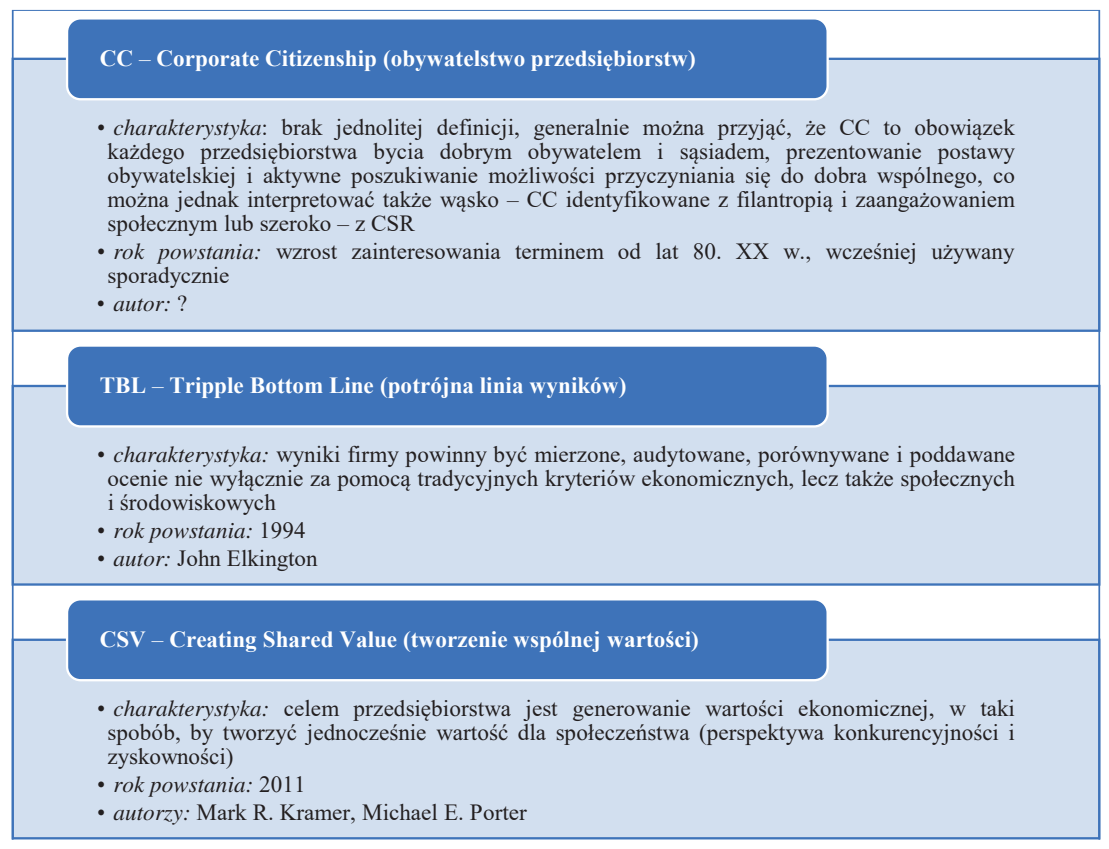

Rys. 3. Porównanie wybranych koncepcji pokrewnych do CSR. Źródło: opracowanie własne na podstawie: Kramer i Porter 2011; Crane, Matten i Moon 2008;

Elkington 1997.

\section{Zakończenie}

Koncepcja społecznej odpowiedzialności biznesu narodziła się i ewoluowała w odpowiedzi na wyzwania globalne i wynikające $\mathrm{z}$ nich oczekiwania społeczne. W początkowym okresie swojego rozwoju interpretowana była przede wszystkim w kategorii filantropii, która, sta- 
nowiąc „pieniądze sumienia”, siłą rzeczy rozpatrywana była wyłącznie jako potrzeba moralna, z czego wynikał brak prowadzonego monitoringu jej efektów, przekładający się na przekonanie o nieopłacalności społecznej odpowiedzialności. Wraz z rozwojem CSR zaczęto kłaść coraz większy nacisk na podejście strategiczne i korzyści płynące $z$ wdrażania tej koncepcji dla firmy i jej interesariuszy. Unijna interpretacja społecznej odpowiedzialności przedsiębiorstw skupia się na wpływie tej koncepcji na konkurencyjność firmy. Jednak jeszcze wyraźniej podejście skoncentrowane na wymiarze wartościowym można dostrzec na przykładzie szybko upowszechniającego się modelu raportowania zintegrowanego (pokazującego, w jaki sposób strategia, sposób zarządzania, wyniki i perspektywy w kontekście otoczenia zewnętrznego organizacji, prowadzą do tworzenia wartości dla wszystkich interesariuszy w krótkiej, średniej i długiej perspektywie) czy koncepcji CSV, której twórcy podkreślają, że „wytwarzanie wartości ekonomicznej przez wytwarzanie wartości społecznej nie jest przejawem filantropii, lecz działaniem we własnym interesie" (Kramer i Porter 2011). Ewolucja CSR związana jest $\mathrm{z}$ samodoskonaleniem się tej koncepcji, a pojawiające się koncepcje pokrewne najczęściej punktowały to, co w przypadku CSR zawodziło.

Wayne Visser w 2010 r. stwierdził, że - biorąc pod uwage globalne wskaźniki wpływu biznesu na środowisko i społeczeństwo - pomimo swojego dynamicznego rozwoju, CSR nie sprawdził się. Jego zdaniem, ewolucja CSR okazała się niewystarczająca - konieczna jest rewolucja na wzór transformacji z Web 1.0 na Web 2.0. Analogiczne zmiany powinny dotknąć CSR 2.0 (i oznaczać przejście na partnerskie relacje firmy ze wszystkimi interesariuszami oraz angażowanie ich), czego wyrazem byłoby nowe odczytywanie skrótu CSR - jako Corporate Sustainability and Responsibility (Zrównoważony i Odpowiedzialny Biznes) - dla podkreślenia, że rozwój zrównoważony jest celem, a odpowiedzialność określa sposób dotarcia do niego (Visser 2010). Część ekspertów idzie jeszcze dalej: ich zdaniem, wraz z ogłoszeniem w 2015 r. nowych 17 Celów Zrównoważonego Rozwoju ONZ (Sustainable Development Goals - SDGs), skończył się CSR, ponieważ od tego momentu firmy nie będą już pisać strategii CSR dotyczących wybranych obszarów, istotnych z punktu widzenia ich i interesariuszy, lecz zaczną określać te, na które 
z SDGs mają istotny wpływ i swoją działalność będą dopasowywać do tych globalnie ustalonych zadań.

Nieważne, czy CSR będzie dalej ewoluował, przejdzie rewolucję czy też zniknie, a na jego miejsce pojawi się kolejna koncepcja (lub koncepcje). W całej tej dyskusji pewne jest jedno - chodzi o opracowanie i wdrożenie takiego modelu biznesowego, dzięki któremu tworzenie lepszego świata dla wszystkich interesariuszy będzie skuteczne i efektywne.

\section{Bibliografia:}

Bowen, Howard R. 1953. Social responsibilities of the businessman. New York: Harper\&Row.

Carroll, Archie B. 1991. The pyramid of corporate social responsibility: Toward the moral management of organizational stakeholders. Business Horizons, 34(4), 39-48.

Carroll, Archie B. 2008. A history of corporate social responsibility. Concepts and practices. W: The Oxford handbook of corporate social responsibility, red. Andrew Crane et al., 19-42. New York: Oxford University Press.

Crane, Andrew, Dirk Matten i Jeremy Moon. 2008. The Emergence of Corporate Citizenship: Historical Development and Alternative Perspectives. W: Handbook of Research on Corporate Citizenship, red. Andreas Georg Scherer i Guido Palazzo, 25-49. Cheltenham: Edward Elgar Publishers.

Dahlsrud, Alexander. 2008. How Corporate Social Responsibility is Defined: an Analysis of 37 Definitions. Corporate Social Responsibility and Environmental Management, 15(1), 1-13.

Dodd, Merrick E. Jr. 1932. For whom are corporate managers trustees? Harvard Law Review, 45(7), 1145-1163.

Elkington, John. 1997. Cannibals with Forks: Triple Bottom Line of 21st Century Business. Oxford: Capstone Publishing Limited.

European Commission. 2001. Green Paper. Promoting a European framework for Corporate Social Responsibility, 18.7.2001, COM (2001) 366 final. Brussels. Dostęp: 11.02.2017. http://eur-lex.europa.eu/LexUriServ/LexUriServ.do?uri=COM:2001:0366:FIN:EN:PDF. 
Freeman, Edward R. 1984. Strategic management: a stakeholder approach. Boston: Pitman.

Friedman, Milton. 1970. The Social Responsibility of Business is to Increase its Profits. The New York Times Magazine, September 13.

Komisja Europejska. 2011. Komunikat Komisji do Parlamentu Europejskiego, Rady, Europejskiego Komitetu Ekonomiczno-Społecznego i Komitetu Regionów. Odnowiona strategia UE na lata 2011-2014 dotyczaca społecznej odpowiedzialności przedsiębiorstw, 25.10.2011 KOM(2011) 681 wersja ostateczna. Bruksela.

Kramer, Mark R. i Michael E. Porter. 2011. Tworzenie wartości dla biznesu i społeczeństwa. Harvard Business Review Polska, 99, 36-57.

OECD. 2015. Policy Framework for Investment 2015 Edition.

OECD. 2017. Policy Framework for Investment. Policy areas. Responsible business conduct. Overview. Dostęp: 11.02.2017. www.oecd.org/investment/toolkit/policyareas/responsiblebusinessconduct/.

PKN. 2012. Norma PN-ISO26000. Wytyczne dotyczace spotecznej odpowiedzialności. Warszawa.

Sethi, S. Prakash. 1975. Dimensions of Corporate Social Performance: An Analytical Framework. California Management Review, 17(3), 58-64. DOI: $10.2307 / 41162149$.

ŚKŚR (Światowa Komisja ds. Środowiska i Rozwoju). 1991. Nasza wspólna przyszłość, tłum. Urszula Grzelońska i Ewa Kolanowska. Warszawa: Państwowe Wydawnictwo Ekonomiczne.

UN. 1987. Report of the World Commission on Environment and Development: Our Common Future. New York: Oxford University Press.

Visser, Wayne et al. 2010. The A to $Z$ of Corporate Social Responsibility, 2nd Revised and Updated Edition. Chichester: John Wiley \& Sons.

Visser, Wayne. 2010. The Evolution and Revolution of Corporate Social Responsibility. W: Responsible Business: How to Manage a CSR Strategy Successfully, red. Manfred Pohl i Nick Tolhurst, 311-328. Chichester: John Wiley \& Sons. 


\section{CZĘŚ́ IV \\ EDUKACYJNE ASPEKTY \\ ZRÓWNOWAŻONEGO ROZWOJU}



Magdalena Kołodziejska ${ }^{1}$

magdakol@gmail.com

Marta Czerniak-Czyżniak ${ }^{1,2}$

martaczcz@o2.pl

${ }^{1}$ Akademia Pedagogiki Specjalnej im. M. Grzegorzewskiej w Warszawie

${ }^{2}$ Uniwersytet Warszawski - Wydział Geografii i Studiów Regionalnych

\section{Pedagogika na rzecz zrównoważonego rozwoju}

\section{Wstęp}

Termin „zrównoważony rozwój” jest trudny do jednoznacznego zdefiniowania, choć od dawna jest używany w różnych dokumentach międzynarodowych, literaturze naukowej, a nawet aktach prawnych. Po raz pierwszy pojęcie „zrównoważony rozwój” (ZR) zostało wymienione w raporcie ONZ Nasza wspólna przyszłość w 1987 roku i w Agendzie 21. Podkreślało ono, że jedną z podstawowych funkcji środowiska jest dalszy rozwój cywilizacyjny świata wraz z gospodarką i sprawami socjalnymi (Tuszyńska 2015, 13). W raporcie przygotowanym pod kierunkiem Gro Harlem Brundtland przedstawiono pełną definicję ZR rozumianego jako „rozwój, który zapewnia zaspokojenie obecnych potrzeb bez uszczerbku dla możliwości zaspokajania potrzeb przyszłych pokoleń” (ŚKŚR 1991, 27). Ta definicja ma i wymiar moralny, i pedagogiczny, ponieważ wskazuje na działanie pedagogiczne ukierunkowane na dbanie o środowisko, życie i pomyślny rozwój człowieka. To człowiek, który powinien żyć zgodnie z naturą, jest podmiotem zrównoważonego rozwoju.

\section{Zrównoważony rozwój a teoria pedagogiczna}

Zrównoważony rozwój w teorii pedagogicznej opiera się o następujące paradygmaty: konstruktywizm, humanizm, demokrację i pragmatyzm. 


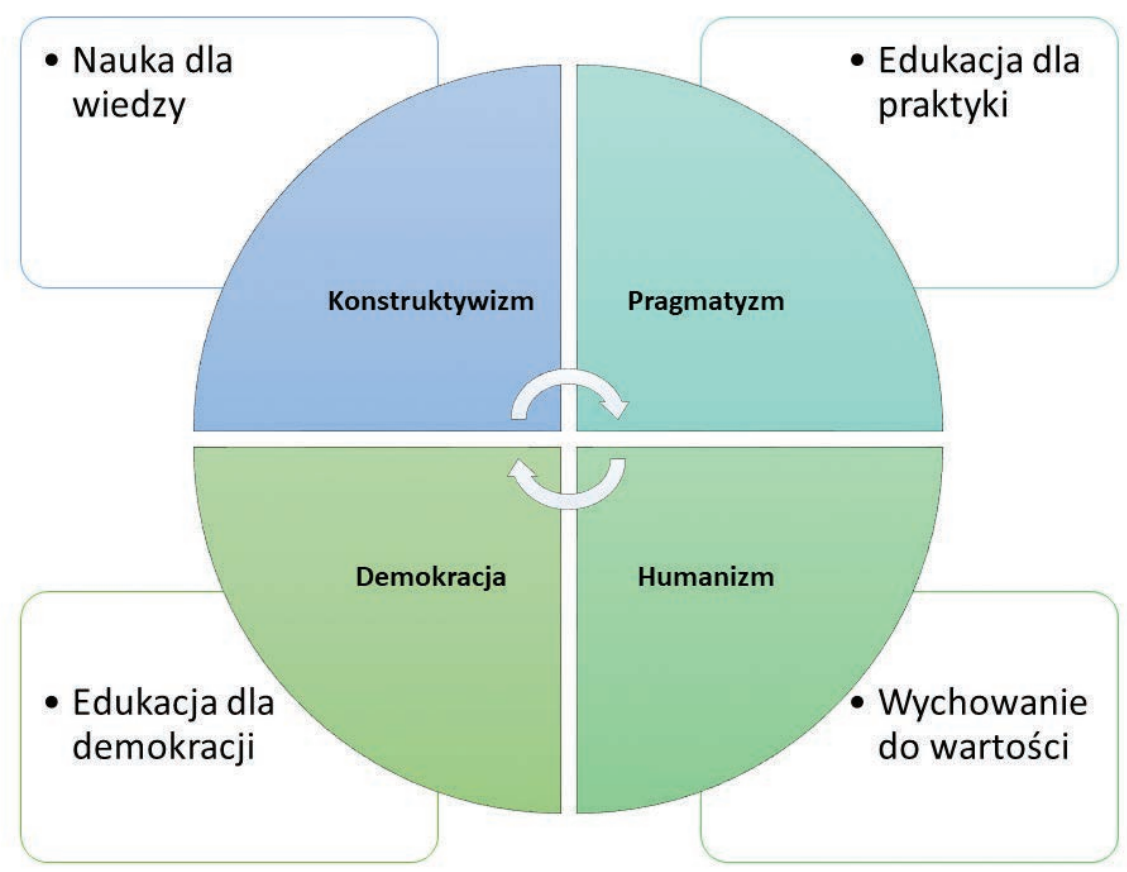

Rysunek 1. Zrównoważony rozwój w teorii pedagogicznej

(Tuszyńska 2016, 108).

Zgodnie z ideą konstruktywizmu „rzeczywistość, którą poznajemy, jest indywidualną konstrukcją ucznia, ale tworzoną za pomocą narzędzi kulturowych i dochodzenia do rozumienia znaczeń" (Bałachowicz 2003, 22). W takim ujęciu wiedza jest konstrukcją umysłu zależną od posiadanych doświadczeń i poglądów. Uczenie się w duchu konstruktywizmu koncentruje się na podstawowych pojęciach, a nie na wiedzy encyklopedycznej. Proces uczenia się rozpoczyna się od zainteresowania dziecka daną tematyką poprzez odwoływanie się do tego, co jest mu już znane, co pobudza chęć poznawczą dziecka. Większe znaczenie ma zatem wyposażenie ucznia w narzędzia zdobywania wiedzy niż przekazywanie suchych faktów.

Konstruktywizm nakierowany na samodzielność badawczą ucznia, na samodzielne wyciąganie wniosków na podstawie danych źródłowych wywiera coraz silniejszy wpływ na edukację przyrodniczą (Tuszyńska 2015, 22). 
W edukacji nie może zabraknąć przestrzeni dla indywidualnego rozwoju osobowości każdego człowieka. Dlatego tak ważna jest tutaj idea humanizmu, która „oznacza idee swobodnego rozwoju człowieka, wolności, wyzwolenia go z wszelkich przesądów, pobudzania umysłu ludzkiego do samodzielnych badań nad człowiekiem” (Okoń 2007, 141). Ważnym aspektem edukacji jest kształtowanie samodzielnego i krytycznego myślenia, wypracowywanie niezależności sądów. Jest to obszar, w który doskonale wpisują się cele z zakresu edukacji przyrodniczej, która wprowadza dziecko w świat wartości, uczy odróżniać dobro od zła i działać na rzecz dobra.

Demokracja jest ustrojem, w którym społeczeństwo uczestniczy w podejmowaniu decyzji politycznych. W edukacji demokracja oznacza współuczestniczenie uczniów w procesie własnego kształcenia. Uczniowie, dzięki możliwości wspólnego działania, podejmowania wspólnych wysiłków na rzecz rozwiązywania problemów badawczych, uczą się demokracji w praktyce. Wzbogacają swoją wiedzę o innych ludziach, o ich duchowości. Uczą się unikania konfliktów lub ich rozwiązywania bez stosowania przemocy fizycznej. Uczą się zrozumienia dla drugiego człowieka.

Pragmatyczne ujęcie edukacji pozwala spojrzeć na nią jako na praktyczne przedsięwzięcie, które może pomóc człowiekowi w codziennym życiu. Aktywność ucznia jest podstawą zdobywania doświadczeń życiowych. Każde pozytywne doświadczenie wzmacnia działania człowieka w danym zakresie, natomiast negatywne - pozwala unikać wcześniej popełnionych błędów. Zdobywanie kolejnych doświadczeń uczy przewidywania skutków własnych działań. Aby działać, należy łączyć wiedzę z umiejętnością działania. Takie połączenie jest podstawą zdobywania różnych kwalifikacji i kompetencji.

Realizacja modelu edukacji mającej na celu zrównoważony rozwój jednostki wydaje się być trudna na gruncie polskiej szkoły. Stoi ona bowiem w opozycji do ciągle chętnie stosowanego przez nauczycieli transmisyjnego modelu edukacji.

\section{Przyroda jako wartość dla zrównoważonego rozwoju}

Idea zrównoważonego rozwoju zakłada przewartościowanie dotychczasowego sposobu myślenia i działania człowieka przy założeniu 
dalszego rozwoju cywilizacyjnego. Wskazuje na potrzebę rozwoju duchowego człowieka i zamianę celów rozwojowych $\mathrm{z}$ materialnych na niematerialne, bowiem tylko taka zmiana gwarantuje prawidłowy rozwój cywilizacyjny.

Wartości, aby zostały przyswojone przez człowieka, nie mogą być jedynie abstrakcyjnymi hasłami. Ich rozpoznawaniu i doświadczaniu powinien towarzyszyć komponent emocjonalny. Według M. Schelera, jednego z najwybitniejszych filozofów XX wieku, nie tylko poznanie wartości, ale również poznanie rzeczywistości musi zostać oparte na komponencie emocjonalnym, ponieważ człowiek, nadając czemuś znaczenie, przypisując temu swoje odczucia, może uznać to coś za bliskie, godne włączenia w swoje życie lub odrzucić jako coś niespełniającego jego potrzeb. We współczesnym świecie okazywanie emocji często jest traktowane jako uleganie własnym słabościom, co może stanowić przeszkodę na drodze wychowania do wartości.

Obserwując dzieci działające w świecie przyrody, można zauważyć oznaki towarzyszących im emocji. Uśmiechnięte twarze, błyszczące oczy, zdziwienie są dowodami radości czerpanej z odkrywania świata. Jednak ta radość często przeplata się z niepokojem czy troską np. o życie napotkanych roślin i zwierząt. Najczęściej właśnie w świecie przyrody dzieci po raz pierwszy spotykają się z tematem śmierci. Zaczynają poszukiwać odpowiedzi na pytania dotyczące łańcucha troficznego w przyrodzie i zastanawiać się, dlaczego jedne organizmy zwalczają drugie? Pytanie to może stanowić punkt wyjścia dla poszukiwania sensu życia i jego wartości. Jak twierdzi Nowak, wartości „posiadają moc uwodzenia człowieka” (1996, 254), co oznacza, że wywierają kształtujący wpływ na osobę. Człowiek, doświadczając konkretnej wartości, nie pozostaje wobec niej obojętny, lecz musi się do niej odnieść. W związku z tym, wartość staje się przedmiotem wyboru i wywiera wpływ na życie wewnętrzne człowieka.

Dziecko już od urodzenia wprowadzane jest w świat wartości, które kształtują jego postawy. Proces ten jest ciągły i długotrwały, bowiem wartości nie są dane człowiekowi raz na zawsze, ale są wypracowywane. Zadaniem rodziców i wychowawców jest pobudzanie dziecka do rozwoju aksjologicznego. Silne zakorzenienie w normach i wartościach jest 
bowiem czynnikiem chroniącym wychowanków przed zachowaniami ryzykownymi czy destrukcyjnymi w przyszłości (Rupik 2015).

Bardzo często w realnym życiu wartości deklarowane przez człowieka nie pokrywają się z wartościami realizowanymi, co stanowi problem $\mathrm{w}$ procesie wychowania, bowiem może powodować dezorientację, nieufność i cynizm wśród dzieci i młodzieży. Jeśli więc chronione środowisko dziś traktowane jest jako wartość (takie jest założenie zrównoważonego rozwoju), to w procesie edukacji nie można pomijać zagadnień związanych z przyrodą. Natura odgrywa doniosłą rolę w systemie aksjologiczno-wychowawczym. Proces edukacji w środowisku przyrodniczym można zobrazować za pomocą „odwróconego modelu uczenia się o przyrodzie":

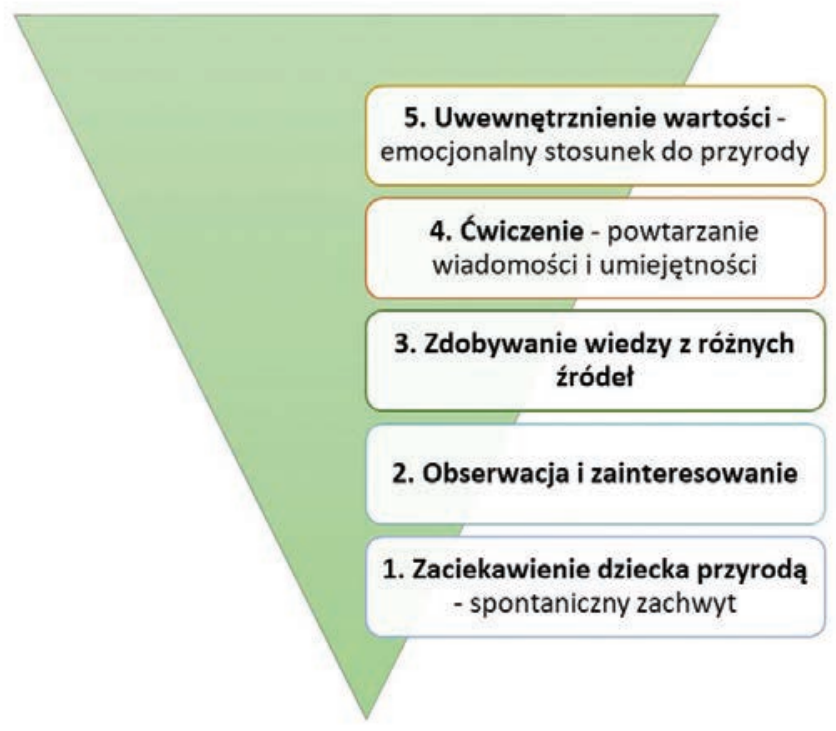

Rysunek 2. Odwrócony model uczenia się o przyrodzie, w przyrodzie, dla przyrody (Tuszyńska 2016, 108).

Model ten zakłada samodzielne, spontaniczne działanie dziecka w świecie przyrody. Nauczyciel uczy się razem z uczniami, jest partnerem procesu edukacyjnego. 


\section{Edukacja przyrodnicza w perspektywie uczenia się przez całe życie}

W myśl zapisów raportu dla UNESCO Edukacja: jest w niej ukryty skarb (1998) edukacja jest podstawowym prawem człowieka oraz uniwersalną wartością. Powinna podejmować działania wspierające pełny rozwój człowieka, które przygotują go do nieustannego działania, zwiększają jego zdolność do autonomii oraz osobistej odpowiedzialności. Człowiek XXI wieku powinien wykorzystywać wszystkie możliwe okazje do aktualizowania, pogłębiania i wzbogacania swojej podstawowej wiedzy i dostosowywać się do zmieniającego się świata. Dlatego też zdaniem J. Delorsa ${ }^{1}$ (Edukacja. Jest $w$ niej ukryty skarb 1998, 100102) działania edukacyjne należy oprzeć na czterech filarach, aspektach kształcenia, które powinny stanowić podstawę nowych zakresów edukacji powszechnej, pozaszkolnej i edukacji dorosłych. Te filary to:

- uczyć się, aby wiedzieć - aspekt poznawczy; należy wyposażyć uczniów w narzędzia rozumienia rzeczywistości; nauczyć ich samodzielnego zdobywania wiedzy, aby mogli korzystać z możliwości, jakie stwarza edukacja przez całe życie;

- uczyć się, aby działać - aspekt praktyczny; wyposażyć uczniów w umiejętność oddziaływania na swoje środowisko;

- uczyć się, aby żyć wspólnie - aspekt społeczny; nauczyć uczniów współpracy z innymi na różnych płaszczyznach działalności ludzkiej;

- uczyć się, aby być - aspekt indywidualny; uczenie się powinno umożliwiać wszechstronny rozwój jednostki.

Dwa pierwsze filary mają wymiar edukacyjny natomiast dwa kolejne wpisują się w aspekt wychowawczy. Pomimo iż każdy z filarów jest inny i samodzielny, to wszystkie wzajemnie się przenikają i uzupełniają. Tak zorganizowana edukacja pozwala na kształtowanie i rozwój m.in. takich wartości jak: wiedza, współpraca, integracja, kreatywność i empatia.

Aby edukacja mogła być skuteczna, należy określić jej cele, czyli „świadomie założone skutki, które społeczeństwo pragnie osiągnąć przez funkcjonowanie systemu oświaty. Zależą one zatem od charakteru każdego społeczeństwa i jego systemu oświaty" (Okoń 2007, 39).

${ }^{1}$ J. Delors był przewodniczącym Międzynarodowej Komisji do spraw Edukacji dla XXI wieku, która opracowała raport pt. Edukacja: jest w niej ukryty skarb. 
Według Bolesława Niemierko cele edukacyjne to „klucz do wszystkich drzwi pedagogicznych" (Niemierko 1991, 49). Konieczność właściwego formułowania celów dydaktyczno-wychowawczych dostrzegał już w XVII wieku Amos Komeński. Swoją myśl zawarł w dziele Wielka dydaktyka (Żuchelkowska 2015, 31).

Józefa Bałachowicz podjęła próbę uporządkowania celów edukacji wczesnoszkolnej w odniesieniu do wymienionych powyżej filarów edukacji (Bałachowicz 2015, 36-37). Cele te zostały wyrażone w postaci wartości wpisujących się w poszczególne filary. Wartości edukacji z obszaru wiedzy to: „otwartość i dociekliwość poznawcza, potrzeba uczenia się, umiejętność wyrażania swoich myśli, refleksyjność i krytyczny ogląd świata”. Z kolei w obszar „działać” można wpisać takie wartości jak: „odwaga w podejmowaniu zadań, poczucie skuteczności własnego działania, kreatywność, odpowiedzialność za efekty działań”. Wartości stanowiące cele edukacji na rzecz wspólnego życia to: „szacunek i troska o innych, dialogowość, tolerancja, współpraca i partycypacja, budowanie więzi”. Natomiast „autonomia, zaufanie wobec świata, wolność, ugodowość, odpowiedzialność” są wartościami wpisującymi się w obszar „być”.

\section{Rola edukacji dla zrównoważonego rozwoju}

Przyroda jest środkiem, za pomocą którego można kształtować relacje człowieka z samym sobą oraz z otoczeniem. Te ostatnie przejawiają się także w przyjmowaniu pozytywnych postaw wobec przyrody. Celem edukacji przyrodniczej staje się twórczy człowiek posiadający kompetencje poznawcze o charakterze badawczym oraz umiejętność samokształcenia.

Bezpośredni kontakt z przyrodą powinny mieć już najmłodsze dzieci, bowiem w myśl powiedzenia „od poznania do przyjaźni droga niedaleka" to one - dzięki nawiązaniu bliskiej relacji z przyrodą - będą w przyszłości gotowe stawać w jej obronie. Na etapie szkoły podstawowej zaleca się przede wszystkim koncentrację na rozbudzaniu u uczniów ciekawości świata przyrody i zainteresowaniu ich nauką przedmiotów przyrodniczych (Grajkowski et al. 2014). Trudno jest tego dokonać, korzystając jedynie z książki lub multimediów. Dla dziecka ważny jest aktywny kontakt z przyrodą, bo tylko wtedy może przeżyć i doświadczyć jej wszystkimi zmysłami, w sposób zindywidualizowany i osobisty. Szczególnie nauczyciel edukacji wczesnoszkolnej powinien umieć 
dostrzec i docenić potencjał środowiska przyrodniczego dla rozwoju człowieka. Gerald Huther i Uli Hauser (2014, 137-139) w swojej książce pt. Wszystkie dzieci są zdolne, zwracają uwagę, że większość dzieci najpóźniej po dwóch latach chodzenia do szkoły traci wrodzoną ciekawość życia. O niszczeniu geniuszy przez szkołę wspomina również w swoim artykule Magdalena Boćko-Mysiorska (2016). Odpowiedzialnością za taki stan, autorzy obarczają nauczycieli, którzy bez przerwy pouczają dzieci, zamiast stwarzać im warunki do nieustannego odkrywania i badania rzeczywistości, zadawania pytań i przyswajania wciąż nowych faktów. Huther i Hauser przestrzegają, że dzieci, które zatracą potrzebę odkrywania świata, będą przypominały większość dzisiejszych dorosłych - pasywnych i zobojętniałych na wszystko, „co na tym pięknym świecie jest jeszcze do odkrycia, zbadania i rozpoznania”.

\section{Znaczenie zajęć terenowych}

Idea prowadzenia zajęć poza salą szkolną nie jest pomysłem nowym. W Polsce zrodziła się w latach dwudziestych XX wieku, kiedy to pojawiła się koncepcja wiejskich ognisk wychowawczych dla szkół wielkomiejskich. Pomysł takich ośrodków umożliwiających realizację edukacji dzieci i młodzieży w bliskim kontakcie z przyrodą został zaczerpnięty z Czechosłowacji i Niemiec, gdzie takie placówki istniały już wcześniej. Polskim prekursorem w tym zakresie był wybitny polski pedagog Bogdan Nawroczyński, który przedstawił swój projekt na Zjeździe Dyrektorów Szkół Państwowych w 1927 roku. Już rok później powstało kilka placówek terenowych, a w roku 1933 czternaście polskich szkół posiadało własne „osiedla szkolne”. Wśród nich było dziewięć szkół warszawskich. Program edukacyjny i wychowawczy realizowany w ramach pobytu w ośrodkach terenowych był bogaty, bowiem „nie ograniczano się do lekcji czy prac w ogrodzie, było wiele wycieczek geograficznych, przyrodniczych, krajoznawczych, z fotografowaniem, rysowaniem natury, obserwacji i analizy zjawisk przyrodniczych. W programie były nawet opisy lasu w językach obcych, analiza zbiorowisk przyrodniczych, przyrodnicze gry terenowe. Osiedla stwarzały liczne okazje do prowadzenia lekcji historii, poznawania zabytków, folkloru i kultury regionalnej, na przykład opracowywania monografii miejscowości, służyły także rozwijaniu świadomości obywatelskiej” (Ambrosiewicz 2015, 32). 
Doświadczenia pedagogów minionych dekad w zakresie znaczenia kontaktu z przyrodą dla rozwoju dziecka są kompatybilne $\mathrm{z}$ aktualnymi obserwacjami ich norweskich kolegów. Norwescy pedagogowie zauważyli, że przebywanie na łonie przyrody „wspiera kreatywność dzieci, zdolność rozwiązywania problemów, zdrowie fizyczne oraz poczucie wszechstronnego radzenia sobie we współdziałaniu z przyrodą" (Halvorsen 2015,19$)$. Ich zdaniem edukację środowiskową warto rozpoczynać od przyzwyczajenia małego dziecka do systematycznego kontaktu z przyrodą. Na tym etapie ważne jest, aby dziecko odkrywało piękno natury i czerpało radość z możliwości przebywania na jej łonie, bowiem stanowi to punkt wyjścia do odkrywania różnorodności występującej w świecie przyrody. Ważne jest, aby dziecko miało możliwość angażowania wszystkich zmysłów w proces uczenia się o przyrodzie. Zapewnić to może jedynie działanie dziecka w realnym świecie, w odpowiednio zorganizowanym środowisku edukacyjnym.

\section{Przykłady dobrej praktyki}

W latach 2015-2016 zespół nauczycieli akademickich Akademii Pedagogiki Specjalnej im. Marii Grzegorzewskiej realizował projekt „Edukacja środowiskowa dla zrównoważonego rozwoju w kształceniu nauczycieli”. Celem tego projektu było m.in.: podniesienie świadomości ekologicznej zwłaszcza w zakresie ochrony środowiska wśród studentów pedagogiki wczesnoszkolnej, opracowanie metodologii zajęć terenowych oraz uwzględnienie ich w programie studiów przyszłych nauczycieli wczesnej edukacji, a także korzystanie z norweskich doświadczeń w zakresie metodyki prowadzenia zajęć z edukacji przyrodniczej w terenie.

Istotna jest ochrona przyrody i uczenie o tym już na najwcześniejszym etapie edukacyjnym. Dzieci rozwijają w ten sposób w sobie poczucie troski o inne żywe organizmy. Nauczanie zatem powinno prowadzić do pełnego rozumienia praw natury, jej sił, a także wpływu człowieka na biosferę i uczyć szacunku dla całej przyrody. Dlatego też w projekcie zwrócono uwagę na całościowe i głębokie zanurzenie w naukach przyrodniczych, które jest kluczowym elementem zrównoważonej edukacji.

W ramach projektu odbywały się seminaria w ośrodkach naukowych zarówno w Norwegii, jak i w Polsce. Opracowany został program przedmiotu „Przyrodnicze Laboratoria Terenowe” oraz odbyło się szkolenie 
nauczycieli akademickich w zakresie nauczania edukacji środowiskowej. Podsumowanie wraz z przebiegiem całego projektu zostało opisane w publikacjach projektowych.

\section{Podsumowanie}

Warunkiem powodzenia realizacji celów zrównoważonego rozwoju jest edukacja, bowiem „tylko dobrze i we właściwym kierunku wyedukowane jednostki mogą dokonywać świadomych wyborów w sferze zrównoważonej konsumpcji dóbr i usług, podejmować świadome decyzje na poziomie podstawowej komórki społecznej, zespołów i grup społecznych i politycznych, samorządów i administracji, kolektywnie współdziałać w realizacji wspólnych celów (...) edukacja jednostek powinna być prowadzona w sposób ciągły, rozpoczynając od właściwego wychowywania w rodzinie, poprzez systemy edukacji formalnej, czyli przez szkolnictwo podstawowe, ponadpodstawowe i wyższe, do edukacji nieformalnej koncentrującej się m.in. na programach i promocji odpowiednich zachowań. Przy tym założeniu, edukacja i ciągłe podnoszenie poziomu wiedzy i świadomości stanowić musi element stale towarzyszący życiu i działalności jednostek" (Strategia Zrównoważonego Rozwoju Polski do 2025 roku 26). Z kolei w Strategii Edukacji dla Zrównoważonego Rozwoju, edukację określono jako jedno z podstawowych praw człowieka i „istotne narzędzie właściwego zarządzania, podejmowania uzasadnionych decyzji oraz promowania demokracji” (Europejska Komisja Gospodarcza ONZ 2008, 3). Zapisy powyższych dokumentów zostały uwzględnione w podstawach programowych kształcenia ogólnego w szkołach, w standardach kształcenia oraz w krajowych ramach kwalifikacji w szkolnictwie wyższym. Ponadto równie ważnym dokumentem strategicznym związanym z edukacją dla zrównoważonego rozwoju było stworzenie przez Zgromadzenie Ogólne ONZ Dekady Edukacji na temat Zrównoważonego Rozwoju, która zakończyła się w 2014 roku. Głównym jej celem było „wspieranie dążeń promujących zrównoważony rozwój społeczny, gospodarczy i ekologiczny”. Zgodnie z celami edukacji dla zrównoważonego rozwoju istotne jest dążenie do osiągnięcia między innymi równowagi pomiędzy „społecznym i ekonomicznym dobrem oraz kulturą, tradycją i ochroną zasobów naturalnych Ziemi. Edukacja na 
rzecz Zrównoważonego Rozwoju podkreśla potrzebę respektowania godności ludzkiej, poszanowania różnorodności, ochrony środowiska naturalnego i zasobów naszej planety" (Dekada Edukacji).

\section{Bibliografia:}

Ambrosiewicz, Maciej. 2015. Przedwojenne zielone szkoły nad Wigrami. Wigry, 1-2, 29-32.

Bałachowicz, Józefa. 2003. Konstruktywizm w teorii i praktyce edukacji. Edukacja, 3, 21-29.

Bałachowicz, Józefa. 2015. Zmiany współczesnych kontekstów edukacji dziecka. W: Edukacja środowiskowa w kształceniu nauczycieli. Perspektywa teoretyczna, red. Józefa Bałachowicz, Kirsti Vindal Halvorsen i Anna Witkowska-Tomaszewska, 11-62. Warszawa: Wydawnictwo APS.

Boćko-Mysiorska, Magdalena. 2016. Dlaczego dzieci nie lubia szkoły i jak pomóc im odnaleźć się w rzeczywistości? Dostęp: 12.01.2017. http:// dziecisawazne.pl/dlaczego-dzieci-nie-lubia-szkoly/.

Dekada Edukacji na temat Zrównoważonego Rozwoju (2005-2014). Dostęp: 03.05.2017. http://www.unic.un.org.pl/edukacja_rozwoj/.

Dymara, Bronisława, Stanisław Michałowski i Lidia Wolman-Mazurkiewicz. 1998. Dziecko w świecie przyrody. Kraków: Impuls.

Edukacja. Jest w niej ukryty skarb, red. Jacques Delors. 1998. Toruń: SOP (UNESCO).

Europejska Komisja Gospodarcza ONZ. 2008. Strategia Edukacji dla Zrównoważonego Rozwoju. Warszawa: Ministerstwo Środowiska.

Gliński, Piotr. 1988. Świadomość ekologiczna społeczeństwa polskiego - dotychczasowe wyniki badań. Kultura i społeczeństwo, 3, 181-196.

Grajkowski, Wojciech, Barbara Ostrowska i Urszula Poziomek. 2014. Podstawy programowe $w$ zakresie przedmiotów przyrodniczych w wybranych krajach. Warszawa: Instytut Badań Edukacyjnych.

Halvorsen, Kirsti Vindal. 2015. Kształcenie dla zrównoważonego rozwoju z perspektywy Norweskiej. W: Edukacja przyrodnicza w terenie. W stronę pedagogiki zrównoważonego rozwoju, red. Józefa Bałachowicz i Ligia Tuszyńska, 13-19. Warszawa: APS. 
Hunther, Gerald i Uli Hauser. 2014. Wszystkie dzieci sa zdolne. Jak marnujemy wrodzone talenty, tłum. Andrzej Lipiński. Słupsk: Wydawnictwo Dobra Literatura.

Kołodziejska, Magdalena i Ligia Tuszyńska. 2015. Kształtowanie kompetencji kluczowych na lekcjach przyrody w oparciu o nowoczesne technologie. W: Biuletyn Polskiego Stowarzyszenia Nauczycieli Przedmiotów Przyrodniczych. Nauczanie przedmiotów przyrodniczych, red. Józefina Turło, 50-55. Toruń: Polskie Stowarzyszenie Nauczycieli Przedmiotów Przyrodniczych.

Koźmińska, Irena i Elżbieta Olszewska. 2007. Z dzieckiem w świat wartości. Warszawa: Świat książki.

Kupisiewicz, Czesław. 1966. Nauczanie programowane. Warszawa: PZWS.

Locke, Lawrence, Spirduso Wannen i Wyrick Silverman. 2007. Proposals that work: A guide for planing dissertations and grant proposals. Thousand Oaks, CA: Sage.

Louv, Richard. 2014. Ostatnie dziecko lasu, tłum. Anna Rogozińska. Warszawa: Grupa Wydawnicza Relacja Sp. z o.o.

Medved, Michael i Diana Medved. 1999. Saving Childhood. New York: HarperCollins Publisher/Zondervan Publishing House.

Mikołuszko, Wojciech. 2015. W domach z betonu ludzie chca dziczeć. Dostęp: 10.03.2016. http://wyborcza.pl/1,145452,18433793,w-domach-z-betonu-ludzie-chca-dziczec.html?disableRedirects=true.

Musialik, Małgorzata, Barbara Ostrowska i Urszula Poziomek. 2014. Nauczyciele przedmiotów przyrodniczych. W: Licza się nauczyciele. Raport o stanie edukacji 2013, red. Marek Chrobak, 241-272. Warszawa: Instytut Badań Edukacyjnych.

Mysłakowski, Zygmunt. 1965. Wychowanie człowieka w zmiennej społeczności. Warszawa: Książka i Wiedza.

Nawroczyński, Bogdan. 1947. Życie duchowe. Zarys filozofii kultury. Kraków-Warszawa: Księgarnia Wydawnicza F. Pieczątkowski i S-ka.

Niemierko, Bolesław. 1991. Między ocena szkolna a dydaktyką. Warszawa: Wydawnictwa Szkolne i Pedagogiczne. 
Niewinowski, Paweł. 2014. Aksjologiczne aspekty relacji człowiek natura - technika: refleksje edukacyjne. Studia Płockie, 40, 143-163.

Nowak, Agnieszka. 1996. Problematyka ekologiczna w edukacji uczniów klas początkowych. Życie szkoły, 7, 415-421.

Nowak, Stefan. 2007. Metodologia badań społecznych. Warszawa: Wydawnictwo Naukowe PWN.

Okoń, Wincenty. 1995. Wprowadzenie do dydaktyki ogólnej. Warszawa: Wydawnictwo „Żak”.

Okoń, Wincenty. 2007. Nowy słownik pedagogiczny. Warszawa: Wydawnictwo Akademickie „Żak”.

Parczewska, Teresa. 2009. Edukacja ekologiczna w przedszkolu. Lublin: Wydawnictwo Uniwersytetu Marii Curie-Skłodowskiej.

Pawłowski, Artur. 2009. Teoretyczne uwarunkowania rozwoju zrównoważonego. Dostęp: 15.02.2017.http://old.ros.edu.pl/text/pp_2009_071.pdf.

Pilch, Tadeusz. 1995. Zasady badań pedagogicznych. Warszawa: Wydawnictwo „Żak”.

Potyrała, Katarzyna i Alicja Walosik. 2011. Edukacja przyrodnicza wobec wyzwań wspótczesności. Krzeszowice: Wydawnictwo Kubajak.

Ranoszek, Ewa. 1993. O edukacji ekologicznej w szkole. Aura, nr 6, Dodatek ekologiczny nr 10 dla szkół.

Rousseau, Jan Jakub. 1995. Emil, czyli o wychowaniu. W: Źródła do dziejów wychowania i myśli pedagogicznej. T. 1: Od wychowania pierwotnego do końca XVIII stulecia, red. Stefan Wołoszyn. Warszawa: Państwowe Wydawnictwo Naukowe.

Rupik, Magdalena.2015. Wartościa wychowanie dziecka. Dostęp:30.05.2016. http://edukacja.andrychow.eu/placowki/przedszkola/przedszkole-nr-3-w-andrychowie-102/dokumenty/wartosci-a-wychowanie-dziecka-467.

Sagor, Richard. 2013. Badanie przez działanie. Jak wspólnie badać, żeby lepiej uczyć, tłum. Krzysztof Kruszewski. Warszawa: CEO.

Skinner, Burrhus Frederic. 1954. The Science of Learning and the Art of Teaching. Harvard Educational Review, 24, 86-97. 
Skowroński, Antoni. 2006. Zrównoważony rozwój perspektywą dalszego postępu cywilizacyjnego. Problemy ekorozwoju, 1(2), 47-57.

Stawiński, Wiesław. 1999. Podstawy nauczania środowiska przyrodniczego. Kraków: Wydawnictwo Naukowe WSP.

Strategia Zrównoważonego Rozwoju dla Polski do 2025 roku. 2000. Warszawa: Ministerstwo Środowiska.

Szymański, Mirosław Józef. 2000. Młodzież wobec wartości. Próba diagnozy. Warszawa: Instytut Badań Edukacyjnych.

ŚKŚR (Światowa Komisja ds. Środowiska i Rozwoju). 1991. Nasza wspólna przyszłość, tłum. Urszula Grzelońska i Ewa Kolanowska. Warszawa: Państwowe Wydawnictwo Ekonomiczne.

Tashakkori, Abbas i John W. Creswell. 2007. Editorial: the New Era of Mixed Methods. Journal of Mixed Methods Research, 1(1), 3-7.

Tuszyńska, Ligia. 2008. Diagnoza stanu edukacji środowiskowej społeczności lokalnych w wybranych regionach Polski. Warszawa: Wydawnictwo UW.

Tuszyńska, Ligia. 2015. Nauki o środowisku przyrodniczym. W: Edukacja środowiskowa $w$ ksztatceniu nauczycieli w perspektywie praktycz$n e j$, red. Adamina Korwin-Szymanowska, Ewa Lewandowska i Ligia Tuszyńska, 9-36. Warszawa: Wydawnictwo APS.

Tuszyńska, Ligia. 2016. Przyroda jako wartość wczesnej edukacji dziecka na drodze do zrównoważonego rozwoju. W: Koncepcja Zrównoważonego Rozwoju w ksztatceniu nauczycieli klas poczatkowych, red. Ligia Tuszyńska, 101-124. Warszawa: Wydawnictwo APS.

Wędzińska, Magdalena. 2013. Człowiek na drodze do wartości. Myśl etyczna Maxa Schelera - implikacje pedagogiczne. Przeglad pedagogicz$n y, 1,31-43$.

Więckowski, Ryszard. 1997. Edukacja ekologiczna. Życie szkoty, 2, 67-70.

Wilczek, Zygmunt. 1994. Edukacja ekologiczna dzieci przedszkolnych na zajęciach terenowych. Aura, nr 5, Dodatek ekologiczny dla szkół.

Żuchelkowska, Krystyna. 2015. Edukacja przyrodnicza w przedszkolu. Bydgoszcz: Wydawnictwo Uniwersytetu Kazimierza Wielkiego. 
Małgorzata Jagodzińska

Wyższa Szkoła Biznesu i Nauk o Zdrowiu w Łodzi - Wydział Nauk o Zdrowiu

Elżbieta Buchcic

Uniwersytet Jana Kochanowskiego w Kielcach - Wydział Matematyczno-Przyrodniczy ebuchcic2@wp.pl

\section{Wykorzystanie dorobku Raportu Brundtland w edukacji dla zrównoważonego rozwoju}

\section{Wstęp}

Raport Brundtland Nasza wspólna przyszłość odegrał istotną rolę w kształtowaniu nowego sposobu myślenia o wzajemnych relacjach pomiędzy człowiekiem, gospodarką i zasobami środowiska przyrodniczego. Został on przygotowany w 1983 r. przez Światową Komisję do Spraw Środowiska i Rozwoju przy ONZ i zaprezentowany w 1987 r. przez przewodniczącą grupy roboczej, norweską polityk Gro Harlem Brundtland. Centralną kategorią Raportu stało się pojęcie rozwoju zrównoważonego.

Pięć lat po ogłoszeniu Raportu odbyła się Konferencja w Rio de Janeiro (1992), której efektem były przyjęte przez kraje uczestniczące dokumenty, zalecające wdrażanie koncepcji zrównoważonego rozwoju (ZR). W Polsce takie rekomendacje pojawiły się w większości dokumentów dotyczących ochrony środowiska oraz w Konstytucji RP (rozdz. I, art. 5: „Rzeczpospolita Polska (...) zapewnia ochronę środowiska, kierując się zasadą zrównoważonego rozwoju”). W Rio de Janeiro opracowany został jeden z najważniejszych dokumentów, związanych ze zrównoważonym rozwojem Agenda 21, czyli wszechstronny plan działania na wiek XXI dla Narodów Zjednoczonych, rządów i grup społecznych w każdym obszarze, w którym człowiek ma wpływ na środowisko.

\section{Organizowanie pracy nad edukacją dla zrównoważonego roz- woju (EZR)}

To właśnie przystąpienie naszego kraju do realizowania zapisów Agen$d y$ dało podwaliny pod EZR. Agenda 21 podkreśla dominującą rolę edukacji ekologicznej. Rozdz. 25 Dzieci i młodzież w zrównoważonym rozwoju w p. A. dotyczy zwiększenia roli młodzieży i angażowania jej w ochronę 
środowiska i promocję gospodarczego i społecznego rozwoju $\mathrm{z}$ uwagi na fakt, że świat będzie należał do nich. Ponieważ młodzi ludzie muszą być zaangażowani w podejmowanie decyzji, trzeba ich uczyć, jak należy tym światem kierować. W p. B. Dzieci i zrównoważony rozwój chodzi o konieczność ochrony zdrowia dzieci i poprawę stanu ich edukacji. Rozdz. 36 Upowszechnianie edukacji, świadomości społecznej i podnoszenie kwalifikacji w p. A. Dostosowanie edukacji do potrzeb zrównoważonego rozwoju dotyczy umożliwienia każdemu dostępu do podstawowej edukacji: w ciągu trzech lat rządy powinny włączyć zagadnienia środowiska i rozwoju oraz ich wzajemne relacje w program edukacji na wszystkich poziomach, zapewniając nauczycielom i administracji odpowiednie wsparcie i środki. Szkoły wyższe powinny stwarzać sieci wzajemnych powiązań oraz ośrodki wiedzy związanej z rozwojem i środowiskiem. Promować należy edukację nieformalną i edukację ludzi dorosłych. Punkt B. Podnoszenie świadomości społecznej obliguje organizacje rządowe do tworzenia i wspierania ciał doradczych za pomocą nowoczesnych technologii komunikacyjnych, zapewnianie usług informacyjnych w zakresie zagadnień środowiska i rozwoju, a ponadto, we współpracy ze środkami masowego przekazu, przemysłem rozrywkowym i reklamowym „kształtować zachowania społeczne i wzorce konsumpcji” (RSCEE 1993).

Refleksja nad Raportem Brundtland zaowocowała organizacją II Konferencji „Środowisko i Rozwój” w Johannesburgu (2002). Poddano tam ocenie efekty wdrażania zasad ZR. Brak postępu w tym zakresie skłonił do zintensyfikowania wysiłków i ogłoszenia Dekady Edukacji dla Zrównoważonego Rozwoju (Decade of Education for Sustainable Development) na lata 2005-2014, zlecając koordynację UNESCO. Głównym zadaniem, jaki uchwała ONZ wiąże $\mathrm{z}$ edukacją na rzecz ZR, jest „uwrażliwienie wszystkich mieszkańców naszego globu na powiązaną ze sobą problematykę społeczno-ekonomiczno-środowiskową" (Kostecka 2009, 105). Zadanie to można rozumieć szerzej, jako „uwrażliwienie na integrację działań na płaszczyznach: moralnej, społecznej, ekonomicznej, ekologicznej, a także technologicznej, prawnej i politycznej" (Kostecka 2009, 105).

\section{Dekada 2005-2014 a EZR}

W ramach działań Dekady kraje Europejskiej Komisji Gospodarczej ONZ przyjęły kolejny, strategiczny dokument - Strategię Edukacji dla 
Zrównoważonego Rozwoju. W Polsce została opracowana „Narodowa Strategia Edukacji Ekologicznej przez Edukację do Zrównoważonego Rozwoju”. Zgodnie z zapisami, EZR ma umożliwiać przewidywanie, zapobieganie i rozwiązywanie problemów, które pośrednio lub bezpośrednio zagrażają życiu na naszej planecie; edukacja ta ma również rozpowszechniać wartości i normy tkwiące u podstaw zrównoważonego rozwoju. Zaliczają się do nich „równość płci, tolerancja społeczna, redukcja obszarów biedy, ochrona środowiska, ochrona zasobów naturalnych planety i sprawiedliwe, pokojowe społeczeństwa" (Kostecka 2009, 102). Treści ZR powinny się znaleźć na wszystkich poziomach nauczania. W dokumencie, podkreślono, że edukacja ta, „ukazując zależność człowieka od przyrody, uczy odpowiedzialności za zmiany dokonywane w środowisku naturalnym" (MŚ 2001).

W 2012 r. przedstawiciele ponad 100 krajów spotkali się na Szczycie Ziemi w Rio de Janeiro, zatytułowanym „Rio+20”. Przyjęto wówczas dokument Future We Want (Przyszłość, jakiej chcemy), w którym podkreślono znaczenie trójaspektowego podejścia do problematyki ZR, uwzględniającego wzajemne powiązanie trzech dziedzin: społecznej, ekonomicznej i środowiskowej, które generują różne grupy zagadnień dla Strategii EZR, adekwatnie do trzech wyżej wymienionych perspektyw.

\section{Koncepcja edukacji dla zrównoważonego rozwoju}

EZR najczęściej jest określana jako edukacja, która:

$\checkmark$ umożliwia uczącemu się zdobywanie umiejętności, wiedzy i przymiotów zapewniających mu trwały rozwój,

$\checkmark$ jest jednakowo dostępna na wszystkich szczeblach i we wszelkich społecznych kontekstach,

$\checkmark$ buduje odpowiedzialność obywatelską i promuje demokrację poprzez uświadomienie jednostce jej praw i obowiązków,

$\checkmark$ oparta jest na zasadzie nauki przez całe życie,

$\checkmark$ wspiera równomierny rozwój jednostki (Polski Komitet ds. UNESCO 2006).

EZR powinna mieć wymiar holistyczny, polegający na prowadzeniu nauczania/uczenia się zarówno w ramach edukacji formalnej, jak i pozaformalnej, w ramach udziału w różnych projektach badawczych 
i edukacyjnych, happeningach i akcjach społecznych. Chodzi o kształtowanie kompetencji przyszłości, czyli wiedzy, umiejętności i postaw koniecznych dla świadomego, odpowiedzialnego za siebie i swoje otoczenie młodego człowieka. Jest to możliwe dzięki zwróceniu uwagi na całościowe pojmowanie środowiska jako układu stosunków przyrodniczych, ekonomicznych, społecznych, kulturowych; otwarcie drzwi szkoły do lasu, na łąkę, pole czy staw, wprowadzenie metod badawczych i skutecznych form kształcenia (zielone szkoły, projekty edukacyjne); włączenie do działań edukacyjnych lokalnych społeczności, włączenie się szkół w realizację lokalnych programów środowiskowych (zgodnie z zaleceniami zawartymi w Agendzie 21). Wymaga to interdyscyplinaryzmu (Stoltenberg i Michelson 1999) i aktywizujących metod pracy $\mathrm{w}$ procesie nauczania/uczenia się.

$\mathrm{Z}$ tej perspektywy warto zwrócić uwagę na różnice pomiędzy terminami: edukacja ekologiczna, edukacja środowiskowa, edukacja dla zrównoważonego rozwoju, które w różnych opracowaniach są stosowane zamiennie, przy czym pojęcie EZR jest używane najrzadziej. Warto nadmienić, że są to odmienne nurty edukacyjne, których koncepcje zostały ukształtowane w różnych historycznie okresach.

W koncepcji edukacji ekologicznej priorytetem jest nacisk na holistyczne ujmowanie różnych aspektów środowiska oraz powiązanie kwestii środowiskowych z ekonomicznymi i społecznymi. Sposoby realizacji zaczerpnięte z doświadczeń Wielkiej Brytanii to: edukacja „w środowisku”; edukacja „o środowisku” i edukacja „dla środowiska”.

EZR nie ma zastępować edukacji ekologicznej, ale ją poszerzać i wzbogacać (Gajuś-Lankamer i Wójcik 2010, 29). Wymaga ona szerszego kontekstu wykraczającego poza studiowanie natury i zajęcia terenowe. Ten rodzaj edukacji bardziej ogniskuje się na sprawach związanych z egzystencją ludzką i uznaje, że prawa ludzi i sprawiedliwość społeczna są tak samo istotne dla zrównoważonego rozwoju jak utrzymanie w stanie równowagi biologicznej środowiska naturalnego (Gajuś-Lankamer i Wójcik 2010, 30).

Edukacja ekologiczna propaguje działania na rzecz ochrony środowiska (powstrzymywanie zanieczyszczeń, oszczędne korzystanie z zasobów natury, naprawianie szkód), podczas gdy EZR uznaje prawa ludzi, 
propagując efektywne korzystanie z zasobów naturalnych (nowy sposób życia). Uczy, w jaki sposób godzić wzrastające potrzeby konsumpcyjne współczesnych społeczeństw z malejącymi zasobami naturalnymi naszej planety.

Pojęcie EZR mieści w sobie obszary, które są przedmiotem kolejno: edukacji przyrodniczej, ekologicznej, sozologicznej i środowiskowej, rozszerzając formułę o treści związane $\mathrm{z}$ edukacją społeczną, ekonomiczną, etyczną, estetyczną i kulturalną, ukierunkowane na propagowanie i wdrażanie całościowego, nowego paradygmatu, generującego nową wizję ładu zintegrowanego (Borys 2006, 19). EZR jest więc całokształtem czynności i procesów, które mają na celu uświadomienie i zmotywowanie potencjalnych jej odbiorców do podejmowania działań, przejawiania zachowań i przyjmowania postaw, które pośrednio lub bezpośrednio przyczyniać się będą do zaprowadzania, upowszechniania, utrwalania i ochrony ładu, przejawiającego się kompleksowo w wymiarach społecznym, gospodarczym, politycznym, kulturowym i przyrodniczym, opartego na idei zrównoważonego rozwoju (Domeradzki i Tyburski 2011, 245). W tej perspektywie edukacja społeczeństwa dla zrównoważonego rozwoju jest bardzo trudnym zadaniem, gdyż obejmuje swoim zasięgiem większe spektrum zagadnień.

Edukacja jest społeczną wartością i kapitałem oraz nadzieją, a także wielkim obszarem zadań. Powinna być także w swych celach i metodach pracy poważnym sprzeciwem wobec wielu antywartości oraz negatywnych zjawisk i zagrożeń ludzkiego bytu (Banach 1996, 111).

W tym miejscu warto zwrócić uwagę na edukację środowiskową, która najczęściej jest ukazywana w ujęciu pedagogicznym, co oznacza ogół czynności i procesów, które umożliwiają uczniom orientację w rzeczywistości przyrodniczej i wpływają na ich stosunek do otaczającego środowiska (Encyklopedia pedagogiczna 2011). Rola edukacji środowiskowej polega na ukierunkowaniu procesu dydaktyczno-wychowawczego na problematykę środowiskową, a jej celem ma być uzupełnienie wiedzy na temat funkcjonowania środowiska przyrodniczego oraz wpływu działalności człowieka na środowisko, ukształtowania właściwych relacji między przyrodą a społeczeństwem (Demeshkant 2011, 21). Edukacja środowiskowa - to przygotowanie młodzieży do ekoro- 
zwoju, tzn. do prowadzenia wszelkiej działalności gospodarczej w harmonii z przyrodą, tak aby nie spowodować nieodwracalnych zmian w przyrodzie (Cichy 2002, 15). Natomiast podstawowym celem EZR jest przekazanie wszystkim ludziom wiedzy i motywacji potrzebnej do działania na rzecz ZR i życia zgodnie z jego zasadami. Dzięki temu ich działalność ma ukierunkować się na stworzenie sprawiedliwego społeczeństwa, bezpieczeństwa ekonomicznego, równowagi ekologicznej i umocnienie demokracji. EZR może być postrzegana jako ciągły proces w zmieniającym się świecie. Jej długofalowym celem jest osiągnięcie najlepszego możliwego poziomu życia w taki sposób, żeby nie szkodzić innym ludziom ani otaczającemu nas środowisku, mając na uwadze zarówno dzień dzisiejszy jak przyszłość następnych pokoleń. Osiągnięcie tego celu będzie wymagać od każdego z nas poprawienia zdolności do działania na rzecz ZR, będzie wymagać rozwinięcia wiedzy i odpowiedniej motywacji (Jutvik i Liepina 2000).

\section{Formy edukacji}

W tym kontekście należy mówić o uczeniu się przez cale życie (ang. lifelong learning), w różnych formach kształcenia: formalnym, nieformalnym i incydentalnym. Takiej klasyfikacji dokonał w 1973 roku P. Coombs (Malewski 2000, 47).

Kształcenie formalne: system kształcenia oparty na stałych pod względem czasu i treści nauki formach (klasy, stopnie, szkoły, programy i podręczniki) prowadzący od nauczania początkowego do uniwersytetu i włączający - obok kursów - wiele programów specjalnych oraz instytucji stacjonarnego kształcenia technicznego i zawodowego (Okoń 1992). Kształcenie formalne oferowane jest przez instytucje edukacyjne lub szkoleniowe, zorganizowane (w sensie określenia celów, czasu nauki oraz pomocy udzielanej uczniom), jest intencjonalne, zamierzone. Edukacja ta prowadzi w kierunku uzyskania kwalifikacji potwierdzonych świadectwem, zaświadczeniem o ukończeniu szkoły, certyfikatem, dyplomem.

Kształcenie nieformalne: świadoma i zorganizowania działalność ształcąco-wychowująca prowadzona poza ustanowionym formalnym systemem szkolnym, umożliwiająca określonej grupie uczestników osiągnięcie 
założonych celów kształcenia (Okoń 1992). Odbywa się poza, a czasami równolegle do głównego nurtu systemów edukacji i szkolenia, i zwykle nie prowadzi do formalnych świadectw. Może mieć miejsce w pracy, w działaniach społeczeństwa obywatelskiego, organizacji i grup (młodzieżowe, związki zawodowe i partie polityczne). Może być także zapewniana przez organizacje lub usługi ustanowione w celu uzupełnienia systemów formalnych (takich jak kursy lub prywatne korepetycje w celu przygotowania do egzaminu). Ze względu na aktywne metody nauczania i pracy określana jest mianem uczenia się przez praktykę. Edukacja nieformalna najczęściej jest realizowana przez organizacje pozarządowe, stowarzyszenia, kluby, centra edukacyjne działające w przedsiębiorstwach, nadleśnictwach, urzędach. Może się ona dokonywać poprzez oddziaływanie bierne lub czynne. Przy oddziaływaniu biernym wykorzystuje się środki masowego przekazu, opracowuje materiały w postaci ulotek, broszur, informatorów, książek, które dostosowane są do poziomu wykształcenia i wieku; przeprowadza się różnego typu przedsięwzięcia edukacyjne, szkolenia, wystawy realizowane na różnych szczeblach, od lokalnego do globalnego, przy okazji różnorodnych wydarzeń ekologicznych. W ramach oddziaływania czynnego mamy do czynienia $\mathrm{z}$ aktywnym uczestnictwem edukacyjnym (Hłobil 2010, 91).

Kształcenie incydentalne: trwający przez całe życie niezorganizowany i niesystematyczny proces nabywania przez każdego człowieka wiadomości, sprawności, przekonań i postaw na podstawie codziennego doświadczenia oraz wpływów wychowawczych otoczenia (Okoń 1992). Wynika z codziennych sytuacji zaistniałych w środowisku pracy, w rodzinie, w trakcie wypoczynku, które następują niespodziewanie i nie są efektem z góry powziętego zamiaru czy planowania.

\section{Edukacja nieformalna - dobre praktyki}

Sektor kształcenia nieformalnego w Polsce jak dotychczas posiada stosunkowo niewielką ofertę kształcenia w zakresie ZR. Większość programów ukierunkowana jest raczej na podnoszenie wiedzy i świadomości różnych grup odbiorców odnośnie do poszczególnych obszarów zrównoważonego rozwoju, np. gospodarki odpadami komunalnymi, czy też na ochronę bioróżnorodności, a nie całościowego ujmowania 
problemu. EZR w sektorze nieformalnym, w każdej dziedzinie powinna uwzględniać wyjściowe potrzeby, wiedzę, postawy docelowych grup odbiorców. Wydaje się więc, że prócz treści nauczania niezwykle istotne w edukacji dla ZR są: dostosowanie treści do potrzeb lokalnych społeczności oraz metody nauczania, które powinny kłaść nacisk na aktywność, twórczość i decyzyjność kształconych osób (Grodzińska-Jurczak et al. 2010, 104). Tradycyjne metody informowania (dystrybucja materiałów pisanych, tj. ulotki, plakaty itp.) są stosunkowo mało efektywne, jeśli na nich się poprzestaje. Najlepsze wyniki, jak dotąd, dały akcje oparte o aktywne metody komunikacji nastawione na zmiany dotychczasowych zachowań i postaw, w efekcie prowadzące do wzrostu motywacji społeczeństwa do uczestnictwa w działaniach prośrodowiskowych (Grodzińska-Jurczak et al. 2010, 104). Szczególnie trafną metodą prowadzącą do trwałej zmiany zwyczajów mieszkańców, a przez to do znacznego wzrostu tonażu segregowanych odpadów, okazała się brytyjska metoda komunikacji - metoda doradców domowych (home advisors), która, w zmodyfikowanej wersji, została wprowadzona w gminach Dorzecza Górnej Raby i Krakowa (Grodzińska-Jurczak et al. 2003, 67-88). Działania edukacyjno-informacyjne oparte o tę metodykę prowadzone są w gminach Związku Dorzecza Wisłoki, Zakliczynie i Jordanowie. Metoda ta polega na odwiedzaniu i informowaniu mieszkańców o problematyce gospodarki odpadami komunalnymi przez tzw. doradców domowych. Dla podniesienia efektywności programu często organizowane są uzupełniające działania, tj. cykle szkoleń i warsztatów dla pracowników urzędów gminnych, sołtysów, przedstawicieli rad sołeckich, nauczycieli, jak też liczne działania informacyjne ( $\mathrm{tj}$. dystrybucja ulotek promujących segregację i ograniczanie ilości wytwarzanych odpadów, wywieszanie plakatów informacyjnych o akcji doradców domowych i lokalnym systemie selektywnej zbiórki, artykuły w lokalnych gazetkach i na stronach internetowych, konkursy na najlepiej segregującą rodzinę w gminie). Zarówno w Wielkiej Brytanii jak i Polsce akcja doradców miała bezpośrednie przełożenie na efektywność działania systemów selektywnej zbiórki w gminach. Dwa lata pracy doradców doprowadziły do wzrostu tonażu segregowanych odpadów (Grodzińska-Jurczak et al. 2010, 103). 
Warto wspomnieć, że UE w zakresie EZR poszukuje różnych rozwiązań i sposobów oddziaływania na społeczeństwo i uczestników życia gospodarczego celem zaangażowania ich w działania praktyczne. Jednym ze sposobów są szkolenia online. Przykładem może być zrealizowany już projekt Dolceta - Online consumereducation (edukacja konsumencka online). Powstał on na zlecenie Dyrekcji Generalnej ds. Zdrowia i Ochrony Konsumentów (DG SANCO), finansowany jest przez Komisję Europejską, a zarządzany przez EUCEN - Europejską Sieć Uniwersytetów Kształcenia Ustawicznego. W realizacji projektu Dolceta uczestniczyły wszystkie kraje członkowskie UE, a w każdym $\mathrm{z}$ nich za jego realizację odpowiada zaproszona instytucja. W wyniku współpracy powstał unijny Portal Edukacyjny Dolceta (Portal Dolceta 2011), który stanowi przykład e-edukacji realizowanej w wymiarze europejskim. Jego istotą jest zestaw narzędzi edukacyjnych z zakresu edukacji konsumenckiej, zgrupowanych w moduły, z których każdy prezentuje inną problematykę przydatną konsumentom UE. W portalu, poza informacjami dla konsumentów, znajdują się sekcje przeznaczone dla nauczycieli.

Innym działaniem realizowanym $\mathrm{w}$ ramach edukacji nieformalnej jest „Akademia Zrównoważonego Rozwoju”, wspólne przedsięwzięcie fundacji Forum Inicjatyw Rozwojowych oraz partnera projektu Ramboll DK (Dania), mająca na celu podniesienie świadomości ekologicznej oraz promocję obywatelskich postaw proekologicznych. W ramach projektu zrealizowane zostały programy szkoleniowe skierowane do 40 przedstawicieli JST, organizacji pozarządowych oraz przedstawicieli małych i średnich przedsiębiorstw. W ramach 256 godzin szkoleń uczestnicy podnieśli wiedzę z zakresu m.in.: Teorii i praktyki zrównoważonego rozwoju, Zielonych miejsc pracy, Zielonych zamówień publicznych, Ekofundrisingu - pozyskiwania środków na projekty ekologiczne, Modeli współpracy partnerskiej, Praktycznych aspektów zrównoważonego rozwoju w funkcjonowaniu JST i firm (Godlewska 2009, 15).

Na podkreślenie zasługuje działalność Fundacji Ośrodka Edukacji Ekologicznej, który realizuje ogólnopolski program wsparcia i certyfikacji, podnoszący jakość pracy placówek oświatowych w obszarze ZR pt. „Zielony Certyfikat. Placówka Oświatowa jako Ośrodek Zrównowa- 
żonego Rozwoju". Poprzez procedury przyznawania znaku jakości mobilizuje do doskonalenia się i działań najwyższej jakości, a jednocześnie umożliwia wdrażanie zasad ZR w codzienne funkcjonowanie szkół. „Zielony Certyfikat” mobilizuje całą społeczność placówki, inspiruje do współpracy ze środowiskiem lokalnym, poprzez konieczność wprowadzania rozwiązań systemowych daje poczucie uczestniczenia w długotrwałym procesie, którego efekty są na bieżąco oceniane i wykorzystywane do dalszych, jeszcze lepszych działań (National Geografic 2009).

\section{Zakończenie}

Implementacja zrównoważonego rozwoju w codzienne życie trwa cały czas i jest poddawana ocenie. W 2012 r. na zlecenie Ministerstwa Środowiska przeprowadzono ekspertyzę dotyczącą EZR w Polsce (MOŚ 2012a). W ramach ekspertyzy przeprowadzono badanie pt. EZR $w$ opiniach nauczycieli - Diagnoza sytuacji w zakresie realizacji EZR przez nauczycieli wybranych szkół. Głównym celem badania było zdiagnozowanie sytuacji w zakresie realizacji EZR rozwoju przez nauczycieli wybranych szkół (MOŚ 2012b). Okazało się, że koncepcja EZR jest dla nauczycieli niezrozumiała i wieloznaczna. Nauczyciele, nie widząc w tej koncepcji żadnej wartości dodanej, nie czują potrzeby poszukiwania nowych środków, metod czy sposobów jej realizacji (MOŚ 2012b). Nauczyciele nie prowadzą podejmowanych działań w sposób zaplanowany. Duża część akcji czy tematów lekcji, które nauczyciele uznają za EZR, jest inicjatywą uczniów, czyli nie jest to świadomie planowany element aktywności pedagogicznej, ale odpowiedź na oczekiwania, zainteresowania i pytania młodzieży. Działania podejmowane w ramach EZR mają zatem charakter doraźny i nie mają na celu systematycznego rozwijania wiedzy czy umiejętności młodzieży w jasno określonym kierunku.

W ramach ekspertyzy dokonano też identyfikacji zapisów istniejących w dokumentach strategicznych i programowych dotyczących EZR oraz weryfikacji, jak w rzeczywistości istniejące zalecenia są realizowane przez głównych interesariuszy. Na podstawie analizy i interpretacji uzyskanych danych uznano, że realizacja EZR w Polsce nie jest satysfakcjonująca. Brak jest jednego, spójnego rozumienia pojęcia EZR oraz samego zrównoważonego rozwoju, wizji EZR w Polsce oraz spójnej struktury koordynującej działania różnych podmiotów w tym zakresie. 
Zdaniem ekspertów powinien powstać systemowy program cyklicznych badań dotyczących oceny stanu wdrażania EZR w Polsce, a badania powinny być prowadzone przy użyciu tej samej metody badawczej, co umożliwi dokonanie porównawczej analizy wyników.

\section{Bibliografia:}

Banach, Czesław. 1996. Społeczeństwo polskie wobec wyzwań transformacji systemowej. W: Edukacja w zmieniajacym się społeczeństwie, red. Ireneusz Białecki, 103-114. Warszawa: „Tepis”.

Borys, Tadeusz. 2006. Edukacja dla zrównoważonego rozwoju jako wyzwanie globalne. W: Edukacja dla zrównoważonego rozwoju, red. Tadeusz Borys, 16-22. Białystok: Ekonomia i Środowisko.

Cichy, Danuta. 2002. Ewaluacja zmian w edukacji środowiskowej wprowadzanych reformą szkolną. W: Edukacja środowiskowa. Założenia i rzeczywistość po reformie szkolnej, red. Danuta Cichy, 15. Warszawa: PAN.

Demeshkant, Natalia. 2011. Świadomość środowiskowa studentów wyższych uczelni rolniczych Polski i Ukrainy oraz ich gotowość do podejmowania proekologicznych działań zawodowych. Wrocław: Wyd. Uniwersytet Przyrodniczy.

Domeracki, Piotr i Włodzimierz Tyburski. 2011. Podstawy edukacji i kształtowania świadomości społecznej w duchu zrównoważonego rozwoju. Edukacja do zrównoważonego rozwoju. W: Zasady kształtowania postaw sprzyjających wdrażaniu zrównoważonego rozwoju, red. Włodzimierz Tyburski, 233-283. Toruń: Wyd. Naukowe UMK.

Encyklopedia pedagogiczna XXI wieku. 2003. T. 1: A-F. Warszawa: Wyd. Akademickie „ŻAK”.

Gajuś-Lankamer, Ewa i Anna Wójcik. 2010. Edukacja dla zrównoważonego rozwoju. Poradnik dla studentów i nauczycieli. Lublin: UMCS.

Godlewska, Joanna. 2009. Edukacja dla zrównoważonego rozwoju. W: Zrównoważony rozwój - aspekty rozwoju społeczności, red. Magdalena Skup, 15-20. Białystok: Fundacja Forum Inicjatyw Rozwojowych.

Grodzińska-Jurczak, Małgorzata et al. 2003. Increasing Participation in Rational Municipal Waste Management - a Case Study Analysis in Jaslo City (Poland). Resources, Conservation and Recycling, 38(1), 67-88. 
Grodzińska-Jurczak, Małgorzata et al. 2010. Potrzeby i warunki edukacji na rzecz zrównoważonego rozwoju w Polsce. Problemy Ekorozwoju - Problems of Sustainable Development, 5(2), 95-106.

Hłobil, Agnieszka. 2010. Teoria i praktyka edukacji ekologicznej na rzecz zrównoważonego rozwoju. Problemy Ekorozwoju - Problems Of Sustainable Development, 5(2), 87-94.

Jutvik, Gitte i Inese Liepina. 2000. Edukacja ku zmianie: Podręcznik edukacji na rzecz zrównoważonego rozwoju. Dostęp: 15.01.2017. www.balticuniv.uu.se/index.php/.../doc.../204-education-for-change-handbook-polish.

Kostecka, Joanna. 2009. Dekada edukacji dla zrównoważonego rozwoju - wizja, cel, strategia. Problemy Ekorozwoju, 4(2), 101-106.

Malewski, Mieczysław. 2000. Modele pracy edukacyjnej z ludźmi. Teraźniejszość - Człowiek - Edukacja, 1(9), 47-63.

Malewski, Mieczysław. 2000. Teoretyczne problemy edukacji dorosłych i polityki oświatowej. Edukacja Dorosłych, 2(11), 47-63.

Ministerstwo Środowiska (MŚ). 2001. Przez Edukację do Zrównoważonego Rozwoju. Narodowa Strategia Edukacji Ekologicznej. Warszawa: Ministerstwo Środowiska.

MOŚ. 2012a. Badania dotyczące edukacji dla zrównoważonego rozwoju. Dostęp: 14.01.2017. https://www.mos.gov.pl/srodowisko/edukacja-ekologiczna/badania/badania-dotyczace-edukacji-dla-zrownowazonegorozwoju/.

MOŚ. 2012b. Edukacja dla zrównoważonego rozwoju w opiniach nauczycieli (badanie jakościowe) - diagnoza sytuacji w zakresie realizacji edukacji dla zrównoważonego rozwoju przez nauczycieli wybranych szkót. Dostęp: 12.02.2017. https://www.mos.gov.pl/g2/big/2012_12/550ce6500d794c6d9450a971ba6da957.pdf.

National Geografic. 2009. Wręczenie zielonych certyfikatów. Dostęp: 12.02.2017. www.national-geographic.pl/aktualnosci/wreczenie-zielonych-certyfikatow.

Okoń, Wincenty. 1992. Stownik pedagogiczny. Warszawa: PWN. 
Polski Komitet ds. UNESCO. 2006. UNESCO a Zrównoważony Rozwój. Dostęp: 14.01.2017. www.unesco.pl/edukacja/dekada-edukacji-nt-zrownowazonego-rozwoju/unesco-a-zrownowazony-rozwoj/.

Portal Dolceta. 2011. Dostęp: 23.01.2017. www.dolceta.eu.

Regionalne Samorządowe Centrum Edukacji Ekologicznej przy Sejmiku Samorządowym we Wrocławiu (RSCEE). 1993. Szczyt Ziemi: Rio'92. Agenda 21. Przewodnik dla samorząów. Dostęp: 21.01.2017. http://multiversum.org/wp-content/uploads/2014/02/przew_agenda_21.pdf.

Stoltenberg, Ulte i Gerd Michelsen. 1999. Lernen nach der Agenda 21. W: Umweltbildung: den Möglichkeitssinn wecken, red. Renate Strohschneider, 45-54. Niedersachsen: Alfred Toepfer Akademie für Naturschutz.

Zespół Konsultantów ITTI. 2012. Ekspertyza dotyczaca edukacji dla zrównoważonego rozwoju w Polsce. Dostęp: 22.01.2017. https://www. mos.gov.pl/fileadmin/user_upload/Ekspertyza_ dotyczaca_edukacji_ dla_zrownowazonego_rozwoju_w_Polsce.pdf. 



\section{Małgorzata Kaniewska}

Wyższa Szkoła Gospodarki Euroregionalnej im. Alcide De Gasperi w Józefowie

- Wydział Nauk Społecznych

gochakaniewska@gmail.com

Marcin Klimski

Uniwersytet Kard. Stefana Wyszyńskiego w Warszawie - Wydział Filozofii Chrześcijańskiej m.klimski@uksw.edu.pl

\section{Edukacja globalna wzmocnieniem procesu budowania solidarnego i sprawiedliwego świata}

\section{Wstęp}

Pojęcie globalizacji jest przedmiotem licznych debat i dyskusji, których celem jest wyjaśnienie istotnych zmian zachodzących $\mathrm{w}$ dzisiejszym świecie. Globalizacja w ostatnim stuleciu stała się faktem. Składa się na to powstanie ogólnoświatowych relacji gospodarczych, rozwój komunikacji i działalności międzynarodowych korporacji. Błyskawiczny przepływ informacji i globalny ruch towarów uświadamiają ludziom wzrastający potencjał współzależności. Globalizacja wiąże się nierozerwalnie z nowoczesnością. Pomimo wielu pozytywnych aspektów związanych z tym pojęciem należy zauważyć, że obecna gospodarka rynkowa prowadzi do pogłębiania się różnic, przede wszystkim ekonomicznych, pomiędzy bogatą Północą a biednym Południem. Przyczynia się także do prowadzenia rabunkowej polityki wykorzystywania zasobów naturalnych oraz dewastacji i degradacji obszarów oddalonych od centrów dużych miast.

Stale rozwijający się świat, przepełniony nowoczesnymi technologiami, stawia nas przed zupełnie nowymi problemami i wyzwaniami, których zasięg przekracza nie tylko nasze najbliższe otoczenie, ale również granice krajów i kontynentów. Aby przeciwdziałać nowym problemom potrzebne jest innowacyjne podejście do edukacji, które umożliwi zrozumienie zależności pomiędzy własnym życiem i życiem innych ludzi na całym świecie, w stale zmieniającej się wielokulturowej, globalnej społeczności. Naprzeciw nowym dylematom wychodzi edukacja glo- 
balna, u podstaw której leżą wartości o charakterze kognitywnym. Rozumiane $\mathrm{w}$ ten sposób mogą być wsparciem dla edukacji, motywacją do działania czy przesłanką do rozwiązywania konfliktów w środowisku społeczno-przyrodniczym.

\section{Edukacja globalna - wyjaśnienie pojęcia}

Wyjaśnienie pojęcia edukacja globalna (ang. global education) jest trudne, gdyż brak jest jednej, obowiązującej powszechnie definicji. W Deklaracji Edukacji Globalnej z Maastricht (ang. The Maastricht Global Education Declaration), która została przyjęta przez Europejski Kongres Edukacji Globalnej, możemy odnaleźć następującą definicję: „Edukacja globalna otwiera ludziom oczy i umysły na rzeczywistość panującą na świecie oraz uświadamia o konieczności podejmowania działań na rzecz większej sprawiedliwości, równości i przestrzegania praw człowieka dla wszystkich. Edukacja globalna jest globalnym wymiarem edukacji obywatelskiej i obejmuje edukację rozwojową, edukację o prawach człowieka, edukację o zrównoważonym rozwoju, edukację na rzecz pokoju i zapobiegania konfliktom oraz edukację interkulturalną". (Globalna.edu.pl 2017). Z kolei w Encyklopedii Powszechnej PWN edukacja globalna definiowana jest jako: „koncepcja umiędzynarodowienia edukacji, której celem jest wyposażenie młodego pokolenia w globalną świadomość" (Encyklopedia.pwn.pl 2017). Natomiast definicja edukacji globalnej, która została opracowana w 2011 roku przez międzysektorowy zespół złożony z przedstawicieli Ministerstwa Edukacji Narodowej, Ministerstwa Spraw Zagranicznych, Ministerstwa Środowiska, ośrodków doskonalenia nauczycieli, uczelni wyższych i organizacji pozarządowych brzmi następująco: „Edukacja globalna to część kształcenia obywatelskiego i wychowania, która rozszerza ich zakres przez uświadamianie istnienia zjawisk i współzależności globalnych. Jej głównym celem jest przygotowanie odbiorców do stawiania czoła wyzwaniom dotyczącym całej ludzkości. Przez współzależności rozumiemy wzajemne powiązania i przenikanie systemów kulturowych, środowiskowych, ekonomicznych, społecznych, politycznych i technologicznych" (Zagranica.org.pl 2017). Autorzy dokumentu podkreślają, że podobny zakres znaczeniowy do terminu edukacja globalna ma edukacja rozwo- 
jowa, edukacja na rzecz zrównoważonego rozwoju, edukacja na rzecz globalnego obywatelstwa. Brak jednej definicji zrównoważonego rozwoju rzutuje na trudności w rozróżnianiu, uszczegółowianiu wyżej wymienionych terminów. Osoby podejmujące tę problematykę w swoich pracach koncentrują się głównie na sposobach promowania edukacji na rzecz zrównoważonego rozwoju, edukacji globalnej oraz na osadzeniu ich w kulturze poszczególnych krajów za pomocą edukacji, a nie na samym zakresie pojęciowym. „Podstawowym celem edukacji na rzecz zrównoważonego rozwoju jest przekazanie wszystkim ludziom wiedzy i motywacji potrzebnej do działania na rzecz zrównoważonego rozwoju i życia zgodnie z jego zasadami (...) może być postrzegana jako ciągły proces w zmieniającym się świecie” (Jutvik i Liepina, 21).

Brak jednej, powszechnie obowiązującej definicji edukacji globalnej, edukacji na rzecz zrównoważonego rozwoju może być również powiązany z faktem, że w różnych krajach edukacje te odpowiadają na różne potrzeby i problemy. Bez wątpienia są one odpowiedzią edukacyjną na procesy globalizacyjne. Autorzy niniejszego opracowania zwracają uwagę, że edukacja globalna w bardziej szczegółowy sposób niż edukacja na rzecz zrównoważonego rozwoju akcentuje stworzenie partnerskiego modelu współpracy pomiędzy narodami, kulturami, religiami, zarówno na poziomie mikro, jak i makro. Kluczowe miejsce w edukacji globalnej zajmuje pojęcie współzależności. Ukazanie korelacji występujących i działających we wszystkich kierunkach i na różnych poziomach: gospodarczym, politycznym, środowiskowym, kulturowym należy do głównych celów tej edukacji.

\section{Główne zagadnienia podejmowane w ramach edukacji globalnej}

Edukacja globalna może i powinna być realizowana na wszystkich etapach edukacyjnych, poczynając od przedszkola. Powinna też obejmować edukację formalną i nieformalną, poprzez działania edukacyjne w formie np. zajęć dodatkowych, warsztatów, akcji, konkursów, festynów, happeningów itp. Edukacja globalna obejmuje swoim zakresem niezwykle szerokie spektrum zagadnień i tematów. Do głównych wyzwań możemy zaliczyć dążenie do zrównoważonego rozwoju, w tym (Zagranica.org.pl 2017): 
$\checkmark$ zapewnienia pokoju i bezpieczeństwa na świecie;

$\checkmark$ ochrony praw człowieka;

$\checkmark$ poprawy jakości życia w krajach słabo rozwiniętych;

$\checkmark$ ochrony środowiska naturalnego;

$\checkmark$ budowania partnerskich relacji pomiędzy państwami bogatej

Północy i biednego Południa.

Edukacja globalna stawia sobie bardzo ambitne i rozległe zadania. Należy jednak zauważyć, że podejmowane w jej ramach tematy nie są czymś nowym. Powyższe zagadnienia stanowią raczej wszechstronną myśl przewodnią nauczania na wszystkich poziomach. Kompleksowość tematów wymusza bardzo długotrwały proces przekazywania treści, które ponadto podlegają silnej dynamice zachodzących stale przemian. Edukacja globalna nie jest przedmiotem, ale kierunkiem, który rozciąga się na cały program nauczania. Jego celem jest pomoc odbiorcom edukacji w zrozumieniu wszystkich informacji i opinii, jakie codziennie napływają do nich z całego świata.

Do podstawowych celów edukacji globalnej należy zaliczyć umożliwienie ludziom udziału w kształtowaniu lepszej, wspólnej przyszłości dla świata. Edukacja globalna podkreśla jedność i wzajemną zależność społeczności światowej. Jest dążeniem do pozytywnego uświadomienia sobie różnorodności kulturowej, do afirmacji sprawiedliwości społecznej i praw człowieka, a także budowania pokoju i działania na rzecz zrównoważonej przyszłości w różnych czasach i miejscach.

Promowanie założeń edukacji globalnej staje się w ostatnich latach coraz bardziej powszechne. Należy podkreślić rolę, jaką w tej kwestii odegrało Europejskie Centrum na rzecz Współzależności i Solidarności Światowej - Centrum Północ-Południe (ang. North-South Centre - European Centre for Global Interdependence and Solidarity). Jest to instytucja działająca w ramach Rady Europy, której celem jest stworzenie struktur dla europejskiej współpracy, aby zwiększyć świadomość społeczeństw na temat globalnych współzależności, a także promować politykę solidarności zgodnej z założeniami i celami Rady Europy, szacunkiem dla praw człowieka, demokracją i sprawiedliwością społeczną. Działania Centrum skupiają się wokół dwóch obszarów: 
a) Filar instytucjonalny:

$\checkmark$ udoskonalenie zasad, partnerstwa w dziedzinie edukacji globalnej;

$\checkmark$ prace nad rozwojem europejskich ram dla edukacji globalnej i uznaniem edukacji globalnej przez decydentów (ang. Global Education Recommendations);

$\checkmark$ zapewnienie przestrzeni do dialogu, aby można było dzielić się doświadczeniami i określić wspólne priorytety (poprzez krajowe i regionalne seminaria);

$\checkmark$ wzmacnianie sieci zainteresowanych stron na szczeblu globalnym i europejskim, ze zwróceniem szczególnej uwagi na nowe państwa członkowskie Unii Europejskiej (sieć GEW, ang. The Global Education Week);

$\checkmark$ promocja praktyki edukacji globalnej i zachęcanie do jej wdrożenia (Tydzień Edukacji Globalnej).

b) Filar edukacyjny:

$\checkmark$ oferowanie wytycznych i kursów szkoleniowych dla wychowawców (z sektorów formalnych i nieformalnych), aby mogli zrozumieć i praktykować edukację globalną (Coe.int 2017).

Celem powyższych działań jest poszerzanie wiedzy, umiejętności, wartości i postaw potrzebnych do zapewnienia sprawiedliwego, zrównoważonego świata, w którym każdy ma prawo i możliwości do wykorzystywania swojego potencjału. Dążenia te muszą być realizowane już od początkowych etapów edukacyjnych poprzez ukazywanie uczniom wpływu jednostki na procesy globalne i wpływu tychże procesów na jednostkę, niwelowanie istniejących stereotypów, uprzedzeń i dyskryminacji, kształtowanie umiejętności krytycznego myślenia, przedstawianie perspektywy życia ludzi w różnych częściach globu, pokazywanie różnic pomiędzy ludźmi, ale również ich cech wspólnych, budowanie świadomości podejmowanych decyzji i działań. Ważne jest promowanie różnorodności obyczajowej, kulturowej bez oceniania i wartościowania w stosunku do rzeczywistości, którą znamy. 
U podstaw edukacji globalnej znajduje się odwołanie do takich wartości jak: sprawiedliwość, solidarność, odpowiedzialność, wolność, pokój, równość. Możemy je odnaleźć w czterech głównych obszarach edukacji globalnej wskazanych przez Dakmarę Georgescu, są to:

$\checkmark$ edukacja empatyczna, która kształtuje umiejętność rozumienia i stawiania się na miejscu innych, spoglądania na problemy oczami innych ludzi;

$\checkmark$ edukacja dla solidarności, wyzwalająca poczucie wspólnoty wykraczającej poza granice, grupy, kraju czy rasy społeczności oraz rozwijanie poczucia budowania tej wspólnoty;

$\checkmark$ edukacja dla wzajemnego szacunku i zrozumienia, umacniająca postawy skłaniające do integracji z innymi kręgami kulturowymi i gotowość do przyjęcia ich we własnym kręgu;

$\checkmark$ edukacja przeciwko nacjonalizmowi, rozwijająca świadomość równości z obywatelami innych społeczeństw, z pominięciem uprzedzeń i zakorzenionych stereotypów; budowanie umiejętności „otwierania się" na inne narody oraz komunikowanie się (Georgescu 2017).

Jednym z warunków skuteczności edukacji globalnej jest umiejscowienie w centrum uwagi refleksji moralnej.

\section{Budowanie normatywnego systemu reguł postępowania jako etyczna podstawa edukacji globalnej}

Każde działanie, jakie podejmuje osoba, powinno być przeprowadzone w oparciu o określony, wcześniej zaplanowany schemat postępowania. Jest to szczególnie istotne wtedy, gdy dotyczy procesu edukacji, który nierzadko urzeczywistniany jest w różnych grupach społecznych. W edukacji globalnej realizacja założeń skierowana jest m.in. do najmłodszej grupy społecznej - dzieci i odbywa się zazwyczaj w oparciu o konkretne programy kształcenia. Kształtowanie już od najmłodszych lat u dzieci umiejętności krytycznego i systemowego myślenia, przełamywanie stereotypów i uprzedzeń, ukazywanie wartości ludzkiego życia, godności osoby ludzkiej, równości, pokoju, tolerancji, solidarności czy poczucia wspólnotowości wymaga skrupulatnie przeprowadzonego procesu. Ma to służyć zmianie postaw, zachęceniu do podejmowania 
konkretnych działań, zaniechania stereotypowego myślenia o otaczającym świecie. W programach kształcenia istnieje zatem potrzeba odwoływania się do wypracowanego na gruncie etyki katalogu wartości, które będą służyły osiągnięciu zasygnalizowanego celu.

Rozważania nad etyką, jej rolą w wychowaniu i nauczaniu podjęto już w starożytności i wciąż są kontynuowane. T. Styczeń proponuje, aby w kontekście refleksji nad etyką przyjąć zbiór uporządkowanych oraz uargumentowanych stwierdzeń odnoszących się do wartości moralnej humanistycznego postępowania (Styczeń 1984, 26). Jest to nauka regulująca wszelkie działania człowieka w kontekście osiągania konkretnego dobra. Inną propozycję definicji etyki podaje T. Ślipko: „Etyka jest to nauka filozoficzna, która ustala moralne podstawy i reguły ludzkiego działania przy pomocy wrodzonych człowiekowi zdolności poznawczych" (Ślipko 1974, 17). Skoro etyka odnosi się do ludzkiego działania i należy ją przypisywać tylko ludziom, to w konsekwencji musi uwzględniać wpływ władz poznawczych i pożądawczych, które współdziałają ze sobą dla rozpoznania prawdy, dobra i ich pragnienia. Byt osobowy, określany również jako istota psychofizyczna, jest podmiotem tych władz. T. Ślipko zaznacza, iż na gruncie rozumowań filozoficzno-etycznych odwoływać się można tylko do jednej władzy poznawczej, jaką stanowi intelekt. Dalszą konsekwencją jest wyszczególnienie w intelektualnej władzy poznawczej, wykorzystywanej w diagnozie filozoficzno-etycznej, poznania ściśle rozumowego oraz doświadczenia. Ogólnie w naukach filozoficznych, a zatem również w etyce, poznanie ściśle rozumowe określa się jako zdolność myślenia abstrakcyjnego, którą posiada wyłącznie byt osobowy. Za pomocą tej umiejętności jest on w stanie formułować ogólne kategorie moralne oraz stosowne normy działania. Doświadczenie w perspektywie etycznej oznacza podjętą przez każdą osobę refleksję nad swoją świadomością moralną. W związku z tym zasadne jest implementowanie wartości i norm etycznych do szeroko rozumianego procesu edukacji globalnej.

Zagadnienie wartości podejmowane jest w wielu szczegółowych obszarach refleksji humanistycznej. Dzieje się to za sprawą odwoływania się człowieka, w jego powszechnym postępowaniu, do odpowiedniego systemu wartości. Proces ten pozwala mu na obranie właściwego kierunku działań wraz z równoczesnym dążeniem 
do określonego celu. Wartości odgrywają istotną rolę w procesach poznawczych i aktach decyzyjnych zwłaszcza wtedy, gdy człowiek staje przed koniecznością wybierania spośród możliwości determinujących z kolei późniejsze działania. W związku z zadaniami, jakie pełnią wartości w życiu każdego człowieka, pojawia się kwestia posiadania takiego katalogu wartości, który będzie kierował ku dobru. „Wartość” stanowi pojęcie zakresowo bardzo szerokie i zarazem podstawowe dla człowieka. Sam akt wartościowania moralnego danego czynu właściwy jest człowiekowi i rozumieć go należy w kontekście umiejętności dokonywania ocen moralnych. Za sprawą wartości moralnych można kształtować osobowość człowieka, nadając jej niepodzielny wymiar (Dyk 2002, 45).

Odwoływanie się do jakiegokolwiek katalogu wartości, który funkcjonuje w rzeczywistości społecznej, wiąże się z wybieraniem tych wartości, które są w danej sytuacji dla człowieka najbardziej korzystne. Dobrze oddaje ów mechanizm koncepcja człowieka wybierającego (homo eligens), którą opracował Andrzej Siciński, prowadząc badania nad stylami życia Polaków. Ujmował on kulturę jako repertuar wartości, symboli, znaków, wzorów osobowych, z którego jednostki, w sposób mniej lub bardziej świadomy, wybierają określone wartości, kształtując indywidualne style życia (Siciński 1985, 48, 51). „Styl życia - pisał - zostaje zakotwiczony w kulturze danego narodu. Kultura ma charakter repertuaru proponującego pewne możliwości, a jednostka dokonuje w nim wyboru (...). Styl życia jest przejawem jakiejś zasady (zasad wyboru) codziennego postępowania spośród repertuaru zachowań możliwych w danej kulturze" (Siciński 1985, 53). W tej perspektywie nasuwa się pytanie, jak dochodzi do budowania w zbiorowości ładu aksjologicznego, który zapewnia konsensus i ład społeczny umożliwiający komplementarne interakcje interpersonalne prowadzące do realizacji ich celów, a który sprzeciwiałby się skrajnemu relatywizmowi aksjologicznemu i hiperindywidualizmowi. Jednym z rozwiązań jest budowanie konsensusu w zakresie wartości podstawowych, który byłby zachowywany i przekazywany przez instytucje wychowujące, takie jak: rodzina, szkoła, kościoły, massmedia.

Systemy wartości są zatem zhierarchizowane, ale czerpanie z nich odbywa się w sposób indywidualny. Adekwatne do zaistniałych okoliczności posługiwanie się wartościami wymaga jednak pewnej wiedzy o nich. Do- 
starczają jej wspomniane różne dyscypliny naukowe, na gruncie których wybitni myśliciele podejmowali trud usystematyzowania ich oraz badali relacje, jakie między wartościami zachodzą. J. Tischner w swoich badaniach skupiał uwagę na zagadnieniu tzw. „myślenia według wartości”. Chodziło mu przede wszystkim o sprawdzenie, czym są one dla samego człowieka. Wartości określają pewne wybory, jakich dokonuje człowiek. Stają się również pewnego rodzaju „beneficjentem” relacji, jakie zachodzą pomiędzy ludźmi. J. Tischner poszukiwał wartości we wszystkim, co stanowi rzeczywistość, a zwłaszcza w człowieku (Węgrzecki 2002, 93).

Z poczynionych wcześniej ustaleń wynika, iż wartości towarzyszą człowiekowi niemal w każdej działalności. Rola, jaka mu przypadła w aksjologicznym postępowaniu, jest dwutorowa. W pierwszym przypadku realizowanie się człowieka jako bytu społecznego zależy od cywilizacji, w której się znajduje, oraz od kultury, jaka w niej panuje. W konsekwencji jest on poniekąd uzależniony od wartości, jakie są w tej rzeczywistości kultywowane. Druga płaszczyzna aksjologicznej strategii życia wskazuje, że każdemu człowiekowi dozwolone jest tworzenie lub uznawanie czegoś za wartość. Dlatego dla jednego człowieka wartością jest określona cecha lub postawa, a dla drugiego już niekoniecznie. Zatem uznanie czegoś za wartość jest procesem subiektywnym. Oczywiste jest też, że aksjologiczne odwołanie winno występować w każdej fazie przedwstępnej naszego działania i zamierzonych przedsięwzięć. To postuluje m.in. etyka środowiskowa w jej ogólnym rozumieniu. Wartości, które propagowane są w poszczególnych koncepcjach, stanowią drogowskaz dla człowieka, aby jego postępowanie względem środowiska naturalnego było słuszne. Środowisko stanowi ten obszar, w którym sam człowiek może się realizować. Bez natury, rozumianej jako środowisko przyrodnicze, kultura twórcza i wytwórcza gatunku Homo sapiens nie może zaistnieć. Aksjologia etyki środowiskowej „(...) jest ogólną orientacją ukierunkowującą myślenie i działanie na to, co najbardziej elementarne, a jednocześnie szczególnie wartościowe i doniosłe" (Tyburski 2011, 108). Powszechnie uznane jest stwierdzenie, że człowiek myśli według wartości. Wobec tego zasadne jest formowanie świadomości dotyczącej poprawnego bytowania człowieka w środowisku społeczno-przyrodniczym w oparciu o zagadnienia aksjologiczne. Zasygnalizowana relacja, człowieka z przyrodą, może być poprawnie realizowana 
wówczas, gdy byt ludzki będzie mógł odwołać się do katalogu wartości uwzględniającego także interesy istot pozaosobowych. Ponadto wszelka działalność człowieka, której celem jest zagospodarowywanie rzeczywistości, coraz częściej scalająca zadania w sferze teorii i praktyki, właśnie w oparciu o wartości może zyskać nowy wymiar. Wszelkie praktyki skupiające się na kształtowaniu nowego myślenia w dziedzinie etyki, w tym środowiskowej, nawiązują do przesłanek aksjologicznych. Uwzględnienie wartości w praktyce dnia codziennego staje się możliwe w dużej mierze dzięki odbytemu wcześniej procesowi edukacji. Podczas jego trwania człowiek uczy się właściwego egzystowania w środowisku społeczno-przyrodniczym, a tym samym ma on szanse stać się świadomym obywatelem rzeczywistości globalnej.

W. Tyburski w kilku punktach wyraża zasadność odwoływania się do systemu wartości w odniesieniu do ich charakteru:

wartości cechuje wymiar wiedzotwórczy, ponieważ za ich pomocą człowiek jest informowany o fundamentalnych założeniach określonej koncepcji;

$\checkmark$ poprzez wartości człowiek może wyrazić subiektywną opinię na temat teorii czy programów, które pretendują do praktycznego wdrożenia, dlatego wartości pomocne są $\mathrm{w}$ doprecyzowywaniu takich przedsięwzięć;

$\checkmark$ poprawnie utworzone katalogi wartości wraz z ich uprawomocnieniem stymulują nie tylko pojedynczego człowieka, ale również i społeczeństwo bądź organizacje, do działania w oparciu o nie;

$\checkmark$ wartości jasno przedstawiane stają się podstawą do rozwiązywania i przeciwdziałania konfliktom zaistniałym na styku człowiek - ekonomia - środowisko przyrodnicze; ponadto stymulują do podejmowania działań nienaruszających elementarnych priorytetów człowieka i świata przyrody;

$\checkmark$ w wartości wpisany jest również wymiar praktyczny, gdyż pomagają tworzyć właściwe ustawy, kodeksy, rozporządzenia czy ogólnie zasady postępowania systematyzujące odniesienie człowieka do środowiska społeczno-przyrodniczo-gospodarczego (Tyburski 2011, 109). 
Opierając się na systemie wartości należy wyprowadzać normy, które posłużą do znajdowania jak najlepszego konsensusu dla sytuacji spornych w relacji człowiek - przyroda, co stwarza także szansę na zaistnienie solidarnego i sprawiedliwego świata. Jest kwestią oczywistą, że bytowanie gatunku ludzkiego w środowisku nie może odbywać się bez pozostawiania w nim nawet najmniejszego śladu. Chodzi o to, by wszelkie ludzkie postępowanie uwzględniało moralne następstwa tych czynów. Równie ważne jest, aby wartości i normy stymulowały jednostki do realizowania działań na rzecz ochrony środowiska społeczno-przyrodniczego (Tyburski 2011, 110). Pewne skutki, jakie antroposfera odcisnęła na biosferze, są nieodwracalne, ale zadanie, jakie stoi przed współczesnym człowiekiem, kieruje go również do formowania środowiska przyjaznego i bezpiecznego nie tylko dla niego samego, ale również i komponentów tego środowiska. Biosfera, do której zalicza się też człowiek, winna być miejscem realizacji ładu i harmonii, oczywiście w miarę realnych możliwości. Edukowanie w perspektywie globalnych problemów nie może odbywać się z pominięciem wartości i norm wypracowanych na kanwie refleksji filozoficzno-etycznej. „Przyjmowany system wartości rzutuje na całość procesów myślowych człowieka, na jego decyzje, a zatem i jego postawy oraz zachowania. Dlatego też ta sfera oddziaływań edukacyjnych pozostaje w sferze zainteresowań całego społeczeństwa" (Wosik-Kowala i Zubrzycka-Maciąg 2011, 31). W badaniach etyki pedagogicznej wyodrębniona została dziedzina społecznych, etycznych wartości wychowania, które odnoszą się do współegzystencji z innymi. Odniesienie się do tych wartości pozwala na odpowiednie funkcjonowanie w społeczeństwie, warunkuje bowiem prawidłowe kooperowanie z innymi ludźmi w rozmaitych środowiskach czy wspólnotach (Homplewicz 1996, 147).

\section{Urzeczywistnianie wartości solidarności i wspólnotowości jako cel edukacji globalnej}

Solidarność i wspólnotowość to wartości, które można uznać za podstawę edukacji globalnej. Ich znaczenie jest kluczowe dla budowania zrównoważonego świata, przez co są artykułowane w różnych koncepcjach etyki globalnej czy środowiskowej. W efekcie ukazuje się konieczność pielęgnowania idei wspólnoty ludzkiego świata ze światem 
przyrody. Wyrazem tego jest np. holistyczne ujęcie etyki środowiskowej prezentowane $\mathrm{w}$ poglądach $\mathrm{A}$. Leopolda oraz biocentrycznie zorientowana argumentacja, w której odwołanie się do procesu ewolucji ma na celu pokazanie takiej samej drogi przystosowawczej człowieka, jak i innych gatunków. Zatem solidarność staje się wartością autoteliczną, „(...) wyznaczającą ideał człowieka zharmonizowanego w strukturze koniecznej wspólnoty gatunkowej" (Lipiec 1999, 219). Wartości solidarności i wspólnotowości wyrażone są również w koncepcji antropocentrycznej. Chociaż człowiek transcenduje świat bytów pozaludzkich, to wartości te obligują go do odpowiednich zachowań i działań na rzecz środowiska społeczno-przyrodniczego.

Postulowana na gruncie różnych etyk wartość solidarności wraz z jednoczesnym budowaniem wspólnoty ludzi z przyrodą nie sprowadza się tylko do zaleceń normatywnych. Uwzględnianie jej wymaga przemyślanego formułowania wytycznych służących rozwojowi cywilizacji. Wszelki postęp społeczno-gospodarczy nie może odbywać się z pominięciem interesów bytów pozaludzkich. Aspekt ten dobrze wzmacnia stwierdzenie, iż „każda sensowna koncepcja rozwoju cywilizacyjnego musi uwzględniać aksjomat o wspólnocie losów człowieka i przyrody" (Tyburski 2011, 147-148). Wśród innych przejawów, jakie wartości solidarności i wspólnotowości wnoszą do praktyki edukacyjnej, są: konieczność podjęcia problemów ekologicznych w wymiarze międzynarodowym oraz troska o przyszły stan środowiska, z którego zasobów będą korzystały następne generacje ludzi. W efekcie zakłada się zaistnienie w rzeczywistości społeczno-przyrodniczej tzw. solidarności globalnej przyczyniającej się do kreowania nowego stylu myślenia i działania niepodlegającego zróżnicowaniom politycznym i kulturowym (Tyburski 2011, 148).

\section{Zakończenie}

Edukacja globalna obejmuje swoim zakresem niezwykle szerokie spektrum tematów i zagadnień, skupionych wokół zagrożeń globalnych takich jak m.in. ubóstwo, migracje, przeludnienie, konflikty zbrojne, zmiany klimatyczne. Ta złożoność wymusza prowadzenie długotrwałego procesu przekazywania pełnych i rzetelnych informacji, pozwalających na obiektywną ocenę współczesnych zagadnień. Jest to trudne, gdyż treści te pod- 
legają silnej dynamice zachodzących stale przemian. Bez wątpienia kluczowe dla promocji edukacji globalnej w polskich szkołach jest umieszczenie konkretnych wytycznych i wymagań w podstawie programowej.

Należy podkreślić, że edukacja globalna powinna rozpoczynać się już na etapie edukacji przedszkolnej i wczesnoszkolnej, aby umożliwić stworzenie stabilnych podstaw do dalszego jej rozwoju w całym procesie kształcenia. Wczesna edukacja pozwoli na zdobycie wiedzy, umiejętności oraz ukształtuje postawy otwarte na tę problematykę.

Programy kształcenia, uwzględniające zagadnienia o charakterze globalnym powinny obejmować refleksję moralną i wyraźnie odwoływać się do wartości. Łączenie treści opartych na naukowych faktach $\mathrm{z}$ aksjologią podkreślającą m.in. znaczenie solidarności i sprawiedliwości wpisuje się w globalny proces budowania zrównoważonego świata. W tym znaczeniu edukacja globalna ujmowana jest systemowo oraz pragmatycznie. Właśnie w tym wymiarze ma szansę nie tylko uświadamiać społeczeństwo o współczesnych zagrożeniach dla zdrowia i życia czy globalnych problemach, ale także proponować i zarazem ukierunkowywać na taki katalog wartości, którego implementacja będzie oznaczać realną i odpowiedzialną reakcję na potrzeby ludzkości.

\section{Bibliografia:}

Borys, Tadeusz. 2006. Edukacja dla zrównoważonego rozwoju. Białystok: Wydawnictwo Ekonomia i Środowisko.

Coe.int. 2017. Global education activities. Dostęp: 9.04.2017. http:// www.coe.int/t/dg4/nscentre/GE/ge1_EN.asp?.

Dyk, Wiesław. 2002. Etyczny wymiar człowieka. Szczecin: Wydawnictwo Naukowe Uniwersytetu Szczecińskiego.

Encyklopedia.pwn.pl. 2017. Edukacja globalna. Dostęp: 15.03.2017. http://encyklopedia.pwn.pl/szukaj/edukacja\%20globalna.html.

Georgescu, Dakmara. 2017. Global Education Charter. Dostęp: 20.03.2017. https://www.coe.int/t/dg4/nscentre/Resources/Publications/ Global\%20Education\%20Charter.pdf.

Globalna.edu.pl. 2017. Edukacja globalna. Dostęp: 9.04.2017. http:// www.globalna.edu.pl/edukacja_globalna $1 /$. 
Homplewicz, Janusz. 1996. Etyka pedagogiczna. Rzeszów: Wydawnictwo Wyższej Szkoły Pedagogicznej.

Jutvik, Gitte i Inese Liepina. Edukacja ku zmianie: podręcznik edukacji na rzecz zrównoważonego rozwoju. Program Uniwersytet Bałtyckiego.

Lipiec, Józef. 1999. Prolegomena etyki globalnej. W: Idea etyczności globalnej, red. Janusz Sekuła, 197-235. Siedlce: Wydawnictwo Seculum.

Siciński, Andrzej. 1985. Styl życia - kultura - wybór. Kultura i Społeczeństwo, 2, 48-53.

Styczeń, Tadeusz. 1984. W drodze do etyki. Lublin: Redakcja Wydawnictw KUL.

Ślipko, Tadeusz. 1974. Etos chrześcijański. Zarys etyki ogólnej. Kraków: Wydawnictwo Apostolstwa Modlitwy.

Tyburski, Włodzimierz. 2011. Etyka środowiskowa i jej wkład w budowanie świadomości sprzyjającej wdrażaniu idei zrównoważonego rozwoju. W: Zasady kształtowania postaw sprzyjajacych wdrażaniu zrównoważonego rozwoju, red. Włodzimierz Tyburski, 85-157. Toruń: Wydawnictwo Naukowe Uniwersytetu Mikołaja Kopernika.

Walosik, Alicja. 2013. Przez edukację do zrównoważonego rozwoju. Kraków: Wydawnictwo Naukowe Uniwersytetu Pedagogicznego.

Węgrzecki, Adam. 2002. Czym jest myślenie według wartości. W: Pytając o człowieka. Myśl filozoficzna Józefa Tischnera, red. Władysław Zuziak, 91-98. Kraków: Wydawnictwo Znak.

Wosik-Kawala, Danuta i Teresa Zubrzycka-Maciąg. 2011. Znaczenie wartości w wychowaniu. W: Wychowanie wobec wyzwań wspótczesności, red. Janusz Kirenko, Danuta Wosik-Kawala i Teresa Zubrzyckia-Maciąg, 29-45. Lublin: Wydawnictwo UMCS.

Zagranica.org.pl. 2017. Raport $z$ procesu międzysektorowego na temat edukacji globalnej. Dostęp: 20.03.2017. http://zagranica.org.pl/sites/ zagranica.org.pl/files/attachments/Dokumenty/Ministerialne/raport_z_procesu_miedzysektorowego_eg.pdf. 
Anna Kalinowska

Uniwersytet Warszawski - Uniwersyteckie Centrum Badań nad Środowiskiem

Przyrodniczym i Zrównoważonym Rozwojem

anna.kalinowska@pro.onet.pl

\section{Dekada ONZ dla Bioróżnorodności 2011-2020 \\ - recepty na zwiększenie świadomości społecznej znaczenia różnorodności biologicznej dla osiągania Celów Zrównoważonego Rozwoju 2030}

\section{Wstẹp}

Przyjęta podczas Konferencji ONZ „Środowisko i Rozwój” w Rio de Janeiro w 1992 r. Konwencja o różnorodności biologicznej (CBD) jest największą międzynarodową umową obejmującą kompleksowo złożone aspekty naszych związków z przyrodą ożywioną (Dokumenty Końcowe 1993, Kalinowska 2008; 2014b). Tak jak i wszystkie dokumenty przyjęte w Rio 1992 r. Konwencja przykłada wielką wagę do roli świadomości społecznej, poświęcając edukacji i komunikacji cały Artykuł 13 (Kalinowska 2008). Kolejne Konferencje Stron CBD (tzw. COP/CBD) wprowadzały różne rozwiązania służące kształtowaniu świadomości społecznej, by w efekcie zmniejszało się tempo utraty różnorodności biologicznej.

W celu skierowania publicznej uwagi na ten problem, w roku 2000 COP 4 wystąpił do ONZ o ustanowienie 22 maja jako Światowego Dnia Różnorodności Biologicznej. W roku 2002 COP 6 zaproponował międzynarodowa inicjatywę służącą rozwojowi metod edukacji pod nazwą „Komunikacja, Edukacja i Świadomość Społeczna" (Communication, Education, Public Awareness - CEPA/CBD) (Kalinowska 2008, Biodiversity 2016). Aby wzmocnić utrwalanie w powszechnej świadomości znaczenia całej sieci życia, na wniosek CEPA, ONZ ogłosiło rok 2010 Międzynarodowym Rokiem Bioróżnorodności - IBY 2010. Niestety, nawet taki zabieg promocyjny nie przyniósł oczekiwanych rezultatów. Skutki zmniejszania się różnorodności biologicznej, choć coraz drastyczniej ograniczają dobrostan ludzkości, doraźnie nie są tak spektakularne i nie przyciągają tak uwagi mediów i polityków jak zmiany klimatu. 
Doceniając powagę sytuacji, COP $10 \mathrm{w} 2010$ r. w Nagoi zatwierdził Strategiczny Plan dla Różnorodności Biologicznej 2011-2020 i jego 20 celów zwanych Celami z Aichi. Pierwszy z nich głosi: w roku 2020 ludzkość będzie świadoma wartości różnorodności biologicznej oraz tego, jakie kroki należy podjąć, by ją chronić i korzystać w sposób zrównoważony (Cele z Aichi 2016).

Wspierając ten ambitny cel i kompensując niespełnioną misję IBY 2010, ONZ ogłosiło Dekadę dla Bioróżnorodności 2011-2020 (DoB). Aby zdynamizować jej przebieg, Sekretariat CBD powołał międzynarodowy zespół ekspertów - Nieformalny Komitet Doradczy CEPA - Informal Advisory Committee, w skrócie CEPA/IAC. Obserwacja uczestniczącej w pracach Komitetu autorki, wynikająca z powołania w skład CEPA/ IAC, pozwala na przedstawienie wniosków z prac Komitetu, nowych trendów w edukacji dla różnorodności biologicznej oraz najciekawszych inicjatyw podjętych w różnych krajach w ramach DoB, w tym programu Uniwersyteckiego Centrum Badań nad Środowiskiem Przyrodniczym i Zrównoważonym Rozwojem. Na podstawie oceny synergii między dokumentami strategicznymi dotyczącymi różnorodności biologicznej i zrównoważonego rozwoju analizowane też będzie znaczenie edukacji i świadomości społecznej jako warunku osiągania Celów Zrównoważonego Rozwoju 2030 (SDGs 2030).

\section{Kierunki prac CEPA/IAC}

Zadaniem Komitetu Doradczego działającego przy Sekretariacie CBD w Montrealu jest wspieranie procesu wprowadzania w życie programu pracy Konwencji w dziedzinach objętych Artykułem 13. W jego skład wchodzą eksperci wybrani spośród osób zgłoszonych na zaproszenie Sekretarza Wykonawczego CBD przez poszczególne kraje. Obecnie w pracach CEPA/IAC uczestniczy 15 przedstawicieli rządów (w tym Polski), przedstawiciel społeczności lokalnych i ludów tubylczych oraz 12 reprezentantów kompetentnych organizacji, jak np. Międzynarodowa Unia Ochrony Przyrody IUCN czy WWF.

Uczestnictwo autorki w pracach CEPA/IAC (jako reprezentantki Polski i Europy Środkowej) umożliwia bezpośrednie podzielenie się informacjami o kierunkach działań Komitetu oraz wnioskami z dyskusji 
dotyczącej aktualnych problemów edukacji w różnych obszarach CBD. W posiedzeniach CEPA/IAC uczestniczą także eksperci zewnętrzni przedstawiciele innych konwencji związanych z CBD oraz agend ONZ (UNESCO, UNEP, GEF/UNDP), podając przykłady działań edukacyjnych i komunikacji społecznej prowadzonej przez ich instytucje.

W takim składzie Komitet został zwołany w lipcu 2016 r. w siedzibie Sekretariatu CBD w Montrealu, aby, dzieląc się osobistą oraz instytucjonalną wiedzą i doświadczeniem ekspertów, wspierać wykonanie decyzji COP 12, zobowiązującej do intensyfikacji działań komunikacji i edukacji służących osiąganiu celów Strategii CBD. Zawiera się w tym inspirowanie aktywności wzbogacających przebieg Światowej Dekady Bioróżnorodności 2011-2020 (Decade on Biodiversity 2011-2020) oraz inicjowanie prac nad Globalną Strategią Komunikacji i Edukacji dla Różnorodności Biologicznej, która powinna być wdrożona do końca roku 2020. Strategia taka ma zakreślić teoretyczne i praktyczne ramy działania dla instytucji państwowych i organizacji społecznych oraz placówek edukacyjnych i naukowych. Główna dyskusja ekspertów koncentrowała się wokół trudnego problemu, jak przekazywać przesłanie dokumentu Cele Aichi (Cele z Aichi 2016; Kalinowska 2013b). Komunikacja tego dokumentu strategicznego zawierającego aż 20 celów jest bardzo trudna, bo część z nich może być abstrakcyjna dla przeciętnego odbiorcy. Niektóre są kierowane do rządów, a tylko niektóre odnoszą się do indywidualnych działań i stylów życia. Uczestnicy dyskusji podkreślali konieczność dostosowania przekazu Celów z Aichi do zainteresowań konkretnych grup odbiorców i poszukiwania atrakcyjnych form dotarcia do nich, np. przez zaangażowanie charyzmatycznych przywódców i celebrytów. Podkreślano też potrzebę zaangażowania w kampanie dotyczące różnorodności biologicznej różnych sektorów życia publicznego oraz biznesu.

Bardzo ważne jest też przetłumaczenie dokumentów powstających podczas prac Konwencji na lokalne języki. To trudne, ale ważne wyzwanie, jako że niejednokrotnie trzeba poszukać opisowych określeń, bo naukowe terminy podane dosłownie są niemożliwe do pojęcia przez zwykłych ludzi bez fachowego przygotowania. Tylko wtedy, gdy dysponujemy interpretacją zgodną z duchem każdego języka, można zwięk- 
szyć znajomości zagadnień Konwencji oraz umożliwić szeroko korzystanie ze wspólnego poradnika metodycznego, jakim do tej pory jest opracowany z inicjatywy IUCN Biodiversity CEPA Toolkit (Hesselink et al. 2007). Kolejne wydanie tego przewodnika powstałego w 2007 r. powinno już uwzględniać nowe osiągnięcia badawcze na polu komunikacji społecznej i marketingu.

Członkowie Komitetu podkreślili też potrzebę rozszerzenia treści edukacji o zagadnienia interesujące specjalnie grupy o różnych oczekiwaniach, takich jak rolnicy, młodzież czy biznesmeni. Dopasowanie sposobu przedstawiania treści dotyczących bioróżnorodności do wymagań różnych adresatów jest zagadnieniem szeroko dyskutowanym również w Polsce (Kalinowska 2011). Taki przewodnik zawierający zbiór narzędzi dydaktycznych opracowany na podstawie analizy potrzeb użytkowników będzie szczególnie przydatny przy wdrażaniu Strategicznego Planu dla Różnorodności Biologicznej 2011-2020. W tym celu COP 12 zalecił przeprowadzenie warsztatów służących przeglądowi aktualnej wiedzy i dokonaniu analizy „białych plam” w tej dziedzinie z udziałem przedstawicieli różnych grup interesariuszy. W analizie takiej niezbędne jest uwzględnienie zdobyczy wiedzy psychologicznej i behawioralnej tak, by dopasować przekaz do potrzeb konkretnych grup docelowych w kontekście poszczególnych Celów z Aichi (Cele z Aichi 2016; Kalinowska 2014a i 2014b). Konsultacja wniosków z tego opracowania będzie następnym zadaniem członków CEPA/IAC.

\section{Przykłady dobrych praktyk komunikowania Celów z Aichi}

Przedstawiane przez ekspertów IAC programy i przykłady dobrych praktyk charakteryzowała wielka różnorodność przy równoczesnym nastawieniu na konkretne działania, zwłaszcza w krajach Afryki i Azji. Także w Europie uznanie wzbudzały inicjatywy promujące działania, na przykład organizowany w Belgii Dzień Różnorodności Biologicznej celebruje się konkretnymi akcjami w terenie, a publikacje edukacyjne przedstawiają możliwości i sposoby indywidualnych działań dla przyrody. W większości krajów coraz powszechniejsze jest wykorzystanie w komunikacji dotyczącej bioróżnorodności mediów społecznościowych. Także Sekretariat CBD odnotował systematyczny wzrost aktyw- 
ności w mediach społecznych: Twitterze, Facebooku oraz Instagramie. Eksperci pochwalili skuteczność korzystania z różnorodnych mediów społecznościowych, jednak zauważyli ich ograniczenia wynikające $\mathrm{z}$ mniejszej dostępności tych mediów w niektórych krajach oraz w starszych grupach wiekowych. W związku z tym wskazywano na konieczność łączenia różnych technik komunikacyjnych. Zwracano też uwagę na specyfikę komunikacji ze względu na to, czy skierowana jest do mężczyzn czy kobiet. Takie zróżnicowanie jest istotne ze względu na inne, zależnie od płci, sposoby oddziaływania na zasoby różnorodności biologicznej oraz trudniejszy w wielu krajach dostęp kobiet do edukacji. Podkreślano także rolę seniorów w odniesieniu do różnorodności biologicznej i niewykorzystane możliwości przekazywania przez nich wiedzy tradycyjnej.

Nowym nastawieniem w edukacji jest położenie nacisku na przekaz pozytywny, a odchodzenie od epatowania dramatycznymi statystykami. Dobrym tego przykładem jest wielka międzynarodowa kampania IUCN „NatureForAll” będącą kontynuacją poprzedniej „Love, Not Loss”. Kampania ta oparta jest na budzeniu pozytywnych uczuć do przyrody, a nie na strachu związanym z jej dramatycznymi stratami. Kampania ta ma 49 wielkich partnerów, między innymi Google.

\section{Przykłady dobrych praktyk edukacyjnych z Polski}

Ze strony Polski jako przykłady dobrych praktyk mogących mieć zastosowanie nie tylko w Europie przedstawiono kompleksowe działania edukacyjne prowadzone przez Uniwersyteckie Centrum Badan nad Środowiskiem Przyrodniczym i Zrównoważonym Rozwojem. Zainteresowanie wzbudził ogólnopolski program prowadzony we współpracy z Fundacją Ziemia i Ludzie dotyczący edukacji seniorów na temat różnorodności biologicznej. Program ten jest przygotowany i przeprowadzony w kilkudziesięciu Uniwersytetach Trzeciego Wieku (UTW) na terenie całej Polski. Wraz z opublikowanymi podręcznikami Różnorodność biologiczna to także my (Kalinowska i Batorczak 2014) oraz Przyszłość, jakiej chcemy dla naszych wnuków (Kalinowska i Batorczak 2012) zainspirował przedstawicieli wielu krajów. Oba podręczniki zawierają w jednej książce część skierowaną do dziadków i część skierowaną do dzieci tak, by umożliwić 
dziadkom przekazywanie wiedzy wnukom, inspirują seniorów do działania i owocują lawiną ich własnych inicjatyw lokalnych.

Edukację międzypokoleniową prowadzoną w rodzinie i przedszkolach przez dziesiątki uczestników szkoleń na UTW uznano za ewenement światowy (Różnorodność Biologiczna to także my 2016). W obliczu starzejących się społeczeństw i niedocenianiu potrzeb i możliwości pokolenia seniorów w podtrzymywaniu lokalnych tradycji, program ten, jak i podręczniki, chce wykorzystać do prowadzenia edukacji międzypokoleniowej m.in. Indyjskie Centrum Edukacji Ekologicznej. Zainteresowanie wzbudziły też rezultaty Europejskiego Programu „University Educators for Sustainable Development" (UE4SD), w którym uczestniczyły 54 uczelnie z całej Europy, w tym Uniwersytet Warszawski (Kalinowska i Batorczak 2015). Przygotowane w tym programie materiały służące podnoszeniu kompetencji kadry akademickiej we wprowadzaniu w nauczanie swoich przedmiotów zasad zrównoważonego rozwoju zostały uznane przez wielu ekspertów za dobre rekomendacje dla szkolnictwa wyższego w odniesieniu do Dekady Bioróżnorodności.

\section{Oczekiwania wobec Dekady Bioróżnorodności}

Ponieważ jednym z zadań CEPA/IAC jest doradzanie Sekretariatowi w takich dziedzinach, jak organizacja Dekady Bioróżnorodności w skali światowej i uzgadnianie tematów Dnia Różnorodności Biologicznej, eksperci relacjonowali przebieg Dekady w swoich krajach. Mimo kilku nośnych inicjatyw, uznano, że szansa związana z możliwościami edukacyjnymi Dekady jak do tej pory nie została w pełni wykorzystana. Sekretariat CBD zobowiązał się do utworzenia strony internetowej Dekady i zachęcenia poszczególnych państw do zamieszczania informacji o ważniejszych inicjatywach w ich krajach tak, by powstała światowa mapa aktywności (Decade on Biodiversity 2016; United Nations Decade on Biodiversity 2010). Wielu ekspertów zalecało korzystanie w przebiegu drugiej połowy Dekady RB z doświadczeń zgromadzonych podczas Dekady Edukacji dla Zrównoważonego Rozwoju (DEZR) w latach 2004-2014. W Polsce doświadczenia te są dobrze udokumentowane (Kalinowska 2010b i 2010c). Warto podkreślić, że w Japonii powstała, podobnie jak w czasie trwania DEZR, ogólnokrajowa platforma koor- 
dynująca aktywności Dekady Bioróżnorodności. Eksperci zgodzili się, że utworzenie koalicji różnych aktorów umożliwi lepszą koordynację działań i nagłośnienie mniej znanych tematów związanych z takimi aspektami CBD, jak ochrona zasobów genetycznych czy ABS, czyli dostęp do dzielenia się korzyściami.

Temat Dnia Różnorodności Biologicznej w 2017 r. to: Różnorodność Biologiczna i Zrównoważona Turystyka. O wyborze zadecydował fakt, że rok 2017 jest już ustanowionym przez ONZ Rokiem Zrównoważonej Turystyki. Takie skorelowanie pozwoli zintegrować działania promocyjne. Interesująca jest tu też możliwość wykazania związku między rozwojem zrównoważonym i zachowaniem różnorodności biologicznej a jakością życia lokalnej ludności, co stanowi przekonywający argument w edukacji (Kalinowska 2010a; 2011a; 2013c).

Ze strony Polski padła propozycja, by temat Dnia Różnorodności Biologicznej przedstawiać do publicznej wiadomości z wyprzedzeniem, by mógł być hasłem nie tylko Dnia, ale i roku, co przynajmniej końcowym latom Dekady nadać by mogło bardziej wyrazisty charakter.

\section{Edukacja podczas COP $13 \mathrm{w}$ Cancun (Meksyk) 4-17 grudnia 2016 r.}

Ważnym osiągnięciem COP 13 była wymiana doświadczeń i dobrych praktyk w dziedzinie edukacji w trakcie ściśle związanej z Konferencją sekcji towarzyszącej pod nazwą CEPA Fair (CEPA Fair 2016). Tak nazwano trwający przez cały okres COP przygotowany przez Sekretariat CBD program prezentacji $\mathrm{w}$ formie wystąpień seminaryjnych i posterów poświęcony kształtowaniu świadomości społecznej. Ten wyznaczający kierunki edukacji „Jarmark Edukacji i Świadomości Społecznej” towarzyszący Konferencjom Stron, ma już długą tradycję, poczynając od COP 8 w Bonn (Kalinowska 2008). Ponieważ uczestniczą w nim z prezentacją swoich osiągnięć praktycy edukacji reprezentujący krajowe i międzynarodowe instytucje edukacyjne i organizacje społeczne, spełnia rolę forum dyskusyjnego i giełdy inspirujących pomysłów. Ze względu na ograniczony czas sesji, Sekretariat CBD spośród zgłoszonych wybrał około 100 prezentacji i kilkadziesiąt posterów dokumentujących dokonania w dziedzinie komunikacji społecznej i edukacji ze wszystkich kontynentów. Autorka niniejszego artykułu, jako jedyna z Polski, przedstawiła poster dotyczący kampanii Uniwersytetu War- 
szawskiego poświęconej promocji Dekady Różnorodności Biologicznej oraz wykład na temat roli uczelni w popularyzacji różnorodności biologicznej (CEPA Fair 2016).

CEPA Fair było też okazją do dyskusji nad możliwościami jednoczesnego realizowania Celów z Aichi i Celów Zrównoważonego Rozwoju 2030. Panuje opinia, że wszystkie z 17 Celów Zrównoważonego Rozwoju są kompatybilne z 20 Celami z Aichi. Cele wyznaczone w każdym z tych dokumentów wzajemnie się wspierają i wzmacniają swoje efekty, tak więc wdrażanie jednego współuczestniczy w osiągnięciach drugiego (Biodiversity and the 2030 Agenda 2016). Ta synergia dotyczy zwłaszcza tej części obu dokumentów, które poświęcone są edukacji. I tak zilustrować można najbardziej bezpośrednie powiązania między: celem 4 SDGs - „zapewnić inkluzyjną i jakościowo dobrą edukację oraz stworzyć wszystkim ludziom możliwość uczenia się przez całe życie”, a cytowanym już we wstępie celem 1 z Aichi oraz celem 19 z Aichi: „Dzielenie się informacjami i wiedzą”. Pośrednio jednak cele mówiące o edukacji i świadomości dotyczą wszystkich celów każdego z dokumentów (Biodiversity and the 2030 Agenda 2016).

\section{Zakończenie}

Nie sposób w ramach krótkiej publikacji odnieść się do wszystkich zagadnień poruszanych przez ekspertów CEPA/IAC. Jednak warto podkreślić, że z punktu widzenia edukacji dla różnorodności biologicznej w Polsce szczególnie cenne są następujące zalecenia:

Konieczność lepszego wykorzystania dla podnoszenia społecznej świadomości szansy, jaką dają ostatnie lata (2016-2020) Dekady Różnorodności Biologicznej. Niestety, w większości krajów (także i w Polsce) słabo wykorzystano tę możliwość w pierwszej połowie DRB.

$\checkmark$ Promowanie corocznie wyznaczanych tematów Dnia Bioróżnorodności jako zagadnienia przewodniego dla każdego całego roku Dekady Bioróżnorodności.

$\checkmark$ Zaangażowanie w przebieg DRB różnych partnerów, w tym partnerów biznesowych, oraz utworzenie krajowej platformy koordynującej 
i inspirującej przebieg DRB tak, jak to miało miejsce podczas DEZR w wielu krajach (m.in. w Niemczech i w Polsce).

$\checkmark$ Odpowiednie, uwzględniające kontekst kulturowy, tłumaczenie dokumentów i materiałów dodatkowych Konwencji o różnorodności biologicznej na języki krajowe.

$\checkmark$ Większe wykorzystanie do promocji zagadnień różnorodności biologicznej szerokiej gamy mediów społecznościowych, przy równoczesnym niezaniedbywaniu innych form komunikacji z różnymi grupami społecznymi.

Wszyscy uczestnicy spotkania, z tak różnych krajów i zaplecza kulturowego, wyrażali przekonanie, że mimo wciąż niezadowalających efektów, receptą na powstrzymanie utraty różnorodności biologicznej pozostaje doskonalenie edukacji prowadzącej do wzrostu świadomości społecznej. W Europie stwierdzenie, że wraz z poziomem edukacji wzrasta świadomość znaczenia różnorodności biologicznej, znalazło potwierdzenie w wynikach różnych przekrojowych badań społecznych (Kalinowska 2014b). Wśród ekspertów CEPA/IAC powszechną zgodę budził też pogląd, że w edukacji większy nacisk niż na przekazywanie wiedzy teoretycznej, należy położyć na przygotowanie do lokalnych działań oraz promowanie zrównoważonego stylu życia. Najlepszą do tego motywacją jest wykazanie powiązania między stanem różnorodności biologicznej a dobrostanem ludzi. Członkowie IAC wskazywali również na potrzebę współpracy między innymi konwencjami oraz $\mathrm{z}$ innymi tematycznie powiązanymi organizacjami jak np. UN Habitat czy Czerwony Krzyż.

Podsumowując - 30 lat od Raportu Brundtland wciąż trzeba podkreślać, że warunkiem zrównoważonego rozwoju jest zatrzymanie utraty różnorodności biologicznej jako absolutnie niezbywalnego zasobu, bez którego ludzkość nie może egzystować. Niezależnie od stopnia rozwoju cywilizacji sami jesteśmy ogniwem w łańcuchu życia. Niestety, ostatnia ocena stanu różnorodności biologicznej Global Biodiversity Outlook 4 (Global Biodivrsity 2014) wskazuje, że niewielkie są szanse, by do $2020 \mathrm{r}$. zahamować tempo utraty bogactwa przyrody. Ta pesymistyczna perspektywa nie może jednak osłabiać, a musi zwiększać mobilizację we 
wszystkich krajach do podejmowania kolejnych wysiłków edukacyjnych, ale coraz bardziej przemyślanych pod kątem skuteczności.

\section{Bibliografia:}

Biodiversity and the 2030 Agenda for Sustainable Development. Technical Note. 2016. Montreal: Secretariat of the Convention on Biological Diversity.

CEPA Fair. Dostęp 30.12.2016. http://www.cbd.int/cepafair/2016/cbd.

Cele z Aichi. Dostęp: 30.12.2016. https:www.mos.gov.pl/srodowisko/ przyroda/konwencje międzynarodowe/ konwencja-o-różnorodności-biologicznej-cbd/cele.

Decade on Biodiversity (2011-2020). Dostęp: 1.12.2016. https//www. cbd.int/2011-2020.

Dokumenty Końcowe Konferencji Narodów Zjednoczonych „Środowisko i Rozwój” Szczyt Ziemi Rio de Janeiro 1992. 1993. Warszawa: Instytut Ochrony Środowiska.

Global Biodiversity Outlook 4. A mid-term assessement of Progress towards the implementation of the Strategic Plan for Biodiversity 2011-2020. 2014. Montreal: Secretariat of the Convention on Biological Diversity.

Hesselink, Fritz. et. al. 2007. Communication, Education and Public Awareness. A Toolkit for National Focal Points and NBSAP Coordinators. IUCN, Montreal: Secretariat of Convention on Biological Diversity.

Informal Advisory Committee on Communication, Education and Public Awareness. Dostęp: 1.12.2016. https//www.cbd.int/doc/meeting= CEPAIAC-2016-01.

Kalinowska, Anna. 2008. Artykuł 13. W poszukiwaniu społecznego wsparcia $w$ zarządzaniu Konwencja o różnorodności biologicznej. Polska praktyka na tle doświadczeń światowych. Warszawa: Agencja Wydawnicza A. Grzegorczyk.

Kalinowska, Anna. 2010a. Dla trwałości życia - rola wartości duchowych w budowaniu świadomości społecznej podczas Dekady Edukacji dla Zrównoważonego Rozwoju i Międzynarodowego Roku Różnorod- 
ności Biologicznej. W: Nauki humanistyczne i sozologia, red. Jacek Czartoszewski, 177-187. Warszawa: Wyd. Uniwersytetu Kardynała Stefana Wyszyńskiego.

Kalinowska, Anna. 2010b. Zrównoważona Europa dla lepszego świata - Dekada ONZ edukacji dla zrównoważonego rozwoju (2005-2014) w krajach Unii Europejskiej. W: Edukacja środowiskowa w społeczeństwie wiedzy, red. Ligia Tuszyńska, 8-18. Warszawa: Wyd. Wydział Biologii Uniwersytetu Warszawskiego.

Kalinowska, Anna. 2010c. Dekada ONZ Edukacji dla Zrównoważonego Rozwoju (2005-2014) i miejsce, jakie w niej znajduje edukacja o różnorodności biologicznej. W: Na spotkanie różnorodności biologicznej. Szkolne obserwacje drzew - poradnik nauczyciela, red. Anna Batorczak i Anna Kalinowska, 58-68. Warszawa: Wyd. Uniwersyteckie Centrum Badań nad Środowiskiem Przyrodniczym.

Kalinowska, Anna. 2011. Dla trwałości życia - różnorodność biologiczna a dobrostan ludzkości. W: Wybrane zagadnienia z ekologii i ochrony środowiska. Różnorodność biologiczna w wielu odsłonach, red. Anna Kalinowska, 9-11. Warszawa: Wyd. Uniwersyteckie Centrum Badań nad Środowiskiem Przyrodniczym.

Kalinowska, Anna i Anna Batorczak. 2012. Przyszłość jakiej chcemy dla naszych wnuków. O zrównoważonym rozwoju dla słuchaczy Uniwersytetów Trzeciego Wieku. Warszawa: Wyd. Fundacja Ziemia i Ludzie.

Kalinowska, Anna. 2013a. Contemporary Man in Dialogue with the Environment? W: Bulletin. Polish National Commission for UNESCO Review. Warszawa: Polski Komitet ds. UNESCO.

Kalinowska, Anna. 2013b. Prawo a edukacja dla zrównoważonego rozwoju w 20 lat po Rio. Konfrontacja rzeczywistości z zapisami w Konwencjach przyjętych na Szczycie Ziemi w 1992 r. W: Międzynarodowe prawo ochrony środowiska XXI wieku, red. Zdzisław Galicki i Aleksander Gubrynowicz, 58-68. Warszawa: Stowarzyszenie Absolwentów Wydziału Prawa i Administracji UW.

Kalinowska, Anna. 2014a. Biodiversity Loss and Public Opinion: What Is the Situation In Central Europe? W: Current challenges of Cen- 
tral Europe: society and environment, red. Jan Vavra, Marina Lapka i Ewa Cudlinowa, 68-82. Praga: Univerzita Karlova w Praze.

Kalinowska, Anna. 2014b. Polski krajobraz edukacji dla ochrony przyrody na tle tendencji światowych. W: Nature Conservation In Poland and Current Civilization Challenges, red. Zbigniew Mirek i Anna Nikel, 151-173. Kraków: Komitet Ochrony Przyrody PAN.

Kalinowska, Anna i Anna Batorczak. 2014. Różnorodność biologiczna to także my. Zielona Wiedza dla Uniwersytetów Trzeciego Wieku. Warszawa: Wyd. Fundacja Ziemia i Ludzie.

Kalinowska, Anna i Anna Batorczak. 2015. Universities for sustainability - New challenges from the perspective of the University of Warsaw. Environmentale Socio-economic Studies, 3(1), 26-34.

Różnorodność biologiczna to także my. Dostęp: 3.12.2016. www.bioróżnorodność.pl/pl/aktualnosci.

United Nations Decade on Biodiversity 2011-2020, COP 10. 2010. UNEP Montreal: Secretariat of CBD. 
Jan Chudzyński

jchudzynski@gmail.com

\section{Podstawy psychologiczne zachowań prośrodowiskowych}

\section{Wstęp}

O pewnym paradoksie wydaje się świadczyć fakt, że w epoce coraz częściej określanej przez badaczy mianem antropocenu rozważania na temat sposobów ograniczania problemów środowiskowych do niedawna pomijały naturę głównego sprawcy całego zamieszania. I tak dopiero w piątym raporcie podsumowującym prace Międzyrządowego Panelu ds. Zmian Klimatu (IPCC), poza biologicznymi, technicznymi i ekonomicznymi aspektami możliwych do podjęcia działań, autorzy włączyli w swoje wyliczenia także wiedzę z zakresu psychologii (Kunreuther et al. 2014) Tymczasem badania psychologiczne od lat zgłębiają mechanizmy kierujące ludzkim zachowaniem, a także dostarczają dowodów na istnienie błędów poznawczych, które mogą mieć znaczący wpływ na podejmowane przez nas decyzje.

Dominujący w naukach społecznych paradygmat, zgodnie z którym człowiek jest racjonalną jednostką, był przez długi czas jedynie lekko podważany, aż wreszcie, wraz z rozwojem ekonomii behawioralnej oraz wydaniem popularnonaukowych bestsellerów (Kahneman 2012; Thaler i Sunstein 2008), odkrycia psychologów uzyskały rozgłos. Mimo to wiedza z zakresu psychologii, w tym psychologii środowiskowej, wciąż nie jest wystarczająco wykorzystywana w działaniach na rzecz zrównoważonego rozwoju (Van den Berg i Steg 2013, 311).

Niniejszy artykuł ma na celu zwrócenie uwagi na badania w zakresie psychologicznych aspektów zachowań prośrodowiskowych i możliwości, jakie wiedza psychologiczna oferuje w zakresie ograniczania negatywnego wpływu ludzkiej działalności na środowisko. W jego pierwszej części, w oparciu o dorobek psychologii środowiskowej, przedstawione zostanie najnowsze ujęcie teorii wyjaśniających ludzkie zachowanie ze szczególnym uwzględnieniem zachowań prośrodowiskowych. W drugiej wyjaśnione zostaną najważniejsze konsekwencje badanej przez psychologię kognitywną i ekonomię behawioralną ograniczonej racjonal- 
ności. W trzeciej, ostatniej części, zebrane są rozwiązania inspirowane wynikami obu nurtów badań.

\section{Zachowania prośrodowiskowe $\mathrm{w}$ świetle teorii psychologicznych}

Psychologia środowiskowa jest subdyscypliną psychologii, która zajmuje się badaniem relacji między człowiekiem a środowiskiem naturalnym (biofizycznym) oraz tym powstałym w wyniku ludzkich działań. Do końca pierwszej połowy XX wieku psychologia skupiała się jednak bardziej na środowisku wytworzonym, a więc na budynkach, miejscu pracy i przestrzeni mieszkalnej. Dopiero w latach 60., gdy zaczęto dostrzegać zagrożenia, jakie dla środowiska naturalnego stanowi działalność człowieka, podjęto próby wyjaśnienia i odwrócenia niepokojących tendencji. W konsekwencji badania prowadzone w ramach psychologii środowiskowej w większym stopniu skupiły się na ludzkim zachowaniu względem środowiska naturalnego, jak również na wpływie wywołanych przez człowieka problemów środowiskowych na jego zdrowie i samopoczucie. Ważnymi tematami stały się zanieczyszczenie powietrza, miejski hałas, ocena jakości środowiska, a także zużycie energii. Współcześnie, gdy świadomość problemów środowiskowych i wpływu człowieka na ich powstawanie jest już powszechna, jednym z celów psychologii środowiskowej stało się poszukiwanie sposobów zmiany zachowań na prośrodowiskowe (Steg, Van den Berg i de Groot 2013).

W tym miejscu warto sprecyzować, że za zachowania prośrodowiskowe uznaje się zachowania przyjazne środowisku, bez względu na ich motywację i to, czy są one zamierzone czy nie. Z kolei jako zachowania środowiskowe określa się zachowania mające wpływ na środowisko, bez względu na to, czy są one mu przyjazne, czy działają na jego szkodę (Gatersleben 2013, 132-133).

Psychologię środowiskową charakteryzuje podejście interdyscyplinarne i zróżnicowane metody badawcze, jednak w dużym stopniu opiera się ona na koncepcjach wypracowanych w psychologii społecznej i psychologii poznawczej (Steg, Van den Berg i de Groot 2013). Przedstawiona poniżej teoria celów kształtujących (Goal Framing Theory) oddaje złożoność zagadnień badanych w ramach całej dziedziny, czerpiąc z kilku ważnych teorii, które jednak dla zachowania zwięzłości nie zostaną omówione w niniejszym artykule. 


\section{Teoria celów kształtujących (Goal Framing Theory)}

Teoria celów kształtujących (Goal Framing Theory) jest syntezą teorii wyjaśniających ludzkie zachowania i zakłada, że o naszym postępowaniu decydują cele, którymi kierujemy się w danej sytuacji. To one mają wpływać na to, jak człowiek przetwarza informacje; do jakich zasobów wiedzy sięga, podejmując decyzje; co lubi, a czego nie; oraz czego oczekuje od innych. Równocześnie mogą być aktywne różne cele, ale to cel dominujący w danej sytuacji ma największy wpływ na zachowanie. Cele działające w jego tle nie są jednak bez znaczenia, mogą bowiem wzmacniać lub osłabiać cel dominujący (Lindenberg 2013, 121).

Zgodnie z teorią celów kształtujących istnieją trzy kategorie celów:

$\checkmark$ cele hedonistyczne (hedonic goals) - związane z poszukiwaniem natychmiastowej przyjemności;

$\checkmark$ cele korzyści (gain goals) - wyrażające potrzeby zabezpieczenia środków koniecznych do realizacji innych celów;

$\checkmark$ cele normatywne (normative goals) - charakteryzujące się chęcią zachowania się odpowiednio, zgodnie z normami.

Autorzy rozwijający tę teorię zakładają, że motywacje stojące za zachowaniami prośrodowiskowymi nie są jednorodne, dlatego łączy się $\mathrm{w}$ ich modelu zagadnienia analizowane dotychczas osobno przez różne teorie (Steg i Vlek 2009, 311). I tak cele hedonistyczne odnoszą się do ustaleń teorii dotyczących zachowań afektywnych, teorie podkreślające rolę kalkulacji korzyści i kosztów w kształtowaniu zachowania znajdują swoją reprezentację w postaci celów korzyści, zaś modele skupiające się na normach osobowych (teoria aktywizacji norm i teoria zachowań prośrodowiskowych wartość - przekonanie - norma) są inspiracją dla kategorii celów normatywnych (Steg i Nordlund 2013, 193).

Zgodnie z teorią celów kształtujących, zachowania prośrodowiskowe zachodzą przede wszystkim w sytuacjach, w których dominują cele normatywne. Oczywiście zdarza się też, że tak jak w przypadku sprawiającej przyjemność konsumpcji produktów ekologicznych czy generującego oszczędności korzystania z odnawialnych źródeł energii (OZE) podstawą zachowania będą cele hedonistyczne i cele korzyści, jednak 
to cele normatywne są najstabilniejszą podstawą tego typu działań. Cele hedonistyczne i cele korzyści są bowiem podatne na zmiany nastrojów i wpływ czynników ekonomicznych (De Groot i Steg 2009).

Najsilniejsze są cele hedonistyczne, które z natury mają tendencję do dominacji. Z kolei cele normatywne, by w danej sytuacji stać się dominującymi, potrzebują wzmocnienia od którejś z pozostałych kategorii celów (Steg i Nordlund 2013, 193). Zmiana dominującego celu odbywa się nieświadomie i może być wynikiem naturalnych skłonności lub sygnałów płynących z otoczenia.

Autorzy publikacji An Integrated Framework for Encouraging Pro-environmental Behaviour: The role of values, situational factors and goals (Steg et al. 2014) kluczową rolę w kształtowaniu potencjalnej siły celów przypisują wyznawanym wartościom, czyli głównym zasadom, jakimi ludzie kierują się w życiu. W odróżnieniu od celów, wartości rzadko podlegają zmianom, dlatego to właśnie kompozycja wartości hedonistycznych, egoistycznych, altruistycznych i biosferycznych ma być czynnikiem decydującym o aktywności poszczególnych celów w danej sytuacji. Zorientowanie na wartości hedonistyczne oznacza, że to cele hedonistyczne będą potrzebowały relatywnie najmniejszego wzmocnienia, by dominować. Wartości egoistyczne podtrzymują w gotowości cele korzyści, z kolei uaktywnienie się celów normatywnych (szczególnie silnie związanych z zachowaniami prośrodowiskowymi) jest bardziej prawdopodobne, gdy wyznawane są wartości altruistyczne i biosferyczne.

Zewnętrznymi czynnikami wpływającymi na cele są tzw. sygnały sytuacyjne (situational cues), które mogą zarówno przypominać o nadrzędnych wartościach, jakimi osoba kieruje się w życiu, jak również wzmacniać na co dzień wartości z pozoru mniej znaczące. Najważniejszymi sygnałami płynącymi z otoczenia są: obecność lub brak innych ludzi w otoczeniu, sygnały świadczące o stosowaniu się do norm, przedmioty kojarzące się z którymś z celów oraz sygnały wskazujące szanse na uzyskanie korzyści. $Z$ reguły większość sygnałów wzmacnia cele hedonistyczne i cele korzyści, tym samym relatywnie osłabiając cele normatywne, które są wzmacnianie jedynie przez nieliczny zestaw sygnałów (Lindenberg 2013, 122).

Ważnym czynnikiem wpływającym na kształtowanie się relatywnej siły celów są też koszty zachowania. Mimo że ludzie decydują się na 
podejmowanie zachowań prośrodowiskowych nawet wówczas, gdy ich koszty są w miarę wysokie, po przekroczeniu pewnego poziomu obciążenia cele korzyści zwiększają swoją siłę względem celów normatywnych, doprowadzając tym samym do ograniczenia przesadnie kosztownego zachowania. Dzieje się tak, gdy zbyt wysokie koszty materialne lub behawioralne, np. koszty finansowe lub społeczne, czas lub wysiłek związany z danym zachowaniem uniemożliwiają realizację innych, poza biosferycznymi, istotnych wartości (Steg et al. 2014, 110).

\section{Zachowania prośrodowiskowe wobec ograniczonej racjonalności}

Sposób, w jaki podejmujemy decyzje, przeczy przyjmowanemu $\mathrm{w}$ wielu naukach społecznych założeniu o pełnej racjonalności człowieka. U teoretycznych podstaw badań w ramach psychologii kognitywnej i ekonomii behawioralnej leży założenie tzw. ograniczonej racjonalności (bounded rationality) oraz koncepcja wskazująca na istnienie dwóch trybów myślenia, różniących się między sobą szybkością i stopniem refleksyjności. Są to dwa odrębne systemy myślenia - System 1, który odpowiada za myślenie szybkie i intuicyjne, oraz System 2 opierający się na myśleniu wolnym i refleksyjnym. Dzięki stosowaniu heurystyk, czyli prostych metod wnioskowania, System 1 umożliwia wykonywanie szybkich operacji myślowych opartych na przeszłych doświadczeniach i utworzonych dzięki nim tzw. związkach asocjacyjnych, przez co nie wymagają one większego wysiłku. Z kolei myślenie w ramach Systemu 2 charakteryzuje się zamierzonymi operacjami umysłowymi i wymaga więcej uwagi (Kahneman 2012, 19-30).

Podobnie jak w przypadku większości decyzji, decyzje o podjęciu lub zaniechaniu zachowań prośrodowiskowych również mogą być zniekształcone wskutek działania błędów poznawczych. Poniżej przedstawione zostaną szczególnie istotne zagadnienia związane $\mathrm{z}$ tym problemem, a więc przyzwyczajenia, błędne szacowanie ryzyka oraz niechęć do straty.

2.1. Przyzwyczajenia jako przykład ograniczonej racjonalności

Przyzwyczajenia pojawiają się, gdy jakaś czynność wykonywana jest często, odbywa się w warunkach charakteryzujących się małą zmiennością i kończy się sukcesem. W takich okolicznościach zachowanie celowe 
przeradza się w zwyczajowe, a myślenie - zamiast w ramach Systemu 2 - odbywa się zgodnie z zasadami Systemu 1 (Klöckner i Verplanken 2013, 198).

Korzyścią z wytworzenia się automatyzmów i zastąpienia myślenia w ramach Systemu 2 myśleniem zgodnie z zasadami Systemu 1 jest szybsze działanie i odciążenie umysłu, które umożliwia zaangażowanie uwolnionego potencjału poznawczego $\mathrm{w}$ inne toczące się równolegle procesy myślowe lub czynności (Kahneman 2012, 31-38). Przyzwyczajenia okazują się jednak problemem w sytuacjach wymagających myślenia $\mathrm{w}$ większym stopniu poddającego pod rozwagę dostępne informacje, a więc myślenia w ramach Systemu 2. Co szczególnie istotne dla podjętego w niniejszym artykule wywodu, może to dotyczyć zachowań prośrodowiskowych. Badania pokazują bowiem, że automatyzmy blokują podejmowanie prośrodowiskowych zachowań poprzez osłabianie intencji i norm osobistych, zmniejszają też zainteresowanie zachowaniami alternatywnymi wobec tych znanych i już wyuczonych (Klöckner i Verplanken 2013).

\subsection{Podejmowanie decyzji w warunkach ryzyka}

Okolicznością wzmagającą negatywne konsekwencje myślenia intuicyjnego jest konieczność działania w warunkach ryzyka, kiedy to kierowanie się emocjami i przyzwyczajeniami niekoniecznie prowadzi do optymalnych decyzji. W taki sposób dochodzi do błędów poznawczych polegających na zaniżeniu oceny poziomu ryzyka i przesadnym optymizmie co do przyszłych zdarzeń (Böhm i Tanner 2013, 17-19).

Te przejawy ograniczonej racjonalności są szczególnie istotne w kontekście problemów środowiskowych, w tym zmian klimatu, które choć są zdarzeniami wiążącymi się z poważnymi konsekwencjami, bywają lekceważone ze względu na odległą perspektywę i pozornie niewielkie prawdopodobieństwo wystąpienia. W takich okolicznościach wymienione błędy prowadzą do zaniechania działań zapobiegawczych lub minimalizujących straty, np. ograniczania poziomu emisji czy zakupu ubezpieczenia (Kureuther i Weber 2014, 9).

Kolejną barierą mogącą powstrzymywać ludzi od podejmowania zachowań prośrodowiskowych jest niechęć do straty (loss aversion), a więc tendencja do silniejszego doświadczania poczucia straty niż poczucia uzyskanej korzyści. Ten błąd poznawczy może wyjaśniać 
niechęć do ponoszenia nakładów finansowych lub innych wysiłków związanych z łagodzeniem problemów środowiskowych. Powodem mają być odczuwalne od razu koszty (behawioralne lub materialne) działań, które pozornie przewyższają trudne do wyobrażenia przyszłe korzyści płynące z zapobiegania wystąpieniu negatywnych zdarzeń (Kunreuther i Weber 2014, 10).

\section{Sposoby wspierania prośrodowiskowych zachowań w świetle wiedzy psychologicznej}

W psychologii środowiskowej działania zachęcające do podejmowania zachowań prośrodowiskowych dzieli się na informacyjne i strukturalne. Te pierwsze powodują zmianę poziomu wiedzy i świadomości, wpływają na normy i postawy. Z kolei działania strukturalne skupiają się na sferze materialnej i kształtują okoliczności mogące decydować o zachowaniach prośrodowiskowych, np. wskutek wzrostu dostępności przyjaznej środowisku infrastruktury, produktów i usług (Abrahamse i Matthies 2013, 224).

Działania informacyjne najczęściej polegają na dostarczaniu wiedzy na temat istoty problemu środowiskowego oraz możliwych rozwiązań. Innymi technikami stosowanymi w ramach działań o charakterze informacyjnym jest zachęcanie ludzi do ustalania celów (goal setting) albo zobowiązań (commitment) do podejmowania działań prośrodowiskowych. W ten sposób pojedyncze osoby albo całe grupy motywowane są do ograniczania zużycia energii lub zmiany innych zachowań. Techniki te dodatkowo mogą być wspierane przez wysyłanie informacji zwrotnej (feedback) na temat postępów w dążeniu do ustalonego celu i wywiązywaniu się z zobowiązań (Abrahamse i Matthies 2013, 225-229).

Zdaniem autorów publikacji An Integrated Framework for Encouraging Pro-environmental Behaviour: The role of values, situational factors and goals (Steg et al. 2014, 111-113), niezwykle ważne jest, by interwencje zmniejszające wysiłek i koszt związany z zachowaniami prośrodowiskowymi, a więc odwołujące się do celów hedonistycznych i celów korzyści, nie osłabiały jednocześnie celów normatywnych. Autorzy zauważają bowiem, że dotychczasowe działania zachęcające do zachowań prośrodowiskowych zbyt rzadko koncentrują się na ich normatywnym aspekcie i wspieraniu wartości biosferycznych. 
Przykładem kompleksowego wykorzystania wiedzy z zakresu psychologii środowiskowej jest program wysyłania indywidualnych raportów zużycia energii przez firmę OPOWER w USA. Listy otrzymywane przez użytkowników zawierały porównanie ich zużycia energii z wynikami podobnych gospodarstw domowych oraz porady pomagające ograniczyć zużycie w przyszłości. W ten sposób, w pilotażowej akcji udało się doprowadzić do ograniczenia zużycia energii o od 1,1 do 2,8\%, co odpowiada przewidywanemu efektowi podwyżki cen energii o ponad 15\% (Allcott 2011).

Innego rodzaju rozwiązań o charakterze informacyjnym dostarczają badania w dziedzinie psychologii kognitywnej (poznawczej) oraz ekonomii behawioralnej, które, jak już wcześniej wspomniano, skupiają się na ograniczonej racjonalności i procesie podejmowania decyzji. Na podstawie uzyskanej w ten sposób wiedzy opracowano rozwiązania łagodzące działania błędów poznawczych.

Jednym z rozwiązań jest odpowiednie przedstawienie zagadnienia (framing), a więc opisanie problemu wraz z proponowanymi działaniami w sposób, który nie zniechęca do podjęcia zachowania. Metoda ta znajduje zastosowanie także w działaniach popularyzujących zachowania prośrodowiskowe. Badania pokazują bowiem, że forma przedstawienia prośrodowiskowych zachowań i produktów ma wpływ na nasze decyzje. Dowodzą tego eksperymenty dotyczące dodatkowych, dobrowolnych opłat środowiskowych proponowanych przy zakupie biletu lotniczego. Jak się okazuje, kupujący bilety chętniej ponosili dodatkowy koszt, gdy przedstawiano go jako opłatę kompensacyjną (offset), a nie jako podatek (Böhm i Tanner 2013, 18).

Ciekawą strategią zachęcania do podejmowania zachowań prośrodowiskowych jest odpowiednie projektowanie opcji wyboru. Rozwiązanie to inspirowane jest koncepcją impulsów (nudges) autorstwa Thalera i Sunsteina (2008) i polega na przedstawieniu najkorzystniejszego społecznie wyboru jako domyślny (default option). Rozwiązanie to oparte jest na badaniach dowodzących, że domyślna opcja jest często wybierana z powodu naszej bierności, a także tzw. zakotwiczenia (anchoring), czyli nieświadomego preferowania pierwszej spośród dostępnych opcji wyboru (Kunreuther i Weber 2014, 15). 
Przykładem stosowania przyjaznych środowiskowo wyborów domyślnych są oferty firm energetycznych, w których - obok energii pochodzącej ze źródeł konwencjonalnych - można wybrać też „zielone” taryfy. Ustawienie „zielonych” taryf jako opcji domyślnej okazuje się wyjątkowo skuteczne, powodując znaczny wzrost udziału użytkowników kupujących energię generowaną przez odnawialne źródła energii (Pichert i Katsikopoulos 2008). Warto podkreślić, że wprowadzenie tego rozwiązania na szeroką skalę rozważane jest przez działający przy prezydencie USA zespół wspierający politykę publiczną, który wykorzystuje wiedzę z zakresu psychologii poznawczej i ekonomii behawioralnej (SBST 2016, 17-18).

\section{Zakończenie}

Badania w ramach psychologii środowiskowej pozwalają zrozumieć czynniki prowadzące do podejmowania lub zaniechania zachowań prośrodowiskowych. Wskazują one na istotną rolę zarówno czynników informacyjnych (i kulturowych), a więc wiedzy, świadomości, postaw i norm, jak i czynników strukturalnych, czyli dostępu do odpowiedniej infrastruktury, produktów i usług. Teoretyczne rozważania i dotychczasowe doświadczenia pokazują, że najbardziej optymalną strategią popularyzacji zachowań prośrodowiskowych jest łączenie działań o charakterze informacyjnym i strukturalnym, ze szczególną dbałością o promocję wartości biosferycznych.

Z kolei psychologia kognitywna i ekonomia behawioralna dostarczają wiedzy na temat błędów poznawczych świadczących o ograniczonej racjonalności ludzi. Rozwiązania łagodzące negatywne skutki tych błędów mają charakter informacyjny i koncentrują się na tzw. architekturze wyboru. Są one coraz częściej wykorzystywane przez administracje w ramach różnych polityk publicznych i mogą byćteżstosowanew działaniach mających na celu popularyzację zachowań prośrodowiskowych, zwiększając tym samym szanse na realizację celów zrównoważonego rozwoju.

\section{Bibliografia:}

Abrahamse, Wokje i Ellen Matthies. 2013. Informational strategies to promote pro-evironmental behaviour: Changing knowledge, awareness and attitudes. W: Environmental Psychology: An Introduction, red. 
Linda Steg, Agnes E. Van der Berg i Judith I.M. de Groot, 223-232. Chichester: The British Psychological Society and John Wiley \& Sons.

Allcott, Hunt. 2011. Social Norms and Energy Conservation. Journal of Public Economics, 95(9-10), 1082-1095. DOI: 10.1016/j.jpubeco.2011.03.003.

Böhm, Gisela i Carmen Tanner. 2013. Environmental risk perception. W: Environmental Psychology: An Introduction, red. Linda Steg, Agnes E. Van der Berg i Judith I.M. de Groot, 15-25. Chichester: The British Psychological Society and John Wiley \& Sons.

De Groot, Judith I.M. i Linda Steg. 2009. Morality and prosocial behavior: the role of awareness, responsibility and norms in the norm activation model. Journal of Social Psychology, 149(4), 425-449. DOI: 10.3200/SOCP.149.4.425-449.

Gatersleben, Birgitta. 2013. Measuring environmental behaviour. W: Environmental Psychology: An Introduction, red. Linda Steg, Agnes E. Van der Berg i Judith I.M. de Groot, 131-140. Chichester: The British Psychological Society and John Wiley \& Sons.

Kahneman, Daniel. 2012. Thinkingfast and slow. London: Penguin Books.

Klöckner, Christian A. i Bas Verplanken. 2013. Yesterday's habits preventing change for tomorrow? The influence of automaticity on environmental behaviour. W: Environmental Psychology: An Introduction, red. Linda Steg, Agnes E. Van der Berg i Judith I.M. de Groot, 197-209. Chichester: The British Psychological Society and John Wiley $\&$ Sons.

Kunreuther, Howard et al. 2014. Integrated Risk and Uncertainty Assesment of Climate Change Response Policies. W: Climate Change 2014: Mitigation of Climate Change. Contribution of Working Group III to the Fifth Assessment Report of the Intergovernmental Panel on Climate Change, red. Ottmar Edenhofer et al., 151-205. Cambridge-Nowy York: Cambridge University Press.

Kunreuther, Howard i Elke U. Weber. 2014. Aiding decision-making to reduce the impacts of climate change. NBER Working Paper Series. Dostęp: 10.02.2017. http://www.nber.org/papers/w19776. 
Lindenberg, Siegwart. 2013. How cues in the environment affect normative behaviour. W: Environmental Psychology: An Introduction, red. Linda Steg, Agnes E. Van der Berg i Judith I.M. de Groot, 119-128. Chichester: The British Psychological Society and John Wiley \& Sons.

Pichert, Daniel i Konstantinos V. Katsikopoulos. 2008. Green defaults: Information presentation and pro-environmental behaviour. Journal of Environmental Psychology, 28(1), 63-73. DOI: 10.1016/j.jenvp.2007.09.004.

SBST. 2016. Social and Behavioral Sciences Team Annual Report. Dostęp: 10.02.2017. https://sbst.gov/download/2016\%20SBST\%20Annual\%20Report.pdf.

Steg, Linda et al. 2014. An Integrated Framework for Encouraging Pro-environmental Behaviour: The role of values, situational factors and goals. Joural of Environmental Psychology, 38, 104-115. DOI: 10.1016/j.jenvp.2014.01.002.

Steg, Linda i Annika Nordlund. 2013. Models to explain environmental behaviour. W: Environmental Psychology: An Introduction, red. Linda Steg, Agnes E. Van der Berg i Judith I.M. de Groot, 185-195. Chichester: The British Psychological Society and John Wiley \& Sons.

Steg, Linda i Charles Vlek. 2009. Encouraging pro-environmental behaviour: An integrative review and research agenda. Journal of Environmental Psychology, 29(3), 309-317. DOI: 10.1016/j.jenvp.2008.10.004.

Steg, Linda, Agnes E. Van den Berg i Judith I.M. de Groot. 2013. Environmental psychology: History, scope and methods. W: Environmental Psychology: An Introduction, red. Linda Steg, Agnes E. Van der Berg i Judith I.M. de Groot, 1-11. Chichester: The British Psychological Society and John Wiley \& Sons.

Thaler, Richard H. i Cass R. Sunstein. 2008. Impuls. Jak podejmować właściwe decyzje dotyczace zdrowia, dobrobytu i szczęścia, tłum. Justyna Grzegorczyk. Poznań: Zysk i S-ka.

Van den Berg, Agnes E. i Linda Steg. 2013. Conclusion: Summary, trends and future perspectives in environmental psychology. W: Environmental Psychology: An Introduction, red. Linda Steg, Agnes E. Van der Berg i Judith I.M. de Groot, 303-313. Chichester: The British Psychological Society and John Wiley \& Sons. 

Anna Batorczak

Uniwersytet Warszawski - Uniwersyteckie Centrum Badań nad Środowiskiem

Przyrodniczym i Zrównoważonym Rozwojem

a.batorczak@uw.edu.pl

\section{Doskonalenie kompetencji nauczycieli akademickich w zakresie edukacji dla zrównoważonego rozwoju}

\section{Wstęp}

Powszechnie przyjmuje się, że inicjowanie, wprowadzanie i utrwalanie zasad zrównoważonego rozwoju może nastąpić tylko poprzez skuteczną edukację. Edukację, która dostarcza wiedzy oraz umożliwia rozumienie i ocenianie złożonych zjawisk rozwoju cywilizacyjnego. Edukację, która rozwija świadomość i umożliwia nabywanie umiejętności prowadzących do podejmowania działań zapewniających ochronę środowiska przyrodniczego oraz służących społecznemu i ekonomicznemu dobrostanowi zarówno dla obecnych jak i przyszłych pokoleń.

Szkolnictwo wyższe jest szczególnie ważnym miejscem dla prowadzenia edukacji w myśl zrównoważonego rozwoju, ponieważ przygotowuje przyszłe pokolenia profesjonalistów i liderów, podaje w wątpliwość obowiązujące paradygmaty oraz inicjuje i prowadzi przełomowe badania (Kalinowska i Batorczak 2015, 26). Interdyscyplinarny i holistyczny charakter wiedzy i umiejętności związanych z podejmowaniem wyzwań zrównoważonego rozwoju spełnia coraz większe oczekiwania pracodawców i tym samym zwiększa konkurencyjność absolwentów na rynku pracy. Wprowadzanie zasad zrównoważonego rozwoju i odpowiedzialności społecznej przyczynia się do zmian instytucjonalnych i organizacyjnych, a także do rozwoju osobistego. Jak zauważają autorzy przewodnika Edukacja dla Zrównoważonego Rozwoju (EZR) dla nauczycieli akademickich w Wielkiej Brytanii, wszyscy absolwenci uczelni wyższych będą ponosić odpowiedzialność za stan środowiska przyrodniczego i sprawiedliwość społeczną - jako pracodawcy, obywatele i w wielu przypadkach również jako rodzice i mentorzy dla przyszłych pokoleń (Longhurst et al. 2014, 6). Jeśli jednak uniwersytety mają skutecznie przyczyniać się do przemian w sposobie myślenia i podejmowa- 
nia działań urzeczywistniających zrównoważony rozwój, konieczna jest transformacja procesu nauczania. Odpowiednie przygotowanie nauczycieli akademickich, tak aby poprzez swoje programy i metody nauczania skutecznie przygotowywali studentów do mierzenia się z zagadnieniami zrównoważonego rozwoju, zostało uznane w raporcie UNESCO podsumowującym Dekadę Edukacji dla Zrównoważonego Rozwoju (Dekada EZR) za jedno z najgłówniejszych wyzwań edukacji dla zrównoważonego rozwoju w szkolnictwie wyższym (UNESCO 2014, 112). To wyzwanie zostało podjęte $\mathrm{w}$ międzynarodowym projekcie Uniwersyteccy Edukatorzy dla Zrównoważonego Rozwoju (UE4SD), którego celem było zapoczątkowanie zmian służących prowadzeniu skuteczniejszej edukacji dla zrównoważonego rozwoju na uczelniach wyższych poprzez rozwój kompetencji zawodowych nauczycieli akademickich.

W pierwszej części niniejszego artykułu została przedstawiona charakterystyka i wyzwania edukacji dla zrównoważonego rozwoju w kontekście edukacji akademickiej oraz pożądanych kompetencji. W części drugiej zaprezentowano wnioski wynikające z badań i osiągnięć międzynarodowego projektu Uniwersyteccy Edukatorzy dla Zrównoważonego Rozwoju (UE4SD).

\section{Charakterystyka i wyzwania edukacji dla zrównoważonego rozwoju w kontekście edukacji akademickiej}

W opracowanym w 2014 r. w Wielkiej Brytanii przewodniku dla nauczycieli akademickich poświęconym edukacji dla zrównoważonego rozwoju (Education for Sustainable Development: Guidance for UK higher education providers) autorzy podkreślają, że jest to edukacja, która otwiera dialog pomiędzy różnymi dyscyplinami naukowymi, tworzy powiązania interdycyplinarne i łączy różne obszary wiedzy. Jej celem jest rozwijanie u studentów umiejętności rozumienia i oceniania zależności występujących między tak dużymi i kompleksowymi problemami jak nierówność społeczna, globalna konsumpcja, utrata różnorodności biologicznej i granice naturalnych systemów, zapewnienie bezpieczeństwa energetycznego. Ucząc się o zrównoważonym rozwoju i dla zrównoważonego rozwoju, studenci są przygotowywani do inicjowania, prowadzenia oraz włączania się do debat na temat wieloaspektowych 
zagadnień, takich jak: bycie obywatelem globalnej społeczności i konsekwencje tego statusu, odpowiedzialne planowanie i zarządzanie, zużywanie zasobów w sposób zrównoważony oraz determinanty granic wzrostu (Longhurst et al. 2014, 6-7).

Edukacja dla zrównoważonego rozwoju ma charakter:

Multidyscyplinarny. Zagadnienia zrównoważonego rozwoju mogą być podejmowane w zakresie każdej dyscypliny wiedzy, choć są nauki w szczególności zajmujące się tematyką zrównoważonego rozwoju.

$\checkmark$ Interdyscyplinarny. Podejmowanie zagadnień zrównoważonego rozwoju z perspektywy różnych dziedzin przyczynia się do powstania nowej wiedzy i rozwoju badań naukowych odmiennych od tych reprezentowanych przez poszczególne dziedziny.

$\checkmark$ Holistyczny. Zastąpienie nauczania przedmiotowego koncentrującego się na fragmentarycznej wiedzy o pojedynczych zjawiskach nauczaniem szukającym korelacji i przedstawiającym spójny obraz świata oraz przygotowującym do działania w nim. W podejściu edukacji holistycznej dla efektywnego uczenia się niezbędne jest zaangażowanie emocjonalne oraz działanie. Tym samym musi to być edukacja osadzona w kontekście prawdziwego życia i zintegrowana z codziennym doświadczeniem uczniów (Majewska 2017, 1).

Stosowane na uczelniach metody nauczania powinny odzwierciedlać potrzebę holistycznego podejścia do wyzwań zrównoważonego rozwoju współczesnej cywilizacji. Dominujący podział na wąskie dyscypliny naukowe w nauczaniu akademickim wymaga otwarcia na dialog multidyscyplinarny lub nawet interdyscyplinarny (Lozano et al. 2015; UE4SD 2015, 32). Jest to niezbędne dla przygotowywania studentów do prawidłowego postrzegania i rozwiązywania złożonych problemów współczesnej cywilizacji. Wizja i ogólne zasady holistycznej transformacji edukacji akademickiej zostały przedstawione w traktacie o szkolnictwie wyższym Rio +20 (Rio+20 Treaty on Higher Education). Treść porozumienia zainicjowanego podczas konferencji ONZ „Szczyt Ziemi Rio+20: Przyszłość, jakiej chcemy”, która odbyła się w czerwcu 2012 w Rio de Janeiro, bazuje na zobowiązaniach międzynarodowych, 
krajowych deklaracjach oraz inicjatywach, wymianie doświadczeń i dialogu. W przygotowaniu dokumentu brało udział 30 instytucji szkolnictwa wyższego z całego świata. Obecnie liczba sygnatariuszy liczy ponad 100 uniwersytetów i instytucji wspierających szkolnictwo wyższe.

Mimo licznych wskazań oraz długiej tradycji włączania edukacji dla zrównoważonego rozwoju do nauczania akademickiego, ten rodzaj edukacji nie upowszechnił się w szkolnictwie wyższym w stopniu takim jak w placówkach edukacyjnych niższych szczebli nauczania. Zdaniem ekspertów głównymi barierami dla wprowadzania EZR w szkolnictwie wyższym są: brak nacisku ze strony społeczeństwa, wolność akademicka, sposób oceniania placówek i konserwatywna administracja (UE4SD 2015, 24).

W raporcie UNESCO podsumowującym Dekadę EZR do najgłówniejszych wyzwań edukacji dla zrównoważonego rozwoju w szkolnictwie wyższym zaliczono:

$\checkmark$ potrzebę zmiany na poziomie polityk krajowych, planowania programów nauczania akademickiego, zarządzania instytucjonalnego i zapewnienia finansowania;

$\checkmark$ przełamanie barier dyscyplin naukowych;

$\checkmark$ odpowiednie przygotowanie nauczycieli akademickich, tak aby poprzez swoje programy i metody nauczania skutecznie przygotowywali studentów do mierzenia się z zagadnieniami zrównoważonego rozwoju (UNESCO 2014, 112).

Powszechnie podkreśla się, że EZR jest procesem wykraczającym poza nabywanie wiedzy oraz poznawanie teorii i wartości odnoszących się do zrównoważonego rozwoju. Istotą tej edukacji jest rozwijanie umiejętności: zadawania pytań, wyobrażania sobie pozytywnej przyszłości, precyzowania swoich własnych wartości, myślenia systemowego, wykorzystywania możliwości uczenia się, stosowania dialektyki w odniesieniu zarówno do tradycji jak i do innowacji (Tilbury 2011, 8; UE4SD 2015, 31). Rozwijanie tych kompetencji może być osiągnięte tylko poprzez odpowiednie podejście i metody nauczania, co stanowi o tym, że właściwa pedagogika jest sercem EZR na każdym poziomie nauczania, również w szkolnictwie wyższym. 
Potrzeba rozwoju kompetencji edukatorów w zakresie EZR została podkreślona w Strategii Edukacji dla Zrównoważonego Rozwoju przyjętej w 2005 r. w Wilnie przez Ministrów do spraw Środowiska i Edukacji państw regionu Europejskiej Komisji Gospodarczej ONZ (Europejska Komisja Gospodarcza ONZ 2008, 14). W następstwie, eksperci działających przy EKG ONZ określili kluczowe kompetencje edukatorów EZR (UNECE 2011, 7-8). Wśród nich znalazły się następujące kompetencje:

$\checkmark$ podejście holistyczne, które prowadzi do zmiany myślenia i działania;

$\checkmark$ przewidywanie zmiany, która rozważa alternatywne przyszłości, uczy się od przeszłości i inspiruje do angażowania się w chwili obecnej;

$\checkmark$ osiąganie transformacji, która służy zmianie sposobu uczenia się, oraz systemów, w których ta nauka jest osiągana.

Matryca kompetencji edukatorów EZR opracowana przez ekspertów działających przy EKG ONZ posłużyła jako punkt wyjścia do podjęcia projektu Uniwersyteccy Edukatorzy dla Zrównoważonego Rozwoju.

\section{Kompetencje nauczycieli akademickich $\mathrm{w}$ zakresie prowadzenia EZR na uczelniach w Europie}

Wspieranie skutecznej edukacji dla zrównoważonego rozwoju na uczelniach wyższych poprzez rozwój kompetencji zawodowych nauczycieli akademickich było impulsem do podjęcia międzynarodowego projektu Uniwersyteccy Edukatorzy dla Zrównoważonego Rozwoju (University Educators for Sustainable Development EU4SD) finansowanego przez Komisję Europejską z programu „Life Long Learning Programme - Erasmus Academic Networks”. Celem tego trwającego trzy lata projektu (2013-2016), w którym wzięły udział 52 instytucje partnerskie (głównie uniwersytety) z 33 krajów Unii Europejskiej, było dokonanie przeglądu praktyk oraz opracowanie wskazówek dotyczących rozwoju zawodowego nauczycieli akademickich dla potrzeb EZR w szkolnictwie wyższym.

W pierwszym etapie projektu dokonano przeglądu innowacyjnych praktyk w dziedzinie doskonalenia kompetencji wykładowców uniwersyteckich w krajach Unii Europejskiej pod kątem prowadzenia skutecznej edukacji dla zrównoważonego rozwoju. Wyniki obejmują dane 
dotyczące ponad 3000 uczelni i ponad 24 milionów studentów z 33 krajów Europy, a ich analiza została przedstawiona w raporcie A state of the art. Report across 33 UE4SD partner countries. Raport pokazuje, że EZR zyskuje coraz większe znaczenie w szkolnictwie wyższym w całej Europie. W wielu krajach uczestniczących w projekcie UE4SD istnieją prawne dokumenty i wytyczne uznające znaczenie EZR i nakazujące jej realizację, chociaż nie we wszystkich przypadkach odnoszą się one bezpośrednio do roli szkolnictwa wyższego. Rośnie liczba instytucji szkolnictwa wyższego, które przyjęły misje i opracowały strategie działań promujących zrównoważony rozwój i EZR choć odnosi się to głównie to krajów zachodu i północy Europy (UE4SD 2014, 15-16). Istnieją uczelnie, na których edukacja dla zrównoważonego rozwoju i praktyczne wprowadzanie zasad zrównoważonego rozwoju przenika funkcjonowanie całej instytucji. W wielu jednak krajach ten proces jest zaledwie inicjowany $\mathrm{w}$ formie akademickiej dyskusji.

Ogółem zidentyfikowano 29 przykładów możliwości doskonalenia kompetencji dydaktycznych kadry akademickiej w zakresie EZR, które mogłyby być naśladowane. Jednak tyko w nielicznych krajach, na wybranych uniwersytetach, prowadzi się kompleksowe i obowiązkowe programy rozwoju zawodowego nauczycieli akademickich zawierające kształcenie kompetencji EZR. W większości krajów ten rodzaj doskonalenia zawodowego jest możliwy jedynie w wypadku osobistego zainteresowania i poszukiwania odpowiedniego szkolenia przez indywidualnego wykładowcę. Zdaniem liderów projektu UE4SD, kluczowe jest to, by wykładowcy uniwersyteccy uznali fakt, że EZR obejmuje zarówno to, „co jest nauczane”, jak i „w jaki sposób” jest nauczane. Tymczasem znakomita większość istniejących możliwości rozwoju zawodowego w zakresie tematyki zrównoważonego rozwoju dotyczy badań naukowych lub nauczania tematycznego, a nie rozwoju metod dydaktycznych i kompetencji EZR (UE4SD 2014, 54-55).

Kolejnym działaniem projektu UE4SD było wyłonienie i spopularyzowanie przykładów najlepszych praktyk rozwoju kompetencji nauczycieli akademickich w zakresie EZR. W listopadzie 2015 r. ukazała się kolejna publikacja projektu: Leading Practice Publication: Professional development of university educators on Education for Su- 
stainable Development in European countries zawierająca 13 przykładów najlepszych praktyk wybranych spośród wszystkich zebranych w projekcie.

Poza przykładami dobrych praktyk, w publikacji omówiona została charakterystyka kompetencji EZR nauczycieli akademickich. Dokonano przeglądu strategicznych dokumentów zalecających prowadzenie EZR oraz wskazano, jakie działania na szczeblu politycznym potrzebne są do osiągnięcia praktycznego wprowadzania tej edukacji na uczelniach. Zawarto również wskazówki i rekomendacje dla dalszych możliwości doskonalenia praktyk rozwoju zawodowego uniwersyteckich edukatorów w zakresie EZR.

Na podstawie analizy najlepszych przykładów z uniwersytetów europejskich stwierdzono, że:

Najczęściej inicjatywy rozwoju zawodowego w zakresie EZR na uniwersytetach są wynikiem współpracy $\mathrm{w}$ ramach istniejących sieci uniwersytetów. Obejmują one działania o charakterze międzynarodowym, narodowym oraz działania na poziomie instytucjonalnym.

$\checkmark$ Podejście pedagogiczne uwzględnia m.in. podejmowanie praktycznych działań w zakresie wcielania zasad zrównoważonego rozwoju, zachęcanie studentów do rozwiązywania konkretnych problemów, uczenie oparte na współpracy zarówno kadry i studentów, jak i wspólnych grup badawczych ze społeczeństwem pozauniwersyteckim, aktywne uczestnictwo w szkoleniach i możliwość wymiany doświadczeń, poszukiwanie angażujących metod nauczania.

$\checkmark$ Rozwój kompetencji EZR nauczycieli akademickich i zmiana w podejściu do nauczania w dużej mierze zależy od władz uczelni. Przychylna atmosfera i gotowość do otwartej debaty na temat jakości nauczania ma decydujące znaczenie dla zaistnienia tego typu inicjatyw.

$\checkmark$ Przykłady dobrych praktyk wyłonione i opisane w projekcie UE4SD pokazują, że ważny jest również czynnik finansowy. Wsparcie finansowe, czy to ze strony poszczególnych instytucji, czy ze źródeł zewnętrznych, umożliwiło realizację i sukces każdego z opisanych przykładów dobrych praktyk (UE4SD 2015, 124-125). 
Niektóre z podanych przykładów dotyczyły międzynarodowych projektów i sieci współpracy, dzięki którym skorzystały setki nauczycieli i studentów. Działania na poziomie instytucjonalnym dały wsparcie dla znacznie mniejszej liczby osób. Bez względu na skalę podejmowanych szkoleń, podnoszenie jakości nauczania i orientowanie go na rzeczywiste wyzwania współczesnej cywilizacji ma pozytywny wpływ na społeczeństwo jako całość.

\section{Podsumowanie}

Znaczenie EZR jako warunku kluczowego dla zaistnienia i realizacji zrównoważonego rozwoju jest powszechnie podkreślane przez ekspertów od samego początku powstania koncepcji zrównoważonego rozwoju. Jest to też pierwszy wniosek zawarty w raporcie UNESCO podsumowującym osiągnięcia Dekady Edukacji dla Zrównoważonego Rozwoju (2005-2014).

Prowadzenie skutecznej edukacji jest również wpisane w realizację każdego z celów zrównoważonego rozwoju (CRZ), ale ustalenie celu 4: „Zapewnienie edukacji włączającej na wysokim poziomie oraz umożliwienie wszystkim ludziom edukacji przez całe życie", szczególnie mocno podkreśla zasadnicze znaczenie edukacji dla powodzenia wszystkich CZR.

Międzynarodowe działania i zobowiązania, takie jak Dekada EZR, Strategia Edukacji dla Zrównoważonego Rozwoju EKG ONZ, Program Działań Globalnych Edukacji dla Zrównoważonego Rozwoju (Global Action Programme on Education for Sustainable Development - GAP) będący kontynuacją Dekady EZR, zapewniły ramy wdrażania EZR również w szkolnictwie wyższym.

Uniwersytety są jednostkami stosunkowo autonomicznymi w większości swoich działań i niezależnymi od polityk krajowych, dlatego dla transformacji nauczania akademickiego niezwykle ważne jest podtrzymywanie dyskusji na temat teorii edukacji i wymiana praktycznych doświadczeń (UE4SD 2015, 27). Badania przeprowadzone w ramach międzynarodowego projektu UE4SD pokazują, że już istnieją znakomite metody rozwoju kompetencji nauczycieli akademickich w zakresie EZR podejmowane w różnych kontekstach kulturowych w całej Europie i że mogą one służyć jako wzorcowe przykłady dla rozwoju inicjatyw dosko- 
nalenia zawodowego dla kadry szkolnictwa wyższego. Takie inicjatywy są potrzebne, ponieważ wciąż na wielu europejskich uniwersytetach nie są podejmowane żadne działania służące EZR.

Kształcenie nauczycieli akademickich w zakresie kompetencji EZR skupiające się na aktywnych, angażujących metodach i podejmowaniu konkretnych działań w rezultacie prowadzi do tego, że uniwersytet zaczyna funkcjonować zgodnie z zasadami zrównoważonego rozwoju.

Ważnym wsparciem dla powstawania różnych form rozwoju zawodowego - od dużych międzynarodowych konsorcjów do stosunkowo małych sieci instytucjonalnych i wspólnot edukacyjnych - może być uczestnictwo w międzynarodowych sieciach uniwersytetów na rzecz zrównoważonego rozwoju.

\section{Bibliografia:}

Europejska Komisja Gospodarcza ONZ. 2008. Strategia Edukacji dla Zrównoważonego Rozwoju. Warszawa: Ministerstwo Środowiska.

Kalinowska, Anna i Anna Batorczak. 2015. Universities for sustainability - new challenges from the perspective of the University of Warsaw. Environment \& Socio-economic Studies, 3(1), 26-34.

Longhurst, James at al. 2014. Education for Sustainable Development: Guidance for UK higher education providers. Dostęp: 8.02.2017. http:// www.qaa.ac.uk/en/Publications/Documents/Education-sustainable-development-Guidance-June-14.pdf.

Lozano, Rodrigo at al. 2015. A review of commitment and implementation of sustainable development in higher education: results from a worldwide survey. Journal of Cleaner Production 108 (Part A), 1-18. DOI: http://dx.doi.org/10.1016/j.jclepro.2014.09.048.

Maciejewska, Monika.2017. Edukacja Holistyczna. Dostęp: 20.01.2017. http://www.npseo.pl/action/dictionary/make/view/item/121/.

Tilbury, Daniele. 2011. Education for Sustainable Development: An Expert Review of Processes and Learning. Paris: UNESCO. Dostęp: 30.01.2017. http://unesdoc.unesco.org/images/0019/001914/191442e.pdf.

UE4SD. 2014. Mapping opportunities for professional development of university educators in Education for Sustainable Development: A state of 
the art report across 33 UE4SD partner countries. Cheltenham: University of Gloucestershire.

UE4SD. 2015. Leading Practice Publication: Professional development of university educators on Education for Sustainable Development in European countries. Prague: Charles University in Prague.

UNECE. 2011. Learning for the future: Competences in Education for Sustainable Development, ECE/CEP/AC.13/2011/6. Dostęp: 15.02.2017. http://www.unece.org/fileadmin/DAM/env/esd/6thMeetSC/Learning\%20for\%20the\%20Future_\%20Competences\%20for\%20 Educators\%20in\%20ESD/ECE_CEP_AC13_2011_6\%20COMPETENCES\%20EN.pdf.

UNESCO. 2014. Shaping the Future We Want. UN Decade of Education for Sustainable Development (2005-2014). FINAL REPORT. Paris: UNESCO. Dostęp: https://sustainabledevelopment.un.org/content/documents/1682Shaping\%20the\%20future\%20we\%20want.pdf. 
Ligia Tuszyńska

Akademia Pedagogiki Specjalnej im. Marii Grzegorzewskiej w Warszawie

- Wydział Nauk Pedagogicznych

ltuszynska@wp.pl

\section{Wczesnoszkolna edukacja zrównoważonego rozwoju w Polsce i w Norwegii. Analiza porównawcza praktyki pedagogicznej $\mathrm{w}$ aspekcie przyrodniczym}

\section{Wprowadzenie}

Edukacja na rzecz zrównoważonego rozwoju (EZR) stała się niezbędnym instrumentem do realizacji programów formalnych i nieformalnych instytucji takich jak: przedszkola, szkoły i społeczności lokalne (samorządy). Bez świadomego włączenia się społeczeństwa w realizację strategii zrównoważonego rozwoju nawet najlepsze programy wychowawcze nie będą skuteczne dla wychowania społeczeństwa obywatelskiego. Znaczącym elementem polityki rozwiniętych państw świata jest edukacja środowiskowa. Kształtowanie świadomości ekologicznej poprzez edukację dla zrównoważonego rozwoju powinno odbywać się równolegle na wszystkich poziomach kształcenia, według koncepcji kształcenia przez całe życie. Europejskim pionierem EZR jest Harlem Gro Brundtland, Norweżka, która jako pierwsza, w jasny i skuteczny sposób, wprowadziła do polityki i edukacji termin „zrównoważony rozwój”. W artykule jeden z paragrafów poświęcono właśnie norweskiej Minister Ochrony Środowiska, a następnie premier norweskiego rządu, jej poglądom i działaniom na rzecz ZR. Celem artykułu jest wskazanie elementów ZR w podstawach programowych kształcenia ogólnego w Norwegii i w Polsce. Porównanie tych dwóch dokumentów skonfrontowano $\mathrm{z}$ doświadczeniami wyniesionym z projektu polsko-norweskiego zatytułowanego „Edukacja środowiskowa w kształceniu nauczycieli dla zrównoważonego rozwoju”, który był realizowany przez APS z polskiej strony i Uniwersytet Agder po stronie norweskiej. W drugiej części artykułu zwrócono uwagę na to, jaki wpływ na zmianę wzorców edukacyjnych miała kwestia zrównoważonego rozwoju w Norwegii i w Polsce. W zakończeniu postawiono Czytelnikowi pytanie retoryczne: Czego my 
nauczyciele wczesnej edukacji możemy nauczyć się od Norwegów? Odpowiedź pozostaje do uzupełnienia.

\section{Gro Harlem Brundtland - przełomowa koncepcja zrównoważonego rozwoju}

Autorka raportu Nasza wspólna przyszłość, w którym zawarty jest główny paradygmat zrównoważonego rozwoju zasługuje na to, aby jej biografia była źródłem inspiracji dla wielu pokoleń również w Polsce. Gro Harlem Brundtland urodziła się 20 kwietnia 1939 roku w stolicy Norwegii Oslo. Jej matka była działaczką Partii Pracy, a ojciec był lekarzem i znanym społecznikiem. Pod wpływem rodziców Gro Harlem wykazywała się aktywnością społeczną od najmłodszych lat.

Pod wpływem swojego ojca, lekarza, późniejszego ministra spraw społecznych i zdrowia, oraz matki, działaczki Partii Pracy, młoda Gro Harlem wstąpiła do organizacji Progress Group, zrzeszającej dzieci. W tej organizacji dość wcześnie poznała i przyswoiła wartości, jakimi są sprawiedliwość społeczna, poszanowanie praw człowieka, jak również kształtowała się jej świadomość ekologiczna w wymiarze globalnym.

Idąc śladami swojego ojca oraz za swoimi marzeniami, Gro Harlem ukończyła studia medyczne na Uniwersytecie w Oslo. Następnie wraz z mężem wyjechała do Stanów Zjednoczonych, gdzie studiowała zdrowie publiczne na Uniwersytecie Harvarda. Studia te wpłynęły na zwrócenie uwagi i zainteresowanie Gro Harlem Brundtland coraz bardziej powszechnymi na świecie problemami, jakimi są ubóstwo, wzrost liczby ludności, wyżywienie, bezpieczeństwo oraz zdrowie publiczne. Zwróciła uwagę, że wszystkie te kwestie są nierozerwalnie związane z problemami ochrony środowiska. W 1965 roku, bogatsza o nowe doświadczenia, Gro Harlem Brundtland wróciła do Norwegii i podjęła pracę w Departamencie Higieny w Krajowej Dyrekcji Zdrowia Publicznego, a następnie w Miejskim Zarządzie Zdrowia w Oslo, gdzie głównie zajmowała się sprawami ochrony zdrowia dzieci.

Od pobytu w USA Brundtland wyraźnie dostrzegała ścisły związek między zdrowiem publicznym a kondycją środowiska, którą zawsze wiązała z ochroną przyrody. Za to została zauważona na arenie politycznej i w wieku 35 lat, w 1974 roku, objęła stanowisko ministra środowiska 
Norwegii. W czasie pełnienia tej funkcji Gro Harlem Brundtland w dużej mierze przyczyniła się do zmiany świadomości Norwegów w postrzeganiu środowiska naturalnego. Wydarzeniem przełomowym dla tej zmiany była jej postawa wobec katastrofy ekologicznej. W 1977 roku wydarzył się wypadek na jednej z platform wiertniczych wchodzących w skład pola naftowego Ekofisk na Morzu Północnym. Nastąpił niekontrolowany wyciek oleju. Dzięki właściwej reakcji i natychmiastowym działaniom, koordynowanym przez Harlem Brundtland, na wczesnym etapie udało się zapobiec wyciekowi oleju na większą skalę i zminimalizować szkody w środowisku naturalnym. Od tej pory Norwegowie traktują wszelkie działania na rzecz środowiska jako równoznaczne $\mathrm{z}$ inwestycją w przyszłość ich kraju. A zasługi doktor Gro Harlem Brundtland zostały zauważone w kraju i w 1981 roku została wybrana na liderkę Norweskiej Partii Pracy. Obdarzona zaufaniem społecznym, została równocześnie pierwszą kobietą na stanowisku premiera Norwegii, najmłodszym w historii szefem rządu w tym kraju. Norwegia jest dziś postrzegana jako kraj bogaty, dlatego że posiada złoża ropy naftowej. A dzięki G. H. Brundtland stała się krajem przodującym w ochronie środowiska, który dzieli się swoimi doświadczeniami na forum międzynarodowym (UN 2017).

W grudniu 1983 roku norweska premier, dzięki swoim zasługom i wieloletniemu doświadczeniu w rozwiązywaniu problemów dotyczących ochrony środowiska, objęła przewodnictwo Światowej Komisji ds. Środowiska i Rozwoju ONZ. Jako przewodnicząca Komisji wsławiła się niespotykanym entuzjazmem i umiejętnością kierownictwa. Zyskała uznanie na całym świecie za działalność na rzecz zdrowia publicznego. Było to między innymi: ustanowienie systemu wsparcia dla obywateli krajów ubogich w dostępie do szczepionek czy ograniczenie konsumpcji tytoniu poprzez ustanowienie Ramowej Konwencji w sprawie Kontroli Tytoniu. Jej główne kredo brzmiało: „... to naprawdę proste. Zdrowie ludzi i zdrowie ekosystemów są czymś nie dającym się rozdzielić”. Z pełną determinacją, w roku 1987, doprowadziła do opublikowania raportu Nasza wspólna przyszłość (Our Common Future), który oparty był na przełomowej koncepcji zrównoważonego rozwoju. Nowatorska koncepcja zakłada rozwój, który powinien zaspokajać potrzeby dzisiejszego 
pokolenia, nie zagrażając zarazem możliwościom zaspokojenia potrzeb przyszłych pokoleń. Ten paradygmat opiera się na równowadze zaspokojenia podstawowych potrzeb ludzi (w szczególności najbiedniejszych) oraz ograniczeń środowiska związanych z wydolnością systemu ekologicznego. Model zrównoważonej gospodarki zakłada odpowiednio ukształtowane relacje pomiędzy wzrostem gospodarczym, dbałością o środowisko i zdrowiem człowieka. Raport Nasza wspólna przyszłość dotyczy zasobów ludzkich, bezpieczeństwa żywności, bioróżnorodności ekosystemów, energetyki, przemysłu, gospodarki międzynarodowej, przedstawia też rozwiązania, które kraje całego świata powinny wdrożyć w kierunku zrównoważonego rozwoju. To Raport Gro Harlem Brundtland był impulsem do zorganizowania w 1992 roku Szczytu Ziemi w Rio de Janeiro (Konferencji Narodów Zjednoczonych na temat Środowiska i Rozwoju). Podczas Konferencji podpisano dokument o nazwie Agenda 21, który stał się programem na XXI wiek. W 1994 roku G. H. Brundtland otrzymała Międzynarodową Nagrodę Karola Wielkiego, a dziesięć lat później brytyjski „Financial Times” uznał ją za jedną z czterech najbardziej wpływowych osób na świecie, obok Jana Pawła II, Michaiła Gorbaczowa i Margaret Thatcher. Dzięki entuzjastycznej pracy na rzecz ochrony środowiska, Gro Harlem Brundtland stała się prekursorem postrzegania środowiska naturalnego jako wartość. Pojęcie „zrównoważony rozwój" znalazło swoje miejsce w norweskich podstawach programowych na wszystkich szczeblach kształcenia. W Norwegii rozwinęła się również bogata sieć ośrodków edukacji ekologicznej, które prowadzą edukację społeczności lokalnych (UN 2017; WHO 1998).

\section{Globalna zmiana wzorców w Norwegii - kwestia zrównoważonego rozwoju z perspektywy polskiej}

Kiedy po raz pierwszy pojęcie zrównoważonego rozwoju zostało użyte w raporcie ONZ Nasza wspólna przyszłość, premier Norwegii Gro Harlem Brundtland kierowała Światową Komisją do Spraw Środowiska Naturalnego i Rozwoju. Po tym wydarzeniu w norweskim Ministerstwie Nauki wprowadzono do podstaw programowych pojęcie „zrównoważony rozwój”, definiując je w następujący sposób: zrównoważony rozwój jest takim rozwojem, w którym potrzeby obecnie żyjących ludzi 
są zaspokajane bez niszczenia możliwości zaspokojenia potrzeb przez przyszłe generacje (Halvorsen 2015, 13-19). Termin ZR pojawił się $\mathrm{w}$ podstawach programowych kształcenia. W norweskiej Strategii ZR zwrócono uwagę, że ZR obejmuje trzy wymiary:

środowiskowy - dotyczący różnorodności biologicznej, ochrony środowiska, wykorzystania zasobów naturalnych i zmian klimatycznych;

$\checkmark$ społeczny - koncentruje się na prawach człowieka, różnorodności kulturowej, zdrowiu i równouprawnieniu mężczyzn i kobiet;

$\checkmark$ ekonomiczny - skupia się na walce z ubóstwem, sprawiedliwym podziale zasobów, narodowej i globalnej gospodarce rynkowej.

Zrównoważony rozwój jest kompleksowym pojęciem, wskazującym na wartości i zawiera globalną perspektywę pokoleniową. Zrównoważony rozwój wymaga zrozumienia tego, że jesteśmy całkowicie zależni od przyrody, że współdziałanie pomiędzy ludźmi powinno być nacechowane takimi wartościami, jak wzajemne zaufanie, demokracja i równouprawnienie. Wizja norweskich władz przewiduje stworzenie systemu kształcenia, który przyczyni się do lokalnego i globalnego zrównoważonego rozwoju (KD 2012). W Polsce „szkoła norweska zostaje niezauważalna, niedoceniona. Autentyczna jak dawniej, pielęgnująca podstawowe wartości i tradycję, dba o swoich uczniów. Tak mało o niej wiemy, czerpiemy z wzorców zachodnich, nasi anglojęzyczni sąsiedzi wydają się wzorem do naśladowania... Chciałabym ukazać geniusz, a zarazem pomysłowość..., jej podstawowy element, jakim jest outdoor education" (Mańkowska 2009, 76-89).

W kształceniu przyrodniczym norweska tradycja regularnych wycieczek była drogą do wyzwolenia u małych dzieci miłości do przyrody, współpracy z innymi dziećmi i dorosłymi. Wczesna edukacja w Norwegii skupia się na dwóch wymiarach, z podanych trzech, w zrównoważonym rozwoju: na środowisku i społeczeństwie. Do przykładów projektów przyroda - dzieci w ich pionierskiej fazie, której celem było wspieranie kształcenia dla zrównoważonego rozwoju w latach 90. XX wieku, nawiązuje Halvorsen (1993 i 1995). Norweska podstawa programowa wskazuje na aktywny udział ucznia w proce- 
sie własnego uczenia się. Zadaniem szkoły jest „zachęcać dziecko do odwagi, podejmowania wysiłków i nie poddawania się..., ponieważ wewnętrzna dociekliwość dzieci jest ogromną siłą. Wyraźnie eksponuje się założenie, iż uczniowie rozwijają się w wyniku podejmowania wysiłku poznawania, odkrywania, kreowania nowych pomysłów, negocjowania, dyskutowania itp. Dziecięca bezgraniczna ciekawość powinna być skierowana na przygotowywanie projektów i współpracę z innymi, przedstawianie pomysłów i wyników pracy, dyskutowanie itp. Siłą napędową uczenia się jest tu wewnętrzna motywacja, zaciekawienie, entuzjazm, potrzeba odkrywania, traktowanie edukacji jak wspaniałej przygody. Zwraca się uwagę na to, że dzieci w ogromnym stopniu uczą się jedne od drugich.

W Polsce wciąż dominuje model pedagogiki instrukcyjnej oparty na przekazie wiedzy i sprawdzaniu jej przyswojenia według sztywnych reguł. W polskiej podstawie programowej wprawdzie mówi się o programie skoncentrowanym na dziecku i na jego indywidualnym tempie rozwoju, ale używany język nie wskazuje na zaangażowanie dziecka w uczenie się, tylko raczej na przekaz nauczyciela (Bałachowicz i Gawrońska 2015, 39-49). Pomimo stałej ewolucji i zmian w polskiej Podstawie programowej, wymieniane w niej cele i osiągnięcia (np. uczeń wie, zna, wymienia, nazywa, przedstawia) nie odnoszą się do wartości, które dziecko powinno przyswoić w procesie uczenia się i wychowania w grupie rówieśniczej. Z takiego zapisu wynika, że wyposażanie ucznia w umiejętności nie czyni go sprawcą własnego rozwoju, świadomego własnego procesu uczenia się, a raczej stawia je w roli odtwórcy. Z zapisów dokumentów norweskich wynika, że dziecko, jako podmiot w szkole, powinno rozwijać: krytyczny osąd i umiejętności naukowego myślenia, metody pracy badawczej, umiejętności refleksji i stawiania nowych pytań, eksperymentowanie i obserwację, szukanie wyjaśnień dla obserwowanych fenomenów... itd. Nauczyciel ma rozwijać i wspierać zaangażowanie dziecka, traktować je jako aktywnego uczestnika interakcji edukacyjnych. Koncentrując się na wymiarze środowiskowym zrównoważonego rozwoju, warto przytoczyć przykłady, które wskazują, jak norweskie przedszkola i szkoły radykalnie zmieniły swoje praktyki. Powszechne jest uczenie się w otocze- 
niu przyrody, w środowisku, w najbliższej okolicy. Niektóre placówki oświatowe praktykują systematyczne wychodzenie z dziećmi na łono natury przez cały rok jeden raz w tygodniu. Jednocześnie rozwinięto model środowiskowy na kolejnych etapach edukacyjnych, aby zapewnić postęp przez całoroczne (i wieloletnie) cotygodniowe obcowanie i doświadczanie przyrody (Halvorsen 1993). Na kolejnych etapach wczesnej edukacji dzieci zaczynają powoli odkrywać różnorodność roślin i zwierząt oraz zjawiska i związki istniejące w przyrodzie. Regularne wycieczki mogą rozwinąć empatię dziecka dla wszystkiego, co żyje. Taki model kształcenia jest podstawą do tego, by w przyszłości uczniowie, jako osoby dorosłe, mogli mieć wpływ i czuć odpowiedzialność za przyszłość. Model środowiskowy integruje się z wymiarem społecznym i kulturowym zrównoważonego rozwoju.

\begin{tabular}{|c|c|}
\hline Brać odpowiedzialność za przyszłość & \\
\hline Oddziaływać i współdziałać & \\
\hline Odkrywać związki & \\
\hline Odkrywać różnorodność & \\
\hline Być na łonie przyrody i kochać ją & \\
\hline
\end{tabular}

Rys.1. Środowiskowy i społeczny wymiar w kształceniu dzieci dla zrównoważonego rozwoju (Halvorsen 2015, 13-19).

Społeczny i kulturowy wymiar zrównoważonego rozwoju w norweskiej edukacji szkolnej przejawia się w demokracji i poszanowaniu praw człowieka. Nauczyciel, planując plenerowe wyjście z uczniami, jest przygotowany do prowadzenia zajęć dotyczących konkretnego zagadnienia, np. obserwowania owadów występujących na łące. Jeżeli jednak w czasie wycieczki wydarzy się ciekawa sytuacja (np. dzieci napotkają gniazdo kuropatwy z młodymi) i to pochłonie ich całą uwagę, nauczyciel musi wybrać pomiędzy dwiema możliwościami: może realizować swój plan, w większym lub mniejszym stopniu używając swojej władzy, by zmusić dzieci do zapoznania się z owadami, może też porzucić swój 
pierwotny plan i improwizować, wykorzystując to, że dzieci odkryły gniazdo dzikich ptaków i przeżywają różne emocje: zachwyt i empatię oraz radość z odkrycia. Włączenie się nauczyciela i rozmowy z dziećmi na temat tego zdarzenia są sposobem okazywania respektu dla przyrodniczych odkryć dzieci. Daje im możliwość wspólnego działania przy zmianie ustalonego planu wycieczki i wspiera zafascynowanie dzieci przyrodą oraz rozwija ich ciekawość.

Zgodnie z wytycznymi zawartymi w podstawie programowej, edukacja przyrodnicza w Norwegii powinna być realizowana poprzez tworzenie zróżnicowanych okazji edukacyjnych, którymi są: badania przyrody $\mathrm{w}$ terenie, eksperymenty w laboratorium i wycieczki do muzeów, ośrodków naukowych i przedsiębiorstw handlowych/przemysłowych. Wpływa to na zwiększenie możliwości edukacyjnych w zakresie nauk przyrodniczych, rozbudza potrzebę zastanowienia się, ciekawości i fascynacji, a to właśnie takie kompetencje dają dobrą podstawę do kształcenia zawodowego, dalszych badań i kształcenia przez całe życie, zarówno w pracy, jak i w czasie wolnym.

$\mathrm{Na}$ poziomie szkoły podstawowej w Norwegii zaplanowano blok przedmiotowy pod nazwą „Nauki przyrodnicze”. Został on podzielony na pięć głównych obszarów tematycznych, które są rozszerzane na poszczególnych etapach nauki. Podobnie jak w Polsce, sformułowano przyrodnicze cele kompetencyjne, które określają zakres wiedzy i umiejętności, jakie uczeń powinien zdobyć po każdym etapie kształcenia. Tabela 1. przedstawia ogólny wykaz kompetencji w norweskiej i polskiej podstawie programowej w zakresie przedmiotów przyrodniczych w szkole podstawowej (Lewandowska i Witkowska-Tomaszewska 2015, 53-69; RMERCA 1994 i 2015). 


\begin{tabular}{|c|c|}
\hline \multicolumn{2}{|c|}{ Zakres kompetencji przyrodniczych w szkole podstawowej } \\
\hline Podstawa programowa - Norwegia & Podstawa programowa - Polska \\
\hline $\begin{array}{l}\text { Obszar tematyczny „młody naukowiec”: } \\
\text { uczeń powinien rozwijać takie umiejętności, } \\
\text { jak: formułowanie hipotez, eksperymento- } \\
\text { wanie, systematyczna obserwacja, dyskusja, } \\
\text { krytyczna ocena, argumentacja, umiejętność } \\
\text { wyciągania wniosków i ich prezentacji. } \\
\text { „Różnorodność w naturze”: uczeń ma rozwi- } \\
\text { nąć wiedzę na temat przyrody i umiejętności } \\
\text { poszanowania jej różnorodności. Proces kształ- } \\
\text { cenia w tym obszarze skupia się także na zrów- } \\
\text { noważonym rozwoju, czyli określeniu miejsca } \\
\text { człowieka w przyrodzie, oraz tym, w jaki sposób } \\
\text { działalność człowieka zmieniła i nadal zmienia } \\
\text { środowisko naturalne lokalnie oraz globalnie. } \\
\text { „Ciało człowieka”: Celem tego obszaru } \\
\text { tematycznego jest również kształcenie u } \\
\text { uczniów odpowiedzialności za swoje ciało } \\
\text { oraz zdrowie fizyczne i psychiczne. Przed- } \\
\text { miot skoncentrowany jest wokół zagadnień } \\
\text { związanych z organizmem człowieka: zmian } \\
\text { w trakcie rozwoju, funkcjonowania, współ- } \\
\text { działania poszczególnych części ciała, wpływ } \\
\text { stylu życia na ciało i zdrowie ludzkie. } \\
\text { „Zjawiska i substancje”: W tym obszarze cele } \\
\text { zajęć obejmują umożliwienie uczniom opisania i } \\
\text { pokazania, jakZiemia, Księżyci Słońce poruszają } \\
\text { się w stosunku do siebie i wyjaśnienia pór roku, } \\
\text { dnia/nocy i faz Księżyca; opisania i uporządko- } \\
\text { wania substancji na podstawie obserwowalnych } \\
\text { cech; przeprowadzenia eksperymentów z wodą i } \\
\text { światłem oraz omówienia obserwacji. } \\
\text { „Technologia i projektowanie”: Cele zajęć } \\
\text { obejmują umożliwienie uczniom wykonania } \\
\text { artefaktów, które będą w stanie poruszać się } \\
\text { za pomocą wody lub powietrza i opowiedze- } \\
\text { nia innym o tym, jak działają; wykonania } \\
\text { artefaktów, które będą wykorzystywać odbi- } \\
\text { cie światła i opowiedzenia innym o tym, jak } \\
\text { działają; zaplanowania, zbudowania i prze- } \\
\text { testowania prostych modeli konstrukcji bu- } \\
\text { dowlanych i udokumentowania procesu od } \\
\text { pomysłu do gotowego produktu. }\end{array}$ & $\begin{array}{l}\text { Obszar: „Edukacja przyrodnicza”. Uczeń: } \\
\text { obserwuje i prowadzi proste doświadczenia } \\
\text { przyrodnicze, analizuje je i wiąże przyczy- } \\
\text { nę ze skutkiem; opisuje życie w wybranych } \\
\text { ekosystemach: w lesie, ogrodzie, parku, łące } \\
\text { i zbiornikach wodnych; nazywa charakte- } \\
\text { rystyczne elementy typowych krajobrazów } \\
\text { Polski: nadmorskiego, nizinnego, górskiego; } \\
\text { wymienia zwierzęta i rośliny typowe dla wy- } \\
\text { branych regionów Polski; rozpoznaje i nazy- } \\
\text { wa niektóre zwierzęta egzotyczne; wyjaśnia } \\
\text { zależności funkcjonowania przyrody od pór } \\
\text { roku; podejmuje działania na rzecz ochrony } \\
\text { przyrody w swoim środowisku; wie, jakie } \\
\text { zniszczenia w przyrodzie powoduje człowiek } \\
\text { (wypalanie łąk, zaśmiecanie lasów, nadmier- } \\
\text { ny hałas, kłusownictwo); zna wpływ przy- } \\
\text { rody nieożywionej na życie ludzi, zwierząt i } \\
\text { roślin; określa wpływ światła słonecznego na } \\
\text { cykliczność życia na Ziemi; znaczenie powie- } \\
\text { trza i wody dla życia; znaczenie wybranych } \\
\text { skał i minerałów dla człowieka (np. węgiel } \\
\text { i glina); nazywa części ciała i organów we- } \\
\text { wnętrznych (np. serce, płuca, żołądek); } \\
\text { zna podstawowe zasady racjonalnego odży- } \\
\text { wiania się; rozumie konieczność kontrolo- } \\
\text { wania stanu zdrowia i stosuje się do zaleceń } \\
\text { stomatologa i lekarza; } \\
\text { dba o zdrowie i bezpieczeństwo swoje i in- } \\
\text { nych, (na miarę swoich możliwości); orientu- } \\
\text { je się w zagrożeniach ze strony roślin i zwie- } \\
\text { rząt, a także w zagrożeniach typu powódź, } \\
\text { huragan, śnieżyca, lawina itp.; wie, jak trzeba } \\
\text { zachować się w takich sytuacjach. }\end{array}$ \\
\hline
\end{tabular}

Tabela 1. Wykaz kompetencji przyrodniczych zalecany w podstawach programowych. 
Jak wynika $\mathrm{z}$ analizy treści podstaw programowych, zarówno cele jak i treści kształcenia w szkole podstawowej w Polsce i w Norwegii są bardzo podobne. Należy zwrócić uwagę, że obydwa dokumenty jednak znacznie się różnią obudową tych treści. Część ogólna w norweskiej podstawie skierowana jest głównie do nauczyciela. Część ta przedstawia uwarunkowania historyczne i kulturowe. Wskazuje na zrozumienie zasad zrównoważonego rozwoju i na edukację zgodnie z zasadami demokracji, współdziałania, współodczuwania i perspektywicznego myślenia międzypokoleniowego. Porównanie polskiej i norweskiej Podstawy programowej zwraca uwagę na różnice w pojmowaniu dziecka i jego rozwoju. Warto „zaznaczyć, iż sposób mówienia o edukacji, konstruowania znaczeń i wiązanych z tym wartości w oficjalnym dyskursie edukacyjnym wyznacza sposoby konstruowania praktyki edukacyjnej i odpowiednio do tego kształcenie nauczycieli" (Bałachowicz 2015, 39-52). Należy zwrócić uwagę, że choć dążymy do osiągnięcia statusu społeczeństwa wiedzy przez kształcenie się przez całe życie, to wiedza nauczycielska powinna być wzmacniana również $\mathrm{w}$ aktach prawnych dotyczących edukacji. W polskiej podstawie programowej brak jest jasnego sformułowania zadań szkoły w zakresie przygotowania uczniów do realizacji programu zrównoważonego rozwoju. Niezrozumiałe wydaje się pominięcie tych zagadnień w poszczególnych przedmiotach (Kowalak 2009, 313-317). Trudno wyobrazić sobie realizację idei zrównoważonego rozwoju bez uświadomienia sobie związków przyrody i kultury oraz człowieka z przyrodą.

\section{Konkluzja}

Niezależnie od różnic w zapisach podstaw programowych w Norwegii i w Polsce, warto podzielić się refleksją z praktyki i wskazać na znaczenie rozumienia przez nauczycieli pojęcia „zrównoważony rozwój”. Znajomość biografii Gro Harlem Brundtland może pomóc w zrozumieniu, jak ważny jest to problem. Doskonalenie nauczycieli poprzez udział w projektach międzynarodowych może przyczynić się do wzrostu poziomu ich kompetencji do prowadzenia zajęć w najbliższym środowisku przyrodniczym. W Polsce w kształceniu nauczycieli jest jeszcze wiele do zrobienia, aby najlepsi absolwenci studiów wyższych chcieli pracować w szkole, na- 
leży zadbać o wyższą jakość kształcenia akademickiego, więcej praktyki pedagogicznej i uspołecznienie studentów. Oznacza to również wyższe wymagania zarówno wobec nauczycieli akademickich jak i studentów. Formuła szkoły opartej na wykładzie i przekazywaniu wiedzy międzypokoleniowej stopniowo się wyczerpuje. Należy również zwrócić uwagę studentów na to, że wiele źródeł wiedzy podaje informacje sprzeczne, będące ze sobą w konflikcie. Nowoczesny model edukacji polega nie tylko na przyswajaniu wiedzy, ale także - i może przede wszystkim - na wskazywaniu sposobów: jak się uczyć, jak czerpać wiedzę z różnych źródeł i jak odróżniać źródła rzetelne od pseudonaukowych. Szkoła ma ogromną rolę w socjalizacji uczniów i motywowaniu do współpracy. W polskiej szkole wciąż obserwujemy raczej tradycyjne podejście do wychowania. A przez wychowanie należy rozumieć zaszczepienie pewnego rodzaju poglądów i wartości, ale też przygotowanie do harmonijnego współżycia w zróżnicowanym społeczeństwie (Herbst 2016, 33-35).

Na zakończenie proponuję zastanowienie się nad tym: czego my nauczyciele wczesnej edukacji możemy nauczyć się od Norwegów i czego nauczyciele norwescy mogą się nauczyć od nas? Oto moje przyjazne rady dla nauczycieli, zachęcające do prowadzenia zajęć terenowych i wynikające $\mathrm{z}$ obserwacji przyrodniczych zajęć terenowych podczas projektu polsko-norweskiego, lista odpowiedzi pozostaje otwarta:

$\checkmark$ „zwracajmy się do ucznia w koniunktywie, a nie w imperatiwie, po którym trzeba, po którym należy postawić wykrzyknik!

$\checkmark$ uczmy się razem z dziećmi;

$\checkmark$ nie ignorujmy zaciekawienia dziecka przyrodą, bo na tym polega edukacja;

$\checkmark$ nie ma złej pogody dla kontaktu z przyrodą, jest tyko nieodpowiednie ubranie;

$\checkmark$ dziecko może odważyć się używać np. ostrych narzędzi, ale musi być skoncentrowane na pracy;

$\checkmark$ warto odważyć się, aby coś zrobić po raz pierwszy...”.

Nauczyciel, który nie uczy się razem z uczniami, nie jest dobrym edukatorem. 


\section{Bibliografia:}

Bałachowicz, Józefa i Beata Gawrońska. 2015. System kształcenia nauczycieli w Norwegii. W: Edukacja przyrodnicza $w$ terenie. W strone pedagogiki zrównoważonego rozwoju, red. Józefa Bałachowicz i Ligia Tuszyńska, 39-49. Warszawa: Wydawnictwo APS.

Halvorsen, Kirsti Vindal. 1993. Barn upptäcker naturen. Otta: Lantbruksforlaget.

Halvorsen, Kirsti Vindal. 1995. Steps in the Plantain Project: The Ideas, Activities, and Experiences of the Plantain Project, a Scheme to Safeguard Children and their Environment. Children's Environments, 12(4), 444-456.

Halvorsen, Kirsti Vindal. 2015. Kształcenie dla zrównoważonego rozwoju z perspektywy norweskiej. W: Edukacja przyrodnicza w terenie. $W$ stronę pedagogiki zrównoważonego rozwoju, red. Józefa Bałachowicz i Ligia Tuszyńska, 13-19. Warszawa: Wydawnictwo APS.

Herbst, Marcin. 2016. Szkolne błędy, Polityka 46(3085) z 8 listopada, 33-35.

KD. 2012. Wiedza dla wspólnej przyszłości. Zrewidowana strategia kształcenia dla zrównoważonego rozwoju. Dostęp: 2.05.2015. https:// www.regjeringen.no/globalassets/upload/kd/vedlegg/uh/rapporterog planer/strategi_for_ubu.pdf.

Kowalak, Adam. 2009. Realizacja idei zrównoważonego rozwoju w podstawie programowej dla II i III etapu kształcenia. Problemy Ekologii, (6), 313-317.

Lewandowska, Ewa i Anna Witkowska-Tomaszewska. 2015. System kształcenia uczniów klas I-III szkoły podstawowej. W: Edukacja przyrodnicza $w$ terenie. W stronę pedagogiki zrównoważonego rozwoju, red. Józefa Bałachowicz i Ligia Tuszyńska, 53-65. Warszawa: Wydawnictwo APS.

Mańkowska, Anna, 2009. Przemiany programu nauczania obowiązkowego w Norwegii. Przegląd Pedagogiczny, (2), 76-89. Dostęp: 21.01.2017. http://repozytorium.ukw.edu.pl/handle/item/548.

RMERCA (The Royal Ministry of Education, Research and Church Affairs). 1994. Core Curriculum for Primary, Secondary and Adult Education in Norway. Dostęp: 27.01.2017. http://www.ibe.unesco.org/curricula/norway/no_alfw_1994_eng.pdf. 
RMERCA. 2015. Core Curriculum for Primary, Secondary and Adult Education in Norway. Dostęp: 2.05.20015. https://www.udir.no/kl06/NAT1-03.

UN. 2017. Biography of Dr Gro Harlem Brundtland. Dostęp: 27.01.2017. http://www.un.org/News/dh/hlpanel/brundtland-bio.htm.

WHO. 1998. Dr Gro Harlem Brundtland, Director-General. Dostęp: 27.01.2017. http://www.who.int/dg/brundtland/bruntland/en/. 



\section{CZĘŚĆ V INSTRUMENTY \\ ZRÓWNOWAŻONEGO ROZWOJU}



Janusz Radziejowski

Wszechnica Polska Szkoła Wyższa w Warszawie

janusz.radziejowski@gmail.com

\section{Idea zrównoważonego rozwoju w planowaniu przestrzennym}

\section{Wprowadzenie}

Celem niniejszej pracy jest omówienie roli, jaką w Polsce, w świetle istniejących dokumentów, ogrywać powinno planowanie przestrzenne w kształtowaniu zrównoważonego rozwoju. Wykazano także, jakie, zadaniem Autora, są przyczyny niskiej efektywności tak ważnego narzędzia, którym jest planowanie przestrzenne, w kształtowaniu przestrzeni naszego kraju oraz co należy zrobić, by to zmienić.

Od końca XX wieku powszechnie używamy pojęcia zrównoważonego rozwoju. Mówimy więc o zrównoważonej gospodarce, zrównoważonym rozwoju, zrównoważonym korzystaniu z dóbr natury. Chcemy również, by nasza gospodarka przestrzenna rozwijała się w sposób zrównoważony, czyli w poszanowaniu dla niezbędnych potrzeb człowieka z jednej strony, a zgodnie $\mathrm{z}$ zasadami zachowania walorów środowiska przyrodniczego z drugiej.

Przypomnieć należy, że pojęcie zrównoważonego rozwoju pojawiło się w latach osiemdziesiątych XX wieku i znalazło swoje miejsce w Raporcie Komisji ONZ Środowisko i Rozwój z roku 1987 pt. Nasza wspólna przyszłość (ŚKŚR 1991). Idea ta skonkretyzowana została w dokumentach Konferencji ONZ „Środowisko i Rozwój” , która odbyła się w Rio de Janeiro w roku 1992. W przyjętym wtedy dokumencie Agenda 21 zdefiniowano m.in. podstawowe cele trwałego i zrównoważonego rozwoju miast dla poprawy warunków gospodarczych, środowiskowych i socjalnych. Zakładano też, że planowanie przestrzenne będzie stanowić jedno z narzędzi służących zrównoważonemu rozwojowi (Agenda 21 1993).

Idea zrównoważonego rozwoju została przejęta również przez Unię Europejską. Chociaż samo planowanie przestrzenne nie jest regulowane przez acquis communautaire, to w dokumentach poświęconych np. zrównoważonemu rozwojowi zwraca się uwagę na problemy, które wiążą się z tym zagadnieniem. W ramach realizowanego w latach 2000-2012 6 Programu działań na rzecz środowisk „Europa 2010 - Nasza przyszłość, 
nasz wybór", powstało szereg dokumentów strategicznych w tym Strategia tematyczna $w$ sprawie środowiska miejskiego z roku 2006 (KWE 2006). W dokumencie tym przewiduje się cztery priorytetowe tematy: gospodarkę miejską, zrównoważony rozwój transportu, budownictwo oraz właśnie planowanie przestrzenne, m.in. poprzez zrównoważone planowanie urbanistyczne, które ma pomóc w ograniczeniu bezładnej zabudowy oraz przeciwdziałaniu utraty siedlisk przyrodniczych i różnorodności biologicznej. Zwrócić należy uwagę, że również w obecnym 7 Programie (który ma być realizowany do 2020 r.) przewiduje się zasadę zrównoważonego rozwoju miast (EC 2013-2020).

Również Polska wprowadziła zasadę zrównoważonego rozwoju do szeregu oficjalnych dokumentów, o czym poniżej.

\section{Zrównoważony rozwój w wybranych polskich dokumentach strategicznych}

Najważniejsze zalecenia zawarte w międzynarodowych aktach prawnych stanowią podstawę, na której opierają się również polskie dokumenty. Przypomnieć należy, że pojęcie „zrównoważony rozwój” jest obecne w szeregu dokumentów prawnych i programowych w Polsce z Konstytucją RP na czele, w której (art. 5) mówi się, że: „Rzeczpospolita Polska ...zapewnia ochronę środowiska, kierując się zasadą zrównoważonego rozwoju”. Jako definicję zrównoważonego rozwoju należy przyjąć tę, która została zapisana w polskiej ustawie z 2001 roku o prawie ochrony środowiska (Dz.U. 2013 poz. 1232), gdzie: „rozwój zrównoważony to taki rozwój społeczno-gospodarczy, w którym następuje proces integrowania działań politycznych, gospodarczych i społecznych, z zachowaniem równowagi przyrodniczej oraz trwałości podstawowych procesów przyrodniczych, w celu zagwarantowania możliwości zaspokajania podstawowych potrzeb poszczególnych społeczności lub obywateli zarówno współczesnego pokolenia, jak i przyszłych pokoleń” (art. 3 pkt. 50). Ta definicja została przeniesiona do ustawy z dnia 27 marca 2003 roku o planowaniu i zagospodarowaniu przestrzennym (art. 2 pkt 1). Z punktu widzenia planowania przestrzennego istotna jest treść art. 8 tej ustawy o ochronie środowiska, z której wynika, że wszelkie polityki, strategie, plany lub programy dotyczące gospodarki oraz gospodarki 
przestrzennej i wykorzystywania terenu powinny uwzględniać zasady ochrony środowiska i zrównoważonego rozwoju. Również wspomniana wyżej ustawa o planowaniu i zagospodarowaniu przestrzennym z 2003 roku zakłada, że podstawą działań w zakresie polityki przestrzennej winien być, oprócz ładu przestrzennego, także zrównoważony rozwój.

Podstawowym dokumentem, który powinien mieć wpływ na zrównoważony rozwój w ramach gospodarki przestrzennej w Polsce jest Koncepcja Przestrzennego Zagospodarowania Kraju do roku 2030 (KPZK 2011). Dokument ten stwierdza, że podstawą polityki przestrzennej jest ustrojowa zasada zrównoważonego rozwoju. Wynikają z niej: zasady racjonalności ekonomicznej, zasady preferencji odnowy nad zajmowaniem nowych obszarów pod zabudowę, zasada przezorności ekologicznej. KPZK wyznacza następujące cele w zakresie zagospodarowania kraju do roku 2030: podwyższenie konkurencyjności głównych ośrodków miejskich, przywrócenie i utrwalenie ładu przestrzennego, rozwój budownictwa zgodnego z zasadami zrównoważonego rozwoju (co oznacza ograniczanie materiałochłonności i energochłonności), rozwój terenów zielonych. Ważnym zadaniem ma być rewaloryzacja i rewitalizacja terenów miast. Jeden z celów KPZK zakłada przywrócenie i utrwalenie ładu przestrzennego m.in. poprzez politykę ładu zintegrowanego, co oznacza łączenie ładu społecznego, ładu ekonomicznego i ładu ekologicznego oraz ładu przestrzennego (KPZK 2011, 74-161). Ustalenia KPZK winny być realizowane poprzez dokumenty planistyczne, które, jak wynika ze wspomnianej ustawy z 2003 roku o planowaniu i zagospodarowaniu przestrzennym, mają być realizowane również w duchu zrównoważonego rozwoju. Dokumenty te to:

$\checkmark$ Koncepcja Przestrzennego Zagospodarowania Kraju, która funkcjonuje na szczeblu centralnym (za przygotowanie aktualnej jego edycji z 2011 roku odpowiadał Minister Rozwoju Regionalnego). W oparciu o ten dokument ministrowie i kierownicy urzędów centralnych mają obowiązek przygotować programy zawierające zadania rządowe służące realizacji celów publicznych o znaczeniu krajowym.

$\checkmark$ Plany zagospodarowania przestrzennego województw, sporządzane przez marszałków województw, a uchwalane przez sejmiki woje- 
wódzkie. Ich ustalenia winny być wprowadzone do planów miejscowych.

$\checkmark$ Dwa typy dokumentów na poziomie gmin i miast: studia uwarunkowań i kierunków zagospodarowania przestrzennego gminy oraz miejscowe plany zagospodarowania przestrzennego (m.p.z.p). Oba dokument sporządzają wójtowie (burmistrzowie, prezydenci miast), a uchwalają rady samorządowe (gmin, miast). Studia uwarunkowań są dokumentami o charakterze strategicznym, obejmującym całość obszarów administracyjnych gminy, których ustalenia są wiążące dla organów gminy, nie jest to jednak dokument prawa miejscowego (a więc jego ustalenia bezpośrednio nie obowiązują obywateli). Studia wskazują też tereny, które muszą być objęte miejscowymi planami przestrzennego zagospodarowania - wynika z tego, że posiadanie planów miejscowych, które są dokumentami prawa miejscowego, nie jest obligatoryjne. Nie muszą one też obejmować całej gminy.

$\checkmark$ W przypadku braku planu miejscowego wójt (burmistrz, prezydent) może wydać decyzję o warunkach zabudowy, która staje się podstawą lokalizacji inwestycji. Nie jest wymagane, by była ona zgodna z zapisami studium - co pogłębia bałagan w naszej przestrzeni.

We wszystkich dokumentach planistycznych uwzględniane są problemy ochrony środowiska. Zawierają one także bardzo rozbudowane procedury dotyczące środowiska.

Do najważniejszych problemów - wyzwań stojących przed planowaniem przestrzennym w Polsce - zaliczyć należy: racjonalizację gospodarki przestrzennej, w tym ochronę otwartej przestrzeni jako waloru przyrodniczego; rozwój osiedli ludzkich ze szczególnym uwzględnieniem obszarów metropolitalnych; ograniczenie zmian klimatu i adaptację do tych zmian, ochronę terenów występowania obiektów o wysokich walorach przyrodniczych.

Najwyższy niepokój o przyszłość racjonalnej gospodarki przestrzenią w naszym kraju wywołuje też instytucjonalna słabość planowania przestrzennego w skali miejscowej oraz ciągły brak skutecznych mechanizmów planowania regionalnego, które mogłoby bronić podstawowych struktur przestrzennych, opartych o tradycję użytkowania tych 
obszarów oraz ich strukturę przyrodniczą. Do najważniejszych problemów można tu zaliczyć wspomnianą zasadę wydawania decyzji o warunkach zabudowy. Brak jest też tradycji lokalnych wzorców i standardów użytkowania przestrzeni, nie sprzyja też temu prawo. W Polsce nic faktycznie nie ogranicza możliwości dzielenia posesji na coraz mniejsze parcele budowlane, nic też nie chroni (poza nielicznymi przypadkami) miejscowości przed inwestycjami mogącymi zmienić ich dotychczasowy charakter. Łatwość zmian w planach przestrzennego zagospodarowania, uchwalanie "planów” dotyczących fragmentów miejscowości, ułatwia ten proceder. Wszystko to powoduje, że tak cenny zasób środowiska, jakim jest przestrzeń, jest traktowany w naszym kraju wyjątkowo brutalnie. Praktycznie otwarta przestrzeń, o ile nie podlega specjalnemu prawu (np. ustawie o ochronie przyrody), nie jest niczym chroniona, a podejmowane nieraz przez lokalne władze dla zaspokojenia doraźnych potrzeb decyzje lokalizacyjne będą skutkowały przez następne stulecie. Oczywiście to nie sprzyja zrównoważonemu rozwojowi. Podsumowując, Polska przestrzeń charakteryzuje się:

$\checkmark$ ekstensywnym rozwojem miast, zajmowaniem przestrzeni ponad rzeczywiste potrzeby wynikające z liczby mieszkańców i prognoz demograficznych;

$\checkmark$ zajmowaniem terenów rolniczych, terenów otwartych, rekreacyjnych;

$\checkmark$ dzieleniem, „rozkawałkowaniem” terenów o wysokich wartościach przyrodniczych, co skutkuje utratą walorów różnorodności biologicznej, rozkawałkowaniem przestrzeni, utratą walorów krajobrazu;

$\checkmark$ zanieczyszczeniem środowiska, kłopotami z budową i eksploatacją wspólnej infrastruktury ochrony środowiska;

$\checkmark$ nadmiernymi emisjami gazów cieplarnianych spowodowanymi rozwiniętym transportem samochodowym oraz brakiem systemów ogrzewczych, eliminujących indywidualne, mało efektywne paleniska - to ostatnie skutkuje zanieczyszczeniem powietrza różnymi szkodliwymi substancjami, co jest przyczyną podniesionej śmiertelności w Polsce;

$\checkmark$ nadmiernym rozwojem transportu samochodowego wymuszającego rozbudowę dróg kołowych; 
$\checkmark$ brakiem spójnych systemów transportu publicznego, zwłaszcza w zakresie transportu szynowego - wobec faktu nieskoordynowanego rozwoju osiedli ludzkich;

$\checkmark \quad$ większymi kosztami funkcjonowania jednostek osadniczych.

Dodać należy, że większość obiektów powstaje poza wszelkimi planami na podstawie indywidualnych decyzji, a niejednokrotnie także w drodze samowoli budowlanej. W dodatku szereg planów ma charakter nierealistyczny, co przejawia się miedzy innymi nadmiernie zaplanowanymi obszarami osadniczymi. Wszystko to przekreśla możliwości realizacji zrównoważonego rozwoju w obrębie jednostek administracyjnych.

Ważnym elementem polityki przestrzennej mogłyby być obszary metropolitalne rozumiane jako przestrzeń sformalizowana przez wspólne zarządzanie $\mathrm{w}$ zakresie rozwoju przestrzennego, struktury transportowej, lokalizacji nowych osiedli - komplementarnych w stosunku do głównych miast. Zarządzanie w granicach obszaru metropolitalnego może być bardzo efektywne pod względem zrównoważonego rozwoju. Poważnym problemem jest brak planowej polityki osiedleńczej. Powstaje, na ogół bezplanowo, szereg rozproszonych osiedli. Brak jest nowych jednostek osadniczych mających cechy miast, a także osiedli o charakterze „satelitarnym” do ośrodków metropolitalnych. Do tego typu miast można zaliczyć „miasta-ogrody”, które powstawały w Polsce w latach dwudziestych i trzydziestych ubiegłego wieku. Były one planowane na ogół jako osiedla wyposażone w infrastrukturę (systemy transportowe, kościoły, kasyna, sklepy). Dawało to szansę na tworzenie się lokalnych społeczności, zapewniało możliwości sprawnego komunikowania się $\mathrm{z}$ ośrodkami centralnymi. Obecnie miejscowości te funkcjonują bądź jako dzielnice miast, wyróżniające się swym charakterem i strukturą społeczną, bądź jako samodzielne miasta.

Jeśli chodzi o zmiany klimatu, to takie zjawiska jak nadzwyczajne fale upałów, susze, dotkliwe mrozy i intensywne śnieżyce paraliżujące całe regiony, gwałtowne burze powiązane $\mathrm{z}$ silnymi huraganowymi wiatrami czy też ulewnymi deszczami, w konsekwencji których, mamy do czynienia z niszczącymi powodziami - coraz częściej występują również w Polsce. Jest oczywiste, że szczególną uwagę należy poświęcić proble- 
matyce wrażliwości miast na zjawiska towarzyszące zmianom klimatu oraz możliwościom adaptacji do tych zmian, gdyż właśnie miasta stanowią największe skupiska ludności oraz główne centra gospodarki i kultury. Z doświadczeń ostatnich lat wynika, że konsekwencje upałów, gwałtownych dreszczów, huraganów czy śnieżyc mogą być bardzo trudne do opanowania nawet dla największych i najnowocześniejszych metropolii, położonych w najbardziej rozwiniętych krajach świata. Również w Polsce $\mathrm{w}$ ostatnich latach mieliśmy do czynienia $\mathrm{z}$ wielkimi powodziami obejmującymi całe dorzecza, a także gwałtownymi powodziami typu „flash flood”, zagrażającym naszymi miastom (MŚ 2013) Teoretycznie wiadomo, jakie działania techniczne, planistyczne i organizacyjne należy przedsiębrać, by zapobiec najgorszym konsekwencjom dynamicznie zmieniającego się klimatu.

\section{Przyczyny niskiej efektywności w zarządzeniu przestrzenią w naszym kraju w zakresie zrównoważonego rozwoju}

Jakie są przyczyny tego, że - mimo rozbudowanego systemu planowania przestrzennego w Polsce - ciągle mamy do czynienia z bałaganem przestrzennym wpływającym tak negatywnie na zrównoważony rozwój? Z pewnością winę można zrzucić na kryzys planowania przestrzennego w Polsce, co przejawia się brakiem planów o charakterze strategicznym, które w sposób kompleksowy rozwiązywałyby wszystkie problemy stojące przed gospodarką przestrzenną w naszym kraju. Ale jest i jeszcze jeden problem, który ostatnio dostrzegają także władze naszego państwa. Jest to brak spójnej polityki przestrzennej, która w sposób całościowy rozwiązywałaby w szczególności kierunki rozwoju osiedli ludzkich, a także zapobiegałyby rozproszonej, ułomnej suburbanizacji, chroniąc w ten sposób tereny otwarte, tereny produkcji rolnej, tereny o wybitnych walorach środowiskowych.

Podsumowując, należy zwrócić uwagę na najczęściej wzmiankowane mankamenty naszego systemu planowania przestrzennego:

$\checkmark$ Obecna sytuacja przyczynia się do pogłębiania się chaosu w planowaniu przestrzennym, gdzie w ciągu ostatnich dziesięciu lat aż trzykrotnie zmieniano zasady jego funkcjonowania, unieważniano pla- 
ny, zmieniano zasady ich sporządzania itp. Wszystkie te działania powodują utratę wiarygodności instytucji planowania przestrzennego w opinii obywateli.

$\checkmark$ Planowanie przestrzenne charakteryzuje się brakiem stabilności, co spowodowane jest częstymi zmianami ustaleń planów, a także brakiem hierarchiczności.

$\checkmark$ Planowanie przestrzenne jest rozdrobnione. W praktyce bardzo często powstają plany obejmujące kilka - kilkanaście działek; wiele inwestycji powstaje $\mathrm{w}$ wyniku indywidualnych decyzji.

$\checkmark$ Są obszary kraju faktycznie pozbawione planów. Sytuacja ta jest szczególnie niepokojąca w obszarze dużych miast, gdzie planami pokrytych jest od kilku do kilkunastu procent powierzchni.

$\checkmark$ Brak jest planów o charakterze strategicznym, obejmujących całe jednostki administracyjne, co pozwoliłoby na ściślejsze powiązania problemów rozwoju gospodarczego, ochrony środowiska i planowania przestrzennego poprzez formułowanie długofalowych, strategicznych celów, na których opierać się powinny miejscowe plany przestrzennego zagospodarowania jako jedno z narzędzi takiego rozwoju.

\section{Kierunki poprawy}

Szansę na uporządkowanie tych problemów dałaby reforma zarządzania przestrzenią w Polsce. M.in. potrzebna jest reforma, w wyniku której powstałyby administracyjne możliwości pozwalające na efektywne zarządzanie obszarami miejskimi oraz ich suburbiami. Jednostki takie przejęłyby dotychczasowe zadania powiatów i województw w zakresie niezbędnym do obsługi regionów funkcjonalnych (np. regionów metropolitalnych i innych obszarów miejskich). Do ich zadań należałoby tworzenie planów regionalnych, rozbudowa regionalnych systemów infrastruktury, ochrona środowiska w skali ponadlokalnej, nadzór i współudział w tworzeniu regionalnego systemu transportu publicznego. Takie plany winny brać pod uwagę obszarowe dostosowanie terenów miejskich do zmian klimatu. Zarysowana tutaj propozycja reformy zarządzania terenami miejskimi mogłaby przyczynić się do racjonalnego użytkowania środowiska przyrodniczego i poprawy jego jakości w obrębie aglomeracji miejskich, a także zapewnić podstawy do zrów- 
noważonego rozwoju. Ustawa z dnia 9 października 2015 r. o związkach metropolitalnych (Dz.U. 2015 poz. 1890) stanowi dobrą podstawę do realizacji reformy zarządzania przestrzenią w Polsce.

Dla całościowej realizacji reformy planowania przestrzennego w Polsce niezbędne będzie:

ustanowienie organu odpowiedzialnego za całokształt polityki przestrzennej państwa, w tym za przygotowanie koncepcji strategicznych, nadzór nad ich wdrażaniem, monitorowanie stanu zagospodarowania przestrzennego kraju;

$\checkmark$ wzmocnienie planowania przestrzennego na wszystkich szczeblach od krajowego do lokalnego w kierunku wzorców europejskich, wprowadzenie planów ogólnych (struktury, strategicznych) obejmujących całe jednostki administracyjne;

$\checkmark$ opracowanie koncepcji racjonalnego kształtowania sieci osadniczej, z wyznaczeniem obszarów jej koncentracji oraz korytarzy infrastruktury łączącej elementy sieci, jako podstawowego dokumentu wyznaczającego strategie działań państwa w tym zakresie;

$\checkmark$ opracowanie koncepcji rozwoju nowych jednostek osadniczych w obrębie aglomeracji, jako terenów koncentracji inwestycji mieszkaniowych, usługowych i in.;

$\checkmark$ wprowadzenie (np. wzorem niektórych krajów skandynawskich, Wielkiej Brytanii) ochrony obszarów otwartych i szczególnej ochrony granic pomiędzy obszarami zurbanizowanymi a otwartymi, wprowadzenie przepisów o strefach zieleni wokół miast („zielone pierścienie"), ograniczenie zabudowy wzdłuż tras komunikacyjnych poza terenami zabudowanymi;

$\checkmark$ uwzględnianie zasady wprowadzania do wszystkich działań planistycznych, administracyjnych i inwestycyjnych zasad adaptacji obszarów miejskich do zmian klimatu;

$\checkmark$ wprowadzenie mechanizmów zarządzania obszarami miejskimi, poprzez stworzenie odpowiednich organów administracji, odpowiedzialnych za koordynację rozwoju w ich obrębie. 


\section{Podsumowanie}

W Polsce obserwujemy szereg negatywnych zjawisk związanych z gospodarowaniem w przestrzeni. Dzieje się tak pomimo istnienia szeregu dokumentów i aktów prawnych mających na celu uporządkowanie wszystkich zagadnień związanych z planowaniem przestrzennym, Niestety, brak realizacji uchwalonych i przyjętych dokumentów (jak np. KPZK) czy też ułomności w zapisach aktów prawnych pozwala na bałagan w naszej przestrzeni. Trzeba wyraźnie podkreślić, ze takie zjawiska jak niekontrolowana suburbanizacja, rozpraszanie się osadnictwa, a co za tym idzie konieczność rozbudowy infrastruktury technicznej, rozcinanie przestrzeni, wywołuje szereg niekorzystnych zjawisk. Mamy więc do czynienia z takimi zjawiskami, jak nadmierna emisja zanieczyszczeń, zmiany mikroklimatu, marnotrawstwo przestrzeni. Wszystko to utrudnia, a nawet uniemożliwia zarządzanie przestrzenią w duchu zrównoważonego rozwoju. Aby rozwijać się zgodnie z ideą zrównoważonego rozwoju, niezbędna jest głęboką i konsekwentna reforma gospodarki przestrzennej oraz reformy $\mathrm{w}$ administrowaniu przestrzenią, a także oczekiwana przez urbanistów i samorządowców reforma prawa w zakresie planowania przestrzennego, jak również wzmocnienie planowania strategicznego m.in. poprzez realizację reformy metropolitalnej.

\section{Bibliografia:}

EC (European Commission). 2013-2020. 7th Environment Action Programme (EAP). Dostęp: 20.02.2017. http://ec.europa.eu/environment/action-programme/index.htm.

Konferencja Narodów Zjednoczonych w Rio de Janeiro. 14 czerwca 1992. Agenda 21. W: Dokumenty końcowe Konferencji Narodów Zjednoczonych „Środowisko i Rozwój”. Warszawa: Instytut Ochrony Środowiska 1993.

KPZK (Koncepcja Przestrzennego Zagospodarowania Kraju 2030). 2011. Dostęp: 20.02.2017. http://rpo2020.lubuskie.pl/wp-content/ uploads/2013/01/Koncepcja_Przestrzennego_Zagospodarowania_Kraju_203013.pdf.

KWE (Komisja Wspólnot Europejskich). 2006. Komunikat Komisji do Rady i Parlamentu Europejskiego dotyczacy strategii tematycznej w spra- 
wie środowiska miejskiego z 11.01.2006. Dostęp: 21.02.2017. http://eur-lex.europa.eu/legal-content/PL/ALL/?uri=CELEX:52005DC0718.

MŚ (Ministerstwo Środowiska). 2013. Strategiczny plan adaptacji dla sektorów i obszarów wrażliwych na zmiany klimatu do roku 2020 z perspektywa do roku 2030. Dostęp: 20.02.2017. http://rpo.opolskie.pl/wp-content/uploads/Strategiczny_plan_adaptacji_2020.pdf.

ŚKŚR (Światowa Komisja ds. Środowiska i Rozwoju). 1991. Nasza wspólna przyszłość, tłum. Urszula Grzelońska i Ewa Kolanowska. Warszawa: Państwowe Wydawnictwo Ekonomiczne.

Ustawa z dnia 27 kwietnia 2001 r. prawo ochrony środowiska. Dziennik Ustaw, 2013 poz. 1232.

Ustawy z dnia 27 marca 2003 roku o planowaniu i zagospodarowaniu przestrzennym. Dziennik Ustaw, 2003 nr 80 poz. 717.

Ustawa z dnia 9 października 2015 r. o związkach metropolitalnych. Dziennik Ustaw, 2015 poz. 1890. 

Joanna Godlewska

Politechnika Białostocka - Wydział Zarządzania

j.godlewska@pb.edu.pl

\section{Recykling odpadów jako sposób realizacji zasady likwidacji zanieczyszczeń u źródła w Polsce}

\section{Wstęp}

Podstawy zasady likwidacji zanieczyszczeń u źródła, zwanej też zasadą prewencji, pojawiły się już w Raporcie Nasza wspólna przyszłość w 1987 roku. W obecnym brzmieniu sformułowano ją w dokumentach końcowych konferencji Organizacji Narodów Zjednoczonych nt. „Środowiska i rozwoju" w Rio de Janeiro w 1992 roku. Zasada prewencji została wprowadzona do polskiej polityki ekologicznej. W artykule zajęto się jednym wybranym obszarem, którego dotyczy zasada prewencji, a mianowicie recyklingiem odpadów. Jest to jeden z kluczowych obszarów zarówno w koncepcji zielonej gospodarki, jak i gospodarki o obiegu zamkniętym (circular economy). Pierwsza $\mathrm{z}$ nich jest obecnie promowana na arenie międzynarodowej, druga zaś w krajach Unii Europejskiej. Koncepcja gospodarki o obiegu zamkniętym została zaprezentowana w komunikacie Komisji Europejskiej Ku gospodarce o obiegu zamkniętym: Program „zero odpadów" dla Europy, opublikowanym w 2014 roku. Zakłada ona poprawę efektywności gospodarki odpadami poprzez wzrost ilości odpadów poddawanych odzyskowi i recyklingowi, a tym samym zminimalizowanie ilości odpadów składowanych (EUR-lex.eu 2014).

W realizacji zasady likwidacji zanieczyszczeń u źródła w Polsce istnieją znaczące różnice w podejściu do recyklingu w zależności od rodzaju odpadu. Celem artykułu jest dokonanie analizy i oceny stanu recyklingu odpadów przemysłowych i komunalnych w Polsce oraz zidentyfikowanie i wyjaśnienie głównych przyczyn występowania różnic $\mathrm{w}$ tym zakresie. W pracy zastosowano metodę analizy literatury przedmiotu, aktów prawnych oraz danych statystycznych GUS. Dobór analizowanego okresu był zdeterminowany dostępnością informacji $\mathrm{w}$ statystyce publicznej ${ }^{1}$. W artykule przedstawiono genezę i istotę za-

\footnotetext{
${ }^{1}$ Badania zostały zrealizowane $\mathrm{w}$ ramach pracy S/WZ/1/2015 i sfinansowane ze środków na naukę MNiSW.
} 
sady likwidacji zanieczyszczeń u źródła. Dokonano diagnozy w jednym z kluczowych obszarów tej zasady, a mianowicie w odzysku i recyklingu odpadów, oraz wskazano na główne przyczyny różnic w tym zakresie.

\section{Zasada likwidacji zanieczyszczeń u źródła w polityce ekologicznej państwa}

Zasada likwidacji zanieczyszczeń u źródła ma swoją genezę w dokumentach końcowych konferencji Organizacji Narodów Zjednoczonych nt. „Środowiska i rozwoju” w Rio de Janeiro w 1992 roku. W Deklaracji $z$ Rio w sprawie środowiska i rozwoju znajdują się dwie zasady odnoszące się do zasady prewencji:

$\checkmark$ Zasada 8. Aby osiągnąć zrównoważony rozwój i wyższą jakość życia dla wszystkich ludzi, państwa powinny zredukować bądź wyeliminować niezrównoważone systemy produkcji lub konsumpcji oraz promować odpowiednią politykę demograficzną.

$\checkmark$ Zasada 15. Wszystkie państwa powinny szeroko zastosować zapobiegawcze podejście w celu ochrony środowiska, mając na uwadze ich własne możliwości. Tam gdzie występują zagrożenia poważnymi lub nieodwracalnymi zmianami, brak całkowitej naukowej pewności nie może być powodem opóźniania efektywnych działań, których realizacja prowadziłaby do degradacji środowiska (Deklaracja z Rio 1992).

W pierwszej polityce ekologicznej państwa z 1991 roku zasada prewencji została określona w ten sposób, że przeciwdziałanie negatywnym skutkom dla środowiska powinno być podejmowane na etapie planowania i realizacji przedsięwzięć w oparciu o posiadaną wiedzę, wdrożone procedury ocen oddziaływania na środowisko oraz monitorowanie prowadzonych przedsięwzięć (Polityka ekologiczna państwa 1991). Dodatkowo została określona hierarchia wyboru środków zapobiegawczych oraz sposobów likwidacji skutków zanieczyszczeń. Na tej podstawie T. Borys zidentyfikował trzy główne obszary zasady jako prewencji (likwidacji zanieczyszczeń u źródła) i reagowania na istniejące zagrożenia:

$\checkmark$ zapobieganie powstawaniu zanieczyszczeń i innych uciążliwości, to jest działanie na rzecz przebudowy modelu produkcji i konsumpcji 
w kierunku zmniejszania presji na środowisko - w szczególności poprzez stosowanie najlepszych dostępnych technik (BAT),

stosowanie recyklingu i zintegrowanego podejścia do ograniczania i likwidacji zanieczyszczeń i zagrożeń,

$\checkmark$ ciągła ocena oddziaływania na środowisko i zaniechanie realizacji projektów (działań), które mogą wywołać nieodwracalne zmiany w ekosystemach (Borys 2005, 193).

Zasada prewencji $\mathrm{w}$ tym samym brzmieniu została powtórzona w dokumencie polityki ekologicznej państwa z 2000 roku.

Zasada prewencji, według G. Dobrzańskiego, należy do kategorii zasad trwałości społeczno-gospodarczej wynikających z uwarunkowań ekologicznych. Określają one działania w systemach społeczno-gospodarczych niezbędne do zrealizowania zasad trwałości ekologicznej (Dobrzański 2005, 27-29).

\section{Odzysk i recykling odpadów przemysłowych}

Zgodnie $\mathrm{z}$ przyjętą $\mathrm{w}$ polskim prawie hierarchią postępowania $\mathrm{z}$ odpadami, odzysk i recykling są drugie w kolejności po zapobieganiu powstawaniu odpadów. Recykling zdefiniowany jest jako taki odzysk, $\mathrm{w}$ ramach którego odpady są ponownie przetwarzane na produkty, materiały lub substancje wykorzystywane w pierwotnym celu lub innych celach. Obejmuje to ponowne przetwarzanie materiału organicznego (recykling organiczny), ale nie obejmuje odzysku energii i ponownego przetwarzania na materiały, które mają być wykorzystane jako paliwa lub do celów wypełniania wyrobisk (Ustawa o odpadach 2012). Inna definicja recyklingu określa go jako system cyklicznego gospodarczego wykorzystania odpadów jako surowców wtórnych z wyeksploatowanych, wadliwych lub uszkodzonych produktów. Możliwość ponownego ich wykorzystania wynika $\mathrm{z}$ faktu, że produkty te są wykonane $\mathrm{z}$ materiałów odnawialnych, co oznacza, że można przywrócić im pierwotne właściwości, odzyskać z nich poszczególne składniki lub usunąć niebezpieczne elementy poprzez odpowiednie postępowanie z nimi (Rosik-Dulewska 2015, 38).

W Polsce, według danych Głównego Urzędu Statystycznego, w ostatnich latach, co roku wytwarzanych jest ponad 120 mln ton odpadów 
przemysłowych. Jest to dziesięciokrotnie wyższa wartość w porównaniu do ilości wytwarzanych odpadów komunalnych (rys. 1).

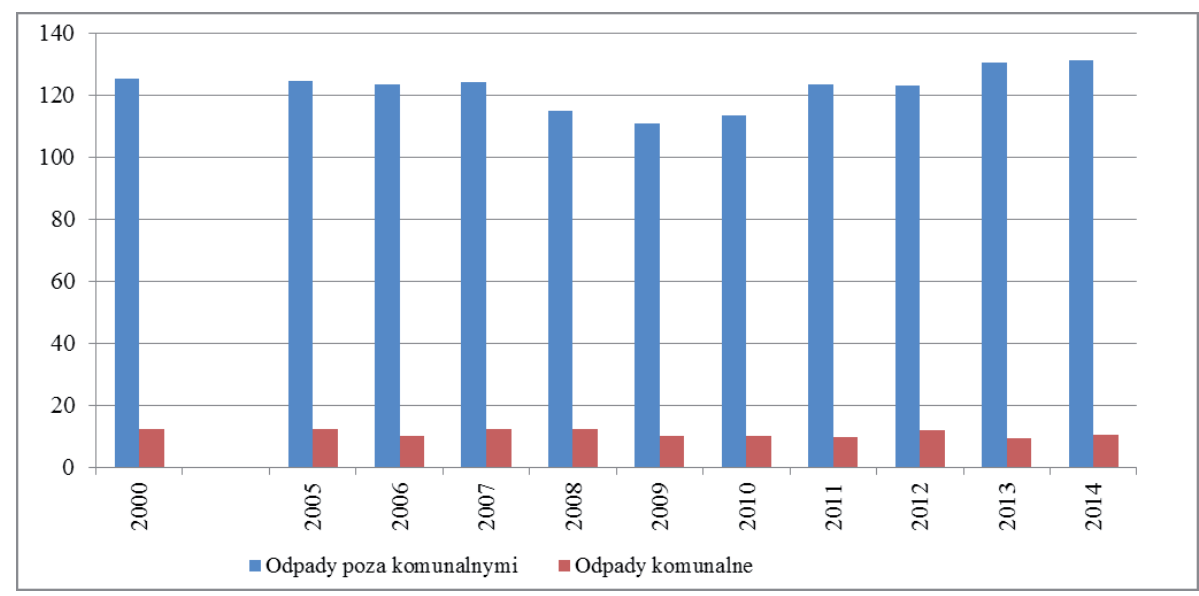

Rys. 1. Odpady wytworzone w Polsce w latach 2000-2014 [w mln ton]. Źródło: opracowanie własne na podstawie (Ochrona środowiska 2004, 2007, 2008, 2010, 2012, 2014, 2016).

W stosunku do ogólnej ilości odpadów przemysłowych w statystyce publicznej nie ma dostępnych danych dotyczących recyklingu. Można natomiast określić poziom ich odzysku, rozumianego jako taki proces, w wyniku którego odpady będą służyły użytecznemu zastosowaniu przez zastąpienie nimi materiałów, które zostałyby użyte do spełnienia danej funkcji. Ponadto występuje pojęcie odzysku energii, który oznacza termiczne przekształcanie odpadów w celu odzyskania energii (Ustawa o odpadach 2012). Od 2007 do 2012 roku poziom odzysku odpadów przemysłowych wynosił ponad $70 \%$. W ostatnim analizowanym roku 2014, według GUS, poziom ten wyniósł zaledwie 27,6\%, jednak ze względu na istotne zmiany prawa w tym czasie, nie należy traktować tych danych jako odzwierciedlenia faktycznego poziomu odzysku. Są one raczej wynikiem różnic w sprawozdawczości dotyczącej wykonania obowiązku odzysku odpadów przez przedsiębiorstwa.

Wysoki poziom odzysku odpadów przemysłowych związany jest z tym, że w stosunku do niektórych rodzajów odpadów przemysłowych został ustanowiony prawnie obowiązek do zapewnienia minimalnych 
poziomów odzysku i recyklingu. Według ustawy o obowiązkach przedsiębiorców w zakresie gospodarowania niektórymi odpadami oraz opłacie produktowej dotyczy on odpadów opakowaniowych, zużytych opon, olejów oraz baterii i akumulatorów. W sytuacji nieosiągnięcia odpowiednich poziomów odzysku i recyklingu przedsiębiorcy są zobowiązani do ponoszenia opłaty produktowej (Ustawa o obowiązkach 2001).

Obowiązujące poziomy odzysku i recyklingu odpadów są różne w zależności od rodzaju odpadu i ulegają zwiększeniu w kolejnych latach. Przykładem mogą być zużyte opony, dla których wymagany poziom odzysku w latach 2014-2015 wynosił 75\%, a recyklingu 15\%. W przypadku tego odpadu stosowany jest głównie odzysk energetyczny w cementowniach, zaś w drugiej kolejności recykling materiałowy.

Według danych GUS, w 2011 roku odzyskowi poddano największą jak dotychczas masę zużytych opon, bo aż 213,2 tys. ton, a recyklingowi $-67,9$ tys. ton. W latach 2012-2013 wartości te malały. W 2015 roku poddano odzyskowi więcej, bo już 175,3 tys. ton zużytych opon, a 47,9 tys. ton - recyklingowi. Na rysunku 2 przedstawiono porównanie wymaganych prawem i faktycznie osiągniętych poziomów odzysku i recyklingu odpadu przemysłowego, jakim są zużyte opony.

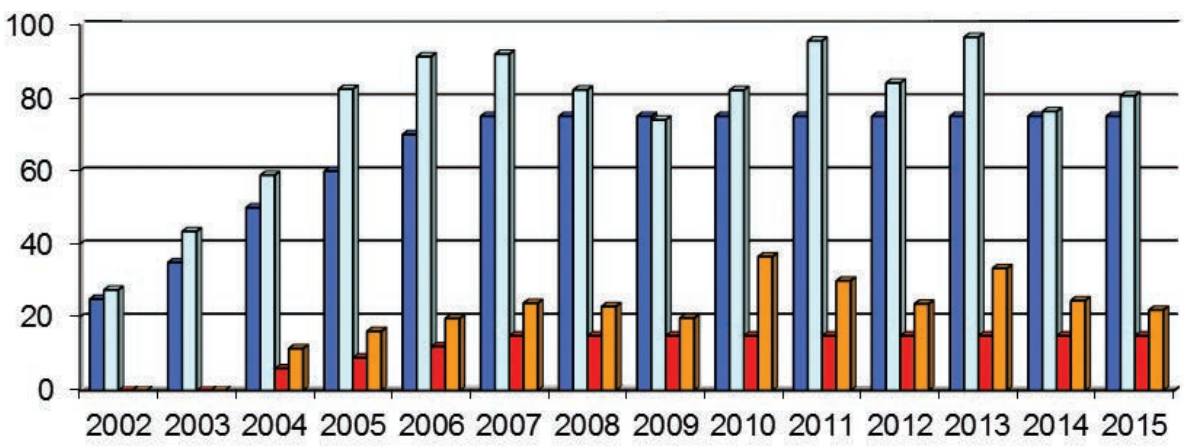

$$
\begin{array}{ll}
\text { 口Poziom odzysku wymagany } & \text { 口Poziom odzysku osiągnięty } \\
\text { 口Poziom recyklingu wymagany } & \text { 口Poziom recyklingu osiągnięty }
\end{array}
$$

Rys. 2. Wymagane i zrealizowane poziomy odzysku i recyklingu opon w latach 2002-2015 [w \%]. Źródło: opracowanie własne na podstawie

(Ochrona środowiska 2007, 2010, 2016). 
Do 2008 roku wymagane poziomy odzysku i recyklingu opon były osiągane. Tylko w 2009 roku poziom odzysku był niższy (74\%). Natomiast już w 2010 roku przekroczył on wymaganą prawem wartość i wyniósł ponad $82 \%$. W tym samym roku zanotowano rekordowy poziom recyklingu zużytych opon (36,6\%). W 2013 roku osiągnięto rekordowy poziom odzysku zużytych opon (96,6\%). Poziom recyklingu również był wysoki i wyniósł wówczas 33,4\%. Związane było to ze zmianą prawa polegającą na likwidacji od 2014 roku możliwości przenoszenia na następny rok „nadwyżek” tonażowych (Ustawa o gospodarce opakowaniami 2013). W ten sposób w 2013 roku rozliczono zarówno faktycznie wykonany $\mathrm{w}$ tym roku odzysk i recykling zużytych opon, jak i nadwyżki uzyskane z wcześniejszych lat. W 2015 roku poziom odzysku opon wyniósł już 80,6\%, a poziom recyklingu $22 \%$, co oznacza, że wymagania prawne w tym zakresie zostały spełnione.

Zużyte opony stanowią przykład zmiany z niepotrzebnego, szkodliwego odpadu w pożądany produkt. Jeszcze kilka lat temu przyjęcie ich przez cementownie do odzysku energetycznego związane było z koniecznością poniesienia kosztów tej usługi, podczas gdy obecnie to cementownie płacą za dostarczone opony. Jest to pozytywny trend, zgodny z wytycznymi unijnej polityki ekologicznej dotyczącej gospodarki odpadami.

\section{Recykling odpadów komunalnych}

Odpady komunalne powstają $\mathrm{w}$ gospodarstwach domowych, ale mogą też pochodzić od innych wytwórców odpadów, pod warunkiem, że nie zawierają odpadów niebezpiecznych oraz ze względu na swój charakter lub skład są podobne do odpadów powstających w gospodarstwach domowych.

Podstawy prawne gospodarki odpadami komunalnymi na szczeblu lokalnym zawarte są w ustawie z 1 lipca 2011 r. o zmianie ustawy o utrzymaniu czystości i porządku w gminach oraz niektórych innych ustaw. Na jej mocy od połowy 2013 roku wprowadzono w polskich gminach nowy system gospodarki odpadami. Jego celem jest: 
$\checkmark$ prowadzenie selektywnej zbiórki odpadów komunalnych „u źródła”,

$\checkmark$ zmniejszenie ilości odpadów komunalnych, w tym odpadów ulegających biodegradacji, kierowanych na składowiska odpadów,

$\checkmark$ zwiększenie liczby nowoczesnych instalacji do odzysku, w tym recyklingu oraz unieszkodliwiania odpadów komunalnych w sposób inny niż składowanie odpadów,

$\checkmark$ całkowite wyeliminowanie nielegalnych składowisk odpadów,

$\checkmark$ prowadzenie właściwego sposobu monitorowania postępowania z odpadami komunalnymi zarówno przez właścicieli nieruchomości, jak i przedsiębiorców prowadzących działalność w zakresie odbierania odpadów komunalnych od właścicieli nieruchomości,

$\checkmark$ zmniejszenie dodatkowych zagrożeń dla środowiska wynikających $\mathrm{z}$ transportu odpadów komunalnych $\mathrm{z}$ miejsc ich powstania do miejsc odzysku lub unieszkodliwiania, przez podział województw na regiony gospodarki odpadami (Ustawa o zmianie 2011).

Główną zmianą w nowym systemie gospodarki odpadami komunalnymi było obligatoryjne przejęcie przez gminy obowiązków właścicieli nieruchomości w zakresie zagospodarowania tych odpadów. Związane jest to $\mathrm{z}$ realizacją takich zadań jak:

zapewnianie warunków ograniczenia masy odpadów komunalnych ulegających biodegradacji kierowanych do składowania,

$\checkmark$ osiągnięcie poziomów odzysku i recyklingu odpadów opakowaniowych,

$\checkmark$ zapewnianie budowy, utrzymania i eksploatacji własnych lub wspólnych $\mathrm{z}$ innymi gminami czy też przedsiębiorcami instalacji i urządzeń do odzysku i unieszkodliwiania odpadów komunalnych albo zapewnienie warunków do budowy, utrzymania i eksploatacji instalacji i urządzeń do odzysku i unieszkodliwiania odpadów komunalnych przez przedsiębiorców,

$\checkmark$ selektywne zbieranie odpadów komunalnych, obejmujące co najmniej następujące frakcje odpadów: papier, metale, tworzywa sztuczne, szkło, opakowania wielomateriałowe, odpady komunalne ulegające biodegradacji, w tym odpady opakowaniowe ulegające biodegradacji (Grabowski 2011, 6-8). 
W zakresie wykonywania obowiązku selektywnej zbiórki odpadów komunalnych gmina jest zobowiązana do tworzenia punktów selektywnego zbierania odpadów komunalnych w sposób zapewniający łatwy dostęp dla wszystkich mieszkańców gminy oraz wskazania miejsc, w których mogą być prowadzone zbiórki zużytego sprzętu elektrycznego i elektronicznego pochodzącego z gospodarstw domowych.

Podobnie jak w przypadku odpadów przemysłowych, w odniesieniu do niektórych rodzajów odpadów komunalnych istnieje prawny obowiązek osiągania poziomów recyklingu. Przedstawiono je w tabeli 1 .

\begin{tabular}{|c|c|c|c|c|c|c|c|c|c|}
\hline Rodzaj odpadu & 2012 & 2013 & 2014 & 2015 & 2016 & 2017 & 2018 & 2019 & 2020 \\
\hline $\begin{array}{c}\text { Papier, metal, } \\
\text { tworzywa sztuczne, } \\
\text { szkło }\end{array}$ & 10 & 12 & 14 & 16 & 18 & 20 & 30 & 40 & 50 \\
\hline $\begin{array}{c}\text { Odpady budowane } \\
\text { i rozbiórkowe }\end{array}$ & 30 & 36 & 38 & 40 & 42 & 45 & 50 & 60 & 70 \\
\hline
\end{tabular}

Tabela 1. Wymagane poziomy recyklingu odpadów komunalnych w kolejnych latach [w \%]. Źródło: Rozporządzenie Ministra Środowiska 2016.

O ile w przypadku odpadów przemysłowych można zauważyć pozytywne zmiany w sposobach ich zagospodarowania, to w odniesieniu do odpadów komunalnych sytuacja jest problematyczna. W 2014 roku faktyczny poziom recyklingu tych odpadów w Polsce wyniósł $21,1 \%$. Był on jednak zróżnicowany regionalnie. W województwie dolnośląskim osiągnięto najwyższy poziom recyklingu w kraju i wynosił on $32,6 \%$, natomiast w województwie podlaskim - zaledwie 11,6\% (Ochrona środowiska 2016). Oznacza to, że nie wszystkie regiony Polski osiągnęły wymagany prawem poziom recyklingu.

Porównanie sytuacji Polski w zakresie recyklingu odpadów komunalnych do sytuacji w innych krajach europejskich przedstawia tabela 2. 


\begin{tabular}{|c|c|}
\hline $\begin{array}{c}\text { Poziom recy- } \\
\text { klingu }\end{array}$ & Kraj \\
\hline$<5 \%$ & Łotwa, Czarnogóra, Serbia, Bośnia i Hercegowina \\
\hline $5-10 \%$ & Malta, Rumunia, Słowacja \\
\hline $11-20 \%$ & Grecja, Hiszpania, Chorwacja, Cypr, Portugalia, Finlandia \\
\hline $21-30 \%$ & $\begin{array}{c}\text { Bułgaria, Czechy, Dania, Francja, Włochy, Litwa, Luksemburg, } \\
\text { Węgry, Holandia, Austria, Polska, Wielka Brytania, Norwegia }\end{array}$ \\
\hline $31-40 \%$ & Belgia, Estonia, Irlandia, Szwecja, Islandia, Szwajcaria \\
\hline$>40 \%$ & Niemcy, Słowenia \\
\hline
\end{tabular}

Tabela 2. Poziom recyklingu odpadów komunalnych w krajach europejskich w 2014 roku. Źródło: EUROSTAT.eu 2016.

Średni poziom recyklingu odpadów komunalnych w krajach europejskich to $28 \%$, co oznacza, że w Polsce był on niższy. Ponadto raporty wojewódzkich inspekcji ochrony środowiska wskazują na istniejący od lat problem nielegalnych praktyk postępowania $\mathrm{z}$ odpadami komunalnymi: wyrzucania odpadów na „dzikie” składowiska oraz ich spalania w domowych piecach. Według wyników badań przeprowadzonych w 2010 roku przez zespół B. Poskrobki, w dziewięciu gminach zlokalizowanych na terenie trzech województw: dolnośląskiego, lubelskiego i podlaskiego mocno niepokojący jest fakt, że są w społeczeństwie jednostki, które akceptują spalanie odpadów w piecach domowych, w tym 5\% - zawsze, a aż 32\% - dopuszcza to czasami. Jednak, ze względu na drażliwość tego pytania i rozumienie przez respondentów faktu, że spalanie odpadów w piecach jest zachowaniem społecznie niepożądanym, mogli oni zatajać faktyczne preferencje i odpowiadać zgodnie z oczekiwaniami badaczy (Sidorczuk-Pietraszko i Zawistowska 2011, 46). Pomimo upływu lat, problemy ze smogiem wywołanym niską emisją w Polsce nie ustępują. Dlatego ważną rolę powinien tu odegrać instrument społecznego oddziaływania, jakim jest edukacja ekologiczna społeczeństwa. 


\section{Zakończenie}

Zasada likwidacji zanieczyszczeń u źródła w odniesieniu do odzysku i recyklingu jest różnie realizowana $\mathrm{w}$ zależności od rodzaju odpadu. W przypadku odpadów przemysłowych osiągane są wysokie poziomy odzysku i recyklingu dzięki skutecznym zmianom istniejącego prawa, w tym skutecznym instrumentom ekonomicznym (opłata produktowa). Istnieją pozytywne przykłady zmian, kiedy to odpad staje się pożądanym surowcem do produkcji. Jest to w pełni zgodne z polityką ekologiczną Unii Europejskiej dotyczącą poprawy efektywności wykorzystania zasobów w gospodarce $\mathrm{w}$ ramach priorytetowego celu, jakim jest zmiana odpadów w surowce (European Commision.eu 2016).

Odmienna jest sytuacja w zakresie recyklingu odpadów komunalnych. Różnice wynikają $\mathrm{z}$ różnego okresu wprowadzenia instrumentów prawnych i ekonomicznych, ponieważ w przypadku odpadów przemysłowych działają one od 2001 roku, a przypadku odpadów komunalnych dopiero od 2013 roku. Ponadto odpady przemysłowe są często jednorodne, co wpływa na niższe koszty i większe możliwości techniczne ich odzysku i recyklingu. Odpady komunalne składają się z różnych frakcji i muszą być segregowane. W gospodarce odpadami komunalnymi istnieją też problemy związane z powstawaniem dzikich wysypisk oraz paleniem odpadów w piecach domowych. Dlatego w tym przypadku, oprócz instrumentów prawnych, powinien być położony nacisk na wdrażanie instrumentów oddziaływania społecznego (edukacja ekologiczna), ponieważ występuje problem niskiej świadomości ekologicznej społeczeństwa.

\section{Bibliografia:}

Deklaracja $z$ Rio $w$ sprawie środowiska i rozwoju. Dokumenty koncowe konferencji Narodów Zjednoczonych „Srodowisko i rozwój”. 1998. Warszawa: Instytut Ochrony Środowiska.

Dobrzański, Grzegorz. 2005. Podstawy rozwoju trwałego i zrównoważonego. Białystok: Dział Wydawnictw i Poligrafii Politechniki Białostockiej.

EUR-lex.eu. Komunikat Komisji do Parlamentu Europejskiego, Rady, Europejskiego Komitetu Ekonomiczno-Społecznego i Komitetu Regionów. Ku gospodarce o obiegu zamkniętym: program „zero odpadów” dla Europy. 2014. Dostęp: 1.02.2017. http://eur-lex.europa.eu. 
European Commision.eu. 2016. The 7th Environment Action Programme (EAP). European Commision. Environment. Dostęp: 3.12.2016. www.ec.europa.eu .

EUROSTAT.eu. Waste statistics 2016. Dostęp 4.03.2017. http://ec.europa.eu/eurostat/statistics-explained/index.php/Waste_statistics\#Waste_treatment.

Grabowski, Zbigniew. 2011. Wytyczne dla gmin dotyczace wdrażania systemu gospodarowania odpadami komunalnymi. Warszawa: Ministerstwo Środowiska. Dostęp: 12.12.2016. https://www.mos.gov.pl/ fileadmin/user_upload/odpady/Wytyczne_dla_gmin_dotyczace_wdrazania_systemu_gospodarowania_odpadami.pdf.

Ochrona środowiska 2004. 2004. Warszawa: GUS.

Ochrona środowiska 2007. 2007. Warszawa: GUS.

Ochrona środowiska 2008. 2008. Warszawa: GUS.

Ochrona środowiska 2010. 2010. Warszawa: GUS.

Ochrona środowiska 2012. 2012. Warszawa: GUS.

Ochrona środowiska 2014. 2014. Warszawa: GUS.

Ochrona środowiska 2016. 2016. Warszawa: GUS.

Polityka ekologiczna państwa. 1991. Warszawa: Rada Ministrów.

Rosik-Dulewska, Czesława. 2015. Podstawy gospodarki odpadami. Warszawa: PWN.

Rozporządzenie Ministra Środowiska z dnia 14 grudnia 2016 r. w sprawie poziomów recyklingu, przygotowania do ponownego użycia i odzysku innymi metodami niektórych frakcji odpadów komunalnych (Dz. U. 2016 poz. 2167).

Sidorczuk-Pietraszko, Edyta i Alicja Zawistowska. 2011. Stan gospodarowania energia w gminach w świetle wyników badań. Białystok: Wyższa Szkoła Ekonomiczna w Białymstoku.

Ustawa z dnia 1 lipca 2011 r. o zmianie ustawy o utrzymaniu czystości i porządku w gminach oraz niektórych innych ustaw (Dz.U. Nr 152, poz. 897). 
Ustawa z dnia 11 maja 2001 r. o obowiązkach przedsiębiorców w zakresie gospodarowania niektórymi odpadami oraz opłacie produktowej (tekst ujednolicony opracowany na podstawie Dz. U. 2014 poz. 1413 i Dz.U. 2015 poz. 933).

Ustawa z dnia 13 czerwca 2013 roku o gospodarce opakowaniami i odpadami opakowaniowymi (Dz. U. 2013, poz. 888).

Ustawa z dnia 14 grudnia 2012 r. o odpadach (Dz. U. 2013, poz. 21).

Wskaźniki zrównoważonego rozwoju, red. Tadeusz Borys. 2005. Warszawa-Białystok: Wyd. Ekonomia i Środowisko. 
Maria Klonowska-Matynia

Politechnika Koszalińska - Katedra Ekonomii

maria.klonowska-matynia@tu.koszalin.pl

\section{Regionalne zróżnicowanie zrównoważonego rozwoju w Polsce. Analiza przestrzenna}

\section{Wstęp}

Istnieje ogólnie zgodna opinia, że społeczno-gospodarczy rozwój krajów europejskich (ale i nie tylko) może być uzyskany przez następne pokolenia tylko wtedy, gdy zostanie zachowana koherencja pomiędzy trzema składowymi rozwoju, tj. środowiskiem naturalnym, społeczeństwem i gospodarką (Jones i Schneider 2006, 71-93). Tę spójność gwarantuje idea zrównoważonego rozwoju (sustainable development), stanowiąca kompromis pomiędzy działaniem określonym jako ekonomicznie żywotne a działaniem ekologicznie bezpiecznym i społecznie akceptowalnym. Koncepcja zrównoważonego rozwoju ma charakter złożony i interdyscyplinarny, co wynika z połączenia, w pewnej przestrzeni, działalności ludzkiej z wartościami ekologicznymi, celami ekonomicznymi i warunkami społecznymi. Rodzi to liczne problemy definicyjne i skłania do poszukiwania optymalnej ścieżki wyjaśniania tego pojęcia. W rezultacie poziom zrównoważenia (lub też niezrównoważenia) jest zazwyczaj oceną subiektywną i konsekwencją wyznawanych w danej grupie społecznej wartości (Dobrzański 2010, 61), co wskazuje na to, że nie ma w literaturze przedmiotu pełnej zgodności co do wyższości danego aspektu nad pozostałymi (np. ekologicznego nad społecznym i ekonomicznym).

Od momentu ogłoszenia raportu Nasza wspólna przyszłość w 1987 r. przez Komisję Brundtland, tematyce zrównoważonego rozwoju poświęcono wiele uwagi (Daly1990; Folke et al. 2002; Baker et al. 2012). Uwzględniając aktualność problemu i niekwestionowaną potrzebę wdrażania zasad zrównoważonego rozwoju, w artykule podjęto próbę oceny i udzielenia odpowiedzi na pytania o to: jak silnie zróżnicowana jest przestrzeń w Polsce pod względem poziomu zrównoważonego rozwoju oraz jakie zmiany zaszły na przestrzeni badanego okresu w zakresie poziomu rozwoju w obszarze komponentów: gospodarka, środowisko, społeczeń- 
stwo? Analizę przeprowadzono w ujęciu przestrzennym na poziomie regionów, co jest uzasadnione, bowiem pozwala wyjaśniać mechanizmy odpowiedzialne za powstawanie dysproporcji rozwojowych pomiędzy krajami, a także regionami czy gminami (Stanny 2013, 42-44).

\section{Zakres danych i metoda}

Różnorodność definicyjna zrównoważonego rozwoju sprawia, że próbom operacjonalizacji tego pojęcia często towarzyszą wątpliwości. Bezdyskusyjny jest natomiast fakt, że zrównoważony rozwój jest kwestią poddającą się badaniu empirycznemu (Stanny 2013, 66). Subiektywność interpretacyjna dokonywana przez pryzmat różnych wartości i celów społecznych sprawia, że tematem stale otwartym jest poszukiwanie syntetycznej jego miary. Było to poważnym ograniczeniem również i w niniejszym postępowaniu badawczym. W celu przeprowadzenia klasyfikacji badanych obiektów i porównania ich pod względem osiągniętego poziomu zrównoważonego rozwoju zastosowano własną miarę syntetyczną, pozwalającą na liniowe uporządkowanie obiektów przestrzennych w skali lokalnej bez wyznaczania tzw. jednostki wzorcowej. Charakterystyczną cechą otrzymanej miary syntetycznej jest porządkowanie zjawiska złożonego za pomocą jednej wartości, pozwalającej przeprowadzić analizy porównawcze $\mathrm{w}$ taki sposób, aby, nie zmieniając uporządkowania obiektów, ułatwić interpretację otrzymanej hierarchii (Kukuła 2000, 150-157).

W postępowaniu przyjęte do badania cechy poddano normalizacji na podstawie poniższej formuły:

$$
Z i j=\frac{X i j-\min \{x i j\}}{\max \{x i j\}-\min \{x i j\}}
$$

gdzie:

i - indeks obliczanego wskaźnika cząstkowego - przyjmuje wartości od 1 do n (n - liczba wskaźników cząstkowych);

$j$ - indeks danego regionu - przyjmuje wartości od 1 do 16 (liczba regionów);

$x i j$ - konkretna wielkość $i$-tego czynnika osiągnięta przez $j$-ty region $\mathrm{w}$ danym roku;

$\min \{x i j\}$ - minimalna wartość $i$-tego czynnika osiągnięta przez regiony w danym roku; 
$\max \{x i j\}$ - maksymalna wartość $i$-tego czynnika osiągnięta przez regiony w danym roku.

Po zsumowaniu znormalizowanych uprzednio wartości, te $\mathrm{z}$ nich, które są destymulantami, przekształcono, mnożąc ich wartości przez -1. Otrzymano w ten sposób syntetyczny wskaźnik, a w efekcie każdemu z regionów przyporządkowano określoną wartość w skali $<0 ; 1>$, opisującą łączny poziom zrównoważonego rozwoju danego regionu. Większa wartość wskaźnika klasyfikuje dany obiekt wyżej wobec innego pod względem kryterium ogólnego. Zgodnie z obowiązującą nomenklaturą NUTS analizę przeprowadzono na poziomie głównych regionów w Polsce NUTS 2, rozumianych jako województwa (GUS). Badaniem objęto wszystkie województwa w Polsce. Źródłem danych przyjętych do badania był GUS, który publikuje szereg tzw. wskaźników zrównoważonego rozwoju w obszarze: ład społeczny, gospodarczy, środowiskowy i instytucjonalno-polityczny. Do modelu wprowadzono 14 zmiennych, zdaniem autora najistotniejszych, dla dokonania oceny poziomu zrównoważonego rozwoju. Baza GUS-u udostępnia znacznie szerszy zbiór danych opisujących zrównoważony rozwój niż ten przyjęty do badania. Ostatecznie arbitralną decyzją autora zrezygnowano $\mathrm{z}$ włączenia cech z komponentu instytucjonalno-politycznego i bazowano na trzech obszarach: środowiskowym, społecznym i gospodarczym, wzorując się na doborze wskaźników monitorujących w Strategii Europa 2020 (Klonowska-Matynia i Sasin 2015, 771-791). Do analizy przyjęto lata 2004-2014, co było podyktowane dostępnością publikowanych przez GUS danych. Szczegółowy opis danych zaprezentowano w tabeli 1.

\begin{tabular}{|c|c|c|c|}
\hline Cecha & Wskaźnik - charakterystyka & $\begin{array}{c}\text { Źródło i } \\
\text { zakres czasowy }\end{array}$ & $\begin{array}{c}\text { Destymu- } \\
\text { lanta } \\
\text { /stymulanta }\end{array}$ \\
\hline \multicolumn{3}{|c|}{ Komponent - Lad gospodarczy (5) } \\
\hline X1 & $\begin{array}{c}\text { Wsk. zatrudnienia osób z wyższym wy- } \\
\text { kształceniem w \% }\end{array}$ & $\begin{array}{c}\text { GUS 2005/ } \\
2014\end{array}$ & S \\
\hline X2 & $\begin{array}{c}\text { Wsk. zatrudnienia osób z co najwyżej wy- } \\
\text { kształceniem gimnazjalnym lub niższym \% }\end{array}$ & $\begin{array}{c}\text { GUS 2005/ } \\
2014\end{array}$ & D \\
\hline X3 & $\begin{array}{c}\text { Nakłady na działalność badawczą i rozwo- } \\
\text { jową (B+R) w \% }\end{array}$ & GUS 2005/2013 & S \\
\hline X4 & PKB pc (\% średniej krajowej) & GUS 2004/2013 & S \\
\hline
\end{tabular}




\begin{tabular}{|c|c|c|c|}
\hline Cecha & Wskaźnik - charakterystyka & $\begin{array}{c}\text { Źródło i } \\
\text { zakres czasowy }\end{array}$ & $\begin{array}{l}\text { Destymu- } \\
\text { lanta/sty- } \\
\text { mulanta }\end{array}$ \\
\hline X5 & $\begin{array}{l}\text { Udział powierzchni ekologicznych go- } \\
\text { spodarstw rolnych (z certyfikatem) w po- } \\
\text { wierzchni użytków rolnych ogółem w \% }\end{array}$ & GUS 2006/2014 & $S$ \\
\hline \multicolumn{4}{|c|}{ Komponent - Lad społeczny (5) } \\
\hline $\mathrm{X} 6$ & $\begin{array}{l}\text { Udział długotrwale bezrobotnych (dłużej } \\
\text { niż } 1 \text { rok) w bezrobotnych zarejestrowa- } \\
\text { nych ogółem w \% }\end{array}$ & GUS 2006/2014 & $\mathrm{D}$ \\
\hline $\mathrm{X} 7$ & $\begin{array}{l}\text { Udział zgonów według wybranych przy- } \\
\text { czyn w ogólnej liczbie zgonów w \% (nowo- } \\
\text { twory i choroby układu krążenia) }\end{array}$ & GUS 2005/2014 & $\mathrm{D}$ \\
\hline $\mathrm{X} 8$ & $\begin{array}{c}\text { Wskaźniki obciążenia demograficznego } \\
\text { w \% }\end{array}$ & GUS 2004/2014 & $\mathrm{D}$ \\
\hline X9 & $\begin{array}{l}\text { Wskaźniki jakości kształcenia i poziomu } \\
\text { wiedzy uczniów w \% }\end{array}$ & GUS 2005/2014 & S \\
\hline $\mathrm{X} 10$ & $\begin{array}{c}\text { Osoby dorosłe uczestniczące w kształceniu } \\
\text { i szkoleniu w \% }\end{array}$ & GUS 204/2014 & S \\
\hline \multicolumn{4}{|c|}{ Komponent - Lad środowiskowy (4) } \\
\hline $\mathrm{X} 11$ & $\begin{array}{c}\text { Nakłady pc na środki trwałe służące ochro- } \\
\text { nie środowiska związane z oszczędzaniem } \\
\text { energii elektrycznej }\end{array}$ & GUS 2005/2014 & S \\
\hline $\mathrm{X} 12$ & $\begin{array}{c}\text { Emisja dwutlenku węgla z zakładów szcze- } \\
\text { gólnie uciążliwych }(\mathrm{t} / \mathrm{r})\end{array}$ & GUS 2004/2014 & $\mathrm{D}$ \\
\hline $\mathrm{X} 13$ & $\begin{array}{c}\text { Odpady komunalne zebrane selektywnie } \\
\text { w relacji do ogółu odpadów komunalnych } \\
\text { zebranych w ciągu roku w \% } \\
\end{array}$ & GUS 2005/2014 & S \\
\hline $\mathrm{X} 14$ & $\begin{array}{l}\text { Udział energii odnawialnej w produkcji } \\
\text { energii elektrycznej ogółem (\%) }\end{array}$ & GUS 2005/2014 & S \\
\hline
\end{tabular}

Tabela 1. Cechy przyjęte do badania w ramach komponentów. Źródło: opracowanie własne.

\section{Zróżnicowanie przestrzenne zrównoważonego poziomu - hie- rarchia regionów w Polsce}

Na podstawie oszacowanej miary syntetycznej $\mathrm{WZR}^{1}$ przeprowadzono klasyfikację regionów pod względem osiągniętego poziomu zrównowa-

\footnotetext{
${ }^{1}$ Miara syntetyczna WZR ozn. syntetyczny wskaźnik zrównoważonego rozwoju.
} 
żonego rozwoju. Przyjmując przedziały równoliczne, regiony sklasyfikowano w ujęciu hierarchicznym w pięciu klasach: od klasy I, cechującej się najwyższym poziomem rozwoju zrównoważonego, do klasy $\mathrm{V}$ o najniższym poziomie rozwoju. Każda $\mathrm{z}$ wyodrębnionych klas charakteryzuje się zróżnicowaniem wewnętrznym pod względem przyjętych do badania cech w ramach poszczególnych komponentów. Statystyki opisowe wskazują, że największą zmiennością cechują się takie cechy jak: nakłady na $\mathrm{B}+\mathrm{R}$, udział powierzchni ekologicznych gospodarstw rolnych (z certyfikatem) w powierzchni użytków rolnych ogółem² ${ }^{2}$ a w komponencie środowiskowym: gazowe zanieczyszczenia powietrza, nakłady na środki trwałe służące ochronie środowiska, odnawialne źródła energii ${ }^{3}$. Najmniejsze zróżnicowanie obserwuje się w komponencie społecznym we wszystkich przyjętych do badania cechach. W efekcie końcowym uzyskano obraz przestrzeni polskiej pokazujący w sposób syntetyczny zmiany, jakie zaszły w układzie przestrzennym regionów pod względem osiąganego poziomu rozwoju w 2014 w stosunku do 2004 r. (rys. 1.).
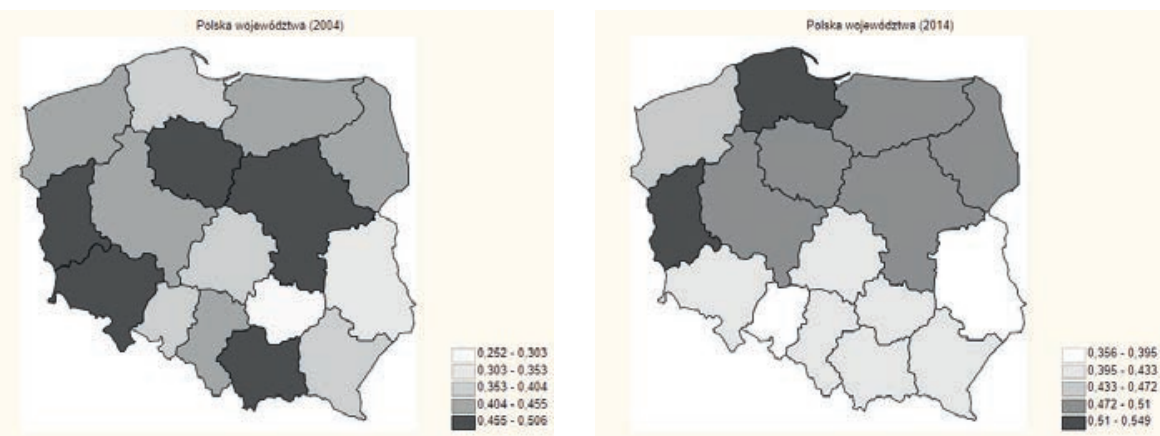

Rys. 1. WZR Miara syntetyczna - 2004 i 2014.

Źródło: opracowanie własne na podstawie danych GUS.

Uzyskany rozkład przestrzenny regionów w Polsce skłania do oceny, iż są one zróżnicowane pod względem osiągniętego poziomu rozwoju. Jest to widoczne w obu momentach czasowych. Trudną rzeczą pozostaje wychwycenie prawidłowości, które mogą determinować istniejący układ przestrzenny. Rozmieszczenie przestrzenne regionów otrzymane w 2004 r.

\footnotetext{
${ }^{2}$ Współczynnik zmienności odpowiednio v $=60 \%, \mathrm{v}=91 \%$.

${ }^{3}$ Współczynnik zmienności odpowiednio v = 92\%, v = 101\%, v = 146\%.
} 
nie daje ku temu wystarczających podstaw. Zaobserwowano, że regiony o niższym poziomie rozwoju częściej występują w południowej części Polski (podkarpackie, lubelskie, świętokrzyskie, łódzkie). Incydentalnie w tej części kraju ponadprzeciętnym poziomem rozwoju wyróżnia się małopolskie. W 2014 roku zauważalne jest rozlewanie obszarów o niższym poziomie rozwoju na linii środka w kierunku południa. Zwarty przestrzennie obszar cechujący się wyższym poziomem rozwoju układa się w kierunku przeciwnym, czyli na północ. Szczegółowe wartości wskaźnika i jego zmiany w latach 2004 i 2014 dla poszczególnych regionów, wraz z pozycjonowaniem w klasyfikacji, zaprezentowano w tabeli 2.

\begin{tabular}{|c|c|c|c|c|c|c|}
\hline \multirow{2}{*}{ Region } & $\mathbf{2 0 0 4}$ & $\begin{array}{c}\text { WZR } \\
\text { Relatywny } \\
\text { \% }\end{array}$ & $\begin{array}{c}\text { WZR } \\
\text { w hierar- } \\
\text { chii }\end{array}$ & $\begin{array}{c}\text { Miejsce } \\
\text { 2014 }\end{array}$ & $\begin{array}{c}\text { WZR } \\
\text { Relatywny } \\
\text { \% }\end{array}$ & $\begin{array}{c}\text { Miejsce } \\
\text { regionu } \\
\text { wierarchii }\end{array}$ \\
\cline { 2 - 8 } & \multicolumn{3}{|c|}{$\mathbf{2 0 0 4}$} & \multicolumn{2}{|c|}{$\mathbf{2 0 1 4}$} \\
\hline Dolnośląskie & 0,505 & 22 & 1 & 0,410 & -9 & 13 \\
\hline $\begin{array}{c}\text { Kujawsko- } \\
\text {-pomorskie }\end{array}$ & 0,465 & 12 & 4 & 0,476 & 6 & 6 \\
\hline Lubelskie & 0,334 & -20 & 15 & 0,357 & -21 & 16 \\
\hline Lubuskie & 0,461 & 11 & 5 & 0,548 & 22 & 1 \\
\hline Lódzkie & 0,369 & -11 & 13 & 0,414 & -8 & 11 \\
\hline Małopolskie & 0,475 & 14 & 2 & 0,411 & -9 & 12 \\
\hline Mazowieckie & 0,473 & 14 & 3 & 0,508 & 13 & 3 \\
\hline Opolskie & 0,395 & -5 & 11 & 0,383 & -15 & 15 \\
\hline Podkarpackie & 0,364 & -12 & 14 & 0,410 & -9 & 14 \\
\hline Podlaskie & 0,447 & 8 & 6 & 0,500 & 11 & 4 \\
\hline Pomorskie & 0,382 & -8 & 12 & 0,513 & 14 & 2 \\
\hline Śląskie & 0,413 & -1 & 10 & 0,424 & -6 & 10 \\
\hline Świętokrzyskie & 0,252 & -39 & 16 & 0,425 & -6 & 9 \\
\hline $\begin{array}{c}\text { Warmińsko- } \\
\text {-mazurskie }\end{array}$ & 0,445 & 7 & 7 & 0,485 & 8 & 5 \\
\hline Wielkopolskie & 0,437 & 5 & 8 & 0,476 & 6 & 7 \\
\hline $\begin{array}{c}\text { Zachodniopo- } \\
\text { morskie }\end{array}$ & 0,425 & 2 & 9 & 0,467 & 4 & 8 \\
\hline średnia & 0,415 & $100 \%$ & & 0,451 & $100 \%$ & \\
\hline
\end{tabular}

Tabela. 2. Podstawowe charakterystyki regionów w Polsce - miara syntetyczna WZR 2004 i 2014 r. Źródło: opracowanie własne na podstawie danych GUS. 
Bazując na oszacowanej wartości wskaźnika syntetycznego, poziom zrównoważonego rozwoju w Polsce w układzie regionalnym ocenić należy jednak jako niski. Zakres referencyjny wskaźnika syntetycznego może zawierać się w przedziale od zera do jeden, podczas gdy otrzymane średnie wartości nie przekroczyły poziomu 0,4151 w 2004 roku i 0,4505 w 2014 r. W badanym okresie pewnym zmianom uległy przeciętne wartości wskaźnika szacowane dla wszystkich wyodrębnionych klas regionów (tab. 3). Najsilniejszy wzrost poziomu wskaźnika zaobserwowano w klasie o najniższym poziomie rozwoju, tj. klasie $\mathrm{V}$ (o prawie 53\%). Porównywalne zmiany wystąpiły w klasie II i III (ok. 24\%), najsłabsze w klasie I i II. Zmianie uległy także liczebności poszczególnych klas. Udział regionów w klasie I i III uległ zmniejszeniu (odpowiednio o -18 p.p. i -19 p.p.). Odwrotny kierunek zaobserwowano w klasach o najniższym poziomie rozwoju, tj. klasie IV i V (wzrost liczebności o odpowiednio 32 p.p. i 7 p.p.). Szczegóły zawiera tab. 3.

\begin{tabular}{|c|c|c|c|c|c|}
\hline \multirow{2}{*}{ Klasa } & \multicolumn{2}{|c|}{$\begin{array}{c}\text { Średnia wartość } \\
\text { wskaźnika }\end{array}$} & Dynamika WZR & \multicolumn{2}{c|}{$\begin{array}{c}\text { Udział obiektów w da- } \\
\text { nej klasie w \% }\end{array}$} \\
\cline { 2 - 6 } & $2004 \mathrm{r}$. & $2014 \mathrm{r}$. & $2004=100 \%$ & $2004 \mathrm{r}$. & $2014 \mathrm{r}$. \\
\hline Klasa I & 0.476 & 0.523 & $109.9 \%$ & $31 \%$ & $13 \%$ \\
\hline Klasa II & 0.433 & 0.484 & $111.8 \%$ & $31 \%$ & $31 \%$ \\
\hline Klasa III & 0.377 & 0.467 & $123.9 \%$ & $25 \%$ & $6 \%$ \\
\hline Klasa IV & 0.334 & 0.417 & $124.9 \%$ & $6 \%$ & $38 \%$ \\
\hline Klasa V & 0.252 & 0.384 & $152.4 \%$ & $6 \%$ & $13 \%$ \\
\hline
\end{tabular}

Tabela 3. Podstawowe charakterystyki wyodrębnionych klas regionów w oparciu o wskaźnik syntetyczny. Źródło: opracowanie własne na podstawie danych GUS.

Na podstawie oszacowanego wskaźnika syntetycznego przeprowadzono analizę przestrzennego zróżnicowania regionów pod względem poziomu zrównoważonego rozwoju w ujęciu relatywnym, tj. w stosunku do średniego poziomu wskaźnika w każdym badanym roku (tj. 2004 i 2014 r.). Zastosowanie miary relatywnej pozwoliło ocenić, które z regionów prezentują wyższy lub niższy poziom zrównoważonego rozwoju względem średniego poziomu rozwoju w kraju (por. rys. 2 i tab. 2). 


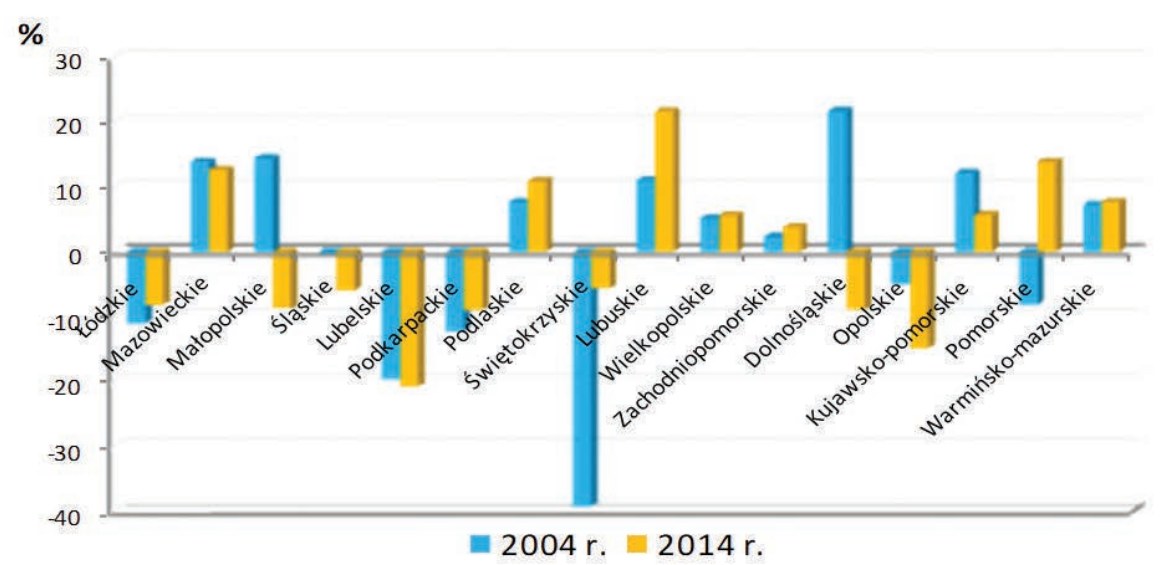

Rys. 2. Miara syntetyczna WZR w ujęciu relatywnym 2004 i 2014.

Źródło: opracowanie własne na podstawie danych GUS.

Analizując oszacowane wartości wskaźnika w ujęciu relatywnym, stwierdzono, że w 2004 r. dziewięć regionów utrzymywało wyższy poziom rozwoju niż przeciętnie w kraju. Liderem było województwo dolnośląskie oraz mazowieckie i małopolskie. Na granicy średniej krajowej znajdowało się zachodniopomorskie i śląskie. W 2014 r. w grupie regionów o ponadprzeciętnym poziomie rozwoju liderem było lubuskie, za nim pomorskie i mazowieckie (tab. 3). Najbardziej odległe od średniego poziomu rozwoju w 2004 r. okazały się być: świętokrzyskie, podkarpackie (odpowiednio $-39 \%,-12 \%,-20 \%)$, oraz woj. lubelskie, które to województwo w 2014 r., obok opolskiego, pozostało jednym $\mathrm{z}$ najbardziej odstających regionów (-21\%). Poniżej średniego poziomu rozwoju w obu momentach badania były regiony: łódzkie, śląskie, lubelskie, podlaskie, opolskie. Spośród wszystkich badanych regionów dwa, tj. pomorskie i świętokrzyskie, wydają sie w największym stopniu odrabiać straty, chociaż w przypadku tego drugiego, poziom średniej krajowej nadal nie został osiągnięty. Pozytywnie ocenić należy widoczny proces odrabiana strat przez to województwo. Negatywne zmiany, jakie zaszły w 2014 r. w regionie małopolskim i dolnośląskim, spowodowały, że utraciły one swoją ponadprzeciętną sytuację i poziom rozwoju w 2014 r. był relatywnie niższy niż w 2004 r. (rys. 2). Zaobserwowane zmiany w poziomie rozwoju skłoniły autorkę do podjęcia próby zweryfikowania, czy pomiędzy poziomem klasy, obrazującej 
poziom rozwoju, a dynamiką zmian istnieje współzależność. Badanie korelacji wykazało, że pomiędzy badanymi cechami istnieje bardzo silna zależność. Im niższa klasa poziomu rozwoju, tym wyższą dynamiką zmian cechuje się dany region, zatem silniejsze zmiany w poziomie wskaźnika rozwoju cechują grupy regionów o niższym poziomie rozwoju ${ }^{4}$.

\section{Analiza poziomu zrównoważonego rozwoju poszczególnych klas regionów według komponentów rozwoju: społeczeństwo - gospodarka - środowisko}

W celu dokonania porównania wyodrębnionych klas i zachowania przejrzystości wykresu zaprezentowano średnie wartości znormalizowane oszacowane dla poszczególnych komponentów. Parametry zawierają się w przedziale $<0 ; 1>$. W 2004 roku szacowane wartości wykazują większe odchylenia w poszczególnych klasach regionów niż w $2014 \mathrm{r}$. Klasa I cechuje się ponadprzeciętną sytuacją społeczną, klasa II przewyższa ją kondycją gospodarczą, pozostając w obszarze środowiska porównywalnie na poziomie klasy V. Ponadprzeciętną sytuacją w obszarze ładu społecznego wyróżnia się klasa IV. W 2014 r. rozkład poszczególnych parametrów układa się w taki sposób, że im wyższa klasa regionów, tym wyższe wartości osiągane są we wszystkich analizowanych komponentach. Pewne odchylenia występują w klasie III wyróżniającej się od pozostałych klas (poza kasą I) lepszą sytuacją środowiskową, jednocześnie osiągane przez regiony tej klasy wartości w obszarze społecznym są porównywalne do tych osiąganych w klasie V (por. rys. 3).
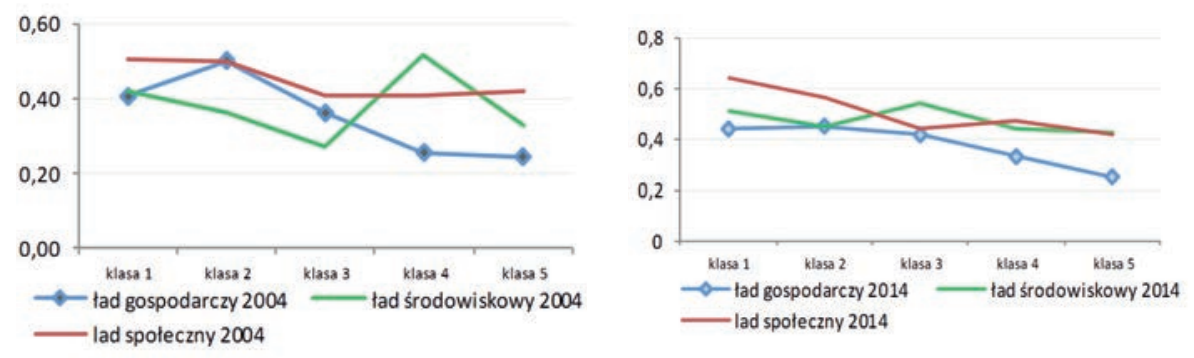

Rys. 3. Średnie wartości komponentów składowych zrównoważonego rozwoju - klasy regionów 2004 i 2014. Źródło: opracowanie własne na podstawie danych GUS.

${ }^{4}$ Współczynnik korelacji Pearsona r = - 0,95 w 2004 r. i r = - 0,9 w 2014 r. 


\begin{tabular}{|c|c|c|}
\hline Klasa & Regiony 2004 & Regiony 2014 \\
\hline Klasa 1 & $\begin{array}{c}\text { lubuskie, mazowieckie kujawsko-po- } \\
\text { morskie, małopolskie, dolnośląskie }\end{array}$ & lubuskie, pomorskie \\
\hline Klasa 2 & $\begin{array}{c}\text { podlaskie, wielkopolskie, warmiń- } \\
\text { sko-mazurskie, zachodniopomor- } \\
\text { skie, śląskie, }\end{array}$ & $\begin{array}{c}\text { mazowieckie, kujawsko-pomor- } \\
\text { skie, podlaskie, wielkopolskie, } \\
\text { warmińsko-mazurskie }\end{array}$ \\
\hline Klasa 3 & $\begin{array}{c}\text { pomorskie łódzkie, podkarpackie, } \\
\text { opolskie, }\end{array}$ & zachodniopomorskie \\
\hline Klasa 4 & lubelskie & $\begin{array}{c}\text { małopolskie, dolnośląskie, śląskie, } \\
\text { lódzkie, podkarpackie, świętokrzyskie }\end{array}$ \\
\hline Klasa 5 & świętokrzyskie & opolskie, lubelskie \\
\hline
\end{tabular}

Tabela 4. Klasy regionów - klasyfikacja w 2004 i 2014 r.

Źródło: opracowanie własne na podstawie danych GUS.

Analizując tempo wzrostu wskaźnika rozwoju w ujęciu relatywnym, tj. w relacji do średniego poziomu wskaźnika w 2004 roku, zaobserwowano jednokierunkowe dodatnie tempo zmiany wskaźnika rozwoju we wszystkich regionach, ale o zróżnicowanym natężeniu. Przyjmując, że średnie tempo wzrostu wskaźnika rozwoju w latach 2004-2014 wynosiło ok. 11\%, a średni poziom wskaźnika rozwoju w 2004 wyniósł 0,415, regiony sklasyfikowano w 4 grupach. Grupa 1, cechująca się wyższym niż przeciętnym tempem wzrostu poziomu wskaźnika WZR i wyższym niż średnim relatywnym poziomem rozwoju w $2004 \mathrm{r}$. Jest to najliczniejsza grupa obejmująca sześć regionów: pomorskie, podlaskie, mazowieckie, podkarpackie, zachodniopomorskie, kujawsko-pomorskie. Grupa 2, cechująca się wyższym niż przeciętnym tempem wzrostu poziomu wskaźnika WZR i niższym niż średnim relatywnym poziomem rozwoju, obejmuje pięć regionów: wielkopolskie, opolskie, dolnośląskie, małopolskie, łódzkie w granicy z grupą 3. Grupa 3 wyróżnia się niższym niż przeciętnym tempem wzrostu wskaźnika WZR i niższym niż średnim relatywnym poziomem rozwoju. Pozycjonowano w niej dwa regiony, tj. świętokrzyskie i lubuskie, pozostające w granicy z grupą 4, wyróżniającą się niższym niż przeciętnym tempem wzrostu poziomu wskaźnika WZR i wyższym niż średnim relatywnym poziomem rozwoju. Są to regiony: śląskie, lubelskie, warmińsko-mazurskie. Rozkład regionów w ramach poszczególnych komponentów zaprezentowano na rys. 4. 
a) miara syntetyczna WZR

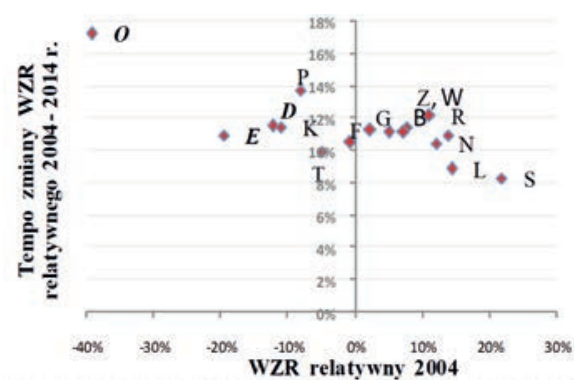

c) komponent środowiskowy

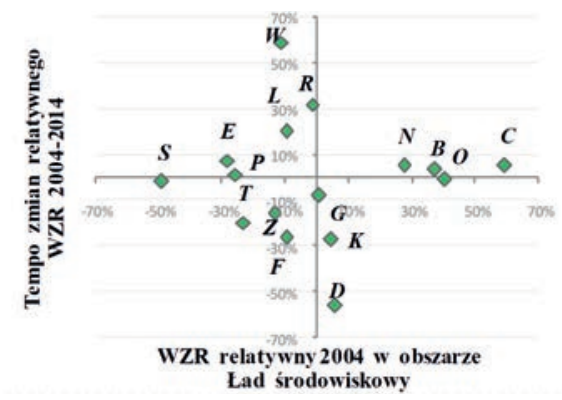

b) komponent gospodarka

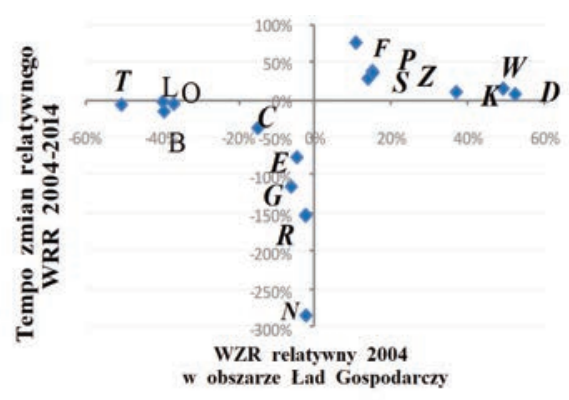

d) komponent społeczeństwo

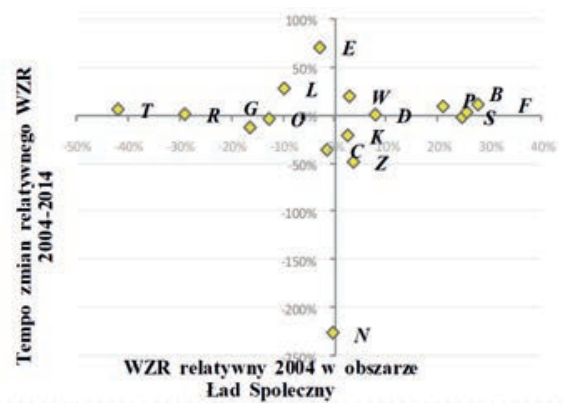

Rys. 4. Zróżnicowanie tempa i poziomu relatywnego wskaźnika zrównoważonego rozwoju: miara syntetyczna i cząstkowa w obszarze komponentów:

społeczeństwo - gospodarka - środowisko. Ujęcie regionalne.

* zastosowane oznaczenia zgodnie z przyjętą klasyfikacją wyróżników województw i powiatów dla tablic rejestracyjnych pojazdów w Polsce za http://zylla.wipos.p.lodz. $\mathrm{pl} / \mathrm{ut} / \mathrm{num}$-rej.html. Źródło: opracowanie własne na podstawie danych GUS.

\section{Zakończenie}

Przedmiotem analiz w artykule było przestrzenne zróżnicowanie regionalne $\mathrm{w}$ Polsce pod względem osiągniętego poziomu zrównoważonego rozwoju. Przeprowadzona klasyfikacja obiektów w dwóch momentach czasowych, tj. 2004 i 2014, pozwoliła wyodrębnić grupy regionów względnie jednorodnych wewnętrznie pod względem osiągniętego poziomu rozwoju. Scharakteryzowano również zmiany, jakie zaszły na przestrzeni badanego okresu, zarówno w obszarze miary syntetycznej, jak i w poszczególnych jej składowych, tj.: społeczeństwo - gospodarka - środowisko. 
Na podstawie zebranego materiału empirycznego ocenia się, że w 2014 roku nastąpił wzrost przeciętnego poziomu rozwoju zrównoważonego w kraju (średnio o 9\%) w stosunku do 2004 r. Oszacowane wartości wskaźnika syntetycznego w wymiarze ogólnym dla kraju skłaniają do przyjęcia oceny, że przeciętny poziom rozwoju w kraju jest niski. W 2004 roku prawie $44 \%$ regionów w Polsce cechowało się niższym niż przeciętny poziomem rozwoju zrównoważonego. W 2014 roku udział tych regionów wzrósł o kolejne 6 p.p., co oznacza, że połowa terytorium Polski to obszary znajdujące poniżej średniej krajowej. Narastające rozwarstwienie ocenić należy jako zjawisko niekorzystne dla dalszego rozwoju.

$\checkmark$ Dynamika zmian w poszczególnych regionach pozostaje odmienna i różnokierunkowa $\mathrm{w}$ każdym $\mathrm{z}$ trzech przyjętych do badania komponentów rozwoju. W układzie regionalnym spadek dynamiki wzrostu zanotowano w trzech regionach, tj. małopolskim, dolnośląskim i opolskim. Pozostałe regiony cechowały się dodatnią stopą wzrostu. W wymiarze ogólnym spadek dynamiki wzrostu przeciętnego poziomu rozwoju zaobserwowano w ładzie gospodarczym (o 7\%), w przeciwieństwie do dwóch pozostałych. Najsilniejszą, dodatnią stopę wzrostu zanotowano w obszarze ładu środowiskowego (23\%), słabszą, ale również dodatnią, w obszarze ładu społecznego $(10,4 \%)$.

$\checkmark$ Powyższy materiał dowodzi, że w Polsce zachodzi nierówny proces niwelowania dysproporcji rozwojowych pomiędzy regionami. Zjawisko to obserwuje się w każdym komponencie przyjętym do badania. Pomiędzy najwyżej a najniżej stojącym w hierarchii regionem dystans w obszarze gospodarczym zwiększył się o 50\%, a w obszarze środowiskowym o 16\%. Zwiększenie spójności nastąpiło jedynie w komponencie społecznym, a szacowana odległość pomiędzy jednostkami skrajnymi zmniejszyła się o $12 \%$.

$\checkmark$ Proces odrabiania zaległości rozwojowych jest silnie zróżnicowany przestrzenie. Dającą się uchwycić prawidłowością jest to, że większa dynamika wzrostu towarzyszy regionom o przeciętnie niższym poziomie rozwoju. Regiony bogatsze rozwijają się wolniej, ponieważ osiągnęły już pewną dojrzałość. Opisywana zależność wpisuje się w nurt ogólnej teorii rozwoju regionalnego. Podobną prawidłowość autorka zaobserwowała w innych badaniach nad rozwojem społeczno-gospodarczym na szczeblu porównań międzynarodowych (Klo- 
nowska-Matynia i Sasin 2015, 771-791; Klonowska-Matynia 2015, 379). Wcześniejsze badania autorki prowadzone w różnych momentach czasowych, tj. 2004, 2012 i 2014 r., dowodzą, że Polska na tle innych krajów europejskich cechuje sie ponadprzeciętną dynamiką wzrostu, pozostając liderem zmian społeczno-gospodarczych. Równolegle, powyższe badania wskazują, że wewnętrznie dynamika zmian jest silnie zróżnicowana regionalnie.

Bazując na trzech filarach, tj. sferze społecznej, gospodarczej i środowiskowej, ocenia się, że proces wyrównywania dysproporcji rozwojowych jest procesem wieloletnim i powolnym. Aktualnie silne zróżnicowanie przestrzenne regionów w Polsce pod względem rozwoju nadal się utrzymuje, pomimo niekwestionowanych dynamicznych i pozytywnych zmian zachodzących we wszystkich regionach w Polsce.

\section{Bibliografia:}

Baker, Susan at al. 2012. The Politics of Sustainable Development: Theory. Policy and Practice Within the EU. London-New York: Routlege.

Daly, Herman E. 1990. Toward Some Operational Principles Of Sustainable Development. Ecological Economics, (2), 1-6.

Dobrzański, Grzegorz. 2010. Problemy edukacji ekonomicznej na rzecz zrównoważonego rozwoju. W: Ekonomia zrównoważonego rozwoju. Zarys problemów badawczych i dydaktyki, red. Bazyli Poskrobko, 6175. Białystok: WSE.

Folke, Carl at al. 2002. Resilience and Sustainable Development: Building Adaptive Capacity in a World of Transformations. A Journal of the Human Environment, 31(5), 437-440.

GUS. 2017. Nomenklatura NTS. Dostęp: 25.01.2017 http://stat.gov. $\mathrm{pl} /$ statystyka-regionalna/jednostki-terytorialne/nomenklatura-nts/.

Jones, Garett i Joel E. Schneider. 2006. Intelligence. Human Capital. And Economic Growth. A Bayesian Averaging Of Classical Estimates (Bace) Approach. Journal of Economic Growth, 11(1), 71-93. DOI: 10.1007/s10887-006-7407-2. 
Klonowska-Matynia, Maria i Maria Sasin. 2015. EU Countries socio-economic development in the context of Europe 2020 strategy. Rocznik Ochrona Środowiska, (17), 771-791.

Klonowska-Matynia, Maria. 2015. European Countries Socio-Economic Development in the Context of Europe 2020 Strategy. China-USA Business Review, 18(8), 379-394. DOI:10.17265/1537-1514/2015.08,001.

Kukuła, Karol. 2000. Metoda unitaryzacji zerowanej. Warszawa: PWN.

Stanny, Monika. 2013. Przestrzenne zróżnicowanie rozwoju obszarów wiejskich $w$ Polsce. Warszawa: IRWiR PAN. 
Anna Bernaciak

Uniwersytet Ekonomiczny w Poznaniu - Wydział Zarządzania

anna.bernaciak@ue.poznan.pl

\section{Planowanie na rzecz rozwoju zrównoważonego na szczeblu lokalnym w Polsce - uwarunkowania formalno-prawne}

\section{Wstęp}

Samorząd terytorialny, szczególnie na najniższym ze szczebli, wykonuje szereg zadań z zakresu ochrony środowiska. Barczak i Kowalewska $(2015,25)$ podnoszą nawet, że ochrona środowiska to jedno z głównych zadań samorządu terytorialnego. Jest to o tyle ważne, że wiąże się zarówno $\mathrm{z}$ wielością i różnorodnością zadań, jak i ich powiązaniami z szeregiem innych obszarów działalności samorządu. Najczęstsza klasyfikacja aktywności ochronnych odnosi się do charakteru prawnego i treści obowiązków, które ciążą w zakresie ochrony środowiska na jednostkach samorządu terytorialnego. Wyróżnia się zatem zadania o charakterze bezpośrednio wykonawczym (kreatywne, organizatorskie), zobowiązująco-reglamentacyjnym oraz kontrolno-nadzorczym (Barczak i Kowalewska 2015, 47). W praktyce samorządowej zadania te są ściśle za sobą powiązane, przenikają się wzajemnie, a często wykraczają poza aktywność w obszarze stricte ochrony środowiska. Z tego względu zorganizowane zarządzanie zadaniami ochronnymi zarówno na szczeblu strategicznym (w dokumentach o charakterze strategii ogólnych oraz planów i programów sektorowych) oraz przede wszystkim operacyjnym (w codziennej praktyce administracyjnej) wydaje się być znaczącym wyzwaniem. Dodatkowym czynnikiem komplikującym jest dynamicznie zmieniające się otoczenie prawne, które wymaga dostosowywania przyjętych procedur postępowania, wypracowanych wzorców rozwiązań, a niejednokrotnie także całych rozwiązań systemowych, do aktualnych uwarunkowań legislacyjnych. Stawia to władze samorządowe w sytuacji, w której muszą wykazywać się szczególną czujnością, zaangażowaniem merytorycznym oraz gotowością do dynamicznego, elastycznego reagowania na zmiany otoczenia. 
W kontekście wartości nadrzędnych, jak np. zasada zrównoważonego rozwoju, które powinny być uwzględniane w odniesieniu do całokształtu polityki strategicznej jednostek samorządu terytorialnego, w tym przede wszystkim gmin, wspomniane trudności dodatkowo się uwypuklają. Większość jednostek samorządu, realizując obowiązki ustawowe czy zalecenia wynikające z programów i strategii szczebla krajowego, koncentruje się na spełnieniu cząstkowych wymagań, związanych z zakresem, formą i sposobem opracowania szeregu dokumentów strategicznych, nie dbając o ich spójność, komplementarność czy kompleksowość ${ }^{1}$. Także na etapie opracowywania poszczególnych dokumentów pojawiają się ułomności i niekonsekwencje (Guzal-Dec 2015, 128; Sobol 2013; NIK 2011).

Wydaje się zatem istotne, aby dokonać uporządkowania rodzaju, zakresu i podstaw prawnych opracowania poszczególnych dokumentów strategicznych z zakresu ochrony środowiska i rozwoju zrównoważonego w gminach. Istotne znaczenie ma również wskazanie potencjalnych powiązań między dokumentami, jeśli to możliwe, a także relacji nadrzędności i podrzędności oraz ich obligatoryjności.

\section{Dokumenty strategiczne $w$ gminach $i$ ich oddziaływanie na zrównoważony rozwój}

Jako dokument o charakterze strategicznym rozumie się dokument implementujący strategię organizacji, poprzedzony jej identyfikacją, definiowaniem lub redefiniowaniem w reakcji na zmiany otoczenia bądź ich symptomy (Zarządzanie strategiczne. Koncepcje, metody 2007, 97). W odniesieniu do samorządu terytorialnego dokument strategiczny stanowi element realizacji procesu zarządzania strategicznego określanego jako „ukierunkowany na przyszłość proces planowania i wyboru celów rozwoju oraz zadań realizacyjnych, wdrażania przyjętych postanowień, a także monitorowania i kontroli wykonania przyjętych ustaleń" (Gawroński 2010, 31-32). Proces ten powinien cechować się m.in. kompleksowością, efektywnością, wielowymiarowością. Z uwagi na specyfikę funkcjonowania samorządów szczebla gminnego w Polsce oraz zakres ich kompetencji, a także uwarunkowania prawne, jakie determinują ich działalność, trudno mówić o jednym dokumencie strategicznym szcze-

\footnotetext{
${ }^{1}$ Por. zestawienie metod zarządzania w polskich gminach (Ziółkowski 2015) oraz raport z wyników kontroli Najwyższej Izby Kontroli (NIK 2011).
} 
bla gminnego. Rolę taką w praktyce pełni wprawdzie strategia rozwoju (czy program rozwoju), jednak równocześnie na szeregu pozostałych pól strategicznych - zarządzania przestrzenią, środowiskiem, programowania rewitalizacji, wsparcia społecznego - przyjmowane są także dokumenty o charakterze strategii. Wytyczają one cele, kierunki działań czy formułują wizję, która odnosi się często do całokształtu rozwoju gminy rozpatrywanego w wybranym kontekście. Można je wprawdzie, korzystając z nomenklatury zarządzania strategicznego, uznać za rodzaj strategii obszarów funkcjonalnych czy strategii sektorowych, jednak w odniesieniu do specyfiki zarządzania w samorządzie terytorialnym tego typu hierarchizacje nie znajdują swojego bezpośredniego przełożenia (Zarzadzanie strategiczne. Systemowa koncepcja biznesu 2005, 48). Wciąż sfery przestrzeni czy środowiska naturalnego, a także gospodarki i społeczeństwa, pozostają w bezpośredniej łączności z całokształtem procesów rozwojowych w gminie.

Naczelnym dokumentem strategicznym w gminie jest strategia rozwoju. Jak podaje Sztando (2009, 212-213), „w ujęciu merytorycznym jest to zbiór samorządowych, wielopłaszczyznowych, lecz spójnych idei rozwoju lokalnego, natomiast $\mathrm{w}$ ujęciu formalnym to dokument planistyczny zawierający dynamiczną czasowo analizę wnętrza i otoczenia gminy, zestaw celów harmonijnego rozwoju gminy oraz zsynchronizowany i skoordynowany program działań, które mają doprowadzić do ich osiągnięcia"2. Chądzyński, Nowakowska i Przygodzki (2008) dodają także, że jest podstawą skutecznego i efektywnego zarządzania, pełniąc szereg funkcji: efektywnościową, koordynacyjną, porządkującą, kontrolną, informacyjną, edukacyjną i promocyjną. Obecnie, $\mathrm{z}$ formalno-prawnego punktu widzenia, zgodnie ze znowelizowaną ustawą z 6 grudnia 2006 r. o zasadach prowadzenia polityki rozwoju, samorządy gminne prowadzą politykę rozwoju w oparciu o dokument określony mianem programu rozwoju (art. 2 i 19). Sama zaś polityka rozwoju definiowana jest jako „zespół wzajemnie powiązanych działań podejmowanych i realizowanych w celu zapewnienia trwałego i zrównoważonego rozwoju kraju, spójności społeczno-gospodarczej, regionalnej i przestrzennej, podnoszenia konkurencyjności gospodarki oraz two-

\footnotetext{
${ }^{2}$ Szerzej o polityce i planowaniu rozwoju miasta pisze także Nowakowska (2016a, 2016b).
} 
rzenia nowych miejsc pracy w skali krajowej, regionalnej lub lokalnej" (art. 3 ust. 3). Znaczący nacisk kładzie zatem ustawodawca na kwestie nadrzędnych celów, jakie polityka ma realizować. Jako cel główny wskazano trwały i zrównoważony rozwój kraju, a w dalszej kolejności także spójność, konkurencyjność oraz tworzenie nowych miejsc pracy. Wraz z wejściem w życie ustawy pojawiła się w obszarze zarządzania strategicznego w gminach pewna konfuzja, dotycząca rodzaju dokumentów, jakie mają być opracowane. Czy wciąż zasadne jest przyjmowanie strategii rozwoju, czy powinien zostać uchwalony program rozwoju? Zgodnie z opinią ekspertów Ministerstwa Administracji i Cyfryzacji, wydaną w oparciu o przepisy wspomnianej ustawy o zasadach prowadzenia polityki rozwoju, jednostki samorządu terytorialnego na szczeblu lokalnym zobligowane są wyłącznie do przyjęcia programu rozwoju, co nie wyklucza jednak możliwości przyjęcia także strategii rozwoju (Wartowiedzieć.org 2017). Zarówno zakres jak i horyzont czasowy ewentualnej strategii oraz jej relacja do programu rozwoju nie zostały dookreślone.

W ustawie o zasadach prowadzenia polityki rozwoju wskazano natomiast, co powinien w szczególności określać program rozwoju: diagnozę sytuacji społeczno-gospodarczej, główny cel i cele szczegółowe, priorytety oraz kierunki interwencji w zakresie terytorialnym, sposób monitorowania i oceny stopnia osiągania celu głównego i celów szczegółowych, plan finansowy, a także podstawowe założenia systemu realizacji (art. 17, ust. 1). Zakres formalny i merytoryczny strategii i programu nie różni się zatem znacząco. Ponadto gminy przyjmowały dokumenty nazywane strategiami rozwoju oraz programy rozwoju także na długo przed wejściem w życie nowelizacji wprowadzonej ustawą z dnia 24 stycznia 2014 r. $\mathrm{Na}$ potrzeby niniejszego opracowania przyjmuje się zatem, że w gminach mogą funkcjonować dwa odrębne dokumenty w randze strategii rozwoju - strategia i program, których podstawy prawne przyjęcia będą różne, podobnie jak wymagania w zakresie ich zawartości, jednakowoż ich rola będzie w dużej mierze tożsama. Trudno wskazać zależność hierarchiczną czy operacyjną w sytuacji nieprecyzyjnych przepisów prawa oraz dość krótkiego czasu obowiązującej w tym zakresie praktyki samorządowej. Z punktu widzenia implementacji zasad rozwoju zrównoważonego, program rozwoju będzie miał jednak większe znaczenie, chociażby ze względu na formalno-prawny obowiązek jego uchwalenia 
oraz zdefiniowany w ustawie cel nadrzędny dla tego typu dokumentów, jakim jest wspomniane zapewnienie trwałego i zrównoważonego rozwoju w skali kraju. Strategia nie ma tak silnego umocowania ustawowego, nie jest też wskazane, jakie cele nadrzędne powinna uwzględniać.

Kolejnym dokumentem o charakterze strategicznym opracowywanym na szczeblu gminnym jest studium uwarunkowań i kierunków zagospodarowania przestrzennego, przygotowywane w oparciu o przepisy ustawy z dnia 27 marca 2003 r. o planowaniu i zagospodarowaniu przestrzennym. Rozpatrywanie studium jako dokumentu strategicznego ma dwojakie podłoże. Z jednej strony jest to dokument obejmujący cały obszar gminy, za pomocą którego prowadzi się politykę przestrzenną, w tym lokalne zasady zagospodarowania przestrzennego (art. 9). Niejako $\mathrm{z}$ definicji zatem jest narzędziem formułowania strategii $\mathrm{w}$ odniesieniu do przestrzeni gminy. Ponadto nie ma charakteru powszechnie obowiązującego, stanowi zatem narzędzie podobnej natury co strategia rozwoju. Z drugiej strony, jak podnoszą Barczak i Kowalewska (2015, 77), studium to „filozofia rozwoju przestrzenno-gospodarczego na przyszłość mogąca zachęcić do inwestowania”. Jest więc zarazem narzędziem strategii i promocji. Operacjonalizacja zapisów studium następuje w momencie uchwalenia na jego podstawie miejscowego planu zagospodarowania przestrzennego. Plan powinien być zatem kontynuacją identyczności zasad zagospodarowania terenu, które w studium sformułowane są w sposób ogólny (Barczak i Kowalewska 2015, 77). Oba te dokumenty powinny być skoordynowane z przyjętym w gminie dokumentem w randze strategii rozwoju (strategią, programem) ${ }^{3}$. Wynika to przede wszystkim z zasad zarządzania strategicznego, a także z szeregu wytycznych i wymagań, jak choćby warunki formułowane przez Komisję Europejską w celu skutecznego wykorzystania funduszy unijnych, odnoszące się do konieczności prowadzenia zintegrowanego podejścia do planowania/programowania rozwoju (Sobol 2013, 74). Istotne jest również znaczenie dokumentów z zakresu planowania przestrzennego $\mathrm{w}$ implementacji zasad rozwoju zrównoważonego. $\mathrm{Z}$ punktu widzenia

\footnotetext{
${ }^{3}$ Dodatkowo opracowanie projektu mpzp i studium powinno być poprzedzone przygotowaniem opracowania fizjograficznego, zgodnie z przepisami ustawy prawo ochrony środowiska (art. 72) oraz rozporządzenia Ministra Środowiska z dnia 9 września 2002 r. w sprawie opracowań ekofizjograficznych.
} 
przepisów, u podstaw całokształtu planowania i zagospodarowania przestrzennego leży, oprócz ładu przestrzennego, rozwój zrównoważony. Część badaczy podkreśla jednak, że zapisy te: 1) mają charakter klauzul generalnych niepopartych zasadami materialnymi, co utrudnia egzekwowanie ich implementacji, 2) mają charakter ogólny i deklaratywny, co powoduje, że w praktyce nie są w pełni realizowane, 3) dają możliwość postrzegania pojęć w sposób fragmentaryczny, co wypacza ich istotę, 4) w połączeniu $\mathrm{z}$ brakiem obligatoryjnego wymogu, aby studia opierały się na podbudowie ekonomicznej, realizacja klauzul generalnych nie ma charakteru operacyjnego, 5) nie zostały wyposażone $\mathrm{w}$ towarzyszące im mechanizmy regulacyjne i kontrolne, co daje dużą swobodę elastycznego formułowania sposobów zagospodarowania i funkcji terenu, a w efekcie pomijanie interesów społecznych, ochrony przyrody itp. (Gawroński 2010; Stanek 2011; Sobol 2013; Zachariasz 2013). Mimo wskazanych ułomności studia i plany miejscowe wciąż pozostają naczelnymi narzędziami kształtowania strategii przestrzennego zagospodarowania gminy, a ich rola w tym zakresie powinna być świadomie wykorzystywana.

Kolejnym ze strategicznych dokumentów o istotnym wpływie na kształtowanie zrównoważonego rozwoju gminy są programy ochrony środowiska. Znowelizowana ustawa prawo ochrony środowiska precyzuje obecnie, że programy opracowywane na szczeblach wojewódzkim, powiatowym i gminnym są podstawą prowadzenia polityki ochrony środowiska, obok dokumentów (strategii, programów i dokumentów programowych), o których mowa w ustawie o zasadach prowadzenia polityki rozwoju (art. 14). Nie wskazuje także ich zawartości, którą wcześniej odnoszono per analogiam do zawartości polityki ekologicznej państwa ${ }^{4}$. Utrzymano jedynie wymóg sporządzania i prezentacji co dwa lata raportów z ich wykonania. Jednocześnie zakres i sposób przygotowania tych dokumentów został znacząco doprecyzowany w wytycznych Ministra Środowiska z 2015 r. (Ministerstwo Środowiska 2015). Obejmują one zarówno podstawowe zasady tworzenia programów i ich

\footnotetext{
${ }^{4}$ Funkcjonującą we wcześniejszym kształcie politykę ekologiczną państwa przemianowano na politykę ochrony środowiska będącą zespołem działań mających na celu stworzenie warunków niezbędnych do realizacji ochrony środowiska, zgodną z zasadą zrównoważonego rozwoju. $\mathrm{W}$ praktyce zaś stała się elementem składowym strategii sektorowej.
} 
strukturę jak i obszary interwencji oraz katalog wskaźników, jakie powinny zostać przypisane do celów. Są zatem dokumentami, w których koncentrują się zadania i cele środowiskowe, stanowiąc de facto strategię ochrony środowiska w gminach (Barczak i Kowalewska 2015, 66). Strategię, która powinna uszczegóławiać środowiskowe zagadnienia ze strategii rozwoju gminy i studium uwarunkowań, będąc z nimi spójną w ujęciu zadaniowym, czasowym i przede wszystkim strategicznym.

Ponadto na szczeblach gminnych, w związku z wymaganiami innych aktów prawnych, powinny być uchwalane: 1 ) wieloletnie plany rozwoju i modernizacji urządzeń wodociągowych i urządzeń kanalizacyjnych, 2) plany gospodarowania na gruntach położonych na obszarach ograniczonego użytkowania istniejących wokół zakładów przemysłowych, 3) programy opieki nad zwierzętami bezdomnymi oraz zapobiegania bezdomności zwierząt, 4) regulaminy utrzymania czystości i porządku na terenie gminy. Szczególnym elementem są także, funkcjonujące według nowych wytycznych prawnych ustawy z dnia 9 października 2015 r. o rewitalizacji, gminne programy rewitalizacji. Ustawodawca przewidział, że jednym z kluczowych czynników delimitacji obszarów zdegradowanych i rewitalizacji może być, obok koncentracji negatywnych zjawisk społecznych, koncentracja negatywnych zjawisk środowiskowych (w szczególności przekroczenia standardów jakości środowiska, obecności odpadów stwarzających zagrożenie dla życia, zdrowia ludzi lub stanu środowiska). Powoduje to, że w gminach, w których było to jednym z kryteriów wyznaczenia obszarów, funkcjonuje kolejny dokument, którego spójność i komplementarność względem pozostałych należy zapewnić.

Ze strategii obowiązujących na poziomie krajowym i międzynarodowym wynikają także wytyczne w zakresie opracowania: 1) programów usuwania azbestu i wyrobów zawierających azbest (Ministerstwo Gospodarki 2010), 2) programów ograniczania niskiej emisji/planów gospodarki niskoemisyjnej (traktowane jako programy wykonawcze do gminnych programów ochrony środowiska przyjmowane na podstawie list przedsięwzięć priorytetowych WFOŚiGW), 3) planów zrównoważonej mobilności (Komisja Europejska 2013), 4) programów edukacji ekologicznej (Ministerstwo Środowiska 2001). 


\section{Zintegrowane planowanie na rzecz rozwoju zrównoważonego na szczeblu gminnym}

Niezbędnym krokiem do integracji planowania na rzecz rozwoju w gminach jest identyfikacja całokształtu najważniejszych dokumentów programowych i wskazanie ich wzajemnych powiązań. Z uwagi na ramy opracowania ograniczono się jedynie do pierwszego $\mathrm{z}$ wymienionych działań oraz propozycji ogólnego zarysu schematu powiązań, pozostawiając otwarte pole do formułowania dalszych, modelowych propozycji.

Kwestie modelowania zintegrowanego planowania rozwoju miast były przedmiotem zainteresowania wielu autorów (m.in. Zintegrowane planowanie rozwoju miast 2011; Mantey 2013; Nowakowska 2016b; Gospodarowanie przestrzeniq miast i regionów 2015). Brak jednak w literaturze podejścia operacjonalizującego, które uwzględniałoby całokształt dokumentów, które są opracowywane w gminach, i ich wzajemne relacje. Propozycją takiego uporządkowania może być przykładowa struktura podstawowych dokumentów strategicznych i operacyjnych w równoważeniu rozwoju gmin (rys. 1). Zakłada ona występowanie trzech zasadniczych szczebli organizacji: 1) strategicznego (strategia i operacjonalizacja finansowa strategii jako narzędzie niezbędne do jej skutecznej realizacji), 2) strategicznego sektorowego, 3) sektorowego operacyjnego. Do pierwszego poziomu (strategicznego) zaliczono strategię rozwoju lub dokument równoważny w postaci programu rozwoju wraz z ich niezbędną operacjonalizacją $\mathrm{w}$ postaci wieloletniej prognozy finansowej (są to opracowania komplementarne). Na poziomie strategii sektorowych, celowo ograniczonych do kluczowych z punktu widzenia skutecznej realizacji zasad rozwoju zrównoważonego, zaliczono studia uwarunkowań, programy ochrony środowiska oraz w wybranych wypadkach (gdy odnoszą się choćby częściowo do kwestii środowiskowych) także gminne programy rewitalizacji. Dokumentami o charakterze quasi wykonawczym względem nich będą sektorowe programy środowiskowe i społeczne oraz, w przypadku studium, szczególny dokument, jakim jest plan miejscowy posiadający rangę aktu prawa miejscowego (stąd decyzja o wyodrębnieniu go w strukturze na osobnym poziomie). U podstaw całego systemu powinny leżeć dokumenty z zakresu aktywności inwestycyjnej i zapewniające możliwość finansowania ( $\mathrm{z}$ uwagi na ich szeroki zakres oddziaływania - nie można przypisać ich do konkretnego sektora). Zarówno założenia jak i cele nad- 
rzędne powinny w przypadku tak zaproponowanej struktury schodzić do jej niższych szczebli w sposób kaskadowy, a każdy kolejny poziom powinien je uszczegóławiać i operacjonalizować.

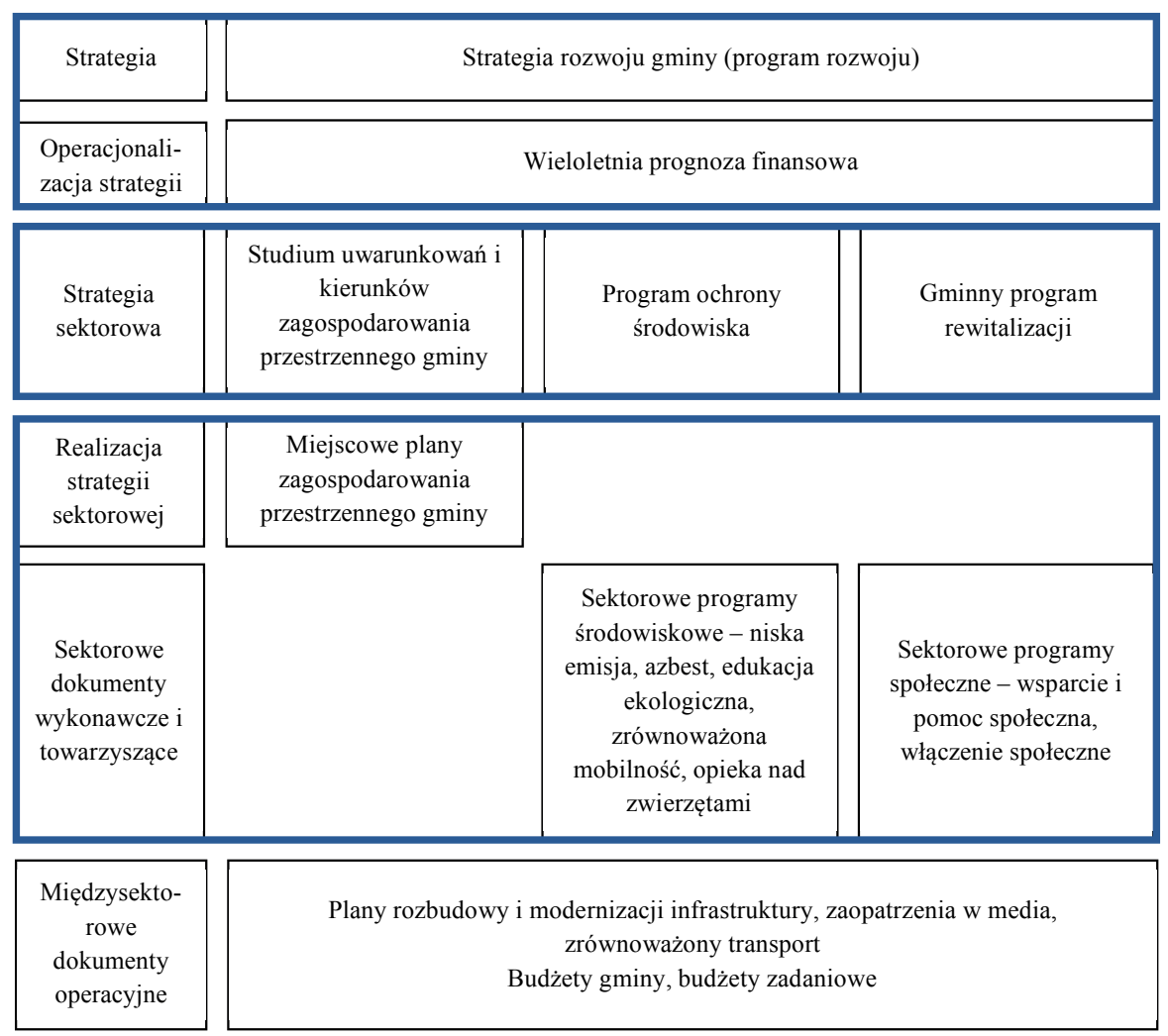

Rys. 1. Struktura podstawowych dokumentów strategicznych i operacyjnych w równoważeniu rozwoju gmin. Opracowanie własne.

\section{Zakończenie}

Wielość i różnorodność dokumentów o charakterze strategicznym w gminach, które odnoszą się do kwestii ochrony środowiska i rozwoju zrównoważonego, znacząco utrudnia ich właściwą organizację oraz zintegrowane planowanie w tych obszarach. Dokumenty często powstają w wyniku chwilowego zapotrzebowania związanego z możliwością pozyskania dofinansowania zewnętrznego albo jako realizacja wymogu ustawowego, często bez głębszej refleksji nad ich rolą i miejscem w sys- 
temie zarządzania gminą. Głównymi problemami, jakie identyfikuje się w odniesieniu do skutecznego planowania na rzecz rozwoju zrównoważonego w gminach, są: 1) dynamicznie zmieniające się przepisy prawa i związany z tym chaos organizacyjny oraz kompetencyjny, 2) brak wypracowanych, trwałych rozwiązań systemowych w zakresie sposobów opracowania dokumentów i ich zawartości, ewentualnie wytycznych, które w sposób ewolucyjny dostosowywać się będą do zmieniającego się otoczenia formalno-prawnego i organizacyjnego (przykładowo, nowe wytyczne w zakresie programów ochrony środowiska pojawiły się po 13 latach od wprowadzenia ich po raz pierwszy, wprowadzając bardzo duże zmiany w sposobie ich opracowania), 3) brak weryfikacji merytorycznej opracowań zarówno na szczeblu gminnym jak i w odniesieniu do jednostek kontroli (wyjątek stanowią lokalne programy rewitalizacji), 4) niejasne zasady współzależności między dokumentami, brak ich hierarchiczności, kaskadowości zarówno na poziomie formalnym jak i w praktyce planistycznej gmin, 5) niedostatki wiedzy o sposobie integracji narzędzi zarządzania rozwojem na szczeblu gminnym (zarówno wśród decydentów jak i osób zajmujących się zagadnieniami ochrony środowiska), 6) rozłączne traktowanie zadań własnych samorządu, brak systemowych powiązań wewnątrz urzędów i mała popularność rozwiązań z zakresu zarządzania projektowego. Systematyczna organizacja przepisów prawa, szkolenie i edukacja kadr oraz skuteczne rozwiązania o charakterze systemowym mogą doprowadzić do stopniowego eliminowania wskazanych niedostatków i skuteczniejszej realizacji koncepcji rozwoju zrównoważonego na wszystkich szczeblach organizacji terytorialnej kraju, w tym w szczególności w gminach.

\section{Bibliografia:}

Barczak, Anna i Ewa Kowalewska. 2015. Zadania samorzadu terytorialnego w ochronie środowiska. Aspekty materialne i finansowe. Warszawa: Wolters Kluwer.

Chądzyński, Jacek, Aleksandra Nowakowska i Zbigniew Przygodzki. 2008. Region i jego rozwój w warunkach globalizacji. Warszawa: CeDeWu.

Gawroński, Henryk. 2010. Zarządzanie strategiczne w samorząach lokalnych. Warszawa: Oficyna a Wolters Kluwer business. 
Gospodarowanie przestrzenia miast i regionów - uwarunkowania i kierunki, red. Tadeusz Kudłacz i Piotr Lityński. 2015. Warszawa: PAN.

Guzal-Dec, Danuta. 2015. Strategie rozwoju lokalnego jako narzędzie zarządzania rozwojem gmin położonych na obszarach przyrodniczo cennych województwa lubelskiego. Roczniki Naukowe Stowarzyszenia Ekonomistów Rolnictwa i Agrobiznesu, 17(3), 125-130.

Komisja Europejska. 2013. Wytyczne. Opracowanie i wdrożenie planu zrównoważonej mobilności miejskiej. Bruksela.

Mantey, Dorota. 2013. Potrzeba zintegrowanego zarządzania miastami i obszarami metropolitalnymi. Samorzad Terytorialny, 6, 5-14.

Ministerstwo Gospodarki. 2010. Program Oczyszczania Kraju z Azbestu na lata 2009-2032. Warszawa.

Ministerstwo Środowiska. 2001. Przez edukację do zrównoważonego rozwoju. Narodowa strategia edukacji ekologicznej. Warszawa.

Ministerstwo Środowiska. 2015. Wytyczne do opracowania wojewódzkich, powiatowych i gminnych programów ochrony środowiska. Warszawa.

Najwyższa Izba Kontroli (NIK). 2011. Informacja o wynikach kontroli zarządzania środowiskiem w gminach. Warszawa.

Nowakowska, Aleksandra. 2016a. Polityka i planowanie rozwoju miasta. W: EkoMiato\#Zarzadzanie, Zrównoważony, inteligentny i partycypacyjny rozwój miasta, red. Zbigniew Przygodzki, 45-60. Łódź: Wydawnictwo Uniwersytetu Łódzkiego.

Nowakowska, Aleksandra. 2016b. Zintegrowane strategie rozwoju miast. W: EkoMiato\#Zarządzanie, Zrównoważony, inteligentny i partycypacyjny rozwój miasta, red. Zbigniew Przygodzki, 61-82. Łódź: Wydawnictwo Uniwersytetu Łódzkiego.

Rozporządzenie Ministra Środowiska z dnia 9 września 2002 r. w sprawie opracowań ekofizjograficznych. Dziennik Ustaw, 2002 nr 155, poz. 1298.

Sobol, Agnieszka. 2013. Gospodarka przestrzenna a lokalny rozwój zrównoważony. Ekonomia i Środowisko, 3(46), 70-78. 
Stanek, Leszek. 2011. Studium uwarunkowań i kierunków zagospodarowania przestrzennego gminy jako narzędzie równoważenia rozwoju obszarów wiejskich. Infrastruktura i Ekologia Terenów Wiejskich, 1, 91-102.

Sztando, Andrzej. 2009. Planowanie lokalnego rozwoju gospodarczego w strategii rozwoju gminy. W: Polityka gospodarcza w Polsce i Unii Europejskiej na początku XXI w., red. Andrzej Barteczek, Agnieszka Lorek i Andrzej Rączaszek, 211-220. Katowice: Wydawnictwo Akademii Ekonomicznej.

Ustawa z 27 kwietnia 2001 r. Prawo ochrony środowiska. Dziennik Ustaw, 2016 poz. 672 ze zm.

Ustawa z 27 marca 2003 r. o planowaniu i zagospodarowaniu przestrzennym. Dziennik Ustaw, 2016 poz. 778 ze zm.

Ustawa z 6 grudnia $2006 \mathrm{r}$. o zasadach prowadzenia polityki rozwoju. Dziennik Ustaw, 2016 poz. 383 ze zm.

Ustawa z 9 października 2015 r. o rewitalizacji. Dziennik Ustaw, 2015 poz. 1777, ze zm.

Wartowiedziec.org. 2017. Strategia rozwoju czy program rozwoju samorządowy dylemat. Dostęp: 01.02.2017. http://wartowiedziec.org/ index.php/start/aktualnosci/26857-strategia-rozwoju-czy-programrozwoju-samorzdowy-dylemat.

Zachariasz, Igor. 2013. Prawne uwarunkowania efektywności zagospodarowania przestrzennego w Polsce. Zarzadzanie Publiczne, 1(23), 5-16.

Zarzadzanie strategiczne. Koncepcje, metody, red. Rafał Krupski. 2007. Wrocław: Wydawnictwo Akademii Ekonomicznej.

Zarzadzanie strategiczne. Systemowa koncepcja biznesu, red. Mieczysław Moszkiewicz. 2005. Warszawa: PWE.

Zintegrowane planowanie rozwoju miast, red. Grażyna Korzeniak. 2011 Kraków: Instytut Rozwoju Miast.

Ziółkowski, Marek. 2015. Strategiczne zarządzanie rozwojem gminy. Ruch Prawniczy, Ekonomiczny i Socjologiczny, 1, 145-163. 
Agnieszka Rzeńca

Uniwersytet Łódzki - Wydział Ekonomiczno-Socjologiczny

agnieszka.rzenca@uni.lodz.pl

Adam Wojech

Uniwersytet Łódzki - Studenckie Koło Naukowe SPATIUM

adam.wojech@gmail.com

\section{Zrównoważony rozwój miast. Perspektywa władz lokalnych i mieszkańców - przykład Łodzi}

\section{Wprowadzenie}

Miasto jest areną koalicji i partnerstw, ścierania się i rywalizacji różnych grup interesów oraz zależności pomiędzy interesariuszami miasta mającymi odmienne cele, potrzeby i interesy (teoria reżimów miejskich, Stone 1989). Z jednej strony ramy instytucjonalne, obejmujące podmioty publiczne i prywatne oraz podmioty trzeciego sektora i społeczeństwo, określają zakres przedmiotowy ich działania, jak i mechanizmy interakcji między nimi i w efekcie determinują politykę rozwoju miasta. $\mathrm{Z}$ drugiej zaś miasto stanowi miejsce (living $l a b), \mathrm{w}$ którym wspólnie $\mathrm{z}$ wieloma partnerami realizuje przedsięwzięcia najlepiej dostosowane do warunków lokalnych i odpowiadające lokalnym potrzebom. Istotne jest zatem zwiększanie i wzmocnienie współpracy instytucjonalnej z szeroką grupą interesariuszy, tj. instytucji publicznych, organizacji pozarządowych, podmiotów gospodarczych, mieszkańców, mających realny wpływ na kształtowanie warunków życia oraz prowadzenie aktywności społecznych i gospodarczych w mieście. Partycypacja społeczna stanowi ważny argument przemawiający za podnoszeniem efektywności polityki miejskiej oraz celowością współzarządzania miastem. Kluczowa jest zatem identyfikacja potrzeb i oczekiwań społeczności miejskiej oraz inicjowanie i aktywizowanie działań na rzecz poprawy jakości życia w mieście.

Koncepcja rozwoju zrównoważonego wskazała nadrzędne cele rozwoju, których implementację podjęto na różnych poziomach organizacji terytorium (miast, regionów, kraju). Stała się ona impulsem do przeorientowania polityki miejskiej. Europejska Karta Miejska 
(European Urban Charter 1992) i jej aktualizacja (European Urban Charter II 2008) oraz wiele koncepcji rozwoju miast (urbanistycznych, ekonomicznych, socjologicznych) wyraźnie podkreślają, że miasta należą do ich obywateli, a sukces gospodarczy, społeczny i kulturalny, który należy przekazać przyszłym pokoleniom, wymaga kompromisu między celami gospodarczymi, społecznymi i środowiskowymi. Istotne jest, iż zrównoważony rozwój miast wiązany jest $\mathrm{z}$ ochroną środowiska na wysokim poziomie (European Commission 2011). Podejście takie ściśle odwołuje się do Deklaracji z Rio (zasada 4), w której podkreślono rolę ochrony środowiska w osiąganiu zrównoważonego rozwoju, wskazując ją jako kluczowy i integralny element procesu rozwoju (Kozłowski 1994).

Dla kreowania zrównoważonego rozwoju miast istotne jest zapewnienie zrównoważonego użytkowania i korzystania z zasobów środowiska oraz współpraca i współdziałanie w procesie ich ochrony. Odpowiedzialność za miasto i wybór ścieżki jego rozwoju spoczywa na wszystkich jego użytkownikach, nie tylko na władzach lokalnych. Zatem istotnym problemem badawczym jest spojrzenie na kwestie ochrony środowiska i stymulowania zrównoważonego rozwoju miasta z perspektywy władz lokalnych i społeczności miejskiej, identyfikacji zagrożeń środowiskowych oraz wyzwań w zakresie ochrony środowiska.

Głównym celem artykułu jest wskazanie roli władz lokalnych i społeczności miejskiej w kreowaniu zrównoważonego rozwoju miast, szczególnie w obszarze budowania potencjału przyrodniczego miasta i poprawy jakości środowiska. Studium przypadku stanowi miasto Łódź, miasto o korzeniach i tradycji przemysłowej i wielokulturowej, miasto poprzemysłowe, niegdyś obszar ekologicznego zagrożenia ${ }^{1}$, które dziś rozwija się dynamiczne miedzy innymi za sprawą aktywności i kreatywności mieszkańców oraz ich inicjatyw na rzecz miasta. W artykule przedstawiono wyniki badań, które były realizowane dwutorowo, tj. badań ankietowych realizowanych $\mathrm{w}$ formie wywiadu kwestionariuszowego wśród mieszkańców oraz przedstawicieli władz

${ }^{1}$ Zdefiniowanie pojęć i analiza danych w publikacji wydanej przez GUS (Obszary ekologicznego zagrożenia w Polsce 1992). 
lokalnych (radnych) i administracji samorządowej Łodzi ${ }^{2}$ oraz badania desk research budżetu partycypacyjnego w Łodzi.

\section{Partycypacja społeczna i jej rola w kreowaniu zrównoważonego rozwoju miast}

Istotą zrównoważonego rozwoju miast (Karta Lipska 2007) jest integracja i synchronizacja działań wokół kluczowych wyzwań, takich jak: jakość życia, gospodarka innowacyjna i niskoemisyjna, zasobooszczędne gospodarowanie oraz adaptacja do zmian klimatu. Istotne jest kompleksowe planowanie i projektowanie polityki miejskiej przy współudziale wszystkich użytkowników miasta, szczególnie w obszarze miejskiego transportu zbiorowego i mobilności, efektywności gospodarowania oraz ochrony różnorodności biologicznej w miastach. Po pierwsze, mieszkańcy (użytkownicy) miast poprzez określone zachowania konsumenckie związane z codziennym użytkowaniem zasobów środowiska (wody, przestrzeni, energii), wybór środka transportu czy segregację odpadów w istotnym zakresie wpływają na kondycję środowiska. Po drugie, mieszkańcy poprzez różnorodne formy i procedury partycypacji społecznej (debaty, konsultacje społeczne, seminaria, warsztaty) współtworzą politykę miejską. W efekcie możemy powiedzieć, iż zrównoważony rozwój miast determinują zarówno bierni użytkownicy zasobów miasta, jak i aktywni obywatele, formalne i nieformalne grupy, organizacje czy instytucje publiczne (Rzeńca 2016, 108).

Partycypacja społeczna jest jednym z fundamentów rozwoju samorządności i społeczeństwa obywatelskiego oraz przykładem realnego zaangażowania mieszkańców w rozwój lokalny. Świadomi, partycypujący (współuczestniczący) mieszkańcy wpływają na efektywniejsze zaspokajanie potrzeb lokalnych, racjonalizację wydatków publicznych czy jakość usług świadczonych przez samorząd (Kalisiak-Mędelska 2015,

\footnotetext{
${ }^{2}$ Badania pt. Zasobooszczędne gospodarowanie w miastach Łódzkiego Obszaru Metropolitalnego oraz w wybranych miastach Regionu Łódzkiego (pilotaż w Łodzi) zrealizowano w marcu 2016 r. Badaniami objęto 1370 mieszkańców Łodzi powyżej 18 . roku życia $(0,22 \%$ populacji w wieku 18 lat i więcej), 20 radnych Rady Miejskiej w Łodzi (50\% populacji) oraz pracowników administracji samorządowej reprezentujących wskazane komórki (biura, oddziały) Urzędu Miasta Łodzi oraz miejskie jednostki organizacyjne zajmujące się bezpośrednio lub pośrednio sprawami ochrony środowiska, inwestycji, planowania przestrzennego, zarządzania strategicznego. W przypadku badań władz lokalnych i administracji samorządowej zastosowano dobór próby celowo-okolicznościowy (dobór próby nielosowy).
} 
138-143). Partycypacja społeczna jako styl rządzenia ma swoich zwolenników jak i przeciwników, często budzi kontrowersje oraz skrajne emocje. Mimo iż wiele samorządów i samorządowców skutecznie unika tej formy uczestnictwa mieszkańców we współrządzeniu w środowisku lokalnym, jest ona coraz bardziej popularna.

Pozytywny wpływ partycypacji społecznej na rozwój miast (gmin) powinien być oczywisty. Wprawdzie nie zawsze efekty widziane są natychmiast, ale niemal zawsze na partycypacji zyskują wszyscy mieszkańcy. Wspólnota samorządowa dzięki wymianie zdań, poglądów i dialogu może dokonać pewnych zmian, które wpłyną in plus na rozwój danej jednostki. Pokłosiem uczestnictwa mieszkańców w sprawach ważnych dla gminy może być wypracowanie interesujących i kreatywnych sposobów rozwiązania lokalnych problemów czy wdrażanie innowacji i dobrych przykładów, co jest niezbędne do kreowania polityki równoważnego rozwoju miast (Boryczka 2016, 129-130).

Jedną z form partycypacji społecznej jest budżet obywatelski (BO) wymiennie nazywany budżetem partycypacyjnym (BP). Budżet obywatelski jest wyrazem demokracji bezpośredniej, procesem, w ramach którego ludzie mogą debatować i decydować o polityce publicznej i budżecie (Taylor 2014,20). Wiąże się z podejmowaniem decyzji, w ramach której obywatele dyskutują i negocjują dystrybucję publicznych środków finansowych (Wampler 2007, 21). Budżet obywatelski jest instrumentem w zakresie wydatkowania środków publicznych, a pośrednio współtworzenia polityki wydatkowej jednostki terytorialnej. Ma charakter operacyjny i decyzyjny, bowiem współdecydowanie polega na wyborze zgłoszonych przez mieszkańców projektów, które będą realizowane w oparciu o środki publiczne (Kębłowski 2013, 8). Jest istotnym narzędziem pozwalającym na uspołecznienie polityki budżetowej jednostki terytorialnej odpowiadającej na oczekiwania i postulaty mieszkańców.

Mimo krótkiej historii budżetu obywatelskiego (od 1989) ${ }^{3}$, zyskał on akceptację i stał się istotnym narzędziem polityki rozwoju lokalne-

\footnotetext{
${ }^{3}$ Po raz pierwszy budżet obywatelski został wprowadzony w brazylijskim mieście Porto Alegre. W 1989 burmistrz wywodzący się z Partii Robotników (Worker’s Party) przedstawił mechanizm polegający na włączaniu społeczności lokalnych w proces dystrybucji finansów publicznych. Formuła miała za zadanie dokapitalizować zaniedbane obszary miasta, na których występowały nasilone problemy społeczne.
} 
go. W Polsce budżet obywatelski po raz pierwszy został wprowadzony w 2010 roku za sprawą sopockich społeczników. Idea okazała się wyjściem naprzeciw potrzebom lokalnych grup działania. Popularność mechanizmu włączania społeczności lokalnych w sprawy budżetowe rosła rokrocznie, tak że w 2014 r. BO został zrealizowany w 88 różnych jednostkach samorządu terytorialnego (Szaranowicz-Kusz 2016). Budżet obywatelski nie ma umocowania prawnego ${ }^{4}$, niemniej jednak kilka lat jego funkcjonowania pozwoliło wypracować określone zasady i reguły. Są one indywidualnie doprecyzowywane przez jednostki terytorialne w zależności od uwarunkowań. Wytyczone zasady w większości jednostek opierają się na bliźniaczych wzorcach i zazwyczaj bazują na sześciu podstawowych etapach, czyli: opracowaniu zasad realizacji budżetu obywatelskiego (1), promocji i edukacji (2), zgłoszeniu propozycji zadań (3), analityczno-prawnym (4), głosowaniu i ogłoszeniu wyników (5), ewaluacji (6) ${ }^{5}$. Etapy te powinny stanowić zamknięty samouczący się układ, w którym - wraz z końcem realizacji ostatniego punktu (ewaluacja) - powinno się podejmować działania celem wypracowania nowych i ulepszonych zasad funkcjonowania kolejnej edycji budżetu partycypacyjnego. Istotnym warunkiem skutecznego procesu partycypacji w formie budżetu obywatelskiego i pierwszym krokiem jest edukacja społeczeństwa i konsultacje nad jego istotą. Działania te pozwalają mieszkańcom na uzyskanie pełnej informacji, rzeczywiste zaangażowanie i identyfikowanie się z projektami budżetu. Wdrożenie budżetu obywatelskiego nie powinno być związane $\mathrm{z}$ chęcią posiadania takiego narzędzia wyłącznie dla jego posiadania. Wprowadzenie $\mathrm{BO}$ z uwagi na "modę" i próbę konkurencji z innymi gminami może być czynnikiem, który spowoduje skutki odwrotne od zamierzonych. Innymi słowy jego wprowadzenie powinno być związane $\mathrm{z}$ realizacją zrozumiałych i mierzalnych celów:

\footnotetext{
${ }^{4}$ Polskie prawo definiuje pojęcia, ale nie określa zasad funkcjonowania budżetu obywatelskiego czy budżetu partycypacyjnego. Samorządowcy najczęściej wykorzystują podstawę prawną umożliwiającą powołanie się na zarządzenie organu wykonawczego (wójt, burmistrz, prezydent). Aby skorzystać z tej metody „budżetu obywatelskiego”, należy odwołać się do art. 33 z ustawy o samorządzie gminnym oraz lokalnych uchwał przedstawiających organizację rady gminy

${ }^{5}$ Załącznik nr 7 do zarządzenia 2914/VII/16 Prezydenta Miasta Łodzi z dnia 19 lutego 2016 r. Harmonogram przygotowań budżetu obywatelskiego na 2017 rok.
} 
$\checkmark \quad$ społecznych (stymulowanie mieszkańców do partycypacji w debatach publicznych prowadzące do wzrostu poziomu społeczeństwa obywatelskiego);

$\checkmark$ administracyjnych (przybliżenie i zmniejszanie dystansu pomiędzy urzędem a lokalnymi mieszkańcami; aktywni obywatele powinno być postrzegani partnersko, jako wartość dodana dla urzędu);

$\checkmark$ politycznych (zwiększenie demokratyzacji działań urzędu (gminy) dzięki włączeniu zasad demokracji partycypacyjnej) (Rytel-Warzocha 2010, 94-95).

Przedmiotowy zakres celów budżetu obywatelskiego może wiązać się z poprawą jakości życia mieszkańców i może dotyczyć: zagospodarowania i poprawy atrakcyjności przestrzeni, poprawy bezpieczeństwa, zagospodarowania terenów zieleni, rozwoju infrastruktury itp. Podejmowane działania oddolne poprzez budżet obywatelski istotnie mogą stymulować zrównoważony rozwój miasta (gminy).

\section{W kierunku zrównoważonego rozwoju Łodzi - wyniki badań}

Łódź to jedno $\mathrm{z}$ największych polskich miast położone w centralnej części kraju i Europy. O dzisiejszym unikatowym charakterze stolicy województwa łódzkiego i jej predyspozycjach zdecydowała odmienna niż w przypadku większości miast w Polsce geneza miasta i inne czynniki rozwojowe. Choć Łódź posiada średniowieczny rodowód, to do jej dzisiejszej wyjątkowości przyczyniły się XIX-wieczne procesy gospodarcze, a zwłaszcza powstanie osad rękodzielniczych i fabrycznych. Niezwykłe tempo rozwoju przemysłu włókienniczego zainicjowane w latach 20. XIX w. sprawiło, że Łódź z rolniczego miasteczka zamieszkiwanego pod koniec XVIII w. przez zaledwie kilkuset mieszkańców przekształciła się $\mathrm{w}$ okresie stulecia $\mathrm{w}$ przemysłową kilkusettysięczną metropolię (ok. 500 tys. w 1915 r.). Towarzyszące olbrzymiej dynamice wzrostu ludnościowego procesy rozwoju przestrzennego przyczyniły się do ukształtowania specyficznego układu przestrzennego o zróżnicowanej fizjonomicznie i architektonicznie tkance miejskiej, w której w ich konsekwencji doszło do przenikania się obszarów i przemieszania oraz sąsiadowania ze sobą budynków pełniących różne funkcje: mieszkalne 
- kamienice czynszowe i domy robotnicze (nazywane lokalnie famułami), rezydencjonalne - wille i pałace fabrykanckie czy produkcyjne (tkalnie, przędzalnie, magazyny itp.).

W XX wieku, zwłaszcza po II wojnie światowej, zaszły wyraźne zmiany przestrzenne w tendencjach rozwojowych i Łódź zaczęła rozbudowywać się poza linią tzw. kolei obwodowej. Wznoszono wówczas głównie bloki z „wielkiej płyty”, kreując wielkie PRL-owskie jednostki mieszkaniowe (np. Widzew, Retkinia, Dąbrowa, Teofilów). Rozwój przemysłu i wzrost liczby ludności w Łodzi, ale również w jego obszarze funkcjonalnym, doprowadziły do uznania, w latach 80. i 90., tego obszaru za obszar ekologicznego zagrożenia ze względu na koncentrację zanieczyszczeń środowiska (ścieki nieoczyszczone, emisja pyłów i gazów, odpady nagromadzone).

Ostatnia dekada poprzedniego wieku przyniosła miastu gwałtowne przemiany społeczno-polityczno-gospodarcze, utratę dotychczasowych rynków zbytu i opłacalności produkcji, co w konsekwencji zaowocowało głębokimi przemianami struktur społeczno-gospodarczych, przede wszystkim upadkiem przemysłu i dużym bezrobociem. Powołanie samorządu terytorialnego i przypisanie zadań własnych gminom, zintensyfikowało działania na rzecz ochrony środowiska w mieście. Rozwój infrastruktury ochrony środowiska oraz likwidacja głównych przemysłowych źródeł zanieczyszczeń przyniosły sukcesywną poprawę stanu środowiska. Mimo istotnych zmian, ze względu na koncentrację ludności i różnorodności aktywności gospodarczych, miasto boryka się z wieloma problemami środowiskowymi, które identyfikowane są jako uciążliwości i zagrożenia.

Przeprowadzone badanie ankietowe (2016 r.) wśród mieszkańców i radnych miasta Łodzi oraz pracowników administracji samorządowej pozwoliły zidentyfikować uciążliwości i problemy środowiskowe w tym mieście. Kluczowe problemy niemal jednogłośnie zostały wyartykułowane przez obie grupy respondentów. Byli oni zgodni, iż istotny jest brak bieżącej (codziennej) dbałości o czystość otoczenia. Problemem jest zaśmiecanie, niesprzątanie po psach, brudne ulice i chodniki itp. (rys. 1). Tym samym respondenci wyraźnie wskazali, główne źródła problemu, który z jednej strony jest pochodną zachowania samych użytkowników miasta, a z drugiej - niesprawności służb miejskich w tym zakresie. 


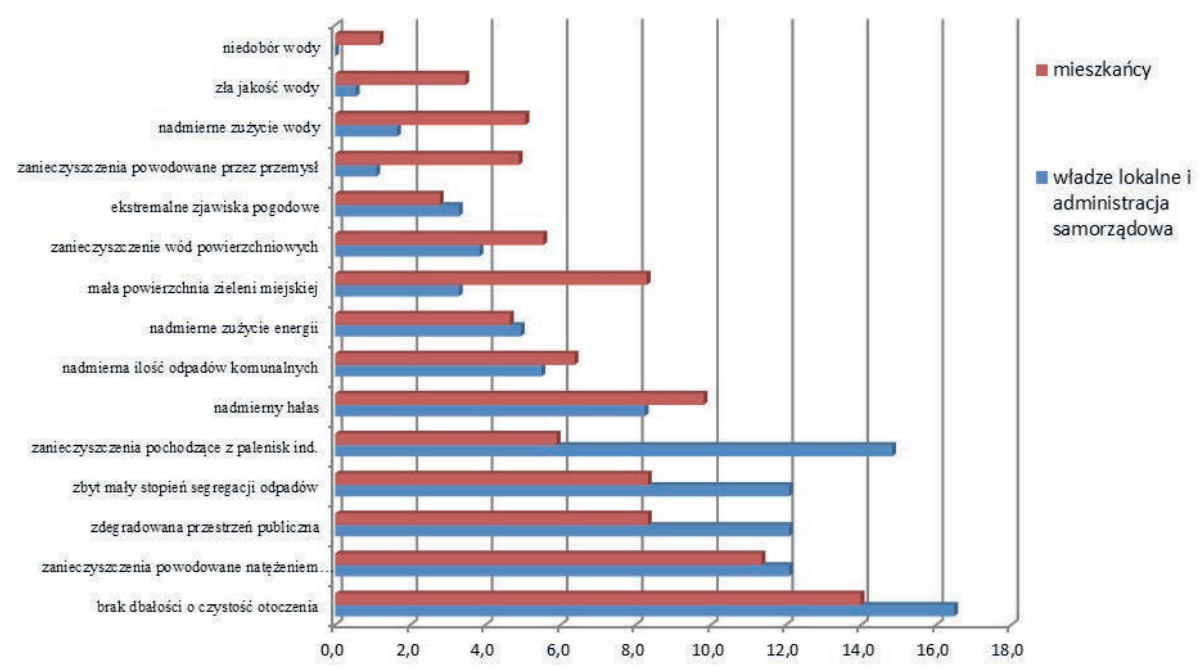

Rysunek 1. Zagrożenia środowiskowe w świetle przeprowadzonych badań. Źródło: opracowanie własne na podstawie badań ankietowych.

Z przeprowadzonych badań można wyprowadzić następujące wnioski dotyczące zagrożeń:

1. Obie grupy respondentów wskazały zagrożenia, których źródłem jest transport indywidualny (samochodowy), tj. nadmierny hałas i zanieczyszczenia powietrza. Natężenie ruchu samochodowego spowodowane jest przede wszystkim gwałtownym wzrostem liczby samochodów zarejestrowanych w Łodzi (na przestrzeni 6 lat wzrost o 1/4, tab.1).

2. Dla administracji i władz samorządowych istotnym zagrożeniem jest również niska emisja (2 lokata wśród wybranych odpowiedzi), będąca efektem nadal funkcjonujących w mieście palenisk indywidualnych opalanych węglem i drewnem oraz wzmożonego rozwoju transportu samochodowego. Jest to duży problem i wyzwanie w kontekście likwidacji jej źródeł i działań z zakresu adaptacji miast do zmian klimatu (tab. 1).

3. Obie grupy respondentów wskazały niską jakość przestrzeni publicznej, która jest efektem historii przemysłowej miasta oraz rozszerzania strefy zurbanizowanej i granic administracyjnych miasta, co dopro- 
wadziło do nieproporcjonalnie przerośniętego powierzchniowo miasta. Spadek liczby ludności ${ }^{6}$, przy jednoczesnych tendencjach migracyjnych na „zewnątrz” miasta, pogłębił degradację śródmiejskiej tkanki Łodzi.

4. Wymieniana jest niewłaściwa gospodarka odpadami, obie grupy respondentów wskazały jako zagrożenie nadmierną ilość odpadów, a przede wszystkim niski stopień ich segregacji.

5. Mieszkańcy Łodzi wskazują również na zbyt małą powierzchnię terenów zieleni, czego nie potwierdza jednak druga grupa respondentów ${ }^{7}$.

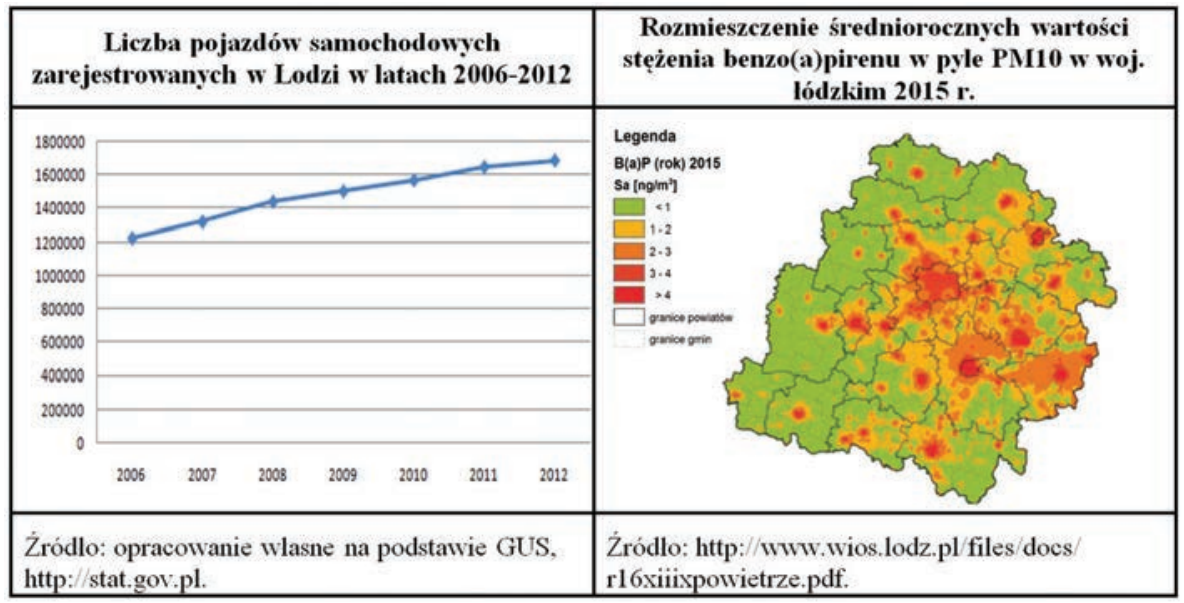

Tabela 1. Zanieczyszczenie powietrza w Łodzi i jego źródło.

Przeprowadzone badania wyraźnie wskazują zainteresowanie mieszkańców Łodzi sprawami środowiska i jego ochrony. Odczuwają oni potrzebę reorientacji spojrzenia na ochronę środowiska ze względu na koncentrację, charakter i zróżnicowanie uciążliwości środowiskowych (hałas, niska emisja) i ich bezpośredni wpływ na jakość życia.

\footnotetext{
${ }^{6}$ W 2015 r. Łódź zamieszkiwało o niespełna 62000 mieszkańców mniej niż 15 lat wcześniej, co oznacza spadek o $8 \%$.

${ }^{7}$ Tereny zieleni stanowią 15\%, a parki miejskie są wizytówką miasta. W jego granicach znajduje się również 5 kompleksów leśnych z jednym z największych kompleksów w granicach miasta Lasem Łagiewnickim.
} 
O tym, że kwestie te są ważne dla mieszkańców miasta, świadczy skala i charakter działań w ramach budżetu obywatelskiego, który jest rzeczywistym wyrazem zaangażowania mieszkańców na rzecz miasta.

W Łodzi formuła budżetu obywatelskiego została wprowadzona po raz pierwszy w 2013 roku. Projekty zgłaszane w 2013 r. były realizowane w 2014 r. Podczas pierwszej edycji, która została zrealizowana na przełomie lat 2013/2014, przewidziano dwie kategorie zadań, tj.: zadania ogólnomiejskie (mogły być realizowane na terenie całego miasta) oraz zadania dzielnicowe (według dawnego podziału administracyjnego miasta $)^{8}$. Na realizację zdań przeznaczono wówczas $20 \mathrm{mln}(0,49 \%$ budżetu miasta): $5 \mathrm{mln}$ na zadania ogólnomiejskie oraz $15 \mathrm{mln}$ zł na dzielnicowe. W kolejnym roku pula środków wzrosła o 100\% (10 mln na ogólnomiejskie, 30 mln na pozostałe ${ }^{9}$ i została utrzymana na tej wysokości. Budżet obywatelski od samego początku cieszył się dużym powodzeniem wśród łodzian, którzy aktywnie włączyli się w „projektowanie” miasta ${ }^{10}$ (tab. 2).

\begin{tabular}{|c|c|c|c|c|}
\hline Projekty & $2013 / 2014$ & $2014 / 2015$ & $2015 / 2016$ & $2016 / 2017$ \\
\hline Zgłoszone & 908 & 871 & 645 & 1572 \\
\hline Wybrane & 47 & 65 & 87 & 218 \\
\hline Wybrane (\%) & 5,17 & 7,46 & 13,48 & 13,86 \\
\hline
\end{tabular}

Tabela 2. Budżet obywatelski w Łodzi.

Źródło: Opracowanie własne na podstawie http://uml.lodz.pl [dostęp: 22.02.2017].

\footnotetext{
${ }^{8}$ Łódź została podzielna na pięć kategorii, które swoją powierzchnią odpowiadały podziałowi na pięć dzielnic (Bałuty, Górna, Polesie, Śródmieście, Widzew).

${ }^{9}$ Zasady funkcjonowania BO zostały zmienione na przełomie 2016/2017 roku. Zmiany dotyczyły nazewnictwa oraz zakresu i puli finansowej przeznaczonej na nowe zadania. W czwartej edycji zadania dzielnicowe i ogólnomiejskie zostały zamienione na zadania osiedlowe i ponadosiedlowe. Pula finansowa do wykorzystania na każdym z osiedli została oszacowana na podstawie stałej kwoty oraz zmiennej uzależnionej od liczby zameldowanych mieszkańców. Stała kwota wynosiła 200000 zł i była przyznawana dla każdej jednostki, natomiast zmienna wynikająca z algorytmu opartego na statystyce zameldowań uzupełniała tę kwotę. Ostatecznie osiedle z najmniejszą liczbą mieszkańców (765) zostało wycenione na 230000 zł, osiedle natomiast o największej liczbie mieszkańców (49 791) zostało wycenione na 1920000 zł. Pula przeznaczona na działania osiedlowe została zwiększona o 50000 zł, do 30050000 zł. W przypadku projektów ponaosiedlowych zmiana polegała głównie na dostosowaniu nazwy do nowo stworzonej orientacji osiedlowej.

${ }^{10}$ Projekty BO mogli zgłaszać wszyscy mieszkańcy miasta (brak konieczności przedstawienia meldunku), podobnie zasady funkcjonowały podczas głosowania.
} 
W pierwszej edycji BO zgłoszono aż 908 wniosków, przy jednoczesnej realizacji 47 z nich, co stanowi 5,17\%. Na przełomie 2014/2015 roku udało się zrealizować 7,46\% zgłoszonych projektów zadań, w kolejnych latach wskaźnik ten wzrastał. Zmiany w regulaminie BO, tj. „przypisanie" BO do osiedli, spowodowały radykalny wzrost liczby zgłoszonych wniosków. Przy 1572 zgłoszonych wnioskach udało się zrealizować 218 $\mathrm{z}$ nich. Pomimo rekordowej liczby zgłoszonych projektów zachowano dotychczasowy poziom ich realizacji (13,86\%). Współczynnik ten jest istotny z punktu widzenia wnioskodawcy. Im jest on większy, tym większe zadowolenie $\mathrm{z}$ formuly budżetu obywatelskiego i tym lepsze opinie o funkcjonowaniu idei.

Analiza projektów zgłoszonych do budżetu obywatelskiego wykazała, że wiele projektów jest związanych z szeroko rozumianą ochroną środowiska lub działaniami proekologicznymi. Wśród nich możemy wyróżnić trzy grupy projektów:

1. projekty, których głównym i nadrzędnym celem jest ochrona środowiska, np. rozwój infrastruktury rowerowej (ścieżek rowerowych, parkingów, oznakowanie) zagospodarowanie terenów zieleni, renowacja i rekultywacja zbiorników i cieków wodnych, budowa ekranów akustycznych, wymiana oświetlenia;

2. projekty, w których działania $\mathrm{z}$ zakresu ochrony środowiska są komplementarne w stosunku do głównego celu, np. budowa/modernizacja infrastruktury sportowej lub drogowej oraz zagospodarowanie terenów zieleni (zieleń towarzysząca, zieleń izolacyjna);

3. projekty, których realizacja pośrednio wpływa na ochronę środowiska, np. remonty torowiska (ograniczanie hałasu komunikacyjnego), termomodernizacja obiektów publicznych (wymiana okien, docieplanie), poprawa płynności ruchu.

Wśród zgłoszonych projektów jest wiele kompleksowych i innowacyjnych rozwiązań, szczególnym powodzeniem cieszą się woonerfu (podwórce miejskie), których celem jest uspokojenie ruchu oraz po- 
prawa atrakcyjności przestrzeni publicznych ulic. Szczegółowa analiza dwóch edycji budżetu obywatelskiego ${ }^{11}$ wykazała, iż 1/3 złożonych projektów bezpośrednio lub pośrednio dotyczy ochrony środowiska (tab. 3). Może to świadczyć o braku lub niewystarczającej liczbie udogodnień o charakterze prośrodowiskowym w mieście lub o ich niskiej jakości. Ważne jest również, iż mieszkańcy zwrócili uwagę na działania, które poprawiają komfort i jakość życia i wiążą je z ochroną środowiska swojego najbliższego otoczenia i miasta. Intensywny wzrost liczby projektów środowiskowych, szczególnie dotyczących terenów zieleni, ścieżek rowerowych, infrastruktury rekreacyjnej może być skutkiem realizacji podobnych działań w poprzednich edycjach budżetu obywatelskiego i chęci implementacji dobrych przykładów w innych częściach miasta.

\begin{tabular}{|c|c|c|c|c|}
\hline \multirow{2}{*}{ Projekty } & \multicolumn{2}{|c|}{$2014 \mathrm{r}}$. & \multicolumn{2}{c|}{$2015 \mathrm{r}}$. \\
\cline { 2 - 5 } & Liczba & $\begin{array}{l}\text { Udział w ogóle } \\
\text { projektów (\%) }\end{array}$ & Liczba & $\begin{array}{c}\text { Udział w ogóle } \\
\text { projektów (\%) }\end{array}$ \\
\hline Zgłoszone & 268 & 30,76 & 218 & 33,79 \\
\hline Zrealizowane & 17 & 6,35 & 30 & 13,76 \\
\hline
\end{tabular}

Tabela 3. Projekty proekologiczne w budżecie obywatelskim w Łodzi w 2014 i 2015 r. Źródło: opracowanie własne na podstawie złożonych wniosków, sprawozdań oraz danych Urzędu Miasta w Łodzi.

Powyższa tabela może sugerować, iż udział realizowanych projektów prośrodowiskowych jest niewielki w stosunku do złożonych tego typu. Niemniej jednak, gdy zestawimy i przeanalizujemy projekty zrealizowane (tab. 2 i 3), zauważymy, że ponad $1 / 3$ z nich to projekty, które bezpośrednio lub pośrednio tyczą się środowiska i jego ochrony (w $2015 \mathrm{r}$. $40 \%$, w 2016 r. $-35 \%)$.

\footnotetext{
${ }^{11}$ Odrzucono dwie skrajne edycje, ponieważ w sposób znaczny mogłyby zaburzyć rzetelność badań. Pierwsza edycja miała charakter pilotażowy, nie udało się uniknąć problemów czy błędów. Poza tym mniejsza pula pieniężna przeznaczona na realizacje zadań z budżetu partycypacyjnego również miałaby istotny wpływ na wyniki badań. Edycje z przełomu 2014/2015 i 2015/2016 były realizowane na podobnych zasadach. Na przestrzeni dwóch lat zostały poczynione zmiany, których celem była poprawa funkcjonowania budżetu obywatelskiego, ale z całą pewnością należy przyznać, że wybrane edycje pod względem zasad funkcjonowania są najbardziej zbieżne i jednorodne.
} 


\section{Podsumowanie}

Ze względu na zróżnicowanie miast oraz ich charakterystyczne cechy i problemy kluczowa jest indywidualizacja polityki miejskiej w kierunku równoważenia rozwoju. Budżet obywatelski daje możliwość godzenia celów gospodarczych, społecznych i środowiskowych miasta poprzez aktywne działanie mieszkańców i władz lokalnych. Jest z jednej strony rzeczywistym przejawem aktywności obywatelskiej i odpowiedzialności społecznej, z drugiej zaś skutecznym instrumentem operacyjnym polityki miejskiej. Jak wykazały badania, łodzianie aktywnie włączają się w proces budowania kapitału przyrodniczego. Projekty, które zgłaszają mieszkańcy w ramach budżetu obywatelskiego, wpisują się w działania wskazywane przez władze lokalne jako wyzwania:

1. Blisko 70\% respondentów jako wyzwanie wskazało: lepsze wykorzystanie i zarządzanie przestrzenią miasta, budowanie świadomości ekologicznej i postaw proekologicznych wśród mieszkańców oraz rozwój niskoemisyjnego i zasobooszczędnego systemu transportowego.

2. Niemal połowa podkreślała znaczenie efektywnego korzystania z zasobów (wody, energii, przestrzeni), wykorzystania odnawialnych źródeł energii oraz poprawy efektywności energetycznej.

3. Wykorzystanie i zarządzanie przestrzenią miasta, budowanie świadomości ekologicznej i postaw proekologicznych wśród mieszkańców oraz rozwój niskoemisyjnego i zasobooszczędnego systemu transportowego, to wyzwania wskazywane przez $1 / 3$ respondentów.

Przeprowadzone dualnie badania wskazują, iż, jednogłośnie, mieszkańcy, władze oraz administracja samorządowa, koncentrują się m.in. na kwestiach: lepszego wykorzystania i zarządzania przestrzenią, rozwoju zrównoważonego transportu, podnoszenia świadomości ekologicznej oraz poprawy warunków życia w mieście. Postulaty zrównoważonego rozwoju miasta, tj. zasobooszczędne gospodarowanie, rozwój transportu publicznego, ochrona przestrzeni przyrodniczej, są identyfikowane i są przedmiotem troski zarówno mieszkańców, jak i władz lokalnych. 


\section{Bibliografia:}

Boryczka, Ewa. 2016. Partycypacja społeczna. W: EkoMiasto\#Społeczeństwo. Zrównoważony, inteligentny i partycypacyjny rozwój miast, red. Aleksandra Nowakowska, Zbigniew Przygodzki i Agnieszka Rzeńca, 129-130. Łódź: Wydawnictwo Uniwersytetu Łódzkiego.

European Commission, Directorate General for Regional Policy, Brussels. 2011. Cities of tomorrow: Challenges, visions, ways forward. Dostęp: 10.01.2017. http://ec.europa.eu/regional_policy/sources/docgener/studies/pdf/citiesoftomorrow/citiesoftomorrow_summary_pl.pdf.

European Urban Charter. 1992. Dostęp: 10.02.2017. https://wcd.coe. int/ViewDoc.jsp? $\mathrm{p}=\& \mathrm{id}=887405 \&$ direct $=$ true.

European Urban Charter II - Manifesto for a new urbanity. 2008. Dostęp: 06.02.2017. https://wcd.coe.int/com.instranet.InstraServlet?command $=$ com. instranet. CmdBlobGet $\&$ InstranetImage $=1269544 \& S e c-$ Mode $=1 \&$ DocId=1243924\&Usage $=2$.

Kalisiak-Mędelska, Magdalena. 2015. Partycypacja społeczna na poziomie lokalnym jako wymiar decentralizacji administracji publicznej $w$ Polsce. Łódź: Wydawnictwo Uniwersytetu Łódzkiego.

Karta Lipska na rzecz zrównoważonego rozwoju miast europejskich. 2007. Dostęp: 9.09.2016. http://www.sarp.org.pl/pliki/karta_lipska.pdf.

Kozłowski, Stefan. 1993. Rio Szczyt Ziemi - początek ery ekologicznej. Łódź: Biblioteka Ery Ekologicznej, AKAPIT PRESS.

Obszary ekologicznego zagrożenia w Polsce w latach 1982 i 1990. 1992. Warszawa: Główny Urząd Statystyczny.

Rytel-Warzocha, Anna. 2010. Partycypacja społeczna w sprawach budżetowych. Model Porto Alegre jako pierwowzór rozwiązań europejskich. Przegląd Prawa Konstytucyjnego, (1), 94-95.

Rzeńca, Agnieszka. 2016. Wyzwania i dylematy polityki miejskiej w obliczu kryzysu ekologicznego. Studia Ekonomiczne Regionu Łódzkiego, 21,108.

Stone, Clarence N. 1989. Regime Politics: Governing Atlanta. Lawrence: University Press of Kansas. 
Szaranowicz-Kusz, Marta. 2016. Budżet partycypacyjny w Polsce. Dostęp: 22.02.2017. http://www.orka.sejm.gov.pl/WydBAS.nsf/0/ E2A1331AC540CD42C1257F3F00432714/\$file/Infos_205.pdf.

Taylor, Paul. 2004. 72 Frequently Asked Questions about Participatory Budgetin. Quito: UN-HABITAT. Dostęp: 20.02.2017. http://www.internationalbudget.org/themes/PB/72QuestionsaboutPB.pdf.

Wampler, Brian. 2007. A guide to participatory budgeting. W: Participatory budgeting, red. Anwar Shah, 21. Washington: The Word Bank. 

Joanna Fajfer ${ }^{1}$

joanna.fajfer@pgi.gov.pl

Paulina Kostrz-Sikora ${ }^{1}$

pkos@pgi.gov.pl

Bronisława Chechelska-Paliga ${ }^{2}$

bronislawa.chechelska-paliga@um.jaworzno.pl

${ }^{1}$ Państwowy Instytut Geologiczny - Państwowy Instytut Badawczy

${ }^{2}$ Urząd Miejski w Jaworznie

\section{Program ochrony środowiska jako narzędzie realizacji idei zrównoważonego rozwoju na terenie miasta Jaworzna}

\section{Wstęp}

Programy ochrony środowiska, zgodnie z obowiązującymi przepisa$\mathrm{mi}$, to dokumenty strategiczne, opracowywane przez organy wykonawcze wszystkich szczebli administracji samorządowej w celu realizacji polityki ochrony środowiska rozumianej jako: „zespół działań mających na celu stworzenie warunków niezbędnych do realizacji ochrony środowiska, zgodnie z zasadą zrównoważonego rozwoju" (art. 13 ustawy z dnia 27 kwietnia 2001 r. Prawo ochrony środowiska (Ustawa Prawo ochrony środowiska 2016). W tym kontekście dokumenty te należy traktować jako narzędzie umożliwiające integrację interesów społeczno-gospodarczych wyrażanych potrzebą rozwoju cywilizacyjnego z działaniami ukierunkowanymi na ochronę zasobów środowiska naturalnego. Nadrzędnym celem tej integracji jest zaś zagwarantowanie możliwości zaspokajania podstawowych potrzeb poszczególnych społeczności lub obywateli zarówno współczesnego pokolenia, jak i pokoleń przyszłych.

Niniejszy artykuł ma na celu przedstawienie praktycznych przykładów realizacji zasady zrównoważonego rozwoju w polityce ochrony środowiska $\mathrm{w}$ oparciu o zapisy kolejnych edycji programów ochrony środowiska opracowanych dla miasta Jaworzna. Ze względu na niezwykle obszerny zakres tematyczny dokumentów (uwzględniający szerokie spektrum zagadnień środowiskowych przedstawionych w kontekście 
uwarunkowań społecznych, gospodarczych i ekonomicznych), w dalszej części odniesiono się do czterech wybranych przykładów działań skupiających się wokół rewitalizacji terenów poprzemysłowych, edukacji ekologicznej i ochrony przyrody.

\section{Funkcjonalność programów ochrony środowiska}

Zasadnicza konstrukcja programów ochrony środowiska skupia się wokół precyzyjnie wyodrębnionych sektorów środowiska (obszarów interwencji), dla których - na podstawie szczegółowego rozpoznania stanu aktualnego zakończonego analizą SWOT - definiowane są kluczowe cele, kierunki działań i zadania. Te ostatnie ujmowane są $\mathrm{w}$ formie harmonogramu rzeczowo-finansowego, w którym wskazane zostają nie tylko koszty realizacji poszczególnych przedsięwzięć (zarówno inwestycyjnych jak i pozainwestycyjnych), ale również podmioty odpowiedzialne za ich realizację, planowane źródła finansowania oraz termin wykonania.

Realizacja programu ochrony środowiska podlega bieżącej kontroli, zaś jednym $\mathrm{z}$ mierników $\mathrm{w}$ tym zakresie jest wymagane przez ustawodawcę raportowanie w cyklach dwuletnich (Ustawa Prawo ochrony środowiska 2016). Układ taki zapewnia z jednej strony możliwość nadzoru nad stopniem wykonania poszczególnych celów, kierunków działań oraz samych zadań, w tym na dostrzeżenie ewentualnych nieprawidłowości w tym zakresie, $\mathrm{z}$ drugiej zaś gwarantuje, że na etapie aktualizacji dokumentu wprowadzone zostaną odpowiednie korekty, które pozwolą na dalszy, konsekwentny i zgodny z przyjętymi założeniami rozwój jednostki.

\section{Historia jaworznickich programów ochrony środowiska}

Jednym z przykładów jednostek administracyjnych, które praktycznie wykorzystują potencjał wynikający z programów ochrony środowiska, jest Jaworzno. O randze i znaczeniu dokumentu w kształtowaniu polityki ochrony środowiska przez władze miasta świadczy chociażby fakt, że opracowanie podlega regularnej aktualizacji, stwarzając tym samym ramy dla realizowanych działań.

Pierwszy Program Ochrony Środowiska dla miasta Jaworzna został uchwalony przez Radę Miejską 4.03.2004 r. (Uchwała nr XXI/222/2004) (Program Ochrony Środowiska 2004). Dokument ten został zaktualizowany w 2008 roku (Uchwała nr XXVII/362/2008 Rady Miejskiej w Ja- 
worznie z 27.11.2008 r.) (Program Ochrony Środowiska 2008), następnie w 2012 r. (Uchwała nr XXVI/363/2012 Rady Miejskiej w Jaworznie z 29.11.2012 r.) (Aktualizacja Programu Ochrony Środowiska 2012), zaś obecnie obowiązująca wersja została przyjęta w 2016 r. (Uchwała $\mathrm{Nr}$ XXII/324/2016 Rady Miejskiej w Jaworznie z 27.10.2016 r.) (Program Ochrony Środowiska 2016).

Okres obowiązywania programów, obejmujący ponad 12 lat, był dla Jaworzna czasem wielu zachodzących w środowisku przemian, które wynikały $\mathrm{z}$ realizacji działań strategicznych zapisanych $\mathrm{w}$ wymienionych dokumentach.

\section{Jaworzno - miasto o wielkim potencjale}

Jaworzno, położone we wschodniej części województwa śląskiego, jest jednym z największych w skali kraju miast o wysokim potencjale gospodarczym, uwarunkowanym historycznie. Na jego sytuację gospodarczą (obecną, jak i w przeszłości) wpływ wywierały głównie dwa sektory: energetyczny i wydobywczy oraz sektor chemiczny. Nie bez znaczenia w tym aspekcie jest fakt, że w obrębie miasta złoża kopalin zajmują ok. $80 \%$ jego powierzchni, z czego ok. $77 \%$ udziału posiada węgiel kamienny (Program Ochrony Środowiska 2016, 84). Restrukturyzacja przemysłu wpłynęła zarówno na dominujące kierunki działalności gospodarczej jak i na krajobraz funkcjonalno-przestrzenny Jaworzna. Obszary zmienione antropogenicznie nierozerwalnie związane z historyczną działalnością przemysłową, wyrażają się znaczącymi przekształceniami powierzchni terenu i zmianami stosunków hydrogeologicznych. Fakt ten szczegółowo odnotowano już w pierwszym Programie Ochrony Środowiska (2004, 144-162), wskazując, że wśród licznych terenów zmienionych antropogenicznie, głównie związanych z działalnością górniczą, poważnym zagrożeniem dla środowiska wymagającym podjęcia stosownych działań są tereny poprzemysłowe. Wówczas na terenie miasta obszarami antropogenicznie zmienionymi były tereny zajęte pod zakłady przemysłowe oraz zwałowiska odpadów wydobywczych, osadniki wód kopalnianych, składowiska przemysłowe odpadów innych niż niebezpieczne i niebezpiecznych oraz wyrobiska po eksploatacji piasku i dolomitu. Część z tych terenów zlokalizowana była i jest w centrum miasta i w sposób trwały wyłączała te 
obszary z prawidłowego funkcjonowania w obrębie przestrzeni miejskiej. W wyniku przeprowadzonych procesów rekultywacji i remediacji obszary te stanowić będą inwestycje w przyszły krajobraz funkcjonalno-przestrzenny Jaworzna.

Należy zwrócić uwagę, że pomimo zaawansowanych procesów urbanizacji i uprzemysłowienia, Jaworzno posiada także znaczne zasoby walorów krajobrazowych, przyrodniczych i kulturowych, które są rozwijane i chronione w taki sposób, aby mogły służyć społeczności miejskiej. Poza nimi w krajobrazie wyraźnie zaznaczają się tereny leśne, jak również obszary i obiekty cenne przyrodniczo, objęte ochroną prawną, a także tereny rolnicze oraz zieleń urządzona.

Mozaika form zagospodarowania przestrzennego powoduje, że zachowanie równowagi pomiędzy sferą infrastrukturalno-gospodarczą i przyrodniczą wymaga od władz lokalnych podejmowania zintensyfikowanych działań prośrodowiskowych realizowanych zgodnie z ideą zrównoważonego rozwoju.

\section{Zrównoważony rozwój - sukcesy wpisane w jaworznickie prog- ramy ochrony środowiska}

Analiza kolejnych programów ochrony środowiska opracowanych dla Jaworzna jest dowodem na to, że władze miasta przywiązują dużą wagę do konsekwentnej realizacji wyznaczonych celów. W strukturze dokumentów widoczna jest ciągłość w wyznaczanych dla poszczególnych obszarów interwencji kierunkach działań i zadaniach. Jak już wspomniano, tereny i obszary zmienione antropogenicznie zajmuja szczególne miejsce w polityce środowiskowej miasta. Po pierwsze dlatego, że wyłączyły one z przestrzeni użytkowej znaczne powierzchnie, które mogłyby zostać ponownie zagospodarowane, a po drugie - ponieważ oddziałują negatywnie na środowisko miasta. W wyniku podejmowanych działań, zarówno przez władze miasta jak też przez przedsiębiorców, liczba i powierzchnia tych terenów zmniejsza się sukcesywnie. W 2001 r. wynosiła ona 365,73 ha, co stanowiło $2,39 \%$ obszaru miasta, w tym pod składowiska odpadów zajęte było 193,3 ha (50 obiektów i terenów przekształconych) (Program Ochrony Środowiska 2004, 20 i 144-162). Natomiast w 2012 roku powierzchnia ta zmniejszyła się do 129,73 ha, tj. 0,85\% powierzchni Jaworzna, z czego zajęte pod 
składowiska odpadów było 99,1 ha (8 obiektów i terenów przekształconych) (Aktualizacja Programu Ochrony Środowiska 2012, 67-69 i 127). W przywołanym okresie likwidacji oraz rekultywacji poddano część obiektów po działalności przemysłu wydobywczego i energetycznego. Są to działania długofalowe, które będą kontynuowane na terenie miasta również w najbliższych latach. Natomiast główne kierunki skupiały się i będą skupiać na rekultywacji i rewitalizacji terenów zanieczyszczonych w wyniku działalności przemysłu chemicznego (działania zmierzające do rozwiązania problemu odpadów niebezpiecznych zgromadzonych w dolinie potoku Wąwolnica) (Program Ochrony Środowiska 2016, 138). Ponadto miasto, mając na względzie fakt, że edukacja ekologiczna jest nieodłącznym elementem idei zrównoważonego rozwoju, podejmuje działania związane z przyszłym jego rozwojem wyrażające się inwestycją w przyszłe pokolenia przez stworzenie warunków do prowadzenia w sposób profesjonalny edukacji mieszkańców, w szczególności tych najmłodszych, adaptując do tego przedsięwzięcia tereny poprzemysłowe (po eksploatacji kopalin).

$\mathrm{Na}$ uwagę również zasługuje racjonalna ochrona istniejących bogatych walorów przyrodniczych miasta, wyróżniająca Jaworzno na tle innych miast regionu.

4.1. Rekultywacja i rewitalizacja terenów zanieczyszczonych w wyniku działalności przemysłu chemicznego

$\mathrm{Na}$ przestrzeni lat priorytetową kwestią $\mathrm{w}$ polityce ochrony środowiska Jaworzna była rekultywacja i rewitalizacja gleb oraz wód powierzchniowych i podziemnych zanieczyszczonych wskutek oddziaływania odpadów niebezpiecznych pochodzących z działalności dawnych państwowych Zakładów Chemicznych „Azot”. Tereny zanieczyszczone zlokalizowane są w dolinie potoku Wąwolnica i obejmują głównie teren zakładu (dawnych budynków, magazynów i pozostałości instalacji), obszar CSO „Rudna Góra”, wyrobiska popiaskowego Pole K i Pole A. Na tych terenach, wg szacunków, zdeponowanych jest ok. 195 tys. $\mathrm{Mg}$ odpadów niebezpiecznych, w tym ok. 40 tys. Mg odpadów $\mathrm{HCH}$ (heksachlorocykloheksan) - substancji szczególnie szkodliwej dla środowiska wodnego (Program Ochrony Środowiska 2016, 89-90). Stąd już w pierwszym dokumencie, wskazano te problemy i wytyczono dla 
sektora „Powierzchnia ziemi” cel strategiczny: „Rekultywacja terenów zdegradowanych”, zaś wśród kierunków działań wymieniono: „Opracowanie i wdrożenie projektu pilotowego związanego z przekształceniem terenów poprzemysłowych". W następnych latach zagadnienia te były uwzględniane $\mathrm{w}$ kolejnych dokumentach wraz $\mathrm{z}$ aktualizacją obszarów priorytetowych i realizowanych zadań. Konsekwencją tych ostatnich była modyfikacja harmonogramu, $\mathrm{w}$ aspekcie m.in.: umieszczenia tego terenu na liście „gorących punktów” Helcom o zadanie dotyczące: „Ograniczenia rozprzestrzeniania się trwałych zanieczyszczeń organicznych i innych substancji szczególnie szkodliwych dla środowiska wodnego z terenów fabrycznych i wyrobiska Rudna Góra”. W 2008 r. władze Jaworzna zdecydowały się na przystąpienie do międzynarodowego projektu badawczego FOKS (Kluczowe Źródła Zagrożeń Środowiskowych), w ramach którego w sposób kompleksowy rozpoznane zostało ryzyko środowiskowe, wskazane zostały główne miejsca emisji zanieczyszczeń oraz optymalna technologia ich powstrzymania.

Równocześnie prowadzone były działania w celu umieszczenia problemu zanieczyszczenia doliny potoku Wąwolnica na liście programu likwidacji „bomb ekologicznych” wraz z rekomendacją do udzielenia na jego realizację wsparcia finansowego przez Narodowy Fundusz Ochrony Środowiska i Gospodarki Wodnej w ramach programu priorytetowego „Rekultywacja terenów zdegradowanych i likwidacja źródeł szczególnie negatywnego oddziaływania na środowisko". W lipcu 2013 r. podpisana została umowa z NFOŚiGW na dotację na przeprowadzenie badań uzupełniających (badania geofizyczne), wykonanie analizy techniczno-środowiskowej planowanych działań naprawczych, wybór optymalnej z punktu widzenia środowiska i ekonomii technologii usuwania istniejącego zagrożenia, opracowanie studium wykonalności oraz raportu oddziaływania przedsięwzięcia na środowisko, przygotowanie pełnej dokumentacji technicznej przedsięwzięcia i rekultywacji obszaru znajdującego się na terenie Zakładów Chemicznych "Organika Azot” S.A., w tym, przede wszystkim, wyrobiska „Rudna Góra” oraz pozostałych zanieczyszczonych miejsc na terenie miasta Jaworzna. Projekt zakończono w $2016 \mathrm{r}$.

Jaworzno, kontynuując działania w zakresie remediacji terenów zanieczyszczonych, uczestniczy od września 2016 r. w projekcie AMIIGA 
„Zintegrowane zarządzanie jakością wód podziemnych w miejskich obszarach funkcjonalnych". Projekt ten będzie koncentrował się na realizacji zintegrowanych strategii oceny, rekultywacji i zarządzania jakością wód podziemnych w miejskich obszarach funkcjonalnych, w ramach zadania zostanie także przetestowana próbna bariera reaktywna.

W celu kontynuacji realizowanych działań w ramach polityki środowiskowej miasta, w kolejnej edycji dokumentu przewidziano jako jedno z zadań wskazanych dla sektora „Gospodarka odpadami” przedsięwzięcie ukierunkowane na remediację zanieczyszczeń w dolinie potoku Wąwolnica $\mathrm{w}$ Jaworznie zgodnie $\mathrm{z}$ posiadaną przez miasto dokumentacją, która wymusza konieczność kompleksowego i hierarchicznego podejścia dla całego obszaru zanieczyszczonego.

4.2. Rekultywacja i rewitalizacja terenów zanieczyszczonych w wyniku działalności przemysłu wydobywczego

Kolejnym działaniem wpisującym się w cel strategiczny „Rekultywacja terenów zdegradowanych” i kierunek działań „Zagospodarowanie terenów zrekultywowanych” jest rekultywacja terenów zanieczyszczonych w wyniku działalności górniczej. Na uwagę zasługuje tu teren po byłym szybie KWK Kościuszko, na którym obecnie zlokalizowane są: galeria handlowa GALENA oraz Park Planty Jaworznickie. Działaniem wpisującym się w wytyczony w Programie (Program Ochrony Środowiska 2004, 161) kierunek „Rekultywacja terenów poprzemysłowych” są także przedsięwzięcia realizowane w ramach projektu „GBŚ - rekultywacja i odwodnienie składowiska odpadów pogórniczych Rejon Piłsudski w Jaworznie" związane z rekultywacją terenu po dawnym centralnym składowisku odpadów pogórniczych byłej kopalni KWK Jaworzno - Rejon Piłsudski (Program Ochrony Środowiska 2016, 91 i 138).

Oba z przytoczonych działań znajdują swoją kontynuację w kolejnych dokumentach wytyczających politykę środowiskową miasta, tj. kolejnych aktualizacjach programu ochrony środowiska. Celem pierwszego działania było utworzenie publicznych przestrzeni zieleni urządzonej (parków, skwerów, zieleńców, szpalerów drzew i innych) na terenie po byłym Szybie Kościuszko w rejonie ul. Rzemieślniczej i Grunwaldzkiej $\mathrm{z}$ zachowaniem dziedzictwa kulturowego tego miejsca. Utworzono zieloną przestrzeń miejską dla mieszkańców z elementami edukacyjnymi 
związanymi z historią terenu - wykonano i umieszczono makietę szybu kopalni Jacek-Rudolf (Raport 2016, 15). Bezpośrednio przy parku znajduje się galeria handlowa GALENA, która jest jednym z najnowocześniejszych centrów handlowych na terenie miasta. Inwestycja ta jest przykładem na zagospodarowanie terenów pogórniczych w sposób integrujący funkcje społeczne, kulturowe i gospodarcze.

W ramach drugiego działania zostanie wykonana rekultywacja terenu po dawnym centralnym składowisku odpadów pogórniczych byłej kopalni KWK Jaworzno - Rejon Piłsudski o pow. 67,3 ha. Podjęte już działania skupiają się na realizacji zapisów umieszczonych w projekcie budowlanym (Program Ochrony Środowiska 2016, 91).

\subsection{Edukacja ekologiczna}

Kolejnym przykładem przedsięwzięcia wpisującego się w strukturę programów ochrony środowiska i odzwierciedlających ideę zrównoważonego rozwoju jest utworzony w nieczynnym kamieniołomie Sadowa Góra Ośrodek Edukacji Ekologiczno-Geologicznej GEOsfera. GEOsfera jest nie tylko gwarancją realizacji edukacji ekologicznej, a więc zagadnienia, które w programach ochrony środowiska - poprzez jego horyzontalne ujęcie - dotyczy wszystkich sektorów środowiska, ale również jest dowodem na możliwość zagospodarowania terenu, na którym zakończono prowadzenie działalności gospodarczej, w sposób eksponujący jego walory przyrodnicze.

Cechami wyróżniającymi ośrodek są odsłonięcia skał zawierających w sobie liczne szczątki szkieletowe szkarłupni, mięczaków, głowonogów, ryb, a także kości Nothosaurusa. Na terenie GEOsfery odkryto także niezwykle cenne stanowisko paleontologiczne megariplemarków. Całości dopełniają liczne kolekcje roślinne.

Zadanie dotyczące przedstawionej powyżej inwestycji ujęto wprost w dokumencie z 2012 r. (Program Ochrony Środowiska 2012, 115) w harmonogramie wskazano przedsięwzięcie polegające na utworzeniu na terenie kamieniołomu Sadowa Góra wielkoobszarowego nowoczesnego miejsca edukacyjno-turystycznego umożliwiającego obserwację i poznanie różnorodnych zjawisk geologicznych i śladów dziedzictwa górniczego, a także podziwianie walorów przyrody ożywionej. Idea ta integrowała kilka sektorów środowiska ujętych w dokumencie bazo- 
wym (edukacja ekologiczna, ochrona przyrody i krajobrazu). Również w ostatniej edycji opracowania (Program Ochrony Środowiska 2016, 137) w harmonogramie przyjęto zadanie ukierunkowane na rozbudowę GEOsfery w zakresie infrastruktury okołoturystycznej, przyjmując, że inwestycje w tym zakresie zwiększą atrakcyjność ośrodka, a tym samym umożliwią dotarcie z działaniami edukacyjnymi do szerszego grona odbiorców.

4.4. Racjonalna ochrona istniejących bogatych walorów przyrodniczych miasta

Jaworzno, pomimo przemysłowego charakteru, posiada na swoim terenie również bogate walory przyrodnicze, na które składają się zarówno rozległe kompleksy leśne, tereny otwarte (występujące w postaci zróżnicowanych przestrzennie i gatunkowo łąk, muraw, remiz leśnych, pasów i kęp zarośli), jak i niewielkie enklawy spontanicznej roślinności zlokalizowane wewnątrz obszarów zabudowanych i tereny zieleni urządzonej. Najcenniejsze przyrodniczo obszary położone są we wschodniej (Niecka Wilkoszyńska, Kotlina Biskupiego Boru) i południowej części miasta (Zrębowe Pagóry Imielińskie). Poza znaczeniem krajobrazowym i turystyczno-rekreacyjnym, pełnią one także niezwykle istotne funkcje w kształtowaniu i utrzymywaniu lokalnej oraz ponadlokalnej bioróżnorodności (ze względu na występujące na ich obszarze cenne i chronione gatunki roślin i zwierząt).

W wyniku realizacji działań zapisanych w kolejnych edycjach programów ochrony środowiska wskaźnik lesistości na terenie miasta na przestrzeni lat zwiększył się o około $2 \%$ i obecnie wynosi $36,7 \%$. Wzrosła także powierzchnia gruntów leśnych w granicach administracyjnych Jaworzna o blisko 11\% w porównaniu do roku 2003 (Program Ochrony Środowiska 2004, 101; Program Ochrony Środowiska 2016, 104-106). Zwiększenie powierzchni leśnej na terenie miasta jest wynikiem prowadzonych sukcesywnie działań w zakresie gospodarki leśnej, w tym zalesień i odnowień, które były sformułowane $\mathrm{w}$ dokumencie jako "Ochrona i pielęgnacja zasobów leśnych”. Również zmiany wynikające z prowadzonych działań w zakresie ochrony przyrody, a dotyczące zarówno pomników przyrody (ich ilość zmniejszyła się na przestrzeni lat - powodem był zły stan zdrowotny drzew), jak i obszarów chronio- 
nych (tj.: obszarów NATURA 2000, obszarów chronionego krajobrazu, użytków ekologicznych i rezerwatów przyrody), których powierzchnia w stosunku do lat poprzednich zwiększyła się z 3,81\% (2001 r.) do $4,84 \%$ obszaru miasta, wpisują się w priorytet określony jako „Ochrona i kształtowanie bioróżnorodności oraz walorów krajobrazowych” i kierunek działan „Ustanawianie nowych form ochrony przyrody”. Władze miasta, wypełniając zapisy dokumentów i realizując opracowaną politykę środowiskową miasta, chronią elementy środowiska naturalnego poprzez objęcie ich ochroną prawną. Na mocy uchwał Rady Miejskiej, w okresie obowiązywania zapisów kolejnych programów, ustanowiono cztery użytki ekologiczne (remiza leśna Bucze, Zakola Białej Przemszy, Góra Wielkanoc oraz Łąki w Ciężkowicach), jeden zespół przyrodniczo-krajobrazowy Sadowa Góra oraz Park Gminny Gródek.

Przedstawione powyżej przedsięwzięcia są przykładami działań ujętych w kolejnych programach ochrony środowiska, których realizacja wskazuje, że w przypadku Jaworzna dokumenty te mają praktyczne zastosowanie. Wymiernym efektem podejmowanych działań są korzystne przekształcenia funkcjonalno-przestrzennego krajobrazu miasta, które bezpośrednio przekładają się na atrakcyjność Jaworzna. Zagospodarowanie nieczynnego kamieniołomu w sposób zapewniający zachowanie jego unikatowych walorów i jednocześnie sprzyjający wypoczynkowi oraz edukacji znacząco wpływa na wzrost potencjału turystyczno-wypoczynkowego i promocję miasta $\mathrm{w}$ skali ponadregionalnej. $\mathrm{Z}$ kolei rewitalizacja i zagospodarowanie terenów zanieczyszczonych w wyniku działalności przemysłu wydobywczego może być postrzegane jako interakcja $\mathrm{z}$ sektorem gospodarczym: powstałe centrum handlowe jest pierwszym tego typu obiektem w mieście. Obok głównego profilu działalności, galeria oferuje również mieszkańcom i gościom Jaworzna przestrzeń kulturalno-rozrywkową (obejmującą kino, kręgielnię oraz klub fitness), nade wszystko zaś - na płaszczyźnie społeczno-gospodarczej - stwarza miejsca pracy. Rekultywacja i rewitalizacja terenów zanieczyszczonych w wyniku działalności przemysłu chemicznego to z kolei przykład przedsięwzięcia, które ma na celu przywrócenie ładu środowiskowego, a poprzez to ograniczenie niekorzystnych presji na zdrowie i życie mieszkańców. Działania podejmowane w celu ochrony walorów przyrodniczych miasta wyrażające się m.in. zwiększaniem powierzchni 
leśnych, tworzeniem nowych obszarowych form prawnie chronionych, obok pozytywnego wpływu na zagospodarowanie przestrzenne, stanowią równowagę dla presji urbanizacyjnej. Są miejscami wypoczynku mieszkańców, którzy mogą znaleźć przestrzeń o charakterze rekreacyjnym w swoim bezpośrednim sąsiedztwie, a równocześnie pozytywnie wpływają na warunki klimatyczne w obrębie miasta.

\section{Podsumowanie}

Programy ochrony środowiska bez wątpienia mogą być i są - jak pokazuje przykład Jaworzna - skutecznymi narzędziami realizacji zasady zrównoważonego rozwoju w polityce ochrony środowiska. O sukcesie decyduje tu dopasowanie zapisów dokumentów do faktycznych potrzeb danej jednostki administracyjnej - rozpoznanie stanu aktualnego, wnikliwie przeprowadzona analiza SWOT oraz priorytetyzacja i integracja działań. Przykład Jaworzna pokazuje, że nie bez znaczenia jest również konsekwencja i zaangażowanie władz, które są odpowiedzialne za wdrożenie programów. Znaczna cześć przedsięwzięć ujętych w dokumentach wymaga bowiem kilkuletniego, a nawet kilkudziesięcioletniego procesu inwestycyjnego (znacznie dłuższego niż kadencja wybieranych organów), a także bardzo dużych środków finansowych, których pozyskanie może stwarzać realne problemy. Czynniki te są w zasadzie głównymi zagrożeniami dla skutecznej realizacji dokumentów i dotyczą wielu jednostek administracyjnych. Odwołanie się do przykładu Jaworzna pozwala stwierdzić, że kluczem wydaje się tu być systematyczność: raportowanie z wykonania dotychczasowych działań, analiza czynników, które wpływają na ewentualne opóźnienia w wykonywaniu zadań lub na ich niewykonywanie, monitoring wskaźników realizacji programu, jak również zachowanie ciągłości pomiędzy poszczególnymi edycjami dokumentu. W przestrzeni ekonomicznej o powodzeniu decyduje natomiast umiejętność poszukiwania pozabudżetowych źródeł finansowania.

\section{Bibliografia:}

Aktualizacja Programu Ochrony Środowiska dla Jaworzna - miasta na prawach powiatu na lata 2012-2015 z uwzględnieniem perspektyw na lata 2016-2019. 2012.Warszawa: PIG-PIB. Dostęp: 8.02.2016. http://bip. jaworzno.pl/Article/get/id,15509.html. 
Program Ochrony Środowiska dla Jaworzna - miasta na prawach powiatu na lata 2008-2011 z uwzględnieniem perspektywy na lata 20122015 - Aktualizacja. 2008. Katowice: IGO Sp. z o.o. Dostęp: 8.02.2016. http://bip.jaworzno.pl/Article/get/id,15509.html.

Program Ochrony Środowiska dla Jaworzna - miasta na prawach powiatu na lata 2016-2019 z uwzględnieniem perspektyw na lata 20202023. 2016. Warszawa: PIG-PIB. Dostęp 09.02.2016. http://bip.jaworzno.pl/Article/get/id,29899.html.

Program Ochrony Środowiska dla miasta Jaworzna. 2004. Warszawa: PIG. Dostęp: 6.02.2016. http://bip.jaworzno.pl/Article/get/id,15509.html.

Raport $z$ wykonania $w$ latach 2014-2015 „Programu Ochrony Środowiska dla Jaworzna - miasta na prawach powiatu na lata 2012-2015 z uwzględnieniem perspektyw na lata 2016 -2019”. 2016. Warszawa: PIG-PIB. Dostęp: 8.02.2016. http://bip.jaworzno.pl/Article/get/id,29471.html.

Ustawa z dnia 27 kwietnia 2001 r. Prawo ochrony środowiska. Dziennik Ustaw, 2016 poz. 672 z późn. zm. 


$$
\begin{gathered}
\text { CZĘ́ŚC VI } \\
\text { ZRÓWNOWAŻONA GOSPODARKA } \\
\text { I SPOEECZEŃSTWO - PODEJŚCIE SEKTOROWE }
\end{gathered}
$$



Jacek Kwiatkowski

Uniwersytet Warszawski - Wydział Geografii i Studiów Regionalnych jacek.kwiatkowski@uw.edu.pl

\title{
Nowa generacja, nowe potrzeby - miasto reaktywne versus miasto zrównoważone
}

\author{
Reaktywność urbanistyczna to zdolność \\ jednostek, społeczności, instytucji, firm \\ i systemów w mieście do przetrwania, \\ adaptacji i rozwoju niezależnie od tego, \\ jakie są chroniczne stresy i ostre wstrząsy, \\ których doświadczają.
}

Miasto zrównoważonego rozwoju: miasto, w którym promowana jest równowaga pomiędzy wzrostem poziomu życia płynącym $\mathrm{z}$ nowych inwestycji, produkcji, usług i obsługi biznesu a zachowaniem zasobów naturalnych, redukcją zanieczyszczeń, dodatnim bilansem energetycznym.

\section{Wprowadzenie}

Jak wiadomo, miasto to nie tylko funkcje obszarowe, nie tylko infrastruktura, klimat i środowisko przyrodnicze, ale przede wszystkim mieszkańcy i kreowane przez nich aktywności. Miasto jest jednym z najbardziej skomplikowanych organizmów zbudowanych ręką człowieka. Paradoksalnie człowiek, który jest słusznie uważany za twórcę miasta często nie sprawuje, nie podejmuje nad nim pełnej kontroli. Wciąż znajdujemy się w punkcie, kiedy to prognozy dotyczące miast (ich wzrostu czy stagnacji) zaskakują nas, kiedy znajdują potwierdzenie w nadchodzącej później rzeczywistości. Jeszcze 50 lat temu nie dostrzegano powszechnie, że na kontynencie europejskim trwale ukonstytuują się zaledwie 3 megametropolie (nie licząc Stambułu) o liczbie mieszkańców zbliżonej do $10 \mathrm{mln}$, kiedy w tym samym czasie na Dalekim Wschodzie ich liczba zbliży się do 23. Podobnie dzisiaj, kiedy problemy Europejczyków, zapowiadane przez $\mathrm{S}$. Huntingtona, $\mathrm{z}$ niewiarygodną wręcz precyzją i dokładnością materializują się niemal dokładnie po 20 latach od napisania jego słynnej książki Zderzenie Cywilizacji (Huntington 1996), wciąż nie chcemy widzieć w tym prawidłowości, ale szukamy przypadku. 


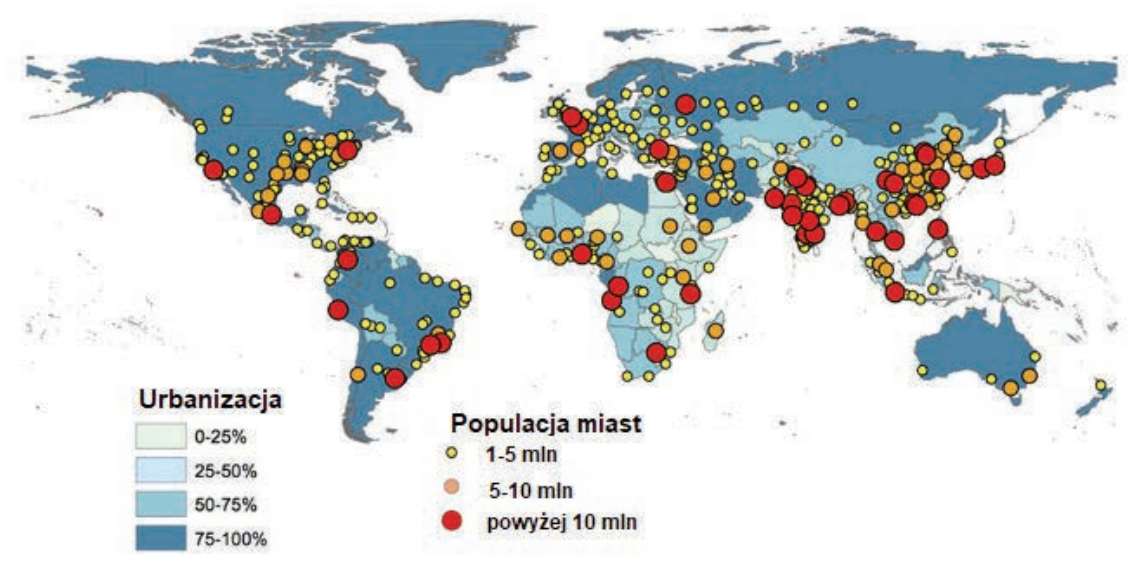

Ilustracja nr 1. Mieszkańcy miast na świecie diagram procentowy oraz megametropolie według danych ONZ 2014. Źródło: http://index.hu/tudomany/2014/07/15/azsia_es_afrika_varosai_2030-ra_lehagyjak_a_vilagot/.

\section{XXI wiek - diagnoza impasu}

Po wkroczeniu w XXI wiek planowanie miejskie, a zwłaszcza współczesna urbanistyka, znalazło się w impasie. Ponad 40 lat temu upadek modernizmu pozostawił po sobie dyspozycyjność przestrzeni względem twórcy jako silny imperatyw, który do dziś praktycznie wciąż funkcjonuje. Jednocześnie nie pojawiły się niestety żadne nowe rozwiązania systemowe. Zapomniano o wartości sąsiedztwa jako kluczowej dla kreacji i prawidłowego funkcjonowania przestrzeni (Jacobs 2011). Przestrzeń miast coraz wyraźniej staje się polem swobodnej interpretacji autorskiej architekta i jego dzieła (star architects) - czyli coraz bardziej spektakularnych zespołów kubaturowych, które chcą zajmować szczególne miejsce w strukturze miasta i w sposób coraz bardziej jaskrawy i agresywny odrzucają klasyczną zasadę hierarchizacji przestrzeni (dotyczy to zwłaszcza przestrzeni publicznych) (Koolhaas 2006). Towarzyszy temu, podobnie jak w latach 60. i 70. $\mathrm{XX}$ wieku, ucieczka od realnych problemów miasta. Kolejny raz powstają utopijne koncepcje zawierające próbę wymyślenia idei miasta od początku, tak jakby blisko 5000 lat urbanizacji nigdy nie istniało. Problemów współczesnej urbanizacji nie można rozwiązać na zasadzie kulinarnego TV-show, w którym degustacja smaków pozwala sięgnąć tylko po to co najsmaczniejsze (na przykład - Nowy Urbanizm) (Urban Spaces No.5 2007). 
W tej negatywnej selekcji, ucieczki od miasta jako organizacji przestrzennej wieloaspektowej aktywności, nie ocalono niestety jednej z nielicznych teorii miasta współczesnego sięgających do istoty jego miejskości. Była nią idea miejskości jako mozaiki subkultur według Christophera Aleksandra, która wyrosła tuż po modernizmie 1977 (Alexander 2008). Zrównoważony rozwój, który pojawił się 10 lat później jako wartość pierwotnie stricte humanistyczna, wynikająca $\mathrm{z}$ troski o człowieka, zaznaczająca dawną ideę zdrowego miasta (Howard 1970), został z czasem utożsamiony jedynie z dyktatem energooszczędności, „zielonej sterylności” (zero emisji $\mathrm{CO}_{2}$; bio-city) czy walki o dostępność - szybką komunikację (chińskie Great City, arabskie Masder City czy Free City - projekt Bernardo Romero). Słabość tych rozwiązań, polega między innymi na tym, że w większości zawierają one radykalną redukcję roli samochodu osobowego jako środka transportu w miastach oraz unifikację potrzeb i zachowań ludzkich w sferze kształtowania przestrzeni. Tymczasem funkcja samochodu jest przecież znacznie szersza niż tylko rola środka szybkiej komunikacji. Warto przypomnieć w tym miejscu, że miasto - ogród E. Howarda - to nostalgiczne marzenie miasta doskonałego, na którym wyrosła cała urbanistyka XX wieku, to przecież miasto szybkiej komunikacji również kołowej (Fishman 1977; Ostrowski 1973). Już futuryści na początku XX wieku widzieli, że samochód jest atrybutem wolności osobistej, poczucia bezpieczeństwa, często formą kreacji własnej osobowości. W czasach, kiedy zapewnienie bezpieczeństwa publicznego staje się coraz większym problemem, kształtowanie przestrzeni miast będzie prowadziło do coraz bardziej indywidualistycznych rozwiązań, a samochód może zostać jedynie zastąpiony inną, indywidualną, szybką formą przemieszczania się, czego współczesne teorie już nie uwzględniają (a widzieli to już chociażby przedstawiciele II fali awangardy - G. Krutikow) (Kwiatkowski 2013). Samochód nie zniknie w wyniku pielęgnowania pewnej poprawności w polityce miejskiej, pewnej wizji przestrzeni, mówi o tym nawet sam Jan Gehl, propagator miasta dla rowerów, kiedy pisze „należy zrozumieć i zaakceptować ludzką chęć posiadania motocykla i samochodu" (Gehl 2014).

\section{Miasto współczesne - dynamika zmian, dynamika zagrożeń}

Dynamika zmian w obszarach zurbanizowanych w ostatnich dziesięcioleciach, w tym również zmian klimatycznych przerosła nasze przewidywania (Höjer, Gullberg i Pettersson 2007). Tempo zmian, i to zmian w samej 
świadomości miasta, doprowadza nas dzisiaj do zderzenia pojęć niedawno przecież wprowadzonych do światowego obiegu. Czym innym jest przecież prawo do miasta ukonstytuowane na Konferencji Habitat II w Stambule w 1996, a czym innym podobne określenie użyte w koncepcji krytycznej teorii urbanizacji Harveya (Harvey 2012). Kiedy spojrzymy na proklamację zrównoważonego rozwoju, która pojawiła się na konferencji w Rio de Janeiro (1992), z perspektywy dnia dzisiejszego, ze zdziwieniem dostrzegamy, że idea ta nie zaspokoiła wiązanych $\mathrm{z}$ nią oczekiwań. Obietnice wygenerowania sprawnego systemu użytkowania przestrzeni z gwarancjami praw do niej dla przyszłych pokoleń okazały się zaskakująco trudne do realizacji. W obliczu zagrożeń współczesnego świata konfliktami regionalnymi, a nawet globalnymi, pojęcie zrównoważonego rozwoju pozostało nazbyt często jedynie formułą popularyzatorską nie zaś praktyką w działaniu.

Dzisiejsza formuła miasta reaktywnego jest już bogatsza o doświadczenia lat minionych. Możliwości, jakie dają Internet i portale społecznościowe, spowodowały, że jesteśmy jako ludzkość w zupełnie innym miejscu niż 25 lat temu. Dużo jaśniej potrafimy zdefiniować współczesne zagrożenia. Rozrastające się miasta poszukują odporności na problemy społeczności lokalnych (również w Internecie), na pojawienie się klęsk żywiołowych i kataklizmów. Już teraz megametropolie stają przed problemem zaspokojenia odpowiednich zasobów wody pitnej, żywności czy osiągnięcia równowagi bioekologicznej. Siedem podstawowych cech takich miast, znanych jako: Reflective (nadążające), Resourceful (zaradne), Robust (odporne), Redundant (niezaangażowane), Flexible (łatwo przystosowujące się), Integrated (zintegrowane), Inclusive (łączące w sobie skonsolidowane), to zaledwie początek. Chociaż istotnie zdefiniowanie tych cech pomaga miastom określić sytuacje kryzysowe, odpowiedzieć na nie, łatwiej dostosować się do wstrząsów i napięć, to w żaden sposób nie wypełniają one tej formuły w całości, a jedynie ją zarysowują.

Przyczyn takiego stanu rzeczy nie należy bagatelizować, gdyż zagrożenia stojące przed miastem współczesnym nie zawierają się jedynie w ryzyku gwałtownych nagłych klęsk żywiołowych, kataklizmów i katastrof, których nigdy do końca przewidzieć przecież nie możemy (takich jak trzęsienia ziemi, wybuchy wulkanów, powodzie czy epidemie). Jesteśmy zszokowani natomiast może dużo bardziej, kiedy patrzymy na wyludnianie się miast o antycznej wielowiekowej tradycji (Ateny), kiedy doświadczamy utraty ich tożsamości. Wtedy zadajemy sobie pytanie, dlaczego tak 
się dzieje? Przyczyn możemy upatrywać oczywiście w obszarze ekonomii, kłopotów w strefie euro czy znacznego przeszacowania wpływów, które miasto zamierzało osiągnąć po historycznej olimpiadzie w 2004 roku, ale nie wszystko da się wytłumaczyć ekonomią. Również natura nie oszczędziła Aten. Do dziś widać ślady potężnego trzęsienia ziemi z 1999 r. Paradoks tej sytuacji polega na tym, że im więcej potrafimy zdiagnozować w sferze technicznej funkcjonowania miasta współczesnego, tym mniejszy wpływ mają te diagnozy na osiągnięcie zadowalającego rezultatu zastosowanych programów naprawczych. Należy w tym momencie przypomnieć, że Ateny spełniają większość kryteriów stawianych miastu reaktywnemu, tak więc pozory mylą. Wniosek jest prosty: muszą istnieć inne jeszcze - niewidzialne czy trudno mierzalne - czynniki decydujące o kondycji współczesnych miast. A jeśli tak, to mogą się one znajdować wyłącznie po tej stronie, której do tej pory nie badaliśmy w sposób kompleksowy, po stronie ludzkich zachowań, aktywności, potencjałów i barier z nimi związanych oraz mechanizmów ich kreacji. Czynniki te dużo mocniej oddziałują na dynamikę rozwoju współczesnych miast niż pozostałe uwarunkowania (infrastrukturalne, przyrodnicze, klimatyczne i inne).

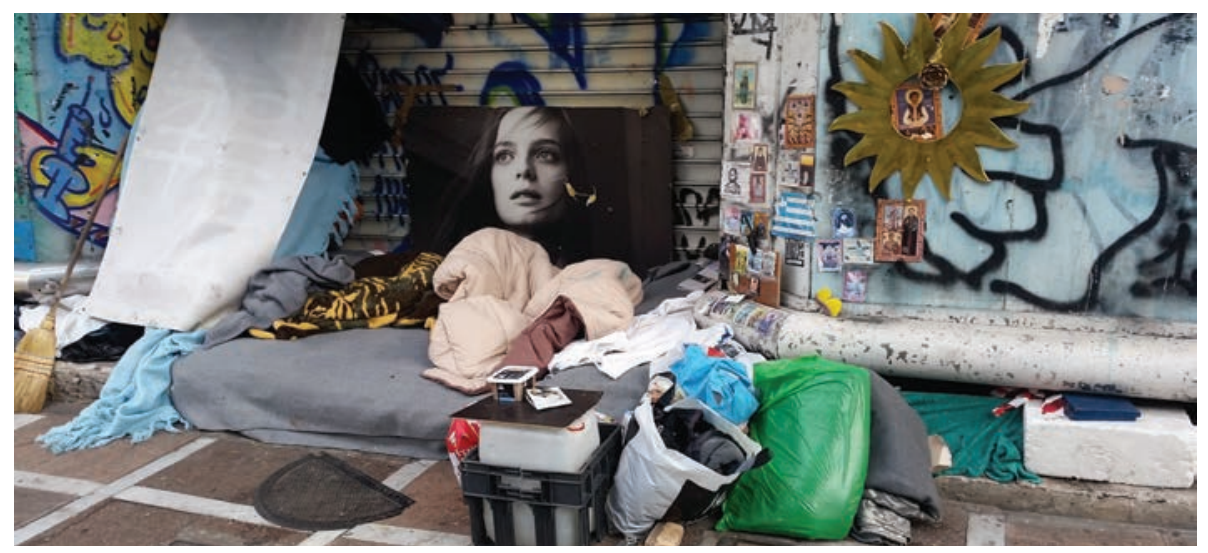

Ilustracja nr 2. Ulica w centrum Aten - luty 2016. Źródło: zbiory własne autora.

\section{Miasto reaktywne zamiast miasta zrównoważonego?}

W poszukiwaniu panaceum na problemy współczesnych miast pojawiła się w ostatnich latach koncepcja miasta reaktywnego, która w przeciwieństwie do koncepcji miasta zrównoważonego będzie się wypełniać nie 
tyle w profilaktyce i wdrażaniu norm, co raczej w kreatywności i adekwatnej odpowiedzi na ogarniające nas coraz szybciej zmiany. Innymi słowy, pytanie o reaktywność miasta to pytanie, jak poradzi sobie, jak może sprostać dany organizm miejski ekstremalnemu zaburzeniu na obszarach swojej wieloaspektowej aktywności zarówno w wyniku działań naturalnych, takich jak na przykład trzęsienia ziemi, jak i w konsekwencji ataku terrorystycznego czy poważnego kryzysu międzynarodowego. Formuła zrównoważonego rozwoju samodzielnie nie wypełnia już dzisiaj potrzeb, z jakimi zmagać się może współczesne miasto. Dysproporcje ekonomiczne - można powiedzieć - drastycznie wyprzedzały proklamacje związane z planowaniem przestrzeni, ostro zarysowały się już w 5 lat po konferencji w Rio, kiedy to aktywa 3 najbogatszych miliarderów przekroczyły PKB 600 milionów najbiedniejszych obywateli naszego globu (Harvey 2008). Formuła zrównoważonego rozwoju jest zbyt pasywna dla dynamiki zmian, zwłaszcza jeśli weźmiemy pod uwagę, że według prognoz Organizacji Narodów Zjednoczonych i OECD już w 2050 roku aż 6 miliardów ludzi będzie żyło $\mathrm{w}$ miastach, a historyczny poziom równowagi w liczbie mieszkańców miasto - wieś przekroczyliśmy już w 2010 r.
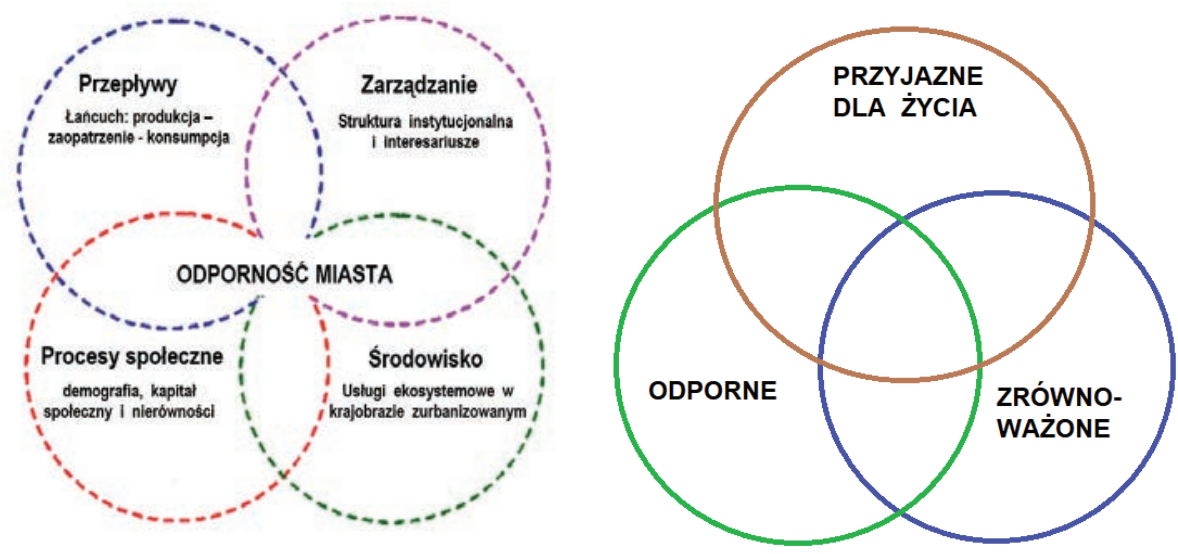

Ilustracja nr 3. Reaktywność versus zrównoważony rozwój.

Źródło: http://lulab.be.washington.edu/omeka/collections/show/8;

https://www.slideshare.net/TalkingTransitionSlides/the-new-resilient-city/38-BLEN-

DING_RESILIENCY_INTO_DESIGNAccom; https://www.thenatureofcities.com /2013/05/08/the-cities-we-want-resilient-sustainable-and-livable/. 
Innymi słowy, elementy miasta zrównoważonego rozwoju oraz elementy miasta reaktywnego muszą się dzisiaj uzupełniać, aby sprostać nowym potrzebom i zagrożeniom livable city (patrz ilustracja nr 2). Mówiąc najprościej, formuła reaktywności to przenikanie się czterech obszarów: możliwości gospodarki, mobilności i zaradności społeczności lokalnej, prawidłowo funkcjonującej administracji rządowej i samorządowej oraz pełnego wykorzystania zasobów środowiska naturalnego. Poszczególne te wartości odpowiedzialne są odpowiednio: sektor gospodarczy - za odporną na przeciążenia produkcję i policentryczną dystrybucję dóbr materialnych i usług (dostępność pełnej gamy usług w każdym punkcie miasta), alternatywne źródła energii poza paliwami ropopochodnymi; sektor społeczny - za rozwijanie potencjału umiejętności i kreatywności społeczności lokalnych; sektor rządowy i samorządowy - za wdrożenie mechanizmów optymalizacji procesów decyzyjnych, przejrzystość i szybkość reagowania na poziomie administracji na wszelkie nieprzewidziane zjawiska dotyczące miasta współczesnego oraz sektor środowiska przyrodniczego, który -oprócz prawidłowego zarządzania zasobami środowiska naturalnego - ma być odpowiedzialny za wizerunek miasta, za przestrzeń nie tylko zieloną, ale też zbudowaną; $\mathrm{w}$ praktyce przejmuje więc również wpływ na środowiska planistów miejskich, w tym aspekcie na przykład za sukcesywne promowanie ruchu pieszego w centrach miast. Miasto reaktywne z założenia ma być też miastem innowacji. Czy jednak zaaplikowanie doskonałej sieci infrastrukturalnej wystarczy dla osiągnięcia mechanizmów wzrostu dla aktywnej wspólnoty (Pinterest. com 2016)? Istotą miasta reaktywnego, o czym pisze J. Gehl w swojej książce New City Life (Gehl 2006), nie jest jednak tylko koordynacja, uzupełnianie się czterech powyżej wspomnianych obszarów, ale stworzenie na ich bazie nowoczesnego, sprawnego systemu, między innymi dywersyfikacji usług, a w związku z tym alokacji miejsc pracy, lepszej dostępności komunikacyjnej, wielobiegunowej sieci transportowej, policentrycznej sieci energetycznej opartej na alternatywnych odnawialnych źródłach energii itd. Budowie miasta reaktywnego nie sprzyja brak żywego laboratorium takich miast. Jednak instrumentarium, które już posiadamy, pozwala wskazać potencjalne miasta reaktywne, takie jak: Antalya i Bursa (w Turcji), Kobe i Kyoto (w Japonii), Ottawa (w Kanadzie), Oslo (w Norwegii), Lizbona (w Portugalii), Tampere (w Finlandii), Cardiff (w Wielkiej Brytanii) czy Belo Horizonte (w Brazylii). 


\section{Mierzalność zjawiska reaktywności miasta}

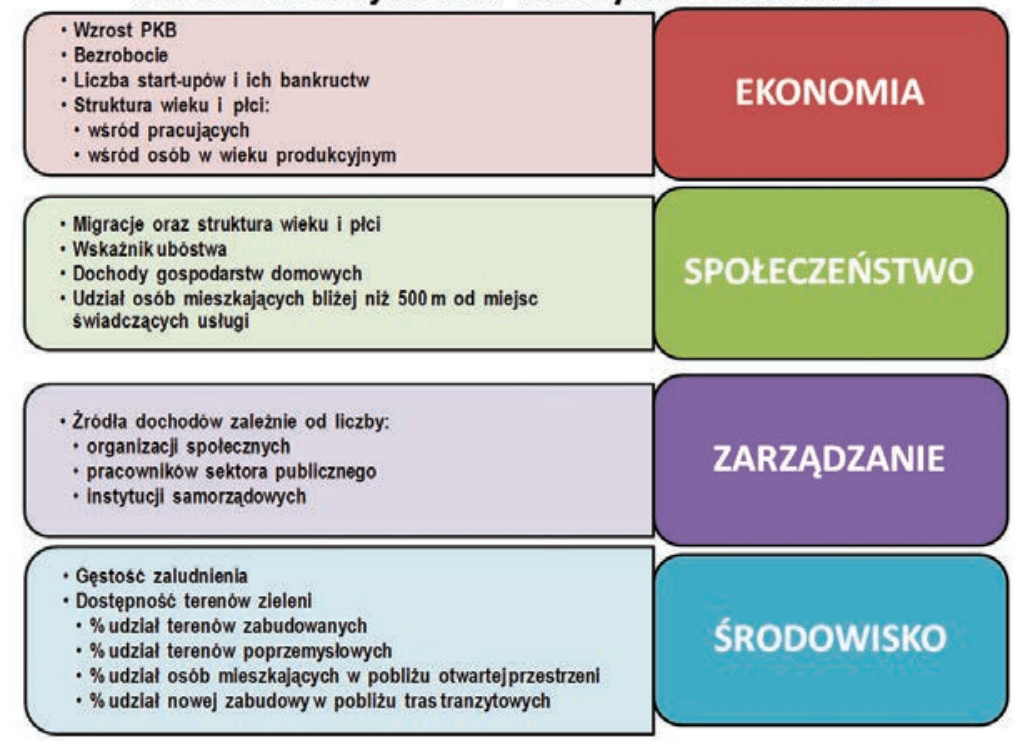

Ilustracja nr 4. Mierzalność zjawiska reaktywności miasta; Measuring city resilience. Źródło: http://www.oecd.org/cfe/regional-policy/resilient-cities.htm.

Najogólniej rzecz ujmując, przeciwieństwem miasta reaktywnego jest miasto podzielone, jednak linia podziału może być wieloraka, często pozornie niewidoczna, ukryta, w rzeczywistości natomiast bardzo głęboka. Miasta o dominującej roli przemysłu, jak Detroit czy Liverpool, ale również miasta, którym brakuje terenów inwestycyjnych, z pewnością nie staną się łatwo miastami reaktywnymi.

Poziom zaawansowania procesów reaktywności miejskiej (ilustracja nr 3) możemy poznać w wyniku przeprowadzenia szeregu szczegółowych analiz w każdym z czterech obszarów wspomnianej wcześniej aktywności. W obszarze społecznym mogą to być: poziom ubóstwa, saldo migracji, jej wiek i płeć, dochody gospodarstw domowych czy procent mieszkańców miasta $\mathrm{z}$ dostępnością do usług w odległości równej lub mniejszej niż $500 \mathrm{~m}$ od miejsca zamieszkania. W obszarze rządowym i samorządowym mogą to być dane na temat liczby organizacji społecznych na danym terenie, jakości samorządów lokalnych, poziomu obsługi mieszkańców przez urzędników sektora publicznego. W sferze ekonomicznej będą to: poziom 
bezrobocia, poziom ubóstwa, wiek i płeć zatrudnionych czy liczba pracujących ogółem, tempo wzrostu produktu krajowego czy liczba nieudanych start-up-ów. W sferze środowiska naturalnego będą to: gęstość zaludnienia, procent powierzchni zabudowanej, procent powierzchni biologicznie czynnej, procent mieszkańców zamieszkujący w sąsiedztwie przestrzeni otwartej w mieście, procent nowej powierzchni komercyjnej i mieszkalnej w sąsiedztwie dróg tranzytowych, procent obszarów poprzemysłowych.

W formule miasta reaktywnego ogromną rolę odgrywa tempo odbudowy zagrożonych zasobów. Im wyższe tempo, tym proces reaktywności jest bardziej zaawansowany. Odgrywają tu rolę zarówno odporność na destrukcję samych zasobów jak i czynnik czasu, czyli czas poświęcony na ich odbudowę (ilustracja nr 4).

(a) Odporność systemów technicznych miasta ( b) Odporność ekologiczna

(a) Odporność systemów technicznych miasta

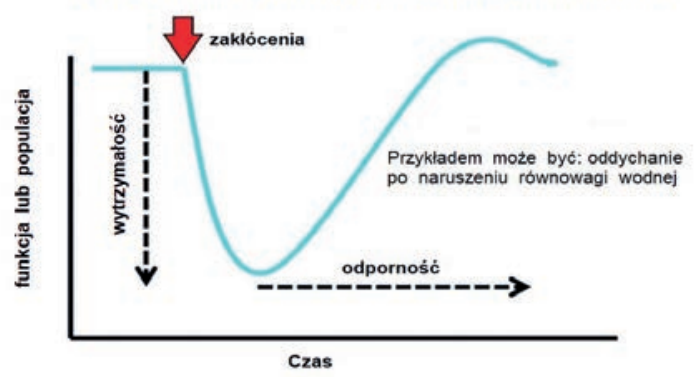

(b) Odporność ekologiczna

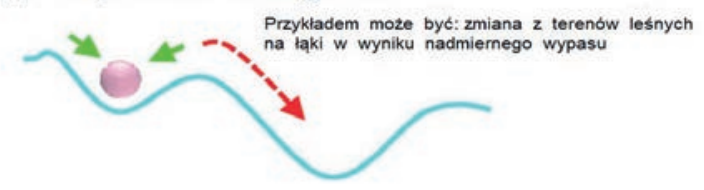

Ilustracja nr 5. Odporność miast reaktywnego: ludzie - aktywność systemów technicznych i środowisko naturalne. Źródło: https://www.researchgate.net/figure/224924552_ fig1_Figure-2-Schematic- representation-of-engineering-a-and-ecological-resilience-b-In. Schematyczne przedstawienie działania systemu (a) i odporności ekologicznej (b). W definicji działania systemu - stabilność określa się przez natychmiastową reakcję na zakłócenia (oporność), a następnie odzyskiwania (potencjału) w czasie (sprężystości). Diagram ukazuje skuteczność działania systemu (w danym środowisku). Odporność jest miarą utrzymania się systemu (koło) w danej niszy środowiska pomimo coraz wyższego poziomu zakłóceń - słabość, czyli niska odporność, to przejście do innej niszy środowiska. 


\section{Smart grid jako strategia kompensacji zagrożeń}

System Smart grid, jako inteligentna sieć informacyjno-elektroenergetyczna i element miasta reaktywnego, ma na celu kompensację części zagrożeń poprzez zintegrowanie rozproszonych odnawialnych źródeł energii (baterie słoneczne, wiatraki, geotermia, wykorzystanie energii kinetycznej wody i inne) oraz zasobów energetycznych już istniejących $\mathrm{w}$ sieciach i produkowanych w dużych elektrowniach na bazie paliwa konwencjonalnego czy jądrowego.

System Smart grid może działać w obie strony, to znaczy będzie przekazywał do systemu energię, kiedy nie będzie jej potrzebował jednostkowy wytwórca i odbiorca zarazem (w tym znaczeniu nawet dom jednorodzinny wyposażony w ogniwa fotowoltaiczne). Włączenie źródeł odnawialnych do sieci, a tym samym zmniejszenie emisji dwutlenku węgla pozwoli również na budowę sieci przesyłowych o nowych parametrach (minimalizacja strat przesyłowych). Pozwoli to również na nasycenie dostępem do energii zagrożonych deficytem regionów i państw i sprawi, że system taki będzie odporny na przerwy w dostawach prądu. Tym samym system ten mógłby w przyszłości przeciwdziałać olbrzymim stratom w gospodarce światowej (sięgającym miliardów dolarów) spowodowanym awariami i nagłym załamaniem w dostawach prądu dla całych aglomeracji. Miało to miejsce aż trzy razy w perspektywie ostatnich 10 lat na przykład w Stanach Zjednoczonych. Mowa jest tu również o sytuacjach przymusowego zmniejszenia mocy przesyłanej do odbiorców podczas upałów, na przykład w Kalifornii w ostatnich kilku sezonach.

Ostatecznie przewiduje się, że w przyszłości Internet mógłby kontrolować zużycie energii elektrycznej, dając możliwość automatycznego przekierowania dostaw energii elektrycznej przy jakiejkolwiek awarii prądu. Inteligentne liczniki będą liczyły zużycie energii, jednocześnie informując o nim użytkownika oraz informując system. Sieć będzie działać elastycznie, chroniąc dostęp do energii elektrycznej zarówno przed atakami terrorystycznymi jak i klęskami żywiołowymi. Inteligentna sieć (Smart grid) zapewni również nowe sposoby magazynowania energii i błyskawiczne jej transfery do miejsc, gdzie wcześniej byłoby to niemożliwe. To magazynowanie energii będzie kluczowym komponentem rozwoju systemu samochodów napędzanych energią elektryczną, gdyż 
system taki pozwoli na akcesje do sieci elektroenergetycznej (na ładowanie samochodu) niemal wszędzie, na każdym parkingu, przed restauracją, galerią handlową, na promie czy przed dworcem kolejowym, na każdym podjeździe przed domem.

Smart grid to nie tylko pełne bezpieczeństwo energetyczne, to również proces optymalnego wykorzystania tych zasobów dla rozwoju zintegrowanych usług związanych z energią. Tym samym Smart grid niesie ze sobą potrzebę nowej standaryzacji i unifikacji w usługach telekomunikacyjnych, budownictwie i architekturze dla osiągnięcia tak zwanej interoperacyjności. Jest to więc zapowiedź również zmian $\mathrm{w}$ obrazie przestrzennym miasta przyszłości.

\section{Smart Grid i zaawansowanie technologiczne w poszczególnych państwach Mapa dojrzałości sieci}

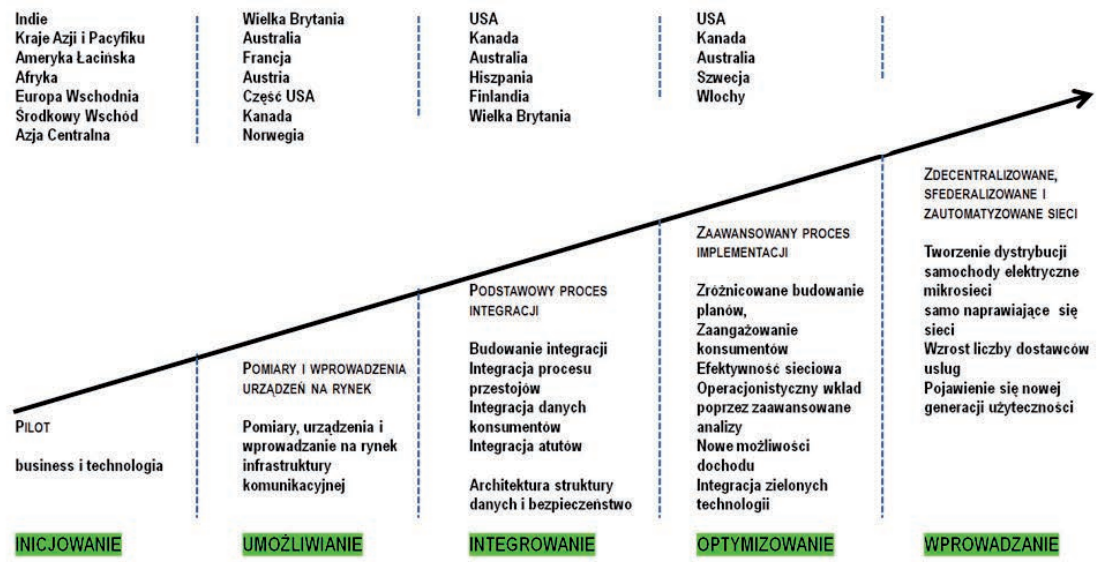

Ilustracja nr 6. Mapa dojrzałości sieci Smart grid i zaawansowanie technologiczne w poszczególnych państwach. Źródło: http://www.wipro.com/industries/utilities/segments/electricity-gas/smart-metering-smart-grid/.

Budowa sieci ma również swoje wrażliwe strony. Są nimi, oprócz olbrzymich kosztów uruchomienia systemu, również kwestie tak zwanego czynnika ludzkiego. Inteligentny dom, jako jeden z elementów systemu, będzie dostarczać informacje na temat zachowań użytkowników. Informacje te $\mathrm{z}$ jednej strony przydatne będą do podnoszenia świadomości w zakresie zużycia energii, z drugiej jednak, będą całkowitą inwigilacją 
mieszkańców. Czuły system będzie w stanie nie tylko wskazać, ile osób znajduje się lub znajdowało $\mathrm{w}$ danej chwili w domu, ale również jakie czynności w danym momencie one wykonują lub wykonywały, gdzie był ładowany ostatnio samochód (a więc również jaką trasę pokonywał) itd. Pozostaje zatem pytanie, czy cena ta, cena wolności indywidualnej i prawa do intymności, nie jest zbyt wysoka za dobrodziejstwo oszczędności energii i gwarancji jej stałej dostawy.

\section{Czy powrót do miasta powtarzalnego?}

Trudno nie zauważyć, że ubocznym zjawiskiem procesów globalizacyjnych, w których się obecnie znajdujemy, jest podatność społeczności lokalnych na zachowania masowe - pojawia się, spotęgowany możliwościami Internetu, pewien rodzaj tożsamości masowej. Wciąż jeszcze jej nie doceniamy i nie umiemy do końca kontrolować. Nie potrafimy również do końca jej zdiagnozować, ażeby wypracować odpowiednie metody reagowania na destabilizację i stagnację rozwoju miast. Rozpoznanie tych procesów ukrytych, a być może jednocześnie już długotrwałych, narastających latami w danym środowisku miejskim, jest, a w każdym razie powinno być, podstawowym zadaniem urbanistyki przyszłości. Zbyt rzadko niestety dostrzegamy, że człowiek - mieszkaniec miasta - jest również elementem jego przestrzeni i to elementem bardzo istotnym, jeśli nie siedzi przed telewizorem lub nie jest „ukryty” w swoim pokoju (Gehl 2013). Zachowania społeczne (jakżeż są ważne!) dostrzeżemy, kiedy zauważymy, jak umiejętnie są wpisane chociażby w procesy funkcjonowania wielkich centrów handlowych i supermarketów. Miasto przecież to wizerunek społecznego piękna, jak chce nam powiedzieć S. Gzell w swoich szkicach O architekturze (Gzell 2014).

Zdefiniowania tych procesów, nowej tożsamości społeczno-przestrzennej w skali makro, możemy poszukiwać na przykład poprzez dyspersję zachowań masowych i ich zatomizowanie w warunkach laboratoryjnych. W tym celu należałoby skonstruować laboratorium społecznych procesów miejskich - laboratorium miasta reaktywnego. Eksperyment ten można byłoby przeprowadzić, powołując do życia serię wirtualnych modeli miasta powtarzalnego, uzupełnioną mapami emocjonalnymi przestrzeni miejskiej wygenerowanymi w wyniku przeprowadzenia wywiadów pogłębionych $\mathrm{z}$ mieszkańcami. Modele te, jako 
przygotowane do przeprowadzenia eksperymentu, byłyby identyczne, tak jak identyczne mamy współczesne produkty przemysłowe (takie jak samochód, telewizor, pralka). Poprzez uruchomienie serii odpowiednich procesów psycho-przestrzennych może nastąpić ujawnienie mechanizmów różnicowania się zachowań i aktywności ludzkich, co może zaowocować przywróceniem w miastach tożsamości sąsiedzkiej.

Sama idea miasta powtarzalnego, co warto przypomnieć, pojawiła się stosunkowo dawno, bo już w Utopii T. Morusa (1516) (Morus 1946), lecz była tam jedynie figurą retoryczną, a nie przestrzenną, szczególną postacią egalitaryzmu. Formułę przestrzenną miasta powtarzalnego znaleźć można natomiast $\mathrm{w}$ rozwiązaniach miast liniowych okresu awangardy w Rosji przełomu lat 20. XX wieku i później już w okresie ZSRR (Kwiatkowski 2013). Jednak nie dały one pozytywnych rezultatów, między innymi dlatego, że priorytetami rozwoju tych miast były wówczas potrzeby wzrostu produkcji przemysłowej i skrajny racjonalizm w wykorzystaniu energii, nie natomiast definiowanie zachowań ludzkich (Khan-Magomedov 2009).

W wyniku takiego eksperymentu można oczekiwać szansy na zdefiniowanie i zlokalizowanie barier powodujących zanikanie społecznych aktywności miejskich. Można oczekiwać również wskazania dróg wyjścia z impasu, w którym znalazło się miasto współczesne, co jeśli nastąpi, byłoby wystarczającą miarą sukcesu takiego przedsięwzięcia.

\section{Bibliografia:}

Alexander, Christofer. 2008. Język wzorców, tłum. Aleksandra Kaczanowska, Karolina Maliszewska i Małgorzata Trzebiatowska. Gdańsk: GWP.

Fishman, Robert. 1977. Urban Utopias in the Twentieth Century: Ebenezer Howard, Frank Lloyd Wright, and Le Corbusier. New York: Basic Books, Inc. Publishers.

Gehl, Jan et al. 1977. The Interface Between Public and Private Territories in Residential Areas. Melbourne: Melbourne University.

Gehl, Jan. 2006. New City Life. Danish Architectural Press.

Gehl, Jan. 2013. Życie między budynkami. Użytkowanie przestrzeni publicznych, tłum. Marta A. Urbańska. Kraków: RAM.

Gehl, Jan. 2014. Miasta dla ludzi, tłum. Szymon Nogalski. Kraków: RAM. 
Gzell, Sławomir. 2014. O architekturze. Szkice pisane i rysowane. Warszawa: Blue Bird.

Habitat I. 1976. The Vancouver Conference of Human Settlements. Vancouver: ONZ (UN).

Harvey, David. 2008. Neoliberalizm. Historia katastrofy, tłum. Artur Domosławski. Warszawa: Instytut Wydawniczy Książka i Prasa.

Harvey, David. 2012. Bunt miast. Prawo do miasta i miejska rewolucja, tłum. Agnieszka Kowalczyk et al. Warszawa: Fundacja Bęc Zmiana.

Höjer Mattias, Anders Gullberg i Ronny Pettersson. 2007. Images of the Future City. Stockholm: Spriger.

Howard, Ebenezer. 1970. Sir Ebenezer Howard and the Town planning Movement, compiled and written by Dugald Macfadyen. Manchester: University Press.

Huntington, Samuel P. 1996. The Clash of Civilizations? New York: Simon and Schuster (polski przekład: Huntington, Samuel P. 1998. Zderzenie cywilizacji, tłum. Hanna Jankowska. Warszawa: MUZA).

Jacobs, Jane. 2011. The Death and Life of Great American Cities. New York: Modern Library.

Khan-Magomedov,Selim O.2009.Михаил Охитович.Издательство Твориы Авангарда. Москва: Фонд «Русский Авнгард».

Koolhaas, Rem. 2006. 2004. Junkspace. W: Theories and Manifeststoes of contemporary architecture, edited by Charles Jencks i Karl Kropf, 370372. Nowy Jork: Wiley Academy.

Kwiatkowski, Jacek. 2013. Oko pod kontrole dotyku duszy. Suprematyzm we wspótczesnym dyskursie intelektualnym. Warszawa: Zakład Graficzny Uniwersytetu Warszawskiego.

Morus, Thomas. 1946. Utopia, tłum. Kazimierz Abgarowicz. Kraków: Instytut Wydawniczy Kultura.

Ostrowski, Wacław. 1973. Urbanistyka wspótczesna. Warszawa: Arkady.

Pinterest.com. 2016. Dostęp: 7.09.2016. https://www.pinterest.com/ johorrocksnz/communitycity-resilience/.

Urban Spaces No.5. Featuring Green Design Strategies, red. John M. Dixon. 2007. New York: A Visual Reference Publications Inc. 
Krzysztof Biernat

Uniwersytet Kard. Stefana Wyszyńskiego w Warszawie - Wydział Filozofii Chrześcijańskiej Przemysłowy Instytut Motoryzacji, Warszawa

k.biernat@uksw.edu.pl

\section{Biogospodarka jako zintegrowany sektor przemysłowy Europy}

\section{Wprowadzenie}

W wyniku przeglądu wdrożeń i prac badawczych prowadzonych w krajach UE (Unii Europejskiej), zmierzających do intensyfikacji procesów wykorzystywania OZE (odnawialnych źródeł energii) okazało się, że prace te mają charakter rozproszony i nie przynoszą spodziewanego efektu, zarówno $\mathrm{w}$ aspekcie środowiskowym jak również w aspekcie oszczędności przetwarzania energii. $Z$ tego względu powstała wizja przemysłu bazującego na surowcach pochodzenia biologicznego, do których także zakwalifikowano odpadowe substancje $\mathrm{z}$ pierwotnych i wtórnych procesów wykorzystywania i przetwarzania biomasy zdefiniowanej $\mathrm{w}$ dyrektywie $\mathrm{w}$ sprawie promowania stosowania energii ze źródeł odnawialnych (Dyrektywa 2009/28/WE). Realizacja tej wizji powinna poprowadzić do przejścia w kierunku tak zwanego społeczeństwa „post-naftowego" poprzez wyraźne oddzielenie wzrostu gospodarczego od wyczerpywania zasobów i wpływu na środowisko.

Po konsultacjach przeprowadzonych w krajach członkowskich określono potrzebę wydzielenia nowej gałęzi przemysłowej określonej jako przemysł bazujący na surowcach pochodzenia biologicznego (Bio-based Industries) (Bridge 2020 2012), który powinien dążyć do optymalizacji wykorzystania gruntów i bezpieczeństwa żywności poprzez zrównoważone, wydajne (efektywne) surowcowo i w znacznym stopniu ograniczające ilość powstających odpadów, przetwórstwo przemysłowe europejskich surowców odnawialnych w szeroką gamę produktów pochodzenia biologicznego, typu: zaawansowane paliwa transportowe; chemikalia; materiały; składniki żywności i pasz; energię. Dzięki temu „bioprzemysł”, stanowiący główny element gospodarki UE określany mianem „biogospodarki” (bioeconomy), będzie odgrywać ważną rolę 
w pobudzaniu zrównoważonego wzrostu i zwiększeniu konkurencyjności Europy poprzez ponowne uprzemysłowienie i rewitalizację obszarów wiejskich, zapewniając $w$ ten sposób dziesiątki tysięcy miejsc pracy z zakresu badań, rozwoju i produkcji w ciągu następnej dekady.

Program biogospodarki dla Europy ma być programem ewolucyjnym. Przewiduje się opracowanie tak zwanych łańcuchów wartości ( $v a-$ lue chains), których realizacja doprowadzi w efekcie do powstania tak zwanych „biorafinerii”, które w kompleksowy i bezodpadowy sposób przetwarzać będą biomasę. Najważniejsze wyzwania technologiczne, polityczne i rynkowe stać zatem będą przed procesem komercjalizacji innowacyjnych rozwiązań na pełną skalę. Wyzwania te nie mogą być przezwyciężone przez poszczególne firmy lub przemysł rozproszony, a więc konieczne jest ujęcie systemowe całej gospodarki biomasą. Jest to szczególnie ważne ze względu na konieczność odwrócenia obecnej tendencji znaczących inwestycji biogospodarczych $\mathrm{w}$ regionach pozaeuropejskich, w których warunki wydają się być bardziej atrakcyjne. Program długoterminowych badań i innowacji finansowany wspólnie przez podmioty publiczne i prywatne może pomóc $\mathrm{w}$ rozwiązaniu tego problemu. Proces ten będzie realizowany poprzez tworzenie i realizację właściwych łańcuchów wartości, co doprowadzi do zmniejszania ryzyka inwestycji w projekty demonstracyjne z zakresu wdrażania procesów innowacyjnych.

Polska jest postrzegana jako ważny kraj dla realizacji programu „Biogospodarka dla Europy” między innymi ze względu na relatywnie wysokie zasoby biomasy. Udział polskich przedsiębiorców i jednostek naukowo-badawczych w tym programie może przyczynić się do intensyfikacji procesów pozyskiwania biomasy i rozwoju technologii jej przetwarzania, co może przynieść wymierne korzyści środowiskowe i społeczne. Dlatego też podstawowym celem, który przyświecał opracowaniu niniejszego materiału, było możliwie szerokie przedstawienie założeń, planowanego zakresu i możliwych korzyści z wydzielenia biogospodarki jako odrębnej gałęzi przemysłowej mieszczącej się całkowicie w gospodarce o obiegu zamkniętym. 


\section{Sposób realizacji zamierzeń sektora biogospodarki}

Doświadczenia europejskie wykazały, że nawet słuszne założenia określone w polityce państw UE, niezbędne dla realizacji celów gospodarczych uwzględniających uwarunkowania środowiskowe, w tym klimatyczne i społeczne, nie doprowadzą do realizacji tych celów bez akceptacji społecznej i pozyskania odpowiednio dużej grupy interesariuszy. Dlatego też do realizacji zdefiniowanych łańcuchów wartości i ich modyfikacji wybrano formę PPP (Partnerstwa Publiczno-Prywatnego), uwzględniającego zarówno interes społeczny jak i dążenie interesariuszy do ukierunkowanego rozwoju ich przedsiębiorstw i osiągania zysku. Partnerstwo Publiczno-Prywatne na rzecz biogospodarki planowane jest więc jako podstawowe i zintegrowane narzędzie Programu „Horyzont 2020”. PPP ma koncentrować się na rozwoju łańcuchów wartości w UE oraz stymulować i przyspieszać przejście do zaawansowanych surowców w biorafineriach.

Partnerstwo Publiczno-Prywatne obejmować będzie:

1. Budowę nowych łańcuchów wartości opartych na rozwoju zrównoważonych systemów zbiórki i dostaw biomasy o zwiększonej wydajności i lepszym wykorzystaniu surowca z biomasy (w tym kogeneracji i zagospodarowania produktów ubocznych), przy jednoczesnym wykorzystaniu i waloryzacji odpadów i biomasy.

2. Dostosowanie istniejących łańcuchów wartości do nowego poziomu poprzez optymalizację wykorzystania surowców i przemysłowych strumieni bocznych, przy jednoczesnym oferowaniu innowacyjnych produktów o wartości dodanej; tym samym stworzenie popytu na rynku oraz wzmocnienie konkurencyjności rolnictwa i przemysłu leśnego UE.

3. Doprowadzenie technologii do stanu zaawansowania poprzez badania i innowacje, a także poprzez modernizację i budowę demonstracyjnych i flagowych instalacji biorafineryjnych, które już przetwarzają biomasę w kierunku otrzymywania innowacyjnych produktów pochodzenia biologicznego.

Uwzględniając fakt ograniczoności zasobów biomasy i potrzeby jej przetwarzania przez przemysł rolno-spożywczy, należy wdrażać proce- 
sy technologiczne w taki sposób, aby nie ograniczać wytwarzania żywności o odpowiedniej jakości oraz ilości. Realizując postawione cele, zgodnie z przyjętymi łańcuchami wartości, PPP ma zapewnić dostępność trwałych i bezpiecznych dostaw biomasy, zarówno do zastosowań spożywczych i pasz, jak i w odniesieniu do produkcji chemikaliów, materiałów, paliw i energii. Konieczne jest także zwiększanie produktywności wydajności biomasy $\mathrm{z}$ europejskich gruntów rolnych i lasów, jednak w sposób zrównoważony, z jednoczesnym wykorzystywaniem potencjału pozostałości i strumieni ubocznych, a także odpadów. Aktualnie pożądane są prace nad optymalizacją procesów wykorzystania istniejącego surowca (biomasy leśnej i rolnej) oraz rozwoju nowych łańcuchów dostaw surowca (np. odpadów leśnych, odpadów rolnych, lignocelulozowych lub specjalnych upraw), a także wykorzystanie strumieni bocznych organicznych odpadów przemysłowych i komunalnych. Zapewnienie nowych rynków dla producentów biomasy wzmocni gospodarki wiejskie i pozwoli na dalszy rozwój i inwestycje w zrównoważonym systemie produkcyjnym. Ponieważ efektywne procesy przekształcania biomasy i odpadów biodegradowalnych nie zostały jeszcze opracowane w sposób umożliwiający ich komercjalizację, to poprzez PPP planuje się rozwiązanie tych problemów do 2020 r., które mają zapewnić: prowadzenie dalszych prac badawczych oraz tworzenie technologii demonstracyjnych.

PPP opierać się ma na silnych przedsiębiorstwach przemysłu rolnego, rolno-spożywczego, leśnictwa i przemysłu papierniczego oraz wiodących firmach z zakresu hodowli roślin, biotechnologii, chemii, energetyki i inżynierii bioprocesowej. Z tych powodów wybór właściwych partnerów przemysłowych, realizujących bardzo istotne elementy programu biogospodarki w ramach PPP, ma ogromne znaczenie dla zagwarantowania powodzenia $\mathrm{w}$ realizacji założonych łańcuchów wartości. W obszarze bioprzemysłu - BBI (Bio-based Industries) planowane jest także wykorzystywanie wiedzy i umiejętności środowisk akademickich, jednostek i organizacji badawczych.

\section{Agenda Strategicznych Innowacji i Badań (SIRA)}

W ramach prac przygotowawczych do uruchomienia działalności europejskiej z zakresu biogospodarki opracowano Plan Strategicznych Innowacji i Badań (SIRA - Strategic Innovation and Research Agenda). 
Dokument ten proponuje spójny zestaw działań, które powinny być realizowane poprzez utworzone konsorcjum BIC (Biobased Industry Consortium), a mianowicie:

- realizację projektów zmierzających w kierunku integracji i wdrażania technologii oraz wyników badań naukowych i wprowadzenie technologii na skalę komercyjną przez wdrażanie projektów demonstracyjnych i flagowych;

- realizację projektów rozwojowych ukierunkowanych na wypełnienie luk w badaniach i innowacjach technologicznych;

- wspieranie projektów podejmujących wyzwania międzysektorowe. Łańcuchy wartości zostały schematycznie przedstawione na rys.1
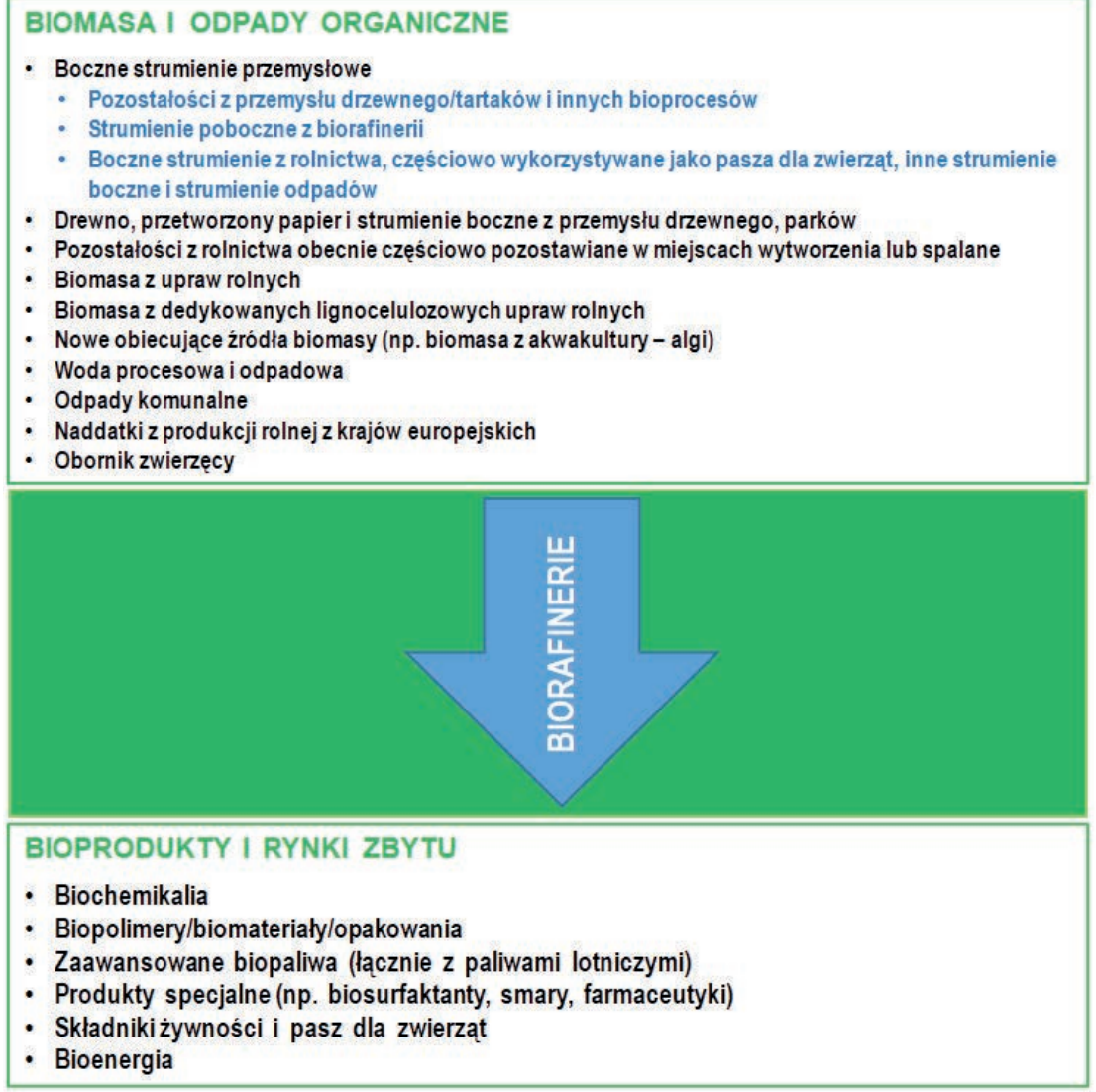

Rys.1. Łańcuchy wartości w biogospodarce (SIRA 2013). 
W Agendzie Strategicznych Innowacji i Badań (SIRA) zdefiniowano te łańcuchy w następujący sposób:

1. Od wsadu lignocelulozowego do zaawansowanych biopaliw, substancji chemicznych i biomateriałów poprzez dobór bazy surowcowej i technologii dla nowej generacji paliw, chemikaliów i materiałów.

2. Wykorzystanie pełnego potencjału biomasy leśnej poprzez racjonalizację zalesień i wrębów oraz tworzenie nowych rynków i produktów o wartości dodanej.

3. Wykorzystywanie agrosurowców umożliwiające trwałość produkcji poprzez efektywną produkcję rolną oraz nowe rynki i produkty o wartości dodanej.

4. Zagospodarowanie odpadów dzięki realizacji zrównoważonych technologii do przetwarzania odpadów na wartościowe produkty.

5. Zintegrowane biorafinerie jako sposoby zrównoważonej produkcji bioenergii, w tym biopaliw, biomateriałów, biochemikaliów itp.

Pierwszy łańcuch wartości obejmuje nowe lub ulepszone dochodowo lignocelulozowe źródła biomasy o wyższej wydajności w produkcji (nawozów, wykorzystania wody, logistyki) i/lub poprawie właściwości przetwórczych w biorafineriach. Spowoduje to zmniejszenie ilości odpadów przemysłowych i poprawę oddziaływania na środowisko, przyczyniając się do zmniejszenia presji na zasoby naturalne, a także europejskiego uzależnienia od importu oraz do zwiększenia rozwoju wsi. Zostaną stworzone zachęty finansowe sprzyjające wyższym dochodom rolników i właścicieli lasów produkujących biomasę po konkurencyjnej cenie. Łańcuch ten powinien zakończyć się demonstracją zaawansowanych technologii hydrolizy i konwersji lignocelulozy.

Cele drugiego łańcucha wartości zostaną osiągnięte poprzez stworzenie z bieżącej bazy surowcowej nowych produktów o wartości dodanej poprzez zwiększenie mobilizacji surowców (odpadów leśnych) oraz poprawienie wykorzystania ubocznych i odpadowych strumieni. W tym celu zostaną wdrożone nowe innowacyjne i wydajne technologie, opracowane innowacyjne produkty oraz produkty uboczne i pozostałości, a także przeprowadzona waloryzacja strumieni bocznych. Poprawi to konkurencyjność europejskich łańcuchów wartości opartych 
na przemyśle leśnym przy jednoczesnym zmniejszeniu presji na zasoby biomasy. Produkty z tego łańcucha wartości mają znacznie mniejsze oddziaływanie na zmiany klimatyczne i realizują wymianę materiałów kopalnych na materiały oparte na biosurowcach z pozytywnym wpływem społecznym. Spełni to zarówno wymagania rynkowe jak i konsumenckie oraz stworzy nowe rynki, dzięki demonstracji ścieżek i koncepcji przetwórstwa nowych innowacyjnych materiałów w nowe produkty.

Trzeci łańcuch wartości zostanie osiągnięty poprzez stworzenie większej ilości produktów o wartości dodanej z aktualnej bazy surowcowej dzięki zwiększeniu produkcji surowców i elastyczność oraz lepsze wykorzystanie strumieni bocznych i pozostałości. Ponadto nowe i udoskonalone dochodowo uprawy o wyższej wydajności w produkcji (stosowanie nawozów i wody, logistyka) spowodują zmniejszenie odpadów przemysłowych i poprawę oddziaływania na środowisko. Dla istniejących i nowych upraw wprowadzane będą innowacyjne i wydajne technologie uprawy, zbioru i logistyki, opracowane zostaną innowacyjne produkty wraz z wykorzystaniem produktów ubocznych i waloryzowaniem pozostałości.

Rozwój i demonstracja łańcuchów wartości w oparciu o aktualnie nieużywane strumienie (poboczne) i odpady z różnych źródeł pochodzenia biologicznego (rolnictwo, leśnictwo, gospodarka ściekowa, osady, komunalne odpady organiczne, odpady ogrodowe, odpady przetwórstwa spożywczego itd.), stanowią cel realizacji czwartego łańcucha wartości. Koszty realizacji konkurencyjnych łańcuchów wartości wytwarzających produkty o wartości dodanej przyczynią się do stworzenia rozwiązań dla środowiskowego problemu stale rosnących przepływów odpadów (częściowo z powodu urbanizacji), zmniejszając jednocześnie presję na nieprzetworzone zasoby naturalne oraz zwiększając konkurencyjność przemysłu.

Realizacja piątego łańcucha wykazać powinna poprawę stabilności i ekonomiki produkcji bioenergii przez konwersję i integrację działania biorafinerii. Tworzenie całego szeregu produktów o wartości dodanej oraz bioenergii z surowców pozwoli na pełne wykorzystanie biomasy, łącznie z niewykorzystywanymi dotychczas zasobami biomasy i spowoduje wzrost konkurencyjności biogospodarki.

Koncepcję tworzenia łańcuchów wartości w programie „Biogospodarka dla Europy" przedstawiono na rys. 2. 


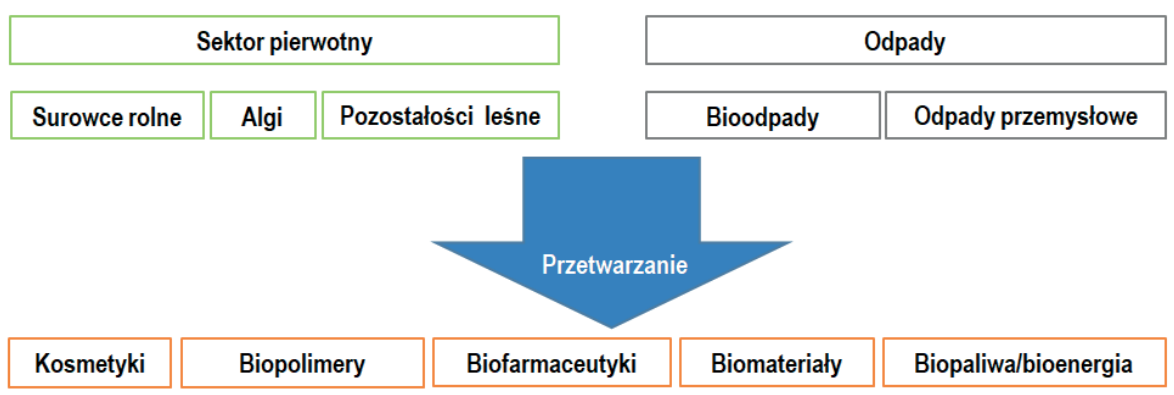

Rys.2. Przykłady łańcuchów wartości bazujących na odnawialnych zasobach energii (Rogulska et al. 2016).

Realizacja tych łańcuchów wartości powinna także przyczynić się do zintensyfikowania tak zwanej produkcji pierwotnej. A zatem powinien nastąpić, według przyjętych założeń, proces ewoluowania całej gospodarki w stosunku do posiadanych zasobów surowcowych. Proces ten poglądowo przedstawiono na rys. 3 .

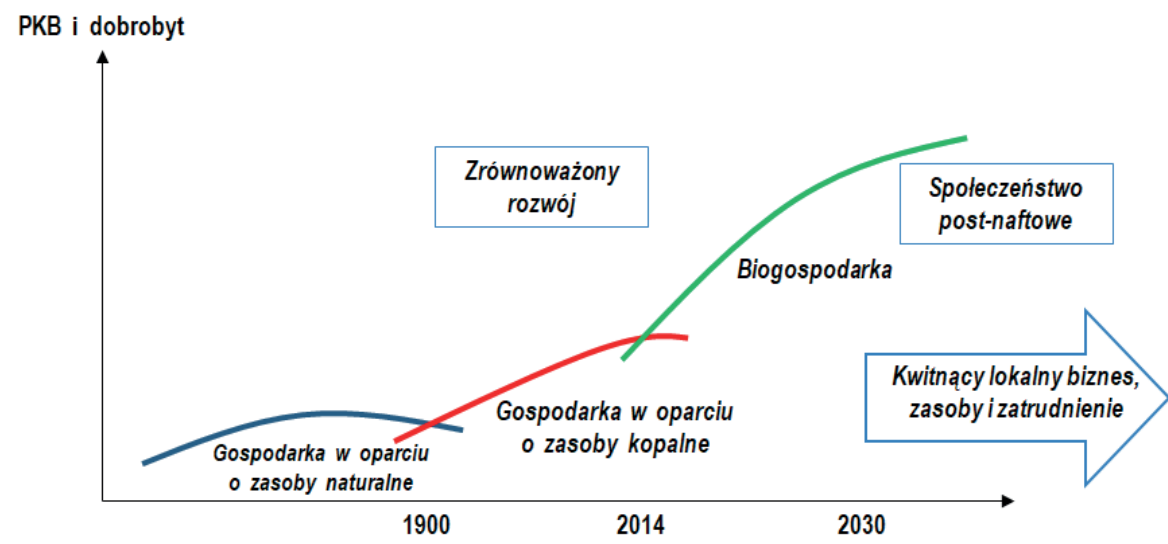

Rys. 3. Ewaluacja rozwoju gospodarczego w odniesieniu do posiadanych zasobów (Nova-Institute 2016).

Jak już wspomniano, proponowane łańcuchy wartości ujmują biomasę jako podstawowe źródło surowcowe w biogospodarce, określanej także jako „zielona gospodarka” (green economy). Jednak według Mię- 
dzynarodowej Agencji Energii, z raportu IEA Bioenergy, Task 42, Biorefineries (Scarlat et al. 2015) wynika, że dla zapewnienia możliwości spełnienia tak zwanych Narodowych Celów Wskaźnikowych w zakresie zastępowania paliw konwencjonalnych biopaliwami pochodzącymi z biomasy Europa jest drugim regionem świata poza Japonią, który musi importować biomasę jako surowiec do produkcji tych paliw. Niezależnie od tego, nie jest jednoznacznie wiadome, jaki udział biomasy odpadowej z naturalnych procesów przyrodniczych może być wykorzystywany jako surowiec do procesów biogospodarczych bez stwarzania zagrożeń środowiskowych dla prawidłowego przebiegu tych procesów. Stąd też w zakresie nośników energii rozważane są inne, poza bezpośrednio przyrodniczymi, źródła biomasy odpadowej jako głównego surowca, to jest odpadowa biomasa $\mathrm{z}$ procesów przemysłowych, $\mathrm{w}$ tym odpady biodegradowalne z rolnictwa, gospodarki drzewnej, przemysłu spożywczego itp. Z tego samego powodu proponuje się zintensyfikowanie rozwoju technologii produkcji innych paliw alternatywnych (poza biopaliwami), które mogą umożliwić bardziej efektywne wykorzystanie biomasy jako surowca deficytowego, głównie do produkcji półproduktów i produktów o wysokiej wartości dodanej, zastępujących, a następnie wypierających pochodne ropy naftowej i węgla.

W zakresie koncepcji rozwoju gospodarczego krajów wysoko uprzemysłowionych, dla spełnienia wymagań związanych z rozwojem trwałym uwzględniającym wymagania środowiskowe, proponuje się tworzenie gospodarki o tak zwanym obiegu zamkniętym (circular economy), który ma polegać na pełnym zamknięciu cyklu życia produktu charakteryzowanego analizą LCA (life cycle assessment) dla tego produktu. W skrócie można zdefiniować ten cykl jako następujące po sobie procesy: pozyskania surowców, produkcji, eksploatacji, utylizacji odpadu poeksploatacyjnego, czyli od "kołyski do grobu” CtG (cradle to grave). Gospodarka w obiegu zamkniętym proponuje cykl CtC (cradle to cradle), polegający na ponownym wykorzystaniu odpadów poeksploatacyjnych w celu wytworzenia nowego produktu (nowych produktów). Takie podejście powodować będzie: ograniczenie zużycia surowców, zmniejszenie ilości składowanych odpadów oraz zwiększenie strumienia odpadów wykorzystywanych w ramach odzysku i recyklingu. Przebieg 
takiego cyklu został zilustrowany w kilku współczesnych publikacjach, przy czym za interesujący można uznać gospodarczy obieg zamknięty. W takim ujęciu biogospodarka oznaczać może znacznie więcej niż gospodarka o obiegu zamkniętym, ponieważ rolnictwo, leśnictwo oraz rybołówstwo, czyli pierwotne sektory gospodarki, są źródłem produkcji surowca, czyli biomasy. Zgodnie z przewidywanymi łańcuchami wartości procesów biogospodarczych, odpadowa biomasa powinna być przetwarzana przede wszystkim na produkty o wartości dodanej, takie jak: żywność i pasze, chemikalia i materiały, z których wytwarzane są bioprodukty, oraz biopaliwa i bioenergia otrzymywane z pozostałości niemożliwej do wykorzystania przy współczesnym poziomie opłacalności technologicznej. $Z$ tego powodu uprawniona jest teza, że biogospodarka oznacza więcej niż gospodarka o obiegu zamkniętym, co ilustruje rys. 4 . 


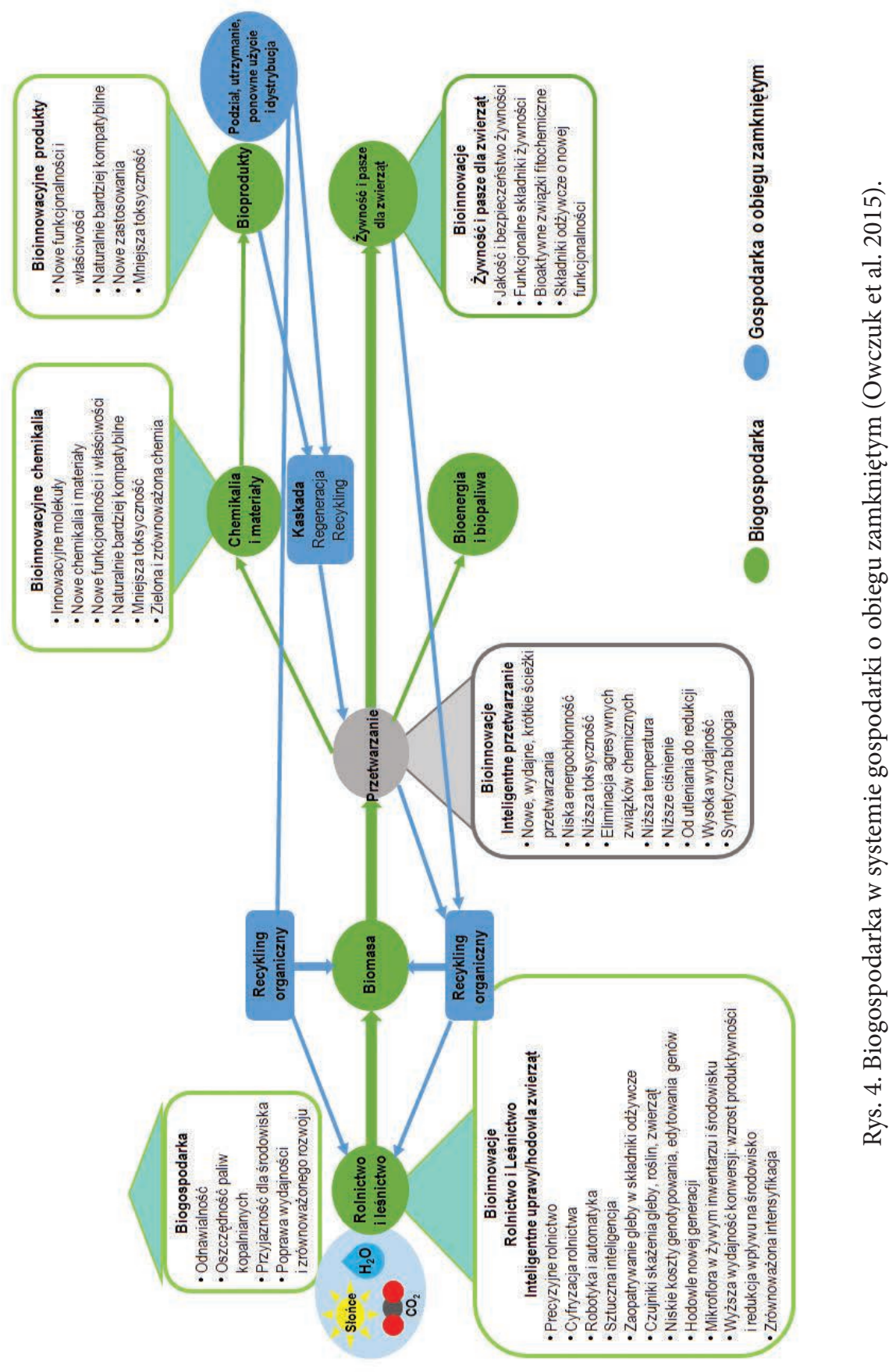


Jak przedstawiono na rys.1, wszystkie łańcuchy wartości prowadzą do uzyskania produktów o wysokiej wartości dodanej poprzez tak zwane procesy biorafineryjne. Procesy te prowadzą do uzyskania przy pomocy różnych wariantów technologicznych substytutów mieszanin węglowodorowych, z których przy pomocy różnych procesów technologicznych możliwa jest synteza lub komponowanie pożądanych produktów. Z przeprowadzonej analizy wynika, że możliwe jest uzyskanie wielu produktów o pożądanej i wysokiej wartości dodanej, co przedstawiono na rys. 5.

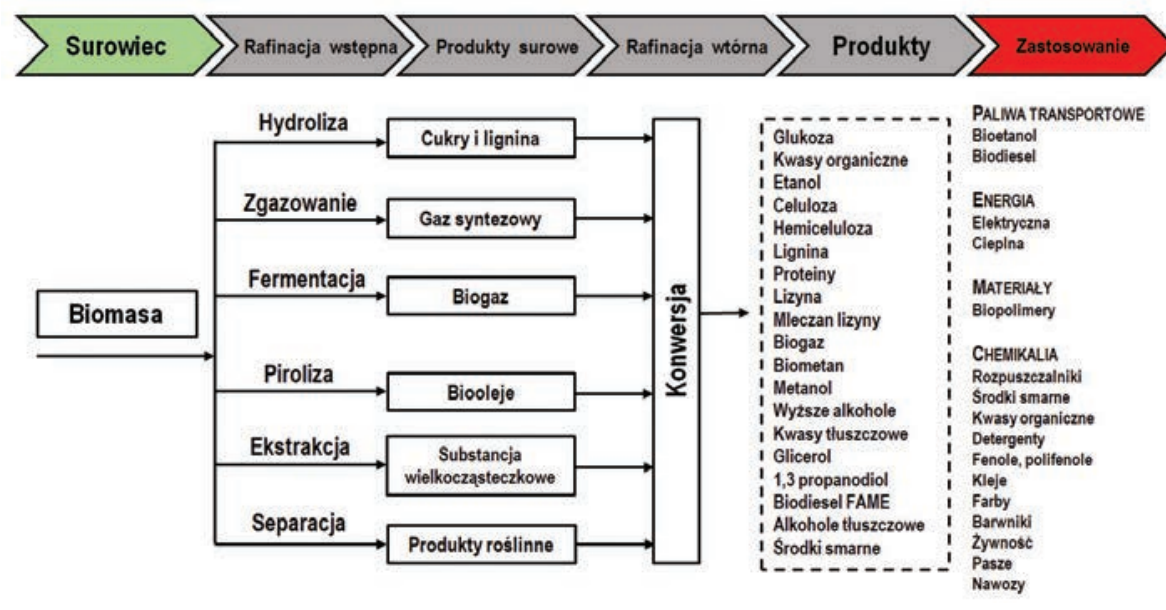

Rys. 5. Ścieżki technologiczne otrzymywania produktów z procesów biorafineryjnych (Szwach i Kulesza 2015).

Procesy biorafineryjne w kontekście przestrzegania zasady optymalnego wykorzystywania zasobów pochodzących $\mathrm{z}$ tak zwanych źródeł odnawialnych zostały szeroko omówione w fińskiej strategii biogospodarki (FBS 2014). Aktualny stan postępu w zakresie technologii oceniany na podstawie bibliografii zawartej w opracowaniach krajowych i europejskich opisujących procesy biorafineryjne (FBS 2014; Biernat i Grzelak 2015; IEA Task 42) - przy czym fińska strategia biogospodarki (FBS 2014) obejmuje także termodynamiczne aspekty przekształcenia biomasy jako źródła naturalnego - oraz prac własnych pozwalają 
na określenie podstawowych i pożądanych kierunków technologicznego wykorzystywania biomasy (odpadowej) zgodnie z przeprowadzaną wstępną analizą LCA, co zostało przedstawione na rys. 6 .

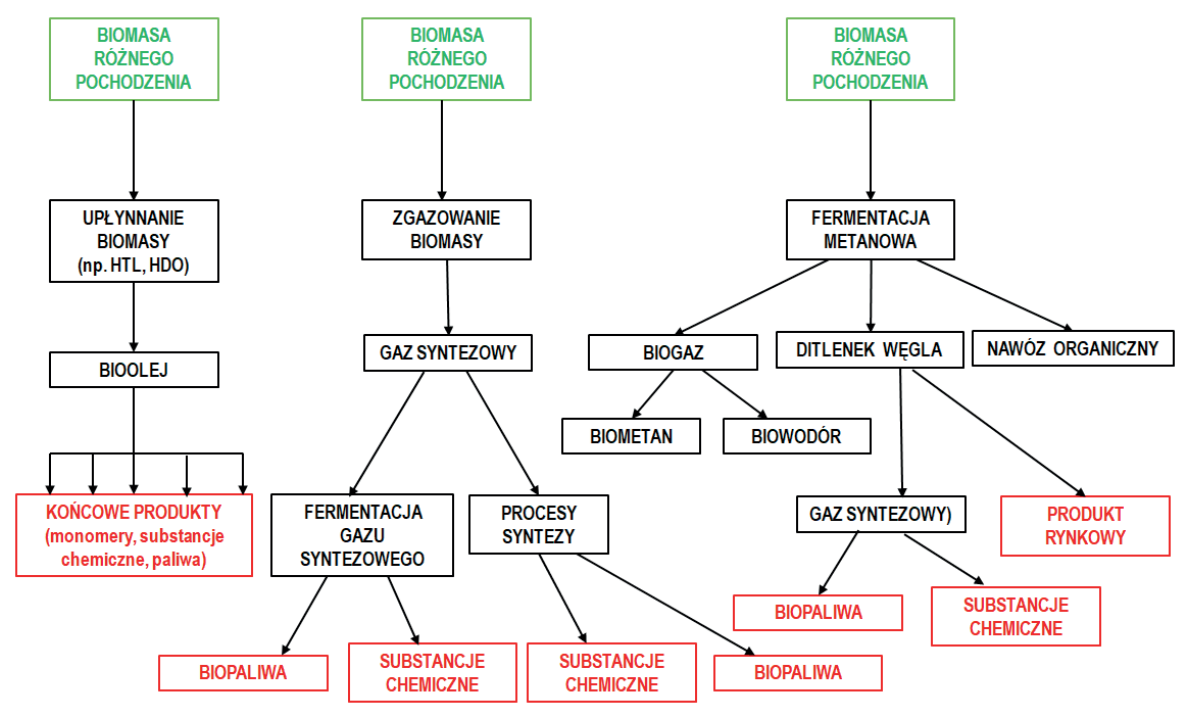

Rys. 6. Współcześnie możliwe kierunki konwersji biomasy w procesach biogospodarczych (IEA Task 42).

Jak wynika z rys. 6, aktualnie istnieją trzy ścieżki wykorzystywania odpadowej biomasy. Pierwsza $\mathrm{z}$ tych ścieżek proponuje przekształcenie biomasy w tak zwana „biosurówkę”, mającą cechy pra-ropy naftowej. Nie wnikając w złożoność dalszych procesów, możliwe jest przekształcanie biosurówki (biooil) w produkty analogiczne do produktów uzyskiwanych z ropy naftowej porównywalnymi technologiami. Druga ścieżka to zgazowanie biomasy, w wyniku którego możliwe są procesy fermentacji gazu syntezowego prowadzące także do powstania struktur izoprenowych oraz do uzyskiwania w procesach dalszej syntezy różnego rodzaju związków chemicznych, a także biopaliw. Ścieżka trzecia polega na wykorzystaniu procesów fermentacji metanowej, co ma istotne znaczenie w wielu procesach wykorzystywania odpadowej biomasy z procesów rolniczych i gospodarki ściekowej. 


\section{Podsumowanie}

Proponowane działania mogą przyczynić się do zwiększenia wykorzystania gruntów, dotychczas niewykorzystanych do 15\% w 2020 r. i $35 \%$ w roku 2030. Spowoduje to $10 \%$ wzrost podaży biomasy w Europie w 2020 r. (20\% w 2030 roku). Wyniki realizacji programu biogospodarczego mogą także przyczynić się do utrzymania i dalszego rozwoju konkurencyjnej gospodarki wiejskiej w Europie opartej na wiedzy i do stworzenia do 400000 nowych wykwalifikowanych miejsc pracy w $2020 \mathrm{r}$. (700000 w 2030 r.), z czego ponad 80\% na obszarach wiejskich, stosunkowo słabo rozwiniętych.

Program „Biogospodarka dla Europy” przyczyni się do stopniowego zastępowania oleoproduktów bioproduktami, tak aby:

- $20 \%$ produkcji chemikaliów i materiałów w Europie do 2020 r. pochodziło z biomasy ( $30 \%$ do 2030 r.);

- do 2020 r. co najmniej 2\% zapotrzebowania energii w transporcie w Europie zostało zaspokojone zaawansowanymi biopaliwami (25\% w $2030 \mathrm{roku})$.

Spełnienie tych podstawowych celów wymaga uwzględnienia następujących uwarunkowań, stanowiących wnioski z przeprowadzonych rozważań:

1. Należy oszacować ilość dostępnej biomasy dla procesów biogospodarczych z uwzględnieniem biomasy niezbędnej dla naturalnych procesów środowiskowych.

2. Wszystkie łańcuchy wartości prowadzą przez systemy biorafineryjne, dlatego konieczny jest rozwój tych systemów uwzględniający konieczność kompleksowego przetwarzania biomasy.

3. Nie jest zasadna budowa rozproszonych elementów systemów przetwarzania biomasy, ponieważ może to powodować zwiększenie zapotrzebowania energetycznego i większe emisje.

4. Kompletny system biorafineryjny powinien obejmować całkowity przerób biomasy dedykowanej temu systemowi w procesie technologicznym optymalnym dla zdefiniowanego surowca.

5. Z technologicznego punktu widzenia, każdy z systemów przetwarzania biomasy, niezależnie od rodzaju i ilości produktów o wartości 
dodanej, powinien uwzględniać możliwość wytwarzania biopaliw, jak to pokazano na rys.6.

Udział w programie BBI (Bio-based Industries) jest możliwy dla wszystkich europejskich podmiotów gospodarczych, którzy zgłoszą akces członkowski do BIC (Bio-based Industry Consortium). Ośrodki akademickie, jednostki badawczo-rozwojowe oraz platformy technologiczne i klastry mogą być członkami stowarzyszonymi. Szczegółowe warunki uczestnictwa zawarte są we wniosku Rozporządzenia Rady Europejskiej w sprawie ustanowienia Wspólnego Przedsięwzięcia na rzecz Bioprzemysłu (EC, COM 2013). Na realizację działalności w ramach BBI, uwzględniając środki programu Horyzont 2020, planowana jest kwota wynosząca 3,8 mln euro.

\section{Bibliografia:}

Biernat, Krzysztof i Paulina L. Grzelak. 2015. Biorefinery Systems as an Element of Sustainable Development. W: Biofuels - Status and Perspective, red. Krzysztof Biernat, Zagrzeb: InTech.

Bridge 2020. 2012. Accelerating Innovation and Market Uptake of Biobased Products. The European Public-Private Partnership on Biobased Industries. Dostęp: 18.04.2017. https://biobs.jrc.ec.europa.eu/ sites/default/files/generated/files/policy/Bridge\%202020\%20Vision\%20 Paper\%20july\%202012.pdf.

Dyrektywa Parlamentu Europejskiego i Rady 2009/28/WE z dnia 23 kwietnia 2009 r. w sprawie promowania stosowania energii ze źródeł odnawialnych zmieniająca i w następstwie uchylająca dyrektywy 2001/77/WE oraz 2003/30/WE.

EC, COM. 2013. Proposal for a Council Regulation on the "Bio-Based Industries Undertaking”. Brussels.

FBS - Finnish Bioeconomy Strategy. 2014. Dostęp: 18.04.2017. http://www. bioeconomy.fi/implementation-of-the-finnish-bioeconomy-strategy/.

IEA Task 42. IEA Bioenergy Task 42 Biorefining. Dostęp: 19.04.2017. http://www.iea-bioenergy.task42-biorefineries.com/en/ieabiorefinery.htm.

Nova-Institute. 2016. Dostęp: 18.04.2017. http://bio-based.eu/graphics. 
Owczuk, Marlena, Magdalena Rogulska i Dorota Bogumił.2011. Perspektywy rozwoju technologii biorafineryjnych. Chemik, 69 (11), 749-758.

Rogulska, Magdalena et al. 2017. Monitorowanie rozwoju sektora „Biogospodarka”. Warszawa: Przemysłowy Instytut Motoryzacji.

Scarlat, Nicolae et al. 2015. The role of biomass and bioenergy in a future bioeconomy: Policiesand facts. Environmental Development, 3-34.

SIRA - Strategic Innovation and Research Agenda. 2013. Biobased and Renewable Industries for Development and Growth in Europe. Brussels.

Szwach, Iwona i Renata Kulesza. 2014. Potencjał biomasy w aspekcie otrzymywania wybranych surowców i produktów chemicznych. Chemik, 68 (10), 893-900. 
Kamila Radlińska

Politechnika Koszalińska - Wydział Nauk Ekonomicznych

kamila.radlinska@tu.koszalin.pl

\section{Ekonomiczne aspekty budownictwa energooszczędnego i pasywnego w Polsce}

\section{Wstęp}

Wzrost świadomości społeczeństwa doprowadził do zwiększenia zapotrzebowania na budynki energooszczędne oraz przyjazne środowisku. W Polsce i na świecie rozwiązania energooszczędne oraz technologie pasywne są coraz powszechniej stosowane w budownictwie. Wynika to przede wszystkim z niskich kosztów użytkowania takich budynków, mimo że stosowanie technologii energooszczędnych i pasywnych na etapie projektowania i realizacji wiąże się $\mathrm{z}$ większymi nakładami finansowymi. Celem referatu jest analiza i ocena kosztów budownictwa energooszczędnego w Polsce.

\section{Wprowadzenie do budownictwa energooszczędnego}

Koncepcja zrównoważonego rozwoju, w tym w budownictwie, jest realizowana na wszystkich szczeblach władzy. Postulaty zawarte w dokumentach światowych, m.in. w Raporcie Brundtland, materiałach Agendy 21, Protokole z Kioto dotyczą konieczności pozostawienia części zasobów przyszłym pokoleniom, angażowania środowisk nauki, przemysłu i biznesu w inicjatywy na rzecz zrównoważonego rozwoju, obniżenia energochłonności gospodarek (Jarzemska et al. 2011, 5-9; Stangel 2010, 13).

W krajach członkowskich Unii Europejskiej zasady promowania budownictwa niskoenergetycznego określają dokumenty unijne. Europejski pakiet ustaw klimatycznych (m.in. Dyrektywa 2009/29/WE; Dyrektywa 2002/91/WE; Decyzja 2009/406/WE) zobowiązuje kraje do zmniejszenia zużycia nieodnawialnej energii pierwotnej, zwiększenia zużycia energii ze źródeł odnawialnych oraz ograniczenia emisji $\mathrm{CO}_{2}$. Idea zrównoważonego rozwoju w Polsce zawarta jest w zapisach Konstytucji RP oraz centralnych i lokalnych aktach prawnych. 
Określenie „dom energooszczędny” pojawiło się w latach 70. XX w. wraz z pierwszymi kryzysami naftowymi. Wtedy to zaczęto badania nad wykorzystaniem alternatywnych źródeł energii, zwrócono szczególną uwagę na możliwości wykorzystania w budownictwie energii słonecznej. Jednak problematyka zrównoważonego rozwoju w budownictwie jest zdecydowanie szersza, ponieważ zaczyna się na etapie projektowania, a kończy w momencie rozbiórki i recyklingu pozostałych odpadów budowlanych.

Obecne wymagania dla budynków w zakresie izolacyjności cieplnej określone są w rozporządzeniu (Rozporządzenie Ministra Transportu, Budownictwa i Gospodarki Morskiej 2013). Przepisy podają, że budynek i jego instalacje powinny być zaprojektowane i wykonane $\mathrm{w}$ taki sposób, aby użytkowanie budynku zgodne z jego przeznaczeniem wiązało się z zużyciem energii elektrycznej i ciepła na racjonalnie niskim poziomie. Wymagania budynków w zakresie izolacyjności cieplnej zostały zaprezentowane w tabeli 1 . Przegrody zewnętrzne budynku muszą spełniać wymagania izolacyjności cieplnej. Rozporządzenie określa również, że wartość rocznego zapotrzebowania na nieodnawialną energię pierwotną (wskaźnik EP) musi być mniejsza od wartości granicznych określonych przez certyfikat energetyczny.

\begin{tabular}{|c|c|c|c|}
\hline \multirow{2}{*}{ Rodzaj wymagań } & \multicolumn{3}{|l|}{ Wymagania } \\
\hline & od 01.01.2014r. & od 01.01.2017 r. & od 01.01.2021 r. \\
\hline $\begin{array}{l}\text { Ściany zewnętrzne } \\
\text { a) gdy ti } \geq 16^{\circ} \mathrm{C} \\
\text { b) gdy ti } \geq 8^{\circ} \mathrm{C} \\
\text { c) pozostałe }\end{array}$ & $\begin{array}{l}0,25 \\
0,45 \\
0,90 \\
\end{array}$ & $\begin{array}{l}0,23 \\
0,45 \\
0,90 \\
\end{array}$ & \begin{tabular}{|l}
0,20 \\
0,45 \\
0,9 \\
\end{tabular} \\
\hline $\begin{array}{l}\text { Ściany wewnętrzne } \\
\text { a) gdy różnica temperatury } \\
\Delta \mathrm{ti} \geq 8^{\circ} \mathrm{C} \text { oraz przy klatce } \\
\text { schodowej, korytarzu } \\
\text { b) gdy różnica temperatury } \\
\Delta \mathrm{ti}<8^{\circ} \mathrm{C} \\
\text { c) pomiędzy pomieszczeniami } \\
\text { ogrzewanymi i nieogrzewa- } \\
\text { nymi }\end{array}$ & $\begin{array}{l}1,00 \\
\text { bez wymagań } \\
0,30\end{array}$ & $\begin{array}{l}1,00 \\
\text { bez wymagań } \\
0,30\end{array}$ & $\begin{array}{l}1,00 \\
\text { bez wymagań } \\
0,30\end{array}$ \\
\hline
\end{tabular}




\begin{tabular}{|c|c|c|c|}
\hline $\begin{array}{l}\text { Ściany przyległe do szczelin } \\
\text { dylatacyjnych o szerokości } \\
\text { a) do } 5 \mathrm{~cm} \text {, trwale zamknię- } \\
\text { tych izolacją o głębokości } \\
\text { min. } 20 \mathrm{~cm} \\
\text { b) pozostałe }\end{array}$ & $\begin{array}{l}1,00 \\
0,70\end{array}$ & $\begin{array}{l}1,00 \\
0,70\end{array}$ & $\begin{array}{l}1,00 \\
0,70\end{array}$ \\
\hline $\begin{array}{l}\text { Ściany kondygnacji } \\
\text { podziemnych } \\
\text { nieogrzewanych }\end{array}$ & bez wymagań & bez wymagań & bez wymagań \\
\hline $\begin{array}{l}\text { Dachy, stropodachy, stropy } \\
\text { mające styczność } \mathrm{z} \text { powietrzem } \\
\text { zewnętrznym } \\
\text { a) gdy ti } \geq 16^{\circ} \mathrm{C} \\
\text { b) gdy ti } \geq 8^{\circ} \mathrm{C} \\
\text { c) pozostałe }\end{array}$ & $\begin{array}{l}0,20 \\
0,30 \\
0,70\end{array}$ & $\begin{array}{l}0,18 \\
0,30 \\
0,70\end{array}$ & $\begin{array}{l}0,15 \\
0,30 \\
0,70\end{array}$ \\
\hline $\begin{array}{l}\text { Podłogi na gruncie } \\
\text { a) gdy ti } \geq 16^{\circ} \mathrm{C} \\
\text { b) gdy ti } \geq 8{ }^{\circ} \mathrm{C} \\
\text { c) pozostałe }\end{array}$ & $\begin{array}{l}0,30 \\
1,20 \\
1,50\end{array}$ & $\begin{array}{l}0,30 \\
1,20 \\
1,50\end{array}$ & $\begin{array}{l}0,30 \\
1,20 \\
1,50\end{array}$ \\
\hline $\begin{array}{l}\text { Stropy nad ogrzewanym po- } \\
\text { mieszczeniem podziemnym } \\
\text { i międzykondygnacyjne } \\
\text { a) gdy różnica temperatur } \\
\Delta \mathrm{t} \geq 8^{\circ} \mathrm{C} \\
\text { b) gdy różnica temperatur } \\
\Delta \mathrm{ti}<8^{\circ} \mathrm{C} \\
\text { c) pomiędzy pomieszczenia- } \\
\text { mi ogrzewanymi i nieogrze- } \\
\text { wanymi }\end{array}$ & $\begin{array}{l}1,00 \\
\text { bez wymagań } \\
0,25\end{array}$ & $\begin{array}{l}1,00 \\
\text { bez wymagań } \\
0,25\end{array}$ & $\begin{array}{l}1,00 \\
\text { bez wymagań } \\
0,25\end{array}$ \\
\hline $\begin{array}{l}\text { Stropy nad pomieszczeniami } \\
\text { nieogrzewanymi } \\
\text { a) gdy ti } \geq 16^{\circ} \mathrm{C} \\
\text { b) gdy ti } \geq 8^{\circ} \mathrm{C} \\
\text { c) pozostałe } \\
\end{array}$ & $\begin{array}{l}0,25 \\
0,30 \\
1,00 \\
\end{array}$ & $\begin{array}{l}0,25 \\
0,30 \\
1,00 \\
\end{array}$ & $\begin{array}{l}0,25 \\
0,30 \\
1,00 \\
\end{array}$ \\
\hline $\begin{array}{l}\text { Okna ( } \mathrm{z} \text { wyjątkiem okien } \\
\text { połaciowych), drzwi balko- } \\
\text { nowe i powierzchnie prze- } \\
\text { zroczyste nieotwieralne } \\
\text { a) przy ti } \geq 16^{\circ} \mathrm{C} \\
\text { b) przy ti }<16^{\circ} \mathrm{C}\end{array}$ & $\begin{array}{l}1,3 \\
1,8\end{array}$ & $\begin{array}{l}1,1 \\
1,6\end{array}$ & $\begin{array}{l}0,9 \\
1,4\end{array}$ \\
\hline
\end{tabular}




\begin{tabular}{|c|c|c|c|}
\hline $\begin{array}{l}\text { Okna połaciowe } \\
\text { a) przy ti } \geq 16^{\circ} \mathrm{C} \\
\text { b) przy ti }<16^{\circ} \mathrm{C}\end{array}$ & $\begin{array}{l}1,5 \\
1,8 \\
\end{array}$ & $\begin{array}{l}1,3 \\
1,6 \\
\end{array}$ & $\begin{array}{l}1,1 \\
1,4 \\
\end{array}$ \\
\hline $\begin{array}{l}\text { Okna w ścianach wewnętrz- } \\
\text { nych } \\
\text { a) przy } \Delta \mathrm{ti} \geq 8^{\circ} \mathrm{C} \\
\text { b) przy } \Delta \mathrm{ti}<8^{\circ} \mathrm{C} \\
\text { c) oddzielające pomieszcze- } \\
\text { nie ogrzewane od nieogrze- } \\
\text { wanego }\end{array}$ & $\begin{array}{l}1,5 \\
\text { bez wymagań } \\
1,5\end{array}$ & $\begin{array}{l}1,3 \\
\text { bez wymagań } \\
1,3\end{array}$ & $\begin{array}{l}1,1 \\
\text { bez wymagań } \\
1,1\end{array}$ \\
\hline $\begin{array}{l}\text { Drzwi w przegrodach ze- } \\
\text { wnętrznych lub w przegro- } \\
\text { dach między pomieszczenia- } \\
\text { mi nieogrzewanymi }\end{array}$ & 1,7 & 1,5 & 1,3 \\
\hline
\end{tabular}

Tabela 1. Wymagania budynków energooszczędnego i pasywnego w zakresie przenikania ciepła przez przegrody. Źródło: opracowanie własne na podstawie Rozporządzenia Ministra Transportu, Budownictwa i Gospodarki Morskiej 2013 r.

Od 1.01.2014 r. w nowo powstających budynkach zmieniły się warunki techniczne dotyczące norm izolacyjności cieplnej przegród zewnętrznych oraz wskaźnika zapotrzebowania na energię pierwotną budynku. Od tego czasu zakłada się, że normy te będą zmieniać się aż do osiągnięcia wartości pożądanych w 2021 roku. Nowe wytyczne to krok w kierunku upowszechnienia budowy domów o niskim zużyciu energii oraz szansa na popularyzację OZE i źródeł ogrzewania bazujących na technologiach energooszczędnych, m.in. pompach ciepła, ogniwach fotowoltaicznych, kolektorach słonecznych etc.

W Polsce, wraz z wprowadzeniem nowych przepisów i wymagań w zakresie budynków oszczędzających energię, konieczne było odświeżenie kryteriów klasyfikacyjnych budynków. Kryteriami podziałowymi stały się m.in. energochłonność, ilość zużycia oleju opałowego w przeliczeniu na $\mathrm{m}^{2}$ ogrzewanej powierzchni na rok. Podział budynków według zapotrzebowania na ciepło $\mathrm{kWh} / \mathrm{m}^{3}$ rok zostały zaprezentowane na rysunku 1. 


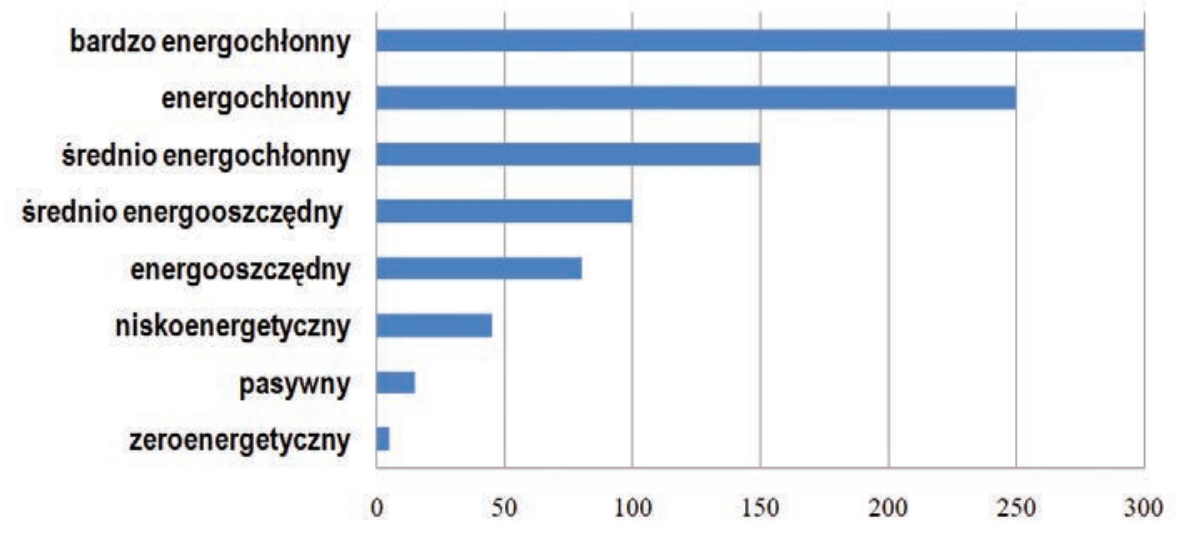

Rys. 1. Klasa energetyczna budynku według zapotrzebowanie na ciepło kWh/

( $\mathrm{m}^{3}$ rok). Źródło: opracowanie własne na podstawie Feist 2006, 42-46.

W literaturze spotkać można także klasyfikację budynków energooszczędnych, w których jako kryterium podziału przyjęto ilość zużycia oleju opałowego $\mathrm{w}$ przeliczeniu na $\mathrm{m}^{2}$ ogrzewanej powierzchni na rok (IBP 2016; Grymin 2013, 44-50). Budynki można wówczas podzielić na: budynki energooszczędne 7-litrowe - charakteryzujące się zapotrzebowaniem na energię cieplną na poziomie około $70 \mathrm{kWh} /$ ( $\mathrm{m}^{2}$.rok), czyli około 7 litrów oleju opałowego $\mathrm{w}$ przeliczeniu na $\mathrm{m}^{2}$ ogrzewanej powierzchni na rok; budynki energooszczędne 5-litrowe, w których zapotrzebowanie na energię cieplną wynosi około $50 \mathrm{kWh} /$ $\left(\mathrm{m}^{2}\right.$.rok), czyli około 5 litrów oleju opałowego w przeliczeniu na $\mathrm{m}^{2}$ ogrzewanej powierzchni na rok; budynki energooszczędne 3-litrowe, w których zapotrzebowanie na energię cieplną wynosi około $30 \mathrm{kWh} /$ $\left(\mathrm{m}^{2}\right.$.rok), czyli około 3 litry oleju opałowego w przeliczeniu na $\mathrm{m}^{2}$ ogrzewanej powierzchni na rok; budynki pasywne charakteryzuje się zapotrzebowaniem na energię cieplną na poziomie około $15 \mathrm{kWh} /$ $\left(\mathrm{m}^{2}\right.$.rok), czyli około 1,5 litra oleju opałowego w przeliczeniu na $\mathrm{m}^{2}$ ogrzewanej powierzchni na rok. 


\section{Budynek energooszczędny - budynek pasywny}

Spełnienie standardu budynku energooszczędnego w Polsce oznacza osiągnięcie wskaźnika zapotrzebowania na energię na poziomie niższym niż $95 \mathrm{kWh} /\left(\mathrm{m}^{2}\right.$.rok) od $1.01 .2017 \mathrm{r}$. i $70 \mathrm{kWh} /\left(\mathrm{m}^{2}\right.$.rok) od $1.01 .2021 \mathrm{r}$. Takie parametry w polskiej strefie klimatycznej są związane z koniecznością uwzględnienia przy projektowaniu budynku czynników dotyczących doboru działki oraz usytuowania na niej budynku, bryły budynku, układu pomieszczeń, jakości materiałów budowlanych, ocieplenia przegród, stolarki drzwiowej i okiennej, wentylacji oraz ogrzewania.

Odpowiednie posadowienie budynku na działce gwarantuje prawidłowe nasłonecznienie pomieszczeń, które dostarcza w ten sposób optymalną ilość ciepła. Innym istotnym elementem jest uwzględnienie strat ciepła przez przegrody zewnętrzne, tj. ściany, podłogi, dach oraz drzwi i okna, (tabela 2). Budynek energooszczędny to obiekt o jak najmniejszej powierzchni przegród zewnętrznych oraz małym jej stosunku do kubatury. Najlepsza w tym wypadku jest bryła zbliżona do sześcianu. Ma to związek z niewielką liczbą narożników, głównych przyczyn strat ciepła. Ważnym aspektem dotyczącym bryły budynku jest odpowiedni dobór wysokości pomieszczeń. Powinny one być zgodne z normami, lecz nie powinny być zbyt wysokie. Jest to uwarunkowane koniecznością ich ogrzania. Energooszczędne domy to domy piętrowe lub domy z poddaszem użytkowym, $w$ nich ciepło przenikające przez strop ogrzewa pomieszczenia na wyższym piętrze.

Kolejnym elementem energooszczędnego budynku jest układ pomieszczeń. Powinien uwzględniać fakt, że pomieszczenia, w których spędza się dużo czasu, np. pokój dzienny, powinny znajdować się od południa. Od południa powinny być także usytuowane weranda, przeszklony ganek. Odkryty taras najlepiej usytuować z południowego wschodu, by nie był narażony na zbytnie nasłonecznienie. Od strony wschodniej powinno umieszczać się np. sypialnie, w których temperatura oraz ilość promieniowania słonecznego ma zapewnić odpowiedni komfort. Od strony wschodniej oraz północnej należy umieszczać pomieszczenia nieogrzewane np. pomieszczenia gospodarcze, kotłownię, garaż, hol, garderobę, ale również z tych stron powinny być umieszczone drzwi wejściowe. Istotnym elementem układu funkcjonalnego jest ograniczenie w domu ilości pomieszczeń. 
Aby budynek był energooszczędny, konieczne jest wybudowanie go z materiałów o odpowiedniej jakości, co związane jest z wyższymi kosztami. Najkorzystniejsze jest wykonanie ścian dwuwarstwowych, składających się z warstwy konstrukcyjnej oraz termoizolacji. Dodatkowo, budynek powinien być wykonany $\mathrm{z}$ materiałów akumulujących ciepło. Ciepło powinno być magazynowane przy słońcu i następnie oddawane po zachodzie słońca. Także ocieplenie w domu energooszczędnym wymaga dodatkowych nakładów finansowych. Budynek będzie energooszczędny, gdy średni współczynnik przenikania ciepła nie przekroczy 0,23 $\mathrm{W} /\left(\mathrm{m}^{2} \mathrm{~K}\right)$ od 1.01.2017 r. oraz 0,20 W/ $\left(\mathrm{m}^{2} \mathrm{~K}\right)$ od 1.01.2021 r. Ocieplane powinny być nie tylko ściany zewnętrzne, ale także każde inne przegrody, które mają styczność ze środowiskiem zewnętrznym, takie jak dach i podłoga na gruncie.

Właściwy dobór stolarki okiennej i drzwiowej pozwala odpowiednio zbilansować straty i zyski ciepła. Przeszklone wyroby powinny w optymalny sposób wykorzystywać wpływy z nasłonecznienia i pozwalać na odpowiednie doświetlenie pomieszczeń. Większe okna powinno się montować w ścianach od południa, mniejsze natomiast od strony północnej. Na izolacyjność cieplną budynku mają wpływ okna wraz z montażem i wynikający z tego wpływ mostków liniowych. Dla osiągnięcia lepszych wyników cieplnych, w domach energooszczędnych należy stosować rolety zewnętrzne lub okiennice, które ograniczają straty ciepła zimą oraz chronią latem pomieszczenia przed przegrzaniem.

Wentylacja to kolejny element budynków energooszczędnych. Wentylacja nawiewno-wywiewna $\mathrm{z}$ rekuperacją to polecana wentylacja dla budownictwa energooszczędnego, zapewnia ona odpowiednią ilość świeżego powietrza, bowiem zmniejsza straty ciepła oraz usuwa zanieczyszczenia powstające w budynku. W budynkach energooszczędnych sprawność odzysku ciepła przez wentylację powinna wynosić min. 70\%.

Duże znaczenie w budynkach energooszczędnych ma także dobór odpowiedniego ogrzewania. Budynki energooszczędne wymagają znacznie mniejszej mocy urządzeń grzewczych. W urządzeniach grzewczych zaleca się wykorzystanie ekologicznych źródeł ciepła m.in. biopaliw, kolektorów słonecznych, ogniw fotowoltaicznych czy pomp ciepła (Czaplicka-Kolarz, Pyka i Pyka 2009, 23). 
Budynki pasywne natomiast to budynki energooszczędne, które spełniają dodatkowe wymagania oraz wykorzystują odnawialne źródła energii, tzn. energię słoneczną, światło, siłę wiatru i chłód ziemi. Podstawowymi standardami budynków pasywnych są: izolacja termiczna o grubości min. $40 \mathrm{~cm}$, mechaniczna wentylacja z odzyskiem ciepła, dodatkowo np. elektrownia wiatrowa, kolektor słoneczny, ogniwa fotowoltaiczne i zbiornik wodny jako akumulator ciepła (Żurawski 2009, 34-36). Budynki te są prawie samowystarczalne, co jest możliwe do osiągnięcia dzięki izolacji oraz stolarce okiennej i drzwiowej, wykorzystywaniu ciepła z zużytego powietrza wentylacyjnego za pomocą wentylacji z odzyskiem ciepła oraz wykorzystaniu energii pochodzącej od słońca. Ciepło i energię uzyskują z systemów pozyskujących i magazynujących energię z promieniowania słonecznego lub wiatru, tj. kolektorów słonecznych, ogniw fotowoltaicznych oraz turbin wiatrowych. Ciepło w domach pasywnych nie jest wytwarzane z paliw kopalnych, a ewentualnie jedynie ze spalania biopaliw, tj. pellet czy brykietu. Budynki te są zwykle przystosowane do wykorzystania energii słonecznej i zacienienia oraz połączone $\mathrm{z}$ akumulatorami ciepła $\mathrm{w}$ celu ustabilizowania dziennych wahań temperatury. Ilość ogrzewanej wody może być zmniejszona przez urządzenia uzdatniające wodę, systemy odzysku ciepła ze ścieków. Dodatkowo, ważnym elementem domów pasywnych jest zamontowany w nich system wytwarzania i zbierania energii z paneli słonecznych, turbin wiatrowych oraz ciepła z biopaliw i kolektorów słonecznych. Przechowana w ten sposób energia może zostać wykorzystana do użytku przez urządzenia domowe i ogrzewania lub chłodzenia.

\section{Ekonomiczne aspekty budownictwa energooszczędnego i pasywnego}

Ograniczeniem w rozwoju budownictwa energooszczędnego i pasywnego jest konieczność poniesienia dodatkowych nakładów na etapie projektowania i budowy. Nakłady te wynikają z konieczności dodatkowego ocieplenia elementów budynku powodujących straty energii. Elementy utraty energii $\mathrm{w}$ budownictwie jednorodzinnym zostały przedstawione $\mathrm{w}$ tabeli 2 . Jednak $\mathrm{w}$ szerszej perspektywie podwyższone koszty na starcie są rekompensowane przez zmniejszone koszty użytko- 
wania i eksploatacji. Dużym atutem budynków energooszczędnych jest fakt, że w porównaniu z budynkiem spełniającym minimalne wymagania prawne mogą zmniejszyć zużycie energii nawet o połowę (Kaczkowska 2009, 62).

\begin{tabular}{|c|c|}
\hline \multicolumn{2}{|c|}{ Element utraty energii } \\
\hline - wentylacja & $30-40 \%$ \\
\hline - ściany & $20-30 \%$ \\
\hline - dach & $10-25 \%$ \\
\hline - drzwi i okna & $10-15 \%$ \\
\hline - podłoga & $3-6 \%$ \\
\hline
\end{tabular}

Tabela 2. Straty energii w budynkach jednorodzinnych tradycyjnych. Źródło: opracowanie własne na podstawie Mojkowska i Gładyszewska-Fiedoruk 2010, 229-231.

Straty ciepła w budynkach energooszczędnych występują przede wszystkim na skutek jego przenikania przez przegrody zewnętrzne, tzn. ściany, dach, okna i drzwi oraz podłogę na gruncie. Straty te powodują zwiększone zapotrzebowanie budynku na energię grzewczą. Dlatego najważniejszym celem budynku energooszczędnego jest zapobieganie utracie ciepła przez przegrody zewnętrzne, które realizowane jest głównie przez ich odpowiednie ocieplenie. Ciepło przenika także przez okna i drzwi, więc i one powinny mieć jak najlepsze parametry cieplne. Poza tym znaczne straty ciepła są spowodowane koniecznością wymiany powietrza w pomieszczeniach. Można je zmniejszyć nawet o kilkadziesiąt procent, instalując w domach system wentylacji mechanicznej z odzyskiem ciepła. Dokonanie tego typu zabiegów jest konieczne na etapie projektowania i wykonania projektu i wymaga zaangażowania większych środków finansowych.

Analiza aspektów ekonomicznych budownictwa energooszczędnego i pasywnego rozpoczyna się od oceny właściwości fizycznych działki oraz usytuowania budynku względem stron świata. Właściwości fizyczne działki, tj. nachylenie terenu czy rodzaj podłoża, wpływają w sposób bezpośredni na całość kosztów budowy i wymagają ich uwzględnienia na etapie planowania. Natomiast prawidłowe umiejscowienie budynku 
na działce nie jest związane bezpośrednio z wyższymi nakładami finansowymi, może natomiast powodować korzyści związane z możliwością wykorzystania energii z promieniowania słonecznego. Korzyści te ujawniają się dopiero na etapie użytkowania domu. W związku z tym różnicę między budową domu energooszczędnego i standardowego nie jest łatwo precyzyjnie określić, ponieważ zależy od wielu czynników. Poza cechami fizycznymi działki i usytuowaniem budynku, są to m.in. metraż budynku, liczba kondygnacji, kształt bryły domu, rodzaj zastosowanych technologii i materiałów oraz metoda budowy domu.

Analiza i ocena ekonomiczna budownictwa energooszczędnego w ramach niniejszego opracowania została dokonana w oparciu o porównanie kosztów budowy domu energooszczędnego względem domu mieszczącego się w klasie energetycznej do $150 \mathrm{kWh} / \mathrm{m}^{3}$ rok o łącznej powierzchni użytkowej $130 \mathrm{~m}^{2} \mathrm{i}$ podobnych parametrach użytkowych. Całkowite koszty budowy domu energooszczędnego w Polsce są wyższe średnio o ok. 30-35\% całkowitych nakładów inwestycyjnych. Istnieją jednak przykłady, w których zaobserwowano niższy przyrost kosztów budowy domów energooszczędnych, np. według analiz przeprowadzonych przez ekspertów w zakresie budownictwa energooszczędnego koszty budowy budynku energooszczędnego są w warunkach polskich wyższe o około $25 \%$ do $30 \%$ niż koszty domu wybudowanego według standardu energetycznego (Węglarz i Stępień 2011, 21). Ostatnie doświadczenia $\mathrm{w}$ realizacji inwestycji $\mathrm{w}$ standardzie energooszczędnymi i pasywnym pozwoliły zaobserwować jeszcze większą obniżkę kosztów budowy tego typu domów. Według badań w Polsce i w krajach Unii Europejskiej przyrost kosztów wyniósł nie więcej niż 15\% całkowitych kosztów (Dąbrowska 2015, 31). Analiza poszczególnych elementów budowy domu energooszczędnego została zaprezentowana w tabeli 3.

\begin{tabular}{|l|c|}
\hline Elementy konstrukcyjne budynku energooszczędnego & $\begin{array}{c}\Delta \text { kosztów } \\
{[\%]}\end{array}$ \\
\hline Fundamenty wraz z posadzkami & 25 \\
\hline Ściany zewnętrzne & 48 \\
\hline Ściany wewnętrzne murowane & 0 \\
\hline
\end{tabular}




\begin{tabular}{|l|c|}
\hline Strop nad parterem & 0 \\
\hline Konstrukcja budynku & 30 \\
\hline Dach i strop poddasza & 16 \\
\hline Okna i drzwi & 41 \\
\hline Schody wewnętrzne & 0 \\
\hline Stolarka zewnętrzna i wewnętrzna & 40 \\
\hline Koszty wentylacji & 60 \\
\hline Całkowity koszt budowy & 32 \\
\hline
\end{tabular}

Tabela 3. Przyrost kosztów budowy domu energooszczędnego.

Źródło: opracowanie własne na podstawie Piotrowski i Dominiak 2012, 22.

Koszty budowy analizowanego domu energooszczędnego przewyższają o ponad 30\% całkowite koszty domów spełniających wymogi domów energochłonnych. Największa różnica kosztów dotyczy instalacji wentylacji oraz okien i stolarki drzwiowej. W domu energetycznym niektóre elementy wykonuje się, nie podwyższając kosztów. Ujawiona różnica w kosztach fundamentu wraz z posadzką dotyczy izolacji przeciwwilgociowej oraz termicznej. W domu energooszczędnym izolacje te są grubsze ze względu na to, by ciepło $z$ wnętrza domu nie przenikało na zewnątrz. Wykonanie ścian zewnętrznych $\mathrm{w}$ domu energooszczędnym jest ważnym elementem, by osiągnąć najlepszą izolacyjność termiczną przegród. Mur nośny najczęściej wykonywany jest z betonu komórkowego i ocieplony płytami z wełny mineralnej. Wewnętrzną izolację termiczną wykonuje się z wełny mineralnej na parterze o grubości min. $8 \mathrm{~cm}$, natomiast izolacja termiczna na poddaszu ma grubość min. $10 \mathrm{~cm}$.

Zastosowanie rozwiązań energooszczędnych w budownictwie powoduje z jednej strony zwiększenie kosztów budowy, jednak z drugiej przyczynia się do zmniejszenia kosztów ogrzewania i eksploatacji. Domy energooszczędne $z$ uwagi na użyte technologie potrzebują mniej energii oraz dodatkowo wykorzystują zyski energii powstałe w czasie naturalnej eksploatacji domu. Jest to ciepło emitowane przez wszystkie urządzenia elektryczne oraz sztuczne oświetlenie, a nawet przez przebywających w pomieszczeniach domowników. Drugim źródłem zysków ener- 
getycznych jest naturalna energia słoneczna, docierająca bezpośrednio do wnętrza domu przez okna oraz pośrednio poprzez nieprzezroczyste przegrody wykonane z materiałów o wysokiej akumulacyjności cieplnej np. ceramiki.

\section{Zakończenie}

Koszty budowy domu pasywnego są wyższe od kosztów budowy domu o minimalnych wymogach energetycznych. W ramach artykułu określono poszczególne elementy kosztów budowy w przyrostach procentowych $\mathrm{z}$ uwzględnieniem materiałów, z których zostały wykonane. Analizowana inwestycja uwzględniała wykorzystanie lepszej izolacyjności oraz termiczności pomieszczeń. Obserwuje się dobre praktyki w zakresie wykonawstwa domów energooszczędnych, co skutkuje tendencją do zmniejszania kosztów ich projektowania i realizacji. Dodatkowo dostępne możliwości rozwiązań energooszczędnych w budownictwie zmniejszają koszty eksploatacji i ujawniają korzyści związane $\mathrm{z}$ dodatnim bilansem energetycznym i z mniejszym zanieczyszczaniem środowiska, jednak z uwagi na objętość niniejszego opracowania nie zostały one ocenione.

\section{Bibliografia:}

Czaplicka-Kolarz, Krystyna i Ireneusz Pyka. 2010. Technologie zeroemisyjne i energooszczędność. Uwarunkowania wdrażania w Polsce. Katowice: Główny Instytut Górnictwa.

Dąbrowska, Anna. 2015. Budownictwo energooszczędne i pasywne. Katalog dobrych przykładów. Warszawa: Instytut na Rzecz Ekorozwoju.

Decyzja 2009/406/WE Parlamentu Europejskiego i Rady z dnia 23 kwietnia 2009 r. w sprawie wysiłków podjętych przez państwa członkowskie, zmierzających do zmniejszenia emisji gazów cieplarnianych $w$ celu realizacji do roku 2020 zobowiązań Wspólnoty dotyczacych redukcji emisji gazów cieplarnianych. Dostęp: 20.04.2017. http://eur-lex.europa.eu/ LexUriServ/ LexUriServ.do?uri=OJ:L:2009:140:0136:0148:PL:PDF.

Dyrektywa 2002/91/WE Parlamentu Europejskiego i Rady z dnia 16 grudnia 2002 r. w sprawie charakterystyki energetycznej budynków. Dostęp: 31.01.2017. http://www.pnec.org.pl/etykietyenergetyczne/page/poradniki/nowe3/Dyr_2002_91_WE.pdf. 
Dyrektywa 2009/29/WE Parlamentu Europejskiego i Rady z dnia 23 kwietnia 2009 r. zmieniająca dyrektywę 2003/87/WE w celu usprawnienia i rozszerzenia wspólnotowego systemu handlu uprawnieniami do emisji gazów cieplarnianych. Dostęp: 20.04.2017. http://eur-lex.europa.eu/ LexUriServ/LexUriServ.do?uri=OJ:L:2009:140:0063:0087:PL:PDF.

Feist, Wolfgang. 2006. Podstawy budownictwa pasywnego, tłum. Renata Kołakowska. Gdańsk: Polski Instytut Budownictwa Pasywnego.

Grymin, Marek. 2013. Perspektywy rozwoju budownictwa energooszczędnego. Acta Innovations, 8, 44-50.

IBP (Instytut Budynków Pasywnych). 2016. Jak zmieniono domy żeby były energooszczędne? Dostęp: 31.01.2017. http://www.ibp.com.pl/Portals/IBP/docs/tagi/Jak\%20zmieniono\%20domy.pdf.

Jarzemska, Monika, Arkadiusz Węglarz i Magdalena Wielomska. 2011. Zrównoważone miasto- zrównoważona energia $z$ perspektywy energetyki przyjaznej środowisku. Warszawa: Fundacja Instytut na rzecz Ekorozwoju.

Kaczkowska, Anna. 2009. Dom pasywny. Krosno: Wydawnictwo KaBe.

Mojkowska, Wanda i Katarzyna Gładyszewska-Fiedoruk. 2010. Analiza strat ciepła domu jednorodzinnego wykonanego w dwóch technologiach. Civil and environment al Engineering, 1, 229-233.

Piotrowski, Ryszard i Paweł Dominiak. 2012. Budowa domu pasywnego krok po kroku. Warszawa: Przewodnik budowlany.

Rozporządzenie Ministra Transportu, Budownictwa i Gospodarki Morskiej z dnia 5 lipca 2013 r. zmieniające rozporządzenie w sprawie warunków technicznych, jakim powinny odpowiadać budynki i ich usytuowanie. Dziennik Ustaw, 2013, poz. 928.

Stangel, Michał. 2010. Zrównoważona urbanistyka. Architektura, 4, 10-16.

Węglarz, Arkadiusz i Renata Stępień. 2011. Pasywny dom. Warszawa: Fundacja Instytut na rzecz Ekorozwoju.

Żurawski, Jerzy. 2009. Budownictwo energooszczędne i pasywne. Materiały Budowlane, 1, 32-37. 

Ewa Matyjaszczyk

Instytut Ochrony Roślin - Państwowy Instytut Badawczy

e.matyjaszczyk@iorpib.poznan.pl

\section{Wdrażanie dyrektywy 2009/128 ustanawiającej ramy wspólnotowego działania na rzecz zrównoważonego stosowania pestycydów w Polsce}

\section{Wstęp}

Dyrektywa Parlamentu Europejskiego i Rady 2009/128 ustanawiająca ramy wspólnotowego działania na rzecz zrównoważonego stosowania pestycydów weszła w życie następnego dnia po opublikowaniu, to jest 25 listopada 2009 roku. W Dyrektywie nakreślono działania, jakie powinny podjąć państwa członkowskie Unii Europejskiej w celu ochrony zdrowia ludzi i środowiska przed ewentualnymi zagrożeniami związanymi ze stosowaniem pestycydów.

Przepisy Dyrektywy 2009/128 dotyczą całej Unii Europejskiej. Państwa członkowskie, w tym Polska, zostały zobowiązane do przyjęcia krajowych aktów prawnych niezbędnych do realizacji jej postanowień do 14 grudnia 2011. Działania związane z jej wdrażaniem, ze względu na ich kompleksowość, rozłożono jednak na lata i poszczególnym etapom nadano odpowiednie terminy realizacji.

Pestycydy dzielą się na dwie podstawowe grupy różniące się przeznaczeniem: środki ochrony roślin stosowane w rolnictwie oraz produkty biobójcze stosowane poza rolnictwem (takie jak muchozol, trutka na szczury albo środki do ochrony mebli przeciw kornikom). Mimo że tytuł Dyrektywy 128/2009 tego nie precyzuje, to jej treść (artykuł 2) mówi wyraźnie, że dotyczy ona tylko jednej z tych grup: środków ochrony roślin stosowanych w rolnictwie.

Zakres działań na rzecz zrównoważonego stosowania środków ochrony roślin różnił się w poszczególnych państwach członkowskich i jednym z celów wprowadzenia unijnych przepisów było osiągnięcie wspólnego ich poziomu. Warto podkreślić, że Polska, podobnie jak wielu naszych sąsiadów, w tym Czechy, Niemcy czy Belgia, wprowa- 
dziła wiele działań na rzecz bezpieczeństwa chemicznej ochrony roślin już przed laty. Zatem w niektórych aspektach nasze wymagania krajowe wprowadzono znacznie wcześniej niż wymagania unijne.

\section{Prezentacja działań}

Artykuł prezentuje $\mathrm{w}$ punktach działania, jakie podjęła Polska w związku z wdrażaniem Dyrektywy 128/2009, i stan realizacji poszczególnych jej wymagań na koniec roku 2016.

1. Sporządzenie krajowych planów działania w celu zmniejszenia zagrożeń ze strony chemicznej ochrony roślin.

Krajowy plan działania na rzecz ograniczenia ryzyka zwiazanego ze stosowaniem środków ochrony roślin został przyjęty w Polsce przez Ministra Rolnictwa i Rozwoju Wsi 6 maja 2013 roku (MRiRW 2013). Jest także publicznie dostępny na stronach internetowych Ministerstwa Rolnictwa i Rozwoju Wsi.

Główne cele Krajowego planu działania na rzecz ograniczenia ryzyka zwiazanego ze stosowaniem środków ochrony roślin to:

Upowszechnienie ogólnych zasad integrowanej ochrony roślin. Jest to niezmiernie istotne, ponieważ integrowana ochrona roślin kładzie nacisk na uzyskanie plonów odpowiedniej jakości przy minimalnych zakłóceniach funkcjonowania ekosystemu rolniczego i zachęca do stosowania naturalnych sposobów zwalczania organizmów szkodliwych. Wiele niechemicznych metod ochrony roślin jest bardzo skutecznych, żeby je stosować rolnicy muszą jednak je znać. Upowszechnianie wiedzy dotyczącej integrowanej ochrony roślin jest zatem sprawą kluczową.

$\checkmark$ Zapobieganie zagrożeniom związanym ze stosowaniem chemicznych środków ochrony roślin.

Sposób realizacji celów krajowego planu działania jest monitorowany. Dyrektywa 2009/128 wymaga określenia mierzalnych celów ilościowych. Najważniejsze mierniki przyjęte w Polsce przedstawiono w tabeli 1. 


\begin{tabular}{|c|c|c|}
\hline Miernik & Wartość & Źródło danych \\
\hline $\begin{array}{c}\text { Odsetek rolników którzy prawidłowo stosują } \\
\text { zasady integrowanej ochrony roślin }\end{array}$ & $\begin{array}{c}\text { powyżej } \\
90 \%\end{array}$ & $\begin{array}{c}\text { Państwowa Inspek- } \\
\text { cja Ochrony Roślin } \\
\text { i Nasiennictwa }\end{array}$ \\
\hline $\begin{array}{c}\text { Udział przekroczeń najwyższych dopuszczal- } \\
\text { nych poziomów pozostałości środków ochrony } \\
\text { roślin w żywności pochodzenia roślinnego }\end{array}$ & $\begin{array}{c}\text { poniżej } \\
1 \%\end{array}$ & $\begin{array}{c}\text { Państwowa Inspek- } \\
\text { cja Sanitarna }\end{array}$ \\
\hline $\begin{array}{c}\text { Udział przekroczeń najwyższych dopuszczal- } \\
\text { nych poziomów pozostałości środków ochrony } \\
\text { roślin w żywności pochodzenia zwierzęcego }\end{array}$ & $\begin{array}{c}\text { poniżej } \\
0,1 \%\end{array}$ & $\begin{array}{c}\text { Państwowa Inspek- } \\
\text { cja Weterynaryjna }\end{array}$ \\
\hline
\end{tabular}

Tabela 1. Najważniejsze mierniki dla monitorowania realizacji celów krajowego planu działania na rzecz ograniczania ryzyka związanego ze stosowaniem środków ochrony roślin, które powinny zostać osiągnięte do końca 2017 roku.

Źródło: Opracowanie własne na podstawie Krajowego planu działania na rzecz ograniczenia ryzyka związanego ze stosowaniem środków ochrony roślin (MRiRW 2013).

W 2015 roku Ministerstwo Rolnictwa i Rozwoju Wsi opublikowało dane dotyczące wdrażania krajowego planu działania na rzecz ograniczania ryzyka związanego ze stosowaniem środków ochrony roślin. Zgodnie z nim, według danych Państwowej Inspekcji Ochrony Roślin i Nasiennictwa, w roku 2014 od 71,8\% do 95,3\% profesjonalnych użytkowników środków ochrony roślin stosowało poszczególne wymogi integrowanej ochrony roślin. W roku 2013 Państwowa Inspekcja Sanitarna stwierdziła w 0,7\% próbek żywności pochodzenia roślinnego, a w 2014 r. w 0,8\% próbek, przekroczenia najwyższych dopuszczalnych poziomów pozostałości, natomiast Inspekcja Weterynaryjna w żadnej z przebadanych w latach 2013-2014 próbek pasz i żywności pochodzenia zwierzęcego nie stwierdziła przekroczeń najwyższych dopuszczalnych poziomów pozostałości (MRiRW 2016, 57-58). Cele krajowego planu działania zostały zatem w dużej mierze osiągnięte.

2. Stworzenie systemu szkoleń w celu podnoszenia świadomości zagrożeń związanych ze stosowaniem środków ochrony roślin dla dystrybutorów i profesjonalnych użytkowników do 14 grudnia 2013. Od 14 grudnia 2015 środki ochrony roślin do stosowania profesjonalnego sprzedawane są w całej Unii Europejskiej tylko rolnikom przeszkolonym i posiadającym certyfikat. 
Jest to jedno z działań, odnośnie do którego prawodawstwo polskie uchwalono znacznie wcześniej niż wymagania unijne. Szkolenia dla użytkowników i sprzedawców pestycydów prowadzone są w Polsce od końca lat dziewięćdziesiątych (Ustawa z 12.07.1995). Kompleksowa analiza danych wykazała, że przepisy wprowadzone w latach dziewięćdziesiątych (między innymi dotyczące szkoleń) przyczyniły się do poprawy bezpieczeństwa ludzi oraz środowiska w Polsce (Matyjaszczyk 2011a).

Wdrożenie dyrektywy ustanawiającej ramy wspólnotowego działania na rzecz zrównoważonego stosowania pestycydów spowodowało konieczność wprowadzenia zmian w polskich przepisach. Przepisy wprowadzone w Polsce w latach dziewięćdziesiątych zakładały bowiem konieczność szkoleń (jak również regularnych szkoleń przypominających) użytkowników oraz sprzedawców środków ochrony roślin zakwalifikowanych jako toksyczne. Tymczasem dyrektywa dotycząca zrównoważonego stosowania pestycydów wprowadziła kategorie użytkowników profesjonalnych i nieprofesjonalnych. Kryterium zakwalifikowania środka ochrony roślin jako przeznaczonego dla użytkowników profesjonalnych jest nie tylko stopień toksyczności, ale również wielkość opakowania. Nawet środek całkowicie nietoksyczny może być zakwalifikowany jako przeznaczony do zakupu i stosowania tylko przez użytkowników profesjonalnych, jeżeli duża wielkość opakowania świadczy o tym, że nie jest przeznaczony do zastosowana amatorskiego (takiego jak działka czy ogród przydomowy). Polskie przepisy dotyczące szkoleń dla użytkowników środków ochrony roślin zostały zaktualizowane na mocy ustawy o środkach ochrony roślin (Ustawa z 8.03.2013) i odpowiednich rozporządzeń wykonawczych.

3. Lepsze informowanie społeczeństwa, w tym nieprofesjonalnych użytkowników środków ochrony roślin, o konieczności przestrzegania zasad stosowania oraz ostrożności i bezpieczeństwa.

W cytowanym wyżej sprawozdaniu Ministerstwa Rolnictwa i Rozwoju Wsi czytamy „W związku z wejściem nowych przepisów (...) o środkach ochrony roślin, Ministerstwo Rolnictwa i Rozwoju Wsi, Państwowa Inspekcja Ochrony Roślin i Nasiennictwa, Centrum Doradztwa Rolniczego jak również instytuty branżowe rozpoczęły w 2013 r. pro- 
wadzenie kampanii informacyjnej dotyczącej środków ochrony roślin. Informacje na temat nowych przepisów dotyczących środków ochrony roślin prezentowane były na licznych konferencjach, w tym przybliżających zakres krajowego planu działania, a także publikowane w prasie. Wśród użytkowników środków ochrony roślin rozprowadzono ulotki" (MRiRW 2016, 31).

4. Przeprowadzanie regularnych kontroli sprzętu do stosowania środków ochrony roślin w celu zmniejszenia narażenia operatorów i zapobieganiu ich nadmiernemu przedostawaniu się do środowiska. Do 14 grudnia 2016 cały sprzęt w państwach członkowskich powinien zostać skontrolowany przynajmniej raz.

To kolejne działanie, co do którego prawodawstwo polskie wyprzedziło wymagania unijne (Ustawa 12.07.1995). Kontrole sprzętu do stosowania środków ochrony roślin prowadzone są w Polsce już od prawie dwudziestu lat. Kontrole są okresowo powtarzane. Także w przypadku tego działania wdrożenie dyrektywy ustanawiającej ramy wspólnotowego działania na rzecz zrównoważonego stosowania pestycydów spowodowało konieczność wprowadzenia zmian w polskich przepisach. Dotychczasowy system dotyczył różnego typu opryskiwaczy rolniczych, tymczasem zgodnie $\mathrm{z}$ nowymi przepisami listę kontrolowanego sprzętu poszerzono o urządzenia służące aplikacji środków ochrony roślin, których nazwa „opryskiwacz” nie obejmuje. Należą do nich między innymi: sprzęt samobieżny lub ciągnikowy przeznaczony do stosowania środków ochrony roślin w formie granulatu oraz instalacje przeznaczone do stosowania środków ochrony roślin w formie oprysku lub zamgławiania w szklarniach lub tunelach foliowych (PIORIN 2016).

Dzięki tak długiemu okresowi obowiązywania przepisów dotyczących obowiązkowych badań sprzętu do stosowania środków ochrony roślin nieprawidłowości w kontrolowanych gospodarstwach są stosunkowo nieliczne (MRiRW 2016, 31). W 2013 roku brak aktualnego badania sprzętu do aplikacji środków ochrony roślin stwierdzono w 3,4\% spośród ponad 20,5 tysiąca gospodarstw skontrolowanych przez Inspekcję Ochrony Roślin i Nasiennictwa, natomiast w roku 2014 w 1,4\% spośród ponad 21 tysięcy skontrolowanych gospodarstw. 
5. Wprowadzenie zakazu aplikacji środków ochrony roślin z użyciem samolotów za wyjątkiem sytuacji wyjątkowych.

Zakaz taki został wprowadzony w Polsce w roku 2013 (Ustawa z 8.03.2013). Aplikacja środków ochrony roślin z powietrza jest dopuszczona prawem tylko wówczas, gdy zwalczanie organizmów szkodliwych przy użyciu sprzętu naziemnego nie jest możliwe lub gdy zastosowanie środków ochrony roślin przy użyciu samolotów stwarza mniejsze zagrożenie dla zdrowia ludzi, zwierząt lub dla środowiska. Ponadto aplikacja środków ochrony roślin z powietrza każdorazowo wymaga zgody właściwego wojewódzkiego inspektora ochrony roślin i nasiennictwa.

Sytuacje, w których zwalczenie organizmu szkodliwego przy użyciu sprzętu naziemnego nie jest możliwe, dotyczą głównie ochrony lasów. Jednak aplikacje chemicznych środków ochrony roślin w lasach są sporadyczne i dotyczą wyłącznie sytuacji szczególnego zagrożenia. W 2012 roku leśnictwo, mimo sporego areału, zużyło jedynie około 1 promila środków ochrony roślin stosowanych w Polsce (Matyjaszczyk 2014 za niepublikowanymi danymi Dyrekcji Generalnej Lasów Państwowych).

6. Stosowanie szczególnych środków ochrony środowiska wodnego przed zanieczyszczeniami przez środki ochrony roślin.

W Polsce od wielu lat prowadzono działania na rzecz ochrony środowiska wodnego. Obejmowały one przede wszystkim ustalenie różnego typu stref ochronnych oraz buforowych wokół zbiorników oraz cieków wodnych. Aktualne wymagania w tym zakresie przedstawia rozporządzenie w sprawie warunków stosowania środków ochrony roślin (MRiRW 2014).

7. Ustalenie obszarów, na których stosowanie środków ochrony roślin jest zakazane lub znacznie ograniczone.

Obszary takie były wyznaczone w Polsce już przed wejściem w życie Dyrektywy 2009/128. Ustawa o środkach ochrony roślin implementująca postanowienia Dyrektywy do prawodawstwa krajowego (Ustawa z 8.03.2013) wprowadziła ograniczenia odnośnie do stosowania środków ochrony roślin na terenie placów zabaw, żłobków, przedszkoli, 
szkół podstawowych, szpitali, stref ochronnych „A” wydzielonych na obszarach uzdrowisk lub obszarach ochrony uzdrowiskowej w rozumieniu przepisów o lecznictwie uzdrowiskowym, uzdrowiskach i obszarach ochrony uzdrowiskowej oraz o gminach uzdrowiskowych.

8. Wprowadzenie nowych zasad postępowania z opakowaniami i pozostałościami po środkach ochrony roślin.

Zasady postępowania $\mathrm{z}$ opakowaniami po środkach ochrony roślin reguluje ustawa $\mathrm{z}$ dnia 13 czerwca 2013 o gospodarce opakowaniami i odpadami opakowaniowymi (Ustawa z 13.06.2013). Zgodnie z jej zapisami opakowania po środkach ochrony roślin zaklasyfikowanych jako środki niebezpieczne podlegają szczególnym zasadom, a w szczególności nie mogą być traktowane jako odpady komunalne. Za zbiór opakowań po środkach ochrony roślin zaklasyfikowanych jako niebezpieczne odpowiada wprowadzający do obrotu i stosowania, czyli producenci środków ochrony roślin. W praktyce w Polsce rolnik ma do dyspozycji dwie drogi pozbycia się opróżnionych opakowań po środkach ochrony roślin:

może oddać je do punktu sprzedaży. Sprzedawcy nie mogą odmówić odbioru takich opakowań i za odbiór nie mogą pobierać od rolników żadnej opłaty. Zgodnie z przepisami koszty zbioru opakowań ponoszą producenci środków ochrony roślin;

$\checkmark$ może zamówić odbiór wprost z gospodarstwa. Po zgłoszeniu pod specjalny numer telefonu 801561461 następuje nieodpłatny odbiór bezpośredni. Termin odbioru jest ustalany telefonicznie z posiadaczem opakowań. Z możliwości tej można skorzystać tylko wtedy, gdy rolnik, lub grupa rolników, zgromadzi w jednym miejscu co najmniej 10 metrów sześciennych opakowań. System ten, zorganizowany przez Polskie Stowarzyszenie Ochrony Roślin (PSOR), działa od ponad 10 lat.

Zgodnie z danymi PSOR rocznie zbieranych jest w Polsce około 60\% opakowań po środkach ochrony roślin, co stanowi dobry wynik w skali europejskiej (PSOR 2017). 
9. Zobowiązanie państw członkowskich do promowania ochrony roślin o niskim zużyciu pestycydów, czyli rolnictwa ekologicznego i integrowanego. Do 30 czerwca 2013 państwa członkowskie miały stworzyć warunki niezbędne dla wdrożenia integrowanej ochrony roślin.

Zgodnie z informacją Ministerstwa Rolnictwa i Rozwoju Wsi rolnictwo ekologiczne jest w Polsce finansowo wspierane z czterech źródeł:

$\checkmark$ budżetu krajowego;

$\checkmark$ budżetu Unii Europejskiej;

$\checkmark$ Programu Rozwoju Obszarów Wiejskich na lata 2014-2020;

$\checkmark$ Mechanizmu Wspólnej Polityki Rolnej (WPR) „Wsparcie działań promocyjnych i informacyjnych na rynkach wybranych produktów rolnych" (MRiRW 2017a).

Stosowanie integrowanej ochrony roślin jest obowiązkowe w Polsce, podobnie jak w innych państwach członkowskich Unii Europejskiej, od 1 stycznia 2014. Wprowadzenie integrowanej ochrony roślin było powiązane z kampanią szkoleniową dla doradców. Działania na rzecz integrowanej ochrony roślin są konsekwentnie prowadzone przez państwo. Wiele zrobiono, zwłaszcza jeżeli chodzi o zebranie już posiadanej wiedzy, usystematyzowanie jej pod kątem potrzeb integrowanej ochrony roślin, zebranie w jednym miejscu i nieodpłatne udostępnienie rolnikom. Spore zasoby wiedzy już są dostępne na stronach Ministerstwa Rolnictwa i Rozwoju Wsi (MRiRW 2017b).

Brakuje jednak funduszy na badania naukowe, w tym zwłaszcza dotyczące wyznaczenia progów szkodliwości organizmów szkodliwych. Badania te są kosztowne, ale kluczowe dla prawidłowego stosowania integrowanej ochrony roślin. Progi szkodliwości mówią rolnikowi, od jakiego nasilenia organizmu szkodliwego wykonanie zabiegu chemicznego ma sens ekonomiczny. Dobrze opracowane zapobiegają wykonywaniu zbędnych zabiegów chemicznych i są kluczowe dla racjonalnego stosowania integrowanej ochrony roślin. Potrzebnych jest także szereg innych działań, w tym upowszechnienie stosowania wśród rolników istniejących systemów wspomagania decyzji o chemicznej ochronie roślin oraz opracowanie nowych. Należy zatem stwierdzić, że w zakresie tworzenia zaplecza integrowanej ochrony roślin wiele już (do stycznia 2017 roku) w Polsce zrobiono, ale wiele pozostało jeszcze do zrobienia. 
W opinii autorki, konsekwentne wspieranie i stosowanie zasad integrowanej ochrony roślin może mieć ogromny wpływ na dobro środowiska ze względu na skalę produkcji. Zgodnie z danymi Głównego Urzędu Statystycznego użytki rolne zajmowały w Polsce w 2013 roku 14,6 mln ha, z czego użytki ekologiczne stanowiły 4,3\% (GUS 2015). Stosowanie integrowanej ochrony roślin przez wszystkich profesjonalnych użytkowników środków ochrony roślin jest obowiązkowe. W praktyce obowiązuje zatem na całym tym areale poza przydomowymi ogrodami i działkami.

10. Pomiar postępów w ograniczaniu zagrożeń ze strony środków ochrony roślin za pomocą właściwych, zharmonizowanych wskaźników.

Opracowanie wskaźników ryzyka dotyczących środków ochrony roślin jest w Polsce w toku i zgodnie z informacjami Ministerstwa Rolnictwa i Rozwoju Wsi powinno się zakończyć w roku 2017 (Rzeźnicki 2017).

\section{Podsumowanie}

Podsumowując, można stwierdzić, że wdrażanie Dyrektywy 2009/128 ustanawiającej ramy wspólnotowego działania na rzecz zrównoważonego stosowania pestycydów odbywa się w Polsce planowo. Nasz kraj posiadał dobrą pozycję wyjściową do rozpoczęcia wdrażania Dyrektywy, bo przy stosunkowo niskim zużyciu środków ochrony roślin (Matyjaszczyk 2011b) posiadał już w XX wieku bardzo dobrze rozwinięty system kontroli ich stosowania (Matyjaszczyk 2011a). Wiele działań zostało już w Polsce zrealizowanych. Obecnie na końcowym etapie jest opracowywanie wskaźników zagrożeń ze strony chemicznej ochrony roślin. Konieczne są także dalsze działania na rzecz integrowanej ochrony roślin.

\section{Bibliografia:}

Dyrektywa Parlamentu Europejskiego i Rady 2009/128/WE z dnia 21 października 2009 r. ustanawiająca ramy wspólnotowego działania na rzecz zrównoważonego stosowania pestycydów L 309/71.

GUS (Główny Urząd Statystyczny). 2015. Rocznik Statystyczny Rolnictwa. Warszawa: Zakład Wydawnictw Statystycznych. 
Matyjaszczyk, Ewa. 2011a. Analiza zmian ustawodawstwa $z$ zakresu ochrony roślin pod katem bezpieczeństwa żywności, ludzi i środowiska. Poznań: Wydawnictwo Instytutu Ochrony Roślin Państwowego Instytutu Badawczego.

Matyjaszczyk, Ewa. 2011b. Selected aspects of plant protection in Poland, five years on from EU accession. Outlook on Agriculture, 40(2), 119-123. DOI: 10.5367/oa.2011.0042.

Matyjaszczyk, Ewa. 2014. Rynek środków ochrony roślin w Polsce w roku 2012 w ujęciu ilościowym i wartościowym. Roczniki Naukowe Stowarzyszenia Ekonomistów Rolnictwa i Agrobiznesu, XVI(3), 177-182.

MRiRW (Ministerstwo Rolnictwa i Rozwoju Wsi). 2013. Krajowy plan działania na rzecz ograniczenia ryzyka związanego ze stosowaniem środków ochrony roślin na lata 2013-2017. Monitor Polski, pozycja 536.

MRiRW (Ministerstwo Rolnictwa i Rozwoju Wsi). 2014. Rozporządzenie Ministra Rolnictwa i Rozwoju Wsi z dnia 31 marca 2014 r. w sprawie warunków stosowania środków ochrony roślin. Dziennik Ustaw, pozycja 516.

MRiRW (Ministerstwo Rolnictwa i Rozwoju Wsi). 2016. Sprawozdanie $z$ realizacji krajowego planu działania na rzecz ograniczenia ryzyka zwiąanego ze stosowaniem środków ochrony roślin za lata 2013-2015. Dostęp: 1.02.2017. http://www.minrol.gov.pl/content/download/55735/306727/version/2/file/za\%C5\%82\%C4\%85cznik\%20 do\%20pisma\%20do\%20BP-\%20KPD\%20na\%20Kierownictwo\%20grudzie\%C5\%84\%202016.pdf.

MRiRW (Ministerstwo Rolnictwa i Rozwoju Wsi). 2017a. Wsparcie rolnictwa ekologicznego. Dostęp:31.01.2017. http://www.minrol.gov.pl/Jakosc-zywnosci/Rolnictwo-ekologiczne/Wsparcie-rolnictwa-ekologicznego.

MRiRW (Ministerstwo Rolnictwa i Rozwoju Wsi). 2017b. Integrowana ochrona roślin. Dostęp: 31.01.2017. http://www.minrol.gov.pl/Informacje-branzowe/Produkcja-roslinna/Ochrona-roslin/Integrowana-ochrona-roslin. 
PIORIN (Państwowa Inspekcja Ochrony Roślin i Nasiennictwa). 2016. Badania sprawności technicznej sprzętu do stosowania środków ochrony roślin. Dostęp: 2.12.2016. http://piorin.gov.pl/srodki-ochrony-roslin/badanie-opryskiwaczy/.

PSOR (Polskie Stowarzyszenie Ochrony Roślin). 2017. System zbiórki opakowań Polskiego Stowarzyszenia Ochrony Roślin. Dostęp: 31.01.2017. http://systempsor.pl/.

Rzeźnicki, Bogusław. 2014. Aktualny stan prac w zakresie wdrażania zasad integrowanej ochrony roślin. Dostęp: 1.02.2017. http://www.cdr. gov.pl/images/Radom/pliki/19-05-14/Aktualny\%20stan\%20prac\%20 w\%20zakresie\%20wdraania\%20zasad\%20integrowanej\%20ochrony\%20rolin.ppt.

Ustawa z dnia 12 lipca 1995 o ochronie roślin uprawnych. Dziennik Ustaw, 1995, nr 90, pozycja 446.

Ustawa z dnia 8 marca 2013 r. o środkach ochrony roślin. Dziennik Ustaw, 2013, pozycja 455.

Ustawa z dnia 13 czerwca 2013 r. o gospodarce opakowaniami i odpadami opakowaniowymi. Dziennik Ustaw, 2013, pozycja 888. 

Arkadiusz Węglarz

Politechnika Warszawska - Wydział Inżynierii Lądowej

Krajowa Agencja Poszanowania Energii S.A.

a.weglarz@il.pw.edu.pl

\section{Polskie budynki spełniające kryteria zrównoważonego rozwoju}

\section{Wstęp}

Budownictwo to dział gospodarki, który ma olbrzymi wpływ na środowisko naturalne i warunki życia człowieka. Nic więc dziwnego, że od czasu zdefiniowania zasad zrównoważonego rozwoju poszukiwano sposobów adaptacji ich w budownictwie. W przypadku nowo projektowanych budynków liczba możliwych rozwiązań technicznych i technologicznych prowadzących do budynków spełniających kryteria zrównoważonego rozwoju jest duża. Inwestor i projektant mogą więc wybrać satysfakcjonujące ich rozwiązanie. Gorzej sytuacja wygląda w przypadku istniejących budynków. Tu osiągnięcie standardów domu pasywnego lub ekologicznego jest już bardzo trudne i wymaga rozwiązania wielu problemów technicznych, czasami dużych nakładów finansowych, a wybór technologii remontowych jak i instalacyjnych często jest zdefiniowany przez istniejące już rozwiązania konstrukcyjne w budynku. Jeszcze gorzej wygląda sprawa, gdy chcemy $\mathrm{z}$ istniejącego budynku osiągnąć w procesie remontowym obiekt spełniający kryteria zrównoważonego rozwoju. Poniżej przedstawiono istotne zdaniem autora zagadnienia mające kluczowy wpływ na rozwój w Polsce budownictwa spełniającego kryteria zrównoważonego rozwoju.

\section{Zasady projektowania budynków spełniających kryteria zrów- noważonego rozwoju w budownictwie}

Budownictwo przyjazne środowisku naturalnemu i człowiekowi realizuje zasady zrównoważonego rozwoju w wyniku takiego oddziaływania, które uwzględnia metody oszczędzenia zasobów naturalnych naszego globu oraz przeciwdziałania zanieczyszczeniu gleby, powietrza i wody. 
Podstawowe zasady respektowane przy budowie obiektów przyjaznych środowisku naturalnemu, a więc wznoszonych zgodnie z zasadami zrównoważonego rozwoju, to:

$\checkmark$ maksymalne wykorzystanie otoczenia naturalnego i wkomponowania w nie projektowanego budynku;

$\checkmark$ uwzględnienie zwyczajów mieszkańców lub użytkowników w procesie projektowania;

$\checkmark$ uwzględnienie ciągłości tradycji i nowoczesności;

$\checkmark$ bardzo dobra izolacyjność cieplna ścian, optymalnie wykorzystana wentylacja naturalna lub zastosowanie wentylacji mechanicznej $\mathrm{z}$ odzyskiem, zastosowanie gruntowego wymiennika ciepła, wykorzystanie niekonwencjonalnych źródeł energii;

$\checkmark$ montaż urządzeń zapewniających oszczędne wykorzystywanie wody do higieny osobistej, wykorzystanie wody deszczowej oraz wód gruntowych do drugiego obiegu, wykorzystanie przefiltrowanej „szarej” wody do nawodnienia terenów;

$\checkmark$ stosowanie do budowy materiałów i wyrobów budowlanych wytwarzanych z materiałów odnawialnych, pochodzących z recyklingu lub dających się wykorzystać ponownie, co wpływa na obniżenie kosztów środowiskowych, związanych z oszczędnością surowców naturalnych;

$\checkmark$ zastępowanie materiałów i wyrobów budowlanych szkodliwych dla środowiska człowieka i środowiska przyrodniczego materiałami „przyjaznymi” temu środowisku;

$\checkmark$ utylizacja materiałów nieodnawialnych $\mathrm{w}$ sposób zapewniający ochronę środowiska przyrodniczego (np. sposób składowania);

$\checkmark$ likwidacja obiektu po zakończeniu jego eksploatacji uwzględniająca możliwość recyklingu.

\section{Przegląd technologii stosowanych $\mathrm{w}$ budownictwie $\mathrm{w}$ aspekcie oddziaływania na środowisko}

Główne technologie służące do wznoszenia budynków w Polsce to:

- technologia drewniana,

- technologia murowana,

- technologia żelbetowa, 
- technologia stalowa,

- technologie bazujące na odnawialnych materiałach pochodzenia roślinnego,

- technologia mieszana.

Do wyboru drewna jako budulca skłaniają przede wszystkim: obfitość surowca w naturze, łatwość obróbki i łączenia, stosunkowo znaczna wytrzymałość, niewielki ciężar oraz dobre własności izolacyjności cieplnej i akustycznej. Z punktu widzenia zrównoważonego rozwoju jest to materiał odnawialny, dostępny lokalne, biodegradowalny, łatwo podlegający recyklingowi i magazynujący dwutlenek węgla. Głównymi wadami drewna natomiast są: łatwopalność, podatność na zniszczenia przez szkodniki (owady, grzyby, pleśnie), możliwość odkształceń pod wpływem zmian wilgotności (pęcznienie, kurczenie i pękanie) oraz wady wynikające $z$ anatomicznej struktury drewna (sęki, sploty i skręty włókien, sinizna), co wpływa na trwałość konstrukcji drewnianych i ich cechy użytkowe.

Technologia murowana to najczęściej stosowana w Polsce metoda wznoszenia budynków. Wpływ ma na to zarówno dostępność na rynku elementów murowych, jak i trwałość budynków budowanych w ten sposób (znacznie większa w porównaniu np. z budynkami drewnianymi). Prawidłowo wykonany budynek w technologii murowanej (tzw. tradycyjnej) jest w stanie służyć wielu pokoleniom bez kosztowych nakładów związanych z utrzymaniem takiego budynku w formie spełniającej nałożone wymagania. Niestety technologia ta wymaga dużych nakładów energetycznych, szczególnie jeśli chodzi o bardzo popularne materiały ceramiczne. Elementy murowe po okresie eksplantacji można odzyskać i powtórnie użyć.

Żelbet i beton są bardzo chętnie stosowanymi materiałami w naszym kraju. Większość obiektów wznoszonych w Polsce jest całkowicie lub przynajmniej częściowo (fundamenty) żelbetowa. Spośród wielu zalet żelbetu można wymienić: możliwość formowania dowolnego kształtu, ognioodporność, mrozoodporność, trwałość. Jednak z punktu widzenia zasad zrównoważonego rozwoju technologia ma bardzo wiele wad. Duży ciężar elementów konstrukcyjnych, energochłonność i emisyjność procesu produkcyjnego składników betonu (żelbetu, np. cementu, 
stali), wysoka przewodność cieplna, trudności w rozbiórce wyeksploatowanych konstrukcji i powtórnym użyciu betonu. Pozyskiwanie kruszywa dla betonu może powodować duże zmiany w lokalnym krajobrazie, np. kamieniołomy, wyrobiska rzeczne itp.

Technologia stalowa wykorzystywana jest głównie w budownictwie przemysłowym (hale), wysokościowym (wieżowce), komunikacyjnym (mosty stalowe), budynkach użyteczności publicznej (hale sportowe, baseny) oraz jako lekki szkielet stalowy do budowy domów mieszkalnych. Budownictwo stalowe ma wiele zalet, takich jak: szybkość realizacji, znaczny stopień prefabrykacji konstrukcji, wieloletnie gwarancje udzielane przez producentów, odporność na czynniki atmosferyczne. Niestety z punktu widzenia zrównoważonego rozwoju jest to technologia energochłonna, wysokoemisyjna, a eksplantacja kopalń niezbędna do wydobycia surowców wykorzystywanych do produkcji stali czyni duże spustoszenie w środowisku naturalnym.

W budownictwie zrównoważonym wykorzystuje się szereg technologii bazujących na odnawialnych materiałach pochodzenia roślinnego. Takimi materiałami są:

$\checkmark$ bambus, słoma, trzcina, itp.

$\checkmark$ kamień, ziemia ubijana,

$\checkmark$ materiały odpadowe z przemysłu obojętne dla środowiska, np. odpady betonowe, odzyskane metale itp.,

$\checkmark$ inne materiały i tworzywa odnawialne, które nie są toksyczne i możliwy jest ich odzysk.

Technologia mieszana może być połączeniem wszystkich wyżej wymienionych technologii i wymaga każdorazowo osobnej analizy pod kontem zasad zrównoważonego rozwoju.

Materiały budowlane zastosowane w poszczególnych technologiach można ocenić, wykorzystując metodę LCA (Analiza Cyklu Życia Obiektu). Ze względu na dostępność danych proponuje się przyjąć dwa kryteria oceny materiału budowlanego metodą LCA:

Kryterium I: Minimum skumulowanej energii pierwotnej, czyli sumy zużytej energii pierwotnej w procesie produkcyjnym od pozyskania surowców do bram fabryki. 
Kryterium II: Minimum skumulowanej emisji $\mathrm{CO}_{2}$, czyli sumy wszystkich emisji $\mathrm{CO}_{2}$ powstałych w procesie produkcyjnym od pozyskania surowców do bram fabryki.

W literaturze technicznej można znaleźć wartości wskaźników skumulowanego zużycia energii (skumulowaną energochłonność wyrobów) oraz emisji $\mathrm{CO}_{2}$ dla większości podstawowych materiałów budowlanych. Należy przy tym pamiętać, że wskaźniki te nie są wartościami jednoznacznie określonymi. Porównując wartości określające energochłonność skumulowaną w różnych krajach, można dostrzec znaczne różnice. Wynikają one głównie z różnic metodycznych, jak na przykład definicji granic systemu, różnic w pochodzeniu i energochłonności surowców, różnic energochłonności procesów produkcyjnych.

W swojej opublikowanej w 2013 roku pracy (Węglarz 2013, 21-23) autor przeprowadził analizę porównawczą metoda LCA dla cegły pełnej ceramicznej i cegły pełnej silikatowej. Wyniki tej analizy zestawiono w tabeli 1.

\begin{tabular}{|c|c|c|c|c|c|}
\hline Lp. & $\begin{array}{c}\text { Nazwa } \\
\text { Materiału }\end{array}$ & Jednostka & $\begin{array}{c}\text { Efekt cieplar- } \\
\text { niany kgCO/ } \\
\text { jednostkę }\end{array}$ & $\begin{array}{c}\text { Energia pier- } \\
\text { wotna [MJ/ } \\
\text { jednostkę] }\end{array}$ & OCENA \\
\hline 1 & cegła silikat & $\mathrm{kg}$ & 0,19 & 1,22 & $\begin{array}{c}\text { Min } \\
(2 \mathrm{kryteria})\end{array}$ \\
\hline 2 & cegła pełna & $\mathrm{kg}$ & 0,53 & 3,65 & $\begin{array}{c}\text { Max } \\
(2 \mathrm{kryteria})\end{array}$ \\
\hline
\end{tabular}

Tabela1. Porównanie cegły pełnej ceramicznej z cegłą pełną silikatową - metoda LCA (2 kryteria). Źródło: Węglarz 2013, 21-25.

Z analizy danych w tabeli 1 . wynika, że materiałem bardziej przyjaznym dla środowiska jest cegła pełna silikatowa. Ponieważ parametry wytrzymałościowe cegły silikatowej są porównywalne z parametrami wytrzymałościowymi cegły pełnej, to można te materiały wzajemnie zastępować.

\section{Systemy certyfikacji ekologicznej budynków}

Ocena poziomu wdrożenia wymienionych wyżej zasad zrównoważonego rozwoju w budownictwie dla konkretnego budynku jest procesem trudnym. Na świecie wiele zespołów pracuje nad tym zagadnie- 
niem. Obecnie wydaje się, że najlepsze rozwiązanie to wykonanie oceny przy pomocy systemów certyfikacji ekologicznej budynków, takich jak: LEED lub BREEAM.

Certyfikacja BREEAM (Building Research Establishment's Environmental Assessment Method) obejmuje zagadnienia związane z wykorzystaniem energii i wody, środowisko wewnętrzne (zdrowie i samopoczucie), zanieczyszczenia, transport, materiały, odpady, procesy ekologiczne i zarządzania (PSBE 2017a). Stosuje metody pomiarów, których wyniki porównuje się ze zdefiniowanymi wskaźnikami. BREEAM uwzględnia szerokie kwestie dotyczące środowiska i zrównoważonego rozwoju, które umożliwiają deweloperom, projektantom i zarządcom budynków wykazanie zalet środowiskowych swoich budynków.

System oceny LEED (Leadership in Energy and Environmental Design) jest oparty na przyznawaniu punktów za przyjazne dla środowiska działania podejmowane w trakcie budowania i użytkowania budynku. Potrzeba co najmniej 40 punktów, aby budynek uzyskał certyfikat. Aby uzyskać poziom „srebrny”, trzeba zdobyć 50-59 punktów, „złoty” - 6079 punktów, a „platynowy” - 80-110 punktów. Poziomy odpowiadaja liczbie punktów uzyskanych w pięciu kategoriach: zrównoważony plac budowy, efektywność wykorzystania wody, energia i atmosfera, materiały i zasoby oraz jakości środowiska wnętrz (PSBE 2017b). W Polsce już ponad 200 budynków posiada certyfikaty LEED lub BREEAM. Przykładowo, Galeria handlowa: Manufaktura w Łodzi, Biurowiec ZEBRA w Warszawie.

Instytut Techniki Budowlanej zaproponował do oceny budynków współczynnik BEE (ang. Building Environmental Efficiency), zwany Współczynnikiem Efektywności Środowiskowej Budynku, wyrażający stosunek jego jakości oraz komfortu do negatywnego oddziaływania na środowisko (ITB 2017). Budynek otrzymuje najwyższą ocenę, jeśli komfort nie jest wytworzony kosztem zwiększenia się negatywnego oddziaływania na środowisko. Wskaźnik BEE przyjmuje wtedy wartość większą od jedności. Obecnie wznoszone budynki uzyskują wartości współczynnika BEE w granicach 0,8-1,4. Wartości współczynnika BEE powyżej 2 uzyskuje się w budynkach spełniających zasady zrównoważonego rozwoju. 
4. Nowe budynki spełniające kryteria zrównoważonego rozwoju

Proces projektowy nowego budynku musi uwzględniać zarówno wymagania technologiczne pod katem spełnienia zasad zrównoważonego rozwoju jak i wymagania estetyczne zgodne z oczekiwaniami inwestorów. Dlatego zaprojektowanie budynku spełniającego wszystkie kryteria jest zadaniem trudnym. Poniżej zaprezentowano dwa przykłady domów jednorodzinnych, dla których w procesie projektowania i wykonawstwa starano się stosować zasady równoważonego rozwoju.

\section{Budynek zlokalizowany wokolicach Warszawy}

Budynek składa się z dwóch brył - dwukondygnacyjnej części mieszkalnej oraz jednokondygnacyjnej części garażowo-gospodarczej (zdjęcie 1). Bryły są proste - są to dwa przenikające się prostopadłościany. Bryła garażowa zorientowana jest równolegle do boków działki, natomiast część mieszkalna jest nieznacznie (o ok. 19,5) odwrócona - tak, aby ściana $\mathrm{z}$ największymi przeszkleniami była zorientowana dokładnie w kierunku południowym. Obie bryły posiadają płaskie dachy o spadku $2 \%$.

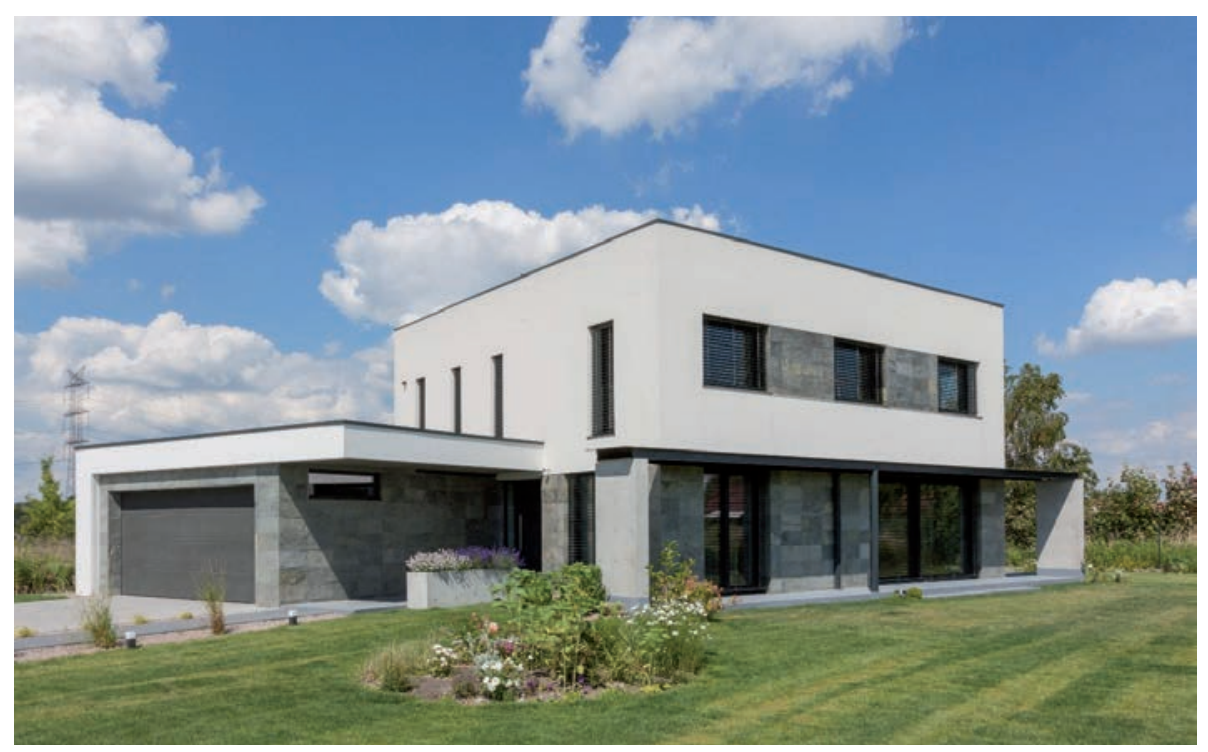

Zdjęcie 1. Dom jednorodzinny w okolicach Warszawy (zdjęcie: M. Pierzchaliski, KAPE S.A). 
Usytuowanie działki jest niekorzystne ze względu na kierunki stron świata, dlatego należało zaprojektować dom w dość nietypowy sposób budynek znajduje się w głębi działki od jej strony północnej, natomiast bryła mieszkalna ze ścianą o największych przeszkleniach została skierowana w kierunku południowym. Starannie zaprojektowano wszelkie detale połączeń różnych elementów budynku, tak aby uniknąć niekorzystnych mostków cieplnych.

Budynek ma niewielkie zapotrzebowanie na energię do ogrzewania, natomiast najbardziej energochłonne stało się przygotowanie CWU, dlatego zastosowano powietrzną pompę ciepła do przygotowania CWU i dodatkowo zastosowano wymiennik na odpływie kanalizacji ścieków szarych. Jest to przeciwprądowy wymiennik „Odzyskwa ściekowa”. Niewielkie zapotrzebowanie na energię do ogrzewania jest pokrywane przez instalację przewodów grzejnych elektrycznych umieszczonych w warstwie szlichty podłogowej. Takie rozwiązanie wybrano na podstawie analizy ekonomicznej. Ogrzewanie przewodami elektrycznymi może wydawać się nieekologiczne, ale jeśli uwzględnimy nakłady środowiskowe w całym cyklu życia przy zastosowaniu metody LCA dla gruntowej pompy ciepła oraz przewodów grzejnych, drugie rozwiązanie może okazać się bardziej przyjazne środowisku. W budynku zastosowano wentylację mechaniczną z odzyskiem ciepła o dużej sprawności. Budynek jest posadowiony na płycie fundamentowej. Ściany są murowane z bloczków silikatowych grubości $18 \mathrm{~cm}$. Ściany i dach są docieplone wełną mineralną skalną i szklaną (szklana w $80 \%$ ze stłuczki szklanej). Projektując budynek, skorzystano z następujących zasad: maksymalnego wykorzystania otoczenia naturalnego $\mathrm{i}$ wkomponowania $\mathrm{w}$ nie projektowanego budynku, uwzględnienie zwyczajów mieszkańców lub użytkowników w procesie projektowania, uwzględnienie ciągłości tradycji i nowoczesności i oczywiście, przede wszystkim, maksymalizacji efektywności energetycznej budynku. Powstały obiekt charakteryzuje się wskaźnikiem zużycia energii użytkowej na ogrzewanie i wentylację na poziomie około $12 \mathrm{kWh} / \mathrm{m}^{2} /$ rok. Jest więc budynkiem pasywnym. Koszt budowy pod klucz $1 \mathrm{~m}^{2}$ tego domu wyniósł około $4000 \mathrm{zł}$. Typowy dom jednorodzinny pod klucz to koszt $3200 \mathrm{zz} / \mathrm{m}^{2}$. Wynika $\mathrm{z}$ tego, że dom pasywny jest droższy o około $20 \%$ od domu standardowego. 


\section{Budynek zlokalizowany w okolicach Hajnówki}

Jest to budynek mieszkalny jednorodzinny wolnostojący, niepodpiwniczony, dwukondygnacyjny (parter i poddasze użytkowe). Bryła budynku jest prosta, to przełamany prostopadłościan, posiadający dach dwuspadowy o nachyleniu 40 stopni, kryty blachą płaską na podwójny rąbek stojący (rys. 1). Konstrukcja domu została zaprojektowana jako szkielet drewniany. Między elementy nośne zostaną umieszczone kostki sprasowanej słomy (gęstość $90-110 \mathrm{~kg} / \mathrm{m}^{3}$ ). Kostki o szer. $45 \mathrm{~cm}$ i długości 58-60 cm (wysokość $40 \mathrm{~cm}$ ). Od zewnątrz ściana zostanie otynkowana surową gliną o grubości około $1 \mathrm{~cm}$ - aby zapewnić lepszą dyfuzję pary wodnej na zewnątrz budynku. Elewacje budynku pokryte zostaną deskowaniem w układzie poziomym. Stolarka okienna i drzwiowa będzie drewniana. Ściany działowe i ściany wewnętrzne będą murowane $\mathrm{z}$ surowych cegieł glinianych. W budynku zastosowano wentylację mechaniczną nawiewno-wywiewną z odzyskiem ciepła. Ciepło na ogrzewanie i przygotowanie CWU będzie przygotowane przy użyciu nowoczesnego kotła na pellet. Nietypowe będzie oczyszczanie ścieków w przydomowej oczyszczalni z wstępnym osadnikiem i rozsączaniem w otwartym zbiorniku z roślinami wodnymi. Dom w okolicach Hajnówki zaprojektowano zgodnie z większością zdefiniowanych $\mathrm{w}$ rozdziale 1. zasad zrównoważonego rozwoju w budownictwie. Jest energooszczędny, zbudowany $\mathrm{z}$ odnawialnych materiałów, racjonalnie zużywa wodę. Niestety, jest jeszcze nieukończony, trudno więc oszacować koszty jego budowy pod klucz.

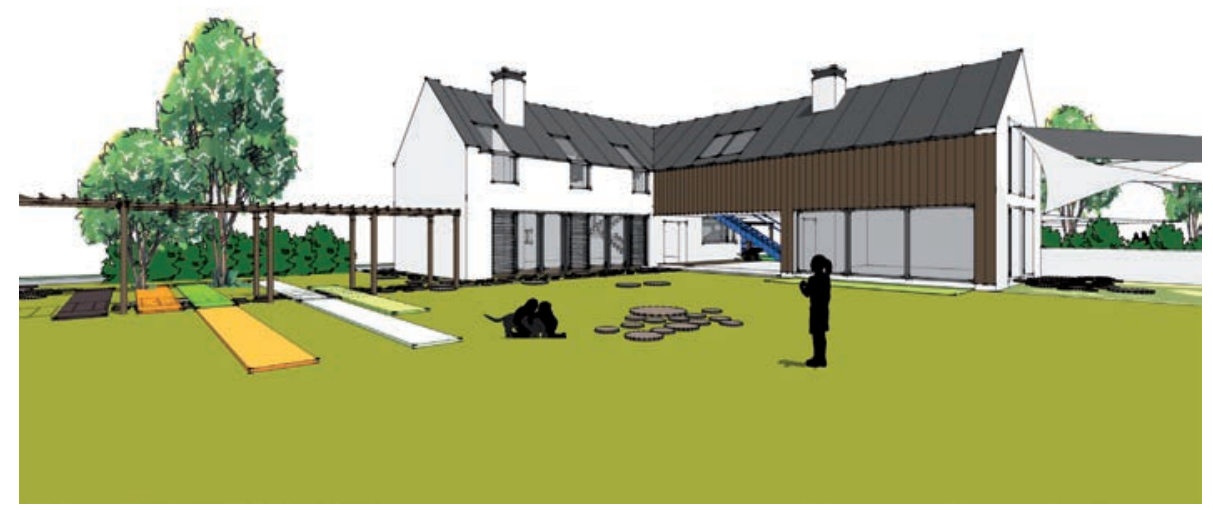

Rys. 1. Wizualizacja budynku w okolicach Hajnówki (autor: Tomasz Żemojcin). 


\section{Zmodernizowane budynki spełniające kryteria zrównoważonego rozwoju}

Modernizacja istniejącego budynku do poziomu obiektu spełniającego kryteria zrównoważonego rozwoju jest zadaniem niezwykle trudnym, dlatego jest niewiele zmodernizowanych budynków, które można umieścić w tej kategorii.

Przykładem działań modernizacyjnych zgodnych z zasadami zrównoważonego rozwoju może być głęboka termomodernizacja domu jednorodzinnego zlokalizowanego w okolicach Siedlec (Pierzchalska i Węglarz 2013, 23-25). Przed modernizacją był to typowy jednorodzinny dom $z$ terenów wiejskich, wybudowany na przełomie lat 60 . i 70., o powierzchni 120 metrów kwadratowych, murowany z cegły ceramicznej pełnej, niepodpiwniczony, z poddaszem nieużytkowym, nieocieplony, ogrzewany piecem kaflowym (zdjęcie 2). Jedynymi elementami zmodernizowanymi był: dach, pierwotnie pokryty eternitem (właściciel wymienił pokrycie na blachodachówki) oraz nowe drzwi zewnętrzne i wewnętrzne. Ogólny stan techniczny budynku był dobry. Izolacyjność termiczna przegród zewnętrznych była niska i znacząco odbiegała od obecnych standardów oraz wymagań w zakresie ochrony cieplnej dla domów jednorodzinnych.

Przy pomocy pracowników Krajowej Agencji Poszanowania Energii S.A. zaplanowano przeprowadzenie kompleksowej, głębokiej termomodernizacji domu, tak aby był ciepły i komfortowy w użytkowaniu. $\mathrm{W}$ ramach tych prac zaproponowano: ocieplenie ścian zewnętrznych, wymianę stolarki okiennej, modernizację źródła ciepła i c.w.u., ocieplenie podłogi na gruncie, ocieplenie dachu, ocieplenie stropu oraz instalację wentylacji z rekuperacją. 


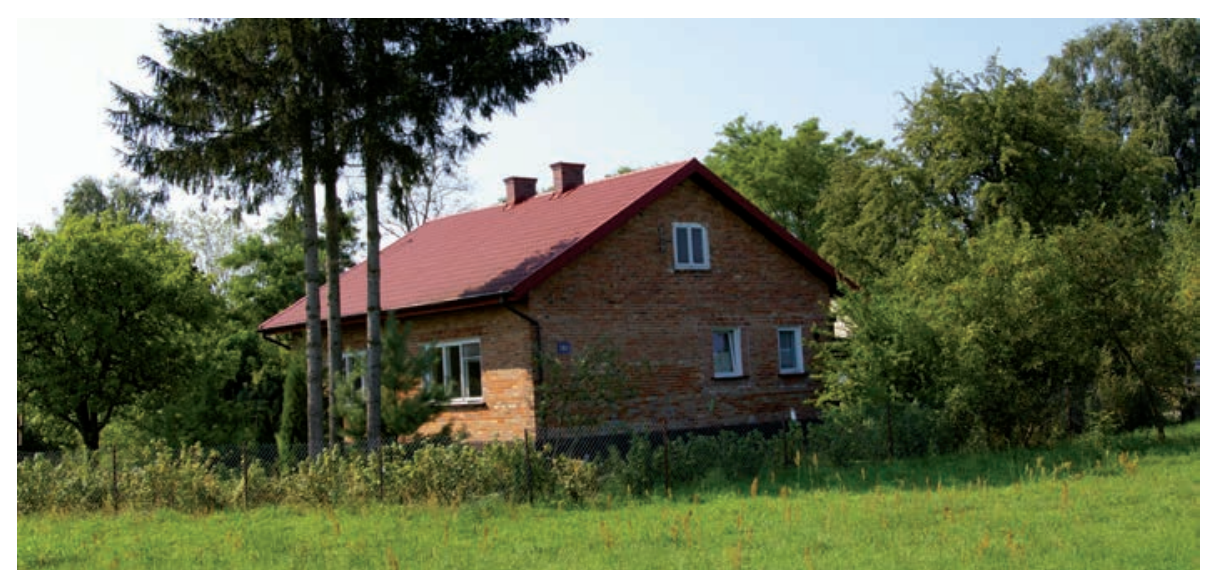

Zdjęcie 2. Dom jednorodzinny w okolicach Siedlec przewidziany do głębokiej termomodernizacji (zdjęcie: KAPE S.A).

Inwestor rozszerzył zaplanowany przez KAPE zakres prac o zmianę funkcji poddasza z nieużytkowego na mieszkalne. Łączyło się to ze wzmocnieniem konstrukcji dachu tak, aby można było go bezpiecznie ocieplić oraz wstawić pięć okien dachowych. Całość prac nie wymagała podnoszenia poddasza, więc budynek nie zmienił swoich gabarytów.

Dzięki przeprowadzeniu kompleksowej termomodernizacji zdołano zmniejszyć obliczeniowe zapotrzebowanie na energię zarówno na c.o. jak również c.w.u. budynku o około $90 \%$ ( z 81,0 do 8,4 GJ/rok). Zmniejszenie zużycia energii jest znaczne, co niestety nie przenosi się na bardzo dobry wynik ekonomiczny inwestycji. Spowodowane jest to bardzo tanią energią, którą inwestor pozyskuje z biomasy. Należy jednak zauważyć, iż komfort użytkowania kotła na biomasę jest znacznie wyższy od pieca kaflowego oraz zwrócić uwagę na fakt możliwości lepszej regulacji temperatury wewnątrz pomieszczeń. Zmiany te znacznie zwiększają komfort życia w domu. Należy także pamiętać, że przed termomodernizacją dom był uznawany przez właściciela za zimny. Istotny jest również duży efekt ekologiczny spowodowany likwidacją przygotowania c.w.u. w podgrzewaczu elektrycznym i zastąpienie go energią pozyskiwaną z biomasy. Koszt modernizacji budynku do standardu pasywnego wyniósł 140.000 zł (bez kosztów adaptacji) poddasza. Roczne 
oszczędności kosztów energii to maksymalnie 2000 zł. Niestety prosty okres zwrotu nakładów wynosi 70 lat.

Przedstawiony przykład głębokiej termomodernizacji domu jednorodzinnego pokazuje, że istnieje techniczna możliwość osiągnięcia znacznych (około 90\%) redukcji zużycia energii przez typowy wiejski dom jednorodzinny wybudowany w latach 60.,70. i 80. ubiegłego wieku. Jednak analiza ekonomiczna tego przedsięwzięcia nie napawa optymizmem. Tego typu domy ogrzewane są najczęściej energią pozyskiwaną lokalnie z biomasy, której koszty dla właściciela domu są znikome. Niestety spalanie znacznych ilości taniej biomasy w nieefektywnych paleniskach powoduje znaczne ilości emisji zanieczyszczeń do powietrza, szczególnie pyłów. Powstałe w ten sposób zanieczyszczenia powietrza powodują znaczące problemy zdrowotne mieszkańców miejscowości, w których powstaje zjawisko tak zwanej niskiej emisji. Dlatego ze względu na redukcję zanieczyszczeń powietrza i zmniejszenie kosztów zewnętrznych warto, mimo braku opłacalności ekonomicznej (przy aktualnych cenach energii), modernizować budynek według zasad zrównoważonego rozwoju.

\section{Podsumowanie i wnioski}

W Polsce decyzje inwestorów, czy budować obiekty spełniające kryteria zrównoważonego rozwoju, wciąż zależą od wielkości kosztów inwestycyjnych, a nie wielkości kosztów całkowitych (inwestycyjnych i eksploatacyjnych) w cyklu życia budynków. Ceny nośników energii są stosunkowo niskie, a technologie budowy z naturalnych materiałów, takich jak ziemia, słoma czy lekkie konstrukcje drewniane, są mało popularne i kojarzone z niską trwałością i biedą poprzednich pokoleń (ziemianki, lepianki i kryte strzechą małe drewniane domki). Jednak wzrost wymogów dotyczących standardów energetycznych wymuszony dyrektywami Unii Europejskiej i wspierany - niestety nie istniejącymi już - programami dofinansowania z NFOŚiGW spowodował rozwój budownictwa energooszczędnego.

Wznoszone budynki charakteryzują się dobrą izolacyjnością cieplną ścian, zastosowaniem wentylacji mechanicznej z odzyskiem, czasami zastosowaniem gruntowego wymiennika ciepła i zastosowaniem instalacji wykorzystujących niekonwencjonalne źródła energii. Projektanci 
trzymają się zasady ciągłości tradycji i nowoczesności oraz uwzględniają zwyczaje mieszkańców lub użytkowników w procesie projektowania. Rzadziej realizowane są zasady dotyczące stosowania odnawialnych lokalnych materiałów, wykorzystania urządzeń do zagospodarowania wody deszczowej i szarych ścieków. Wciąż jednak nie myśli się o tym, co się stanie $z$ budynkiem po okresie jego eksploatacji. Obiektów, które można by zakwalifikować jako wybudowane według zasad zrównoważonego rozwoju, jest w Polsce niewiele. Poza domami jednorodzinnymi zbudowanymi przez pasjonatów, można do nich zaliczyć obiekty posiadające certyfikaty BREEAM i LEED wysokich kategorii. Koszty inwestycyjne budynków spełniających kryteria zrównoważonego rozwoju zależą od powszechności stosowanych rozwiązań materiałowych i instalacyjnych i są wyższe od kliku do kilkudziesięciu procent od tradycyjnych technologii. Na przykład budynki pasywne kosztują maksymalnie do $20 \%$, drożej niż tradycyjne. Ale np. budynki z ziemi ubijanej mogą być nawet tańsze od tradycyjnych.

Przedstawione wyżej przykłady budynków nowych i zmodernizowanych, choć nie zbudowanych według wszystkich opisanych wyżej zasad, można uznać za spełniające kryteria zrównoważonego rozwoju. Budynek idealny z punktu widzenia zrównoważonego rozwoju to taki, który w minimalnym stopniu wpływa na pogarszanie się stanu środowiska naturalnego i jednocześnie zapewnia wysoką jakość środowiska wewnętrznego. Zrównoważone budownictwo oznacza więcej niż tylko budowanie nowych obiektów w odpowiednim ładzie przestrzennym. To przede wszystkim wykorzystanie przyjaznych dla środowiska materiałów oraz nowe technologie minimalizujące zużycie energii i powodujące redukcję emisji $\mathrm{CO}_{2}$ i wszelkich szkodliwych substancji. Zrównoważony rozwój to również aspekty społeczne mające na celu przeciwdziałanie ubóstwu energetycznemu i wykluczeniu społecznemu oraz poszanowanie tradycji.

W kontekście oceny spełnienia przez budynek kryteriów zrównoważonego rozwoju warto zająć się nie tylko budynkiem nowym, ale również budynkiem, który podlega kompleksowej modernizacji. Efektywność ekonomiczna tych inwestycji zależy od relacji kosztów eksploatacyjnych (energia, woda, ścieki, wywóz odpadów) do kosztów inwestycyjnych. 
Im droższe nieodnawialne nośniki energii i woda, tym krótsze proste okresy zwrotu nakładów. Pomiaru poziomu zrównoważenia budynku można dokonać za pomocą systemów certyfikacji typu BREEAM i LEED. Interesujący w tym zakresie wydaje się również wskaźnik BEE. Aby nastąpił rozwój budownictwa spełniającego kryteria zrównoważonego rozwoju, konieczne są zmiana świadomości społecznej oraz systemy wsparcia finansowego inwestycji lub/i odpowiednie regulacje.

\section{Bibliografia:}

ITB (Instytut Techniki Budowlanej). 2017. Metoda ITB oceny środowiskowej budynku. Dostęp: 24.04.2017. www.itb.pl/g/f/2136,metoda-itb-oceny-srodowiskowej-budynku.pdf.

Pierzchalska, Dorota i Arkadiusz Węglarz. 2016. Praktyczna realizacja idei głębokiej termomodernizacji. Materiały Budowlane, 1, 23-25.

PSBE (Polskie Stowarzyszenie Budownictwa Ekologicznego). 2017a. Certyfikacja wielokryterialna BREEAM. Dostęp: 24.04.2017. https:// plgbc.org.pl/certyfikacja-wielokryterialna/breeam/.

PSBE (Polskie Stowarzyszenie Budownictwa Ekologicznego). 2017b. Certyfikacja wielokryterialna LEED. Dostęp: 24.04.2017. https://plgbc. org.pl/certyfikacja-wielokryterialna/leed/

Węglarz Arkadiusz. 2013. Narzędzia wspomagające proces rewitalizacji budynków publicznych zgodnie z zasadami zrównoważonego rozwoju. Materiały Budowlane, (493)9, 21-23. 
Mieczysław Reksnis

Urząd m.st. Warszawy - Biuro Drogownictwa i Komunikacji

mreksnis@um.warszawa.pl

\section{Warszawska Polityka Mobilności}

W 2009 roku Rada Warszawy przyjęła Strategię zrównoważonego rozwoju systemu transportowego Warszawy do 2015 roku i na lata kolejne (uchwała nr LVIII/1749/2009 Rady m.st. Warszawy). Rada potwierdziła $\mathrm{w}$ ten sposób kierunek zrównoważonego rozwoju transportu, który po raz pierwszy został oficjalnie wyznaczony w Polityce transportowej m.st. Warszawy w 1995 roku.

Obecnie został przygotowany dokument Program operacyjny - Warszawska Polityka Mobilności. Ku bardziej przyjaznemu miastu (WPM). Dokument ten przewiduje kompleksowe działania mające na celu zachęcanie mieszkańców do odbywania podróży innymi środkami transportu niż samochód osobowy, tj. komunikacją publiczną, rowerem czy pieszo. Zwraca też uwagę na konieczność przekształcania przestrzeni publicznych i przywracania im społecznej roli; dostosowania parametrów ulic do planowanych funkcji; określenia nowej - ograniczonej roli samochodu w mieście; porządkowania parkowania, transportu ładunków, dostaw towarów i obsługi ruchu turystycznego.

Warszawska Polityka Mobilności nie zastępuje obowiązującej strategii transportowej, która określa kierunki i zasady modernizacji i rozwoju infrastruktury transportowej (drogowej i transportu zbiorowego) oraz poprawy bezpieczeństwa ruchu. Stanowi jej uzupełnienie i rozwinięcie w części dotyczącej działań związanych z zarządzaniem popytem na transport.

\section{Cel generalny}

Nadrzędnym celem WPM jest wzmocnienie skuteczności działań na rzecz zrównoważonego rozwoju, z określeniem nowej roli samochodu w mieście. WPM ma kształtować nowe postawy i nawyki związane z mobilnością, przez co ma wpływać na wielkość popytu na transport i sposób jego zaspokajania, inspirując władze i mieszkańców Warszawy 
do postępowania w zgodzie ze zrównoważonym rozwojem. W pierwszej kolejności ma zachęcać do podróżowania pieszo, rowerami i transportem zbiorowym, ma też zachęcać do ograniczonego wykorzystywania samochodów, zwłaszcza w strefie śródmiejskiej i centrach dzielnic.

WPM podtrzymuje generalny cel polityki transportowej Warszawy, jakim jest stworzenie warunków sprzyjających sprawnemu i bezpiecznemu przemieszczaniu osób i towarów przy ograniczeniu szkodliwego wpływu na środowisko naturalne i warunki życia. Dokument ten bierze pod uwagę, zapisany w polityce kierunków rozwoju systemu transportowego, rozwój układu drogowego i infrastruktury transportu zbiorowego. Porządkuje i wzmacnia także te działania, które odnoszą się do: planowania przestrzennego i planowania transportu, wzrostu roli ruchu pieszego i rowerowego, wpływania na popyt, zarządzania systemem transportowym, porządkowania parkowania i zasad transportu ładunków, procesu podejmowania decyzji (indywidualnych i grupowych) o odbywaniu podróży oraz edukacji transportowej. Dokument ten zakłada również podejmowanie działań, które mają zwiększać aktywność fizyczną mieszkańców oraz możliwość indywidualnego wpływania każdego z użytkowników systemu transportowego na ograniczenie emisji zanieczyszczeń i hałasu. Skuteczność działań prowadzących do zmiany świadomości i postaw społecznych będzie zależeć od współpracy instytucji kluczowych w procesie budowania przyjaznego miasta.

\section{Zagospodarowanie przestrzenne}

Ważną część WPM stanowią działania związane z zagospodarowaniem przestrzennym stolicy. W Warszawie mamy do czynienia ze zjawiskiem rozlewania się zabudowy (urban sprawl). Dlatego plany miejscowe będą wykorzystywane do racjonalizacji rozwoju przestrzennego miasta oraz realizacji polityki mobilności. Wprowadzona zostanie zasada wykonywania planów transportowych do opracowywanych planów miejscowych i decyzji o warunkach zabudowy i zagospodarowania terenu.

WPM przewiduje opracowywanie zintegrowanych programów rozwojowych dla wybranych rejonów strefy śródmiejskiej, otoczenia węzłów komunikacyjnych, korytarzy transportowych obsługiwanych 
wysokiej jakości transportem zbiorowym oraz obszarów planowanych przekształceń obecnej zabudowy. Celem będzie przejęcie przez miasto inicjatywy w planowaniu i programowaniu atrakcyjnych obszarów, a przez to zapewnienie kontroli kierunków ich rozwoju. Tworzenie programów rozwojowych będzie wymagać współpracy z mieszkańcami, inwestorami, właścicielami działek i innymi zainteresowanymi stronami.

W tym celu przeprowadzona zostanie identyfikacja i diagnoza obszarów monofunkcyjnych, a następnie zostaną opracowane i uruchomione programy, których celem będzie zwiększenie stopnia zróżnicowania sposobu użytkowania terenu, ograniczenie zapotrzebowania na transport oraz wzrost atrakcyjności podróżowania pieszo, rowerem i transportem zbiorowym. Problem dotyczy także przekształceń terenów kolejowych. Niezbędna w tym względzie jest współpraca m.st. Warszawy z koleją na rzecz ograniczania uciążliwości, jakie dla miasta stanowią tereny kolejowe - chodzi o ograniczenie efektu bariery komunikacyjnej i fragmentacji obszarów oraz o uzgodnienie zasad zagospodarowywania nieruchomości kolejowych.

Jednym z wyzwań dla Warszawy na najbliższe lata, zwłaszcza w strefie śródmiejskiej, będzie rewaloryzacja ulic i placów, w powiązaniu z odejściem od priorytetowego traktowania obsługi ruchu samochodowego. Aktywne działania w tym kierunku doprowadzą do oczywistych korzyści związanych ze zwiększeniem stopnia integracji społecznej, a także poprawią jakość życia w Warszawie i jej wizerunek miasta przyjaznego mieszkańcom i gościom.

\section{Wpływanie na popyt}

Celem Warszawskiej Polityki Mobilności jest zachęcenie do odbywania podróży pieszo, rowerem lub transportem zbiorowym, co z wielu powodów jest korzystniejsze niż podróżowanie samochodem. Zakłada się, że promowane i wspierane będą działania umożliwiające elastyczne godziny pracy, e-usługi, i telespotkania w miejsce tradycyjnych spotkań, praca zdalna bądź wykonywana częściowo w siedzibie firmy, a częściowo w domu, np. raz w tygodniu. Dzięki temu niektóre elementy systemu transportowego będą mogły być użytkowane w sposób bardziej elastyczny i pełnić wiele innych funkcji. Dobrym tego przykładem mogą 
być: wielofunkcyjne wykorzystanie parkingów prywatnych i parkingów $\mathrm{P}+\mathrm{R}$, wykorzystywanie na potrzeby $\mathrm{P}+\mathrm{R}$ parkingów zlokalizowanych w obszarach peryferyjnych, w rejonie dużych obiektów handlowych obsługiwanych transportem zbiorowym czy też zastępowanie, na obszarach peryferyjnych, tradycyjnej obsługi liniami komunikacji miejskiej zindywidualizowanym transportem publicznym. W celu lepszego organizowania codziennych podróży tworzone będą plany mobilności adresowane do konkretnych użytkowników, zawierające propozycje ułatwiające korzystanie $\mathrm{z}$ transportu zbiorowego i proponujące wybór innej niż samochód osobowy formy transportu.

Wpływanie na zachowania komunikacyjne wiąże się nie tylko ze stosowaniem środków zachęcających do alternatywnych form podróżowania, ale też środków zniechęcających do używania samochodów, takich jak ograniczanie dostępności wybranych obszarów miasta, szczególnie w śródmieściu. Oznaczać to będzie m.in. wyłączanie wybranych ulic z ruchu samochodowego, wyznaczanie naziemnych przejść dla pieszych, ograniczanie liczby miejsc postojowych dla samochodów oraz stosowanie środków technicznych redukujących prędkość ruchu.

\section{Ruch pieszy}

Ruch pieszy pełni ważną rolę w całym łańcuchu podróży miejskich. Jest także częścią podróży transportem zbiorowym (dojścia do/z przystanków, przejścia w węzłach przesiadkowych) i samochodami (dojścia do/z miejsc postoju i parkowania). Zakłada się rosnącą rolę systemu transportu pieszego, z uwzględnieniem potrzeb wszystkich grup użytkowników, w tym w szczególności osób z ograniczoną mobilnością. Celem jest przekroczenie poziomu 25\% podróży odbywanych w Warszawie pieszo. Należy oczekiwać, że wzrost ruchliwości pieszej będzie dotyczyć wszystkich grup użytkowników i motywacji podróży, zwłaszcza podróży związanych ze strefą śródmiejską, oraz przemieszczeń do i w obrębie węzłów przesiadkowych.

Wzmacnianie roli ruchu pieszego będzie dotyczyć całego miasta. Priorytetowo będą traktowane: strefa śródmiejska, centra dzielnic i powiązania pomiędzy nimi oraz dojścia, a także otoczenie węzłów komunikacyjnych. WPM przewiduje uruchomienie programów naprawczych 
w celu zapewnienia wymaganej dostępności ulic dla osób o ograniczonej mobilności (dostosowanie przejść przez jezdnie, likwidacja barier komunikacyjnych, dostosowanie sygnalizacji świetlnych), a także odzyskiwanie przestrzeni publicznych dla funkcji np. kulturalno-usługowych. Działania dotyczące ruchu pieszego będą wspomagane przez wprowadzenie standardów projektowania ciągów i przestrzeni pieszych.

\section{Transport zbiorowy}

Jednym z podstawowych założeń WPM jest utrzymanie dominującej roli transportu zbiorowego w systemie transportowym Warszawy. Będzie to wymagać zapewnienia wysokiej konkurencyjności transportu zbiorowego i jego poszczególnych podsystemów w stosunku do samochodów. Dotyczy to m.in. gęstości sieci tras komunikacyjnych, dostępności przystanków, okresu funkcjonowania, wysokości cen biletów, niezawodności, punktualności, komfortu, bezpieczeństwa i czasu podróżowania. W podróżach wykonywanych środkami transportu, czyli w tzw. podróżach niepieszych, będzie się dążyć do utrzymania udziału transportu zbiorowego, w skali miasta, na poziomie nie mniejszym niż $60 \%$ oraz zwiększenia tego udziału w podróżach do strefy śródmiejskiej do co najmniej $80 \%$ i z obszaru aglomeracji do Warszawy do $50 \%$. Zamierzenia dotyczące rozwoju transportu zbiorowego zostały szczegółowo określone w Strategii Transportowej Warszawy. Odnoszą się one zarówno do rozwoju i modernizacji infrastruktury, taboru, jak i działań o charakterze organizacyjnym.

Celem WPM będzie wzmocnienie konkurencyjności systemu transportu zbiorowego, zwiększenie stopnia integracji systemów transportu, racjonalizacja układu linii tramwajowych i autobusowych, a także kontynuacja rozwiązań z zakresu ITS. Szczególnym zadaniem będzie rozwój systemu poboru opłat w transporcie zbiorowym w kierunku jego ujednolicenia i zwiększenia dostępnych form zakupu biletu.

\section{Rola roweru}

Ograniczaniu roli samochodu towarzyszyć będzie stała poprawa warunków ruchu rowerowego. Celem będzie osiągnięcie w najbliższych latach $10 \%$ udziału ruchu rowerowego w podziale zadań przewozowych. 
Wymaga to stworzenia spójnego systemu tras i parkingów rowerowych łączących wszystkie źródła i cele podróży. Zakłada się kontynuację budowy infrastruktury rowerowej $\mathrm{w}$ formie wydzielonych dróg dla rowerów, pasów i kontrapasów rowerowych; dopuszczenie ruchu rowerowego pod prąd na ulicach jednokierunkowych oraz na wybranych odcinkach pasów autobusowych, a także tworzenie stref uspokojenia ruchu oraz likwidowanie barier w pokonywaniu skrzyżowań. Wzdłuż tras i w pobliżu ważniejszych obiektów organizowane są ogólnodostępne miejsca do parkowania rowerów. Ważnym zadaniem jest ułatwienie ruchu rowerowego na ulicach jednokierunkowych.

Warunkiem rozwoju i bezpiecznego korzystania z rowerów jest zapewnienie odpowiednich parametrów technicznych infrastruktury. W projektowaniu i wykonywaniu tras i parkingów rowerowych stosowane są standardy projektowe i wykonawcze dla systemu rowerowego w m.st. Warszawie. Parkingi $\mathrm{B}+\mathrm{R}$ są organizowane wraz $\mathrm{z}$ systemem $\mathrm{P}+\mathrm{R}$ oraz jako niezależne, lokalizowane $\mathrm{w}$ bezpośrednim sąsiedztwie przystanków kolejowych, metra, tramwajowych i autobusowych.

\section{Rola samochodu}

Warszawska Polityka Mobilności zakłada ograniczenie roli samochodów w mieście, zwłaszcza w strefie śródmiejskiej. Przeciwstawienie się presji zmotoryzowanych ma umożliwić przeznaczenie miejsc dotychczas zajmowanych przez samochody na inne cele, m.in. na poprawę warunków ruchu pieszego i rowerowego oraz rozwój społecznych i kulturowych funkcji ulic, a także poprawę jakości życia w mieście. Celem będzie także obniżanie wysokich kosztów funkcjonowania systemu transportowego, związanych m.in. z nadmiernym inwestowaniem w rozwój układu drogowego i jego utrzymanie. Uwzględniając zasadę strefowania ruchu, utrzymana zostanie swoboda korzystania z samochodów w wybranych obszarach miasta, np. w obszarach luźnej zabudowy oraz na trasach dojazdowych do węzłów przesiadkowych (jako elementu systemów $\mathrm{P}+\mathrm{R}$ i $\mathrm{K}+\mathrm{R})$.

$\mathrm{W}$ ramach WPM będą podejmowane działania zwiększające świadomość mieszkańców Warszawy, jeśli chodzi o zagrożenia związane z ruchem samochodowym oraz koszty posiadania i eksploatowania 
samochodu. Stosowane będą instrumenty zniechęcające do posiadania samochodów (np. ograniczenia ruchu i parkowania, mechanizmy finansowe), a także zachęcające do innego sposobu ich wykorzystywania (np. carsharing i carpooling), przynoszące korzyści społeczne, m.in. w postaci zmniejszenia liczby przejazdów samochodami i zapotrzebowania na parkowanie.

Ograniczeniu wykorzystywania samochodów, zwłaszcza w podróżach do strefy śródmiejskiej, sprzyjać będzie zmniejszanie przepustowości ulic i skrzyżowań. W strefie śródmiejskiej przekształcenia ulic, w tym zmiany w organizacji ruchu i parkowania, będą podporządkowywane priorytetowemu traktowaniu ruchu pieszego.

Zachętą do rezygnacji z posiadania własnego samochodu na rzecz korzystania z samochodów publicznych będzie rozwój systemów carsharingu. Wspierane będzie, zwłaszcza w strefie śródmiejskiej, korzystanie z samochodów o małych gabarytach, z małymi silnikami i z ekologicznymi napędami. W związku z powyższym, podejmowane będą działania edukacyjne i promocyjne, skłaniające do współużytkowania samochodów, zastępowania pojazdów o dużych gabarytach małymi oraz wykorzystywania samochodów w dojazdach do parkingów systemów $\mathrm{P}+\mathrm{R}$ i $\mathrm{K}+\mathrm{R}$.

\section{Parkowanie}

Negatywnym skutkiem rosnącej w Warszawie i aglomeracji motoryzacji są nasilające się problemy z parkowaniem samochodów. Rozwiązanie tych spraw jest niezwykle trudne i delikatne. Dlatego wiele będzie zależało od wyników planowanych przez m.st. Warszawa konsultacji społecznych. Realizacja WPM w tym zakresie będzie związana z porządkowaniem parkowania w mieście między innymi poprzez eliminowanie parkowania niezgodnego z przepisami, a w szczególności zagrażającego bezpieczeństwu ruchu drogowego. Stopniowo, ale konsekwentnie będzie to prowadzić do zmiany sposobu parkowania i zastąpienia parkowania na chodnikach, lub częściowo na chodnikach, parkowaniem na pasach postojowych i w zatokach. Priorytet będą miały działania poprawiające jakość przestrzeni miejskiej Warszawy, zwłaszcza w strefie śródmiejskiej, na wzór przekształceń Krakowskiego Przedmieścia i uli- 
cy Świętokrzyskiej. Polityka ograniczania motoryzacji indywidualnej i parkowania na ulicach obejmie także mieszkających w strefie śródmiejskiej, w obrębie strefy płatnego parkowania niestrzeżonego - SPPN, zwłaszcza biorąc pod uwagę bardzo dobrą w tej strefie dostępność wielu celów podróży pieszo i rowerem oraz możliwości korzystania ze sprawnej obsługi transportem zbiorowym. Parkowanie na ulicach, będzie zastępowane parkowaniem na parkingach wydzielonych. Porządkowanie parkowania będzie wymagać także zwiększenia sprawności funkcjonowania SPPN, w tym skuteczniejszego przeciwdziałania parkowaniu bez opłat i parkowaniu niezgodnemu z przepisami.

Działania związane $\mathrm{z}$ organizacją i porządkowaniem parkowania będą wymagać uruchomienia systemu zarządzania parkowaniem jako części zintegrowanego systemu zarządzania ruchem. System będzie zbierać informacje dotyczące parkowania i udostępniać użytkownikom informację o wolnych miejscach na parkingach miejskich, także miejsca dla autokarów.

\section{Transport ładunków}

Rozwój Warszawy w kolejnych latach będzie powodować wzrost rynku sprzedaży towarów i usług, co w konsekwencji spowoduje zwiększenie zapotrzebowania na transport ładunków. Szczególnym wyzwaniem będzie obsługa strefy śródmiejskiej, a także obszarów wrażliwych, np. stref pieszych, historycznych. Mieszkańcy oraz licznie zlokalizowane $\mathrm{w}$ tej strefie punkty usługowe i handlowe wymagają zapewnienia dostaw towarów. Z drugiej strony zadaniem będzie zmniejszenie negatywnego wpływu ruchu samochodów ciężarowych i dostawczych, w tym znacznych uciążliwości dla miasta, mieszkańców i środowiska. Pogodzenie tych interesów będzie możliwe dzięki nowoczesnemu zorganizowaniu systemu dostaw ładunków, także dostawczego i przesyłek kurierskich, obejmującego m.in. współpracę z centrami logistycznymi przy ustalaniu tras i okresów ruchu samochodów towarowych oraz organizację postoju pojazdów zaopatrzenia.

Oprócz działań na rzecz efektywnego systemu dostaw towarów dążyć się będzie do ograniczenia: natężenia ruchu samochodów ciężarowych w chronionych obszarach miasta, czasu postoju w przestrzeni ulicy na 
czas rozładunku/załadunku towarów, uciążliwości związanych z transportem towarów, blokowania ulic w krytycznych punktach, postoju i parkowania niezgodnego z przepisami i zagrażającego bezpieczeństwu ruchu, negatywnego oddziaływania na środowisko naturalne i mieszkańców, ograniczenie emisji zanieczyszczeń, hałasu i wibracji.

Rozwiązania dotyczące transportu ładunków będą mieć znaczenie dla gospodarki miasta. System logistyki miejskiej będzie kompleksowym rozwiązaniem organizacji dostaw towarów i przesyłek kurierskich w wybranych obszarach miasta, zwłaszcza w strefie śródmiejskiej.

Kontynuowana będzie także polityka ograniczania dostępności poszczególnych obszarów miasta dla samochodów ciężarowych. Zakłada się, że limitowanie (z wyłączeniem pojazdów mających odpowiedni identyfikator zezwalający na wjazd) będzie dotyczyć pojazdów o dopuszczalnej masie całkowitej powyżej $16 \mathrm{t}$ - zakaz wjazdu w obszar wyznaczony przebiegiem Obwodnicy Ekspresowej; pojazdów o dopuszczalnej masie całkowitej powyżej $5 \mathrm{t}$ - zakaz wjazdu w obszar wewnątrz Obwodnicy Śródmiejskiej.

\section{Edukacja i promocja}

Powodzenie realizacji WPM w dużej mierze zależy od działań edukacyjnych i promocyjnych. Priorytetem jest edukacja dzieci i młodzieży. Edukacja w wieku szkolnym w największym stopniu wpływa na rozwój i świadomość społeczeństwa oraz buduje kapitał wiedzy na następne lata. Planuje się wsparcie działań edukacyjnych poprzez tworzenie ośrodków szkoleniowych, dyskusji w ramach Warszawskiego Okrągłego Stołu Mobilności i innych form aktywności na rzecz zrównoważonej mobilności.

Ważna jest skuteczna promocja Warszawskiej Polityki Mobilności oraz postaw zgodnych z zasadami zrównoważonego rozwoju. Promocja WPM będzie prowadzona $\mathrm{w}$ formie akcji i wydarzeń organizowanych w przestrzeni publicznej, z wykorzystaniem mediów tradycyjnych i elektronicznych. Zachęcanie do zrównoważonej mobilności będzie się odbywać także przez dawanie dobrego przykładu przez radnych, władze miasta, urzędników i pracowników jednostek miejskich.

Zakłada się, że działania podejmowane w ramach Warszawskiej Polityki Mobilności będą sprzyjać kontynuacji rozwoju nowoczesnego mia- 
sta, integracji jego obywateli oraz poprawie jakości ich życia i zdrowia w warunkach ochrony środowiska. Aby tak się stało, WPM będzie realizowana w sposób kompleksowy, tak by umożliwiać i zachęcać mieszkańców miasta do podróżowania pieszo, rowerem i środkami transportu zbiorowego przy jednoczesnej rezygnacji z korzystania $\mathrm{z}$ samochodu.

\section{Bibliografia:}

Rada m.st. Warszawy. 2009. Strategia zrównoważonego rozwoju systemu transportowego Warszawy do 2015 roku i na lata kolejne (uchwała nr LVIII/1749/2009 Rady m.st. Warszawy). Dostęp: 29.05.2017. https:// www.ztm.waw.pl/download.php?z=77\&i=13\&l=1\&m=6.

Brzozowski, Andrzej et al. 2016. Program operacyjny - Warszawska Polityka Mobilności. Ku bardziej przyjaznemu miastu. Dostęp: 29.05.2017. http://transport.um.warszawa.pl/sites/default/files/ WPM\%20czerwiec\%202016\%20ca\%C5\%82o\%C5\%9B\%C4\%87_2.pdf. 


\section{CZESŚ́C VII ZRÓWNOWAŻONA GOSPODARKA I SPOEECZENSSTWO - PODEJŚCIE HORYZONTALNE}



Urszula Stefanowicz

Polski Klub Ekologiczny

u.stefanowicz@koalicjaklimatyczna.org

\section{Cele ONZ na poziomie lokalnym. Od Agendy 21 po Agendę 2030 - przyjęcie i wdrażanie na poziomie lokalnym celów ONZ w zakresie zrównoważonego rozwoju}

\section{Wstęp}

Przyjęta w 1992 roku Agenda 21 (ONZ 1992) przypisuje zadania do wszystkich poziomów organizacji, od międzynarodowego po lokalny. Rozdział 28. programu poświęcono wykorzystaniu inicjatywy władz lokalnych w realizacji celów zrównoważonego rozwoju. Wśród zalecanych działań wymieniono przygotowanie w procesie konsultacji z mieszkańcami i różnymi grupami interesariuszy tzw. lokalnych Agend 21. Rozdział 27. poświęcono wzmacnianiu roli organizacji pozarządowych jako partnerów we wdrażaniu programu.

Gdy w roku 1997 po raz pierwszy oceniono postępy w realizacji Agendy 21, wnioski nie były pozytywne. Poziom przeniesienia postanowień z 1992 roku na szczebel lokalny różnił się w zależności od regionu świata i kraju, ale generalnie był dość niski.

Istotne były przyczyny, z powodu których Agenda 21 nie rozwinęła się na poziomie lokalnym zgodnie z oczekiwaniami. Należy wziąć je pod uwagę przy wdrażaniu 17 najnowszych Celów Zrównoważonego Rozwoju (ang. Sustainable Development Goals - SDGs) przyjętych na szczycie ONZ w 2015 roku, a zawartych w dokumencie Przekształcamy nasz świat: Agenda na rzecz zrównoważonego rozwoju 2030 (ONZ 2015a - dalej Agenda 2030).

\section{Przebieg procesu przygotowania dokumentów i zaangażowanie w prace różnych grup interesariuszy}

\subsection{Agenda 21}

W 1983 roku Generalne Zgromadzenie ONZ powołało Światową Komisję ds. Środowiska i Rozwoju Narodów Zjednoczonych (ang. the 
World Commission on Environment and Development). W czasie, gdy Komisja się spotykała, świat mierzył się z głodem w Afryce, poważnymi wypadkami zanieczyszczenia chemicznego, katastrofą w Czarnobylu. Zyskiwały na znaczeniu problemy takie jak pustynnienie, kwaśne deszcze, dziura ozonowa czy zmiana klimatu. Rosła przepaść między państwami rozwiniętymi a rozwijającymi się. Punktem zwrotnym eksperckich analiz i dyskusji był upubliczniony w kwietniu 1987 roku raport Nasza wspólna przyszłość (ŚKŚR 1991). Publikacja Raportu Brundtland nadała debacie politycznej i publicznej na temat zrównoważonego rozwoju nowe tempo. W roku 1989 Zgromadzenie Ogólne ONZ powołało Komitet Przygotowawczy, który podjął pracę nad założeniami dla nowego, bezpiecznego dla środowiska i przyszłych pokoleń ładu społeczno-gospodarczego na potrzeby konferencji dotyczącej środowiska i rozwoju zaplanowanej na 1992 rok.

Organizacyjne spotkanie Komitetu (PrepCom) odbyło się w marcu 1990, po nim zorganizowano cztery sesje merytoryczne. Wartością dodaną tych prac było zwiększenie udziału organizacji pozarządowych (NGO) w międzynarodowym procesie politycznym. Komitet akredytował na swoje sesje łącznie 1378 organizacji. Podczas PrepCom IV wiele propozycji NGO zostało bezpośrednio włączonych do dokumentów rządowych. Dwa lata wspólnej pracy sprawiły, że przedstawiciele przynajmniej części państw i organizacji pozarządowych zaczęli lepiej rozumieć motywy i podstawy działania drugiej strony. Wielu uczestników procesu przyznawało też, że dalsza współpraca będzie konieczna na etapie wdrażania Agendy 21 (PrepComIV 1992).

\subsection{Agenda 2030}

Prace nad Agenda 2030 rozpoczęła decyzja z Konferencji Narodów Zjednoczonych w Sprawie Zrównoważonego Rozwoju Rio+20. Dokument, który był wynikiem negocjacji, został przyjęty 27 lipca 2012 na 66. sesji Zgromadzenia Ogólnego ONZ. Rezolucja 66/288 Przyszłość, jakiej chcemy (ONZ 2012) rozpoznała potrzebę opracowania nowego zestawu celów opartych na Agendzie 21, ale bazujących też na wynikach wcześniejszych szczytów dotyczących różnych aspektów zrównoważonego rozwoju i na już przyjętych przez państwa zobowiązaniach. Uzna- 
no, że cele powinny być zorientowane na działanie uniwersalne i przy tym łatwe do komunikacji, do czego nie przywiązywano takiej wagi 20 lat wcześniej. Przekłada się to na znaczną różnicę w przystępności obu dokumentów na korzyść Agendy 2030.

Uznano, że proces służący opracowaniu celów ma być przejrzysty oraz otwarty dla wszystkich interesariuszy. W styczniu 2013 r. zdecydowano o utworzeniu Otwartej Grupy Roboczej ds. Celów Zrównoważonego Rozwoju składającej się z 30 przedstawicieli nominowanych przez państwa członkowskie z pięciu grup regionalnych ONZ (ONZ 2013). Większość mandatów była dzielona przez kilka krajów.

Główne grupy społeczne i inni interesariusze mogli uczestniczyć w procesie poprzez klastry tematyczne, komentując i dostarczając wkład do wspólnych stanowisk oraz przekazując istotne dla procesu materiały (ONZ 2015b). Każdy klaster był koordynowany przez Komitet Sterujący odpowiedzialny za opracowanie wspólnego stanowiska, które później było przekazane Otwartej Grupie Roboczej.

Do bezpośredniego zaangażowania obywateli wykorzystano wiele narzędzi. W światowej ankiecie ONZ Mój Świat wypowiedziało się ponad 7 milionów osób - aż 75\% zabierających głos miało mniej niż 30 lat ${ }^{1}$. Sięgnięto też po media społecznościowe, co zwiększyło udział ludzi młodych w konsultacjach.

Zapewnienie szerokiego udziału społeczeństwa, przedstawicieli władz samorządowych i sektora prywatnego, częściowo można przypisać czynnikom zewnętrznym, m.in. rozwojowi Internetu. Jednak istotniejsze jest przyjęcie zasady jak najszerszego otwarcia się na głos wszystkich grup społecznych, aktywnego włączania interesariuszy w prace już na etapie ich planowania oraz konsekwentne kontynuowanie dialogu w czasie całego procesu. Ponadto ponad 20 lat budowania zasad udziału społeczeństwa obywatelskiego w procesach negocjacyjnych ONZ było dobrą podstawą do kompleksowego podejścia do prac nad Agendą 2030. Dlatego też uspołecznienie było większe niż w Agendzie 21 .

\footnotetext{
${ }^{1}$ Swój głos można było oddać na specjalnej witrynie internetowej: http://vote.myworld2015. org/.
} 


\section{Organizacje pozarządowe i poziom lokalny w treści dokumentów}

\subsection{Agenda 21}

W preambule Deklaracji $z$ Rio w sprawie środowiska i rozwoju, przyjętej razem z Agenda 21, zaznaczono, iż do osiągnięcia jej celu stworzone zostaną nowe formy współpracy, w tym z podstawowymi grupami społecznymi. W zasadzie 7 krajów rozwiniętych potwierdza odpowiedzialność, którą ponoszą w międzynarodowym dążeniu do zrównoważonego rozwoju w świetle nacisku, jaki do stanu środowiska globalnego przykładają ich społeczeństwa. Zasada 10. zaczyna się od stwierdzenia, że zagadnienia środowiskowe są rozwiązywane najlepiej z udziałem wszystkich zainteresowanych obywateli.

W tekście samej Agendy 21 lokalne społeczności lub władze, ich rola oraz podkreślanie kluczowego ich udziału, potrzeba ich wspierania, kierowane do nich rekomendacje lub zalecenia delegowania na poziom lokalny kompetencji, pojawiają się w niemal każdym z głównych obszarów zadań, w tym m.in. w rozdziałach dotyczących:

$\checkmark$ zdrowia (rozdz. 6 - w związku z miejskimi zagrożeniami dla zdrowia); $\checkmark$ rozwoju osiedli ludzkich (rozdz. 7 - w związku z potrzebą współpracy pomiędzy miastami pod auspicjami zrzeszających je organizacji pozarządowych, jak np. Międzynarodowa Rada na rzecz Lokalnych Inicjatyw Środowiskowych (ICLEI));

$\checkmark$ zarządzania zasobami powierzchni ziemi (rozdz. 10 - w związku z potrzebą zachęcania państw do delegowania kształtowania polityki do najniższego poziomu władzy publicznej);

$\checkmark$ walki z wylesianiem, a także z pustynnieniem i suszą (rozdz. 11 i 12 m.in. zaznaczenie roli lokalnych władz i społeczności w odwracaniu negatywnych procesów);

$\checkmark$ rozwoju terenów górskich i zrównoważonego rolnictwa (rozdz. 13 i 14 - zalecenie tworzenia zachęt dla lokalnych społeczności do podejmowania działań ochronnych i regeneracyjnych).

Udział i wsparcie lokalnych społeczności uznano za element niezbędny do sukcesu także w: ochronie różnorodności biologicznej (rozdz. 
15), ochronie oceanów i mórz (rozdz. 17 - potrzeba konsultacji z lokalną administracją i brania pod uwagę interesów lokalnych społeczności), ochronie i wykorzystaniu wód śródlądowych (rozdz. 18 - decentralizacja zarządzania zasobami wody, przekazanie kompetencji władzom lokalnym i wzmacnianie ich umiejętności), gospodarce odpadami stałymi i osadami z oczyszczalni ścieków (rozdz. 21 - m.in. tworzenie lokalnych programów gospodarki odpadami, zachęt dla władz lokalnych poddających recyklingowi największy procent odpadów).

Organizacje pozarządowe także są wskazywane w różnych kontekstach, w tym angażowania się w działania służące realizacji danego celu, prowadzenia działań edukacyjnych i kampanii informacyjnych itd. Za przykład mogą posłużyć zapisy dotyczące:

$\checkmark$ walki z ubóstwem (rozdz. 3 - zalecenie dla ONZ, by we współpracy, m.in. $z$ organizacjami pozarządowymi, realizowała szereg zadań, takich jak asystowanie rządom w formułowaniu i wdrażaniu krajowych programów zmniejszenia ubóstwa);

$\checkmark$ ochrony zdrowia (rozdz. 6 - zalecenie wsparcia technicznego m.in. dla organizacji pozarządowych);

$\checkmark$ ochrony atmosfery (rozdz. 9 - zalecenie współpracy rządów m.in. z NGO przy wykonywaniu szeregu zadań);

$\checkmark$ zapobiegania wylesieniu (rozdz. 11 - zalecenie promowania udziału organizacji pozarządowych w działaniach związanych z lasami);

$\checkmark$ walki z pustynnieniem i suszą (rozdz. 12 - budowanie współpracy rządów m.in. z komitetami i stowarzyszeniami użytkowników ziemi, odniesienie do lokalnych organizacji rolniczych);

$\checkmark$ rozwoju terenów górskich (rozdz. 13 - m.in. zachęcanie do budowania regionalnych, krajowych i międzynarodowych sieci, w tym także sieci NGO, działających na rzecz rozwoju terenów górskich);

$\checkmark$ gospodarki odpadami (rozdz. 21 - zachęcanie NGO i innych grup do współpracy z lokalnymi władzami w celu budowania poparcia dla recyklingu).

W trzeciej części Agendy 21, poświęconej wzmacnianiu roli głównych grup społecznych i organizacji znajdziemy całe rozdziały poświę- 
cone roli organizacji pozarządowych oraz władz lokalnych. Obie grupy są wskazywane jako kluczowi partnerzy w realizacji celów zrównoważonego rozwoju. Zgodnie z zapisami rozdziału 27. rządy i instytucje międzynarodowe miały m.in.: tworzyć mechanizmy umożliwiające takim organizacjom pełnienie partnerskiej roli w sposób odpowiedzialny i efektywny; przeprowadzać przeglądy procedur dotyczących angażowania się organizacji w kształtowanie polityk, podejmowanie decyzji i ich wdrażanie. Do 1995 roku miał być rozpoczęty dialog miedzy wszystkimi rządami a organizacjami pozarządowymi i ich sieciami, co nastąpiło w ograniczonym zakresie.

Samorządy terytorialne ujęto na liście głównych grup społecznych, ponieważ wiele problemów i rozwiązań, do których odnosiła się Agen$d a$, ma swoje korzenie na poziomie lokalnym. W rozdziale 28. zapisano takie cele jak: rozpoczęcie przez władze lokalne procesów konsultacyjnych ze społecznościami w sprawie Agendy do 1996 r.; zainicjowanie przez społeczność międzynarodową procesów mających na celu zwiększenie współpracy pomiędzy władzami lokalnymi w horyzoncie do 1993 r. oraz do 1994 r. w zdefiniowanych zakresach.

W części dotyczącej wdrażania Agendy dostrzeżono rolę organizacji pozarządowych w realizacji zadań związanych z promowaniem nauczania, kształtowania świadomości społecznej i szkolenia w zakresie zrównoważonego rozwoju i ochrony środowiska (rozdz. 36). Podkreślono, że przy promowaniu szerokiej świadomości społecznej ważne jest przekazywanie kompetencji, odpowiedzialności i środków na poziom najbardziej właściwy, z preferencją dla lokalnego. Wzmocnienie dialogu między strukturami ONZ a organizacjami pozarządowymi zostało też wskazane wśród celów i funkcji Komisji ds. Zrównoważonego Rozwoju (rozdz. 38). Organizacje pozarządowe wskazuje się jako jeden z elementów struktury instytucjonalnej, na której miała opierać się realizacja Agendy.

\subsection{Agenda 2030}

Już w samej Preambule zawarte jest stwierdzenie, że „Niniejsza Agenda będzie wdrażana przez wszystkie kraje i wszystkich interesariuszy poprzez działania w ramach współpracy partnerskiej”. Znamienne jest też zaznaczenie we wstępie Deklaracji, iż przyjęte cele i zadania są 
wynikiem prowadzonych przez ponad dwa lata intensywnych konsultacji społecznych i zaangażowania społeczeństwa obywatelskiego oraz innych zainteresowanych podmiotów na całym świecie.

Zapisy dotyczące roli władz lokalnych i organizacji pozarządowych znajdziemy również w paragrafach 34, 41, 45, 52, 79 i 89 nowej Agendy. Strony deklarują w nich m.in.:

$\checkmark$ w kontekście zapewnienia zrównoważonego rozwoju miast - współpracę z lokalnymi władzami i społecznościami „aby odnawiać i planować miasta i osiedla ludzkie w sposób sprzyjający spójności społecznej i bezpieczeństwu osobistemu oraz stymulować innowacje i zatrudnienie";

$\checkmark$ odnośnie do wdrażania Agendy - uznanie roli „zróżnicowanego sektora prywatnego”, a także „organizacji społeczeństwa obywatelskiego i organizacji dobroczynnych";

$\checkmark$ w związku z realizacją zobowiązań przez rządy i instytucje publiczne - ścisłą współpracę „Z władzami regionalnymi i lokalnymi, instytucjami subregionalnymi, instytucjami międzynarodowymi, środowiskiem akademickim, organizacjami dobroczynnymi, grupami wolontariuszy i innymi podmiotami";

$\checkmark$ w celu podkreślenia roli współpracy przy realizacji Agendy - „wyruszamy dziś w podróż drogą, która zaprowadzi nas do 2030 r. (...) wraz z rządami i parlamentami, strukturami Organizacji Narodów Zjednoczonych i innymi instytucjami międzynarodowymi, władzami lokalnymi, rdzenną ludnością, społeczeństwem obywatelskim, biznesem i sektorem prywatnym, środowiskiem naukowym oraz akademickim i wszystkimi ludźmi. Miliony już się zaangażowały w niniejszą Agendę i będzie to ich Agenda. Jest to Agenda należąca do ludzi, stworzona przez ludzi i dla ludzi - i to, jak wierzymy, zapewni jej sukces";

$\checkmark$ odnośnie do kontynuacji i przeglądu działań - zachęcanie państw członkowskich do tego, by przeglądy uwzględniały „wkład uzyskany od rdzennej ludności, społeczeństwa obywatelskiego, sektora prywatnego i innych zainteresowanych stron” oraz stwierdzenie „Forum polityczne wysokiego szczebla będzie sprzyjać udziałowi głównych 
grup i innych istotnych zainteresowanych stron w procesach monitorowania i oceny".

Samorząadów terytorialnych w największym stopniu dotyczy cel 11: „Uczynić miasta i osiedla ludzkie bezpiecznymi, stabilnymi, zrównoważonymi oraz sprzyjającymi włączeniu społecznemu" oraz przypisane do tego celu zadania. Jednak każdy z pozostałych celów także dotyka pracy lokalnych władz. Zapewnienie czystej wody i dobrych warunków sanitarnych, odpowiedniego poziomu edukacji i opieki zdrowotnej nie może być osiągnięte bez ich udziału.

\section{Wdrażanie}

\subsection{Agenda 21}

Na temat wdrażania Agendy 21 oraz jej poszczególnych celów napisano dziesiątki opracowań, np. The United Nations Commission on Sustainable Development: The First Five Years (Chasek 1997), Review of Implementation of Agenda 21 and The Rio Principles (Dodds, Schneeberger i Farooq 2012), Realizacja polityki ekologicznej w kontekście postanowień Szczytu Ziemi w Rio (Berkowska i Sobolewski 1995), Ocena postępów wdrażania Lokalnej Agendy 21 na świecie (Lorek i Sobol 2003), Kompas RIO + 10 czyli Spoteczna ocena realizacji przez Polskę dokumentów przyjętych na konferencji ONZ „Środowisko i rozwój” w czerwcu 1992 r. $w$ Rio de Janeiro (Kassenberg 2002). Większość z nich ocenia postępy krytycznie, choć doceniany jest między innymi wkład Agendy w podnoszenie świadomości społeczeństwa, rozwój instytucjonalny w ramach ONZ i poza nim oraz rozwój środowisk pozarządowych (Haas, Levy i Parson 1992, 6-11, 26-33).

Lokalna Agenda 21 bywa prezentowana jako sukces, ze względu na rozmiary i rozpowszechnienie programu, szczególnie w krajach europejskich. Jednak w liczbach bezwzględnych lub w porównaniu z liczbą samorządów, w których agenda nie została wprowadzona, sytuacja nie wygląda już tak dobrze (Lorek i Sobol 2003, 111-122). Główną przeszkodą w tworzeniu lokalnych programów zrównoważonego rozwoju był brak odpowiedniego finansowania, szczególnie widoczny w krajach 
rozwijających się. W praktyce po 1992 roku oficjalna pomoc rozwojowa spadała (Chasek 1997, 30). Kraje rozwinięte miały pokrywać znaczną część kosztów poprzez oficjalną pomoc rozwojową, przeznaczając na nią $0,7 \%$ swojego dochodu narodowego. $\mathrm{Z}$ tego zobowiązania wywiązały się jedynie kraje skandynawskie i Holandia (Kozłowski 2005, 289). Utrzymujące się problemy finansowe były powiązane $\mathrm{z}$ innymi przeszkodami, głównie brakiem woli politycznej rządów oraz zainteresowania ze strony społeczeństwa.

Reakcje społeczne na przyjęcie Agendy 21 i propagowanie jej były zróżnicowane. Powstały materiały krytykujące Agendę i instruujące, jak zablokować jej wdrażanie (JBS 2017). Miały one niewielki związek $\mathrm{z}$ rzeczywistą treścią dokumentu ONZ, ale w pewnym stopniu utrudniły upowszechnianie Lokalnej Agendy 21.

W 2002 roku ponad 6000 samorządów lokalnych z całego świata miało przyjętą jakąś formę polityki albo podejmowało działania na rzecz zrównoważonego rozwoju. W Polsce do 2002 rozpoczęto 70 inicjatyw, większość dzięki wsparciu zewnętrznych organizacji i agencji (np. UNDP, ICLEI). Jednak znajomość zagadnień zrównoważonego rozwoju wśród polskich władz lokalnych generalnie pozostawała niska, a realne postępy wdrażania Agendy w polskich gminach trudno oceniać z powodu braku kompleksowego monitoringu na poziomie krajowym (Lorek i Sobol 2003, 117-122). W pracach nad Lokalnymi Agendami brały udział polskie organizacje pozarządowe, np. Koło Miejskie Polskiego Klubu Ekologicznego w Tychach² ${ }^{2}$ Część gmin nadal ma w swoich planach, programach i strategiach odniesienia do Agendy. Tworzą i wdrażają inne dokumenty, w które wplecione są podobne zadania, np. programy ochrony środowiska i strategie rozwoju, a ostatnio także plany gospodarki niskoemisyjnej. Obowiązki nakładane na gminy w zakresie tworzenia dokumentów planistycznych są rozbudowane i często trudne do wykonania, szczególnie dla mniejszych gmin.

Status organizacji pozarządowych wzrósł w pierwszych latach wdrażania Agendy 21, tak jak i liczba NGO zarejestrowanych jako obserwatorzy procesów ONZ. Organizacje zaczęły odgrywać rolę mediatorów, obserwatorów, kontrolerów i ekspertów. Wzrósł poziom ich profesjo-

\footnotetext{
${ }^{2}$ Informacje na ten temat znajdują się na witrynie: http://pke-tychy.ovh.org.
} 
nalizmu i agencje ONZ zbudowały z nimi stosunki korzystne dla obu stron. Nie można jednak wiązać takich zmian jedynie z procesem przygotowania i wdrażania Agendy, ponieważ postęp ten jest w dużej części zasługą zmian o charakterze oddolnym oraz szeroko rozumianego rozwoju społeczeństwa obywatelskiego w wielu krajach. Nadal jest też wiele rządów, które nie prowadzą z organizacjami w swoich krajach otwartego dialogu (Dodds, Schneeberger i Farooq 2012, 6 i 24).

\subsection{Agenda 2030}

Sesja forum Rady Społeczno-Gospodarczej w 2016 dotycząca finansowania rozwoju zakończyła się przyjęciem wniosków i rekomendacji dotyczących wdrażania Celów Zrównoważonego Rozwoju. Powstała lista wskaźników realizacji celów (ONZ 2017). Sekretarz Generalny ONZ przygotował na 70. sesję Zgromadzenia Ogólnego raport zakreślający krytyczne elementy kontynuacji i przeglądów na poziomie globalnym. Wykorzystał przy tym stanowiska 119 państw. Swój wkład do raportu zapewniły też główne grupy społeczne i inni interesariusze.

W lipcu 2016 w Nowym Jorku odbyła się pierwsza sesja Forum Politycznego Wysokiego Szczebla (HLPF) na temat zrównoważonego rozwoju. Podczas spotkania przyjęto Deklarację Ministerialną dotyczącą realizacji Agendy, w której podkreślono m.in. potrzebę zaangażowania $\mathrm{w}$ ten proces władz lokalnych, regionalnych, parlamentu i innych stron zainteresowanych, w szczególności sektora prywatnego, nauki, społeczeństwa obywatelskiego, organizacji dobroczynnych.

ONZ we współpracy z różnymi partnerami prowadzi intensywne działania promocyjne obejmujące prezentację Celów Zrównoważonego Rozwoju i zachęcanie do podejmowania wyzwań z nimi związanych, np.:

48-godzinny globalny hackathon dotyczący 3 celów (9 - przemysł, innowacje i infrastruktura; 10 - ograniczanie nierówności w i pomiędzy krajami, 12 - odpowiedzialna konsumpcja i produkcja);

$\checkmark$ Globalny Festiwal Idei - pierwsze coroczne forum w ramach UN SDG Action Campaign - myśliciele, decydenci, społeczeństwo obywatelskie oraz eksperci od gier i symulacji politycznych zebrani, by

\footnotetext{
${ }^{3}$ Informacje na ten temat znajdują się na witrynie: http://www.connect2effect.com/.
} 
stworzyć pierwszą „rozgrywaną” konferencję polityczną, która ma przekształcić uczestników z pasywnych delegatów w aktywnych graczy (GFI 2015).

Dokonuje się także otwarcie na informacje zwrotne od różnych grup i osób indywidualnych, jak np.: platforma Mój Świat 2030 - http://myworld2030.org, gdzie obywatele mogą przekazać, co jest dla nich ważne w Agendzie. Wykorzystywane są nawet technologie wirtualnej rzeczywistości, żeby pokazać ludzkie historie stojące za wyzwaniami rozwojowymi, zmieniać percepcję i budować empatię .

Wychodzi się też naprzeciw potrzebom miast, tworząc takie źródła użytecznych dla władz lokalnych informacji, jak nowa witryna Localizating the SDGs - http://localizingthesdgs.org/. Do działań przyłączają się organizacje działające na rzecz samorządów, takie jak ICLEI. Już przed przyjęciem Agendy 2030, na światowym kongresie (ICLEI World Congres 2015) omawiano możliwości wdrażania nowych celów w miastach i zakorzeniania zrównoważonego rozwoju na poziomie lokalnym (ICLEI 2015). Organizacja stworzyła też nową witrynę (https://sustainablecities.iclei.org/), na której zebrano wyzwania, przed jakimi stają, oraz rozwiązania, jakie wprowadzają miasta należące do sieci. Inna organizacja, UCLG United Cities and Local Governments, przygotowała analizę wszystkich celów pod kątem zadań istotnych na poziomie lokalnym (UCLG 2015). W jej ocenie 90 ze 169 zadań ma znaczenie dla władz lokalnych.

\section{Podsumowanie}

Zapewnienie równowagi między rozwojem gospodarczym a ochroną środowiska, synergii między nimi, to jedno z najpoważniejszych wyzwań stojących przed społecznością międzynarodową. Przeszkodą jest nadmiernie uproszczony pogląd, iż ochrona środowiska wiąże się z dodatkowymi kosztami i spowolnieniem rozwoju. Porównując Agendę 21 i Agendę 2030, jak i sposób wypracowania ich treści, widać wyraźny wzrost roli podmiotów lokalnych, NGO oraz form dialogu społecznego.

\footnotetext{
${ }^{4}$ Zadanie to realizuje portal United Nations Virtual Reality: https://unitednationsvirtualreality. wordpress.com/.
} 
W Agendzie $2030 \mathrm{w}$ większym stopniu uwzględniono rolę organizacji pozarządowych i samorządów terytorialnych, w tym w zakresie implementacji Agendy oraz jej realizacji i monitorowania. Ten wzrost ich znaczenia powinien przełożyć się, także w Polsce, na uwzględnienie go w krajowych regulacjach.

Oczywiście nadal pojawiają się też reakcje negatywne, podobne do tych związanych z Agendą 21 lub będące wręcz ich kontynuacją (DeWeese 2016). Nowe cele są nazywane „Agendą 21 na sterydach” w znaczeniu pejoratywnym (Dykes i Dykes 2015) lub receptą na globalny socjalizm (Newman 2016), głównie w odniesieniu do celu 10 - Zmniejszenia nierówności w krajach i między krajami. Można wyjść z założenia, że w globalnej sieci znajdziemy każdy zestaw poglądów. Jednak ze względu na efekty błędnego zrozumienia celów Agendy 21 przez niektóre grupy społeczne, przy zmieniających się trendach społeczno-politycznych i narastającej fali nacjonalizmów, warto przyłączyć się do wysiłku wyjaśniania i promowania nowych Celów Zrównoważonego Rozwoju.

\section{Bibliografia:}

Berkowska, Elżbieta i Mirosław Sobolewski. 1995. Realizacja polityki ekologicznej w kontekście postanowień Szczytu Ziemi w Rio, nr 291. Biuro Studiów i Ekspertyz Kancelarii Sejmu.

Chasek, Pamela. 1997. The United Nations Commission on Sustainable Development: The First Five Years. Dostęp: 22.02.2017. http://archive. unu.edu/ona/PDF/Papers/Chasek,\%20PAPER.pdf.

DeWeese, Tom. 2016. Stand with Us Against Agenda 2030! Dostęp: 20.02.2017. http://americanpolicy.org/2016/08/29/stand-us-agenda-2030/.

Dodds, Felix, Kirsty Schneeberger i Ulla Farooq. 2012. Sustainable Development in the 21st century (SD21) Review of Implementation of Agenda 21 and The Rio Principles Synthesis, Stakeholder Forum for a Sustainable Future. Dostęp: 22.02.2017. https://sustainabledevelopment. un.org/content/documents/641Synthesis_report_Web.pdf.

Dykes, Aaron i Melissa Dykes. 2015. Agenda 2030 Translator: How To Read The UN's New Sustainable Development Goals. Dostęp: 22.02.2017. http://www.activistpost.com/2015/09/agenda-2030-translator.html. 
GFI (Global Festival of Ideas). 2015. Dostęp: http://globalfestivalofideas.org/about/festival/.

Haas, Peter, Marc Levy i Edward Parson. 1992. Appraising the Earth Summit: How Should We Judge UNCED’s Success. Environment, (34)8, 6-11, 26-33.

ICLEI. 2015. ICLEI World Congress 2015. Sustainable Solutions for an Urban Future. Dostęp: 22.02.2017. http://worldcongress2015.iclei.org/.

JBS. 2017. Agenda 21. Rollback Maual. Dostęp: 22.02.2017. http://big. assets.huffingtonpost.com/JBSManual.pdf.

Kassenberg, Andrzej. 2002. Kompas RIO + 10 czyli Społeczna ocena realizacji przez Polskę dokumentów przyjętych na konferencji ONZ „Środowisko i rozwój" w czerwcu 1992 r. w Rio de Janeiro. Warszawa: Instytut na rzecz Ekorozwoju.

Lorek, Elżbieta i Agnieszka Sobol. 2003. Ocena postępów wdrażania Lokalnej Agendy 21 na świecie. Studia Regionalne i Lokalne, (12)2, 111-122.

Newman, Alex. 2016. UN Agenda 2030: A Recipe for Global Socialism. Dostęp: 22.02.2017. https://www.thenewamerican.com/tech/environment/item/22267-un-agenda-2030-a-recipe-for-global-socialism.

ONZ. 1992. Agenda 21. Tłumaczenie: Dokumenty końcowe konferencji Narodów Zjednoczonych „Środowisko i rozwój”. Szczyt Ziemi, Rio de Janeiro, 3-14 czerwca 1992 r. 1993. Instytut Ochrony Środowiska.

ONZ. 2012. „Przyszłość, jakiej chcemy”. Rezolucja 66/288 przyjęta przez Zgromadzenie Ogólne ONZ w dniu 27 lipca 2012 r.

ONZ. 2013. Open Working Group on Sustainable Development Goals. Dostęp: 22.02.2017. https://sustainabledevelopment.un.org/owg.html.

ONZ. 2015a. „Przekształcamy nasz świat: Agenda na rzecz zrównoważonego rozwoju 2030". Rezolucja 70/1 przyjęta przez Zgromadzenie Ogólne ONZ w dniu 25 września 2015 r.

ONZ. 2015b. Sustainable Development Goals. Thematic Clusters. Dostęp: 22.02.2017. https://sustainabledevelopment.un.org/index. php?menu=1565. 
ONZ. 2017. Welcome to the Sustainable Development Goal indicators website. Dostęp: 22.02.2017. https://unstats.un.org/sdgs/.

PrepComIV: the Final Stop on the Road to Rio. Earth Summit Bulletin, 27(1992)1, 1-8. Dostęp: 22.02.2017. http://www.iisd.ca/download/ pdf/enb0127e.pdf.

ŚKŚR (Światowa Komisja ds. Środowiska i Rozwoju). 1991. Nasza wspólna przyszłość, tłum. Urszula Grzelońska i Ewa Kolanowska. Warszawa: Państwowe Wydawnictwo Ekonomiczne.

UCLG. 2015. The Sustainable Development Goals What Local Governments Need to Know. Dostęp: 22.02.2017. https://www.uclg.org/sites/default/files/the_sdgs_what_localgov_need_to_know_0.pdf. 
Aleksandra Ciżmowska

Uniwersytet Kazimierza Wielkiego w Bydgoszczy - Wydział Humanistyczny

ocizmowska@wp.pl

\section{Eliminacja ubóstwa jako nadrzędny cel zrównoważonego rozwoju: założenia i rzeczywistość}

\section{Wstęp}

Pogląd, iż „ubóstwo nie jest zjawiskiem zawinionym przez ubogich, lecz skutkiem wad strukturalnych danych społeczności” (Kowalak i Leś 1998, 139) jest dzisiaj dominujący w debatach o istocie ubóstwa we współczesnym świecie. O tworzeniu przez globalną gospodarkę tzw. „nowych ubogich” lub „, ludzi, którzy odpadli” z pracy i są nieuniknionym rezultatem modernizacji i postępu gospodarczego pisał m.in. Zygmunt Bauman (Bauman 2006, 165). Paul Collier - autor książki poświęconej problemowi skrajnego ubóstwa na świecie, identyfikując cztery główne „pułapki”, w które wpadły najuboższe państwa świata, tj.: krwawe wojny domowe, złe rządzenie, nieprzyjazne wrogie sąsiedztwo innych państw i „przekleństwo surowców” (za: Anioł 2010, 21), także wskazuje na obiektywne przyczyny współczesnego ubóstwa.

Walka z ubóstwem na świecie, stała się głównym celem działalności wielu organizacji międzynarodowych, jak i pozarządowych, wśród których szczególną rolę, w ostatnich 30 latach, odgrywa ONZ. Wpisała ona aktywność na rzecz ograniczania ubóstwa na świecie w koncepcję zrównoważonego rozwoju.

Niniejszy referat skupia się na analizie założeń i deklaracji w zakresie zwalczania ubóstwa na świecie, jakie pojawiały się w kluczowych dokumentach ONZ dotyczących zrównoważonego rozwoju począwszy od Raportu Brundtland z 1987 r. aż po Agendę na Rzecz Zrównoważonego Rozwoju 2030 przyjętą w 2015 r. Postaram się też krótko ocenić, na ile udało się rzeczywiście ograniczyć ubóstwo na świecie w minionych trzech dekadach, co nie było łatwym przedsięwzięciem. Ponieważ rezultaty te określa się jako „umiarkowanie niekorzystne zmiany”, konieczne wydało mi się przynajmniej zasygnalizowanie przyczyn rozbieżności pomiędzy wyznaczonymi celami a rzeczywistymi osiągnięciami w zwalczaniu światowej biedy. 


\section{Ubóstwo w kluczowych dokumentach ONZ dotyczących zrówno- ważonego rozwoju}

Pierwszym dokumentem, który nieodłącznie wiąże się ze zrównoważonym rozwojem, jest Raport Światowej Komisji do Spraw Środowiska i Rozwoju, pt. Nasza wspólna przyszłość, opublikowany w 1987 r. Komisja została powołana cztery lata wcześniej, a jej przewodniczącą została Gro Harlem Brundtland. To jej nazwiskiem określa się najczęściej wspomnianą Komisję, jak i przygotowany pod jej kierunkiem dokument. Raport Brundtland jest najczęściej przywoływany jako opracowanie, którego pierwsze zdanie streszcza ideę zrównoważonego rozwoju oraz wprowadza i definiuje dwa pojęcia, które są kluczowe dla prawidłowego zrozumienia, czym jest zrównoważony rozwój, tj. pojęcie podstawowych potrzeb oraz ograniczeń środowiskowych, które limitują zaspokajanie tych potrzeb (Siemiński 1999, 9). Szczegółowa lektura tego dokumentu pozwala odnaleźć wiele odniesień do innych spraw, w tym także do kwestii światowego ubóstwa. Już w Słowie Wstępnym Przewodnicząca Komisji wskazuje, że kiedy w 1982 r. dyskutowano sprawę kompetencji Komisji, niektórzy opowiadali się za ograniczeniem jej zainteresowań do problemów środowiska, ale uznano że „Środowisko jako takie nie istnieje w oderwaniu od ludzkich działań, ambicji i potrzeb” (ŚKŚR 1991, 12). I dlatego „Sprzężenie między ubóstwem, nierównością i degradacją środowiska stanowią główny przedmiot naszej analizy i formułowanych zaleceń" - pisze dalej Gro Harlem Brundtland (ŚKŚR 1991, 13). W założeniach pracy Komisji światowe ubóstwo, ale także związane z nim nierówności, były zagadnieniem priorytetowym, najściślej skorelowanym $\mathrm{z}$ troską o zachowanie naturalnego środowiska człowieka. Potwierdzają to słowa z części wstępnej Raportu pt. Wyzwania globalne: „ubóstwo jest główną przyczyną i zarazem skutkiem kłopotów ze środowiskiem w skali globalnej. Dlatego bezskuteczne są próby rozwiązywania problemów środowiska bez uwzględnienia czynników leżących u podstaw ubóstwa w świecie i nierówności między krajami" (ŚKŚR 1991, 20).

Fakt, że ubóstwo na świecie stało się według Komisji Brundtland „wspólną troską" $\mathrm{i}$ jednym $\mathrm{z}$ „zagrożeń przyszłości” wynikało z niespotykanych wcześniej zarówno rozmiarów tego zjawiska: „w dzisiejszym 
świecie żyje więcej ludzi biednych niż kiedykolwiek przedtem w historii ludzkości i liczba biednych wzrasta (...), jak i z wielkich różnic, które pojawiły się w dochodzie PKB brutto na jednego mieszkańca między poszczególnymi krajami” (ŚKŚR 1991, 50-51).

Wysoka ranga ubóstwa nie znalazła jednak odzwierciedlenia w postanowieniach Raportu dotyczących działań na przyszłość. Problem ten został wpisany jedynie w tzw. wyzwanie 5, dotyczące żywności, wyzwanie 7 zatytułowane Energia: wybory dokonywane w imię środowiska i rozwoju oraz znalazł się w rozdziale 9, w którym wskazano na potrzebę uwzględnienia siedmiu posunięć przybliżających mieszkalnictwo i usługi ludziom biednym. Również, w kończącym dokument Aneksie, pt. Proponowane prawne zasady ochrony środowiska i stabilnego rozwoju przyjęte przez grupę ekspertów, nie ma żadnej zasady czy też obowiązku bezpośrednio odnoszącego się zagadnienia ubóstwa na świecie (ŚKŚR 1991, 449-452). Jednak samo utworzenie Komisji oraz rezultaty jej prac świadczą o tym, że w dobie globalizacji wspólnota międzynarodowa, reprezentowana przez Organizację Narodów Zjednoczonych, ale także przez międzynarodowe organizacje finansowe (BŚ i MFW), poczuła się odpowiedzialna za rosnącą przepaść między bogatymi i biednymi krajami i otworzyła drogę do jej zmniejszenia.

Wspomniana Komisja przyczyniła się do zwołania w 1992 roku w Rio de Janeiro Konferencji ONZ pt. „Środowisko i Rozwój”, zwanej też Szczytem Ziemi. Miała ona stworzyć wizję nowego ładu ekonomicznego i społecznego na świecie u progu nowego tysiąclecia. Przyjęto na niej pięć dokumentów, z których dla zagadnienia ubóstwa znaczenie miały dwa: Deklaracja $z$ Rio w sprawie Środowiska i Rozwoju oraz Globalny Program Działań - Agenda 21.

Deklaracja, prezentująca 27 zasad przyszłych praw i obowiązków państw w ich wysiłkach na rzecz rozwoju ludzkości i dobrych warunków życia, podnosi walkę z ubóstwem oraz nierównościami jako Zasadę 5, wskazując: „Wszystkie państwa i wszyscy ludzie powinni współpracować przy realizacji zasadniczego zadania, jakim jest wykorzenienie ubóstwa - co jest niezbędne do zapewnienia trwałego i zrównoważonego rozwoju oraz do zmniejszenia różnic w poziomie życia większości ludzi na świecie - i dążyć do zaspokojenia ich potrzeb" (Dokumenty końcowe 
1998, 14). W ramach rozwoju zrównoważonego, tym celem najistotniejszym jest jakość życia, do osiągnięcia której potrzeba spełnić wiele wymagań, takich jak np. ustanowienie prawa środowiskowego, utworzenie wspierającego i otwartego międzynarodowego systemu ekonomicznego, promowanie odpowiedzialnej polityki demograficznej, ale także wykorzenienie ubóstwa (Kozłowski 1997, 63-64). Dokument nie precyzuje szczegółowych celów, wskaźników, terminów czy obszarów, do jakich miałyby się odnosić działania państw i społeczeństw w zakresie zwalczania ubóstwa. To zadanie miał wypełnić drugi z przyjętych w Rio de Janeiro dokumentów.

W I części Globalnego Programu Działań - Agenda 21 znalazł się rozdział 3 zatytułowany Walka z ubóstwem, który można określić jako szczegółowy plan działań, jakie powinny zostać podjęte, aby ograniczyć zasięg ubóstwa na świecie. Podstawą tych działań powinna być promocja wzrostu gospodarczego w państwach rozwijających się oraz umocnienie znaczenia administracji lokalnej. Mieszkańcy powinni uczestniczyć w ochronie i zachowaniu zasobów naturalnych, ale powinni mieć także udział w korzyściach uzyskiwanych z wykorzystywania zasobów ich regionu. „Cele, które powinny zostać osiągnięte w ramach walki $\mathrm{z}$ ubóstwem to m.in.:

(a)pilne umożliwienie wszystkim ludziom trwałej możliwości zarabiania na środki utrzymania;

(b)wprowadzenie w życie strategii działań, które promują odpowiedni poziom wynagrodzeń oraz prowadzą do zintegrowania polityki rozwoju środowiska człowieka i rozwoju przyszłych pokoleń" (Dokumenty końcowe 1998, 41-42).

Zapisy dotyczące ubóstwa są nie tylko uszczegółowieniem w zakresie problemu światowego ubóstwa, podjętego w Raporcie Brundtland i 5 Zasadzie Deklaracji, ale dają zupełnie nowe spojrzenie na to, jak rozwiązywać tę kwestię. Biedni nie mogą być uzależnieni od zagranicznej pomocy, najczęściej żywnościowej. Aby trwale zmieniło się ich życie, trzeba umożliwić im pracę i odpowiednie za nią wynagrodzenie oraz włączyć w proces wspierania rozwoju społeczności, do których należą. 
Jednak zwiększenie możliwości pracy zarobkowej dla osób ubogich, poprzez rozwój gospodarczy krajów, w których mieszkają, powinno być ściśle połączone z poszanowaniem środowiska.

Ważnym elementem Agendy $21 \mathrm{w}$ aspekcie ograniczania ubóstwa było szacunkowe określenie kosztów jego realizacji, które miały wynosić 30 mld dolarów rocznie (Dokumenty końcowe 1998, 47) Sprawa finansowania, nie tylko zresztą walki z ubóstwem, wzbudziła na konferencji najwięcej sporów, gdyż Stany Zjednoczone nie chciały się zgodzić na przeznaczanie przez kraje wysoko uprzemysłowione $0,7 \%$ swojego PKB dla krajów rozwijających się (Kozłowski 2002, 70-71).

Deklaracja Milenijna Narodów Zjednoczonych przyjęta w 2000 roku, miała ukierunkować działania społeczności międzynarodowej na dokonywanie znaczących zmian niosących postęp. W kwestii ubóstwa przywódcy państw i szefowie rządów m.in.:

wzywają państwa uprzemysłowione do „przyznania większej pomocy na cele rozwoju, zwłaszcza tym krajom, które podejmują rzeczywiste wysiłki w sferze wykorzystania własnych zasobów do ograniczania ubóstwa";

$\checkmark$ postanawiają „zmniejszyć do 2015 roku o połowę liczbę ludzi, których dzienny dochód nie przekracza jednego dolara, a także ludzi cierpiących głód (...) oraz zmniejszenia o połowę liczby ludzi, którzy nie mają dostępu lub których nie stać na czystą pitną wodę" (Deklaracja Milenijna 2000).

Twórcy Deklaracji nie tylko potwierdzili swoją odpowiedzialność za losy Ziemi i ludzkości, ale także wprowadzili element czasowy, poprzez wyznaczenie terminu realizacji przyjętego zobowiązania $\mathrm{w}$ zakresie ograniczania ubóstwa, i ogólnie sformułowany wskaźnik („o połowę”), który miał zostać osiągnięty. Tym samym rozpoczęto nowy sposób podejścia do wytyczania celów walki ze światowym ubóstwem.

Konferencja w Johannesburgu w 2002 r. oznaczała przejście od generalnych porozumień do skromniejszych, ale konkretnych planów działania. Główny nacisk położono nie na negocjowanie kolejnych traktatów, ale na uzgodnienie konkretnych kroków zmierzających do 
realizacji uchwał konferencji w Rio (Raport o stanie świata 2004, 10). Obydwa dokumenty przyjęte na konferencji w 2002 r., tj. Deklaracja z Johannesburga w sprawie zrównoważonego rozwoju, jak i Plan Działania, potwierdzały wcześniej przyjęte cele, które miały być osiągnięte do 2015 r., czyli przede wszystkim:

$\checkmark$ zmniejszenie o połowę liczby ludności, której wydatki na utrzymanie dzienne nie przekraczają jednego dolara (nadzieja dla 1,1 mld osób); $\checkmark$ utworzenie funduszu solidarności przeznaczonego na walkę z ubóstwem przy zachowaniu jednak dobrowolności wpłat (Droga do Johannesburga 2002).

W opinii niektórych uczestników Szczytu sam fakt, że w ogóle udało się przyjąć dokumenty końcowe, w obliczu ujawniających się od początku negocjacji rozbieżności poglądów i interesów poszczególnych stron, należy uznać za sukces (Sobolewski 2002). Takim sukcesem było też zapewne uznanie w pierwszej części Deklaracji, „że wykorzenienie ubóstwa, zmiana wzorców konsumpcji i produkcji oraz ochrona i zarządzanie bazą zasobów naturalnych dla rozwoju gospodarczego i społecznego stanowią nadrzędne cele i istotne warunki zrównoważonego rozwoju" (Wójtowicz i Pazdan 2003, 47).

Kolejny Szczyt Ziemi, który odbył się znowu w Rio de Janeiro w czerwcu 2012 r., również nie wprowadzał nowych celów w ograniczaniu ubóstwa. W dokumencie końcowym konferencji potwierdzono, że „Eliminacja ubóstwa stanowi obecnie największe wyzwanie globalne, przed jakim stoi świat, i niezbędny wymóg zrównoważonego rozwoju. W tej sprawie dążymy do uwolnienia ludzkości od ubóstwa i głodu jako pilnego zadania” oraz podkreślono "potrzebę dokonania postępu we wdrażaniu wcześniejszych zobowiązań" (Przyszłość jakiej chcemy 2002). Za jedno z głównych narzędzi eliminacji ubóstwa w kontekście zrównoważonego rozwoju, przyjęto postulat rozwoju tzw. zielonej gospodarki (Przyszłość jakiej chcemy 2002). Chociaż analiza dokumentu wskazuje na dominację deklaracji i zapewnień nad konkretnymi zobowiązania$\mathrm{mi}$, to uwzględniono $\mathrm{w}$ nim finansowe zabezpieczenie postulowanych zadań: „kraje wysoko rozwinięte zobowiązały się do przeznaczenia $0,7 \%$ 
ich PNB na rzecz oficjalnej pomocy rozwojowej dla krajów rozwijających się do 2015 r., a kraje o niższym poziomie rozwoju od 0,15\% do 0,2\% PNB w analogicznym okresie" (Czech 2012, 37). Zawiodły jednak oczekiwania decyzji przywódców najważniejszych państw w sprawie utworzenia funduszu żywnościowego, do którego miałoby trafić te $0,7 \%$ PKB bogatych krajów członkowskich ONZ.

Jednym $\mathrm{z}$ rezultatów Rio +20 , była też decyzja o inauguracji procesu na rzecz opracowania zestawu nowych Celów Zrównoważonego Rozwoju, mających stanowić kontynuację Celów Milenijnych, których horyzont czasowy kończył się w 2015 r. Dlatego we wrześniu tegoż roku na Szczycie Agendy Zrównoważonego Rozwoju przyjęto dokument Przekształcamy nasz świat: Agenda na rzecz zrównoważonego Rozwoju 2030 (Rezolucja przyjęta przez Zgromadzenie Ogólne ONZ 2015), który zawiera 17 Celów Zrównoważonego Rozwoju.

Mają one, w aspekcie ubóstwa, szerszy zakres niż Cele Milenijne, gdyż zajmują się także przyczynami ubóstwa, a działania na ich rzecz obejmują więcej dziedzin. Podkreśla się także, że Nowe Cele są powszechne i dotyczą wszystkich ludzi, a nie tylko tych w państwach rozwijających się. Pojawiły się też zapowiedzi opracowania mierników postępu w realizacji wytyczonych celów. Dla każdego zadania miałyby powstać dwa takie mierniki (Zrównoważony rozwój i cele Zrównoważonego Rozwoju 2015).

\section{Postęp w ograniczaniu ubóstwa na świecie i jego uwarunkowania}

Opracowanie mierników ubóstwa i jego przejawów jest właściwym posunięciem, gdyż dane zawarte $\mathrm{w}$ raportach ONZ o rozwoju społecznym, które ukazują się od 1990 r., są w większości przypadków raczej szacunkowe. Brak odpowiednich instrumentów skazuje $\mathrm{z}$ reguły badaczy na ogólne oceny stanu ubóstwa zwłaszcza w państwach słabo rozwiniętych.

W Raporcie o Rozwoju Społecznym z 2002 roku, który przygotowano kiedy obradował Szczyt Ziemi w Johannesburgu, stwierdzono na przykład, że „choć globalizacja umacnia wzajemne zależności, to jednak świat wydaje się coraz bardziej podzielony - na biednych i bogatych" (Omówienie Raportu HDR 2002). Roczny PKB na głowę mieszkańca, który, aby o połowę zmniejszyć liczbę ludzi żyjących za 1 dolara dzien- 
nie, powinien rosnąć w tempie 3,7\%, osiągnął taki poziom tylko w 24 państwach, a w wielu był ujemny. Oznaczało to zwiększanie się odsetka ludzi żyjących w ubóstwie. Za mniej niż dwa dolary dziennie żyło wtedy na świecie 2,8 miliarda ludzi, a $1 \%$ światowej populacji zarabiało w ciągu roku tyle, ile wynoszą łączne dochody 57\% najbiedniejszej ludności świata (Omówienie Raportu HDR 2002).

Trudno jest ocenić postęp w zwalczaniu ubóstwa na świecie od tego czasu, jeśli w Raporcie z 2014 r. można przeczytać, że: „Według wskaźników pomiaru ubóstwa opartych na dochodach, 1,2 miliarda ludzi żyje za 1,25 dolara lub mniej dziennie. Jednak najnowsze szacunki UNDP oparte na Wskaźniku Wielowymiarowości Ubóstwa (...) pokazują, że prawie 1,5 miliarda ludzi w 91 krajach rozwijających się żyje w ubóstwie z powodu niewystarczającej opieki zdrowotnej i edukacji oraz zbyt niskich standardów życia" (Raport o Rozwoju Społecznym 2015). Z kolei przedstawiając Raport o Rozwoju Społecznym 2015, jego główny autor Selim Jahan, zapewnia, że postęp, jaki nastąpił w okresie od ukazania się pierwszego takiego raportu, jest imponujący, o czym ma świadczyć, że na całym świecie około dwóch miliardów ludzi zostawiło za sobą życie na najniższym poziomie egzystencji, a ponad miliard ludzi przezwyciężyło ubóstwo oraz ponad 2,5 mld ma teraz dostęp do czystej wody pitnej, chociaż trzeba pamiętać, że postęp ten nie jest równomierny ani we wszystkich regionach, ani obszarze poszczególnych krajów (Rasper 2015).

Jeszcze trudniej mówić o efektywności działań na rzecz zmniejszania ubóstwa, jeśli sięgniemy do innych źródeł, gdzie dane są, przede wszystkim, nieporównywalne. I tak, Szef Banku Światowego, otwierając w 2013 r. wiosenną sesję tej instytucji oraz MFW, stwierdził, że w ciągu ostatnich trzech dekad liczba ludzi żyjących w ekstremalnej biedzie spadła w krajach rozwijających się z 50\% w 1981 r. do 21\% w 2010 r. Największym problemem jest - i to potwierdzają też raporty ONZ - że co dziesiąta osoba zaliczana do skrajnie ubogich, czyli utrzymujących się za mniej niż 1,25 dolara dziennie, żyła w Afryce subsaharyjskiej. W sumie było to $414 \mathrm{mln}$, podczas gdy w roku 1981 znacznie mniej, tj. ok. $205 \mathrm{mln}$ (Na świecie 1,2 mld ludzi żyje w skrajnej biedzie 2013). Komentując te dane, można mówić raczej o regresie niż o postępie. 
Przyczyn niepowodzeń jest wiele. Znaczny wpływ miała sytuacja gospodarcza na świecie. W krajach rozwiniętych lata 90., w porównaniu z latami 80., były okresem spadku tempa wzrostu gospodarczego. Sytuacja powtórzyła się w końcu pierwszej dekady obecnego stulecia. Zapewnienie więc ludziom biednym postulowanej godziwej pracy i wynagrodzenia było trudne, gdyż generalnie na świecie nastąpiło ograniczenie ilości i jakości miejsc pracy (Mizgajski 2012). Rządy państw, borykając się z sytuacją kryzysową we własnym kraju, są mniej skłonne pomagać innym. Ta skłonność nie jest zresztą dużo większa w okresach prosperity, gdyż na ogół przywódcy preferują interesy narodowe i posiadają tylko „słowną" umiejętność wychodzenia naprzeciw problemom innych społeczeństw. I „dokładając” jeszcze rządzącym w najbardziej wpływowych państwach świata, można wskazać, że, popierając tzw. wielki biznes, stawiają często prywatne interesy ponad potrzeby ludzi i środowiska. W tej grupie przyczyn ekonomicznych i politycznych trzeba też przypomnieć wieloletni opór państw wysokorozwiniętych przed wiążącym zapisem o przeznaczaniu określonej części PKB na cele zrównoważonego rozwoju. Deklaracje nie wchodziły często w stan realizacji albo wpłaty były tylko częściowe.

A więc, z jednej strony przyczyną braku większych sukcesów jest jak wielu przedsięwzięciach - niedostatek środków materialnych, ale można też spotkać opinie, że przyjmowane programy (np. Przyszłość jakiej chcemy) są utopijne ze względu na bardzo wysokie koszty wdrożenia i z powodu braku ustaleń dotyczących źródeł pochodzenia oraz sposobów rozdysponowania tych gigantycznych sum (Mizgajski 2012).

O powodzeniu deklarowanych przedsięwzięć decyduje także charakter postulowanych rozwiązań kwestii światowego ubóstwa. Zarzuca im się chociażby, że mają bardziej ideologiczny niż praktyczny wymiar, co wynika chociażby z tego, że oczekiwania uczestników niektórych państw były od początku nierealistycznie wysokie, a co więcej rozbieżne (Szczyt klimatyczny Rio+20 2012). Nie zgadzam się z takim ujęciem, gdyż nie tylko rozwój gospodarczy, ale także idealistyczne wizje, które ścierają się z realiami tego świata przyczyniają się do postępu w wielu dziedzinach.

I wreszcie, bardziej szczegółowa przyczyna, czyli brak albo niedostateczny rozwój w biednych państwach systemów zabezpieczenia społecz- 
nego. Jeśli ludzi nawet mają pracę, to jeśli ją stracą z powodu choroby, niepełnosprawności czy po prostu starości, często popadają w ubóstwo. Wydaje się, że dotąd w niedostatecznym stopniu zwracano uwagę na tworzenie w krajach rozwijających się publicznych systemów ochrony socjalnej i ubezpieczeń społecznych.

\section{Zakończenie}

Ta krótka, z racji stawianych autorom wymagań, analiza deklaracji i zobowiązań społeczności międzynarodowej w dziedzinie eliminowania ubóstwa zapisanych w kluczowych dokumentach ONZ dotyczących zrównoważonego rozwoju, pozwala sądzić, że najważniejsze problemy i cele zostały już zidentyfikowane. Określone zostały też sposoby ich realizacji, chociaż są one ciągle uszczegóławiane. Dominuje pogląd, że problemu ubóstwa nie można rozwiązać bez przyspieszenia, odpowiednio ukierunkowanego, rozwoju gospodarczego biednych krajów, który nie może jednak wpływać na pogorszenie stanu środowiska. Wiadomo też, że biedne państwa nie poradzą sobie bez pomocy światowych instytucji i ekonomicznych potęg, które jednak ciągle głównie deklarują, zamiast przyczyniać się do realizacji niezbędnych zadań w omawianym obszarze. Nie dostrzegają bowiem, że realizacja zasad zrównoważonego rozwoju pomaga nie tylko ubogim, ale wszystkim ludziom. Może więc trzeba upowszechniać i udowadniać słowa Khalida Malika, dyrektora Biura ds. Raportu o Rozwoju Społecznym, które wypowiedział, omawiając Raport 2014: „Dostarczanie większych zasobów i dostępu do usług biedniejszym, wykluczonym i marginalizowanym pomoże w zwiększeniu możliwości każdego człowieka" (Raport o Rozwoju Społecznym 2015).

\section{Bibliografia:}

Anioł, Włodzimierz. 2010. Jak walczyć ze światowym ubóstwem? W: Polityka publiczna wobec ubóstwa i wykluczenia społecznego, red. Ryszard Szarfenberg, Cezary Żołędowski i Maria Theiss, 19-32. Warszawa: Dom Wydawniczy Elipsa.

Bauman, Zygmunt. 2006. Praca. Konsumpcjonizm i nowi ubodzy. Kraków: Wydawnictwo WAM. 
Czech, Katarzyna. 2012. Szczyt Ziemi Rio+20 - jaka przyszłość zrównoważonego rozwoju? Dostęp: 25.01.2017. http://cejsh.icm.edu.pl/cejsh/ element/bwmeta1.element.desklight-a1c359bc-7b4e-41d5-9a80-22ab34311d50/c/3_K.Czech_Szyt_ziemi_rio_20....pdf.

Deklaracja Milenijna Narodów Zjednoczonych. Dostęp: 15.09.2016. http;//www.unic.un.org.pl deklaracja_milenijna.doc.

Dokumenty końcowe Konferencji Narodów Zjednoczonych „Środowisko i Rozwój” Rio de Janeiro, 3-14 czerwca 1992 r. Szczyt Ziemi. 1998. Warszawa: Instytut Ochrony Środowiska.

Droga do Johannesburga. Dostęp: 04.02.2009. http//www.unic.un.org. $\mathrm{pl} /$ Johannesburg/droga.php.

Kowalak, Tadeusz i Ewa Leś. 1998. Kwestia ubóstwa. W: Polityka Społeczna. Materiały do studiowania, red. Antoni Rajkiewicz, Jolanta Supińska i Mirosław Księżopolski, 109-148. Katowice: Śląsk.

Kozłowski, Stefan. 1997. W drodze do ekorozwoju. Warszawa: Wydawnictwo Naukowe PWN.

Kozłowski, Stefan. 2002. Ekorozwój. Wyzwanie XXI wieku. Warszawa: Wydawnictwo Naukowe PWN.

Mizgajski, Andrzej. 2012. Kolejny szczyt ziemi Rio+20 - czy rozmowami można rozwiązać problemy globalne? Dostęp: 10.02.2017. http:// www.greencrosspoland.org/wp-content/uploads/.../Prof.-Andrzej-Mizgalski-o-Rio20.pdf.

Na świecie 1,2 mld ludzi żyje w skrajnej biedzie. Dostęp: 20.10.2016. http://www.forbes.pl/na-swiecie-1-2-mld-ludzi-zyje-w-skrajnejbiedzie,artykuly,153574,1,1.html.

Omówienie Raportu HDR 2002. Dostęp: 15.09.2016. http://www. unic.un.org.pl/hdr/omowienie-2002.php.

Przyszłość jakiej chcemy. 2002. Organizacja Narodów Zjednoczonych A-CONF.216-L.1* Dostęp: 10.12.2016. http://stat.gov.pl/files/gfx/ portalinformacyjny/pl/defaultstronaopisowa/5993/1/1/przyszlosc_jakiej_chcemy_pl.pdf. 
Raport o Rozwoju Społecznym 2014. 2015. Dostęp: 10.02.2017. http:// www.unic.un.org.pl/unic-activities/raport-o-rozwoju-spolecznym2014\%E2\%80\%9Eutrwalenie-rozwoju-spolecznego:-zmniejszaniewrazliwosci-grup-spolecznych-i-budowa-odpornosci\%E2\%80\%9D/2630.

Raport o stanie świata. O postępie w budowie zrównoważonego społeczeństwa. 2004. Warszawa: KiW.

Rasper, Anka. 2015. Raport ONZ o Rozwoju Społecznym 2015: o rozwoju decyduje nie wzrost tylko kreatywność. Dostęp: 16.01.2017. http://www. dw.com/pl/raport-onz-o-rozwoju-spo\%C5\%82ecznym-2015-o-rozwojudecyduje-nie-wzrost-tylko-kreatywno\%C5\%9B\%C4\%87/a-18917464.

Rezolucja przyjęta przez Zgromadzenie Ogólne ONZ w dniu 25 września 2015 r. 2015. Dostęp: 10.12.2016. http;??www.unic.un.org.pl/zrównoważony - rozwój---cele/agenda-na-rzecz- zrównoważonego -rozwoju-2030.

Siemiński, Janusz L. 1999. Czy rozwój zrównoważony miast? Przestrzeń, (8), 7-15.

Sobolewski, Mirosław. 2002. Ocena dorobku Światowego Szczytu w sprawie Zrównoważonego Rozwoju w Johannesburgu (WSSD). Dostęp:10.12.2016. http://biurose.sejm.gov.pl/teksty_pdf/i-942.pdf.

Szczyt klimatyczny Rio+20. Wielka klęska? 2012. Dostęp: 16.01.2017. http://wiadomosci.gazeta.pl/wiadomosci/1,114873,11990458,Szczyt_ klimatyczny_Rio_20_Wielka_kleska_html.

ŚKŚR (Światowa Komisja ds. Środowiska i Rozwoju). 1991. Nasza wspólna przyszłość, tłum. Urszula Grzelońska i Ewa Kolanowska. Warszawa: Państwowe Wydawnictwo Ekonomiczne.

Wójtowicz, Aleksandra i Wanda Pazdan. 2003. Johannesburg na żywo i co dalej? Warszawa: Agencja Reklamowo-Wydawnicza Arkadiusz Grzegorczyk.

Zrównoważony rozwój i Cele Zrównoważonego Rozwoju. 2015. Dostęp: 10.02.2017. http://www.unic.un.org.pl/strony-2011-2015/zrownowazonyrozwoj-i-cele-zrownowazonego-rozwoju/2860. 
Andrzej Kiepas

Politechnika Śląska - Kolegium Nauk Społecznych i Filologii Obcych

Andrzej.Kiepas@polsl.pl

\section{Zrównoważony rozwój w perspektywie „przemysłu 4.0”}

\section{Wstęp}

Procesy globalizacji, jako główne czynniki dynamizacji współczesnych przemian, charakteryzują się w ogólności określonym stopniem nieprzejrzystości i niekontrolowalności. Jest to wynikiem kompleksowego charakteru tych procesów, w których ilość czynników determinujących jest tak duża, iż - obok tego, co regularne i przewidywalne - pojawiają się różne efekty przypadkowe. Dynamika procesów globalizacji powodowana jest dzisiaj głównie czynnikami natury ekonomicznej i technicznej. W procesach globalizacji spotyka się jednocześnie to, co globalne, z tym, co lokalne, a ich wzajemna determinacja sprawia, że żaden $z$ tych wymiarów nie funkcjonuje całkowicie samodzielnie, bowiem nie ma tu żadnych pierwotnych i niezależnych czynników. Koncepcja zrównoważonego rozwoju, pomimo także właściwej jej nieprzejrzystości, może być uważana za ideę regulatywną w stosunku do procesów globalizacji. Fundamentem koncepcji zrównoważonego rozwoju jest idea sprawiedliwości między- i wewnątrzpokoleniowej, a ta jest trudna do instrumentalizacji, choćby $\mathrm{z}$ uwagi na trudności $\mathrm{w}$ znalezieniu uniwersalnych miar tego, co się komu należy. Idea sprawiedliwości jako idea konstytutywna może być jednak wspierana przez ideę odpowiedzialności, a ta z kolei w większym stopniu aniżeli idea sprawiedliwości poddaje się instrumentalizacji, choć wiąże się to też z określonymi trudnościami i nieuniknionymi „kosztami”. Zmienia się bowiem sposób pojmowania odpowiedzialności i jej wymagań, co stanowi wyzwanie zarówno dla teorii jak i dla praktyki.

\section{Tradycyjne pojmowanie odpowiedzialności i jej ograniczenia}

Tradycyjne rozumienia odpowiedzialności łączyły ją ze sprawcą jako podmiotem odpowiednich działań i to takim, który jest zarazem świadomy następstw, jakie są wynikiem tych działań. Odpowiedzialność 
mieściła się w granicach wiedzy i intencjonalnie działającego podmiotu. Podmiotem odpowiedzialności była jednostka kierująca się odpowiednią intencją i świadomie wywołującą coś, co jest skutkiem jej działań. H. Jonas określa to mianem odpowiedzialności ex post, czyli za to, co zostało uczynione (Jonas 1996, 167nn.).

Horyzont patrzenia na działanie i jego następstwa ograniczał się do bezpośrednich i bliskich przestrzennie i czasowo skutków działań, zaś odpowiedzialność mieściła się w obszarze mocy sprawczych człowieka i tego, co w ich wyniku zostało przez niego uczynione. Podmiotem odpowiedzialności były tylko podmioty indywidualne, przedmiotem powodowane przez nie skutki działań, a instancją sumienie (Ingarden 1987, 97nn.). Takie rozumienie odpowiedzialności wydaje się jednak obecnie niewystarczające $\mathrm{z}$ uwagi na zmienioną naturę ludzkiego działania. Działania człowieka nabierają obecnie nowych cech $\mathrm{z}$ uwagi na to, że:

a) stają się działaniami zbiorowymi, zorganizowanymi instytucjonalnie; podmiotem działania stają się zbiorowości, a nie podmioty indywidualne;

b) skutki odpowiednich działań zbiorowych mogą mieć charakter kumulatywny, gdyż skutki działań jednostkowych sumują się i dają w efekcie odpowiednie rezultaty końcowe;

c) skutki będące wynikiem współdziałania w strukturach, które nie mają charakteru hierarchicznego, lecz sieciowy (heterarchiczny), są wynikiem pojawienia się wielu następstw przypadkowych, które nabierają intencjonalnego charakteru; obok zależności sieciowych, inna z przyczyn pojawiania się tego typu skutków ma też związek z instytucjonalizacją działań oraz z tym, iż nieodłączna od wielu działań technika nie jest środkiem całkowicie neutralnym (Lizut 2014, 71nn.);

d) sumienie i jego rola jako instancji odpowiedzialności są ograniczane, co jest związane między innymi z: cząstkowym charakterem bezpośredniego sprawstwa, czasową i przestrzenną odległością działania i jego następstw, zapośredniczeniem działań poprzez technikę.

Ograniczenie znaczenia tradycyjnego sposobu pojmowania odpowiedzialności sprawia, iż pojawiają się próby rozdzielenia odpowiedzialności i sprawstwa. 
Problem powiązania odpowiedzialności i sprawstwa znalazł swoje częściowe rozwiązanie w koncepcji odpowiedzialności prewencyjnej typu ex ante H. Jonasa (Jonas 1996, 170nn.). Przedmiotem odpowiedzialności nie jest już tylko to, co zostało uczynione, lecz także i przede wszystkim to, co uczynione być może. Koncepcja H. Jonasa odwołuje się jednak nadal do podmiotów jednostkowych i nie uwzględnia roli działań instytucjonalnie zorganizowanych. Problem odpowiedzialności instytucjonalnej - określanej też jako korporacyjna - był, między innymi, przedmiotem różnych dyskusji na gruncie etyki biznesu (Etyka biznesu 1997). Okazało się jednak, iż problem nie jest łatwy do rozwiązania i dlatego też do dzisiaj, pomimo wielu prób, nie mamy właściwie odpowiedniej koncepcji odpowiedzialności odpowiadającej wskazanym wymogom. Spór od strony teoretycznej wydaje się być aktualnie nierozwiązywalny i stąd też ostatecznie kwestie korporacyjnej odpowiedzialności przesunięte zostały na płaszczyznę praktyczną, gdzie pojawiła się koncepcja „społecznej odpowiedzialności organizacji” (corporation social responsibility). Problem odpowiedzialności społecznej organizacji w zderzeniu z perspektywą "przemysłu 4.0” ujawnia jednakże swoje określone ograniczenia ${ }^{1}$.

\section{Przemysł 4.0 - etyka robotów}

Koncepcja „przemysłu 4.0” odnosi się w ogólności do zmian w procesie produkcji i wytwarzania, choć w dalszej konsekwencji prowadzić może również do zmian w procesie zarządzania, funkcjonowania określonych organizacji, jak i do relacji pomiędzy różnymi podmiotami uczestniczącymi w procesach gospodarczych. Oczekiwać można, iż zmiany dotyczyć będą również społeczeństwa i kultury, bowiem pojawią się nowe wymogi np. odnoszące się do odpowiedzialności. U podstaw tej koncepcji leży rozwój technologii informacyjnych i inteligentnych technik i pojawiające się również nowe możliwości ich wykorzystania w procesie gospodarowania. W konsekwencji chodzi o opty-

\footnotetext{
${ }^{1}$ Nazwa „przemysł 4.0” używana jest w Niemczech jako „Industrie 4.0”, zaś w USA określa się to mianem „Smart Manufacturing Leadership Consortium” lub też jako „Smart factory”. Sama ta idea odnosi się pierwotnie do procesów produkcji i wytwarzania i jak dotąd także dyskusje wokół niej zdominowane są przez szeroko rozumiane aspekty „techniczne” (informatyczne). Ewentualne zmiany nie będą się zapewne ograniczać do tego wymiaru, lecz przyjmą szerszy charakter.
} 
malizację działania różnych organizacji, lecz taką, która będzie miała całościowy charakter. Obecnie bowiem optymalizacje mają charakter sektorowy i w konsekwencji nie ma nawet dużych możliwości ich odpowiedniego zsumowania. W rezultacie zakładana elastyczność organizacji miała w praktyce ograniczony i często jedynie deklarowany charakter. Idea „przemysłu 4.0” (Maślanka 2014) zakłada możliwość permanentnej i ciągłej optymalizacji odbywającej się w czasie rzeczywistym, co sprawia, iż elastyczność organizacji osiąga wyższy poziom. Szeroko pojmowana optymalizacja działania odpowiednich organizacji stanowi podstawowy cel związany z realizacją koncepcji „przemysłu 4.0”. Jednym z podstawowych narzędzi realizacji tego celu są odpowiednie programy informatyczne związane z rozwojem nowych technologii informacyjnych, takich jak: chmura obliczeniowa, Big Data czy Internet rzeczy. Inną z podstaw jest tu rozwój inteligentnych technologii tworzących w konsekwencji systemy samokorygujące i samosterujące swoje funkcjonowanie. Umożliwiają one dokonywanie różnych działań optymalizacyjnych w czasie rzeczywistym, co w konsekwencji prowadzić będzie do przemieszania świata realnego i wirtualnego. Nie potrzeba w tym względzie przekraczania jakiejś określonej „masy krytycznej” w celu wywołania zmian.

„Przemysł 4.0” może być z tej perspektywy widziany jako element współczesnej kultury określanej przez M. Castellsa jako kultura realnej wirtualności, gdzie to, co rzeczywiste, i to, co wirtualne, jest tak ze sobą przemieszane, iż w konsekwencji staje się wzajemnie nieodróżnialne (Castells 2007, 378nn.).

W konsekwencji, w wyniku osiągnięcia założonych w idei „przemysłu 4.0" celów, osiągnięte powinno być zbudowanie takiej organizacji, która powinna posiadać pewne charakterystyczne dla niej cechy, a mianowicie:

powinna powstać inteligentna organizacja (smart factory), działająca nie tylko w sposób automatyczny, ale także zdolna do samooptymalizacji, czyli do: szybkiej adaptacji do zmian i odpowiedzi na sygnały pochodzące $z$ otoczenia;

$\checkmark$ organizacja powinna posiadać zdolność i możliwość ciągłego monitorowania własnych wytworów oraz ich korygowania i dostosowywania do indywidualnych potrzeb poszczególnych odbiorców; 
$\checkmark$ cały system realizowany dzięki różnym technologiom informatycznym, w tym także mobilnym, będzie systemem komunikacji pomiędzy różnymi podmiotami uczestniczącymi nie tylko w procesie wytwarzania określonych wyrobów, lecz także w procesach ich upowszechniania i użytkowania;

$\checkmark$ stworzona inteligentna sieć będzie całością realną i wirtualną, a powstały w konsekwencji świat realnej wirtualności będzie powiązaniem tego, co obiektywne, i tego, co subiektywne;

$\checkmark$ sieć będzie w konsekwencji także wrażliwa na określone wartości i ich zmiany, przy czym sposób jej funkcjonowania uzależniony będzie nie tylko od odpowiednio ustrukturalizowanej linearnie wiedzy, lecz również pozostawać będzie ona otwarta na możliwości oddziaływania różnych impulsów i czynników, a powstałe w rezultacie w czasie rzeczywistym stany nie będą $\mathrm{w}$ ten sposób jedynie wynikiem prostych determinacji przyczynowo-skutkowych.

Wskazane tu cechy charakterystyczne dla idei „przemysłu 4.0” wydawać się mogą dzisiaj jeszcze czymś nierealnym, choć wiele z proponowanych tu rozwiązań jest już dzisiaj możliwych ze względu na istniejące aktualnie możliwości informatyczne i techniczne. W wyniku urzeczywistniania koncepcji „przemysłu 4.0” kształtować się też będzie „społeczeństwo 4.0" wraz z upowszechnianą w ten sposób kulturą realnej wirtualności. Idea „przemysłu 4.0” określana jest też czasami jako kolejna, czwarta, rewolucja przemysłowa, po: a) maszynie parowej i powstaniu pierwszych fabryk; b) produkcji masowej realizowanej między innymi poprzez taśmę produkcyjną; c) wstępnych procesach automatyzacji pracy i wdrażaniu systemów informatycznych. Możliwości w tym względzie związane są z robotyzacją i automatyzacją procesów wytwarzania. Poszczególne roboty będą przejmować coraz więcej funkcji tradycyjnie wiązanych $z$ działalnością człowieka, nie tylko o fizycznym, także o intelektualnym charakterze. Poprzez możliwości ich przeprogramowywania staną się one również na swój sposób elastyczne, co umożliwi ich wykorzystanie do wytwarzania różnych produktów. Wspomagane to być może również przez wykorzystanie drukarek 3D. Droga w stronę budowy „przemysłu 4.0” uzależniona jest nie tylko od możliwości 
wykorzystania określonych technik. Zmiany wywołane przez tę postać gospodarowania będą zapewne szersze i dotyczyć będą również sfery społecznej i kulturowej.

Rozwój „przemysłu 4.0” będzie stanowił w tym kontekście wyzwanie w odniesieniu do różnych wymiarów zrównoważonego rozwoju, przy czym ograniczymy się tutaj jedynie do kwestii związanych z odpowiedzialnością. W przypadku "przemysłu 4.0" i związanych z nim procesów automatyzacji i robotyzacji problemy etyczne dotyczą nie tylko człowieka jako podmiotu odpowiednich działań, lecz odnoszą się także do robotów, których funkcjonowanie powinno również obejmować pewne normy etyczne. Pojawiają się w związku z tym pytania o to, w jakim sensie i czy można również robotom przypisać podmiotowość i przyznać im w ten sposób status podmiotów etycznych. W przypadku inteligentnych robotów może być to koniecznością, ponieważ dysponować one mogą określonym zakresem wolności i związaną z tym koniecznością podejmowania odpowiednich wyborów, czyli można będzie przypisać im swoistą podmiotowość.

Idea etyki robotów była swego czasu podjęta przez I. Assimova, który sformułował prawa robotów (Assimov 2013, 25). Miały one regulować relacje pomiędzy robotami a ludźmi w sytuacjach postępującego procesu usamodzielniania się świata maszyn i techniki. Z perspektywy zrównoważonego rozwoju prawa te wydają się nazbyt antropocentryczne, choć jednocześnie rozwój „przemysłu 4.0” będzie powodował wzrost znaczenia relacji człowiek - technika (robot), bowiem zaufanie do techniki będzie jednym z elementów umożliwiających współdziałanie. W jakimś stopniu także roboty będą musiały być wyposażone w odpowiednie systemy normatywne wykraczające poza ramy antropocentryzmu i uwzględniające także systemy wartości i normy zrównoważonego rozwoju. Tym bardziej, iż także im będzie można przypisać pewien zakres odpowiedzialności. Ilościowy i jakościowy rozwój świata robotów stanowić też może w jakimś stopniu zagrożenie dla ludzkości, co sprawia, że zbliżamy się do sformułowanej przez H. Jonasa etyki prewencyjnej, zgodnie z którą „,egzystencja czy istota człowieka jako całość nie może być nigdy stawką w ryzykownej grze" (Jonas 1996, 81). 


\section{Od odpowiedzialności do współodpowiedzialności}

Idea „przemysłu 4.0” zakłada konieczność współdziałania w procesach decyzyjnych i w odpowiednich wyborach i działaniach wielu podmiotów pozostających często dotąd w większej niezależności od siebie. Ograniczeniu podlegać tu będą mianowicie różne tradycyjne sposoby pojmowania odpowiedzialności, w tym także odpowiedzialności społecznej (CSR -corporate social responsibility). Idea społecznej odpowiedzialności postrzegana jest aktualnie jako jedna $\mathrm{z}$ ważnych, teoretycznie i praktycznie, koncepcji w kontekście urzeczywistniania zrównoważonego rozwoju. Wiąże się ona jednak z pewnymi ograniczeniami, a najważniejszy z nich dotyczy jej przedmiotu, bowiem może być nim nie tylko to, co jest bezpośrednim celem działania danej instytucji. Przedmiotem społecznej odpowiedzialności może być wszystko to, co jest wynikiem dobrowolnego zobowiązania odpowiednich podmiotów. Pojawia się tu jednak problem związany np. z tym, iż szkody wywołane przez jakieś działania nie mogą być w pełni rekompensowane przez inne. Pojawia się zatem problem normatywny, aksjologiczny związany z niemożnością zastąpienia jednych wartości przez inne. Społeczna odpowiedzialność $\mathrm{w}$ sensie proceduralnym może być widziana jako związana z zasadą sprawiedliwości wyrównawczej, lecz w wymiarze normatywnym traci ona - przynajmniej w jakimś stopniu - swój regulatywny charakter.

Idea „przemysłu 4.0”, jako wyzwanie skierowane w stronę odpowiedzialności i jej wymogów, wiąże się z określonym poziomem zaufania do odpowiednich systemów technicznych (informatycznych). Funkcjonują one w sposób względnie autonomiczny i stąd też wprowadzenie określonych i intencjonalnie motywowanych impulsów wywoływać może procesy w całym systemie, które nie do końca są możliwe do przewidzenia, a ich efekty muszą być zaakceptowane przez określone podmioty. Efekty te, lub szerzej skutki odpowiednich działań i wyborów, wiązać się będą z ograniczoną wiedzą poszczególnych podmiotów i stąd też potrzeba zaufania, aby cały system mógł funkcjonować w optymalny sposób, co będzie w dużym stopniu gwarantowane przez czynniki techniczne i określone systemy informatyczne. Zakładać przy tym trzeba, przynajmniej na podstawie aktualnie istniejącej w tym względzie wiedzy, iż stopień podatności i elastyczności odpowiednich systemów nie będzie nieograniczony. Intencjonalne 
działania odpowiednich podmiotów zderzać się tu będą z barierami i swoistą podatnością odpowiednich systemów. Zaufanie obejmuje tu nie tylko odniesienie do techniki i sposobu jej funkcjonowania zapewniającego ostatecznie odpowiedni poziom optymalizacji działania całości, lecz także i do innych podmiotów. Musi ono zakładać, iż intencje, jakimi się kierują, są słuszne i dobre, a jeżeli jest przeciwnie, to będą one odpowiednio blokowane, przynajmniej w pewnym stopniu, przez sam system techniczny (informatyczny). Rola zaufania, zarówno w odniesieniu do innych podmiotów jak i do systemów technicznych, przejawia się tu w konsekwencji poprzez to, że:

$\checkmark$ opiera się ono jedynie na ograniczonej wiedzy, czyli w konsekwencji jest ono budowane na świadomości nie tylko wiedzy, ale również określonego poziomu i rodzaju niewiedzy;

$\checkmark$ jest ono jednym z czynników ograniczania złożoności sytuacji, w jaką uwikłane są poszczególne podmioty działające nie $\mathrm{w}$ obszarze wiedzy i pewności, ale w obszarze określonych nieprzejrzystości, niewiedzy i niepewności.

Mamy w tym przypadku do czynienia z innym środowiskiem i warunkami kształtowania się odpowiedzialności, bowiem istotniejszego znaczenia zaczyna $\mathrm{w}$ tym procesie nabierać niewiedza, a nie tylko wiedza, z czym mieliśmy dotąd do czynienia, jeżeli chodzi o wymogi wiązane $\mathrm{z}$ odpowiedzialnością. Budowanie zaufania wiąże się nie tylko z możliwością uczestnictwa poszczególnych podmiotów w procesach realizacyjnych i decyzyjnych, lecz wymaga także odpowiedniej komunikacji pomiędzy tymi podmiotami. Niewiedza jest także tym, co poddawane jest odpowiedniemu zróżnicowaniu (Zimmerli 1987, 92nn.). Obszar współodpowiedzialności obejmuje nie tylko to, co człowiek wie, lecz również i to, czego nie wie. Niewiedza i świadomość niewiedzy, może mieć tu różny przedmiot i zakres i stąd też mogą się z nią wiązać określone i różne zobowiązania. Wiedza i niewiedza wzajemnie się przenikają $\mathrm{i}$ to nie $\mathrm{w}$ wyniku ich rozdzielenia i wskazania na granice wiedzy określić możemy jednocześnie granice współodpowiedzialności różnych podmiotów. Zakres współodpowiedzialności wykracza w tym przypadku poza in- 
tencje współdziałających podmiotów i obejmować musi również obszar tego, co nieintencjonalne. Obszar ten powinien obejmować: a) intencjonalnie powodowane skutki przez inne współuczestniczące w określonych procesach podmioty i b) następstwa wynikające $\mathrm{z}$ niezależnego od tych podmiotów funkcjonowania określonych systemów technicznych (informatycznych). W obydwu tych obszarach mamy do czynienia ze współistnieniem i swoistym ścieraniem się wiedzy i niewiedzy oraz tego, co intencjonalne, i tego, co nieintencjonalne. Możliwości regulacji i kontroli takich kompleksowych procesów, z jakimi w przypadku „przemysłu 4.0" będziemy mieli do czynienia, leżeć będą nie tylko po stronie człowieka jako aktywnego uczestnika, ale także częściowo muszą być wbudowane w sposoby funkcjonowania odpowiednich systemów technicznych (Campa 2011, 69). Wymaga to sformułowania odpowiednich zasad etycznych dla konstruktorów i twórców robotów, jak i dla nich samych. W tym kontekście też formułuje się następujące zasady:

$\checkmark$ robot musi być sterowany przez człowieka;

$\checkmark$ zapobiegać należy niewłaściwemu lub nielegalnemu użyciu robotów;

$\checkmark$ chronić należy dane przechowywane przez robota;

$\checkmark$ działania robota powinny podlegać monitorowaniu;

$\checkmark$ każdy robot powinien być wyposażony w unikalny identyfikator (Campa 2011, 69) $)^{2}$.

W tym przypadku akcentowane jest znaczenie właściwego wykorzystania robotów, co skłaniać powinno do wzbogacania formułowanych zasad o normy i wartości związane ze zrównoważonym rozwojem w podstawowych jego wymiarach: ekologicznym, ekonomicznym i społecznym. Odpowiedzialność poszczególnych podmiotów nie będzie mieściła się jedynie $\mathrm{w}$ zakresie wyznaczonym przez intencjonalny i świadomie spowodowany zbiór następstw, jak również nie będzie ona odpowiedzialnością podzieloną i odpowiednio przyporządkowaną określonym podmiotom. $\mathrm{W}$ tym przypadku wszyscy odpowiadają za wszystko i w ten sposób też przedmiot odpowiedzialności pozostaje dla wszystkich podmiotów ten sam. Nie może być on jednakże z góry

\footnotetext{
${ }^{2}$ Autor powołuje się tu na tzw. kodeks EURON (European Robotics Research Network).
} 
i jednoznacznie ustanowiony ze względu na wspomnianą wyżej elastyczność i otwartość systemu technicznego, w jaki uwikłane będą działania i decyzje poszczególnych podmiotów. Pozostawać one muszą w relacjach do techniki i w relacjach wzajemnych w sytuacji odpowiednio ukształtowanego zaufania i zarazem we wzajemnej komunikacji. Komunikacja będzie w tym względzie jedną $\mathrm{z}$ istotnych podstaw, na których kształtować się będzie współodpowiedzialność jako ważne narzędzie regulacji w przypadku „przemysłu 4.0”. Współczesne techniki medialne umożliwiają tę komunikację i stąd też w ramach „przemysłu 4.0” ich rola będzie podwójna. $Z$ jednej strony będą one jedną z podstaw, na których będą wyrastać główne postacie cyfrowego gospodarowania, ale $\mathrm{z}$ drugiej, będą także ważnym fundamentem dla tworzenia odpowiednich związków i relacji społecznych, w tym także związanych z urzeczywistnianiem współodpowiedzialności.

Współodpowiedzialność wiązana była dawniej z sytuacją podejmowania odpowiedzialności, natomiast $\mathrm{w}$ tym przypadku chodzi już nie tylko o subiektywną decyzję związaną z podjęciem odpowiedzialności, lecz o faktyczne bycie współodpowiedzialnym. Związane z nią warunki sygnalizowane są, między innymi, przez przedstawicieli psychologii moralności. Jeżeli w tym przypadku ważne stają się odpowiednie postacie i formy komunikowania pomiędzy różnymi podmiotami, to racjonalność tego procesu wiązać się może z dwoma postaciami myślenia, a mianowicie:

$\checkmark$ myśleniem eksploracyjnym - dążenie do tego, aby uwzględniać $\mathrm{w}$ sposób bezstronny różne, nawet przeciwstawne, stanowiska i punkty widzenia;

$\checkmark$ myśleniem konfirmacyjnym - opartym na dążeniu do arbitralnego, partykularnego i jednostronnego uzasadnienia odpowiedniego stanowiska.

W przypadku współodpowiedzialności oczekujemy, iż myślenie uczestników gry społecznej, jaka się toczy wokół odpowiedzialności, będzie przybierało właśnie charakter myślenia eksploracyjnego. W tym kontekście, jak pisze J. Haidt, „Odpowiedzialność sprzyja myśleniu eks- 
ploracyjnemu tylko wtedy, gdy spełnione są trzy warunki: (1) decydenci od początku wiedzą, że będą musieli wytłumaczyć swoje stanowisko grupie słuchaczy; (2) poglądy słuchaczy są nieznane; (3) decydenci sądzą, że słuchacze są dobrze poinformowani i że zależy im na poznaniu prawdy" (Haidt 2012, 113-114). Spełnienie tych warunków w praktyce nie jest łatwe, a często nawet niemożliwe. Decydenci bowiem starają się bardzo często unikać tłumaczenia własnego stanowiska, a ponadto zakładają, iż słuchacze nie są wcale dobrze poinformowani i w związku $\mathrm{z}$ tym tak często komunikacja, z jaką mamy do czynienia, przybiera jedynie pozorny charakter, a odwołanie się do prawdy formułowane jest tylko w sposób czysto deklaratywny. „Kiedy wszystkie trzy warunki są spełnione - pisze J. Haidt - ludzie dokładają wszelkich starań, aby dociec prawdy, ponieważ właśnie tego oczekują ich odbiorcy. We wszystkich innych wypadkach - czyli prawie zawsze - presja odpowiedzialności nasila myślenie konfirmacyjne. Ludzie bardziej starają się sprawiać wrażenie, że mają rację, niż rzeczywiście mają rację" (Haidt 2012, 114). To sprawianie wrażenia, że ma się rację, jest nie tylko rodzajem perswazji, lecz także sposobem usprawiedliwiania i przekonywania siebie. Pomimo tych wskazanych trudności w procesie urzeczywistniania współodpowiedzialności, oczekiwania z nią związane będą musiały się w jakimś stopniu realizować, co będzie wymuszane przez sygnalizowane przemiany związane z upowszechnianiem się form „przemysłu 4.0”. Na zmiany techniczne i gospodarcze nakładać się będą, jak już wskazywaliśmy wcześniej, zmiany społeczne i kulturowe. Przemiany, z jakimi będziemy tu mieć do czynienia, będą związane z ewolucją od odpowiedzialności do współodpowiedzialności. Za pośredni etap tych przemian może być uważana koncepcja CSR - społecznej odpowiedzialności organizacji, czy też koncepcja odpowiedzialności prewencyjnej ex ante H. Jonasa. Z pierwszym przypadkiem wiązać można zasadę rekompensaty, a z drugim zasadę prewencji. Jak pisze tu U. Beck: „Zasadę kompensacji zastępuje zasada prewencji (...); generalnie chodzi bowiem o to, aby nie tyle rekompensować to, co zaszło, ale przeciwnie zapobiec temu, czego nie ma i czego nie wiemy; ... czego nie można wiedzieć, temu trzeba zapobiec. Wskutek tego powstaje nowe zagrożenie nad zagrożeniami: środki prewencyjne przeciw katastrofalnym ryzykom wyzwalają z kolei 
ryzyka (...) może nawet większe niż katastrofa, której chciało się uniknąć" (Beck 2012, 176). Pokazuje to ograniczenia odpowiedzialności prewencyjnej w sytuacji ryzyka, które aktualnie jest nieodłączne od różnych decyzji i działań człowieka, a ponadto jego zakres jest dużo większy niż dawniej. Wskazane tu przemiany dotyczące ewolucji wymogów odpowiedzialności zebrać można w postaci tabeli:

\begin{tabular}{|c|c|c|c|c|}
\hline $\begin{array}{c}\text { Rodzaje odpo- } \\
\text { wiedzialności }\end{array}$ & Podmiot & Przedmiot & Instancja & Podstawa \\
\hline Tradycyjna & Jednostka & $\begin{array}{c}\text { Bezpośrednie } \\
\text { i świadomie } \\
\text { wywołane skutki } \\
\text { działań }\end{array}$ & Sumienie & $\begin{array}{c}\text { Wiedza, } \\
\text { wola i świa- } \\
\text { domość } \\
\text { podmiotu }\end{array}$ \\
\hline $\begin{array}{c}\text { CSR - odpo- } \\
\text { wiedzialność } \\
\text { społeczna }\end{array}$ & Instytucje & $\begin{array}{c}\text { Dowolne zobo- } \\
\text { wiązanie }\end{array}$ & Inne instytucje & $\begin{array}{c}\text { Programy, } \\
\text { zgodność } \\
\text { z zasadami }\end{array}$ \\
\hline $\begin{array}{c}\text { Współodpo- } \\
\text { wiedzialność } \\
\text { w perspektywie } \\
\text { „przemysłu } \\
4.0 ”\end{array}$ & Wszyscy & $\begin{array}{c}\text { Produkt i jego } \\
\text { efekty, skutki } \\
\text { upowszechnia- } \\
\text { nia }\end{array}$ & $\begin{array}{c}\text { Sumienie, inni; } \\
\text { ograniczenia } \\
\text { systemowe }\end{array}$ & $\begin{array}{c}\text { Zaufanie do } \\
\text { ludzi i tech- } \\
\text { niki; wiedza } \\
\text { niewiedza }\end{array}$ \\
\hline
\end{tabular}

Tab. 1. Od odpowiedzialności do współodpowiedzialności.

\section{Zakończenie}

W obszarze współodpowiedzialności nie da się jednoznacznie określić i zadekretować zakresu odpowiedzialności poszczególnych podmiotów. Wyznaczane one będą i uzależnione od praktycznego współdziałania tych podmiotów. $\mathrm{Z}$ ich strony oczekiwana będzie gotowość do przyjęcia odpowiedzialności za coś, co nie było przez nie bezpośrednio spowodowane. Współodpowiedzialność pozostaje czymś otwartym i to $\mathrm{z}$ uwagi zarówno na proceduralne warunki jej urzeczywistniania i egzekwowania, jak i ze względu na aksjologiczne treści, jakie będą określały jej przedmiot i sposoby funkcjonowania. W przypadku „przemysłu 4.0” mamy do czynienia $\mathrm{z}$ indywidualizacją tego procesu, ale jednocześnie również z jego swoistym uspołecznieniem będącym wynikiem praktykowania wymogów współodpowiedzialności. Procesy 
wytwarzania nie będą aż tak silnie oddzielone od procesów użytkowania oraz dystrybuowania i upowszechniania określonych dóbr w społeczeństwie. Ukształtowane w konsekwencji „społeczeństwo 4.0” będzie stanowić, jak można sądzić, określoną nową jakość w odniesieniu do procesów wytwarzania i produkcji, lecz także szerzej w odniesieniu do człowieka jako podmiotu innych działań. W ten sposób też współdziałanie i związana z nim współodpowiedzialność będą jedną z podstaw urzeczywistniania zasad zrównoważonego rozwoju. Będzie to zarazem swoisty przyczynek i fundament, na którym wyrastać mogą dalsze decyzje i wybory, takie, aby w konsekwencji idea zrównoważonego rozwoju mogła stawać się praktyką urzeczywistnianą w konkretnych warunkach społecznych, kulturowych, politycznych i gospodarczych, jak również lokalnych i globalnych.

\section{Bibliografia:}

Assimov, Isaac. 2013. Ja robot, tłum. Zbigniew A. Królicki. Poznań: Rebis.

Beck, Ulrich. 2012. Społeczeństwo światowego ryzyka. W poszukiwaniu utraconego bezpieczeństwa, tłum. Bogdan Baran. Warszawa: Scholar.

Campa, Riccardo. 2011. Kodeksy etyczne robotów: zagadnienie kontroli sprawowanej przez człowieka. Pomiary - Automatyka - Robotyka, 169(3), 66-70.

Castells, Manuel. 2007. Społeczeństwo sieci, tłum. Mirosława Marody et al. Warszawa: PWN.

Giddens, Anthony. 2001. Nowoczesność i tożsamość. „Ja” i społeczeństwo w epoce późnej nowoczesności, tłum. Alina Szulżycka. Warszawa: PWN.

Giddens, Anthony. 2008. Konsekwencje nowoczesności, tłum. Ewa Klekot. Kraków: Eidos Wydawnictwo UJ.

Haidt, Jonathan. 2012. Prawy umyst. Dlaczego dobrych ludzi dzieli religia i polityka?, tłum. Agnieszka Nowak-Młynikowska. Sopot: Smak Słowa.

Ingarden, Roman. 1987. O odpowiedzialności i jej podstawach ontycznych. W: Roman Ingarden, Książeczka o człowieku, 71-169. Kraków: Wydawnictwo Literackie. 
Jonas, Hans. 1996. Zasada odpowiedzialności. Próba etyki dla cywilizacji technologicznej, tłum. Marek Klimowicz. Kraków: Platan.

Lizut, Rafał. 2014. Technika a wartości. Spór o aksjologiczna neutralność artefaktów. Lublin: Academicon.

Maślanka, Jarosław. 2014. Przemysł 4.0 - rewolucja czy ewolucja? Dostęp 7.01.2017. http://www.wnp.pl/artykuly/przemysl-4-0-rewolucja-czy-ewolucja,236764.html.

Etyka biznesu. Z klasyki wspótczesnej myśli amerykańskiej, red. Leo V. Ryan i Jacek Sójka, tłum. Leo V. Ryan i Jacek Sójka. 1997. Poznań: W drodze.

Zimmerli, Walther. 1987. Wandelt sich die Verantwortung mit dem technischen Wandel? W: Technik und Ethik, red. Hans Lenk i Günther Ropohl, 92-111. Stuttgart: Philipp Reclam. 
Lech W. Zacher

Akademia Leona Koźmińskiego - Centrum Badań Ewaluacyjnych i Prognostycznych lzacher@kozminski.edu.pl

\section{Człowiek - środowisko: zderzenia racjonalności, ideologii i interesów}

\section{Wstęp}

Relacja człowiek - środowisko jest od zawsze przedmiotem refleksji nie tylko naukowych. Relacja ta jest wielostronnie uwarunkowana i uwikłana; wymaga zrelatywizowania do warunków oraz skontekstualizowania, jeśli chce się wywierać na nią konstruktywny wpływ. W praktyce okazuje się to niezwykle trudne ze względu na wielką złożoność, skomplikowanie „materii” oraz różnorodność stosowanych racjonalności (kryteriów ewaluacji i wyborów), realizowanych interesów (np. politycznych czy ekonomicznych i biznesowych) oraz panujących ideologii (świadomości, przekonań, stereotypów, lęków itp.).

\section{Współczesność jako odmienność ontologiczna}

Współczesny świat (otoczenie naturalne i sztuczne) oraz sam człowiek (w ujęciu zarówno indywidualnym, jak i grupowym) nie są jedynie „nowymi wersjami” dawnej przeszłości (zwłaszcza preindustrialnej). Przeoczenie tej oczywistości nie daje szans na trafne odczytanie współczesnych problemów, ryzyk i wyzwań, nie mówiąc o ich adekwatnej analizie, ewaluacji i opracowaniu zaleceń i działań amelioracyjnych.

Obraz współczesnego świata i człowieka jest bardzo złożony, wymaga podejść innowacyjnych, kreatywnych, opartych na nowych doświadczeniach, metodach, ustalonych naukowo danych. Powyższe postulaty wydają się łatwe do akceptacji, jednakże nawet w sferze naukowej - nie mówiąc o praktyce - nie są w zadowalającym stopniu realizowane. Jest tak, ponieważ - nie od dziś - następują zderzenia racjonalności, ideologii i interesów rozmaitych (bardzo różnorodnych, nawet w jednym społeczeństwie czy regionie) podmiotów wyborów, strategii, działań. Pomimo rozwoju nauk (mówi się nawet obecnie o nowej ich wersji, tzw. 
sustainability science), mimo rosnącej wiedzy, jej społecznej dyfuzji, trudno o konsensus, realny postęp, wspólne działania.

Obraz współczesnego świata (po rewolucji przemysłowej XVIII/ XIX wieku i trwającej ciągle jeszcze rewolucji naukowo-technicznej $\mathrm{XX} / \mathrm{XXI}$ wieku - w obecnej postaci informacyjnej, biotechnologicznej i nanotechnologicznej - Zacher 2000), jak i współczesnego człowieka i społeczeństwa (informacyjnego, sieciowego, cyfrowego itp.) nastręczają kłopoty nie tylko kognitywne ze względu na wielkie zróżnicowanie cywilizacyjne, kulturowe, geograficzne. Co więcej, trudno jest uniknąc wartościowania. Jednakże jakaś „obiektywna fotografia”, nawet „płynnej rzeczywistości", wydaje się konieczna, a zarazem możliwa, jeśli zostanie uświadomiona i metodologicznie obudowana oraz realizowana w międzynarodowej współpracy. Wiele zjawisk, struktur, procesów da się przedstawić $\mathrm{w}$ formie fizykalnej i liczbowej oraz doświadczalnej, sprawdzonej.

Warto przeto identyfikować, rozpoznawać i analizować zdarzenia, zjawiska, procesy, struktury, sieci itp. w ich obiektywnej fizykalnej i wymiernej obiektywności. Interpretacje i waluacje to etap późniejszy, często daleki od obiektywizmu, wyrażający rozmaite interesy (materialne) i ideologie (niematerialne). Podobne uwarunkowania mają przewidywania, prognozy, wizje oraz długoterminowe strategie działań i polityki. W obiektywnej, fizykalnej (opartej o fakty, twarde dane, intersubiektywnie widoczne, mierzalne) „fotografii” widać odmienność ontologiczną obecnego świata i człowieka w stosunku do przeszłości. Oczywiście, fotografia, czy raczej wiele fotografii, odzwierciedlać będzie różnorodność obrazów świata i człowieka. Błędne są czynione nierzadko generalizacje na podstawie jednej fotografii (np. Zachodu, USA, Chin).

\section{Nowe zjawiska, procesy, megatrendy, transformacje $w$ relacji człowiek - środowisko}

Wiara w omnipotencję i przewagę człowieka wobec jego otoczenia naturalnego i sztucznego jest naiwna, bo ahistoryczna. Człowiek, ludzie i ich organizacje przekształcają otoczenie, usztuczniają je, a także siebie samych - nie tylko na zasadzie sprzężenia zwrotnego. W efekcie wielowiekowych działań i oddziaływań (w dużej mierze przy pomocy 
techniki) nastąpiła zmiana proporcji struktur i sił w relacji człowiek otoczenie. Przetworzone otoczenie, choć jest w dużej mierze wytworem człowieka, staje się coraz silniejsze, nawet chyba już dominujące. Paradoksalnie, totalne skolonizowanie Ziemi przez ludzi (rabunkowa eksploatacja zasobów, urbanizacja przestrzeni i przepływ ludzi do miast, eksplozja demograficzna, masowa produkcja żywności na dużych obszarach Ziemi) skłania do mówienia o nowej epoce geologicznej - antropocenie (pomysł noblisty P. Crutzena) i wcale nie zmniejsza uzależnienia (coraz bardziej systemowo-sieciowego) ludzi od „opanowanego” otoczenia (por. np. Zinn 2016). Co więcej, przyczynia się do wzrostu poziomu niepewności i ryzyka (U. Beck ukuł termin społeczeństwo ryzyka, odzwierciedlając globalizację - społeczeństwa światowego ryzyka - Beck 2002, 2012). Globalizacja uniwersalizuje i generalizuje pojęcie ryzyka. Perspektywa trwałego i zrównoważonego rozwoju musi to uwzględniać, jeśli badania, strategie i polityki, rekomendowane wzorce zachowań mają być skuteczne i efektywne.

W kontekście coraz bardziej krytykowanej globalizacji (korporacyjnej, neoliberalnej) mówi się o globalizacjach (w liczbie mnogiej), o globalizacji inkluzywnej, a nawet o deglobalizacji. Tym niemniej operuje się w dyskursie publicznym pojęciem zrównoważonej światowej społeczności (sustainable world community) w oparciu o globalne obywatelstwo (Global Citizenship) ufundowane na wartościach. Globalizacja różnicuje kraje i regiony, jest wdrożeniem zasad i kryteriów globalnej racjonalności (efektywniejszej dla silnych i bogatych aniżeli dla biednych i lokalnych). Co więcej, globalizacja obecnie ma charakter przede wszystkim ekonomiczny (eksploatacja zasobów naturalnych i taniej siły roboczej z biednych regionów), trochę technologiczny (zapewnienie przewagi międzynarodowej), także polityczny (ułatwienia inwestycyjne, rynkowe, działania korupcyjne).

W każdym razie globalność myślenia i działania to novum odzwierciedlające nie tylko materialne procesy rozwojowe (kryzysów nie wyłączając - Zacher 2005), ale również procesy polityczne, społeczne, kulturowe oraz ich wzajemne oddziaływania, interakcje, sprzężenia. Globalizowanie się niemal wszystkiego (także sieci teleinformatycznych, dostępu do informacji, ich przepływu) oznacza radykalną wszechstron- 
ną zmianę strukturalną, również jeśli idzie o jej rozmaite efekty i konsekwencje pozamaterialne (niekoniecznie pozytywne).

Globalizacja, myślenie i działania globalne są konieczne, by świat i ludzkość weszły na trajektorię trwałego rozwoju, by mogły podejmować wspólne działania wobec globalnych zagrożeń, by czyniły to w koordynacji, skutecznie i na czas (czyli przed możliwą globalną czy subglobalną katastrofą związaną np. ze zmianami klimatycznymi - m.in. Giddens 2010, Brown 2009, 2011, Klein 2016). Globalizacja w obecnej postaci zdaje się być na rozdrożu (Zacher 2015a); co więcej, upolitycznia się, wychodzi w Kosmos, upolitycznia swoje kryteria (np. Klementewicz 2013, Welzer 2010), w efekcie wymaga analiz wielokryterialnych, w których różnodziedzinowe kryteria wzajemnie oddziałują, nakładają się, konkurują ze sobą (w zależności od dziedzin i podmiotów). Elementem globalizacji są - choć w kontrze do niej - anty- i alterglobaliści (jak np. cyt. N. Klein), „zieloni”, eko-feministki, różni „ekologiści”, głosiciele kultury ekocentrycznej, eko-aktywiści, ekologiczne organizacje pozarządowe. Reprezentują oni swoisty ekologicznie zorientowany typ racjonalności opozycyjny wobec racjonalności techno-ekonomicznej czy polityczno-militarnej. Krytykują te racjonalności, żądają respektowania innych racjonalności, demaskują stymulowany przez biznes „przemysł negowania zmian klimatycznych” (Dunlap i McKnight 2011). Na temat dalszego biegu procesów i skutków globalizacji oraz proekologicznych organizacji i ruchów są różne poglądy związane $\mathrm{z}$ reguły $\mathrm{z}$ ideologią, polityką, $\mathrm{z}$ interesami biznesu.

W procesach globalizacji odzwierciedlają się nie tylko nowe transformacje kontekstów (wynikające w przeważającej mierze z dynamiki cywilizacji technicznej), ale także zderzenia rozmaitych racjonalności rozumianych jako zestaw kryteriów oceny i wyboru, charakterystycznych dla danej dziedziny, wynikający z jej tożsamości, odrębności i specyfiki i zapewniający tej dziedzinie przetrwanie, rozwój, konkurencyjność czy przewagę nad innymi typami racjonalności. Zharmonizowanie rozmaitych racjonalności dziedzinowych jest bardzo trudne, nie tylko ze względu na ich kontekstowe uwikłania, ale też na ich wzajemne wpływy. W praktyce życia - polityki, gospodarki, biznesu, edukacji, środowiska, kultury rozmaite typy racjonalności występują jednocześnie (Racjonalność myślenia, decydowania i działania 2000), przeplatają się, czasem się znoszą, czasem 
wzmagają. O jakąś racjonalną równowagę trudno. Proporcje wpływów różnych typów racjonalności mogą być „wypadkową” żywiołowości rozwoju, efektem jakiegoś sterowania (przez rządy, wielkie korporacje, różne lobbies, układy międzynarodowe, porządek prawny, kulturę, ideologię, religię). Przeto realizacja koncepcji trwałego i zrównoważonego rozwoju, która jest racjonalnością naszych czasów, lokalnie i globalnie, wymaga mądrego (a nie jedynie politycznego czy technokratycznego) „uzgadniania" warunków brzegowych rozwoju, proporcji, siły różnych dziedzin sterowanych własnymi kryteriami i interesami, nie mówiąc o uwarunkowaniach świadomościowo-ideologicznych.

\section{3. Świadomość kontekstów i ich oddziaływań}

Świadomość nowych procesów i zjawisk, tworzenia czy modyfikowania kontekstów naszych ewaluacji (a nawet identyfikacji i rozpoznawania problemów do rozwiązania) stanowi istotne ograniczenie skłaniające do realizmu ocen i działań. Wiadomo jednak, że procesy (i decyzje) polityczne, społeczne, biznesowe zawierają w sobie elementy gry, emocji, nie mówiąc o przypadkowości, błędach, nieoczekiwanych zjawiskach (jak Talebowskie „czarne łabędzie” - Taleb 2014). Szczególnie trudne jest rozpoznanie i uwzględnienie wzajemnych wpływów i sprzężeń nowych procesów, decyzji oraz ich skutków, zwłaszcza tych niezamierzonych, negatywnych, oddalonych w czasie, generujących dodatkowe koszty. W cywilizacji technicznej, w której żyjemy (różne kraje w różnym stopniu, mimo globalizacji), istnieją od pół wieku metody i procedury pozwalające identyfikować, rozpoznawać, ewaluować i formułować adekwatne strategie, polityki, decyzje. Ich zbiorcza nazwa to ewaluacja techniki (technology assessment), w ujęciu dziedzinowym - ewaluacja skutków społecznych, psychologicznych, środowiskowych i in. Ogólniejszym pojęciem jest ocena skutków (impact assessment) (Nauka - technika - społeczeństwo 2012, Zacher 2015b, 2016a). Wymienione typy analiz w utechnicznionych gospodarkach i społeczeństwach mogą być bardzo użyteczne, ponieważ oceniają ryzyka, koszty społeczne, środowiskowe, także odległe w czasie, również profilują (przez badania, standardy, normy, regulacje prawne) nowe technologie proekologiczne (tzw. eco-innovations). Potrzebna jest nowa wiedza, systemy informacyjne, instytucje wyspecjalizowane, zaangażowanie biznesu (więcej niż 
CSR) i obywateli, nie mówiąc o ciałach decyzyjnych i jurysprudencji. Roli edukacji, badań, mediów, prawa nie da się przecenić. Siła performatywna techniki jest wielka, wszechstronnie działająca, nie do zatrzymania, dotykająca faktycznie wszystkich dziedzin ludzkiego działania, zmieniająca człowieka fizycznie, mentalnie, kulturowo, usztuczniając go, transhumanizując, również przekształcając radykalnie jego otoczenie (zarówno w realu, jak i wirtualu) (Zacher 2016b).

Racjonalność techniczna przejawia się $\mathrm{w}$ rosnących parametrach technicznych, w wymiarze ideologicznym często wiąże się z koncepcją determinizmu technicznego i technokratyzmem, w wymiarze praktycznym służy sektorowi militarnemu i biznesowi produkującemu dobra (i gadżety) technologiczne. Racjonalność ta powinna być - na ile to możliwe - zharmonizowana $\mathrm{z}$ racjonalnością społeczną oraz ekologiczną. Działaniom technicznym, gospodarczym, politycznym można i należy przypisywać wartości. Strategie rozwojowe powinny być ufundowane na systemie wartości społecznych, chociażby na prawach człowieka, na „trosce o wspólny dom” (by zacytować tytuł encykliki papieża Franciszka z 2015). Wymiar aksjologiczny, etyczny, odpowiedzialność wiążą się z racjonalnością społeczną, obywatelską, która zderza się z racjonalnością techniczną i ekonomiczną. Zapewnić ich „przystawalność” (ideałem byłaby ich synergia) jest niezwykle trudno w złożonym, podzielonym, chaotycznym, zglobalizowanym, utechnicznionym świecie. Tylko szerokie i zdecydowane wdrażanie - od szczebla lokalnego do globalnego i kosmicznego - koncepcji rozwoju trwałego, samopodtrzymującego się, przyjaznego dla ludzi, dla przyszłych pokoleń może zapewnić lepszą przyszłość. Problemem jest realizacja ustaleń i zaleceń kolejnych Szczytów Ziemi i wytycznych ONZ wymagająca przezwyciężenia rozlicznych konfliktów interesu państw, biznesów, rozmaitych organizacji itp. Co więcej, trzeba to uczynić na czas.

\section{Zakończenie}

Trudno w krótkim tekście omówić czy choćby wymienić i skomentować wszystkie nowe elementy zmieniającej się relacji człowiek - środowisko. Często trudno je nawet zidentyfikować i rozpoznać. W każdym razie, aby wejść na trajektorię trwałego rozwoju i zrobić 
to maksymalną liczbą dziedzin (nauki, techniki, edukacji, przemysłu, produkcji, ekologii, konsumpcji, stylów życia, wzorców rozwoju), potrzeba uwzględnienia zachodzących transformacji, niezbędna do tego jest prospektywność i konsekwencjonalizm w myśleniu, polityce, działaniu, zachowaniach, przezwyciężenie starowiedzy i tradycjonalizmu, wzięcia odpowiedzialności za przyszłość. Aby trafnie rozpoznać i ocenić sploty celów, warunków, kontekstów, decyzji, działań, ich skutków, także zachowań, potrzeba multikryterialnego i wielowymiarowego modelowania i ewaluacji, potrzeba ujęcia systemowo-sieciowego oraz refleksji prawnej i aksjologicznej.

\section{Bibliografia:}

Beck, Ulrich. 2002. Społeczeństwo ryzyka. W drodze do innej nowoczesności, tłum. Stanisław Cieśla. Warszawa: Scholar.

Beck, Ulrich. 2012. Społeczeństwo światowego ryzyka. W poszukiwaniu utraconego bezpieczeństwa, tłum. Bogdan Baran. Warszawa: Scholar.

Brown, Lester R. 2009. Plan B4.0 Mobilizing to Save Civilization. New York-London: Norton.

Brown, Lester R. 2011. World on the Edge. London-Washington, DC: Norton.

Dunlap, Riley E. i Andrew M. McKnight. 2011. Organized Climate Change Denial. W: Oxford Handbook on Climate Change and Society, red. John S. Dryzek et al., 144-160. Oxford: OUPress.

Edwards, Andrew A. 2005. The Sustainability Revolution - Portrait of a paradigm shift. Gabriola Island, BC: New Society Publishers.

Franciszek. 2015. Encyklika "Laudato Si”".

Giddens, Anthony. 2010. Klimatyczna katastrofa, tłum. Małgorzata Głowacka-Grajper. Warszawa: Prószyński i S-ka.

Klein, Naomi. 2016. To zmienia wszystko. Kapitalizm kontra klimat, tłum. Hanna Jankowska i Katarzyna Makaruk. Warszawa: MUZA.

Klementewicz, Tadeusz. 2013. Geopolityka trwałego rozwoju. Warszawa: Elipsa. 
Nauka - technika - społeczeństwo. Podejścia i koncepcje metodologiczne, wyzwania innowacyjne i ewaluacyjne, red. Lech W. Zacher. 2012. Warszawa: Poltext.

Racjonalność myślenia, decydowania $i$ działania (Problemy stare i nowe), red. Lech W. Zacher. 2000. Warszawa: WSPiZ.

Taleb, Nassim N. 2014. Czarny łabędź. O skutkach nieprzewidywalnych zdarzeń, tłum. Olga Siara. Warszawa: Kurhaus.

Welzer, Harald. 2010. Wojny klimatyczne. Za co będziemy zabijać w XXI wieku?, tłum. Michał Sutowski. Warszawa: Wydawnictwo Krytyki Politycznej.

Zacher, Lech W. 2016a. Innovations for Socially Creating a Sustainable Future. W: Innovations and Emerging Technologies for the Prosperity and Quality of Life, red. Małgorzata Runiewicz-Wardyn, 35-52. Warszawa: PWN.

Zacher, Lech W. 2015a. Rozdroża globalizacji. Niektóre aspekty racjonalno-etyczne. Dialog Edukacyjny, 3-4(30-31), 9-12.

Zacher, Lech W. 2015b. Underestimated Assumption and Contexts of TA Theories and Practices. W: The New Horizon of Technology Assessment, red. Constanze Scherz et al., 279-286, Prague: Technology Centre ASCR.

Zacher, Lech W. 2016b. Cywilizacja techniczna - społeczeństwo informacyjne w perspektywie wiedzy. W: Społeczeństwo - technologia gospodarka w świecie sieciowych powiązań. Ku przyszłości, red. Alina Betlej et al., 87-104. Lublin: Wydawnictwo KUL.

Zacher, Lech W. 2000. Rewolucja naukowo-techniczna. W: Encyklopedia Socjologii. T. 3: O-R, red. Władysław Kwaśniewicz, 300-305. Warszawa: Oficyna Naukowa.

Zacher, Lech W. 2005. Kryzysy i ich badanie a trwały rozwój. Transformacje, grudzień 2005, 118-132.

Zinn, Jens O. 2016. Living in the Anthropocene: towards a risk taking society. Dostęp: 15.02.2016. http://www.tandfonline.com/doi/full/10.10 80/23251042.2016.1233605. 
Agnieszka Sobol

Uniwersytet Ekonomiczny w Katowicach - Wydział Ekonomii

agnieszka.sobol@ue.katowice.pl

\section{Rola mieszkańców w zrównoważonym rozwoju miast}

\section{Wprowadzenie}

Miasta to główne ośrodki życia społecznego - rozwijają się dla mieszkańców, ale też dzięki nim. Miasto zrównoważone, choć współcześnie często mianowane miastem smart, inteligentnym czy kreatywnym, to przede wszystkim miasto świadomych obywateli - świadomych swojej roli w życiu społecznym, gospodarce lokalnej i świadomych swojego wpływu na środowisko naturalne.

Społeczeństwo obywatelskie jest coraz ważniejszym tematem debaty publicznej w Polsce. Jego znaczenie jest istotne nie tylko w kontekście rozwoju demokracji, lecz także w praktycznym wymiarze rozwoju lokalnego. Wiele samorządów wychodzi już poza pytanie, czy wprowadzać mechanizmy partycypacji, lecz dylematem pozostaje stopień zaawansowania demokracji partycypacyjnej oraz wybór metod i narzędzi uspołecznienia rozwoju lokalnego.

Analizy funkcjonowania społeczeństwa obywatelskiego często formułowane są wokół kategorii kapitału społecznego. Według Roberta Putnama, pojęcie kapitał społeczny odnosi się do cech społecznego zorganizowania, takich jak: sieci, normy i społeczne zaufanie. Ułatwiają one osiąganie wzajemnych korzyści dzięki koordynacji działań i współpracy w ramach danej społeczności (Putnam 1996, 17). Francis Fukuyama opisuje kapitał społeczny jako zdolność wynikającą z rozpowszechnienia zaufania w obrębie społeczeństwa lub jego części. Kapitał społeczny różni się według niego od innych form kapitału ludzkiego tym, że jest tworzony i przekazywany za pośrednictwem mechanizmów kulturowych: religii, tradycji oraz historycznego nawyku (Fukuayama 1997, 39). Kultura tworzy normy takie jak: wzajemność, szacunek, uczciwość oraz określa wartość dobra wspólnego. Na niezbędność zaufania dla kształtowania aktywnych wspólnot lokalnych wskazywał także Manuel Castells w swojej pracy City and the grassroots (Castells 1983). W myśl 
teorii działania społecznego, elementy kapitału społecznego kumulują się i wzajemnie wzmacniają. Efekt samowzmacniania prowadzi w efekcie do równowagi społecznej (Szawiel 2003, 132).

Ważnym wskaźnikiem kapitału społecznego jest udział obywateli w życiu publicznym oraz ich wpływ na decyzje władz. Jednakże analiza wyłącznie danych i wskaźników dotyczących np. poziomu frekwencji w wyborach publicznych, ilości organizacji pozarządowych czy budżetów obywatelskich nie prezentuje w pełni kondycji społeczeństwa obywatelskiego. Rzeczywistego obrazu stanu społeczeństwa obywatelskiego dostarcza dopiero wnikliwa obserwacja i refleksja oraz bezpośrednie doświadczenia w jego rozwoju.

Jak zostało wcześniej wskazane, jedną z kluczowych kategorii rozwoju kapitału społecznego jest zaufanie. Według badań, z opinią, że „większości ludzi można ufać", na przestrzeni ostatnich lat zgadzało się zaledwie kilkanaście procent Polaków (Czapiński et al. 2015, 333). Społeczeństwo polskie przeniknięte jest syndromem braku zaufania. Skutkuje to pasywnością obywatelską oraz rezygnacją ze współdziałania. Restytucja zaufania społecznego jest zatem niezbędna $\mathrm{z}$ punktu widzenia budowy społeczeństwa obywatelskiego. Świadome kształtowanie wspólnoty jest efektem długotrwałych i złożonych mechanizmów społecznych, zarówno tych oddolnych, jak i animowanych przez władze lokalne.

\section{Współrządzenie i współdziałanie w mieście}

Pojęcie współrządzenia (governance) opiera się na osadzeniu procesu zarządzania rozwojem lokalnym w sieci relacji pomiędzy różnymi aktorami życia lokalnego. Współrządzenie ma na celu wypracowanie kompromisów w zakresie oferty i rozwiązań dla różnych użytkowników miasta. Współrządzenie jako najbardziej zaawansowany etap uspołecznienia rozwoju lokalnego wymaga woli współdziałania i zaangażowania zarówno podmiotów administracji publicznej, jak i partnerów społecznych, w tym zwłaszcza społeczności lokalnej.

Decyzje o różnych formach uspołecznienia coraz częściej zapadają w polskich miastach. Część podejmowanych działań wynika z przepisów prawa i ma charakter obligatoryjny, podczas gdy niektóre z nich są fakultatywną decyzją samorządów lokalnych. Uspołecznienie w prak- 
tyce odbywa się w drodze konsultacji projektów miejskich, pracy obywatelskich zespołów roboczych i dzielnicowych czy organizacji spotkań zbiorowych i referendów w sprawach publicznych.

Zauważyć jednak należy, że w większości miast w Polsce uspołecznienie realizowane jest głównie $\mathrm{w}$ formule otwartości dla organizacji formalnych, tj. różnego rodzaju stowarzyszeń czy fundacji. To przede wszystkim sektor organizacji pozarządowych (ngo) stał się partnerem i uczestnikiem procesu uspołecznienia. Znaczenie trzeciego sektora zdecydowanie wzrosło wraz z uchwaleniem w 2003 roku ustawy o działalności pożytku publicznego i o wolontariacie. Udział trzeciego sektora w polityce lokalnej wyraża się m.in. w następujących obowiązkach samorządów: powoływaniu Gminnych Rad Działalności Pożytku Publicznego, opracowywaniu rocznego programu współpracy z ngo, konsultowaniu przez ngo strategii rozwoju gminy czy aktów prawa miejscowego w dziedzinach dotyczących działalności statutowej ngo.

$\mathrm{Z}$ drugiej strony niezrzeszony mieszkaniec posiada w Polsce bardzo ograniczone możliwości korzystania z demokracji partycypacyjnej. Wynika to głównie $\mathrm{z}$ faktu stosowania przez samorządy strategii minimum i w większości jedynie obligatoryjnych mechanizmów uspołecznienia. Przepis art. 5a ustawy o samorządzie gminnym wskazuje, iż w wypadkach przewidzianych ustawą oraz w innych sprawach ważnych dla gminy mogą być przeprowadzane na jej terytorium konsultacje z mieszkańcami gminy. Jak wskazuje powyższa regulacja, konsultacje z mieszkańcami mają charakter fakultatywny. Mieszkańcy rzadko kiedy mają okazję do prezentacji swoich preferencji i pomysłów w zakresie rozwoju lokalnego. Narzędzia demokracji partycypacyjnej, które są dla nich dostępne, tj. budżet obywatelski, inicjatywa lokalna czy referendum lokalne, nie są powszechnie i często w Polsce stosowane.

Wiele badań wskazuje na istotną rolę trzeciego sektora w kształtowaniu kapitału społecznego. Jak pisał Durkheim: „Naród może przetrwać tylko wtedy, kiedy między państwem a obywatelami istnieje wiele grup wtórnych, które są na tyle bliskie jednostkom, że wciągają je w swoją sferę działania, wprowadzając tym samym w ogólny strumień życia gospodarczego" (Durkheim 1999, 38). Jednocześnie praktyka wskazuje, iż ludzie w Polsce, którzy chcą coś robić dla swojej społeczności, nie- 
chętnie łączą się w tym celu w związki formalne. Jak pokazują badania, członkami różnego rodzaju organizacji społecznych jest 13,4\% Polaków, a osób deklarujących się jako aktywni członkowie - około 9\% (Czapiński et al. 2015, 279-323). Na poziomie lokalnym istnieje zatem wciąż relatywnie mało organizacji pozarządowych, a te działające są zazwyczaj słabe i często uwikłane w relacje zależności od władz.

Zawężanie partycypacyjnych mechanizmów zarządzania do współpracy władz samorządowych głównie $z$ organizacjami pozarządowymi zaburza procesy reprezentacji obywatelskiej, otwierając dostęp do współrządzenia tylko nielicznym grupom (Herbst 2005). Ograniczanie sieci partnerstwa społecznego stwarza „zagrożenie tworzenia się korupcyjnych i zarazem klientelistyczno-klikowych układów w samorządzie, petryfikujących lokalne układy władzy" (Lewenstein et al. 2010, 7). Kontrowersje budzi także finansowe powiązanie pomiędzy samorządami a organizacjami pozarządowymi. Zależność finansowa ograniczać może bowiem autonomię w podejmowaniu tematów i działań niewygodnych dla grantodawców (Kurczewski 2007; Czubkowska 2016a). Około 60\% organizacji otrzymuje dotacje ze środków publicznych (Czubkowska 2016b). Pozory współrządzenia oraz brak transparentności w działaniu samorządu pogłębiają brak zaufania i pasywność zwykłych mieszkańców.

\section{Ważna rola obywatela}

Wzrost znaczenia roli mieszkańców w życiu publicznym jest efektem wielu bezpośrednich i pośrednich procesów związanych z demokratyzacją i decentralizacją władzy. Wynika także z coraz większej świadomości mieszkańców odnośnie do swojej roli w procesie rozwoju lokalnego. Jednocześnie na gruncie wcześniejszych tez na temat idei governance należy zauważyć, iż mieszkaniec w Polsce ma małe realne możliwości wpływania na politykę lokalną. Poza przykładami dobrych praktyk, zauważalny jest rozdźwięk pomiędzy deklaracjami uspołecznienia rozwoju lokalnego a rzeczywistym wpływem mieszkańców na politykę lokalną. O fasadowości rozwiązań partycypacyjnych pisze się nie tylko w Polsce, lecz także w innych krajach Europy, określając je mianem „pełzającego autorytaryzmu” (Wakeford et al. 2008; Crouch 2004). 
Mieszkańcy polskich miast stanowią zbyt często niewykorzystany rezerwuar wielu potencjałów istotnych z punktu widzenia społeczności lokalnej i dobra wspólnego. Zalicza się do nich: umiejętności i talenty członków społeczności, sieci społeczne, poczucie wspólnoty, przywództwo lokalne, zaufanie, rozumienie wspólnej historii, normy i wartości podtrzymujące współpracę (Goodman et al. 1988).

Aktywność mieszkańców przejawia się w uczestnictwie w życiu danej wspólnoty, samodzielnym podejmowaniu inicjatyw oddolnych oraz angażowaniu się w działania i wydarzenia organizowane przez innych współmieszkańców lub instytucje. Raport Diagnoza społeczna pokazuje, że podobnie jak przy słabym udziale mieszkańców w trzecim sektorze także niesformalizowane angażowanie się w działania na rzecz społeczności lokalnej (gminy, osiedla, miejscowości, w najbliższym sąsiedztwie) jest rzadkim zjawiskiem w Polsce. Tylko około 15\% badanych deklaruje taką działalność (Czapiński et al. 2015, 279).

Działania obywatelskie wzmacniane są przez doświadczenie oraz nawyki aktywności społecznej. Następuje efekt kumulacji - ludzie, którzy należą do organizacji, działają także na rzecz społeczności, pracują dla innych i dla organizacji społecznych oraz biorą udział w zebraniach. Wszystkie te doświadczenia tworzą syndrom obywatelskości. Widoczny jest ponadto związek pomiędzy poziomem wykształcenia a aktywnością na rzecz społeczności lokalnej. Osoby z wykształceniem wyższym angażują się czterokrotnie częściej niż osoby z wykształceniem podstawowym (Czapiński et al. 2015, 326-330).

Zrównoważony rozwój miast wymaga zaangażowanych obywateli. Jedynie przy aktywnym udziale mieszkańców możliwe jest rzeczywiste rozpoznanie ich potrzeb. Dzięki znajomości preferencji mieszkańców możliwa jest optymalizacja oferty miejskiej pod kątem jej użyteczności. Przekłada się to z kolei na lepszą ocenę pracy władz i prowadzonej polityki lokalnej (Sobol 2006).

Definicja smart city akcentująca znaczenie mieszkańca podkreśla rolę miasta jako źródła inspiracji i motywacji dla kreatywności, przedsiębiorczości, aktywności oraz wymiany kultur i wiedzy. Miasta z aktywnymi i zadowolonymi mieszkańcami, bogate w wydarzenia i z żywą przestrzenią publiczną są bardziej atrakcyjnymi miejscami życia. Jedno- 
cześnie konkurencją dla miast stała się wirtualna rzeczywistość, która może wpływać na atomizację mieszkańców oraz ich bierność w sferze publicznej. Nowoczesne rozwiązania technologiczne mogą być jednak także sprzymierzeńcem integracji społecznej. Przemyślana strategia komunikacji samorządów z mieszkańcami może wpływać na wzrost ich aktywności w życiu miejskim, podejmowanie przez nich inicjatyw oddolnych i budowanie więzi międzyludzkich. Bieżący i bezpośredni kontakt $\mathrm{z}$ mieszkańcami buduje zainteresowanie sprawami publicznymi oraz więź z miastem. Prostym, a jednocześnie zaniedbywanym przez władze lokalne systemem współczesnej komunikacji jest telefoniczny komunikator sms oraz system internetowych newsletterów. Narzędzia te skutecznie wykorzystywane przez biznes wciąż są rzadkością w komunikacji z mieszkańcami polskich miast.

\section{Przestrzeń publiczna i przestrzeń wspólna}

Przestrzenie większości polskich miast nie sprzyjają współdziałaniu. Ponadto zmiany cywilizacyjne oraz organizacja życia zmierza raczej w stronę odseparowywania ludzi od siebie, aniżeli organizowania okazji do spotkań. Cechą współczesnej kultury indywidualizmu jest nastawienie przede wszystkim na samorealizację. Działania obywatelskie schodzą wówczas na dalszy plan. Jednocześnie jednostka przyjmuje często roszczeniową postawę względem otoczenia społecznego (Bokszański 2007).

Brak przestrzeni publicznych, indywidualizm i konsumpcjonizm osłabiają impuls do współpracy. Napięcia i konflikty między prawem jednostki a korzyściami dla ogółu społeczeństwa przybierają na sile wraz z rozrastaniem się miast. Zanik kompetencji związanych ze współdziałaniem przejawia się w powierzchowności relacji międzyludzkich i braku zaufania. Jednocześnie funkcja więziotwórcza stanowi istotną determinantę uspołecznienia rozwoju. Jak słusznie zauważył Seręga: „nieobojętnym czynnikiem czy atrybutem lokalności kształtującym poczucie identyfikacji i tożsamości jest stosunek do terytorium, a właściwie szczególny związek między sferą ludzkich zachowań i działań a przestrzenią i sposobem jej użytkowania” (Seręga 1993, 17). Widoczna jest ścisła współzależność pomiędzy poczuciem zaufania do ludzi, poczuciem przynależności oraz możliwościami kontaktów społecznych. Układ tych czynników ma z kolei istotny wpływ na zadowolenie z życia. Relacje w ramach tej sieci charak- 
teryzują się współzależnością, a nie związkami przyczynowo-skutkowymi (Helliwell i Barrington-Leigh 2010).

Rozwój relacji zaufanie - przynależność - kontakty - szczęście determinowana jest $\mathrm{w}$ istotnym stopniu przez projekty urbanistyczne miast. Rozwój przestrzeni publicznych, ich atrakcyjność oraz funkcje zagospodarowania przestrzennego mają szczególny wpływ na możliwości budowania kontaktów społecznych. Restytucji akcentowanego wcześniej zaufania sprzyja kreowanie przestrzeni wspólnych i okazji do spotkań. Wymaga to „uspokojenia” ruchu śródmiejskiego i spowolnienia jego tempa z prędkości samochodu do ruchu pieszego oraz rowerowego. Przykładem przestrzeni łączącej potrzeby różnych użytkowników w miastach są holenderskie woonerfy. Ograniczenie ruchu samochodowego, wprowadzenie zieleni, ławek i innych elementów małej architektury czy placów zabaw stwarza przyjazną przestrzeń. Ukierunkowanie miast na zrównoważony rozwój wiąże się ponadto $\mathrm{z}$ nadaniem miastu „ludzkiego wymiaru” w rozumieniu jego skali (Gehl 2009).

Projekty miast ukierunkowane na zrównoważony rozwój przywiązują dużą wagę do atrakcyjnej przestrzeni publicznej. Znaczenie wartości przestrzeni publicznych w ujęciu partycypacji społecznej i wzmacniania poczucia wspólnoty zostało wykazane $\mathrm{w}$ wielu badaniach międzynarodowych (McMillan i Chavis 1986; Taylor 1988; Semenza 2005). Ciekawych przykładów znaczenia kształtu i formy przestrzeni miejskiej dla życia społecznego dostarcza także Charles Montgomery w książce Miasto szczęśliwe. Przytacza on wyniki badań wskazujące na szkodliwość wpływu ruchu drogowego na psychologiczne aspekty doświadczania przestrzeni publicznych (Montgomery 2015, 236-239). Jan Semenza badał z kolei wpływ estetyki przestrzeni miejskiej na emocje mieszkańców. Zniszczona i brudna przestrzeń wywoływać może uczucie depresji i alienacji, podczas gdy zadbana i zielona przestrzeń wpływa pozytywnie i sprzyja większemu zaufaniu w relacjach międzyludzkich (Semenza 2005, 459-478).

W powyższych pracach wskazywane są liczne błędy projektowania urbanistycznego i architektonicznego, w których pomijany był wpływ kształtu przestrzeni na życie ludzi i zachodzące procesy społeczne. Podporządkowanie tego projektowania aspektom ekonomicznym oraz transportowi indywidualnemu zaburzyło rozwój wielu miast. Niewłaściwie decyzje urbanistyczne powodują, iż wielu 
mieszkańców zamyka się w homogenicznych „gettach”, izolując się od współmieszkańców.

Niestety, pomimo wypracowania dobrych i sprawdzonych praktyk, wiele miast $\mathrm{w}$ imię krótkowzrocznych korzyści ekonomicznych brnie w nieład urbanistyczny i niezrównoważony rozwój. W Danii już w latach 80. XX wieku wprowadzono zakaz lokalizacji banków na głównych ulicach handlowych (Montgomery 2015, 229). W polskich miastach wiele atrakcyjnych ze względu na funkcje społeczne śródmiejskich ulic zamienia się na monousługowe ciągi banków i punktów telefonii komórkowej. Przestrzeń w centralnych częściach miast jest zaniedbana, a rozrastające się przedmieścia niemal zupełnie pomijają przestrzenie do wspólnych kontaktów między mieszkańcami.

Przestrzeń oraz architektura oddziałuje na ludzi. W dobie nasilających się problemów społecznych, ekonomicznych i środowiskowych warto wykorzystać wpływ zagospodarowania przestrzennego na transformację w stronę zrównoważonego rozwoju. Przestrzeń może i powinna odpowiadać na współczesne problemy cywilizacyjne. Należy o nią zadbać zwłaszcza na gruncie negatywnych doświadczeń wynikających z procesów suburbanizacyjnych, zabudowy monofunkcyjnej, rozrostu terenów komunikacyjnych czy zawłaszczania przestrzeni publicznych dla celów prywatnych. Jak pokazują dobre praktyki (np. Rotterdam, Amsterdam - Holandia, Malmo - Szwecja, Curitiba - Brazylia), kształtowanie przestrzeni dla mieszkańców i społecznie zaangażowanej architektury znacząco determinuje zrównoważony rozwój miast. Miasta zrównoważone, jak określa je Jan Gehl, to miasta żyjące, a „ludzie przychodzą tam, gdzie są ludzie” (Gehl 2009, 25). Życie w mieście można rozwijać, jeśli zaoferuje się mieszkańcom ciekawą i bezpieczną przestrzeń publiczną, która stwarza okazję do zatrzymania się i bycia razem. Jak pisała Jane Jacobs: „Miasta wszystkim mają coś do zaoferowania, pod warunkiem, że wszyscy je współtworzą” (Jacobs 2014, 249).

\section{Podsumowanie}

Zmiany dokonujące się w polskich miastach wskazują, iż żyjemy w kraju coraz bardziej efektywnych jednostek i nieefektywnej wspólnoty. Jednocześnie kapitał społeczny warunkuje prawidłowe relacje pomiędzy czynnikami o charakterze społecznym, gospodarczym i śro- 
dowiskowym. Kryzys zaufania, brak etosu obywatelskości oraz kultura i język indywidualizmu i konsumpcjonizmu stoją w opozycji do zrównoważonego rozwoju (Bellah et al. 1996, 14).

Pomimo dyskusji na temat konieczności wsparcia społeczeństwa obywatelskiego w Polsce, w praktyce rozwoju lokalnego proces ten przebiega powoli i opornie. Rola mieszkańców w procesie rozwoju lokalnego pozostaje wciąż na marginesie uwagi samorządów. Zastępowanie dotychczasowego „imperializmu ekspertów” establishmentem organizacji pozarządowych jest ułudą budowania kapitału społecznego i ukierunkowania na zrównoważony rozwój. Działalność organizacji pozarządowych w wielu przypadkach jest użyteczna i buduje dobro wspólne. Jednak dopiero otwarcie na mieszkańców niezrzeszonych wprowadza transparentność, kontrolę oraz możliwości budowania partnerstwa i współdziałania w procesie rozwoju lokalnego.

Charakter demokracji partycypacyjnej i stosowane narzędzia powinny być efektem świadomości ich znaczenia w procesie rozwoju lokalnego. Zdarza się jednak, iż uspołecznienie jest elementem kalkulacji i taktyki władz. Wykorzystywane jest wówczas przede wszystkim jako grunt do legitymizacji decyzji władz. Takie pozorowane uspołecznienie przekłada się na niskie zaangażowanie społeczne oraz $\mathrm{w}$ rezultacie na usprawiedliwienie dla prowadzenia polityki władz.

Władze lokalne poprzez uruchomienie mechanizmów współrządzenia, dobrane metody komunikacji z mieszkańcami oraz kształtowanie przestrzeni miejskich mają istotny wpływ na kształtowanie obywatelskiego stylu życia. Pomimo deklaracji wyboru ścieżki zrównoważonego rozwoju, rzadko jednak korzystają ze swoich możliwości. Z uwagi na niską dojrzałość obywatelską Polaków oraz brak nawyków współdziałania w sferze publicznej to właśnie świadome władze i administracja ponoszą odpowiedzialność za kształtowanie postaw społecznych.

Skoro Polacy tak słabo się zrzeszają i rzadko sami podejmują działania oddolne, to nie mają okazji, by się nauczyć zorganizowanego działania społecznego i nabyć umiejętności potrzebnych do życia w społeczeństwie obywatelskim. Pat sytuacyjny opisany został w następujący sposób: „Polacy mają mało doświadczeń społecznych i obywatelskich (...) nie umieją, bo się tego nie nauczyli z ich ubogiego doświadczenia. Nie umieją, bo nie działają, a nie działają, bo nie umieją - jest to błędne 
koło działań dla społeczności” (Czapiński et al. 2015, 330). Ukierunkowanie na zrównoważony rozwój wymaga wyjścia z tego impasu.

Dialog z mieszkańcami, oferta usług publicznych, przestrzenie miejskie oraz realizowane w nich wydarzenia mają szczególny wpływ na życie społeczne. Kształtują zachowania mieszkańców, możliwości ich kontaktów i współdziałania oraz generalnie poziom zadowolenia z życia. Władze lokalne dysponują zatem ogromnym zasobem i możliwościami wsparcia społeczeństwa obywatelskiego i pobudzenia inicjatyw oddolnych. Budowanie atmosfery współdziałania wymaga przekształcenia instytucjonalnej i biurokratycznej roli władz lokalnych w partnerską relację z mieszkańcami.

\section{Bibliografia:}

Bellah, Robert N. et al. 1996. Habits of the heart, individualism and commitment in American life. New York: Harper and Row Publishers.

Bokszański, Zbigniew. 2007. Indywidualizm a zmiana społeczna. Warszawa: PWN.

Castells, Manuel. 1983. The city and the grassroots. Berkeley: University of California Press.

Crouch, Colin. 2004. Post-Democracy. Cambridge: Polity.

Czapiński, Janusz et al. 2015. Diagnoza społeczna. Warszawa: Rada Monitoringu Społecznego.

Czubkowska, Sylwia. 2016a. Soros pozarządowy. Dziennik Gazeta Prawna, nr 180, 22-23.

Czubkowska, Sylwia. 2016b. Trzecia siła jak bardzo niezależna od rządu i pieniędzy. Dziennik Gazeta Prawna, nr 221, 12-13.

Durkheim, Emile. 1999. O podziale pracy społecznej, tłum. Krzysztof Wakar. Warszawa: PWN.

Fukuyama, Francis. 1997. Zaufanie. Kapitat spoteczny a droga do dobrobytu, tłum. Anna i Leszek Śliwa. Warszawa-Wrocław: PWN.

Gehl, Jan. 2009. Życie między budynkami. Użytkowanie przestrzeni publicznych, tłum. Marta A. Urbańska. Kraków: Wydawnictwo RAM. 
Goodman, Robert M. et al. 1988. Identifying and defining the dimensions of community capacity to provide a basis for measurement. Health and Behaviour, 25 (3), 258-278.

Helliwell, John F. i Christopher P. Barrington-Leigh. 2010. How much is social capital worth? National Bureau of Economic Research, working paper 16025. Dostęp: 22.01.2017. http://www.nber.org/papers/w16025.

Herbst, Jan. 2005. Oblicza społeczeństwa obywatelskiego. Warszawa: Biblioteka Aktywności Lokalnej, Ośrodek Badania Aktywności Lokalnej przy Fundacji Rozwoju Społeczeństwa Obywatelskiego.

Jacobs, Jane. 2014. Życie i śmierć wielkich miast Ameryki, tłum. Łukasz Mojsak. Warszawa: Fundacja Centrum Architektury.

Kurczewski, Jacek. 2007. Lokalne wzory kultury politycznej. Warszawa: Wydawnictwo Trio.

Lewenstein, Barbara, Jacek Schindler i Robert Skrzypiec. 2010. Partycypacja społeczna i aktywizacja $w$ rozwiązywaniu problemów społeczności lokalnej. Warszawa: Wydawnictwa Uniwersytetu Warszawskiego.

McMillan, David. W. i David M. Chavis. 1986. Sense of community: A definition and theory. Journal of Community Psychology, (14), 6-23.

Montgomery, Charles. 2015. Miasto szczęśliwe, tłum. Tomasz Tesznar. Kraków: Wydawnictwo Wysoki Zamek.

Putnam, Robert D. 1996. Bowling Alone. Malejący społeczny kapitał Ameryki. ResPublica Nowa, nr 6, 16-22.

Semenza, Jan C. 2005. Building healthy cities. A focus on interventions. W: Handbook of urban health: populations, methods and practice, red. Sandro Galea i David Vlahov, 459-478. New York: Springer.

Seręga, Zygmunt. 1993. Czynniki rozwoju lokalnego: studium socjologiczne wybranych społeczności wiejskich. Kraków: Uniwersytet Jagielloński.

Sobol, Agnieszka. 2006. Governance for sustainable development conditions and experiences in the Polish communities. W: Citizens and Governance for Sustainable Development, red. Walter L. Filho et al., 2934. Vilnius: Leidykla Technika. 
Szawiel, Tadeusz. 2003. Społeczeństwo obywatelskie. W: Budowanie demokracji. Podziały społeczne, partie polityczne i społeczeństwo obywatelskie w postkomunistycznej Polsce, red. Mirosława Grabowska i Tadeusz Szawiel, 128-163. Warszawa: PWN.

Taylor, Ralph B. 1988. Human territorial functioning: an empirical evolutionary perspective on individual and small group territorial cognitions, behaviours and consequences. New York: Cambridge University Press.

Ustawa z 8 marca 1990 roku o samorządzie gminnym. Dziennik Ustaw, 1990 nr 16 poz. 95 z późn. zm.

Ustawa z dnia 24 kwietnia 2003 r. o działalności pożytku publicznego i o wolontariacie. Dziennik Ustaw, 2003 nr 96 poz. 873 z późn. zm.

Wakeford, Tom et. al. 2008. The jury is out: how far can participatory projects go toward reclaiming democracy? W: Participative Inquiry and Practice, red. Peter Reason i Hilary Bradbury, 333-349. London: Sage Publications. 
Agnieszka Jakubowska

Politechnika Koszalińska - Wydział Nauk Ekonomicznych

agnieszka.jakubowska@tu.koszalin.pl

\section{Nierówności w zdrowiu jako wyraz nierówności społecznych: perspektywa gospodarek UE}

\section{Wstęp}

W literaturze przedmiotu podejmowane są próby wyjaśnienia obserwowanego silnego związku między stanem zdrowia społeczeństwa a poziomem nierówności. Prowadzone w tym zakresie przez Światową Organizację Zdrowia badania wskazują, iż nawet w krajach o wysokich dochodach zarówno sama długość życia, jak i możliwość jego przeżycia w zdrowiu, są wciąż ściśle związane $\mathrm{z}$ sytuacją społeczno-ekonomiczną poszczególnych osób oraz rodzin. Zależności te uwidaczniają się zwłaszcza w sytuacji rosnących w tych krajach nierówności społecznych. Badanie zależności między dochodem i poziomem wykształcenia a zdrowiem wydaje się zadaniem prostym w odniesieniu do krajów rozwijających się, gdzie relatywnie łatwo zauważyć silny związek między wzrostem stopy rozwoju gospodarczego i zwiększeniem dostępu do edukacji a poprawą stanu zdrowia społeczeństwa. W przypadku krajów rozwiniętych relacja ta staje się mniej oczywista, a prowadzone w tym zakresie badania wskazują raczej na silniejszą korelację między stanem zdrowia społeczeństwa a występującymi nierównościami w podziale dochodu niż wielkością dochodu w sensie absolutnym. Problemem w tym kontekście staje się więc poziom ubóstwa względnego, a nie skrajnego, jednakże wciąż istnieje niedosyt w zdefiniowaniu tych relacji.

Celem opracowania jest analiza problemu oddziaływania nierówności społecznych na stan zdrowia społeczeństwa, z uwzględnieniem specyfiki tych procesów $\mathrm{w}$ krajach rozwiniętych. W badaniu podjęto próbę wskazania istniejących zależności w tym obszarze obserwowanych wśród rozwiniętych gospodarek Unii Europejskiej. Analizę oparto o dostępne na poziomie NUTS 1 dane opisujące stan zdrowia społeczeństwa poszczególnych krajów, jak również wskaźniki określające istniejący poziom dysproporcji $\mathrm{w}$ osiąganych dochodach oraz poziomie 
wykształcenia. Badaniu poddano jednocześnie poziom zróżnicowania $\mathrm{w}$ analizowanych parametrach, wykorzystując miary statystyczne określające zakres zmienności badanych cech. Zasadnicze źródła informacji stanowiły dane statystyczne Eurostat opracowane na poziome gospodarek krajowych, co w konsekwencji pozwoliło na ukazanie badanego zjawiska w kontekście zróżnicowania między poszczególnymi krajami UE.

\section{Koncepcje teoretyczne}

Problem wpływu posiadanej pozycji w strukturze społeczno-gospodarczej na stan zdrowia stał się przedmiotem licznych badań powadzonych zarówno w obszarze nauk społecznych (Machenbach 2008; Cutler 2011, 5-8), jak i na gruncie nauk o zdrowiu (Adler 1994; Busse et al. 2010, 27-29). W literaturze zostało zaproponowanych szereg modeli podejmujących próby wyjaśnienia związku między warunkami materialnymi i czynnikami psychospołecznymi a poziomem zdrowia i długowieczności społeczeństwa (Colmam 1988).

Wielowymiarowy charakter zdrowia determinuje konieczność rozpatrywania występujących w tym obszarze nierówności w odniesieniu do różnic w stanie zdrowia i dostępie do opieki zwrotnej, jak również szans związanych ze społecznymi uwarunkowaniami zdrowia (Laskowska 2012). Podejmowane w literaturze próby zdefiniowania pojęcia „nierówności w zdrowiu" utożsamiają to zjawisko z możliwymi do uniknięcia różnicami w stanie zdrowia występującymi między krajami lub grupami społecznymi w ramach danego kraju, wyodrębnionymi ze względu na czynniki społeczne, ekonomiczne, demograficzne itp. (Meyer, Yoon i Kaufman 2013, 3). To właśnie pozycji społecznej i związanym z nią wyborami w zakresie konsumpcji, dostępu do opieki zdrowotnej, sposobu spędzania wolnego czasu oraz poziomowi świadomości zdrowotnej Światowa Organizacja Zdrowia przypisała kluczową rolę w generowaniu tych nierówności (WHO 2010). Fundamentalne znaczenie czynników społeczno-ekonomicznych w kreowaniu nierówności $\mathrm{w}$ zdrowiu potwierdziły również badania innych autorów (Conti i Heckman 2010; Galama i van Kippersluis 2013).

W obszarze analizy uwarunkowań stanu zdrowia nie można jednak pomijać mechanizmu sprzężenia zachodzącego między kondycją zdro- 
wotną człowieka i jego możliwościami osiągania dochodu oraz uczestniczenia w procesie edukacji. Udowodnioną ścieżką powiązań między zdrowiem a statusem społeczno-ekonomicznym jest silny efekt oddziaływania zdrowia na poziom aktywności zawodowej człowieka, jego zatrudnialność na rynku pracy, a w konsekwencji możliwość osiągnięcia odpowiedniego statusu materialnego (Dahl 2010). Prowadzone w tym zakresie analizy jednoznacznie dowodzą, że osoby cieszące się dobrym zdrowiem mają większe szanse zarówno na wydłużenie aktywności zawodowej (Boulhol et al. 2012), jak i dłuższy okres zatrudnienia (OECD 2015). Analiza sytuacji dochodowej osób o ograniczeniach w zdrowiu, w odniesieniu do pozostałej części populacji, potwierdza skalę dyskryminacji i wskazuje na wymierny stopień oddziaływania niepełnosprawności na możliwości osiągania dochodów z pracy zarobkowej (Jakubowska 2016).

\section{Nierówności w zdrowiu w UE}

Przeprowadzona poniżej analiza zróżnicowania wybranych parametrów opisujących poziom nierówności w zdrowiu ma na celu wskazanie skali zróżnicowania tego zjawiska w grupie krajów członkowskich UE. Wyboru analizowanych zmiennych dokonano na podstawie przeglądu prezentowanych w literaturze propozycji metodyki oceny badanego zjawiska. W analizie uwzględniono wpływ dochodu oraz poziomu wykształcenia na samoocenę stanu zdrowia. Uwzględniając specyfikę przyjętych zmiennych, jak również silne oddziaływanie wieku na stan zdrowia, założono przeprowadzenie analizy w podziale populacji za względu na wiek. Biorąc pod uwagę dostępność porównywanych danych, analizie poddano zróżnicowanie w przestrzennym rozkładzie następujących zmiennych:

$\checkmark \quad$ odsetek osób deklarujący zły lub bardzo zły stan zdrowia w skrajnych grupach kwintylowych dochodu (pierwsza i piąta grupa kwintylowa) w populacjach w wieku 16-64 lata oraz 65 lat i więcej;

$\checkmark \quad$ odsetek osób deklarujący zły lub bardzo zły stan zdrowia w grupie osób z wykształceniem gimnazjalnym i niższym (poziom 0-2 Międzynarodowej Standardowej Klasyfikacja Kształcenia ISCED) oraz osób 
posiadających wykształcenie wyższe (poziom 5-8 ISCED) w dwóch populacjach wiekowych 25-64 lata oraz 65 lat i więcej.

Specyfika relacji między dochodem a stanem zdrowia osób starszych zdeterminowana jest zarówno statystycznie wyższym ryzykiem choroby oraz zgonu, jak również potencjalnie większą wrażliwością na nierówności w systemie podziału dochodu. Wyniki prowadzonej w ramach Europejskich badań dochodów i warunków życia (EU-SILC) samooceny stanu zdrowia mieszkańców $\mathrm{UE}^{1}$ wskazują, że w grupie osób w wieku 65 lat i więcej udział osób źle lub bardzo źle oceniających swój stan zdrowia jest statystycznie aż o 15,6 p.p. wyższy niż analogiczny udział w grupie osób w wieku 16-64 lata (Eurostat, dane na rok 2015). W tabeli 1 przedstawiono podstawowe charakterystyki opisujące przyjęte w badaniu determinanty społecznych nierówności w zdrowiu w ujęciu państw członkowskich. W celu uzyskania porównywalności badanych zmiennych w analizie posłużono się wskaźnikami natężenia wybranych zjawisk, odnosząc liczbę wystąpień obserwowanych zdarzeń do określonej wielkości populacji.

\begin{tabular}{|l|c|c|c|c|c|c|c|c|}
\hline \multirow{4}{*}{ Kraj UE } & \multicolumn{3}{|c|}{ Samoocena stanu zdrowia: „zły” i „bardzo zły” (\% populacji) } \\
\cline { 2 - 9 } & \multicolumn{2}{|c|}{ Grupa kwintylowa populacji } & \multicolumn{2}{c|}{ Poziom wykształcenia } \\
\cline { 2 - 9 } & \multicolumn{2}{|c|}{$\mathbf{1 6 - 6 4}$ lata } & \multicolumn{2}{|c|}{$\mathbf{6 5}$ lat i więcej } & \multicolumn{2}{|c|}{$\mathbf{1 6 - 6 4}$ lata } & \multicolumn{2}{c|}{ 65 lat i więcej } \\
\cline { 2 - 9 } & $\begin{array}{c}\text { pierw- } \\
\text { sza }\end{array}$ & piąta & $\begin{array}{c}\text { pierw- } \\
\text { sza }\end{array}$ & piąta & $\begin{array}{c}\text { zo- } \\
\text { ziom } \\
0-2\end{array}$ & $\begin{array}{c}\text { po- } \\
\text { ziom } \\
5-8\end{array}$ & $\begin{array}{c}\text { po- } \\
\text { ziom } \\
0-2\end{array}$ & $\begin{array}{c}\text { po- } \\
\text { ziom } \\
5-8\end{array}$ \\
\hline Belgia & 17,2 & 2,1 & 25,0 & 7,1 & 18,1 & 3,2 & 25,4 & 8,0 \\
\hline Bułgaria & 11,6 & 2,5 & 39,2 & 18,0 & 13,5 & 2,4 & 39,7 & 24,9 \\
\hline Czechy & 14 & 1,8 & 32,3 & 13,8 & 20,2 & 1,3 & 38,5 & 15,0 \\
\hline Dania & 11,2 & 3 & 12,1 & 4,0 & 17,1 & 4,4 & 12,3 & 6,6 \\
\hline Niemcy & 15,9 & 2,5 & 15,8 & 10,8 & 17,3 & 2,9 & 17,7 & 10,4 \\
\hline Estonia & 19,7 & 2,2 & 43,7 & 14,3 & 17,5 & 4,3 & 48,5 & 25,6 \\
\hline
\end{tabular}

\footnotetext{
${ }^{1}$ Samoocena stanu zdrowia wyraża subiektywną ocenę zdrowia dokonaną przez respondenta. W badaniach EU-SILC wykorzystywana jest następująca klasyfikacja stanu zdrowia: bardzo dobry (VGOOD), dobry (GOOD), przeciętny (FAIR), zły (BAD), bardzo zły (VBAD) (Eurostat 2016).
} 


\begin{tabular}{|l|c|c|c|c|c|c|c|c|}
\hline Irlandia & 5,5 & 0,5 & 9,4 & 1,9 & 6,5 & 1,3 & 10,3 & 5,4 \\
\hline Grecja & 5,5 & 2,5 & 38,1 & 17,4 & 9,7 & 1,9 & 32,5 & 12,1 \\
\hline Hiszpania & 4,5 & 2,5 & 25,7 & 12,9 & 6,9 & 1,8 & 22,5 & 10,8 \\
\hline Francja & 10,3 & 2,3 & 22,6 & 10,3 & 12,3 & 2,5 & 19,1 & 9,0 \\
\hline Chorwacja & 20,5 & 4,6 & 67,1 & 28,0 & 25,9 & 4,1 & 60,8 & 26,7 \\
\hline Włochy & 6,9 & 3,5 & 39,3 & 19,0 & 9,7 & 3,1 & 35,3 & 13,7 \\
\hline Cypr & 4,2 & 1 & 25,3 & 5,1 & 7,5 & 1 & 23,6 & 4,2 \\
\hline Łotwa & 14,5 & 3,1 & 50,9 & 25,0 & 13,9 & 4,5 & 57,0 & 32,1 \\
\hline Litwa & 13,5 & 2,2 & 52,9 & 23,6 & 14 & 3,2 & 61,8 & 30,3 \\
\hline Luksemburg & 13,8 & 1,9 & 22,7 & 7,2 & 14,6 & 1,5 & 22,1 & 4,9 \\
\hline Węgry & 15,8 & 3,3 & 48,3 & 24,3 & 23,5 & 4 & 53,9 & 23,5 \\
\hline Malta & 4,4 & 0,6 & 11,5 & 4,4 & 2,9 & 0,3 & 10,9 & 8,3 \\
\hline Holandia & 8,8 & 1,5 & 14,5 & 4,5 & 9,9 & 2,3 & 10,1 & 7,4 \\
\hline Austria & 11 & 3 & 21,2 & 13,0 & 17,1 & 3,5 & 26,9 & 10,7 \\
\hline Polska & 13,7 & 4 & 50,1 & 22,0 & 22 & 2,8 & 46,5 & 24,3 \\
\hline Portugalia & 16,7 & 5,3 & 52,6 & 22,2 & 16,2 & 2,6 & 46,4 & 13,1 \\
\hline Rumunia & 4,8 & 2,3 & 32,0 & 18,2 & 6,6 & 1 & 28,7 & 15,2 \\
\hline Słowenia & 11,5 & 4 & 39,7 & 16,8 & 18,4 & 2,6 & 44,0 & 14,3 \\
\hline Słowacja & 9,2 & 4,4 & 51,3 & 27,9 & 21,7 & 2,6 & 56,0 & 20,1 \\
\hline Finlandia & 7 & 1,7 & 16,2 & 3,1 & 9,5 & 1,6 & 13,4 & 8,0 \\
\hline Szwecja & 5,6 & 1,3 & 10,5 & 1,2 & 6,9 & 2,4 & 7,9 & 3,7 \\
\hline $\begin{array}{l}\text { Wielka } \\
\text { Brytania }\end{array}$ & 12,6 & 2,1 & 14,8 & 6,8 & 15,2 & 3,6 & 18,4 & 7,1 \\
\hline
\end{tabular}

Tabela 1. Samoocena stanu zdrowia populacji UE - udział oceny „zły” i „bardzo zły” w badanych populacjach w 2015 roku (w \%).

Źródło: opracowanie własne na podstawie danych (Eurostat 2017).

Analiza danych przedstawionych $\mathrm{w}$ tabeli 1 wskazuje, iż na obszarze UE nadal występuje znaczny poziom przestrzennego zróżnicowania w stanie zdrowia mieszkańców poszczególnych państw członkowskich. W badanej grupie krajów udział osób w wieku 16-64 lat deklarujących zły lub bardzo zły stan zdrowia w pierwszej grupie kwintylowej (najniższe dochody) wahał się od 4,2 (Cypr) do 20,5\% (Chorwacja). W grupie o najwyższych dochodach udziały te wyniosły od 0,5 (Irlandia) do 5,3\% 
(Portugalia). W przypadku osób w wieku 65 lat i więcej udział osób źle lub bardzo źle oceniających swój stan zdrowia wahał się w przedziale od 9,4 (Irlandia) do 67,1\% (Chorwacja) w grupie o najniższych dochodach oraz od 1,2 (Szwecja) do 28\% (Chorwacja) w przypadku osób osiągających dochody z najwyższego przedziału.

Wysoką rozpiętością cechował się również udział osób „źle” lub „bardzo źle" oceniających swoje zdrowie w populacjach wyodrębnionych ze względu na poziom wykształcenia. W grupie osób w wieku 25-64 z najniższym wykształceniem wskaźnik ten przyjmował wartości od 2,9 (Malta) do $25,9 \%$ (Chorwacja), w przypadku osób z wykształcenia wyższym od 0,3 (Malta) do 4,5\% (Łotwa). Analogicznie w populacji osób w wieku 65 lat i więcej wskaźniki te przyjęły wartości od 7,9 (Szwecja) do 61,8\% (Litwa) w grupie osób z najniższym wykształceniem oraz od 3,7 (Szwecja) oraz do 32,1\% (Łotwa) w grupie o najwyższym poziomie wykształcenia.

Wszystkie badane parametry cechowały się jednocześnie stosunkowo dużym poziomem zmienności - obliczone wskaźniki zmienności przyjmowały wartości w przedziale od 41,7 do $45,8 \%$ dla populacji poniżej 65 lat oraz od 51,2 do 61,0\% w grupie osób w wieku 65 lat i więcej (tab. 2).

\begin{tabular}{|c|c|c|c|c|c|c|c|c|c|}
\hline \multicolumn{2}{|c|}{ 苞. } & 总 & 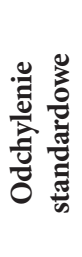 & 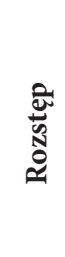 & $\dot{\Xi}$ & $\stackrel{\dot{\Xi}}{\Sigma}$ & 芯 & 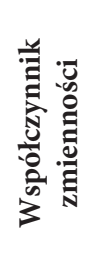 & Z \\
\hline \multirow{6}{*}{ 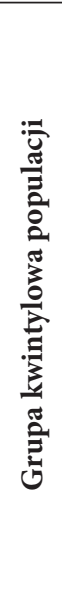 } & \multicolumn{9}{|c|}{ Populacja w wieku 16- 64 lata } \\
\hline & $\begin{array}{c}\text { pierw- } \\
\text { sza }\end{array}$ & 11,1 & 4,8 & 16,3 & $\begin{array}{c}4,2 \\
\text { (Cypr) }\end{array}$ & $\begin{array}{c}20,5 \\
\text { (Chor- } \\
\text { wacja) }\end{array}$ & 11,4 & $43,7 \%$ & 28 \\
\hline & piąta & 2,6 & 1,2 & 4,8 & $\begin{array}{l}0,5 \text { (Ir- } \\
\text { landia) }\end{array}$ & $\begin{array}{c}5,3 \\
\text { (Portu- } \\
\text { galia) }\end{array}$ & 2,4 & $45,8 \%$ & 28 \\
\hline & \multicolumn{9}{|c|}{ Populacja w wieku 65 lat i więcej } \\
\hline & $\begin{array}{c}\text { pierw- } \\
\text { sza }\end{array}$ & 31,6 & 16,2 & 57,7 & $\begin{array}{l}9,4 \text { (Ir- } \\
\text { landia) }\end{array}$ & $\begin{array}{c}67,1 \\
\text { (Chor- } \\
\text { wacja) }\end{array}$ & 28,9 & $51,2 \%$ & 28 \\
\hline & piąta & 13,7 & 8,3 & 26,8 & $\begin{array}{c}1,2 \\
\text { (Szwe- } \\
\text { cja) }\end{array}$ & $\begin{array}{c}28,0 \\
\text { (Chor- } \\
\text { wacja) }\end{array}$ & 13,4 & $61,0 \%$ & 28 \\
\hline
\end{tabular}




\begin{tabular}{|c|c|c|c|c|c|c|c|c|c|}
\hline \multirow{6}{*}{ 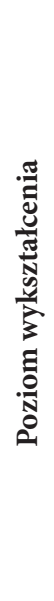 } & \multicolumn{9}{|c|}{ Populacja w wieku 16- 64 lata } \\
\hline & $\begin{array}{c}\text { po- } \\
\text { ziom } \\
0-2\end{array}$ & 14,1 & 5,9 & 23,0 & $\begin{array}{c}2,9 \\
(\mathrm{Mal}- \\
\mathrm{ta})\end{array}$ & $\begin{array}{c}25,9 \\
\text { (Chor- } \\
\text { wacja) }\end{array}$ & 14,3 & $41,7 \%$ & 28 \\
\hline & $\begin{array}{c}\text { po- } \\
\text { ziom } \\
5-8 \\
\end{array}$ & 2,6 & 1,1 & 4,2 & $\begin{array}{c}0,3 \\
(\mathrm{Mal}- \\
\text { ta) }\end{array}$ & $\begin{array}{c}4,5 \\
\text { (Łotwa) }\end{array}$ & 2,6 & $43,3 \%$ & 28 \\
\hline & \multicolumn{9}{|c|}{ Populacja w wieku 65 lat i więcej } \\
\hline & $\begin{array}{c}\text { po- } \\
\text { ziom } \\
0-2\end{array}$ & 31,8 & 17,2 & 53,9 & $\begin{array}{c}7,9 \\
\text { (Szwe- } \\
\text { cja) }\end{array}$ & $\begin{array}{c}61,8 \\
\text { (Litwa) }\end{array}$ & 27,8 & $54,0 \%$ & 28 \\
\hline & $\begin{array}{c}\text { po- } \\
\text { ziom } \\
5-8\end{array}$ & 14,1 & 8,4 & 28,4 & $\begin{array}{c}3,7 \\
\text { (Szwe- } \\
\text { cja) }\end{array}$ & $\begin{array}{c}32,1 \\
\text { (Łotwa) }\end{array}$ & 11,5 & $59,7 \%$ & 28 \\
\hline
\end{tabular}

Tabela 2. Odsetek osób „Źle” lub „bardzo źle” oceniających swoje zdrowie - wyniki charakterystyki opisowej badanych populacji (kraje UE, rok 2015). Źródło: jak w tabeli 1.

Analiza rozkładu samooceny stanu zdrowia w badanych populacjach wykazała znaczące różnice między średnim udziałem osób o złym i bardzo złym stanie zdrowia w zależności od przyjętych kryteriów społeczno-ekonomicznych. W przypadku osób o wysokim statusie materialnym średni udział takiej populacji wyniósł 2,6\% dla osób poniżej 65 lat oraz $13,7 \%$ dla populacji w wieku 65 lat i więcej. Analogiczne wartości obserwowane w grupie osób o najniższym statusie materialnym wyniosły odpowiednio 11,1 oraz $31,6 \%$. Podobne tendencje zaobserwować można w odniesieniu do samooceny stanu zdrowia w populacjach o różnym poziomie wykształcenia. Udział osób w wieku 25-64 deklarujących zły lub bardzo zły stan zdrowia w grupie posiadającej wykształcenie wyższe kształtował się na poziomie 2,6\%, przy średnim udziale tej oceny w grupie osób z najniższym wykształceniem na poziomie $14,1 \%$. Wśród osób w wieku 65 lat i więcej z wykształceniem wyższym zły lub bardzo zły stan zdrowa zdeklarowało 14,1\% populacji, przy 31,8\% osób z wykształceniem podstawowym lub gimnazjalnym. Rozkłady udziałów osób deklarujących zły lub bardzo zły stan zdrowia w obu badanych grupach wiekowych $\mathrm{z}$ uwzględnieniem kryterium dochodu oraz wykształcenia przedstawiono na rys. 1 i rys. 2. 

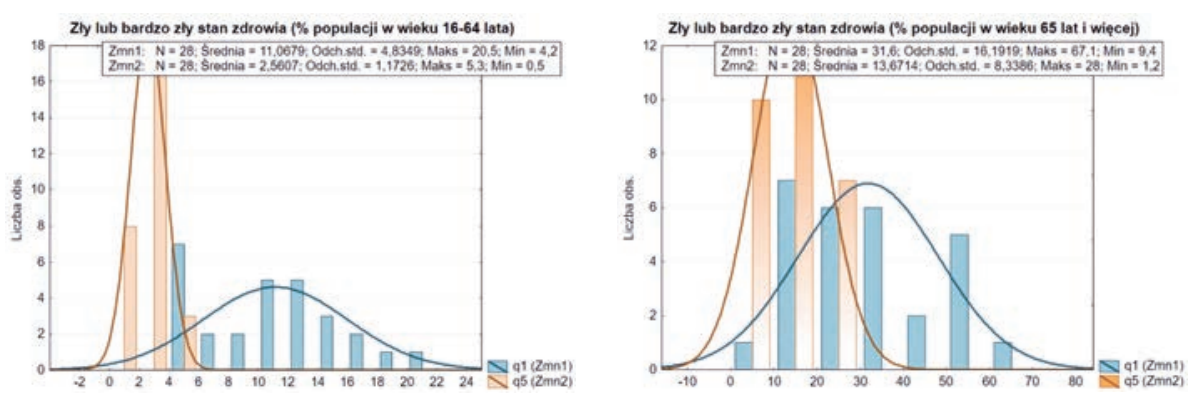

Rysunek 1 . Histogram samooceny stanu zdrowia ze względu na poziom dochodu (q1 - kwintyl pierwszy, q5 - kwintyl piąty), według grup wieku w 2015 rok (kraje UE). Źródło: jak w tabeli 1.
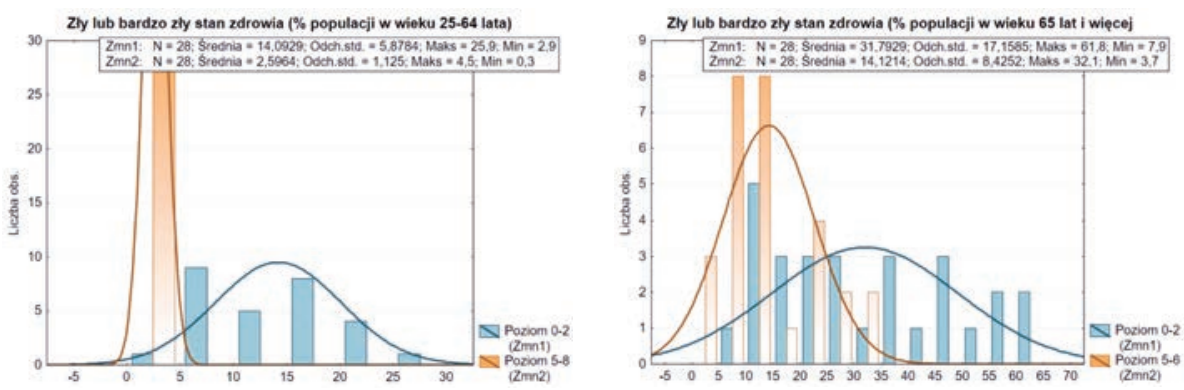

Rysunek 2. Histogram samooceny stanu zdrowia ze względu na poziom wykształcenia, według grup wieku w 2015 rok (kraje UE). Źródło: jak w tabeli 1.

Uzyskane wyniki potwierdzają jednocześnie, że poziom dochodu oraz poziom wykształcenia stanowi istotny czynnik różnicujący poziom samooceny stanu zdrowia w badanych grupach. Prawdopodobieństwo „złego” lub „bardzo złego” stanu zdrowia w grupie osób o najniższych dochodach lub niskim poziomie wykształcenia okazało się kilkukrotnie wyższe niż w analogicznych populacjach o wysokim poziomie dochodu i wykształcenia. Relacja ta jest szczególnie silna w przypadku osób w tzw. wieku produkcyjnym. Widać tu wyraźny związek między obniżeniem się udziału negatywnych ocen stanu zdrowia a poprawą poziomu dochodu lub wykształcenia. Słabsze nasilenie tego efektu wystąpiło natomiast w populacji wieku 65 lat i więcej, co wskazuje na potencjalne zmniejszanie się wraz z wiekiem skali nierówności zdrowotnych determinowanych czynnikami społeczno-ekonomicznymi. 
Szczegółową ocenę nierówności w poziomie samooceny zdrowia z uwzględnieniem dysproporcji w poziomie dochodu oraz wykształcenia oparto dodatkowo na badaniu różnic występujących między grupami o skrajanym poziomie cech. W analizie wykorzystano wskaźnik ilorazu szans OR (ang. odds ratio) pozwalający określić „szansę” na wystąpienie danego zdarzenia $\mathrm{w}$ badanej grupie $\mathrm{w}$ stosunku do możliwości jego wystąpienia w grupie referencyjnej. Określono iloraz szans wystąpienia „złego” lub „bardzo złego” stanu zdrowia w grupie osób o najniższym poziomie dochodu (pierwsza grupa kwintylowa) w stosunku do osób osiągających najwyższe dochody (piąta grupa kwintylowa). Analogiczny poziom „szansy” na zły lub bardzo zły stan zdrowia określono $\mathrm{w}$ przypadku osób $\mathrm{z}$ niskim poziomem wykształceniem w odniesieniu do populacji z wykształceniem wyższym. Uzyskane wyniki wykazały, że „szansa” na złe zdrowie może być nawet kilkunastokrotnie większa w populacji osób o niskich dochodach oraz niskim poziomie wykształcenia w odniesieniu do populacji o najwyższym poziomie zmiennej.

W badanej populacji w wieku 16-64 lata największe względne dysproporcje w „szansie” wystąpienia złego lub bardzo złego stanu zdrowia u osoby z pierwszej i ostatniej grupy dochodowej zaobserwowano w Irlandii (OR na poziomie 11,6), Estonii $(10,9)$ oraz Belgii $(9,7)$. W grupach o skrajnym poziomie wykształcenia najwyższe różnice w potencjalnych „szansach” na złe zdrowie wystąpiły w Czechach (OR na poziomie 19,2), Luksemburgu $(11,2)$ oraz na Słowacji $(10,4)$. W grupie osób w wieku 65 lat i więcej maksymalny poziom wskaźnika OR w odniesieniu do różnic w dochodach zaobserwowano w Szwecji $(9,7)$ oraz w odniesieniu do wykształcenia na Cyprze $(7,0)$.

Analiza rozkładu ilorazu szans dla obu badanych grup wiekowych potwierdza zaobserwowane wcześniej zjawisko obniżenia się wraz $\mathrm{z}$ wiekiem nierówności determinowanych statusem materialnym i poziomem wykształcenia (rys. 3). Średni poziom wskaźnika OR w grupie osób w wieku poniżej 65 lat wyniósł 5,4 w przypadku niskich dochodów oraz 6,8 dla niskiego poziomu wykształcenia. W starszej populacji poziom ilorazu szans wyniósł odpowiednio 3,7 dla czynnika dochodowego oraz 3,2 dla wykształcenia. 

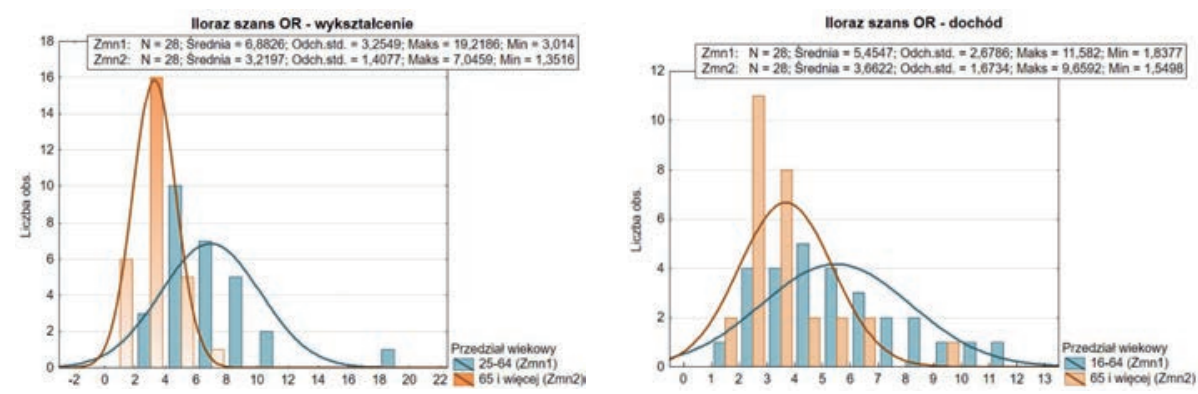

Rysunek. 3. Histogram ilorazu szans OR na „zły” lub „bardzo zły” stan zdrowia w populacji z pierwszego kwintyla w stosunku do populacji z piątego kwintyla dochodowego w 2015 roku, według grup wieku. Źródło: opracowanie własne na podstawie danych w tabeli 1.

\section{Zakończenie}

Pomimo spójności prowadzonych w zakresie europejskiej polityki działań dążących do wyrównania warunków ekonomicznych i społecznych we wszystkich regionach UE kwestia nierówności zdrowotnych występujących między mieszkańcami Wspólnoty nadal pozostaje obszarem wymagającym intensywnych zmian instytucjonalnych. Zidentyfikowane $\mathrm{w}$ przedstawionej analizie znaczne różnice w zdrowiu wystąpiły zarówno między mieszkańcami poszczególnych krajów członkowskich, jak również między grupami ludności o skrajnym gradiencie społecznym w ramach danego kraju. Przeprowadzona ocena skali dysproporcji w samoocenie zdrowia w odniesieniu do badanych populacji potwierdziła, iż w przypadku rozwiniętych gospodarek państw członkowskich poziom zdrowia jest nadal trwale związany ze statusem społeczno-ekonomicznym. Uzyskane wyniki wskazały jednocześnie, że nierówności zdrowotne między grupami mieszkańców UE o niskim i wysokim poziomie społecznym zmniejszają się dopiero po przekroczeniu wieku produkcyjnego, co potwierdza sugerowaną $\mathrm{w}$ literaturze tezę o silnej korelacji między stanem zdrowia a gradientem społecznym determinowanym pozycją na rynku pracy.

\section{Bibliografia:}

Adler, Nancy E. et al. 1994. Socioeconomic status and health: the challenge of the gradient. American psychologist, 49(1), 15-24. DOI: 10.1037/0003-066X.49.1.15. 
Boulhol, Hervé et al. 2012. Improving the Health-Care System in Poland, OECD Economics Department Working Papers, No. 957. Paris: OECD Publishing.

Busse, Reinhard et al. 2010. Tackling Chronic Disease in Europe. Strategies, Interventions and Challenges, World Health Organization. Dostęp: 12.12.2016. http://www.euro.who.int/_data/assets/pdf_file/0008/96632/E93736.pdf.

Coleman, James S. 1988. Social capital in the creation of human capital. American Journal of Sociology, 94, S95-120.

Conti, Gabriella i James J. Heckman. 2010. Understanding the early origins of the education-health gradient: A framework that can also be applied to analyze gene-environment interactions. Perspectives on Psychological Science, 5(5), 585-605.

Cutler, David M., Adriana Lleras-Muney i Tom Vogl. 2012. Socioeconomic Status and Health: Dimensions and Mechanisms. Oxford Handbooks Online. Dostęp: 10.02.2017. http://www.oxfordhandbooks.com/view/10.1093/oxfordhb/9780199238828.001.0001/oxfordhb-9780199238828-e-7.

Dahl, Espen i Ira Malmberg-Heimonen. 2010. Social inequality and health: the role of social capital. Sociology of Health \& Illness, 32(7), 1102-1119.

Eurostat. 2016. EU statistics on income and living conditions (EU-SILC) methodology - definition of dimensions. Dostęp: 02.09.2016. http://ec.europa.eu/eurostat/statistics-explained/index.php/EU_statistics_on_income_and_living_conditions_(EU-SILC)_methodology_-_ definition_of_dimensions.

Eurostat. 2017. Dostęp: 15.02.2017. http://ec.europa.eu/eurostat.

Galama, Titus J. i Hans Van Kippersluis. 2013. Health inequalities through the lens of health-capital theory: issues, solutions, and future directions. W: Health and Inequality, red. Pedro Rosa Dias i Owen O'Donnell, 263-284. Bingley: Emerald Group Publishing Limited. DOI:0.1108/S1049-2585(2013)0000021013.

Jakubowska, Agnieszka. 2016. Health and limitations in health as the determinant of human capital effectiveness: perspective of the EU 
Member States. Journal of International Studies, 9(1), 240-251. DOI: 10.14254/2071-8330.2016/9-1/18.

Laskowska, Iwona. 2012. Zdrowie i nierówności w zdrowiu - determinanty i implikacje ekonomiczno-społeczne. Łodź: Wydawnictwo Uniwersytetu Łódzkiego.

Mackenbach, Johan P. et al. 2008. Socioeconomic inequalities in health in 22 European countries. New England Journal of Medicine, 358(23), 2468-2481. DOI: 10.1056/NEJMsa0707519.

Meyer, Pamela A., Paula W. Yoon i Rachel B. Kaufmann. 2013. Introduction: CDC Health Disparities and Inequalities Report-United States, 2013. Morbidity and Mortality Weekly Report, 62(03), 3-5.

OECD. 2015. Starzenie się i polityka zatrudnienia - Polska 2015: lepsza praca wraz z wiekiem. Warszawa: Centrum Rozwoju Zasobów Ludzkich.

WHO (World Health Organization). 2010. A conceptual framework for action on the social determinants of health. Dostęp: 05.02.2017. http://apps.who.int/iris/bitstream/10665/44489/1/9789241500852_eng. pdf?ua $=1 \& u a=1$. 
Grzegorz Dumieński ${ }^{1}$

grzegorz.dumienski@imgw.pl

Alicja Lisowska ${ }^{2}$

alicja.lisowska@uwr.edu.pl

Marta Bedryj ${ }^{1}$

marta.bedryj@imgw.pl

Andrzej Tiukało ${ }^{1}$

andrzej.tukialo@imgw.pl

${ }^{1}$ Instytut Meteorologii i Gospodarki Wodnej - Państwowy Instytut Badawczy

${ }^{2}$ Uniwersytet Wrocławski - Instytut Politologii

\section{Ocena zrównoważenia polityki przeciwpowodziowej państwa $\mathrm{z}$ wykorzystaniem zintegrowanego ryzyka środowiskowego}

\section{Wstęp}

System społeczno-ekologiczny (z ang. social-ecological system - SES) jest kategorią analityczną, która stanowi podstawę formułowania i realizacji polityki zarządzania ryzykiem powodziowym. Co więcej, swoistość SES sprowadza się do faktu, że może on osiągać swoje cele tylko w warunkach zrównoważonego rozwoju, przy odwołaniu się do kryteriów solidarności międzypokoleniowej jego lokalnych społeczności, a także zasad ochrony zasobów naturalnych. Tylko w takim przypadku będzie można mówić o zrównoważeniu składowych ryzyka powodziowego, mających swoje odzwierciedlenie w polityce zarządzania ryzykiem powodziowym w Polsce.

Postępujące zmiany klimatu wymagają opracowania narzędzi, dzięki którym proces adaptacyjny do tych zmian będzie efektywny. Wzrost częstotliwości występowania katastrofalnych w skutkach zagrożeń naturalnych (dla obszaru Polski zwłaszcza zjawiska powodzi i suszy), wymusza podejmowanie takich działań, które przyczynią się do świadomego kształtowania poziomu ryzyka tych zdarzeń. Przyjęte przez polski rząd Plany Zarządzania Ryzykiem Powodziowym dla Obszarów Dorzeczy i Regionów Wodnych (PZRP) wychodzą naprzeciw takim oczekiwaniom. Stają się one tzw. mapa drogowa kształtowania (redukcji) ryzyka powodziowego w Polsce. 
Obecnie w sposób intuicyjny, w odniesieniu do zjawiska powodzi, mówimy o tzw. polityce przeciwpowodziowej. W prowadzonych przez autorów badaniach na rzecz oceny odporności-zdolności radzenia sobie SES (Dumieński i Tiukało 2016a, 71; Dumieński i Tiukało 2016b, 13) z zagrożeniem powodziowym wskazane jest utożsamić pojęcie polityki przeciwpowodziowej z pojęciem polityki zarządzania ryzykiem powodziowym. Opracowanie nowej definicji stanie się przyczynkiem zarówno do dookreślenia jej podmiotów i celów, jak również pozwoli stworzyć zakres przedmiotowy tak w aspekcie działań politycznych, jak i technicznych.

Głównym celem artykułu jest ocena zrównoważenia polityki przeciwpowodziowej Polski na podstawie analizy przeprowadzonego w Planach Zarządzania Ryzykiem Powodziowym przyporządkowania obszarom zagrożonym powodzią poziomu zintegrowanego ryzyka powodziowego, m.in. w odniesieniu do kategorii środowisko. Dla potrzeb prowadzonych badań sformułowano definicję polityki zarządzania ryzykiem powodziowym, która bezpośrednio odnosi się do kwestii związanych $\mathrm{z}$ zarządzaniem ryzykiem powodziowym analizowanych $\mathrm{w}$ aspekcie działań politycznych.

\section{Polityka zarządzania ryzykiem powodziowym}

Współcześnie zarówno $\mathrm{w}$ ramach nauk prawnych, jak i społecznych, brak jest definicji polityki, która odnosiłaby się bezpośrednio do problematyki ryzyka powodziowego. Co prawda w naukach prawnych funkcjonują regulacje sektorowe odnoszące się do ochrony wód, w tym ochrony przed powodzią, czyli prawo wodne (Ustawa Prawo wodne 2001; Stelmasiak 2009), zaś w naukach społecznych występuje pojęcie polityki wodnej ${ }^{2}$, brak jest jednak pojęcia, które bezpośrednio odnosiłoby się do kwestii związanych z zarządzaniem ryzykiem powo-

\footnotetext{
${ }^{2}$ Pojęcie polityki wodnej (albo polityki dotyczącej ochrony przed powodzią) znajduje się zarówno w Ustawie Prawo wodne jak i tzw. Ramowej Dyrektywie Wodnej. Natomiast kwestie związane z ryzykiem powodziowym regulowane są w ramach tzw. Dyrektywy Powodziowej. W Polsce główne kwestie polityki dotyczącej ochrony przed powodzią reguluje głównie Ustawa Prawo wodne. Zgodnie z nią ochrona przed powodzią jest zadaniem organów administracji rządowej i samorządowej, do współpracy z nimi zobowiązani są też użytkownicy wód. Ochronę przed powodzią prowadzi się z uwzględnieniem map zagrożenia powodziowego (MZP), map ryzyka powodziowego (MRP) oraz planów zarządzania ryzykiem powodziowym (PZRP).
} 
dziowym, analizowanym w aspekcie działań politycznych. Biorąc jednak pod uwagę fakt, iż, po pierwsze, zachodzące obecnie w środowisku zmiany odnoszą się także do kwestii potrzeby zarządzania wodami, jak i, po drugie, członkostwo Polski w Unii Europejskiej nakłada określone obowiązki, w tym w obszarze kształtowania poszczególnych gałęzi prawa oraz rozwiązań politycznych, pożądanym wydaje się być określenie definiensu polityki odnoszącej się do ryzyka powodziowego. W związku z tym, polityka zarządzania ryzykiem powodziowym to sekwencja decyzji, a następnie działań (lub ich zaniechania) podejmowanych przez określone podmioty (aktorów) tejże polityki, czyli zbiorowych uczestników życia politycznego, które powinny być tworzone, a następnie wprowadzane $w$ życie etapami, poczynając od wskazania problemu, a kończąc na ustaleniu i egzekwowaniu koniecznych przedsięwzięć. Celem tak rozumianej polityki jest:

1) ograniczanie występowania zagrożeń powodziowych na terenie całego państwa lub też jego poszczególnych części, w połączeniu z utrzymaniem dobrego stanu wód i związanych z nimi ekosystemów oraz

2) wzmocnienie odporności ( $\mathrm{z}$ ang. resilience) systemu społeczno-ekologicznego poprzez:

a) ograniczenie ekspozycji wrażliwych elementów systemu społeczno-ekologicznego na zagrożenie powodziowe;

b) ograniczenie wrażliwości systemu społeczno-ekologicznego dorzecza (Dumieński i Tiukało 2016b, 7-23) oraz

c) wzrost zdolności adaptacyjnej ( $\mathrm{z}$ ang. adaptive capacity) SES dorzecza rozpatrywanego na różnych poziomach, tj. miasta, gminy, powiatu, województwa czy też państwa (Dumieński i Tiukało 2016a, 67-79).

Podmiotami obecnie prowadzonej polityki zarządzania ryzykiem powodziowym są przede wszystkim państwo (lub też państwa), organy administracji rządowej na poziomie wojewódzkim, samorządowej na poziomie gminy, powiatu i województwa, Krajowy Zarząd Gospodarki Wodnej (KZGW) - główna jednostka odpowiedzialna za opracowanie map zagrożenia powodziowego (MZP) i map ryzyka powodziowego 
(MRP) oraz planów zarząadzania ryzykiem powodziowym (PZRP) wraz z regionalnymi zarząami gospodarki wodnej (RZGW), jednostki badawcze (np. IMGW-PIB), różnorodne grupy nacisku, organizacje społeczne, w tym polityczne, jednostki oraz organizacje międzynarodowe. Podmioty tejże polityki charakteryzuje podejmowanie względnie trwałych, świadomych, suwerennych i zaplanowanych działań, których charakter jest związany z usytuowaniem tychże podmiotów w społecznej i politycznej strukturze. Działania te zmierzają do realizacji określonych potrzeb i interesów, wartości i idei poprzez bezpośrednie sprawowanie, współuczestniczenie w sprawowaniu władzy politycznej bądź też poprzez wpływanie na proces podejmowania decyzji politycznych na różnych szczeblach.

Charakterystyczne dla decyzji, a następnie działań określających istotę polityki zarządzania ryzykiem powodziowym jest to, iż:

1. obejmują swoim zasięgiem przede wszystkim obszar danego systemu społeczno-ekologicznego, percypowanego albo przez pryzmat obszaru danego państwa (powiązania wewnętrzne - poziom gminy, powiatu, województwa), albo też w odniesieniu do jego podziału w układzie zlewniowym z uwzględnieniem obszarów transgranicznych (powiązania zewnętrzne) i obszarów powiązanych. Możliwe jest również wskazanie na oddziaływanie decyzji i działań w ramach polityki zarządzania ryzykiem powodziowym na funkcjonowanie systemu społeczno-ekologicznego w ramach współpracy międzynarodowej (np. działania podejmowane przez Światową Organizację Meteorologiczną WMO - The World Meteorological Organization lub przez międzynarodowe komisje rzeczne), jak również poprzez koordynację służb bądź jednostek z innych państw (np. odpowiedniki IMGW, np. w Niemczech czy Czechach);

2. dążą do zachowania lub wzmocnienia odporności systemu społeczno-ekologicznego poprzez wzmocnienie zintegrowanej odporności w wymiarze społecznym, gospodarczym i środowiskowym;

3. są wyrazem tego, iż polityka prowadzona $\mathrm{w}$ tym obszarze stanowi płaszczyznę ścierania się celów i dążeń wyrażających potrzeby i interesy poszczególnych podmiotów oraz preferowane przez nie wartości. Przyjęta definicja polityki zarządzania ryzykiem powodziowym 
może być analizowana przez pryzmat procesu decyzyjnego, tworzącego określone uwarunkowania, wywołującego konkretne efekty i zachodzącego w autonomicznej sferze życia społecznego.

Założenia wstępne ujmujące politykę zarządzania ryzykiem powodziowym jako proces decyzyjny wskazują, iż:

1. jest możliwe przyjęcie tego rodzaju polityki jako sekwencji sytuacji konfliktowych oraz decyzji stanowiących próbę zapobiegania i rozwiązywania tych konfliktów;

2. w procesie tym występuje ciągłe ścieranie się interesów ekonomicznych, politycznych, społecznych, w tym ekologicznych, poszczególnych podmiotów;

3. wymagane jest od podmiotów dążenie do kompromisu i podjęcia decyzji;

4. poszczególne podmioty mają zróżnicowaną siłę oddziaływania różnią się potencjałem politycznym, ekonomicznym lub poparciem społecznym;

5. system polityczny może wpływać na pozycję przetargową poszczególnych podmiotów (poprzez np. blokowanie lub dopuszczanie możliwości uczestnictwa, likwidacje lub tworzenie instytucjonalnych form artykulacji interesów).

W świetle tak przedstawionej koncepcji pojęcia „polityka zarządzania ryzykiem powodziowym", szczególnego znaczenia nabierają przyjęte obecnie w Polsce rozwiązania.

\section{Ocena zintegrowanego ryzyka powodziowego}

W Polsce o polityce zarządzania ryzykiem powodziowym, bądź kształtowania ryzyka powodziowego, można mówić stosunkowo od niedawna. Można wręcz wysunąć tezę, iż proces tworzenia polityki ochrony przeciwpowodziowej Polski, mimo iż trwający od dziesięcioleci, dopiero obecnie ulega dookreśleniu. Zakończone pod koniec 2015 roku działania pozwoliły na utworzenie zbioru dokumentów, jakim są PZRP dla obszarów dorzeczy i regionów wodnych. Stanowią one pierwsze tego typu dokumenty zawierające holistyczne działania mające na celu racjonalną redukcję zidentyfikowanego ryzyka powodziowego $\mathrm{w}$ Polsce, co jest zgodne z założeniami tzw. dyrektywy powodziowej (Dyrek- 
tywa 2007/WE/2060). W związku z tym, to w ramach przygotowania tych dokumentów przeprowadzono po raz pierwszy wielokierunkowe, interdyscyplinarne analizy mające na celu oszacowanie zintegrowanego ryzyka powodziowego.

Zgodnie z zapisami dyrektywy, istnieją obszary szczególnie podatne na zjawiska powodzi, a mianowicie życie i zdrowie mieszkańców, środowisko, działalność gospodarcza oraz dziedzictwo kulturowe. Dla każdego z tych obszarów oszacowano wielkość niekorzystnych konsekwencji powodzi o różnej intensywności i prawdopodobieństwie ich występowania. Teoretycznie liczba takich niekorzystnych konsekwencji powodzi jest nieograniczona, a ich wybór zależy od celu i zasięgu prowadzonych analiz, ich szczegółowości oraz dostępności danych i informacji. Należy zwrócić uwagę, że szczególnie dostępność danych i informacji ogranicza liczbę analizowanych negatywnych konsekwencji, które prowadzą do trwałych lub okresowych dysfunkcji w systemie społeczno-ekologicznym.

W ramach prac nad PZRP przeprowadzono szereg analiz, których rezultatem było z jednej strony sformułowanie celów głównych i szczegółowych zarządzania ryzykiem powodziowym, z drugiej diagnoza rozkładu przestrzennego obszarów najbardziej zagrożonych powodzią. $\mathrm{Na}$ wstępie dokonano identyfikacji interesariuszy, stanowiących partnerów do konsultacji podczas opracowywania planów. Następnie określono zagrożenie i ryzyko powodziowe oraz dokonano oceny działania obecnego systemu ochrony przeciwpowodziowej w Polsce. Podstawą dla analiz były m.in. MZP i MRP, ale też wiedza ekspercka uczestników prac, w tym ogromnej rzeszy zaproszonych do współpracy interesariuszy reprezentujących zarówno środowisko naukowe, jak i ekspertów oraz praktyków. Wśród obszarów zagrożenia powodziowego wyodrębniono te najbardziej problemowe w skali regionu wodnego (tzw. hot-spoty). Na podstawie wykonanej diagnozy problemów oraz w oparciu o propozycje działań zgłoszonych w ramach prac Zespołów Planistycznych Zlewni, dla każdego regionu wodnego i obszaru dorzecza, dobrano zestaw działań technicznych, jak i nietechnicznych, które w efekcie mogą prowadzić do spełnienia założonych celów głównych i szczegółowych. Z zestawienia tych działań utworzono warianty planistyczne dla danego obszaru problemowego i przeprowadzono ocenę skuteczności proponowanych działań dla redukcji ryzyka powodziowego. Dokonano oce- 
ny zgodności przyjętych ostatecznych wariantów działań z wymogami prawnymi i środowiskowymi, w tym szczególnie $\mathrm{z}$ wymogami ramowej dyrektywy wodnej oraz dyrektyw ptasiej i siedliskowej. Ostatecznie przy zastosowaniu analizy wielokryterialnej oraz analizy kosztów i korzyści dokonano wyboru najefektywniejszego wariantu działań redukujących ryzyko powodziowe (Tiukało i Sadowska 2015, 52-58).

Dla wyodrębnienia, spośród wszystkich obszarów zagrożenia powodziowego regionu wodnego, obszaru o szczególnie dużym poziomie ryzyka powodziowego (tzw. hot-spotu), wymagającego pilnej interwencji ograniczającej to ryzyko, zastosowano zintegrowany wskaźnik poziomu ryzyka powodziowego, stanowiący średnią ważoną ryzyka powodziowego w kategoriach: życie i zdrowie ludzi, środowisko, dziedzictwo kulturowe, działalność gospodarcza. Wagi, charakteryzujące wpływ poziomu ryzyka badanego obszaru w poszczególnych kategoriach na zintegrowany poziom ryzyka powodziowego tego obszaru, wyznaczono w oparciu o metodę hierarchicznej analizy problemu AHP (ang. Analytical Hierarchy Process), tzw. metodę Saaty'ego.

Nie budzi zastrzeżeń przyjęcie najwyższego współczynnika wagowego dla kategorii zdrowie i życie ludzi, gdyż życie ludzkie stanowi wartość autoteliczną. Problematyczny jednak może być poziom przyjętej wartości 0,54 wobec marginalnych 0,07 w kategoriach środowisko i dziedzictwo kulturowe. Tak przyjęte współczynniki wagowe mają swoje odzwierciedlenie w finalnym kształcie zintegrowanego poziomu ryzyka powodziowego SES. Ostatecznie poziom zintegrowanego ryzyka powodziowego dla obszaru SES wyznaczono przy zastosowaniu następującej zależności:

$$
I R=0.54 \cdot \mathrm{R}_{\mathrm{hh}}+\mathbf{0 . 0 7} \cdot \mathbf{R}_{\mathrm{e}}+0.07 \cdot \mathrm{R}_{\mathrm{ch}}+0.32 \cdot \mathrm{R}_{\mathrm{ea}}
$$

gdzie:

\begin{tabular}{|l|l|l|}
\hline$I R$ & - & $\begin{array}{l}\text { poziom zintegrowanego ryzyka powodziowego SES } \\
(I R-\text { ang. integrated risk })\end{array}$ \\
\hline 0,54 & - & współczynnik wagowy dla kategorii $z$ drowie $l u d z i$ \\
\hline 0,07 & - & współczynnik wagowy dla kategorii środowisko \\
\hline 0,07 & - & współczynnik wagowy dla kategorii dziedzictwo kulturowe \\
\hline
\end{tabular}




\begin{tabular}{|l|l|l|}
\hline 0,32 & - & współczynnik wagowy dla kategorii działalność gospodarcza \\
\hline$R_{h h}$ & - & poziom ryzyka powodziowego dla kategorii $z$ drowie $i$ życie ludzi \\
\hline$R_{e}$ & - & poziom ryzyka powodziowego dla kategorii środowisko \\
\hline$R_{c h}$ & - & poziom ryzyka powodziowego dla kategorii dziedzictwo kulturowe \\
\hline$R_{e a}$ & - & poziom ryzyka powodziowego dla kategorii działalność gospodarcza \\
\hline
\end{tabular}

W niniejszym artykule podjęto próbę analizy oceny ryzyka powodziowego w kategorii środowisko, mając na uwadze fakt, iż w podejmowanych dotychczas badaniach wątek środowiskowy - zasadniczy w koncepcji zrównoważonego rozwoju - jest marginalizowany.

\section{Ryzyko powodziowe systemu społeczno-ekologicznego w kate- gorii środowisko}

W obecnym kształcie metodyki wyznaczania poziomu ryzyka powodziowego w kategorii środowisko działania prowadzone były w oparciu o identyfikację obiektów, które zakwalifikowano jako duże bądź potencjalne zagrożenie dla środowiska (Rozporządzenie 2013). Elementy SES, będące jednocześnie wskaźnikami negatywnych konsekwencji powodzi, zestawiono w tabeli 1. Warto zasygnalizować, że sprowadzają się one tylko do identyfikacji wyeksponowanych na powódź obiektów, które mogą być źródłem zanieczyszczenia środowiska i mogą mieć istotny wpływ na funkcjonowanie całego SES w momencie zagrożenia powodziowego.

\begin{tabular}{|l|r|}
\hline kategoria & wskaźnik negatywnych konsekwencji powodzi \\
\hline środowisko & $\begin{array}{l}\text { liczba obiektów stanowiących duże zagrożenie dla śro- } \\
\text { dowiska (zakłady przemysłowe z uwzględnieniem zakła- } \\
\text { dów znajdujących się w rejestrze zakładów o dużym albo } \\
\text { zwiększonym ryzyku wystąpienia poważnej awarii) }\end{array}$ \\
& $\begin{array}{l}\text { liczba obiektów stanowiących potencjalne zagrożenie } \\
\text { dla środowiska (inne potencjalne ogniska zanieczysz- } \\
\text { czeń - składowiska odpadów, oczyszczalnie ścieków } \\
\text { i przepompownie ścieków, cmentarze) }\end{array}$ \\
\hline
\end{tabular}

Tabela 1. Zestawienie wskaźników negatywnych konsekwencji powodzi w kategorii środowisko. Źródło: opracowanie własne na podstawie Rozporządzenia 2013. 
Warto także zaakcentować, iż równolegle do obiektów, które mogą być źródłem zanieczyszczenia środowiska, na MZP i MRP uwzględniono także określone formy ochrony przyrody zagrożone wodami powodziowymi. Były to parki narodowe, rezerwaty przyrody oraz obszary Natura 2000. Na mapach nie uwzględniono natomiast parków krajobrazowych, obszarów chronionego krajobrazu, pomników przyrody, zespołów przyrodniczo-krajobrazowych czy użytków ekologicznych. Należy zauważyć, że potencjalne straty powodziowe dla wskazanych na MZP i MRP elementów obliczane były według stawek kwotowych z rozporządzenia (Rozporządzenie 2013). Jednakże w przypadku tak złożonych form zagospodarowania, jak np. parki narodowe, uwzględniano $\mathrm{w}$ nich straty zgodnie $\mathrm{z}$ faktycznym sposobem zagospodarowania (np. park narodowy w $90 \%$ zajmują lasy, a w 10\% tereny rekreacyjne - strata wyliczana była zgodnie z przyjętymi stawkami dla tych typów-klas zagospodarowania). W konsekwencji oznacza to, że park narodowy może mieć taką samą lub mniejszą wartość, aniżeli powierzchniowo zbliżony obszar lasu w danym województwie. W polskiej literaturze przedmiotu z zakresu ekonomii i inżynierii środowiska wnikliwe analizy stawiające pod znakiem zapytania przyjęte stawki oraz brak ich aktualizacji zawarto w pracach m.in. I. Godyń (np. Godyń 2015, 5-22).

W przypadku potencjalnych strat powodziowych w SES, sposób ich wyznaczenia utrudnia fakt, że tzw. straty środowiskowe bardzo często są niewymierne, ich skutki są $\mathrm{z}$ reguły często odczuwane w odległym czasie, a obecna metodyka nie uwzględnia ich kwantyfikacji i wyceny usług ekosystemowych. Tego typu wycena stosunkowo od niedawna jest traktowana jako podstawa holistycznej oceny, m.in. ryzyka powodziowego. W obecnym kształcie MZP i MRP oraz w PZRP analizy strat pośrednich oraz zakłócenia w świadczeniu usług środowiskowych nie były brane pod uwagę. Dodatkowo klasa użytkowania terenu woda, co w praktycznym przełożeniu oznacza np. straty dla jezior i zbiorników wodnych, nie podlegała wycenie w przypadku przeprowadzenia przez nie fali powodziowej (Pasiecznik-Dominiak, Tiukało i Dumieński 2015, 39-50).

Komentarza wymaga także fakt, iż wyznaczenie zintegrowanego ryzyka powodziowego dla SES w kategorii środowisko oparte było na określeniu wyeksponowanych elementów na zagrożenie powodziowe (rysunek 1). Niemniej jednak należy zauważyć, iż pewne aspekty środo- 
wiskowe, które intuicyjnie przypisano by do kategorii środowisko, znajdują się w kategorii działalność gospodarcza (np. formy ochrony przyrody utożsamiane $\mathrm{z}$ klasą użytkowania terenu, jak np. lasy). Oznaczają one potencjalną stratę powodziową liczoną zgodnie $\mathrm{z}$ rozporządzeniem (Rozporządzenie 2013).

W praktyce oznacza to, że poziom zintegrowanego ryzyka środowiskowego w kategorii środowisko został uzależniony od liczby obiektów zagrożonych wodami powodziowymi. W przeprowadzonych w ramach projektu PZRP analizach nie uwzględniano m.in. zdolności adaptacyjnej zarówno poszczególnych obiektów SES zagrożonych powodzią, jak i całego systemu. Uniemożliwia to przeprowadzenie kompleksowej oceny systemów społeczno-ekologicznych względem określonych parametrów zagrożenia. Takie analizy pozwoliłby m.in. na hierarchizację SES względem priorytetu ich ochrony bądź kierowania środków pomocowych przez państwo.

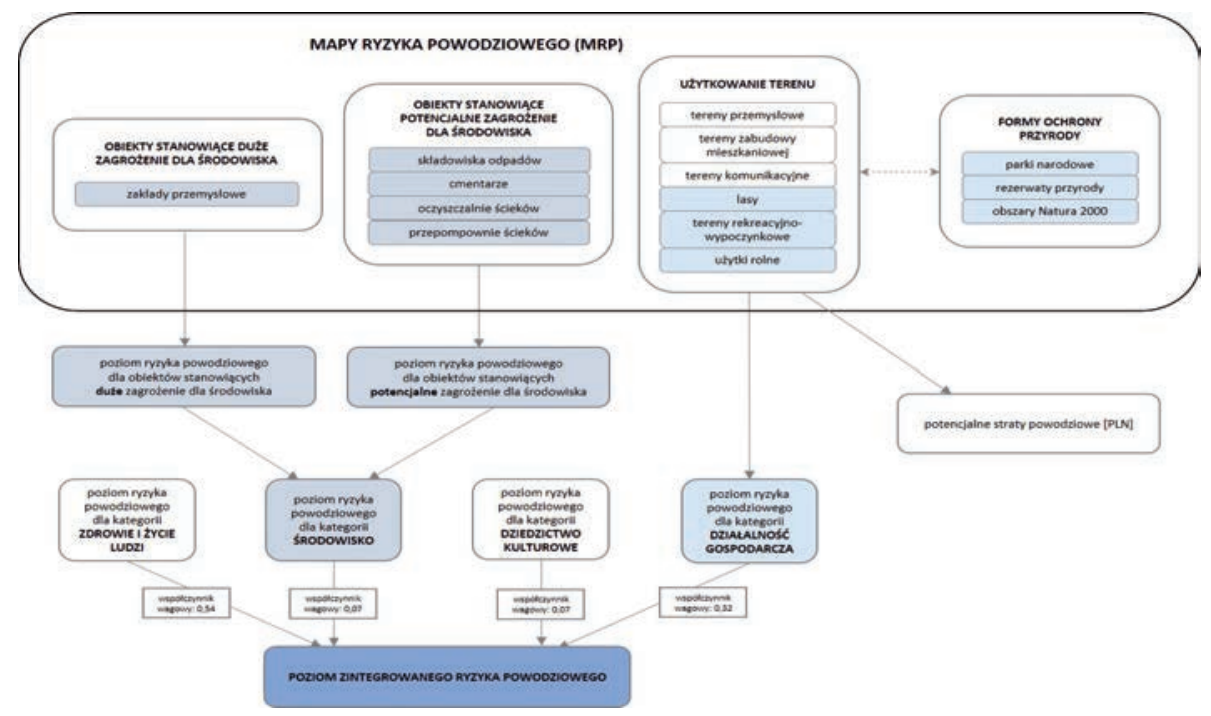

Rysunek 1. Diagram wyznaczania zintegrowanego ryzyka powodziowego w kategorii środowisko przy wykorzystaniu zbioru informacji i danych zaczerpniętych z MZP i MRP. Źródło: opracowanie własne. 


\section{Zakończenie - wnioski}

Zaproponowana na potrzeby prowadzonych analiz definicja polityki zarządzania ryzykiem powodziowym stanowi pierwszą próbę określenia definiensu polityki odnoszącej się do ryzyka powodziowego. Pojawia się zatem pytanie, czy polityka ta, w świetle zintegrowanego ryzyka środowiskowego opracowanego na potrzeby PZRP, jest zrównoważona? Odpowiedź brzmi: nie. O zrównoważonej polityce zarządzania ryzykiem powodziowym w kontekście kategorii środowisko (jak i w ogóle) możemy mówić wówczas, gdy ilość elementów podlegających analizie ryzyka jest kompleksowa, a waga wpływu oceny ryzyka powodziowego w kategorii środowisko na wskaźnik zintegrowanego ryzyka powodziowego będzie większa niż dotychczas stosowana. Przeprowadzona analiza dowodzi, iż w obecnym kształcie PZRP ilość elementów środowiskowego ryzyka została znacznie ograniczona, a przyjęty wagowy udział tej kategorii w zintegrowanym ryzyku powodziowym powoduje jej marginalność. Należy zauważyć, iż polityka zarządzania ryzykiem powodziowym rozumiana jako sekwencja decyzji i działań (lub ich zaniechania) jest specyficznym obszarem działalności politycznej, w którym to ścierają się argumenty różnych grup interesu i nacisku. Warto w tym miejscu zaakcentować, iż dedykowane działania ograniczające ryzyko powodziowe, zawsze muszą znaleźć swoje potwierdzenie w ocenie efektywności ekonomicznej planowanych inwestycji (Tiukało 2013, 23-32; Godyń 2015, 5-22).

O ile PZRP stanowią pierwsze tego typu holistyczne działania mające na celu wielowymiarowe oszacowanie wielkości ryzyka powodziowego w poszczególnych kategoriach, o tyle należy zaakcentować, iż były opracowaniem eksperckim. Autorzy podnoszą konieczność weryfikacji metodyki oceny poziomu ryzyka powodziowego dla wybranych systemów społeczno-ekologicznych w kolejnym cyklu realizacji tzw. dyrektywy powodziowej (Dyrektywa 2007/60/WE). W zasadniczej kwestii sprowadza się to do weryfikacji przyjętych wag (głównie dla kategorii środowisko 0,07), jak i modyfikacji przyjętej listy wskaźników niekorzystnego oddziaływania powodzi. Autorzy postulują m.in. wprowadzenie wskaźników mierzących trwałe lub okresowe niekorzystne oddziaływanie powodzi na podsystem ekologiczny SES oraz wprowadzenie wskaźników określających redukcję średniorocznych wartości strumienia usług środowiskowych świadczonych przez ekosystem, a spowodowanych powodziami. 


\section{Bibliografia:}

Dumieński, Grzegorzi Andrzej Tiukało. 2016a. Gmina jako system społeczno-ekologiczny zagrożony powodzią. W: Interdyscyplinarne zagadnienia $w$ inżynierii i ochronie środowiska. T. 8, red. Bartosz Kaźmierski, Andrzej Kotowski i Katarzyna Piekarska, 67-79. Wrocław: Oficyna Wydawnicza Politechniki Wrocławskiej. Dostęp: 20.03.2017. http://www.eko-dok.pl/2016/106.pdf.

Dumieński, Grzegorz i Andrzej Tiukało. 2016b. Ocena podatności systemu społeczno-ekologicznego zagrożonego powodzią. Prace i Studia Geograficzne, 61(4), 7-23. Dostęp: 20.03.2017. http://py.wgsr.uw.edu.pl/uploads/f_blank/news/t.61.4.art.1.pdf.

Dyrektywa 2007/60/WE Parlamentu Europejskiego i Rady z dn. 23 października 2007 r. w sprawie oceny ryzyka powodziowego i zarządzania nim (OJ L 288, 6.11.2007).

Godyń, Izabela. 2015. Ocena efektywności ekonomicznej inwestycji przeciwpowodziowych. Gospodarka $w$ Praktyce i Teorii, 1(38), 5-22. DOI: 10.18778/1429-3730.38.01.

Pasiecznik-Dominiak, Anna, Andrzej Tiukało i Grzegorz Dumieński. 2015.Analysis of the exposure of Polish lakes to flood threat. Limnological Review, 15(1), 39-50. DOI: 10.2478/limre-2015-0005.

Prawo ochrony środowiska, red. Jerzy Stelmasiak. 2009. Warszawa: LexisNexis.

Rozporządzenie Ministra Środowiska, Ministra Transportu, Budownictwa i Gospodarki Morskiej, Ministra Administracji i Cyfryzacji oraz Ministra Spraw Wewnętrznych z dnia 21 grudnia 2012 r., w sprawie opracowania map zagrożenia powodziowego oraz map ryzyka powodziowego (Dz. U. z 2013 r. poz. 104).

Tiukało, Andrzej i Urszula Sadowska. 2015. Metodologia przygotowania planów zarządzania ryzykiem powodziowym. Przegląd komunalny, 2, 52-58.

Tiukało, Andrzej. 2013. Analysis of instruments for assessment of planned investments in water management. Meteorology Hydrology and Water Management, 1(1), 23-32. Dostęp: 20.03.2017. http://www.mhwm.pl/Analysis-of-instruments-for-assessment-of-planned-investments-in-watermanagement, $0,4 . h t m l$.

Ustawa Prawo wodne z dnia 18 lipca 2001 r. (Dz.U. 2001 Nr 115 poz. 1229). 


\section{CZĘŚĆ VIII \\ ŚRODOWISKO PRZYRODNICZE}



Czesław Wodzikowski

Uniwersytet Kazimierza Wielkiego w Bydgoszczy - Wydział Humanistyczny

czeslawchojnice@wp.pl

\section{Program MAB UNESCO jako praktyczna realizacja idei zrównoważonego rozwoju}

\section{Wstęp}

Organizacja Narodów Zjednoczonych do Spraw Oświaty, Nauki i Kultury (UNESCO) jest kontynuatorką, powołanego na wniosek Rady Ligi Narodów, Międzynarodowego Instytutu Współpracy Intelektualnej (CICI) działającego w Paryżu w latach 1922-1940. Jego utworzenie było odpowiedzią na postulaty wysuwane podczas I Zgromadzenia LN w 1920 roku przez Henriego La Fontaina - polityka i intelektualistę belgijskiego, laureata Pokojowej Nagrody Nobla z 1913 roku, który zaproponował stworzenie organizacji mającej zająć się koordynacją współpracy intelektualnej. Głównym jej celem miało być ożywienie międzynarodowego życia intelektualnego oraz wzajemne poznanie i zbliżenie narodów (Brzeziński 2015, 7-8). Pracę Instytutu przerwał wybuch II wojny światowej. Jednak już w 1942 roku w Londynie spotkali się przedstawiciele państw alianckich, aby nakreślić plan współpracy międzynarodowej dotyczącej oświaty, który miał być realizowany po zakończeniu wojny.

Po utworzeniu w 1945 roku Organizacji Narodów Zjednoczonych (ONZ) zdecydowano, że planowana wcześniej organizacja poszerzy swoją działalność także o sprawy kultury i nauki, kontynuując działalność CICI. UNESCO powstało na mocy Konstytucji podpisanej przez przedstawicieli 37 państw w listopadzie 1945 roku w Londynie. Przyjęto, że wejdzie ona w życie w 1946 roku. Pierwsze spotkanie w ramach Konferencji Generalnej UNESCO odbyło się na przełomie listopada i grudnia 1946 roku w Paryżu.

Obecnie do UNESCO należy 195 państw oraz 8 tzw. członków stowarzyszonych. UNESCO tworzy standardy współpracy poprzez ustanawianie prawa międzynarodowego $\mathrm{w}$ dziedzinach oświaty, nauki i kultury oraz mobilizując społeczność międzynarodową do wspólnych działań. Organizacja aktywnie zabiega o rozwijanie kultury pokoju. 
Przyjmując założenie, że utrzymanie pokoju na świecie opiera się m.in. na poszanowaniu odmienności, UNESCO stało się promotorem dialogu pomiędzy narodami i cywilizacjami. Aktywizacja rządów państw oraz społeczności lokalnych dla idei ochrony dziedzictwa kulturowego, współpracy w dziedzinie nauki i edukacji oraz tworzenia społeczeństwa informacyjnego, to podstawowe zadania UNESCO.

W prezentowanym artykule przedstawiono wyniki kwerendy dokumentów ustanawiających Program „Człowiek i Biosfera” (MAB) oraz ustanawiających i regulujących działalność Rezerwatów Biosfery (RB) z perspektywy zrównoważonego rozwoju. Przyjęto hipotezę, iż RB są obszarami praktycznej realizacji nowej globalnej koncepcji rozwoju, tj. zrównoważonego rozwoju. Uwagę skoncentrowano przede wszystkim na fakcie przynależności UNESCO do ONZ oraz na realizacji celów, które ONZ definiowało w zależności od zmieniającej się sytuacji międzynarodowej. W artykule zastosowano metodę analizy dokumentów źródłowych oraz literatury przedmiotu.

\section{Faza początkowa programu MAB}

Działania na rzecz racjonalnego rozwoju UNESCO podejmuje w połowie lat 60. XX w. Zaproponowano wówczas, aby pierwsza światowa konferencja dotycząca naukowych podstaw racjonalnego wykorzystania i ochrony zasobów biosfery odbyła się w 1968 roku w Paryżu. Chociaż z założenia była to konferencja międzyrządowa, to uczestniczyło w niej 236 delegatów z 63 krajów oraz 88 przedstawicieli organizacji międzynarodowych. Największym jej osiągnięciem było stwierdzenie, że zagadnienia ochrony oraz wykorzystywania zasobów środowiska są nierozłączne. Wskazano jednocześnie na konieczność interdyscyplinarnego podejścia do tych kwestii. Uczestnicy konferencji zobowiązali UNESCO do podjęcia realizacji międzynarodowego programu badań MAB, który obejmowałby swoim zakresem kwestie rozwoju społecznego i gospodarczego w aspekcie ochrony zasobów przyrodniczych.

Rok 1969 to okres szerokich konsultacji dotyczących programu MAB. Koncepcja była w tym okresie dopracowywana. W początkowej fazie zamierzano przyjęte zasady wprowadzać na obszarach już chronionych przez państwa, tj. na obszarach parków narodowych, rezerwa- 
tów przyrody itp. Po raz pierwszy pojawia się też w tym roku pojęcie RB jako specjalnie wydzielonego obszaru.

23 października 1970 roku odbyła się 16 Generalna Konferencja UNESCO. W jej trakcie przyjęto program MAB do realizacji. Jak piszą Lutz Möller i Eva Kammann, przyjęcie programu poprzedziła gorąca dyskusja, a decyzję podjęto w głosowaniu (co było wówczas ewenementem w działalności UNESCO) na pięć minut przed północą, po interwencji przewodniczącego obrad (Möller i Kammann 2007).

W 1971 roku Międzynarodowa Rada Koordynacyjna (ICC) programu MAB określiła 14 głównych obszarów tematycznych programu, obejmujących pełne spektrum ekosystemów występujących na Ziemi. Określono również 31 obszarów badawczych programu. W tym okresie prowadzone w ramach programu MAB przedsięwzięcia były działaniami odizolowanymi i brak było możliwości skonsolidowania uzyskanych przez poszczególne kraje wyników.

Przełom lat 60. i 70. XX wieku to okres tzw. kroków milowych $\mathrm{w}$ kwestii ochrony środowiska powiązanej z rozwojem społeczno-gospodarczym. W 1968 roku odbyła się XXIII Sesja ONZ. Jej owocem była rezolucja o zorganizowaniu w 1972 roku międzynarodowej konferencji poświęconej problemom ekologicznym.W1969 roku ówczesny Sekretarz Generalny ONZ U Thant przedstawił raport Problemy ludzkiego środowiska. Rok 1972 przyniósł kolejne ważne wydarzenia. W Sztokholmie odbyła się konferencja ONZ, której pokłosiem było między innymi przyjęcie deklaracji dotyczącej naturalnego środowiska człowieka. W tym samym roku ONZ powołała Program Narodów Zjednoczonych ds. Środowiska (UNEP), który jest głosem w obronie środowiska w ramach systemu Narodów Zjednoczonych.

Rok 1972 jest również bardzo ważny dla samego programu MAB. W tym właśnie roku przedstawiono cele i funkcje RB. Po pierwsze, miały one stanowić obszary, na których dokonywana będzie ochrona zasobów naturalnych i ekosystemów w taki sposób, aby zachować występującą na nich bioróżnorodność. Po drugie, wskazano na konieczność rozwoju międzynarodowej sieci tych obszarów w celu prowadzenia badań naukowych, edukacji, monitoringu oraz informacji o toczących się tam procesach. Po trzecie, chciano wprowadzić działania mające na celu 
doprowadzenie do rozwoju gospodarczego obszarów RB z poszanowaniem istniejących zasobów przyrodniczych i ochroną środowiska.

W tym okresie zainteresowanie programem MAB było na arenie międzynarodowej bardzo duże. Dowodem są np. zapisy ze szczytu w Moskwie z roku 1974, gdzie ówczesny I sekretarz KPZR Leonid Breżniew i prezydent Stanów Zjednoczonych Richard Nixon poparli tę inicjatywę, zobowiązując się jednocześnie do utworzenia w swoich krajach RB.

W roku 1976 ICC MAB w celu poprawy skuteczności działań poszczególnych RB wychodzi z inicjatywą utworzenia Światowej Sieci Rezerwatów Biosfery (WNBR). Jeszcze w tym samym roku ustanowionych zostaje pierwszych $57 \mathrm{RB}$, a w roku następnym kolejnych 61. Ich funkcjonowanie skupiało się jednak głównie na funkcjach ochronnych i były ustanawiane na obszarach objętych już przez państwa jakąś formą ochrony przyrody.

W 1983 roku na zaproszenie rządu ZSRR, UNESCO oraz UNEP wspólnie zwołały pierwszy Międzynarodowy Kongres Rezerwatów Biosfery w Mińsku. Kongres zorganizowano we współpracy z Organizacją Wyżywienia i Rolnictwa Narodów Zjednoczonych (FAO) i Światową Unią Ochrony Przyrody i Zasobów Naturalnych (IUCN). Działania kongresu doprowadzily do opracowania i przyjęcia w 1984 roku Planu Działań na Rzecz Rezerwatów Biosfery, który został formalnie zatwierdzony przez Konferencję Generalną UNESCO oraz przez UNEP. W Planie zapisano, iż RB mają realizować cztery funkcje: ochronną, dotyczącą badań i monitoringu, edukacji i szkolenia oraz współpracy. Po raz pierwszy autorzy Planu odnoszą się także wprost do zasady zrównoważonego rozwoju. W punkcie 5 zapisano: „IUCN uważa, że rezerwaty biosfery stanowić będą użyteczną koncepcję planowania regionalnego, w którym ochrona jest bezpośrednio powiązana z zasadą zrównoważonego rozwoju, zgodnie z zasadami Światowej Strategii Ochrony Przyrody" (UNESCO 1984).

\section{Ewolucja zrównoważonego rozwoju w programie MAB}

Przywołana Światowej Strategia Ochrony Przyrody określa zrównoważony rozwój, jako: „Przekształcanie biosfery i spożytkowanie zasobów ludzkich i finansowych oraz zasobów żywej i nieożywionej przyro- 
dy dla zaspokojenia potrzeb ludzi i poprawienia jakości ich życia. Aby rozwój mógł być trwały, należy uwzględnić czynniki społeczne, ekologiczne i ekonomiczne, wielkość zasobów ożywionych i nieożywionych oraz korzyści i straty w przypadku wyboru jednej z wielu możliwości w niedalekiej i odległej przyszłości. Ochrona przyrody oznacza kierowanie użytkowaniem biosfery przez człowieka w sposób zapewniający najwyższą i trwałą korzyść współczesnym generacjom oraz zachowanie potencjału przyrodniczego w celu zaspokojenia potrzeb i aspiracji przyszłych pokoleń" (Drewniak 1985, 14).

Uznaję w związku z tym, że formułę rozwoju opartą na koncepcji zrównoważonego rozwoju (sustainable development) przyjęto na długo przed jej zdefiniowaniem przez Komisję Brundtland, a prekursorami tej koncepcji rozwoju były: IUCN, która w roku 1980 zdefiniowała ten model rozwoju globalnego, oraz UNESCO, które w 1984 roku wprowadziło zrównoważony rozwój jako praktykę działań na obszarach $\mathrm{RB}^{1}$.

Wprowadzenie przez UNESCO zrównoważonego rozwoju, raport Światowej Komisji ds. Środowiska i Rozwoju (ŚKŚR) z 1987 roku pt. Nasza wspólna przyszłość, który upowszechnił zrównoważony rozwój w skali globalnej oraz I Szczyt Ziemi z 1992 roku wraz z przyjętą na nim Konwencją o Różnorodności Biologicznej, wymusiły przedefiniowanie celów i zasad funkcjonowania RB.

UNESCO przyjęło, że Plan Działania na Rzecz Rezerwatów Biosfery, na podstawie którego funkcjonuje WNBR, jest co prawda nadal obowiązujący, jednak znacząco zmieniły się uwarunkowania ich funkcjonowania. Wzrost liczby ludności, zwiększone zapotrzebowanie na energię elektryczną i zasoby naturalne, globalizacja gospodarki, erozja odrębności kulturowej, nierównomierny dostęp do innowacji technologicznych czy globalne zmiany klimatyczne, to tylko niektóre z nich. Uznano, że RB mogą być obszarami, na których promuje się godzenie

\footnotetext{
${ }^{1}$ Celowo użyłem tu określenia zrównoważony rozwój, a nie trwały rozwój lub rozwój, aby zwrócić uwagę na pewien fakt. Światowa Strategia Ochrony Przyrody nie jest pełnym tytułem tego dokumentu. Pełen tytuł w wersji oryginalnej brzmi: World Conservation Strategy: Living Resource Conservation for Sustainable Development. Sformułowanie sustainable development najczęściej tłumaczone jest jako zrównoważony rozwój i tak jest obecnie stosowane w literaturze przedmiotu. W 1985 roku za zgodą IUCN Strategia została opublikowana w Polsce przez Zarząd Główny Ligi Ochrony Przyrody. Tłumaczenia dokonał R. Olaczek, który sustainable development tłumaczy jako: trwały rozwój.
} 
ochrony przyrody z potrzebami rozwojowymi lokalnych społeczności, a zrównoważony rozwój jako czynnik rozwoju tych społeczności i podnoszenia jakości ich życia.

W 1995 roku, podczas konferencji poświęconej RB, zorganizowanej przez UNESCO w Sewilli (Hiszpania), przyjęto dwa ważne dokumenty: Nowa Strategię Funkcjonowania Rezerwatów Biosfery w XXI w., która miała odpowiadać wizji rozwoju opartego na zrównoważonym rozwoju oraz Ramowy Statut Światowej Sieci Rezerwatów Biosfery.

Najważniejszą kwestią było określenie podstawowych funkcji RB, tj.: ochronnej, rozwojowej oraz wsparcia logistycznego. Funkcja ochronna miała przyczyniać się do ochrony krajobrazów, ekosystemów, gatunków i zmienności genetycznej; funkcja rozwojowa do wspierania rozwoju gospodarczego i ludzkiego, który jest społeczno-kulturowo i ekologicznie podtrzymywalny, a funkcja wsparcia logistycznego - do rozwijania edukacji ekologicznej, szkoleń i badań oraz monitorowania zagadnień dotyczących zrównoważonego rozwoju i zagrożeń środowiska w skali globalnej, regionalnej i lokalnej. Ponadto RB miały stać się miejscami wyróżniającymi się w poszukiwaniu i wdrażaniu wzorcowego podejścia do ochrony przyrody i zrównoważonego rozwoju w skali regionalnej. W przyjętym Statucie podkreślono, że RB mają być obszarami, na których promowane są zrównoważone relacje między ludźmi a biosferą. Przyjęto również zasadę dotyczącą okresowych ocen działalności rezerwatów. Najważniejszym natomiast zapisem przyjętej strategii z punktu widzenia realizacji zrównoważonego rozwoju jest zalecenie, aby rozszerzyć strefę przejściową rezerwatów tak, aby na możliwie dużych obszarach wprowadzać modele zarządzania zgodne z zasadami zrównoważonego rozwoju.

Rezerwaty biosfery nie miały być od tej pory wyizolowanymi strefa$\mathrm{mi}$, do których dostęp obwarowany jest licznymi chroniącymi je przepisami, lecz miejscami, gdzie człowiek żyje w zgodzie z przyrodą, a rozwój gospodarczy i społeczno-kulturowy prowadzony jest $\mathrm{w}$ równowadze z zachowaniem różnorodności biologicznej. Ich centralna i zasadnicza część, pozostająca pod ścisłą ochroną (strefa centralna), miała zostać otoczona obszarami o coraz mniej restrykcyjnym charakterze (strefą buforową i tranzytową), które byłyby przyjazne wobec ekonomicznego rozwoju regionu. Na uwagę zasługuje również fakt, że w Strategii pod- 
kreślono konieczność udziału lokalnych społeczności w zarządzaniu tymi obszarami oraz konieczność uwzględniania rezerwatów w planowaniu regionalnym. Takie podejście potwierdza zapisaną $\mathrm{w}$ koncepcji zrównoważonego rozwoju konieczność pogodzenia wymogów ochrony przyrody (środowiska) z rozwojem gospodarczym i społecznym oraz zasadę partycypacji społecznej, która jest podstawą społeczeństwa obywatelskiego (UNESCO 1996).

Po pięciu latach od przyjęcia Strategii $z$ Sewilli, w roku 2000 w Pampelunie (Hiszpania), odbyła się konferencja dotycząca oceny funkcjonowania WNRB w latach 1995-2000. Konferencja ta, nazywana również Sewilla +5 , jest kolejnym punktem zwrotnym $\mathrm{w}$ funkcjonowaniu programu MAB oraz RB. W jej trakcie doszło do opracowania koncepcji Transgranicznych Rezerwatów Biosfery (TRB), które miały być tworzone przez co najmniej dwa państwa.

Jest to - podobnie jak przyjęcie zasad zrównoważonego rozwoju w 1984 roku - kolejny moment przełomowy w funkcjonowaniu programu MAB i obszarów, na których ustanawiane są RB. Zarządzanie obszarami TRB zostaje przeniesione na poziom współpracy międzynarodowej. Zrównoważony rozwój staje się tym samym jednym $\mathrm{z}$ obszarów stosunków międzynarodowych w zakresie ochrony transgranicznych ekosystemów. Wskazują na to wyraźnie zapisy Strategii $z$ Sewilli, które odnoszą się do tej kwestii. Zapisano w niej, że granice między państwami są polityczne, a nie ekologiczne, a ekosystemy często rozciągają się poza granicami kraju. W związku z tym sposoby zarządzania i użytkowania takich obszarów są często różne w sąsiadujących ze sobą państwach, a nawet sprzeczne, a tworzenie TRB wymagać będzie uzgodnienia praktyk zarządzania oraz negocjacji w tym zakresie między państwami w celu ich ochrony i zrównoważonego użytkowania poprzez wspólne zarządzanie (UNESCO 2000).

Kolejnym ważnym wydarzeniem dotyczącym zrównoważonego rozwoju realizowanego w ramach programu MAB był III Międzynarodowy Kongres Rezerwatów Biosfery, który odbył się w lutym 2008 r. w Madrycie. Zwołanie kongresu było odpowiedzią UNESCO na najważniejsze ówczesne wyzwania globalnego rozwoju, jak: zaostrzające się ubóstwo i nierówności w dostępie do zasobów środowiska, przyspieszone tempo 
zmian klimatycznych, szybsze niż zakładano tempo utraty różnorodności biologicznej oraz gwałtowny i nieplanowy rozwój urbanizacyjny prowadzący do nieodwracalnych zmian w środowisku. Przyjęto na nim Deklarację oraz Madrycki Plan Działania na lata 2008-2013.

W dokumentach tych podkreślono, że RB dobrze spełniają swoją rolę jako obszary rozwoju wiedzy, planowania, zarządzania, badań naukowych i wymiany doświadczeń w kwestiach łączenia ochrony bioróżnorodności z rozwojem społeczno-gospodarczym. Podkreślono również, że RB to miejsca, w których dochodzi do praktycznego dostosowania globalnych zasad zrównoważonego rozwoju w rozwoju lokalnym. W związku z tym, na obszarach rezerwatów należy stworzyć mechanizmy pozwalające zrównoważony rozwój realizować w sposób partnerski przez interesariuszy reprezentujących różne sektory społeczeństwa (instytucje publiczne i prywatne, organizacje pozarządowe, decydentów, naukowców, lokalne społeczności, właścicieli gruntów, użytkowników zasobów naturalnych, ośrodki naukowo-badawcze i edukacyjne oraz media).

Odnosząc się do zapisów Milenijnej Oceny Ekosystemów (MEA) z 2005 roku, przyjęto, że RB będą obszarami, które umożliwiać będą realizację usług ekosystemowych (UNESCO 2008). MEA wyróżnia cztery takie funkcje: zaopatrzeniową, regulacyjną, kulturalną oraz środowiskotwórczą i odnowieniową. Zaopatrzeniowa polega m.in. na dostarczaniu żywności, wody, surowców oraz opału; regulacyjna - np. na regulacji klimatu, stosunków wodnych oraz kwestii sanitarnych, kulturalna na dostarczaniu pożytków duchowych, estetycznych, rekreacyjnych i edukacyjnych, a funkcja środowiskotwórcza i odnowieniowa na produkcji pierwotnej oraz kształtowaniu gleb. Spełnienie tych funkcji przez ekosystemy pozwoli na zapewnienie materialnych podstaw dobrego życia, czyli: zdrowia, właściwych stosunków społecznych, bezpieczeństwa, wolności wyboru oraz swobody działania. W MEA postawiono tezę, że zachowanie różnorodności biologicznej jest niezbędne do poprawy warunków życia ludzi i ograniczenia biedy, a szybszy postęp w jej ochronie wymaga zwiększenia odpowiedzialności m.in.: użytkowników, zarządców, władz, prawodawców i biznesu (Olaczek 2006, 27-28, 30).

UNESCO, wprowadzając do realizacji zadań RB pojęcie usług ekosystemowych, wskazuje przy tym, że ekosystemy rozumiane są jako układy strukturalno-funkcjonalne łączące przyrodę ożywioną z jej abio- 
tycznymi składnikami. Potwierdza tym samym przyjętą w MEA zasadę holistycznego traktowania natury, której właściwy stan stanowi o jakości życia człowieka.

Ostatnie lata to bardzo ważny okres zarówno dla programu MAB, jak i RB. Od 2014 roku trwały prace nad opracowaniem nowej strategii na lata 2015-2025. Została ona przyjęta wraz z planem działań podczas IV Międzynarodowego Kongresu Rezerwatów Biosfery w Limie (Peru) 19 marca 2016 roku. W przyjętych dokumentach stwierdzono, że MAB wzmocni wsparcie dla ochrony różnorodności biologicznej, odnowy i poprawy usług ekosystemowych, zrównoważonego wykorzystywania zasobów naturalnych, sprawiedliwości społecznej, ochrony zdrowia, rozwoju osiedli ludzkich, a także łagodzenia sutków i adaptacji do zmian klimatycznych oraz innych przejawów globalnych zmian w środowisku. Podkreślono przy tym, że WNRB będzie nadal działać na rzecz realizacji zasad zrównoważonego rozwoju, przez co przyczyni się do realizacji przyjętej w 2015 roku Agendy na Rzecz Zrównoważonego Rozwoju 2030, zawierającej 17 celów zrównoważonego rozwoju, do osiągnięcia których ludzkość powinna dążyć w ciągu najbliższych lat (UNESCO 2015; UNESCO 2015a). Tymi celami są:

1. Wyeliminowanie wszelkich form ubóstwa na świecie.

2. Wyeliminowanie głodu, osiągnięcie bezpieczeństwa żywnościowego, zapewnienie lepszego odżywiania i promocja zrównoważonego rolnictwa.

3. Zapewnienie zdrowego życia i dążenie do zapewnienia dobrostanu wszystkich ludzi, niezależnie od wieku.

4. Zapewnienie edukacji na wysokim poziomie oraz umożliwienie wszystkim ludziom edukacji przez całe życie.

5. Osiągnięcie równość płci i wzmocnienie pozycji kobiet i dziewcząt.

6. Zapewnienie wszystkim ludziom dostępu do wody oraz zrównoważone gospodarowanie jej zasobami i infrastrukturą sanitarną.

7. Zapewnienie wszystkim dostępu do stabilnych, zrównoważonych i nowoczesnych źródeł energii po przystępnej cenie.

8. Promowanie stabilnego, inkluzywnego, zrównoważonego modelu wzrostu gospodarczego oraz pełnego, efektywnego zatrudnienia i godnej pracy dla wszystkich. 
9. Budowanie trwałej infrastruktury, odpornej na skutki katastrof, promowanie zrównoważonego, inkluzywnego modelu rozwoju gospodarczego oraz wspieranie innowacyjności.

10. Zmniejszenie nierówności rozwojowych pomiędzy państwami i w obrębie poszczególnych państw.

11. Tworzenie bezpiecznych, zrównoważonych, odpornych na skutki klęsk żywiołowych miast i osiedli ludzkich.

12. Wypracowanie zrównoważonych modeli konsumpcji i produkcji.

13. Pilne podjęcie działań mających na celu zahamowanie zmian klima tycznych i przeciwdziałanie ich skutkom.

14. Ochrona oceanów i mórz oraz zrównoważone korzystanie z ich zasobów.

15. Ochrona i odbudowa lądowych ekosystemów oraz promocja zrów noważonych metod ich wykorzystywania, gospodarowanie lasami w sposób zrównoważony, przeciwdziałanie pustynnieniu, powstrzymanie i odwrócenie procesów degradacji gleby oraz powstrzymanie strat różnorodności biologicznej.

16. Promowanie pokojowych, inkluzywnych społeczeństw dla zrówno ważonego rozwoju, zapewnienie wszystkim ludziom jednakowych szans i sprawiedliwego traktowania; budowanie efektywnych, odpo wiedzialnych i inkluzywnych instytucji wszystkich szczebli.

17. Wzmacnianie narzędzi wdrażania i odbudowywania globalnego partnerstwa na rzecz zrównoważonego rozwoju.

Przyjmując cele zrównoważonego rozwoju, swoje działania MAB oprze przy tym na szerokim upowszechnianiu modelowych rozwiązań w zakresie zrównoważonego rozwoju, które zostały opracowane i są realizowane na obszarach rezerwatów biosfery (UN 2015).

\section{Zakończenie}

Prawie od samego początku swojego istnienia program MAB realizowany przez UNESCO jest oparty na koncepcji zrównoważonego rozwoju. Co prawda, pierwsze światowe RB opierały się tylko na konserwatorskiej ochronie zasobów, jednak już od 1984 roku podstawą ich funkcjonowania jest zrównoważony rozwój. Wraz z upływem czasu, rozwojem nauki, powstaniem nowych technologii, ale i zagrożeń środowiska, w tym zagrożeń o zasięgu globalnym, przyjęta koncepcja 
ochrony i rozwoju obszarów tworzących RB musiała ulegać zmianom. $\mathrm{Na}$ tę ewolucję niebagatelny wpływ miały również międzynarodowe inicjatywy dotyczące wizji rozwoju globalnego i globalnych zagrożeń środowiska.

Przyjęta przez UNESCO koncepcja zrównoważonego rozwoju również ulegała zmianom. Od kwestii związanych z harmonijnym funkcjonowaniem trzech ładów (społecznego, gospodarczego i ekologicznego), poprzez wprowadzenie partycypacji społecznej w zarządzaniu obszarami RB, umiędzynarodowienia zasad zrównoważonego rozwoju w zarządzaniu TRB, zapewnienia właściwych usług ekosystemowych jako podstawy jakości życia lokalnych społeczeństw - do przyjęcia celów zrównoważonego rozwoju zapisanych w Agendzie na Rzecz Zrównoważonego Rozwoju 2030. Wnioski te w pełni potwierdzają przyjętą we wstępie artykułu hipotezę.

Sieć RB tworzy obecnie 669 RB w 120 krajach, w tym 16 TRB ustanowionych w 23 krajach. Cztery z nich ustanowione zostały na wniosek i we współpracy z Polskim Komitetem Narodowym UNESCO-MAB. Ogółem w Polsce funkcjonuje dziesięć RB. Pierwsze z nich zostały ustanowione w 1976 roku (Rezerwat Biosfery Białowieża oraz Rezerwat Biosfery Jezioro Łuknajno), a ostatni w roku 2010 (Rezerwat Biosfery Bory Tucholskie).

\section{Bibliografia:}

Brzeziński, Andrzej. 2015. Organizacja i formy międzynarodowej współpracy intelektualnej w ramach Ligi Narodów (1922-1939). Przegląd Zachodni, (3), 7-8.

Drewniak, Stanisław. 1985. Światowa Strategia Ochrony Przyrody. Ochrona żywych zasobów dla trwałego rozwoju, tłum. Romuald Olaczek. Warszawa: Liga Ochrony Przyrody.

Möller, Lutz i Eva Kammann. 2007. MAB - Man and the Biosphere. In retrospect. UNESCO today, (2). Dostęp: 15.12.2016. http://www.unesco. de/fileadmin/medien/Dokumente/unesco-heute/uh2-07-p13-15.pdf.

Olaczek, Romuald. 2006. Milenijna Ocena Ekosystemów - czy nowy Raport U Thanta? Acta Botanica Cassubica, (6), 23-32. 
UN. 2015. Transforming our world: the 2030 Agenda for Sustainable Development. Dostęp 10.02.2017. http://www.un.org/ga/search/view_ doc.asp?symbol=A/RES/70/1\&Lang=E.

UNESCO. 1984. Action Plan for Biosphere Reserves. Dostęp 18.12.2016. http://iea-archive.uoregon.edu/pages/MarineMammals/engine/Documents/1-0263-0278.htm.

UNESCO. 1996. The Seville Strategy \& the Statutory Framework of the World Network. Dostęp: 18.01.2017. http://unesdoc.unesco.org/images/0010/001038/103849Eb.pdf.

UNESCO. 2000. Programa sobre el Hombre y la Biosfera SEVILLA + 5 R EUNIÓN INTERNACIONAL SOBRE EL CUMPLIMIENTO DE LA E STRATEGIA DE S EVILLA RELATIVA A LA RED MUNDIAL DE RESERVAS DE BIOSFERAS 1995-2000. Dostęp 27.01.2017. http://proyectos.inecol.edu.mx/mabmexico/docs/Sevilla+5Recomendaciones

UNESCO. 2008. Madrid Action Plan for Biosphere Reserves (2008-2013). Dostęp: 3.02.2017. http://unesdoc.unesco.org/images/0016/001633/163301e.pdf.

UNESCO. 2015. MAB Strategy 2015-2025. Dostęp: 5.02.2017. http:// www.unesco.org/new/fileadmin/MULTIMEDIA/HQ/SC/pdf/MAB_ Strategy_2015-2025_final_text.pdf.

UNESCO. 2015a. Lima Action Plan for UNESCO's Man and the Biosphere (MAB) Programme and its World Network of Biosphere Reserves (2016-2025). Dostęp: 8.02.2017. http://www.unesco.org/new/fileadmin/ MULTIMEDIA/HQ/SC/pdf/Lima_Action_Plan_en_final.pdf. 
Małgorzata Grodzińska-Jurczak

Uniwersytet Jagielloński - Instytut Nauk o Środowisku

m.grodzinska-jurczak@uj.edu.pl

\section{Czy partycypacja ma sens? Efektywne metody włączania ludzi w ochronę bioróżnorodności}

\section{Wstęp}

Globalne zaburzenia w funkcjonowaniu procesów przyrodniczych na Ziemi spowodowane w znacznej mierze działalnością człowieka wymusiły wypracowanie nowego - bardziej efektywnego - modelu zarządzania środowiskiem (ang. environmental governnace). W modelu tym środowisko rozumiane jest szerzej, nie jak dotychczas jedynie jako przyrodnicze, ale jako naturalne, społeczne, ekonomiczne i polityczne. Odpowiedzialność za jego stan nakładana jest nie tylko na instytucje decydenckie (np. administracja publiczna), ale również na szersze grono różnych interesariuszy, w tym poszczególnych obywateli, którym stwarza się możliwość uczestnictwa (partycypacji) w decydowaniu o środowisku i przyrodzie. Taki system zarządzania charakterystyczny jest dla państw demokratycznych, w których dostęp do informacji dotyczących środowiska naturalnego i udział społeczeństwa w procesach decyzyjnych dotyczących środowiska są zagwarantowane legislacyjnie (Lemos i Agrawal 2006).

W Polsce partycypację w ochronie przyrody i środowiska gwarantuje parę aktów prawnych, np.: Ustawa o udostępnianiu informacji o środowisku i jego ochronie, udziale społeczeństwa w ochronie środowiska oraz o ocenach oddziaływania na środowisko (2008); Ustawa o dostępie do informacji publicznej (2001); Rozporządzenie Ministra Środowiska w sprawie wzoru publicznie dostępnego wykazu danych o dokumentach zawierających informacje o środowisku i jego ochronie (2007) w wielu aspektach wzorowanych na zapisach Konwencji z Aarhus o Dostępie do Informacji, Udziale Społeczeństwa w Podejmowaniu Decyzji oraz Dostępie do Sprawiedliwości w Sprawach Dotyczących Środowiska (1998). Konwencja ta, w przeciwieństwie do ratyfikowanych przez nasz kraj umów międzynarodowych z ochrony środowiska i przyrody określających zobowią- 
zania jednego państwa wobec innych państw, dotyczy przede wszystkim zobowiązań państw wobec swoich własnych obywateli.

Partycypacja (udział) różnych grup interesariuszy (tj. instytucji odpowiedzialnych za ochronę przyrody, przedstawicieli władz lokalnych, podmiotów prowadzących lub planujących działalność gospodarczą, właścicieli prywatnych terenów objętych różnymi formami ochrony przyrody, organizacji pozarządowych, przedstawicieli społeczności lokalnych i in.) przyjmuje różne formy. Zainteresowani chcący wyrazić swoją opinię na zadany temat (np. tworzenia nowych aktów prawnych, ustalania zasad zagospodarowania terenu, planów zadań ochronnych, itp.) mogą uczynić to podczas tradycyjnych 21-dniowych konsultacji społecznych samodzielnie - poprzez złożenie opinii osobiście, przesłanie jej pisemnie lub internetowo do danej instytucji, czy też biorąc udział w otwartych spotkaniach dyskusyjnych, pracach tzw. Zespołów Współpracy Lokalnej, lub przekazując swoje uwagi w ankietach, referendach albo podczas innych organizowanych, najczęściej przez samorządy lokalne lub organizacje pozarządowe, akcji, np. odwiedzania mieszkańców przez tzw. doradców domowych czy ankieterów (Luzar-Błaż, Grodzińska-Jurczak i Cent 2017).

Zaangażowanie możliwie jak największej liczby interesariuszy w działania pro-środowiskowe może - poprzez współpracę, tworzenie relacji, interakcje, szukanie kompromisów czy wreszcie podjęcie wspólnej odpowiedzialności - prowadzić do znacznie efektywniejszej i lepszej jakości ochrony konkretnych obiektów przyrodniczych czy elementów środowiska (Grodzińska-Jurczak 2008; Stachowiak-Kudła 2014). I tak, decyzje względem środowiska podjęte na przykład przez organy zarządcze przy aktywnym udziale społeczności lokalnych będą lepiej dostosowane do aspektu lokalnego i bardziej dopasowane do oczekiwań obu stron. Władze lokalne będą usatysfakcjonowane, ponieważ decyzje akceptowalne społecznie będą miały większą skuteczność wdrożenia, a mieszkańcy będą zadowoleni ze wspólnie wypracowanej strategii ochronnej, przy której wzięto pod uwagę ich zdanie (Dubel et al. 2016). Ponadto, ujmowanie szerokiej grupy interesariuszy przyczynia się do zapobiegania konfliktom, często jeszcze zanim one powstaną (Grodzińska-Jurczak i Cent 2011). 
Niniejsza praca dotyczy przeglądu 1) innowacyjnego warsztatu partycypacyjnego wypracowanego przez autorów w celu poprawy sposobu zarządzania ochroną przyrody i środowiska, jak też 2) rezultatów jego aplikowania w praktyce, tj. do wyznaczania terenów Natura 2000, opracowywania planów zadań ochronnych, monitorowania terenów chronionych, gospodarowania odpadami komunalnymi czy energią odnawialną. Autorka prezentuje sposób opracowywania niektórych spośród tych narzędzi uznanych za efektywne (konsultacje społeczne, Zespoły Lokalnej Współpracy, odwiedzanie mieszkańców - home advisors, platformy internetowe i mapowanie partycypacyjne), ograniczając się, ze względu na ograniczenia miejsca, do szczegółowego opisu home advisors i mapowania partycypacyjnego, ich testowania, wdrażania, jak też ewaluacji efektywności. Równolegle pokazuje, w jakim stopniu włączanie społeczności lokalnych wpływa na zmianę ich postaw względem przyrody i jej zasobów.

\section{Opis przypadków}

\section{Doradcy domowi}

Program doradców domowych (ang. home advisors) to brytyjska metoda informowania i zachęcania mieszkańców danego regionu, gminy czy dzielnicy do różnych zachowań, przyzwyczajeń i działań na rzecz środowiska czy przyrody, tj. segregacji (recyklingu) odpadów komunalnych, stosowania odnawialnych źródeł energii, podłączania się do kanalizacji czy oczyszczalni ścieków. Metoda ta polega na bezpośrednim odwiedzaniu i informowaniu mieszkańców na temat danego problemu środowiskowego przez specjalnie w tym celu wyszkolone osoby, tzw. „doradców domowych”. Istnieją różne scenariusze pracy doradców, najczęściej jednak podczas wizyt doradcy przeprowadzają z mieszkańcami krótką ankietę dotyczącą w przypadku odpadów komunalnych systemu segregacji odpadów w ich miejscu zamieszkania, pytają o wskazanie ewentualnych problemów związanych z selektywną zbiórką, a także przyczyn ewentualnego nieuczestniczenia w niej. Dodatkowo, doradcy dostarczają mieszkańcom materiały informacyjne na temat lokalnej zbiórki odpadów, tj. harmonogramy wywozu posortowanych odpadów 
czy szczegóły dotyczące selektywnej zbiórki i jej organizacji (np. kalendarze, ulotki) (Read 1999).

Dotychczas metodę doradców domowych z powodzeniem zastosowano w gminach Londynu, a po jej zmodyfikowaniu i dostosowaniu do warunków lokalnych także w Polsce - w Jaśle, Jordanowie, Zakliczynie, gminach należących do Związku Gmin Dorzecza Wisłoki oraz Związku Gmin Dorzecza Górnej Raby i Krakowa. W obu krajach akcja doradców poprawiła efektywność selektywnej zbiórki odpadów i/lub zwiększyła motywację do stosowania, równolegle do tradycyjnych, alternatywnych źródeł energii (tj. ogniw galwanicznych) w gminach. Takie zmiany w postawach na rzecz środowiska wynikały ze wzrostu poziomu wiedzy odwiedzanych mieszkańców odnośnie do danego problemu środowiskowego. Ewaluacji poziomu wiedzy i zachowań (postaw) dokonywano przy pomocy tzw. pre-post test (czyli ankiet prowadzonych wśród mieszkańców przed i po akcji doradców). W Polsce rolę doradców pełnili uczniowie lokalnych szkół gimnazjalnych lub ponadgimnazjalnych, a także członkowie Ochotniczej Straży Pożarnej, wyszkoleni na specjalnie zorganizowanych warsztatach (Grodzińska-Jurczak, Tarabuła i Read 2003; Grodzińska-Jurczak et al. 2006). Metoda doradców domowych wciąż jest określana jako najbardziej efektywna, ze względu na aktywną i bezpośrednią formę motywowania społeczeństwa do uczestnictwa w działaniach na rzecz środowiska. Inne tradycyjne metody komunikacji czy informacji (kampania w mediach, ulotki, plakaty itp.) są zdecydowanie mniej efektywne i prowadzą zazwyczaj do niewielkiego wzrostu poziomu świadomości i zachowań prośrodowiskowych (Holland 2000).

\section{Partycypacyjne mapowanie przestrzeni (Public Participation GIS - PPGIS)}

Metody zarządzania zasobami przyrodniczymi coraz częściej przyjmują charakter partycypacyjny, włączający do decyzyjności o danym terenie różne grupy osób. Dotyczy to zarówno terenów chronionych jak i obszarów położonych poza nimi. Włączanie opinii interesariuszy, np. w opracowywanie planów zadań ochronnych dla danego terenu, polega 
na zebraniu informacji na temat opinii postrzegania jego walorów przyrodniczych wśród osób zamieszkujących dany teren lub rezydujących w jego okolicy jak też turystów odwiedzających okolicę. W przypadku potrzeb planistycznych najbardziej aplikacyjne wydają się opinie zlokalizowane przestrzennie i przypisane konkretnym grupom osób korzystających $\mathrm{z}$ danego obszaru. Jak wskazuje wiele badań, wiedza taka okazuje się bardzo przydatna w efektywnym zarządzaniu danym terenem, wspomagając decyzje jego użytkowania czy zakresu ewentualnego przekształcania (Beverly et al. 2008).

Stosowana metodyka do zbierania danych przestrzennych to wciąż nowatorskie i rzadko w Polsce stosowane mapowanie partycypacyjne (ang. public participation GIS - PPGIS) łączące metody kartograficzne z metodami badań społecznych lub technikami partycypacji społecznej. W przeciwieństwie do tradycyjnego ilościowego i jakościowego warsztatu badań społecznych PPGIS pozwala na: 1) zebranie informacji jednoznacznie odnoszących się do konkretnego miejsca czy obszaru, 2) stosowanie jako narzędzia zarówno map tradycyjnych jak i on-line (aplikacje internetowe, soft GIS), przez co możliwe jest włączenie dużej i reprezentatywnej próby respondentów dla danego obszaru (Brown 2012). Dotychczas mapowanie partycypacyjne było wykorzystywane głównie do: 1) zbierania informacji nt. postrzegania krajobrazu lub przyrody przez mieszkańców badanego terenu stosowanego później w planowaniu przestrzennym i planowaniu ochrony przyrody na danym terenie, 2) planowania przestrzennego w miastach (identyfikacja miejsc wartościowych, terenów do wypoczynku, tras rowerowych itp.) (Brown i Reed 2009). Ostatnio PPGIS wykorzystuje się także do badania postrzegania usług ekosystemów (Brown i Fagerholm 2015). Koncepcja usług ekosystemów (ecosytem services), czyli wszelkich korzyści uzyskiwanych ze środowiska przez gospodarstwa domowe, społeczności i gospodarkę, pozwala na nowe spojrzenie na relacje gospodarki, społeczeństwa i środowiska, pokazując uzasadnienia ekonomiczne dla ochrony środowiska poprzez szacowanie wartości (ekonomicznej i nie tylko) usług dostarczanych ludziom przez przyrodę. Połączenie mapowania partycypacyjnego z usługami ekosystemów wydaje się szczególnie przydatne $\mathrm{w}$ debatach $\mathrm{z}$ różnymi grupami interesariuszy, gdzie wykorzystanie argumentów nie tylko przyrodniczych i społecznych, ale także 
gospodarczych i finansowych przemawia do nich bardziej, a w efekcie zachęca do współdecyzyjności co do danego terenu.

Mapowanie partycypacyjne z użyciem koncepcji usług ekosystemowych wykorzystano w badaniach na terenach objętych ochroną w ramach Europejskiej Sieci Ekologicznej Natura 2000, których celem było poznanie opinii mieszkańców oraz turystów co do obszarów koncentracji różnych wartości środowiska przyrodniczego, a także miejsc pożądanego wprowadzenia, zintensyfikowania, wyeliminowania lub ograniczenia określonych aktywności człowieka. Mapowanie przeprowadzono przy użyciu tradycyjnych map i/lub też aplikacji internetowej (geo-ankiety). W tym pierwszym przypadku zgromadzeni na zorganizowanych warsztatach przedstawiciele różnych grup zawodowych i społecznych (pracownicy parków narodowych, instytucji zarządzających przyrodą/ środowiskiem, organizacji pozarządowych, Lasów Państwowych, samorządów lokalnych, mieszkańców danego terenu) zaznaczali na mapach usługi ekosystemów postrzegane przez nich jako najistotniejsze z punktu widzenia jakości życia społeczności lokalnych oraz identyfikowali obszary, które generują te wybrane usługi ekosystemów na poszczególnych obszarach. W ten sposób uzyskano informacje na temat: jak różne grupy interesariuszy postrzegają usługi ekosystemów w danym obszarze i które obszary są postrzegane jako dostarczające poszczególnych usług? Dodatkowym atutem metody mapowania partycypacyjnego przeprowadzanego grupowo podczas spotkań jest nie tylko wyrażanie indywidualnych opinii poszczególnych uczestników, ale także wypracowanie wspólnej decyzji o tym, którym miejscom przypisać poszczególne charakterystyki. To znacznie wzmacnia ostatecznie proponowane rozwiązanie, np. planistyczne, o charakter partycypacyjny.

W przypadku aplikacji internetowej (geo-ankiety) informacja przestrzenna jest udzielana przez respondentów samodzielnie poprzez umieszczanie $\mathrm{w}$ wybranym punkcie mapy symbolu oznaczającego daną wartość bądź aktywność. W takim podejściu nie ma możliwości sugerowania się zdaniem innych oraz pozwala zebrać opinię od znacznie większej liczby osób, niż w przypadku warsztatów, co wydaje się być cenne dla przeprowadzanych badań. $Z$ drugiej jednak strony trzeba brać pod uwagę, że samodzielna praca na geo-ankiecie przebiega 
przeważnie krócej i jest mniej dogłębna, przez co wyniki nieco mniej analityczne. Rezultatem badań mapowania partycypacyjnego jest baza danych $\mathrm{z}$ informacjami o sposobie lokowania badanych charakterystyk w przestrzeni, wizualizowana jako mapa lub zestaw map, generowanych najczęściej dla poszczególnych cech lub grup cech pokazujących częstotliwość zaznaczania ich występowania w różnych częściach mapy (Brown et al. 2015).

\section{Dyskusja}

Wyżej opisane metody włączania różnych grup interesariuszy do współdecydowania o środowisku i przyrodzie można uznać za najbardziej efektywne i w większości przypadków przekładające się bezpośrednio na wysokie zaangażowanie $\mathrm{w}$ zarządzanie danymi terenami. Zaangażowanie to może, zgodnie z koncepcją tzw. drabiny partycypacji opracowanej przez Arnstein (1969), przybierać różną moc, od minimalnej, gdzie dane grupy osób nie posiadają żadnego wpływu (tzw. informowanie) na decyzje np. instytucji publicznych, do bardzo istotnej, gdzie decyzja praktycznie w pełni zależy od nich (tzw. współdecydowanie). Współdecydowanie przekłada się na wzrost kapitału społecznego dzięki przyjęciu odpowiedzialności za decyzje, które stają się obowiązujące. To przyczynia się do wzrostu obywatelskości i kompetencji społeczeństwa w zarządzaniu dobrami publicznymi, które stają się wspólne i zagospodarowywane zgodnie z podjętymi decyzjami (Poteete, Janssen i Ostrom 2010). Społeczności partycypacyjne rozwijają się szybciej, pojawiające się problemy rozwiązują sprawniej, a cele osiągają łatwiej. Co więcej, współpraca oparta na partycypacji wyzwala współodpowiedzialność nie tylko za decyzje, ale także za ich realizację oraz wpływa na efektywniejsze zarządzanie poprzez samostanowienie (Ostrom 2010).

Obie przedstawione $\mathrm{w}$ niniejszej pracy metody stanowią propozycje narzędzi do zwiększenia zaangażowania społeczności lokalnych w procesy planowania oraz zarządzania zasobami naturalnymi (Kyttä et al. 2013). Wzrost popularności tak metody PPGIS jak i doradców domowych świadczy o efektywnym pozyskiwaniu tymi drogami informacji do badań z różnych dziedzin społecznych, przyrodniczych lub ekonomicznych. Zebranie podczas wywiadów/rozmów z mieszkańcami czy też podczas 
samodzielnego lub grupowego oznaczania na mapie wybranych atrybutów daje bezsprzeczne korzyści w zbieraniu unikatowych informacji od różnych grup osób, które potem mogą stanowić cenne źródło do wykorzystania przez organy zarządzające danym obszarem (Brown 2012). Nowatorski warsztat partycypacyjny musi jednak być wspomagany odpowiednią legislacją zarządzania zasobami przyrodniczymi pozwalającą na nieograniczony dostęp do udziału w decyzjach dotyczących ochrony środowiska wszystkich grup społecznych i zawodowych.

\section{Bibliografia:}

Arnstein, Sherry R. 1969. A ladder of citizen participation. Journal of the American Institute of planners, 35(4), 216-224.

Beverly, Jennifer L. et al. 2008. Assessing spatial attributes of forest landscape values: an internet-based participatory mapping approach. Canadian Journal of Forest Research, 38, 289-303.

Brown, Gregory i Nora Fagerholm. 2015. Empirical PPGIS/PGIS mapping of ecosystem services: A review and evaluation. Ecosystem Services, 13, 119-133.

Brown, Gregory i Pat Reed. 2009. Public Participation GIS: A New Method for Use in National Forest Planning. Forest Science, 55(2), 166-182.

Brown, Gregory et al. 2015. Cross-cultural values and management preferences in protected areas of Norway and Poland. Journal for Nature Conservation, 28, 89-104.

Brown, Gregory. 2012. Public Participation GIS (PPGIS) for regional and environmental planning: Reflections on a decade of empirical research. URISA Journal, 25(2), 7-16.

Dubel, Anna et al. 2016. Wspólne zarządzanie przyrodą. Partycypacyjne mapowanie terenów chronionych na obszarze Natura 2000 Dolinki Jurajskie PLH120005. Wrocław: Stowarzyszenie Centrum Rozwiązań Systemowych.

Grodzińska-Jurczak, Małgorzata et al. 2006. Effects of an educational campaign on public environmental attitudes and behaviour in Poland. Resources, Conservation and Recycling, 46(2), 182-197. 
Grodzińska-Jurczak, Małgorzata i Joanna Cent. 2011. Can public participation increase nature conservation effectiveness? Innovation: The European Journal of Social Science Research, 24(3), 371-378.

Grodzińska-Jurczak, Małgorzata, Marta Tarabuła i Adam D. Read. 2003. Increasing participation in rational municipal waste management - a case study analysis in Jaslo City (Poland). Resources, Conservation and Recycling, 38(1)1, 67-88.

Grodzińska-Jurczak, Małgorzata. 2008. Rethinking of nature conservation policy in Poland: the need of human dimensions approach. $\mathrm{Hu}$ man Dimensions of Wildlife, 13, 380-381.

Holland, Leigh. 2000. Recycling domestic waste: a proxy for environmental sustainability? International Journal of Sustainable Development World Ecology, 7(3), 271-276.

Konwencja $z$ Aarhus o Dostępie do Informacji, Udziale Społeczeństwa w Podejmowaniu Decyzji oraz Dostępie do Sprawiedliwości w Sprawach Dotyczacych Środowiska - CONVENTION ON ACCESS TO INFORMATION, PUBLIC PARTICIPATION IN DECISION-MAKING AND ACCESS TO JUSTICE IN ENVIRONMENTAL MATTERS - done at Aarhus, Denmark, on 25 June 1998.

Kyttä, Marketta et al. 2013. Towards contextually sensitive urban densification: Location -based softGIS knowledge revealing perceived residential environmental quality. Landscape and Urban Planning, $113,30-46$.

Lemos, Maria C. i Arun Agrawal. 2006. Environmental Governance. Annual Review of Environment and Resources, 31, 1-477.

Luzar-Błaż, Katarzyna, Małgorzata Grodzińska-Jurczak i Joanna Cent. 2017. Włączanie lokalnych społeczności w zarządzanie terenami chronionymi na przykładzie obszaru natura 2000 - Dolinki Jurajskie. Wieś $i$ Rolnictwo (w druku).

Ostrom, Elinor. 2010. Beyond markets and states: polycentric governance of complex economic systems. Transnational Corporations Review, 2(2), 1-12. 
Poteete, Amy R., Marco A. Janssen i Elinor Ostrom. 2010. Working together: collective action, the commons, and multiple methods in practice. Princeton: Princeton University Press.

Read, Adam D. 1999. A weekly doorstep recycling collection, I had no idea we could! Overcoming the local barriers to participation. Resources, Conservation and Recycling, 26(3-4), 217-249.

Stachowiak-Kudła, Monika. 2014. Wartościowanie decyzji publicznych metodą konsultacji z interesariuszami. W: Prawo administracyjne $w$ ujęciu interdyscyplinarnym, red. Bartłomiej Opaliński, 51-68. Warszawa: Oficyna Wydawnicza Uczelni Łazarskiego.

Ustawa o udostępnianiu informacji o środowisku i jego ochronie, udziale społeczeństwa $\mathrm{w}$ ochronie środowiska oraz o ocenach oddziaływania na środowisko. 2008. art. 4, 13 (prawo do informacji), art. 5, 30 (prawo do uczestnictwa w podejmowaniu decyzji).

Ustawa o dostępie do informacji publicznej. 2001 (całość tekstu prawo do informacji).

Ustawa Prawo Ochrony Środowiska - art. 158, ust. 2a, 218 (prawo do uczestnictwa w podejmowaniu decyzji). 
Małgorzata Falencka-Jabłońska

Instytut Badawczy Leśnictwa - Zakład Ekologii Lasu

falenckm@ibles.waw.pl

\title{
Obszary Natura 2000 a rozwój zrównoważony w warunkach polskich
}

\begin{abstract}
Ochrona zasobów przyrody to kierunek naukowy i społeczny, wskazujacy drogi racjonalnego gospodarowania zasobami przyrody.

Bierze on pod uwage dobro nie tylko dzisiejszego pokolenia, ale i przyszłych. Ochrona przyrody i jej zasobów nie jest przeciwnikiem produkcji, ale sprzymierzeńcem.
\end{abstract}

Walery Goetel

\section{Wstęp}

Z inicjatywy Sekretarza Generalnego ONZ w 1983 r. została powołana przez Gro Harlem Brundtland - premier Norwegii (pierwszą kobietę pełniącą w tym kraju taką funkcję) - Światowa Komisja ds. Środowiska i Rozwoju (The World Commission on Environment and Development). Komisja ta opracowała słynny raport Nasza wspólna przyszłość, w którym zawarta została koncepcja zrównoważonego rozwoju. Dokument opublikowano w kwietniu $1987 \mathrm{r}$.

Raport, który powstał trzydzieści lat temu, zawierał ważne ostrzeżenie, że nasza cywilizacja osiągnęła poziom dobrobytu możliwy do utrzymania wylącznie pod warunkiem odpowiedniego gospodarowania zasobami przyrody. Model takiej gospodarki zakłada odpowiednio i świadomie ukształtowane relacje pomiędzy wzrostem gospodarczym, dbałością o środowisko oraz jakością życia, w tym zdrowia człowieka.

Należy podkreślić, że po raz pierwszy określenie zrównoważonego rozwoju wprowadził Hans Carl von Carlowitz, starosta saksoński, który zastosował je w dziedzinie leśnictwa. Początek XVIII wieku to okres, kiedy w Niemczech stale brakowało drewna z powodu znacznego przetrzebienia tamtejszych lasów. Celem poprawy tej trudnej sytuacji w $1713 \mathrm{r}$. H.C. von Carlowitz zarządził odbudowę podlegających mu lasów oraz wprowadził zasady uregulowanego i przyszłościowego postępowania z zasobami naturalnymi. Wkrótce jego model przyjął się w leśnictwie 
całych Niemiec, a następnie stał się wzorcem dla tej ważnej gałęzi gospodarki na całym świecie (Falencka-Jabłońska 2016, 2).

Warto podkreślić, że koncepcja zrównoważonego rozwoju była na początku XIX wieku propagowana przez wszystkie niemieckie wyższe szkoły leśne. Niemieckie leśnictwo cieszyło się wówczas dużym uznaniem, w związku z czym pojęcie to zostało przejęte i wdrożone do praktyki w innych krajach, nie tylko w Europie.

W naszym kraju zasada zrównoważonego rozwoju zyskała rangę konstytucyjną - została zapisana w art. 5 Konstytucji RP, a definicja zrównoważonego rozwoju znalazła się w ustawie Prawo ochrony środowiska. Pod pojęciem tym, zgodnie z art. 3 Ustawy Prawo Ochrony Środowiska z dnia 27 kwietnia 2001 roku, należy rozumieć „rozwój społeczno-gospodarczy, w którym następuje proces integrowania działań politycznych, gospodarczych i społecznych, z zachowaniem równowagi przyrodniczej oraz trwałości podstawowych procesów przyrodniczych, w celu zagwarantowania możliwości zaspokajania podstawowych potrzeb poszczególnych społeczności lub obywateli zarówno współczesnego pokolenia, jak i przyszłych pokoleń".

O randze i konieczności wdrożenia zasad trwałego i zrównoważonego rozwoju świadczy też fakt, że problem ten stał się wiodący w papieskiej encyklice Laudato Si'. Papież zwraca się w niej z ważnym apelem do nas wszystkich: „Naglące wyzwanie ochrony naszego wspólnego domu obejmuje troskę o zjednoczenie całej rodziny ludzkiej w dążeniu do zrównoważonego i zintegrowanego rozwoju, ponieważ wiemy, że wszystko może się zmienić. (...) Ludzkość jest jeszcze zdolna do współpracy w budowaniu naszego wspólnego domu. (...) Kieruję naglące wezwanie, by ponowić dialog dotyczący sposobu, w jaki budujemy przyszłość naszej planety. Potrzebujemy konfrontacji, która nas wszystkich połączy, ponieważ wyzwanie ekologiczne i jego ludzkie korzenie dotyczą i dotykają nas wszystkich" (Franciszek 2015, 13-14).

Przykładem takiej konfrontacji zachowania terenów szczególnie cennych przyrodniczo z zasadami zrównoważonego rozwoju gospodarczego stała się Europejska Sieć Obszarów Chronionych Natura 2000.

Celem niniejszego opracowania jest wskazanie, rozwiązanie jakich problemów natury przyrodniczej, społecznej i gospodarczej stanowi gwarancję funkcjonowania Obszarów Natura 2000 i zachowania cennych zasobów naszej przyrody dla przyszłych pokoleń. 


\section{Europejska Sieć Obszarów Natura 2000 w Polsce, czyli mity i rzeczywistość}

\subsection{Cel i status Obszarów Natura 2000}

Europejska Sieć Ekologiczna Natura 2000 wyznaczana na terenie Unii Europejskiej z założenia miała na celu zachowanie lub odtworzenie różnorodności biologicznej naszego kontynentu. Pierwszym etapem wdrażania Natury 2000 było rozpoznanie zasobów przyrodniczych podlegających ochronie na podstawie dwóch Dyrektyw: Ptasiej (Dyrektywa Rady 79/409/ EWG) i Siedliskowej (Dyrektywa Rady 92/43/ EWG). Zebrane materiały i informacje miały służyć wyznaczeniu granic obszarów, które zagwarantują skuteczną ochronę siedliskom i gatunkom. W ten sposób miał powstać spójny system ochrony przyrodniczego dziedzictwa Europy.

Bogactwo polskiej przyrody w skali Europy zajmuje czołową pozycję. W znacznej mierze przyczyniło się do tego stosunkowo niedawne, bo przed 10 tysiącami lat, ustąpienie lądolodu. Chronimy więc mozaikę krajobrazów, pozostałych po epoce lodowcowej, mozaikę podłoża, prawdziwy skarbiec gatunków flory i fauny. Z tej racji w naszym kraju powołano 144 obszary specjalnej ochrony ptaków (OSO), które stanowią $15,6 \%$ powierzchni Polski i 623 specjalne obszary ochrony siedlisk (SOO), które stanowią 11,05\% jej powierzchni. Łącznie obszary Natura 2000 stanowią 19,7\% powierzchni lądowej kraju, z czego aż 60\% znajduje się na terenach leśnych (Liro 2010, 26). Istnieje zatem konieczność wypracowania skutecznej równowagi między gospodarką i ochroną przyrody na danym terenie.

Na terenie PGLP znajduje się 2.860 tys. ha należących do obszarów Natura 2000, co stanowi 38\% powierzchni Lasów Państwowych. Obszary takie występują na terenie 417 nadleśnictw (Raport 2010, 16).

Wprowadzenie tej nowej formy ochrony przyrody narzuciło również dodatkowe zobowiązania formalno-prawne. Kolejnym etapem wymaganym w funkcjonowaniu obszarów Natura 2000 było opracowanie planów zadań ochronnych na terenie całej Polski. Podstawę prawną wykonania tych dokumentacji stanowiło Rozporządzenie Ministra Środowiska z dnia 17 lutego 2010 roku w sprawie sporządzania Projektu planu zadań ochronnych (PZO) dla Obszarów Natura 2000. Jednocze- 
śnie na podstawie art. 39 ustawy z dnia 3.10.2008 roku z późn. zmianami o udostępnianiu informacji o środowisku i jego ochronie, udziale społeczeństwa w ochronie środowiska oraz ocenach ich oddziaływania na środowisko, wynika, że konsultacje społeczne stanowią integralną część wszystkich etapów sporządzania planów zadań ochronnych.

Obowiązek wyznaczenia na swym terytorium przez wszystkie państwa należące do UE systemu obszarów chronionych o szczególnych walorach przyrodniczych w skali Europy niewątpliwie był zamierzeniem słusznym i chwalebnym. Co więcej cel tego przedsięwzięcia ochrona różnorodności biologicznej jest koniecznym działaniem nie tylko z punktu widzenia interesu narodowego, więc i troska o nie to też obowiązek każdego z nas. Nie wystarczą wyłącznie zapisy formalno-prawne, aby móc zrealizować nawet najbardziej uzasadnione działania. Powołanie obszarów Natura 2000 było sprawą bardzo prostą, ale zapewnienie im funkcjonowania stało się w praktyce wyjątkowo trudnym i skomplikowanym przedsięwzięciem (Falencka-Jabłońska 2012a, 36).

\subsection{Społeczeństwo a Obszary Natura 2000}

Europejska Sieć Ekologiczna Natura 2000 stała się faktem i mimo że istnieje w naszym kraju od szeregu lat, to jednak wiedza na temat tej formy ochrony przyrody wśród Polaków niezależnie od ich metryki jest wyjątkowo skąpa (Falencka-Jabłońska 2012a).W tej sytuacji trudno oczekiwać społecznej akceptacji ochrony przyrody, kiedy może się ona wiązać z pewnymi ograniczeniami dla mieszkańców tych terenów. Kompromis między potrzebami społecznymi a koniecznością zapewnienia status quo szczególnie cennym przyrodniczo terenom dla ochrony różnorodności biologicznej zarówno w skali lokalnej jak i całej Europy nie jest sprawą łatwą.

Istnienie sieci Natura 2000 z założenia ma wspierać zrównoważony rozwój państw łączący rozwój gospodarczy z rozwojem społecznym i kulturowym, gwarantując jednocześnie równowagę przyrodniczą i zachowanie przyrody dla przyszłych pokoleń. Ochrona na tych obszarach rozumiana jest jako utrzymanie, a tam gdzie jest konieczne - odtwarzanie stanu chronionych gatunków i siedlisk przyrodniczych.

Problemy generowane przez Naturę 2000 stały się przedmiotem pierwszych i jedynych ankietowych badań w Polsce o tak szeroko za- 
rysowanej problematyce. Były one przeprowadzone w ramach projektu rozwojowego „Społeczno-gospodarcze uwarunkowania zrównoważonego rozwoju obszarów wiejskich objętych siecią Natura 2000 na terenie Zielonych Płuc Polski” (nr 110012 04), finansowanego przez Narodowe Centrum Badań i Rozwoju. Ich wyniki zawarte zostały w Raporcie Fundacji Europejskiego Funduszu Rozwoju Wsi Polskiej (Bałtromiuk i Zagórski 2011, 5).

Uzyskane wyniki jednoznacznie świadczą o braku komunikacji społecznej dotyczącej obszarów Natura 2000 i związanych z nimi planów zadań ochronnych. Przykładem mogą być rezultaty ankiety w sprawie oceny wpływu zlokalizowania obszaru Natura 2000 na terenie gminy na jej rozwój, która została przeprowadzona wśród wójtów i burmistrzów: $51 \%$ uważa, ze plany zadań ochronnych będą ograniczeniem inwestycji; $37 \%$ traktuje jako kolejny uciążliwy obowiązek do wykonania; $26 \%$ jako źródło konfliktów, a 13\% jako obciążenie budżetu gminy. Za niewielkie utrudnienie uważa PZO tylko $17 \%$ badanych, a $3 \%$ widzi w nich jedynie pozytywne aspekty, np. szanse zachowania walorów przyrodniczych (Bałtromiuk i Zagórski 2011, 11). Te dane ww. raportu mówią same za siebie, a sam jego tytuł Natura 2000 - dobro publiczne, problem prywatny adekwatnie precyzuje problem.

Wyjątkowo trafnie ujęli te relacje organizatorzy konferencji „Natura 2000 jako nowy czynnik w rozwoju obszarów wiejskich”, która odbyła się w czerwcu 2011 roku w siedzibie Polskiej Akademii Nauk w Warszawie: „Jeśli chcemy, aby sieć ta nie była odbierana jako system zakazów i nakazów, każdy problem wymaga kompromisowych rozstrzygnięć między lokalną społecznością, reprezentowaną głównie przez samorządy gminne, a przedstawicielami instytucji sprawującymi nadzór nad Naturą 2000, w tym zwłaszcza Regionalnych Dyrekcji Ochrony Środowiska. Przy wyznaczaniu terenów sieci Natura 2000 popełniono wiele błędów, głównie z przyczyn presji czasowej (Polsce groziły kary za niepowołanie obszarów Natura 2000), które nastawiły negatywnie samorządy do nowych przepisów obowiązujących na terenach objętych nową formą ochrony przyrody. Nastawienie to złagodzić może tylko przemyślana akcja informacyjna oraz włączenie społeczności lokalnych w proces tworzonych obecnie Planów Zadań Ochronnych, a także 
pewne rekompensaty finansowe za powstałe utrudnienia. Bez efektywnego oddziaływania na proekologiczne postawy lokalnych społeczności i prób włączenia ich do procesu zarządzania Naturą 2000 ochrona cennych przyrodniczo terenów i zachowanie ich dla przyszłych pokoleń będzie problematyczne" (Bałtromiuk i Zagórski 2011, 17).

Autorka artykułu była koordynatorem i realizatorem, wraz z gronem ekspertów, opracowania pierwszych w Polsce planów zadań ochronnych dla 5 Obszarów Natura 2000 w woj. podlaskim - RDOŚ Białystok:

$\checkmark$ Dolina Górnej Narwi PLB200007;

$\checkmark$ Ostoja w Dolinie Górnej Narwi PLH200010;

$\checkmark$ Schrony Brzeskiego Rejonu Umocnionego PLH200014;

$\checkmark$ Ostoja Suwalska PLH200003;

$\checkmark$ Jeleniewo PLH200001 (całość PZO dostępna na stronie Regionalnej Dyrekcji Ochrony Środowiska www.bialystok.rdos.gov.pl).

Przedmiotem ochrony w Jeleniewie jest nocek łydkowłosy, a w Ostoi Suwalskiej jednym z przedmiotów ochrony są priorytetowe dla UE siedliska łęgów źródliskowych.

Z doświadczeń prac terenowych i spotkań ze społecznościami lokalnymi na trzech etapach realizacji PZO wynika, że mieszkańcy nie mają świadomości oraz wiedzy co do konsekwencji życia na obszarach Natura 2000. Przykładem może być wypowiedź jednej z przedstawicielek społeczności lokalnej na spotkaniu dyskusyjnym dotyczącym projektu PZO: „my nie chcemy żadnej Natury 2000 i napiszemy protest, ze nie można jej tu ustanowić!”. Spokojna odpowiedź koordynatora PZO brzmiała: „Tak się składa, że od 7 lat już Pani na takim obszarze mieszka". Mieszkanka pełna szczerego zdziwienia: „Jak to? Przecież ja o tym nic nie wiem!”.

Jednocześnie w ramach spotkań dyskusyjnych ze społecznością lokalną (na kolejnych etapach realizacji projektów planu zadań ochronnych) autorzy PZO spotykają się z całkowicie uzasadnionymi dylematami o kluczowym znaczeniu. Na przykład, każdy właściciel gruntu ma prawo gospodarować na nim według własnej koncepcji (gwarantują mu to nawet art. 20-21 Konstytucji RP). Skoro aktualnie, zgodnie z zaleceniami planu, ma się dostosować np. do terminu wypasu, wykaszania, 
a nawet zaniechania użytkowania, to pyta uprzejmie: a gdzie rekompensata? Wiadomo, że obecnie jedynymi rekompensatami są wyłącznie programy rolno-środowiskowe, bo pakiety „naturowe” nadal są w sferze życzeń, opiniowania i ustalania. A wyjątkowo cenne tereny leśne? Jeśli są położone na terenie zarządzanym przez Lasy Państwowe, to trud ochrony biorą one na siebie, jednak nie łączą się z tym żadne dodatkowe fundusze. Problemem są również wyjątkowo cenne siedliska lasów podmokłych, np. łęgów źródliskowych, gdyż nie ma jednoznacznych kryteriów, jak realizować gospodarkę leśną na terenach wyłączonych i jakie działania preferować, co więcej, degradacja tych siedlisk następuje wyjątkowo szybko. Leśnicy z troską pochylają się nad przyszłością tych bardzo cennych siedlisk na gruntach prywatnych. Jak jednak zdopingować właściciela do określonych działań zachowawczych i przedsięwzięć bez zagwarantowania mu konkretnych środków finansowych (Falencka-Jabłońska 2012b, 10)?

Warto też zastanowić się, jaką wiedzę na temat obszarów Natura 2000 ma młode pokolenie Polaków. W 2012 roku badania świadomości ekologicznej wśród gimnazjalistów przeprowadzili pracownicy Instytutu na rzecz Ekorozwoju. Wyniki tej ankiety wskazują, że o obszarach Natura 2000 wśród gimnazjalistów słyszało tylko 16\% respondentów. Zastanawia też fakt, że 77\% uczniów potwierdziło swój udział w ostatnim roku szkolnym w choć jednej akcji na rzecz ochrony środowiska. Ci, którzy wskazywali, że podjęli działania indywidualne, najczęściej wymieniali segregację odpadów (24\%) oraz swój udział w akcji sprzątania świata 18\% uczniów ankietowanych (Stanaszek i Tędziagolska 2011, 8).

\subsection{Obszar Natura 2000 a proces inwestycyjny}

Zgodnie z zapisami ustawy z dnia 16 kwietnia 2004 r. o ochronie przyrody (Dz. U. z 2009 r. Nr 151, poz. 1220, z późn. zm.), ochrona zasobów przyrodniczych na obszarach Natura 2000 opiera się głównie na ograniczaniu działań mogących w znaczący sposób pogorszyć właściwy stan ochrony siedlisk przyrodniczych oraz gatunków roślin i zwierząt, dla których ochrony został on wyznaczony. Zabrania się więc podejmowania działań mogących osobno lub w połączeniu $z$ innymi negatywnie oddziaływać na cele ochrony danego obszaru Natura 2000. 
W szczególnych przypadkach (zgodnie $\mathrm{z}$ art. 34 ustawy o ochronie przyrody) istnieje możliwość realizacji działań mogących znacząco negatywnie oddziaływać na obszary Natura 2000, jeżeli działania te wynikają z przesłanek:

$\checkmark$ nadrzędnego interesu publicznego;

$\checkmark$ udokumentowany zostanie brak rozwiązań alternatywnych;

$\checkmark$ zapewni się wykonanie kompensacji przyrodniczej niezbędnej do zapewnienia spójności i właściwego funkcjonowania sieci obszarów Natura 2000.

Dodatkowo, jeżeli przedsięwzięcie może znacząco negatywnie oddziaływać na siedliska i gatunki priorytetowe, przed wydaniem zgody na jego realizację (w praktyce najczęściej przed wydaniem decyzji o środowiskowych uwarunkowaniach) należy wystąpić o opinię do Komisji Europejskiej. Opinia taka jest konieczna, gdy inwestycja będzie realizowała inny nadrzędny interes publiczny, wykraczający poza cele związane ze zdrowiem publicznym, bezpieczeństwem powszechnym lub pozytywnymi skutkami o pierwszorzędnym znaczeniu dla środowiska. Kwestia oddziaływania poszczególnych działań jest natomiast każdorazowo przedmiotem indywidualnej oceny dokonywanej przez właściwe organy administracji.

Planowane przedsięwzięcia (zgodnie zart. 33 ust. 3 ustawy o ochronie przyrody), które mogą znacząco oddziaływać na obszar Natura 2000, wymagają przeprowadzenia odpowiedniej oceny oddziaływania na zasadach określonych w ustawie z dnia 3 października 2008 r. o udostępnianiu informacji o środowisku i jego ochronie, udziale społeczeństwa w ochronie środowiska oraz ocenach oddziaływania na środowisko (Dz. U. Nr 199, poz. 1227, z późn. zm. - dalej ustawa OOŚ). W przypadku przedsięwzięć zaliczonych do kategorii przedsięwzięć mogących znacząco oddziaływać na środowisko ocena ta przeprowadzana będzie w ramach oceny oddziaływania na środowisko kończącej się wydaniem decyzji o środowiskowych uwarunkowaniach. Obecnie rodzaje tych przedsięwzięć określone są w rozporządzeniu Rady Ministrów z dnia 9 listopada 2010 r. w sprawie przedsięwzięć mogących znacząco oddziaływać na środowisko (Dz. U. Nr 213, poz. 1397). 
W przypadku przedsięwzięć innych niż mogące znacząco oddziaływać na środowisko, mogą one wymagać przeprowadzenia oceny oddziaływania, jeżeli dane przedsięwzięcie może znacząco oddziaływać na obszar Natura 2000, a nie jest bezpośrednio związane z ochroną tego obszaru lub nie wynika z jego ochrony. Dotyczy to jednak tylko tych przedsięwzięć, które wymagają uzyskania jakiejkolwiek decyzji inwestycyjnej, np. decyzji o warunkach zabudowy czy decyzji o pozwoleniu na budowę. Wówczas ocena ta odbywa się w ramach postępowania przed wydaniem decyzji inwestycyjnej i ograniczona jest jedynie do kwestii dotyczących wpływu na obszar Natura 2000.

Podsumowując, warunki realizacji przedsięwzięć mogących znacząco negatywnie oddziaływać na obszary Natura 2000 regulują przepisy ustawy o ochronie przyrody. Natomiast instrumenty służące stwierdzeniu, czy planowane zamierzenie inwestycyjne może wpływać negatywnie na obszary Natura 2000 i czy zachodzą przesłanki do jego realizacji, pomimo jego znaczącego negatywnego wpływu na te obszary, są określone w Ustawie o udostępnianiu informacji o środowisku i jego ochronie, udziale społeczeństwa w ochronie środowiska oraz o ocenach oddziaływania na środowisko. Prawidłowo przeprowadzona ocena oddziaływania na środowisko lub ocena oddziaływania na obszary Natura 2000 umożliwia wybór rozwiązań najkorzystniejszych dla środowiska, w tym dla obszarów Natura 2000, oraz podejmowanie racjonalnych decyzji odnośnie do gospodarowania zasobami środowiskowymi zgodnie $\mathrm{z}$ zasadą zrównoważonego rozwoju. Tym samym procedura ta staje się kluczowym instrumentem ochrony przyrody, umożliwiając zachowanie różnorodności biologicznej i bogactwa przyrodniczego.

Planowana inwestycja wymaga jednak ścisłej współpracy pomiędzy projektantami i inwestorem, jak również przyrodnikami. Celem postępowania w sprawie oceny oddziaływania na środowisko (OOŚ) dla realizacji inwestycji mogącej znacząco oddziaływać na siedliska i gatunki chronione w obszarze Natura 2000 (zlokalizowanej w obrębie obszaru Natura 2000 lub w jego bezpośrednim sąsiedztwie) jest optymalizacja procesu decyzyjnego, aby podejmowane ze względów gospodarczych, społecznych czy innych działania w jak najmniejszym stopniu zagrażały zdrowiu i jakości życia ludzi, a także zachowaniu ogólnie pojętych warunków środowiskowych, w tym różnorodności biologicznej i trwałości 
ekosystemów. Niezależnie od tego, czy jest to ocena samodzielna, czy też stanowiąca część procedury OOŚ, należy odmówić wyrażenia zgody na realizację tych przedsięwzięć, co do których nie udało się uzyskać pewności, że nie będą one negatywnie oddziaływać na cele ochrony obszaru Natura 2000. Metodyka oceny siedliskowej oraz jej umiejscowienie w procesie wydawania zezwoleń na realizację różnych przedsięwzięć i jej szczegóły zawarte zostały w opracowaniu wydanym przez Ministerstwo Środowiska (Engel 2009).

W całej Europie istnieje wiele przykładów przedsięwzięć podejmowanych na obszarach Natura 2000. Zdarza się, że konieczne jest wprowadzenie niewielkich zmian, aby zapewnić koegzystencję współczesnego użytkowania obszarów z ochroną występujących gatunków i siedlisk. Czasem wymagane są również działania kompensacyjne, których celem jest wyrównywanie szkód w środowisku przyrodniczym.

\section{Podsumowanie i wnioski}

Gwarancją zrównoważonego rozwoju oraz zachowania zasobów przyrody dla przyszłych pokoleń jest przede wszystkim wiedza społeczeństwa (wszystkich grup wiekowych) na ten temat oraz zrozumienie praw i mechanizmów rządzących przyrodą. Polska, jako kraj należący do czołówki państw Europy, szczycącej się wyjątkowym bogactwem i różnorodnością przyrody, powinna skutecznie je chronić. Dlatego też z pełną świadomością należy:

$\checkmark$ Zagwarantować stosowne fundusze umożliwiające realizację działań ochronnych na obszarach Natura 2000 oraz rekompensaty „naturowe" dla prywatnych właścicieli za dostosowanie swej gospodarki do wymogów ochrony przyrody;

$\checkmark$ Rozwijać gospodarkę danego regionu na zasadzie kompromisu i wyboru optymalnych rozwiązań, decydujących o trwałym rozwoju, z zachowaniem najcenniejszych walorów przyrodniczych regionu;

$\checkmark$ Prowadzić edukację społeczeństwa w zakresie współegzystencji człowieka, przyrody i rozwoju gospodarczego regionu. Szczególną uwagę zwrócić na kształcenie młodego pokolenia Polaków, od których wiedzy i umiejętności praktycznego jej zastosowania zależeć będzie nie 
tylko zrównoważony rozwój, ale także zachowanie stabilnej równowagi w przyrodzie.

Warto zatrzymać się nad sensem zawartym w myśli św. Franciszka z Asyżu „Zacznijcie od robienia tego co konieczne, potem zróbcie to, co możliwe i nagle zdziwicie się, że robicie to, co niemożliwe" (Petrini 2015, 17).

\section{Bibliografia:}

Bałtromiuk, Artur i Marek Zagórski. 2011. Natura 2000 dobro publiczne, problem prywatny. Warszawa: Fundacja Europejski Fundusz Rozwoju Wsi Polskiej.

Dyrektywa Rady 79/409/ EWG z dnia 2.04.1979 roku w sprawie ochrony dzikich ptaków. Dz. U.WE L.103 z 25.04,1979.

Dyrektywa Rady 92/43/EWG z dnia 21.05.1992 roku w sprawie ochrony siedlisk naturalnych oraz dzikiej fauny i flory Dz. U. WE L.206 z 22.07.1992.

Engel, Jacek. 2009. Natura 2000 w ocenach oddziaływania przedsięwzięć na środowisko. Warszawa: Ministerstwo Środowiska.

Falencka-Jabłońska, Małgorzata. 2012a. NATURA 2000 w Polsce fakty i mity. Głos Lasu, (3), 36-38.

Falencka-Jabłońska, Małgorzata. 2012b. Sieć Obszarów NATURA 2000 w polskich realiach. Aura, (3), 9-11.

Falencka-Jabłońska, Małgorzata. 2016. Różnorodność biologiczna jako wskaźnik zmian ekosystemów leśnych $w$ zrównoważonym zagospodarowaniu lasów w zasięu oddziaływania ENEA Wytwarzanie S.A. Dokumentacja IBL.

Franciszek. 2015. Encyklika „Laudato Si””.

Liro, Anna. 2010. System zarządzania siecia Natura 2000. Warszawa: Generalna Dyrekcja Ochrony Środowiska.

Petrini, Carlo. 2015. Przewodnik po lekturze „Laudato Si”” W: Franciszek. Encyklika „Laudato Si”, tłum. Krzysztof Stopa, 7-17. Częstochowa: Edycja Św. Pawła.

Raport „Europejska Sieć Ekologiczna Natura 2000”. 2010. Warszawa: Generalna Dyrekcja Ochrony Środowiska.

Regionalna Dyrekcja Ochrony Środowiska w Białymstoku. Dostęp: 13.12.2011. http://bialystok.rdos.gov.pl/. 
Rozporządzenie Ministra Środowiska z dnia 17 lutego 2010 roku w sprawie sporządzania Projektu planu zadań ochronnych (PZO) dla Obszarów Natura 2000.

Rozporządzenie Rady Ministrów z dnia 9 listopada 2010 r. w sprawie przedsięwzięć mogących znacząco oddziaływać na środowisko. Dziennik Ustaw, 2010 nr 213 poz. 1397.

Stanaszek, Alina i Magdalena Tędziagolska. 2011. Młodzież a Natura 2000 - raport badania socjologicznego. Warszawa: Instytut na Rzecz Ekorozwoju.

Ustawa z dnia 16 kwietnia 2004 r. o ochronie przyrody. Dziennik Ustaw, $2009 \mathrm{nr} 151$ poz. 1220.

Ustawa z dnia 3 października 2008 r. o udostępnianiu informacji o środowisku i jego ochronie, udziale społeczeństwa w ochronie środowiska oraz o ocenach oddziaływania na środowisko. Dziennik Ustaw, 2008 nr 199 poz. 1227. 
Zbigniew Mirek

Instytut Botaniki im. W. Szafera Polskiej Akademii Nauk

z.mirek@botany.pl

Zbigniew Witkowski

Podhalańska Państwowa Wyższa Szkoła Zawodowa w Nowym Targu

zbigniew.witkowski@onet.eu

\section{Teoria i praktyka w ochronie przyrody - gdzie szukać kompromisu w sprawie Puszczy Białowieskiej?}

\section{Wprowadzenie}

Trzydziestolecie Raportu Brundtland wzywające do krytycznej analizy stanu realizacji koncepcji rozwoju zrównoważonego zmusza nas do refleksji zarówno nad teoretyczną warstwą tej koncepcji jak i jej praktycznym stosowaniem, zarówno w odniesieniu do szeroko rozumianej ochrony przyrody jak i sposobów gospodarowania środowiskiem przyrodniczym. Teoretyczne aspekty koncepcji przeanalizowaliśmy w odrębnym tekście zawartym w niniejszej publikacji (Mirek i Witkowski 2017). Tu natomiast chcemy pokazać, jak wyniki tamtych analiz pozwalają zmierzyć się $\mathrm{z}$ wieloma kontrowersjami, które pojawiły się $\mathrm{w}$ dyskusji publicznej (niekiedy bardzo burzliwej i upolitycznionej) na temat zakresu ochrony i gospodarowania na obszarze Puszczy Białowieskiej.

$\mathrm{W}$ próbie tej odwołujemy się do zaprojektowanej w ramach programu UNESCO MaB („Man and Biosphere” - „Człowiek i Biosfera”) koncepcji rezerwatu biosfery - jednej z pierwszych koncepcji ochrony obszarowej wypracowanej w ramach modelu rozwoju zrównoważonego. Konstatujemy, że model ów daleki jest od najczęstszych, a równocześnie skrajnych, podejść do ochrony przyrody, a także ukazujemy, na ile powiązany jest on $z$ trzecim prezentowanym przez nas (Mirek i Witkowski 2017) podejściem do tej ochrony próbującym łączyć w sposób harmonijny ochronę $\mathrm{z}$ gospodarowaniem. Koncepcja rezerwatu biosfery, jak każda $\mathrm{z}$ form ochrony obszarowej, szuka i musi odnaleźć swoje modelowe zrównoważenie, $\mathrm{w}$ polu zrodzonym $\mathrm{z}$ napięcia pomiędzy trzema podstawowymi składowymi rozwoju zrównoważonego (środowiskową/ przyrodniczą, ekonomiczną i społeczną). 


\section{Spór o Puszczę Białowieską w kontekście modelu jej ochrony i użytkowania wpisanych w model rozwoju zrównoważonego}

Obszary lądowe na Ziemi obejmują ok. $149 \mathrm{mln} \mathrm{km}^{2}$, a łączna powierzchnia wszystkich obszarów chronionych obejmuje ponad $16 \mathrm{mln}$ $\mathrm{km}^{2}$, co oznacza, że ponad 10,7\% lądów jest poddanych jakiejś formie ochrony przyrody (Kareiva i Marvier 2012). W Polsce udział procentowy obszarów poddanych ochronie w stosunku do całej powierzchni kraju jest znacznie wyższy i obejmuje, bez uwzględnienia ostoi Natura 2000 (2014 r.), ponad 32,4\%.

Ochrona przyrody w Polsce ma długie i dobre tradycje. W 1932 r. utworzyliśmy w Pieninach wraz z Czechosłowacją drugi na świecie park narodowy łączący terytoria dwóch państw. W tym samym roku powstał Park Narodowy w Białowieży, który objął ochroną najcenniejsze 4,6 tys. ha na obszarze Nadleśnictwa Rezerwat powstałego w początkach lat 20. ubiegłego stulecia. Już wówczas dochodziło do konfliktów między leśnikami i przyrodnikami w kontekście ochrony i eksploatacji lasów puszczańskich. Jednakże, mimo tych sporów, Polacy w okresie międzywojennym potrafili wylansować walory puszczańskiej przyrody w Europie i na całym świecie. Szczególnie trafnym pociągnięciem było podjęcie prób odtworzenia populacji żubra, łosia, a nawet wprowadzenia niedźwiedzia. Rozgłos Puszczy Białowieskiej opierał się także na opinii jednego z najlepszych terenów łowieckich w Europie._Marka puszczy została wówczas podniesiona do rangi unikatowego obszaru przyrodniczego w całej Europie. Sława puszczy została utrwalona przede wszystkim przez działających tutaj przyrodników takich jak profesorowie: Władysław Szafer, Józef Paczoski, Janusz Bogdan Faliński i Zdzisław Pucek oraz Simona Kossak, a także współcześnie zajmujących się przyrodą puszczy wielu uczonych $\mathrm{z}$ różnych dziedzin przyrodoznawstwa. Wychodzące z puszczy znakomite prace badawcze dodatkowo wzmocniły przekonanie środowisk opiniotwórczych w Europie i na świecie o wielkiej wartości przyrodniczej tego obszaru.

Po II wojnie światowej system ochrony przyrody w Polsce ukształtował się na nowo, w tym także sieć parków narodowych. Obiekty te tworzone były wówczas często z pogwałceniem praw własności lokalnych społeczności, a ponadto obejmowały obszary lasów państwowych, kosz- 
tem ubytku powierzchni gospodarczej. Stąd, jak wynika ze współcześnie prowadzonych badań (Olko 2011), lokalne społeczności nadal są nieufne, a nawet wrogie ochronie przyrody, a stopień braku zaufania do przedstawicieli tych służb jest tym większy, im ludzie są starsi i gorzej wykształceni.

Obecnie Polska część Puszczy Białowieskiej leżąca na powierzchni ok. 62,2 tys. ha objęta jest $w$ całości różnymi formami ochrony przyrody: parkiem narodowym o powierzchni ponad 10,5 tys. ha, rezerwatami przyrody o łącznej powierzchni ponad 12 tys. ha, ostoją Natura 2000 o łącznej powierzchni 63147,6 ha oraz Obszarem Chronionego Krajobrazu, który obejmuje obszar Puszczy Białowieskiej wraz z obrzeżami sąsiadujących gmin o łącznej powierzchni 78538 ha. Ponadto cały obszar puszczy po stronie polskiej i białoruskiej objęty jest dwoma ważnymi formami międzynarodowej ochrony przyrody. Pierwszą z nich jest Rezerwat Biosfery Białowieża, utworzony w 1976 r. w Białowieskim Parku Narodowym w ramach międzynarodowego programu UNESCO MaB. W 2005 r. obszar Rezerwatu został powiększony do ok. 92,4 tys. ha, a zarządcy terenów wchodzących w skład tego obiektu podpisali porozumienie o utworzeniu Komitetu Sterującego Rezerwatu Biosfery Białowieża.

Drugą międzynarodową formą ochrony było powołanie w $2014 \mathrm{r}$. na obszarze całej puszczy Obiektu Światowego Dziedzictwa Ludzkości UNESCO Białowieża Forest, o łącznej powierzchni ok. 141 tys. ha. Obecnie na jego terenie trwają intensywne prace zmierzające do ustanowienia obszarów i stref ochrony, przygotowujące faktyczne funkcjonowanie tego cennego obszaru chronionego.

Wymogi dostosowania obszaru puszczy do ustanowionych kryteriów poszczególnych form ochrony przyrody zawartych $\mathrm{w}$ polskim prawodawstwie, a także wynikające $\mathrm{z}$ zobowiązań międzynarodowych ze względu na wielość form ochrony nie są spełniane, tym bardziej, że nakładanie się celów ochrony przyrody i celów gospodarczych w nadleśnictwach dodatkowo pogłębia chaos decyzyjny.

W tej sytuacji łatwo było o spowodowanie konfliktu, który został wywołany w puszczy koincydencją dwóch zdarzeń. W 2012 r. ówczesny Minister Środowiska zmniejszył kilkukrotnie poziom pozyskiwania drewna w lasach gospodarczych puszczy, zaś rok później (2013) rozpo- 
częła się tutaj jak dotąd największa gradacja kornika drukarza w drzewostanach świerkowych (Witkowska i Witkowski). Leśnicy, skrępowani decyzją ministra, nie byli w stanie opanować gradacji i doszło do wielkopowierzchniowego wymierania świerków w części gospodarczej puszczy. Po zmianie na stanowisku Ministra Środowiska i częściowym przywróceniu etatu rębnego w lasach gospodarczych puszczy, leśnicy zaczęli dramatyczną walkę z kornikiem, wycinając świeżo zasiedlone drzewa, aby zniszczyć ogniska gradacji. Wówczas przyrodnicy i znaczna część organizacji pozarządowych zaczęła kampanię skierowaną przeciw wycinaniu tych drzewostanów, szermując nieprawdziwym argumentem o wycinaniu puszczy ( $w$ istocie dotyczyło to jedynie części zaatakowanych przez kornika drukarza drzewostanów świerkowych). W konsekwencji tych sporów okazało się, że zdecydowana większość przyrodników optuje za rozwiązaniem biocentrycznym, zmierzającym do całkowitego wyparcia leśników i lokalnej społeczności z obszaru puszczy, natomiast leśnicy, wspierające ich nieliczne organizacje pozarządowe i zdecydowana większość mieszkańców okolicznych gmin wyrażali opcję antropocentryczną zmierzającą do utrzymania funkcji gospodarczych puszczy jako ważnej usługi ekosystemowej świadczonej przez ekosystemy leśne (Witkowska i Witkowski).

Przyrodnicy i organizacje pozarządowe argumentują, że Puszcza Białowieska to unikat o randze światowej, a ochrona ścisła w postaci parku narodowego lepiej wypełni potrzeby konserwacji tego obszaru niż ochrona przyrody realizowana w innych, mniej restrykcyjnych formach, takich jak Natura 2000 czy obszar chronionego krajobrazu. Ważne argumenty merytoryczne przyrodników są niestety połączone z niewybrednymi atakami na leśników (Weiner 2016), co utrudnia osiągnięcie jakiegokolwiek porozumienia.

Lasy Państwowe są zwartą i silną korporacją, która działa i będzie nadal działać na obszarach cennych przyrodniczo. Korporacja ta realizuje swoje interesy ekonomiczne, dba też o wizerunek i prestiż. W ramach działań na rzecz wizerunku wspiera ekonomicznie parki narodowe, tworzy liczne, dobrze wyposażone ośrodki ekologiczne, ponadto opiekuje się zdecydowaną większością rezerwatów przyrody i innych form ochrony przyrody w Polsce. W Puszczy Białowieskiej Lasy Państwowe 
powołały pierwszy w Polsce Leśny Kompleks Promocyjny, który ma być wzorcowym przykładem zarządzania gospodarstwem leśnym na obszarach wrażliwych przyrodniczo, położonych przy granicy parku narodowego. Zdaniem autorów, mimo stosunkowo długiego już okresu funkcjonowania Leśnego Kompleksu Promocyjnego w Puszczy Białowieskiej, leśnicy gospodarujący na tym cennym obszarze nie dopracowali się takich metod zarządzania lasem, które zmniejszałyby naturalny konflikt występujący w strefie granicznej między obszarem chronionym a obszarem gospodarczym puszczy. Ponadto to przyrodnicy byli inicjatorami zmian gospodarowania polegających na zaniechaniu eksploatacji drzewostanu w wydzieleniach gospodarczych, gdzie ponad $10 \%$ stanowią drzewa w wieku przekraczającym 100 lat (propozycja Tomasza Wesołowskiego npbl.).

Przyrodnicy słusznie pokazują, że cele gospodarcze związane z pozyskiwaniem drewna są nadal na tym terenie intensywnie realizowane, mimo iż przychody związane z pozyskiwaniem drewna nie pokrywają wydatków.

Zasadniczym problemem sporu o puszczę jest jednak forma jej zabezpieczenia. Przyrodnicy wskazują, że jedynym możliwym rozwiązaniem jest objęcie całego obszaru puszczy parkiem narodowym, leśnicy się temu stanowczo sprzeciwiają. Przyrodnicy w Polsce nie dopuszczają w sporze argumentów niezwiązanych z przyrodą żywą i jej zabezpieczeniem. Tymczasem właśnie to zabezpieczenie w postaci parku narodowego wcale nie jest lepsze niż w postaci innych form ochrony przyrody. Parki narodowe przestały być jednostkami budżetowymi i stały się instytucjami państwowymi dotowanymi przez skarb państwa, tak jak uczelnie, szkoły itp. Zmiana ta spowodowała, że drastycznie zmienił się stan środków finansowych w poszczególnych parkach narodowych. Te obiekty, które są wspomagane przez turystykę i rekreację jak Tatrzański Park Narodowy, Pieniński PN czy Karkonoski PN, nie mają kłopotów finansowych, są jednak i takie, które mają permanentne niedobory finansów i gdyby nie wsparcie właśnie Lasów Państwowych, nie byłyby w stanie domknąć budżetu. Wiele innych parków środki finansowe czerpie z wycinania lasu pod pretekstem przebudowy drzewostanów, które nie są dopasowane do siedliska (Babczuk i Kachniarz 2015). 
Białowieski PN nie jest i nie będzie potentatem w dziedzinie turystyki, a ze względu na przeważający obszar podlegający ochronie ścisłej nie będzie też mógł pozyskiwać środków z tzw. przebudowy drzewostanów. Niektóre parki radzą sobie w inny sposób, pozyskując znaczące środki z funduszy europejskich. W tym parku i ta droga pozyskiwania dodatkowych funduszy jest bardzo ograniczona, ponieważ park ma silną konkurencję w postaci kilku istniejących tu placówek badawczych, które przejmują zdecydowaną większość środków przeznaczonych na badania, a także środki finansowe $z$ turystyki naukowej, organizując konferencje i sympozja zawsze chętnie odwiedzane przez zamożniejszych pracowników naukowych z zagranicznych ośrodków.

Puszcza Białowieska to także w nauce marka światowa, podobna do najbardziej eksponowanych pod względem badań obszarów chronionych takich jak Park Narodowy Galapagos czy parki narodowe tropikalnych puszcz Afryki z największym nagromadzeniem gatunków naczelnych na świecie. Takie obszary są nie tylko dobrze chronione, ale także naukowcy muszą się słono opłacać, żeby prowadzić tam badania, szczególnie związane z pozyskiwaniem materiałów badawczych.

W Polsce badania naukowe w parkach narodowych mogą być prowadzone przez każdą placówkę badawczą, niezależnie od tego, czy badania te służą rozwiązaniu problemów parku lub pogłębieniu wiedzy o nim, czy też rozwiązywaniu własnych hipotez badawczych bez istotnego związku z pogłębieniem wiedzy o parku lub ochroną przyrody. Do wielu naukowców nie dociera bowiem fakt, że z parku pozyskują wartości i dobra; są zatem takimi samymi interesariuszami wobec Puszczy Białowieskiej jak leśnicy, miejscowa społeczność, turyści i obrońcy puszczy, nie mogą zatem narzucać rozwiązań innym, lecz powinni się $\mathrm{z}$ nimi dogadywać w sprawie trwałego korzystania $\mathrm{z}$ wyjątkowych dóbr i usług ekosystemowych tego nadzwyczajnego obszaru.

Puszcza Białowieska jest niewątpliwie źle zarządzana. Nadmiar form ochrony i brak koordynacji powoduje chaos decyzyjny. Rozwiązanie tych zagadnień wymaga nie tylko wiedzy przyrodników, lecz także udziału leśników, miejscowej społeczności i przedstawicieli organizacji pozarządowych, w tym turystycznych.

Cała puszcza, wraz z otaczającymi ją obszarami, objęta jest statusem Rezerwatu Biosfery (ryc.1). Obiekty te w zamierzeniu ich twórców 
(UNESCO MaB) służą realizacji wszystkich celów rozwoju zrównoważonego. W strefie najcenniejszej, wewnętrznej, celem nadrzędnym jest ochrona przyrody.

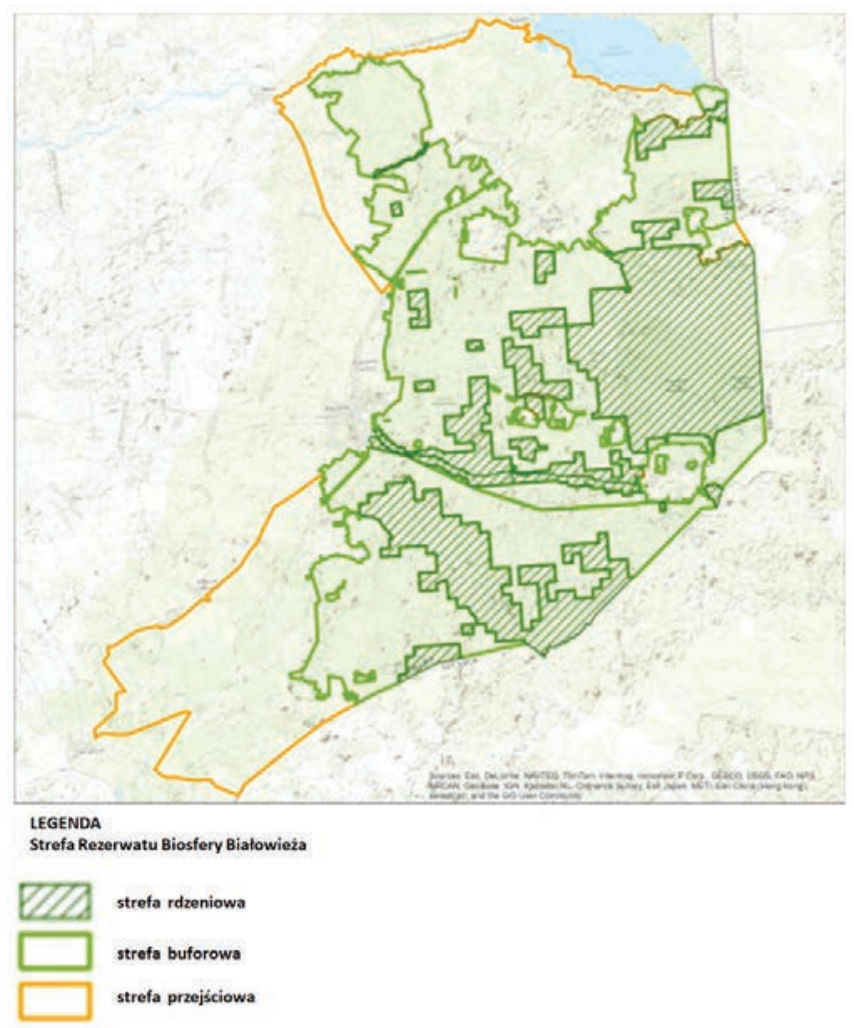

Ryc. 1. Mapa Rezerwatu Biosfery Białowieża (Rezerwat Biosfery Białowieża)." Źródło: Białowieski Park Narodowy, Polski Komitet Narodowy MAB 2013, przygotowanie Joanna Adamczyk

W Puszczy Białowieskiej strefa ta obejmuje ponad 21,9 tys. ha. Zgodnie z zasadami zarządzania rezerwatem biosfery, w zdecydowanej większości powinna ona mieć charakter strefy ochrony ścisłej. Strefa buforowa $(37,8$ tys. ha) obejmuje pozostałą część puszczy w granicach trzech działających $\mathrm{w}$ puszczy nadleśnictw oraz fragmenty Białowieskiego Parku Narodowego podlegające ochronie krajobrazowej. W Rezerwacie Biosfery Białowieża ta strefa jest dodatkowo podzielona. Strefa buforo- 
wa I (15,9 tys. ha) obejmuje obszar najwyższych reżimów ochronnych w ramach gospodarki leśnej, czyli lasy gospodarcze o najlepiej zachowanych walorach przyrodniczych, z drzewostanami naturalnego pochodzenia i ostojami zwierząt. Strefa buforowa II (21,9 tys. ha) to lasy gospodarcze położone na peryferiach puszczy, najbardziej zmienione w wyniku antropopresji. Ostatnia, strefa przejściowa Rezerwatu Biosfery Białowieża (32,7 tys. ha), obejmuje tereny rolniczo-leśne położone na północ i zachód od puszczy, a także zamieszkałe osady znajdujące się wewnątrz puszczy.

W strefie buforowej mamy podział na dwie podstrefy. W pierwszej z nich, przylegającej do najcenniejszej strefy centralnej, cele ochrony przyrody powinny zdecydowanie przeważać nad eksploatacją gospodarczą drzewostanów, w pozostałej części II tej strefy, obejmującej zewnętrzne obszary puszczy, przeważać powinna zrównoważona eksploatacja. I wreszcie obszary zewnętrzne - strefa przejściowa obejmująca poszczególne miejscowości - powinny rozwijać się ekonomicznie zgodnie z zasadami rozwoju zrównoważonego.

W puszczy rezerwat biosfery istnieje od dawna, a od 2005 roku uzyskał status międzynarodowy. Okazuje się jednak, że jest to forma martwa, ponieważ nie ma umocowania prawnego w naszym ustawodawstwie i nie jest respektowana ani przez zarządzających parkiem narodowym, ani przez nadleśnictwa, ani przez Regionalną Dyrekcję Ochrony Środowiska, ani też przez lokalną społeczność. Są w Polsce obszary, na których lokalne porozumienie działa dobrze. Takim obszarem jest Rezerwat Biosfery Babia Góra, gdzie lokalne gminy i leśnicy, przedstawiciele organizacji pozarządowych i turystycznych, a także lokalni biznesmani doskonale się dogadują, inicjując wraz z parkiem narodowym nowe inicjatywy służące ochronie przyrody i celom gospodarczym oraz społecznym miejscowej ludności. Lokalne struktury Lasów Państwowych, park narodowy i samorządowcy powinni podjąć starania o uruchomienie forum porozumienia w sprawie Puszczy Białowieskiej właśnie w oparciu o formułę rezerwatu biosfery, gdzie nikt nie zarządza innymi, a wszyscy mają równe prawo do wypowiedzi. Jasne, że dyrektor parku, nadleśniczy czy wójt mają ostatnie, decydujące zdanie na obszarze przez siebie zarządzanym, jednak warto, aby każdy z tych decydentów przed podjęciem decyzji wysłuchał opinii innych interesariuszy. 


\section{Uwagi końcowe i wnioski}

1. Światowy spór dotyczący ideowych pryncypiów ochrony przyrody (prezentujemy go w odrębnym tekście w niniejszej publikacji - Mirek i Witkowski 2017) w ostatnich latach rozgorzał również w Polsce. Pretekstem było zarządzanie gospodarczą częścią Puszczy Białowieskiej, gdzie leśnicy podjęli intensywną wycinkę drzewostanów świerkowych w obronie przed masową gradacją kornika drukarza. Doszło do tego z powodu niefortunnych okoliczności, kiedy to decyzja Ministra Środowiska o zmniejszeniu wolumenu pozyskiwanego drewna w puszczy zbiegła się w czasie $\mathrm{z}$ szybkim rozrostem populacji tego gatunku chrząszcza. Leśnicy starają się już tylko opóźniać postępy gradacji, która okazała się jedną z największych w ponad stuletniej historii gospodarki leśnej w Puszczy Białowieskiej.

2. Działania leśników spotkały się ze stanowczym sprzeciwem przyrodników i działaczy ekologicznych, którzy wysunęli postulat, aby cały obszar Puszczy Białowieskiej objąć ochroną w postaci parku narodowego. Obie strony zaczęly przerzucać się argumentami, powodując jedynie nasilenie sporu. Po obu stronach obserwuje się też brak chęci do kompromisu oraz podjęcia spokojnego dialogu i ustalenia własnych stanowisk, ich podobieństw, a także dzielących je różnic.

3. Jednym z podstawowych założeń koncepcji zrównoważonego rozwoju jest dążenie do konsensusu. Widzimy to na forum międzynarodowym, w sporach między państwami, np. w kwestii ograniczania emisji dwutlenku węgla, widzimy także w sprawach dotyczących zagadnień rozwiązywanych w obrębie poszczególnych społeczności. Spór o Puszczę Białowieską pozbawiony jest forum dla podejmowania dyskusji i ustalania wspólnych stanowisk. Takim forum mogłaby być stworzona specjalnie w tym celu światowa forma ochrony przyrody - rezerwat biosfery - wprowadzona przez UNESCO w programie MaB. Forma ta została wprowadzona w Puszczy Białowieskiej i od 1995 r. mamy tutaj Międzynarodowy Rezerwat Biosfery Białowieża. Obiekt ten dlatego obejmuje znacznie większe obszary niż tylko ściśle chronione, ponieważ powinien stanowić forum dyskusji interesariuszy skupionych w i wokół puszczy dla rozwiązywania problemów zarządzania zgodnie z zasadami 
rozwoju zrównoważonego. Niestety w Rezerwacie Biosfery Białowieża nie utworzono forum porozumienia interesariuszy i obiekt ten jest $\mathrm{w}$ istocie tworem martwym.

\section{Bibliografia:}

Babczuk, Arkadiusz i Marian Kachniarz. 2015. System Finansowania Parków Narodowych w Polsce. Stan obecny i kierunki pożądanych zmian. Raport wykonany i sfinansowany na zlecenie na zlecenie Zwiazku Pracodawców Polskich Parków Narodowych. Jelenia Góra: Wyd. AD REM.

Główny Urząd Statystyczny i Urząd Statystyczny w Katowicach. Udział powierzchni obszarów prawnie chronionych w powierzchni ogółem. Wygenerowano z Bazy Wskaźników Zrównoważonego Rozwoju (WskaznikiZRP.stat.gov.pl).

Kareiva, Peter i Michelle Marvier. 2012. What is Conservation Science? BioScience, 62(11), 962-969.

Mirek, Zbigniew i Zbigniew Witkowski. 2017. Teoria i praktyka w ochronie przyrody - gdzie szukać kompromisu w sprawie Puszczy Białowieskiej? W: Theoria i praxis zrównoważonego rozwoju, red. Ryszard F. Sadowski, Zbigniew Łepko, s. 609, Warszawa: TNFS.

Olko, Joanna. 2011. Ochrona przyrody w parkach narodowych Małopolski w świadomości wybranych grup społecznych. Rozprawa doktorska wykonana w Instytucie Nauk o Środowisku Uniwersytetu Jagiellońskiego w Krakowie.

Puszcza Białowieska - kalendarium: Okres międzywojenny. Dostęp 10.02.2017. http://darz-bor.info/db/puszcza-bialowieska-kalendariumokres-miedzywojenny.

Rezerwat Biosfery Białowieża. Dostęp 3.02.2017. http://bpn.com.pl/ index.php?option $=$ com_content $\&$ task $=$ view\&id=1845\&Itemid $=312$.

Weiner, January. 2016. Po co nam puszcze. Tygodnik Powszechny, 27 (3 lipca).

Witkowska, Katarzyna i Zbigniew Witkowski. Konsolidacja ekologicznych organizacji pozarzadowych na przykładzie sporu o Puszczę Białowieska, ss. 12 (archiwum autora). 
Krzysztof Berbeka

Uniwersytet Jagielloński - Wydział Zarządzania i Komunikacji Społecznej

krzysztof.berbeka@uj.edu.pl

\section{Czy jesteśmy efektywniejsi? Historyczna analiza wykorzystania zasobów wody w Polsce}

\section{Wstęp}

Proces gospodarowania wodą jest najczęściej bardzo ułomnym konsensusem pomiędzy mocną presją polityczną na te mechanizmy a wymogami gospodarki rynkowej. $Z$ jednej strony akcentowana jest potrzeba oszczędzania zasobów wodnych, a z drugiej konieczność zapewnienia dostępu do tych zasobów po tzw. „akceptowalnych dla odbiorców cenach” w ilości wystarczającej do potrzeb. Pojęcie akceptowalnych cen obiecuje wprost ignorowanie faktycznych kosztów zapewnienia dostępu do wody, pomijając całkowicie problem, kto ma pokrywać różnicę w kosztach, których nie ściągnie się od użytkowników. Takie postrzeganie gospodarki jest pewnego rodzaju fenomenem - pomimo ignorowania rzeczywistego rachunku kosztów oczekuje się bowiem skutecznego funkcjonowania bodźców ekonomicznych i wzrostu efektywności wykorzystania zasobów. Celem niniejszego opracowania jest próba odpowiedzi, czy w Polsce faktycznie mamy do czynienia ze wzrostem efektywności wykorzystania zasobów wodnych. Odpowiedź na takie pytanie pozwala na ocenę skuteczności stosowanych instrumentów (administracyjnych i ekonomicznych), wraz z ewentualnymi rekomendacjami nt. możliwych zmian istniejących bodźców i potencjalnych konsekwencji zaproponowanych zmian.

\section{Przesłanki efektywnego gospodarowania zasobami}

Koncepcje pełnego zbilansowania popytu na wodę obejmują nadzwyczaj szeroki wachlarz rozwiązań od działań typowo inżynierskich po stosowanie instrumentów ekonomicznych prowadzących do zarządzania popytem (Merett 1997, 5-50). O ile inżynierskie rozwiązania bazujące na nowych technologiach cechuje nieustanny progres - to instrumenty ekonomiczne charakteryzują się relatywnie mniejszym postępem, a rozwiązania nowatorskie, takie jak uprawnienia zbywalne, nie weszły do szerokiej prak- 
tyki w zarządzaniu zasobami wodnymi czy też jej jakością (EUWI 2012, 18 oraz Pearce i Turner 1990, 110-117 ). O postępie w dziedzinie instrumentów ekonomicznych możemy mówić w przypadku ich praktycznej i skutecznej aplikacji ukierunkowanej na zarządzanie popytem. Nadal bowiem obserwuje się mocny prymat rozwiązań inżynierskich zwiększających podaż, a wdrożenie koncepcji zintegrowanego zarządzania zasobami wodnymi jest celem wielu strategii i planów z mocno zróżnicowanym stopniem wdrożenia (Integrated Water Resources Management 2009, 205-220).

Oprócz typowej dyskusji związanej z koncepcjami zarządzania zasobami środowiskowymi - w tym zasobami wodnymi - warto postawić nieco kontrowersyjne pytanie, czy oszczędność w gospodarowaniu jest konieczna - czy występuje rzadkość tych zasobów i czy trend ten jest narastający? Uściślając, chodzi o weryfikację stwierdzenia o zmniejszających się zasobach wodnych i czy doświadczamy zmian tej dostępności. Analiza zmian wielkości zasobów wód powierzchniowych dla okresu 1975-2015 wskazuje na brak trendu malejącego tych zasobów przy dużych odchyleniach od wartości średniej z wielolecia. Odchylenie standardowe sięga $21 \%$ od średniej (obliczenia własne na bazie danych GUS 2016c, 143). Biorąc pod uwagę, że zasoby dyspozycyjne stanowią tylko część zasobów całkowitych (pozostawia się tzw. przepływ nienaruszalny wymagany z uwagi na trwałość ekosystemów), rzeczywiste wahania kategorii zasobów dyspozycyjnych są jeszcze większe. W badanym wieloleciu dla tak mocno zagregowanych wartości - dla całego kraju - brak jest jednak wyraźnych zmian wskazujących na nasilenie się zjawisk ekstremalnych. Można jedynie przypuszczać, że analogiczne rozważania przeprowadzone na poziomie lokalnym mogłyby dać zupełnie inne rezultaty. Niestety do chwili obecnej (2016) nie skwantyfikowano lokalnych deficytów wody w Polsce, brak jest zatem zarówno obrazu bieżącego jak i serii historycznej takiego zjawiska. Na gruncie tak zagregowanych danych trudno jest zatem uzasadnić tezę o postępującej rzadkości zasobów wodnych jako argumentu na rzecz ograniczania konsumpcji.

\section{Dyskusja mierników efektywności wykorzystania zasobów wodnych}

Prosta analiza całkowitego zużycia wody w gospodarce w horyzoncie czasowym $\left(\mathrm{w} \mathrm{hm}^{3} / \mathrm{r}\right)$ nie opisuje zmian efektywności wykorzystania zasobów, zmienna w czasie jest bowiem wielkość produkcji przemysłowej 
i rolniczej, rośnie również liczba osób podłączonych do sieci wodociągowych, które objęte są sprawozdawczością statystyczną. Z tego powodu lepszy obraz dają wskaźniki ilorazowe, gdzie wielkość zużycia wody odnosi się do wielkości wartości dodanej brutto (WDB) lub w przypadku sektora komunalnego analizie poddaje się zużycie jednostkowe w sektorze gospodarstw domowych. Świadomie użyto miernika WDB zamiast znacznie popularniejszego produktu krajowego brutto (PKB) (Krajowy Zarząd Gospodarki Wodnej 2013). Za takim podejściem przemawia definicja PKB, który to miernik równa się sumie wartości dodanej wszystkich sekcji i działów powiększonej o podatki od produktów i pomniejszonej o dotacje do produktów. Ostatnie dwie kategorie (podatki i dotacje) nie mają dużo wspólnego z zużyciem wody - skutecznie zacierają rzeczywistą dynamikę zmian efektywności gospodarki. Stąd też koncepcja ograniczenia się do WDB, która takie transfery pomija. Dyskutowane mierniki można jeszcze doprecyzować - wodochłonność WDB powinna zostać skorygowana poprzez wykluczenie zużycia wód chłodniczych (zwracanych w miejscu poboru). Wykorzystanie wody do chłodzenia w przypadku jej zwrotu nie eliminuje możliwości jej powtórnego wykorzystania, zaś ilość wykorzystanej wody w dużej mierze zależy od warunków klimatycznych (temperatura), a nie od poprawy efektywności procesów produkcyjnych.

$\mathrm{Z}$ uwagi na fakt, że wody chłodnicze w strukturze poboru stanowią 60-70\% - zmiana warunków klimatycznych całkowicie dominuje zmiany zużycia, trudno zatem mówić o hipotetycznej reakcji na bodźce ekonomiczne. Celowe wydaje się również zdezagregowanie tego wskaźnika na kluczowe sektory takie jak produkcja przemysłowa czy rolnicza. Analiza efektywności gospodarowania zasobami w sektorze komunalnym jest nieco trudniejsza. Nawet wobec wskaźnika jednostkowego zużycia wody w gospodarstwach domowych można mieć pewne zastrzeżenia. Wskaźnik taki jest bowiem efektem podzielenia ilości wody zużytej przez gospodarstwa domowe przez liczbę osób zameldowanych, a nie zamieszkujących. Z uwagi na fakt, że pomiędzy 2004 a 2015 wyemigrowało z Polski ok 1,4 mln osób (GUS 2016a), czyli ok. 4\% populacji - rachunek zużycia jednostkowego powinien być skorygowany. Osoby te nie zużywają wody, są jednak nadal zameldowane i wliczają się do uwzględnianej w obliczeniach populacji, wskaźnik zużycia jest zatem 
zaniżony. Wskaźnikiem uzupełniającym dla sektora komunalnego jest różnica pomiędzy wodą pobraną a sprzedaną. Kategoria ta obejmuje zarówno straty jak i zużycie na cele techniczne. Z punktu widzenia efektywności wykorzystania zasobów istotna jest jednak opisana różnica, bez względu na to jakie były przyczyny jej powstania. Dynamika tego wskaźnika w wartościach względnych (odniesiona do całego poboru w sektorze) daje obraz kierunku zmian i jest przyczynkiem do oceny efektywności działania operatorów wodno-kanalizacyjnych.

\section{Analiza wskaźników efektywności korzystania z zasobów wodnych}

Dla wcześniej dyskutowanych mierników wodochłonności WDB przedstawiono syntetyczne wyniki widoczne na rys. 1 i rys. 2 . Pierwszy z nich oparty jest na obliczeniu objętości wody w tys. $\mathrm{m}^{3}$ niezbędnej do wytworzenia $1 \mathrm{mln}$ zł WDB. W latach 2000-2015 mamy do czynienia ze spadkiem tej wartości z poziomu 12,2 tys. $\mathrm{m}^{3} / 1 \mathrm{mln} \mathrm{zł}$ do 7 tys. $\mathrm{m}^{3} / 1 \mathrm{mln} \mathrm{zł}$.

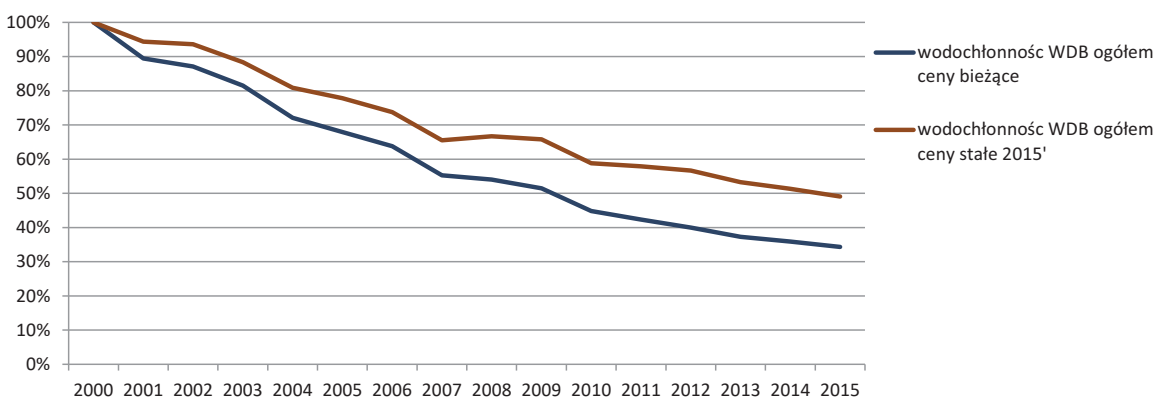

Rysunek 1. Dynamika zmian wodochłonności WDB, rok 2000 jako rok bazowy = 100\%. Źródło: Obliczenia własne na podstawie: kolejnych roczników „Ochrona środowiska” GUS za lata 2001-2016 oraz kolejnych wydań „Rocznik statystyczny Rzeczpospolitej Polskie", GUS za lata 2001-2016. Wskaźniki zmian cen CPI za http://www. inflation.eu/inflation-rates/poland/historic-inflation/cpi-inflation-poland-2015.aspx.

Poprawa efektywności jest zatem szacowana na 49\%. Te wyniki dotyczą analizy WDB w cenach stałych, które to podejście wydaje się najbardziej poprawne i obiektywne. Ta sama analiza w cenach bieżących daje jeszcze korzystniejsze wyniki - wzrost efektywności osiąga 74\%. Pomijanie zmian wartości pieniądza w czasie jest jednak trudne do uza- 
sadnienia. Dlatego bardziej zdezagregowana analiza wg sekcji PKD widoczna na rys. 2 uwzględnia wyłącznie obliczenia w cenach stałych.

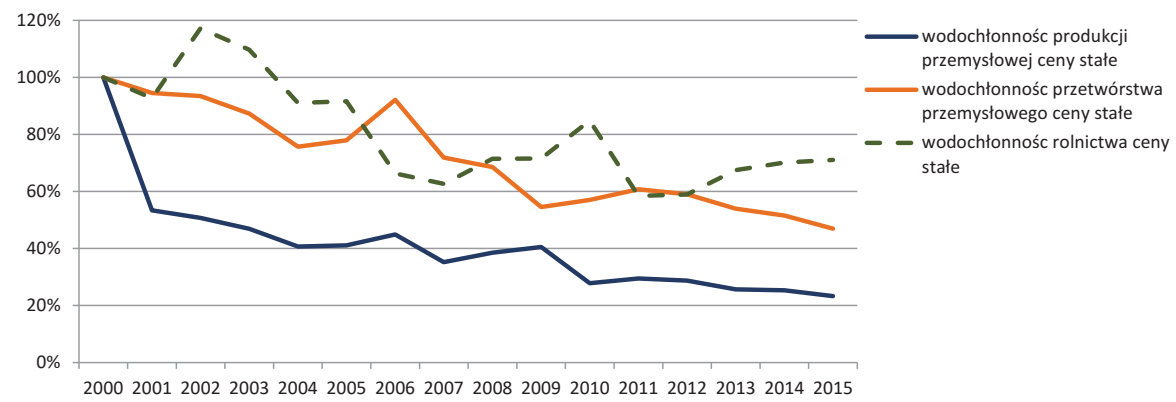

Rysunek 2. Dynamika zmian wodochłonności WDB w poszczególnych sekcjach, rok 2000 jako rok bazowy $=100 \%$. Źródło: Jak do rys. 1 .

Za szczególny sukces uznać należy 4-krotny spadek wodochłonności w produkcji przemysłowej. Wskaźnik dla roku 2014 jest równy 25\% wartości bazowej z roku 2000. Trudniejsza do interpretacji jest dynamika wskaźnika wodochłonności dla rolnictwa. W tym obszarze również mamy do czynienia ze wzrostem efektywności, jednak - biorąc pod uwagę wydajność polskiego rolnictwa (porównując tzw. plony referencyjne z innymi państwami UE) - można mieć wątpliwości, czy kierunek ekstensyfikacji działalności jest faktycznie wskazany.

Nader ciekawa jest analiza zużycia wody przez gospodarstwa domowe. Wartość średnia roczna dla Polski jest wypadkową dwóch przeciwstawnych trendów: systematycznego ograniczania zużycia w miastach (o blisko 25\% w okresie 2000-2015) oraz konsekwentnego wzrostu zużycia na obszarach wiejskich. Spadek zużycia jednostkowego w miastach (i w Polsce ogółem) jest dość łatwo tłumaczony wzrostem cen oraz postępującym wyposażaniem mieszkań $\mathrm{w}$ indywidualne liczniki zużycia. Oba te zjawiska występują również na wsi, co jednak nie prowadzi do obniżenia jednostkowej konsumpcji. 


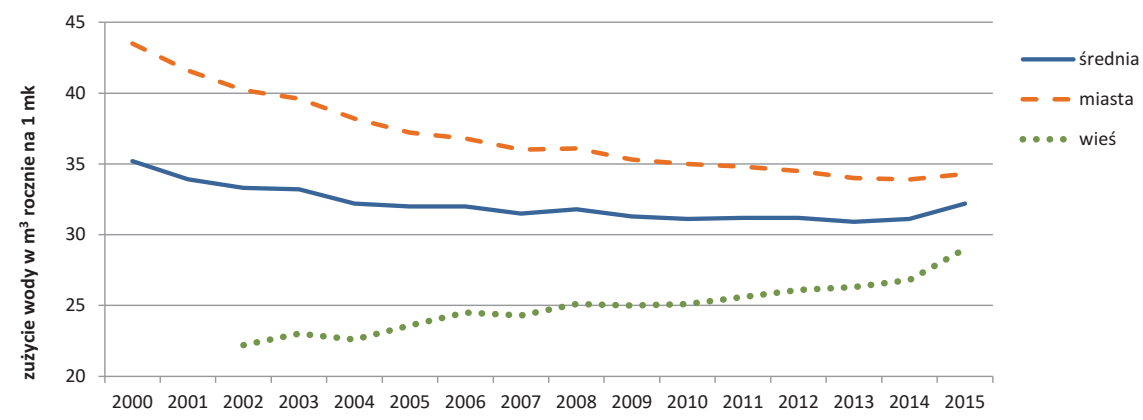

Rysunek 3. Zmiana zużycia jednostkowego wody w gospodarstwach domowych w Polsce. Źródło: opracowanie własne na podstawie kolejnych roczników „Ochrona środowiska” GUS za lata 2001-2016.

Wzrost zużycia towarzyszący wzrostowi cen jest na obszarach wiejskich tłumaczony innym, równoległym procesem. W roku 2003 (dane wcześniejsze są niedostępne) różnica pomiędzy odsetkiem mieszkańców terenów wiejskich mających dostęp do wodociągu, a równocześnie nie mających podłączenia do kanalizacji, wynosiła 54,6 punktów procentowych (p.p.). Gospodarstwa te korzystały najczęściej ze zbiorników bezodpływowych, borykając się z wysokimi kosztami ich opróżniania lub stosując metody pozaprawne. Ta sama różnica w roku 2015 wyniosła 45,6 p.p. (GUS, 2016b). Oznacza to, że ok 3,5 mln mieszkańców wsi uzyskało dostęp do sieci kanalizacyjnych, co pozwoliło gwałtownie zwiększyć zużycie wody. Zjawiska dostępu do obu sieci - wodociągowej i kanalizacyjnej - nie należy traktować w kategoriach negatywnych, jest to współczesny standard cywilizacyjny. W kategoriach negatywnych należy postrzegać korzystanie ze zbiorników bezodpływowych do gromadzenia nieczystości ciekłych. Obliczenia na bazie danych o ich liczbie i wywiezionej objętości nieczystości płynnych podawane przez GUS (2016b) pozwalają obliczyć ilość produkowanych ścieków na poziomie 7 litrów/osobę dziennie. Ten sam wskaźnik dla polskich miast wynosi 94 litry/os/d. Alokacja pozostałej ilości ścieków z obszarów wiejskich jest oficjalnie nieznana, aczkolwiek wyjątkowo wolne tempo poprawy jakości wód powierzchniowych w Polsce wydaje się mieć wyraźne związek z opisanym zjawiskiem. Dlatego też wzrost zużycia wody na 
obszarach wiejskich połączony ze wzrostem stopy podłączenia do sieci kanalizacyjnych również powinien być postrzegany jako zjawisko pozytywne - przynajmniej w kontekście stanu zasobów wodnych w Polsce. $\mathrm{W}$ badaniu zrezygnowano $\mathrm{z}$ uwzględnienia wpływu emigracji na wyniki, dane dotyczące wielkości emigracji są dostępne dopiero od 2004 r., zaś odchylenia związane $\mathrm{z}$ tym procesem oszacowano na maks. 3,5\%, czyli w granicach błędu oszacowania przeciętnego zużycia. Stąd też decyzja o zaniechaniu korekty.

Znacznie prostsze $\mathrm{w}$ interpretacji są procesy poprawy gospodarowania wodą widoczne na poziomie działalności operatorów komunalnych. Relacja pomiędzy wodą sprzedaną a pobraną (odniesiona do wody pobranej - stąd wartości w procentach) świadczy o coraz większej efektywności operatorów.

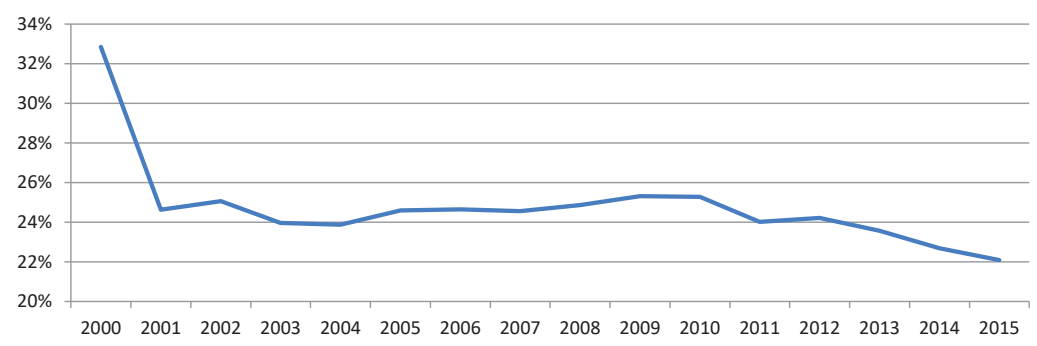

Rysunek 4. Zmiany efektywności gospodarowania wodą przez operatorów wod-kan w Polsce. Źródło: opracowanie własne na podstawie kolejnych roczników „Ochrona środowiska” GUS za lata 2001-2016.

Interpretacja powyższego wykresu jest dość intuicyjna, coraz mniejszy odsetek wody pobranej nie trafia do odbiorców. Względna wartość strat i zużycia na cele techniczne - spada.

\section{Wnioski}

Przedstawione obliczenia pozwalają na sformułowanie optymistycznej opinii na temat zmian efektywności wykorzystania zasobów wodnych w Polsce. Efektywność rośnie we wszystkich sekcjach działalności gospodarczej, a rezultaty osiągnięte od roku 2000 są znaczące 
- minimalna poprawa efektywności wykorzystania wody w analizowanych sektorach to $25 \%$. Takie wyniki obliczeń korzystnie świadczą $\mathrm{o}$ istniejącym systemie zarządzania złożonym $\mathrm{z}$ opłat za korzystanie z wód i pozwoleń na to korzystanie. Pod adresem tego miksu instrumentów można sformułować sporo zastrzeżeń szczegółowych, jednak wskaźniki efektywności bronią przyjętych rozwiązań. Jest oczywiście kwestią zupełnie otwartą, czy inny zbiór instrumentów administracyjno-prawnych byłby efektywniejszy i czy można by osiągnąć lepszą dynamikę zmian. W kontekście próby dość fundamentalnej reformy systemu opłat wprowadzanej obecnie (2016) w ramach nowego projektu ustawy o prawie wodnym należy zadać pytanie, czy nowatorska koncepcja przewiduje mocniejsze bodźce, które mają oddziaływać na oszczędzanie zasobów. Aspekt ten nie był jednak analizowany w ramach proponowanych zmian. Tak optymistyczna konkluzja ogólna nie obiecuje jednak zbilansowania potrzeb wodnych w skali lokalnej. Im większy poziom dezagregacji tym wyższe prawdopodobieństwo wystąpienia lokalnych deficytów. Jest to wyraźny sygnał na rzecz dalszej poprawy efektywności gospodarowania wodą.

\section{Bibliografia:}

EUWI. 2012. Pricing water resources to finance their sustainable management: A think-piece for the EUWI Finance Working Group. EU WaterInitiative - Finance WorkingGroup.

GUS. 2016a. Informacja o rozmiarach $i$ kierunkach emigracji $z$ Polski w latach 2004-2015. Dostęp: 13.11.2016. http://stat.gov.pl/obszary-tematyczne/ludnosc/migracje-zagraniczne-ludnosci/informacja-o-rozmiarachi-kierunkach-emigracji-z-polski-w-latach-20042015,2,9.html.

GUS. 2016b. Infrastruktura komunalna w 2015 roku. Warszawa.

GUS. 2016c. Ochrona środowiska w 2015 roku. Warszawa: Główny Urząd Statystyczny. Dostęp: 18.11.2016. http://www.inflation.eu/inflation-rates/poland/historic-inflation/cpi-inflation-poland-2015.aspx.

Krajowy Zarząd Gospodarki Wodnej. 2013. Opracowanie analizy zwrotu kosztów za usługi wodne z uwzględnieniem prognozy rozwoju na obszarach dorzeczy. Gliwice (maszynopis niepublikowany). 
Integrated Water Resources Management in Practice, red. Roberto Lenton i Mike Muller. 2009. London: Earthscan.

Merett, Stephan. 1997. Introduction to the Economics of Water Resources. London: UCL.

Pearce, David W. i Kerry Turner. 1990. Economics of Natural Resources and Environment. New York: Harvester Wheatsheaf. 

Ewa Jakusik

Oddział Morski IMGW-PIB w Gdyni - Zakład Badań Morskich ewa.jakusik@imgw.pl

\section{Spodziewane zmiany wysokości fali w południowej części Morza Bałtyckiego w XXI wieku}

\section{Wstęp}

Rozkład ciśnienia atmosferycznego nad Europą i Północnym Atlantykiem jest głównym czynnikiem kształtującym wysokość falowania na obszarze Bałtyku (Jakusik 2006, 5-7). Czynniki lokalne wpływające na charakterystykę falowania są rozpoznawalne zwykle przez dalsze funkcje własne jako mniej istotne dla kształtowania warunków hydrologicznych akwenu. Stąd też możliwe staje się wykorzystanie rezultatów stworzonego modelu statystyczno-empirycznego, który w połączeniu $\mathrm{z}$ rezultatami symulacji globalnych modeli klimatycznych pozwala na określenie prawdopodobnych zmian wysokości falowania według scenariuszy emisyjnych: A1B, A2, B1 (IPCC 2009, 11).

Istotnym czynnikiem wpływającym na wyniki symulacji klimatu są założenia strategii rozwoju ekonomicznego świata, a co za tym idzie antycypowane scenariusze emisji gazów cieplarnianych i innych zanieczyszczeń. Jako standard do oceny wpływu zmian klimatu zalecany jest zestaw scenariuszy emisji (GHG - greenhouse gas, gaz cieplarniany) opracowanych na zlecenie Międzyrządowego Zespołu ds. Zmian Klimatu (IPCC - Intergovernmental Panel on Climate Change) opisany w Specjalnym Raporcie o Scenariuszach Emisji (A1, A2, B1 i B2). Każdy ze scenariuszy zakłada różne zmiany kilku podstawowych czynników wpływających na emisję gazów cieplarnianych, takich jak: wzrost liczby ludności, rozwój technologiczny i ekonomiczny, wiodące polityki i zużycie energii. Scenariusze SRES nie uwzględniają żadnych działań, które mogą zostać podjęte w celu zmiany dotychczasowej emisji; te elementy uwzględniają warianty obliczeniowe związane $\mathrm{z}$ daną rodziną scenariuszy bazowych. Leżące u ich podstaw założenia służą za dane wyjściowe do wielu oszacowań wpływu i skutków zmian klimatu. Scenariusze A1 zakładają raptowny wzrost gospodarczy, osią- 
gnięcie szczytowej liczebności populacji globalnej w połowie XXI w. oraz niezwykle szybkie wprowadzanie nowych i bardziej efektywnych technologii. Rodzina A1 dzieli się na 3 grupy opisujące alternatywne kierunki zmian technologicznych: intensyfikację użycia paliw kopalnych (A1F1), źródła energii inne niż paliwa kopalne (A1T) oraz równowage pomiędzy wykorzystaniem tych zasobów (A1B). Scenariusz B1 opisuje świat, w którym wzrost populacji przebiega tak samo, ale zmiany w strukturach ekonomicznych przebiegają szybciej. W scenariuszu B2 zakłada się średni wzrost wielkości populacji i średni wzrost ekonomiczny, z naciskiem na lokalne rozwiązania prowadzące do rozwoju trwałego i zrównoważonego w aspektach ekonomicznym, społecznym i środowiskowym. Scenariusz A2 przedstawia bardzo niejednorodny świat, $\mathrm{z}$ wysokim wzrostem populacji, wolnym wzrostem i rozwojem ekonomicznym i gospodarczym oraz wolnymi zmianami technologicznymi. Dla żadnego ze scenariuszy nie określono prawdopodobieństwa jego wystąpienia.

Bardzo istotnym skutkiem zmian klimatu w południowej części Morza Bałtyckiego jest wzrost intensywności falowania, podnoszenie się poziomu morza i nasilenie się wezbrań sztormowych oraz wystąpienie powodzi i erozji wybrzeży. Osiągnięcie zrównoważonego rozwoju strefy przybrzeżnej, w myśl zasad Agendy 21, możliwe jest poprzez prowadzenie prawidłowej polityki wykorzystania ziemi, wód i działek budowlanych, opracowanie planów Zintegrowanego Zarządzania Obszarami Przybrzeżnymi (ZZOP), podjęcie wyprzedzających ocen dotyczących oddziaływania na środowisko i włączenie najnowszych wyników badań naukowych do procesu decyzyjnego, adaptację infrastruktury do zmieniających się warunków przyrodniczych oraz promowanie technologii zgodnych z ochroną środowiska i zrównoważonego rozwoju.

\section{Cel i zakres prac}

Głównym celem pracy było określenie wpływu regionalnego pola barycznego w rejonie Europy i Północnego Atlantyku na kształtowanie lokalnych warunków oceanograficznych (wysokości falowania) w południowej części Morza Bałtyckiego w okresie 1988-1993. Ponadto - 
opracowanie scenariuszy spodziewanej zmienności wysokości falowania w XXI wieku, ze szczególnym uwzględnieniem okresów 2011-2030 oraz 2081-2010, w celu ewentualnego wykorzystaniu rezultatów przy opracowaniu strategii adaptacji do skutków ewentualnych zmian klimatu.

Realizacja celu pracy wymagała:

a) identyfikacji przestrzennej i czasowej zmienności lokalnego pola wysokości falowania dającego informację o procesach fizycznych zachodzących w południowej części Morza Bałtyckiego,

b) określenia jakościowego i ilościowego związku między regionalną cyrkulacją atmosferyczną a warunkami lokalnymi na analizowanym obszarze,

c) opracowania scenariuszy spodziewanej zmienności falowania w południowej części Morza Bałtyckiego w warunkach ścieżki emisyjnej A2, B1 i A1B.

Podjęte badania pozwolą na określenie roli Bałtyku jako czynnika klimatotwórczego (w skali regionalnej i lokalnej), niosącego również zagrożenie dla środowiska obszarów położonych wzdłuż polskiego wybrzeża, a tym samym dla ludności żyjącej w tym środowisku.

\section{Opis metodyki badań}

Analizie poddano zmiany wysokości falowania w zakresie zróżnicowania wartości kwantyla 95\% w skali roku oraz sezonów: bezsztormowego (kwiecień-sierpień) i sztormowego (wrzesień-marzec) w 293 punktach gridowych rozmieszczonych na Południowym Bałtyku. Poddane analizie dane pochodzą z modelu HYPAS opracowanego przez zespół pracujący w GKSS Forschungzentrum w Geesthacht k. Hamburga (Gayer, Güenther i Winkel 1995, 9).

Model HYPAS (Hybrid Parametrical Shallow Water Wave Model) jest modelem parametrycznym, w którym postać widma częstotliwościowego $F(f)$ jest $z$ góry zadana $w$ formie widma TMA (Texel-Marsen-Arsloe) stanowiącego rozszerzenie standardowego widma JONSWAP (Joint North Sea Wave Program) na obszar płytkowodny. Tryb „hind- 
cast" oznacza zaś symulację falowania z przeszłości w oparciu o znane pola ciśnienia atmosferycznego. Rozdzielczość przestrzenna modelu wynosiła $15,875 \mathrm{~km}$, a integracji widm dokonywano co 15 minut. Zgodnie z zasadami określonymi przez Marine Climatological Summary Scheme - MCSS (WMO 1990, 8; WMO 1994, 14), liczebność populacji elementów opisujących pole falowania na podstawie wspomnianego hindcastu jest w pełni wystarczająca do wyznaczenia 40-letnich statystyk.

$\mathrm{W}$ celu scharakteryzowania struktury przestrzennej i czasowej zmienności wysokości falowania w południowej części Morza Bałtyckiego zastosowano technikę empirycznych funkcji własnych (ang. Empirical Orthogonal Function, EOF). W następnym etapie badań zdecydowano się na przeprowadzenie analizy zależności zmienności falowania w południowej części Morza Bałtyckiego od zmian wymuszającego czynnika wielkoskalowego, w tym wypadku cyrkulacji atmosferycznej na poziomie morza nad regionem Północnego Atlantyku i Europy. Do realizacji nakreślonego zadania wykorzystano metodę zaliczaną do technik downscalingu, tzw. metodę kanonicznych korelacji (ang. Canonical Correlation Analysis, CCA). Cyrkulacja atmosferyczna została scharakteryzowana dla okna zawartego między $50^{\circ} \mathrm{W}$ a $40^{\circ} \mathrm{E}$ i $35^{\circ} \mathrm{N}$ a $75^{\circ} \mathrm{N}$, pozyskana z reanalizy NCEP/NCAR (Kalnay et al. 1996, 12). Relacje między polem regionalnym a lokalnym określono na podstawie danych z okresu referencyjnego 1988-1993.

Scenariusze zmian falowania zostały opracowane w odniesieniu do okresu referencyjnego $\mathrm{z}$ wykorzystaniem zidentyfikowanych metodą CCA relacji między regionalnym polem barycznym a kwantylem $95 \%$ wysokości falowania. Informacje o przyszłych zmianach cyrkulacji atmosferycznej pozyskano z symulacji globalnej ECHAM-5. Przyszłe zmiany falowania $\mathrm{w}$ południowej części Morza Bałtyckiego zostały wyznaczone dla wybranych scenariuszy emisyjnych (B1, A1B, A2 run 1). Spodziewane zmiany falowania opracowano dla całego XXI wieku ze szczególnym uwzględnieniem okresu 2011-2030 oraz 2081-2100.

Ze względu na różnice między symulacją ciśnienia atmosferycznego przez modele globalne a wartościami rzeczywistymi, zaistniała konieczność wprowadzenia do opracowanych scenariuszy korekty 
niwelującej wpływ tych różnic na uzyskane wyniki. W tym celu pozyskano dane z symulacji kontrolnej dla XX wieku (20C3M), będącej rekonstrukcją klimatu dokonaną przez dany model globalny w warunkach zmian koncentracji gazów cieplarnianych w atmosferze rzeczywiście obserwowanych w ciągu XX wieku. Następnie wyznaczono w poszczególnych gridach anomalie ciśnienia atmosferycznego w symulacji 20C3M w stosunku do średnich (1988-1993) wartości z reanalizy NCEP (danych rzeczywistych). W oparciu o tak przygotowaną serię danych dokonano rekonstrukcji falowania w południowej części Morza Bałtyckiego dla okresu referencyjnego 1988-1993 z wykorzystaniem wcześniej opracowanego modelu statystyczno-empirycznego (CCA). Wyliczone dla okresu referencyjnego średnie wartości anomalii stanowią wartość poprawki, o którą należy skorygować scenariusze - w ten sposób wyeliminowano lub przynajmniej ograniczono wpływ różnic w danych pochodzących z dwóch źródeł (reanaliza NCEP, model globalny), pozostawiając wpływ jedynie symulowanych zmian ciśnienia w przyszłości. Korekt dokonano wyłącznie w przypadku średnich wieloletnich wartości. Należy podkreślić fakt, iż symulacje dla wykorzystanych scenariuszy emisyjny stanowią kontynuację symulacji 20C3M, dzięki czemu można zakładać, iż wartości wyznaczonych korekt są stałe w czasie.

\section{Charakterystyka osiągniętych wyników}

\subsection{Kwantyl 95\% wysokości falowania (1988-1993)}

Zakres zmienności wysokości falowania, na Południowym Bałtyku w analizowanym okresie jest bardzo rozległy. Roczna wartość kwantyla 95\% wysokości fali w południowej części Morza Bałtyckiego mieści się w zakresie powyżej 1,5 m (rys. 1). Najwyższe roczne wartości kwantyla 95\% wysokości fali odnotowuje się w Basenie Gotlandzkim, a najniższe w Zatoce Pomorskiej i Gdańskiej oraz u wybrzeży Szwecji.

W sezonie sztormowym (rys. 1) jak i bezsztormowym (rys. 1), największe wartości omawianego kwantyla wysokości fali odnotowuje się na południe od Gotlandii, a najmniejsze w rejonie zatok. Rozkłady przestrzenne 95\% kwantyla wysokości fali potwierdzają, że największe falowanie występuje w centralnej części Bałtyku. 


\section{ROK}

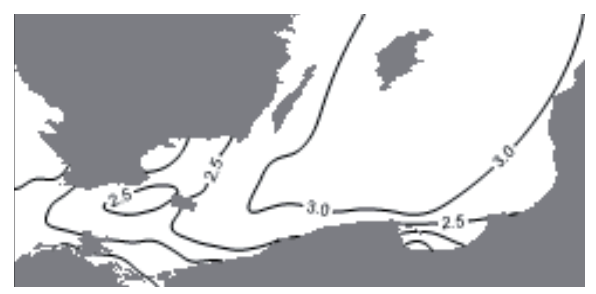

\section{SZTORM}

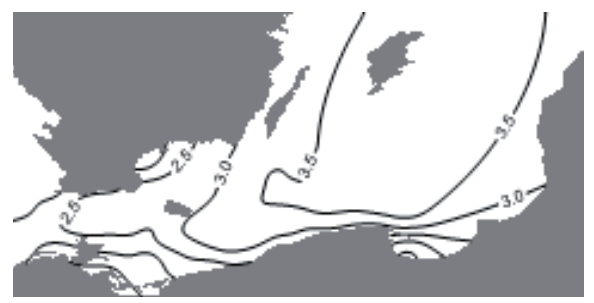

CISZA

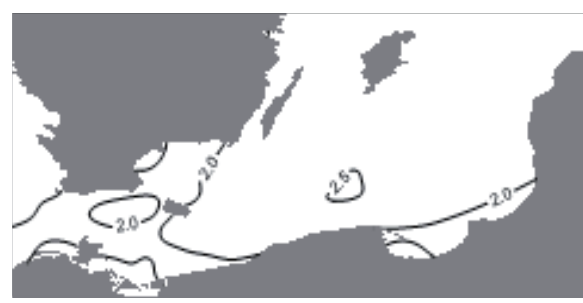

Rys. 1. Kwantyl 95\% wysokości falowania (m) według modelu HYPAS. Źródło: opracowanie własne.

3.2. Związek między regionalnym polem barycznym nad Europą i Północnym Atlantykiem a wysokością fali w południowej części Morza Bałtyckiego

W celu określenia związków między regionalną cyrkulacją atmosferyczną a kwantylem 95\% wysokości falowania wykorzystano metodę korelacji kanonicznych. W przypadku wysokości falowania rozpatrywanego w skali roku, jak i sezonów, uzyskano cztery pary map kanonicznych (tab. 1). Mapy pola lokalnego kwantyla $95 \%$ wysokości falowania w skali roku wyjaśniają łącznie 97,02\% wariancji tego elementu (tab. 1). Wariancja pola ciśnienia jest natomiast wytłumaczona w $67,25 \%$ (tab. 1).

Pierwsza mapa kanoniczna pola dla całego roku wyjaśnia 18,69\% wariancji pola regionalnego i 19,77\% wariancji pola lokalnego (tab. 1). Pole regionalne (rys. 2a) przedstawia rozległą anomalię obejmującą swym zasięgiem praktycznie cały interesujący nas region. Jej centrum jest zlokalizowane na południowy zachód od Irlandii i Wielkiej Brytanii ( $3 \mathrm{hPa}$ ). Jedynie północne i wschodnie krańce regionu są pod wpływem układu o przeciwnym znaku. 
Pierwsza mapa pola kwantyla 95\% wysokości fali (rys. 2b) przedstawia w basenie Morza Bałtyckiego anomalie wysokości fali $(\mathrm{H})$ zgodnego znaku. Największe anomalie wysokości falowania w zakresie zróżnicowania wartości kwantyla 95\% występują w południowej części Wschodniego Basenu Gotlandzkiego, a najmniejsze u południowo-wschodnich wybrzeży Szwecji.

Druga mapa kanoniczna pola barycznego (rys. 3a) wyjaśniająca 26,90\% wariancji pola regionalnego przedstawia rozległy układ baryczny, obejmujący swym wpływem Skandynawię, Islandię, Wyspy Brytyjskie i znaczną część Europy. W jego centrum, zlokalizowanym w rejonie archipelagu Wysp Szetlandzkich, wartość anomalii ciśnienia wynosi $5 \mathrm{hPa}$. Występuje spływ mas powietrza z północy. Odpowiadająca tej mapie regionalnej lokalna mapa kanoniczna (rys. 3b) wyjaśnia aż 19,85\% wariancji kwantyla 95\% wysokości fali. W efekcie w całym basenie Bałtyku występują ujemne anomalie wysokości fali. Ich wartości wzrastają w miarę przesuwania się od zachodu ku wschodowi. Współczynnik korelacji kanoniczej wynosi 0,55 (tab. 1).

\begin{tabular}{|c|c|c|c|c|c|c|c|c|c|}
\hline \multirow{2}{*}{ CCA } & \multicolumn{3}{|c|}{ Rok } & \multicolumn{3}{c|}{ Sezon sztormowy } & \multicolumn{3}{c|}{ Sezon bezsztormowy } \\
\cline { 2 - 10 } & $\mathbf{r}$ & var H & $\begin{array}{c}\text { var } \\
\text { SLP }\end{array}$ & $\mathbf{r}$ & var H & $\begin{array}{c}\text { var } \\
\text { SLP }\end{array}$ & r & $\begin{array}{c}\text { var } \\
\text { H }\end{array}$ & var SLP \\
\hline $\mathbf{1}$ & 0,82 & 19,77 & 18,69 & 0,89 & 21,57 & 21,41 & 0,98 & 9,83 & 29,32 \\
\hline $\mathbf{2}$ & 0,55 & 19,85 & 26,90 & 0,67 & 2,14 & 13,98 & 0,82 & 54,55 & 6,91 \\
\hline $\mathbf{3}$ & 0,49 & 17,58 & 8,06 & 0,49 & 40,09 & 22,65 & 0,68 & 14,81 & 15,40 \\
\hline $\mathbf{4}$ & 0,31 & 39,82 & 13,6 & 0,25 & 33,70 & 19,13 & 0,54 & 17,34 & 13,24 \\
\hline $\mathbf{\Sigma}$ & & $\mathbf{9 7 , 0 2}$ & $\mathbf{6 7 , 2 5}$ & & $\mathbf{9 7 , 5}$ & $\mathbf{7 7 , 1 7}$ & & $\mathbf{9 6 , 5 3}$ & $\mathbf{6 4 , 8 7}$ \\
\hline
\end{tabular}

Tab. 1. Wyjaśniana wariancja (\%) oraz współczynniki korelacji kanonicznej

(r) regionalnego pola barycznego (SLP) oraz pola kwantyla

95\% wysokości fali (H) (CCA). Źródło: opracowanie własne. 
W sezonie sztormowym związek między regionalnym polem barycznym a kwantylem 95\% wysokości fali w południowej części Morza Bałtyckiego określony przez pierwszą parę map przedstawia, że mapa pola barycznego wyjaśnia 21,41\% jego wariancji, a ta właściwa dla pola lokalnego 21,57\% wariancji (tab. 1). Mapa pola barycznego dla tego sezonu prezentuje sytuację, w której anomalie ciśnienia mają taki sam znak ciśnienia jak w przypadku całego roku. Lokalizacja centrum dominującego układu (nad Irlandią i Wielką Brytanią) przypomina położenie w skali roku. W efekcie w całym basenie Bałtyku występują dodatnie anomalie wysokości fali. Ich wartości wzrastają w miarę przesuwania się od zachodu ku wschodowi, osiągając maksimum we Wschodnim Basenie Gotlandzkim na wysokości Głębi Gdańskiej (0,5 m). Współczynnik korelacji kanoniczej jest znaczny i wynosi 0,89 (tab. 1).

Druga mapa kanoniczna pola barycznego, wyjaśniająca 13,98\% jego wariancji, przedstawia północną część Europy, wraz z Bałtykiem, pod wpływem silnego układu z centrum między Islandią a Norwegią. Centrum układu o przeciwnym znaku znajduje się w rejonie Płw. Bretońskiego. Mapa pola lokalnego wyjaśnia 2,14\% wariancji lokalnej, korelacja między polem regionalnym a lokalnym wynosi 0,67 (tab. 1). Odpowiadająca jej mapa pola lokalnego przedstawia w basenie Bałtyku anomalie kwantyla 95\% wysokości fali o zróżnicowanej odpowiedzi na wymuszenie regionalne. We Wschodnim Basenie Gotlandzkim występują ujemne anomalie wysokości fali sięgające do $(-0,2 \mathrm{~m})$. W pozostałej części analizowanego obszaru występują anomalie przeciwnego znaku. Współczynnik korelacji kanonicznej ma wartość 0,67.

Pierwsza para map kanonicznych z sezonu bezsztormowego charakteryzuje się wysokim współczynnikiem korelacji kanonicznej, wynoszącym 0,98 . W przypadku regionalnego pola barycznego wyjaśnia ona 29,32\% jego zmienności, w przypadku pola lokalnego - 9,83\% (tab. 1). Pierwszy wektor kanoniczny pola barycznego przedstawia interesujący nas obszar pod wpływem rozległego układu znajdującego się na zachód od Irlandii ( $4 \mathrm{hPa})$. Układ ten obejmuje swym zasięgiem zachodnią część kontynentu europejskiego i część przylegającego doń oceanu. W rejonie Południowego Bałtyku występują anomalie jednakowego znaku osiągające największe wartości wzdłuż polskiej strefy brzegowej $(0,2 \mathrm{~m})$. 
Druga mapa kanoniczna pola barycznego, wyjaśniająca 6,91\% wariancji pola regionalnego, przedstawia dość skomplikowany układ ośrodków w interesującym nas regionie. Odpowiadająca tej mapie regionalnej lokalna mapa kanoniczna, wyjaśnia aż 54,55\% wariancji wysokości fali (tab. 1). Współczynnik korelacji kanonicznej wynosi 0,82 (tab. 1). Druga mapa kanoniczna wysokości fali przedstawia ujemne wartości anomalii. Największe wartości bezwzględne anomalii występują w centralnej części Wschodniego Basenu Gotlandzkiego, a najmniejsze w Zachodnim Basenie Bornholmskim.

a)

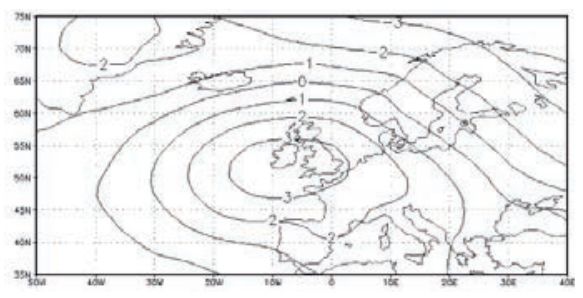

c)

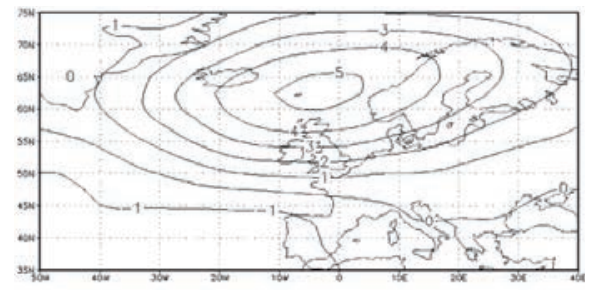

b)

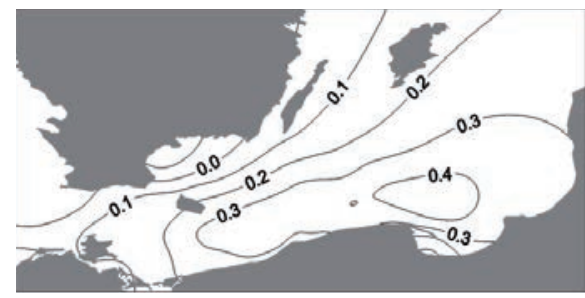

d)

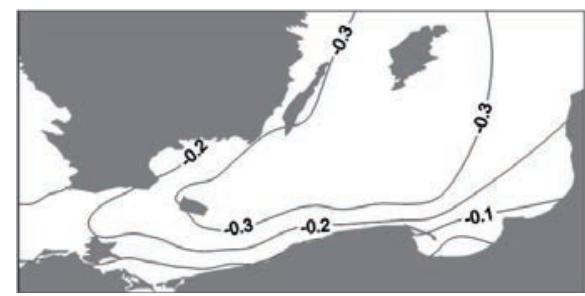

Rys. 2. Pierwsza para map kanonicznych regionalnego pola barycznego (hPa) w rejonie Północnego Atlantyku i Europy oraz wysokości fali (m) w południowej części Morza Bałtyckiego w ciągu roku - 1988-1993. Źródło: opracowanie własne.

\subsection{Weryfikacja modelu}

W celu oceny przedstawionego powyżej modelu wyznaczone relacje między regionalnym polem barycznym (SLP) a elementem lokalnym 
(H) wykorzystano do rekonstrukcji zmian kwantyla 95\% wysokości falowania w południowej części Morza Bałtyckiego. Zdolność modelu do odtwarzania warunków rzeczywistych oceniono na podstawie współczynnika korelacji między serią zrekonstruowaną a serią obserwacyjną, tj. pochodzącą z modelu HYPAS (Miętus i Filipiak 2002, 5). Przy rekonstrukcji wykorzystano maksymalną liczbę par map kanonicznych dla poszczególnych skal czasowych. Walidacji dokonano dla okresu zależnego 1988-1993. W analizowanych skalach czasowych współczynniki korelacji między serią zrekonstruowaną i obserwacyjną mają największe wartości we Wschodnim Basenie Gotlandzkim, na południe od Gotlandii oraz we Wschodnim Basenie Bornholmskim. Najmniejsze wartości współczynnik korelacji przyjmuje w Zachodnim Basenie Bornholmskim i w zatokach: Pomorskiej i Gdańskiej.

\section{Scenariusze zmian falowania w południowej części Morza Bałtyckiego w XXI wieku}

Spodziewane zmiany kwantyla 95\% wysokości falowania w latach 2011-2030, w skali roku, w odniesieniu do okresu 1988-1993 dla analizowanych scenariuszy emisyjnych będą niewielkie i z reguły nie przekroczą $0,15 \mathrm{~m}$. Generalnie należy zaznaczyć, iż w przypadku scenariusza emisyjnego B1 i A1B największych zmian (wzrostów) należy spodziewać się w centralnej części Wschodniego Basenu Gotlandzkiego, natomiast według scenariusza emisyjnego A2 - w rejonie Olandii i w południowej części Wschodniego Basenu Gotlandzkiego. Najmniejszych zmian wartości analizowanego kwantyla należy spodziewać się w zachodniej części polskiego wybrzeża, który nie powinien przekroczyć $0,05 \mathrm{~m}$.

W ostatnim dwudziestoleciu XXI wieku spodziewane zmiany kwantyla $95 \%$ wysokości falowania w skali roku wskazują na wystąpienie znacznego wzrostu wartości analizowanego wskaźnika w odniesieniu do okresu referencyjnego 1988-1993. Największego wzrostu wartości kwantyla 95\% wysokości falowania należy spodziewać się przy uwzględnieniu ścieżki emisyjnej A2 we Wschodnim Basenie Gotlandzkim, który może przekroczyć $0,30 \mathrm{~m}$. W przypadku scenariusza A1B fale mogą maksymalnie wzrosnąć o $0,25 \mathrm{~m}$ na analizowanym obszarze (rys. 4). Najmniejszy wzrost wartości analizowanego elementu przewiduje scenariusz B1, który uwidacznia zmianę rzędu 0,00-0,15 m. Warto podkreślić, iż w przypad- 
ku wszystkich scenariuszy emisyjnych w rejonie Zatoki Pomorskiej oraz wzdłuż wybrzeży Szwecji spodziewane zmiany analizowanego wskaźnika najprawdopodobniej utrzymają się na poziomie z uwzględnianego okresu referencyjnego, czyli będą oscylować wokół wartości 0 .

W przypadku sezonów zarysowuje się silne zróżnicowanie zarówno co do charakteru, jak i tempa spodziewanych zmian wartości kwantyla 95\% wysokości falowania. Rezultaty symulacji przeprowadzonej w odniesieniu do dwudziestolecia 2011-2030 wskazują na wystąpienie znacznego wzrostu wartości omawianego elementu w sezonie bezsztormowym i nieco mniejszego w sezonie sztormowym.

W sezonie sztormowym niemal na całym obszarze badań w dwudziestoleciu 2011-2030 spodziewane są nieznaczne wzrosty wartości kwantyla 95\% wysokości falowania. W podokresie 2011-2030 wzrost wartości elementu nie powinien być większy niż 0,05 (scenariusz B1 i A2) i 0,10 m (scenariusz A1B). Największych zmian, przekraczających 0,10 m należy spodziewać się w południowej części Wschodniego Basenu Bornholmskiego, a dokładnie w rejonie Rynny Słupskiej, a także w rejonie Głębi Gdańskiej. Warto zaznaczyć, iż w przypadku każdego z trzech rozpatrywanych scenariuszy emisyjnych opartych na symulacji modelem ECHAM5 zmiany analizowanego elementu najprawdopodobniej nie zaznaczą się wzdłuż wybrzeży Szwecji, w rejonie Olandii i w przeważającej części Wschodniego Basenu Gotlandzkiego i najprawdopodobniej utrzymają się na poziomie z lat 1988-1993.

W ostatnim dwudziestoleciu XXI wieku w sezonie sztormowym zakres spodziewanych zmian ekstremów falowania znacznie się zwiększy i w przypadku scenariusza emisyjnego A2 spodziewać się można wzrostu wartości o nieco ponad 0,30 $\mathrm{m}$. W przypadku scenariusza emisyjnego A1B wartość analizowanego elementu wynikająca ze zmian mikroskalowych charakterystyk cyrkulacji atmosferycznej ulegnie zmianie o 0,20m w stosunku do wartości z lat 1988-1993 (rys. 4). Spośród trzech analizowanych scenariuszy emisyjnych najmniejsze zmiany wartości kwantyla 95\% wysokości falowania uwidacznia scenariusz B1, fale zwiększą się maksymalnie o $0,10 \mathrm{~m}$ w stosunku do okresu referencyjnego. Obszarem największego wzrostu wartości kwantyla 95\% wysokości falowania w południowej części Morza Bałtyckiego będzie Głębia Bornholmska, Rynna Słupska oraz Głębia Gdańska. Najmniejszych zmian spodziewać 
się należy w zachodniej części Bałtyku, a dokładnie wzdłuż pasa wodnego przy brzegach szwedzkich oraz w Zatoce Gdańskiej.

W sezonie bezsztormowym na całym analizowanym obszarze wyraźnie zaznaczą się wzrosty wartości kwantyla 95\% wysokości falowania. W przypadku dwóch analizowanych wieloleci największych zmian analizowanego wskaźnika należy spodziewać się między Bornholmem a Gotlandią. W podokresie 2011-2030 najmniejsze zmiany (wzrosty) spodziewane są według scenariusza B1 $(>0,15 \mathrm{~m})$, a największe według scenariusza A1B (>0,40 m). W ostatnim dwudziestoleciu XXI wieku w sezonie bezsztormowym spodziewane zmiany wartości kwantyla 95\% wysokości falowania będą wyraźniej zaznaczone niż w okresie 20112030. Najbardziej zaznaczy się to w przypadku scenariusza A2 i B1, gdzie anomalie najprawdopodobniej przekroczą $0,60 \mathrm{~m}$ i będą o ponad 0,40 m wyższe $\mathrm{w}$ stosunku do wielolecia 2011-2030. W przypadku scenariusza A1B anomalie wartości kwantyla 95\% wysokości falowania tylko nieznacznie odbiegną od struktury przestrzennej dla dwudziestolecia 2011-2030 (rys. 4).

2011-2030

Rok

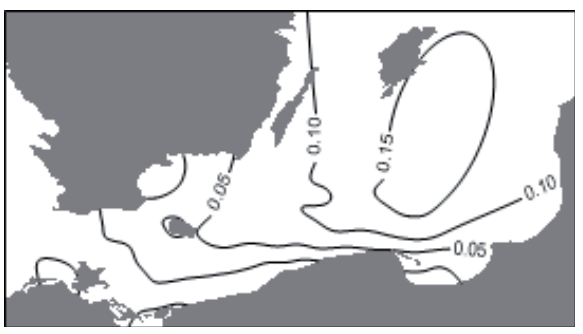

Sezon sztormowy

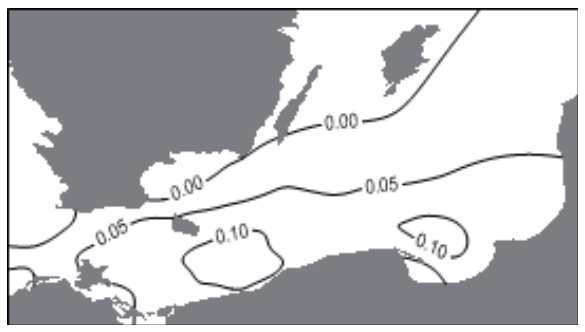

2081-2100

Rok

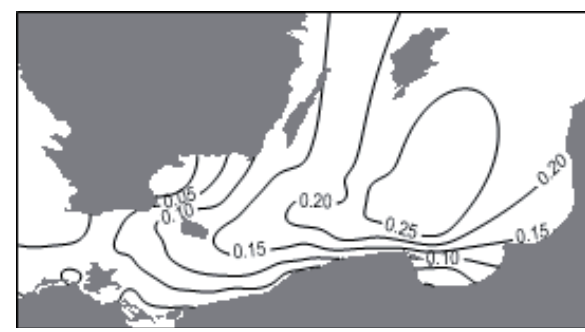

Sezon sztormowy

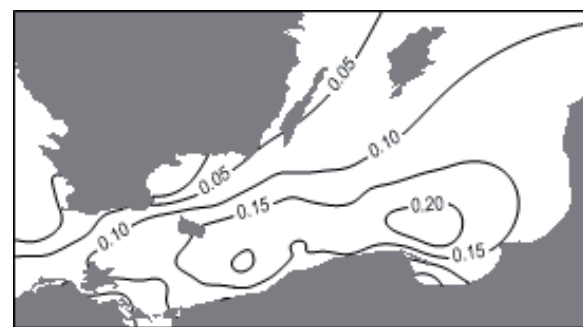


Sezon bezsztormowy

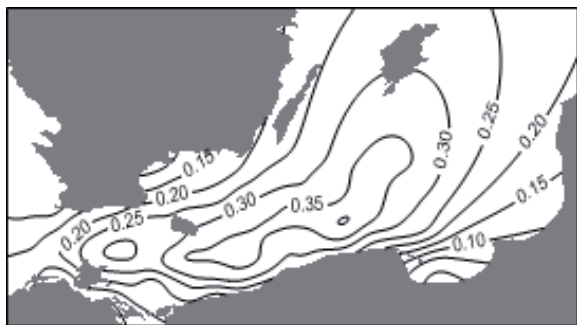

Sezon bezsztormowy

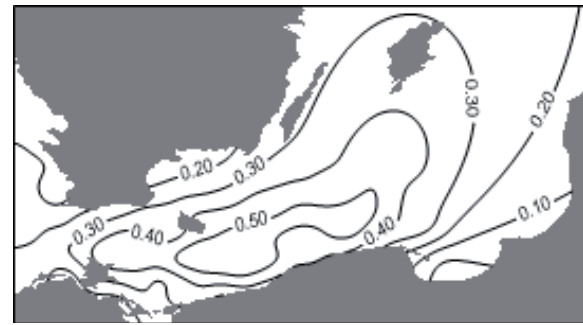

Rys. 4. Spodziewane zmiany (m) wartości kwantyla 95\% wysokości falowania

w latach 2011-2030 i 2081-2100 w skali roku i sezonów w odniesieniu do wartości z lat 1988-1993 według modelu ECHAM5 na podstawie scenariusza emisyjnego A1Br1. Źródło: opracowanie własne.

\section{Zakończenie}

Przeprowadzona analiza potwierdziła istnienie związku przyczynowego między regionalną cyrkulacją atmosferyczną w rejonie Europy i Północnego Atlantyku a wysokością falowania w południowej części Morza Bałtyckiego. Pozwoliła też określić empiryczne funkcje przejścia między regionalnym polem barycznym a wysokością falowania. Podstawową konsekwencją wspomnianego związku jest wzrost anomalii wysokości fali wzdłuż polskiego wybrzeża $\mathrm{z}$ zachodu na wschód lub odwrotnie, w zależności od tego czy cyrkulacja atmosferyczna sprzyja tworzeniu się fal na Bałtyku, czy też nie. Jak pokazały empiryczne funkcje przejścia między regionalnym polem barycznym nad Europą i Północnym Atlantykiem a polem lokalnym, tj. wysokością falowania w południowej części Morza Bałtyckiego, wpływ cyrkulacji atmosferycznej na zmiany falowania jest istotny. Ponadto skonstruowane przy zastosowaniu metody kanonicznej korelacji modele są kilkuwymiarowe, współczynniki korelacji między seriami czasowymi stowarzyszonymi z mapami kanonicznymi mają często wartość powyżej 0,5, a mapy kanoniczne pól lokalnych wyjaśniają ponad $97 \%$ wariancji w skali roku i sezonu sztormowego oraz ponad $96 \%$ w sezonie bezsztormowym.

Opracowane dla falowania w południowej części Morza Bałtyckiego scenariusze zmian tego elementu w latach 2011-2030 na podstawie rezultatów modelu ECHAM5 wskazują na wzrost wysokości falowania w skali roku (z wyjątkiem scenariusza B1) oraz w obu rozpatrywanych 
sezonach. Scenariusze oparte o model ECHAM5 pokazują, że w latach 2011-2030 w sezonie sztormowym kwantyl 95\% wysokości falowania będzie wyższy o 0,00-0,10 m (w scenariuszu A1B), o 0,00-0,05 m (A2 i B1) w stosunku do wartości z okresu referencyjnego 1988-1993. W sezonie bezsztormowym spodziewane zmiany wartości kwantyla 95\% wysokości falowania w południowej części Morza Bałtyckiego zwiększą się o 0,00-0,40 m (w scenariuszu A1B), o 0,00-0,20 (A2) i 0,05-0,15 m (B1) w odniesieniu do lat z 1988-1993.

Ponadto, w ostatnim dwudziestoleciu XXI wieku spodziewane zmiany kwantyla 95\% wysokości falowania w skali roku jak i obu analizowanych sezonów wskazują na wystąpienie znacznie większego wzrostu wartości analizowanego wskaźnika w odniesieniu do okresu scenariuszowego na lata 2011-2030. Przewidywane znaczne zmiany cech falowania będące rezultatem spodziewanych zmian klimatycznych stanowią potencjalne zagrożenia dla polskiej strefy brzegowej, do których należy zaliczyć:

$\checkmark$ zjawisko postępującej erozji brzegu morskiego i zaniku plaż,

$\checkmark$ w przypadku klifów nadmorskich, częściej niż dotąd mogą pojawiać się stosunkowo niewielkie osuwiska spowodowane podcięciem podnóża klifu przez fale,

$\checkmark$ zagrożenie powodziowe w sezonie sztormowym jak również w sezonie bezsztormowym,

$\checkmark$ zniszczone i uszkodzone urządzenia wodne - wały przeciwpowodziowe, falochrony przeciwsztormowe, opaski itp.,

$\checkmark$ degradację cennego pod względem przyrodniczym środowiska strefy brzegowej,

$\checkmark$ spadek atrakcyjności turystycznej nadmorskich miejscowości wypoczynkowych,

$\checkmark$ zagrożenia bezpieczeństwa ludności i jej mienia,

$\checkmark$ znaczny wzrost wydatków finansowych na ochronę brzegów Południowego Bałtyku.

Wieloletnie wyniki pomiarów i obserwacji parametrów hydroklimatycznych wykazują, że południowe wybrzeże Bałtyku podlega coraz 
gwałtowniejszym oddziaływaniom morza. W związku z tym, przedsięwzięcia inżynieryjne wzdłuż polskiej strefy brzegowej muszą uwzględniać przewidywane znaczne wzrosty intensywności falowania oraz podnoszenie się poziomu morza.

Zarządzanie strefą przybrzeżną rozpoczyna się na poziomie lokalnym, dlatego dla właściwego przebiegu tego procesu konieczne staje się podnoszenie świadomości społeczności lokalnych, poprzez zapewnienie pełnej, systematycznej edukacji oraz wyczerpującej informacji. Priorytetem powinno być informowanie i ostrzeganie o warunkach pogodowych (sztorm na Bałtyku) oraz innych czynnikach mogących powodować utrudnienia lub zagrożenia dla zdrowia i życia ludzi. Zaleca się opracowywanie programów edukacyjnych dla różnych poziomów odbiorców (przedszkola, szkoła podstawowa, gimnazja, licea, szkoły wyższe, media i inne podmioty), których celem będzie zmiana mentalności społeczności lokalnych w kierunku ograniczenia ekspansji na tereny zagrożone oraz zmiany sposobu zagospodarowywania zamieszkałych terenów zagrożonych.

Niezbędne jest zastosowanie bardziej strategicznego i długofalowego podejścia w zakresie planowania przestrzennego do potrzeb zrównoważonego rozwoju, zarówno na obszarach lądowych, jak i morskich, w tym w dziedzinach: transportu, rozwoju regionalnego, przemysłu, turystyki i energii. Wskazana jest aktualizacja i ocena funkcjonowania strategii ochrony brzegów, a analizowany w niniejszej pracy parametr falowania powinien stanowić istotny element monitoringu Bałtyku.

\section{Bibliografia:}

Gayer, Gerhard, Heinz Güenther i Norbert Winkel. 1995. Wave climatology and extreme value analysis for the Baltic Sea area off the Warnemunde harbour entrance. Deutsche Hydrographische Zeitschrift, 47(2), 109-130.

IPCC. 2009. Climate Change 2007. The Physical Science Basis. Cambridge: Cambridge University Press.

Jakusik, Ewa. 2006. Charakterystyka falowania $i$ wiatru w południowej części Morza Bałtyckiego. Materiały Badawcze. Seria: Hydrologia i oceanologia - 32. Warszawa: IMGW. 
Kalnay, Eugenia et al. 1996. The NCEP/NCAR 40-year Reanalysis Project. Bulletin of the American Meteorological Society, 77(3), 437-472.

Miętus, Mirosław i Janusz Filipiak. 2002. Wpływ termiki powierzchniowej warstwy wody Północnego Atlantyku na wielkoskalową cyrkulację atmosferyczną w rejonie Atlantyku i Europy oraz na warunki termiczne w Polsce w XX wieku. Warszawa: IMGW.

World Meteorological Organization (WMO). 1990. Manual on Marine Meteorological Services. Geneva: World Meteorological Organization.

World Meteorological Organization (WMO). 1994. Guide to the applications of marine climatology. Geneva: World Meteorological Organization. 
Anna Latawiec

Dziekan Wydziału Filozofii Chrześcijańskiej

Uniwersytet Kard. Stefana Wyszyńskiego w Warszawie

a.latawiec@uksw.edu.pl

\section{Podsumowanie konferencji}

Pomysłodawcy i organizatorzy konferencji „Theoria i praxis zrównoważonego rozwoju" odwołali się do przedstawionego dokładnie 30 lat temu oenzetowskiego raportu pt. Nasza wspólna przyszłość. W dokumencie tym, znanym również jako Raport Brundtland, przedstawiono jedną z najważniejszych idei współczesnego świata, czyli ideę zrównoważonego rozwoju. Zaleca ona taki rozwój ludzkości, który pomyślność obecnego pokolenia wiąże $\mathrm{z}$ pomyślnością pokoleń nadchodzących. Konferencja ta potwierdza więc udział Uniwersytetu Kardynała Stefana Wyszyńskiego w jednej z najbardziej doniosłych debat współczesności, czyli debaty nad przesłaniem idei zrównoważonego rozwoju i możliwościami jej implementacji.

Prowadzone w ośmiu sekcjach tematycznych całodzienne obrady potwierdziły doniosłość wyzwania zawartego w idei zrównoważonego rozwoju. Obrady te potwierdziły także złożoność problematyki inspirowanej tą ideą. Złożoność tę dodatkowo wzbogaca twórcze napięcie pomiędzy dobrą teorią zrównoważonego rozwoju i poszukiwaniem skutecznych sposobów praktycznego jej spożytkowania. Nie dziwi więc, że w debacie nad zrównoważonym rozwojem uczestniczą liczni przedstawiciele różnych dyscyplin naukowych: obok przyrodników i inżynierów w debacie tej uczestniczą także ekonomiści, prawnicy, socjolodzy, politolodzy, psycholodzy, pedagodzy, filozofowie i teolodzy. Ważnym dopełnieniem grona uczestników tej debaty są także przedstawiciele organizacji pozarządowych, organów administracji rządowej i samorządowej, przedsiębiorstw, szkół i osób indywidualnych, którym na sercu leży troska o przyszłe pokolenia. Konferencja „Theoria i praxis zrównoważonego rozwoju” potwierdziła, że wszystkim zależy na przyszłości Ziemi - naszego wspólnego domu. Dowiodła ona tym samym, że postęp w dążeniu do osiągnięcia tego celu jest możliwy jedynie dzięki zgodnej współpracy całej ludzkości. 
Szczególnym wyrazem zaangażowania Uniwersytetu Kardynała Stefana Wyszyńskiego w tę sprawę są prowadzone studia z zakresu ochrony środowiska w Instytucie Ekologii i Bioetyki na Wydziale Filozofii Chrześcijańskiej. Współpraca tego instytutu z Instytutem na rzecz Ekorozwoju i Urzędem m.st. Warszawy zaowocowała organizacją niniejszej konferencji. Podsumowując ją, wyrażam ogromną satysfakcję, że obchody jubileuszu 15-lecia działalności Instytutu Ekologii i Bioetyki na Wydziale Filozofii Chrześcijańskiej UKSW i 25-lecia działalności współorganizatora dzisiejszej konferencji Instytutu na rzecz Ekorozwoju znalazły tak bogatą oprawę i zgromadziły tak licznych uczestników z całej Polski. Należy zatem odnotować, że:

$\checkmark$ prelegenci i autorzy posterów reprezentowali 31 ośrodków naukowo-badawczych, organizacji pozarządowych oraz organów administracji samorządowej;

$\checkmark$ uczestnicy reprezentowali 145 ośrodków naukowo-badawczych, organizacji pozarządowych, organów administracji rządowej i samorządowej, przedsiębiorstw, szkół i osób indywidualnych;

$\checkmark$ łącznie więc w konferencji wzięli udział przedstawiciele ponad 170 instytucji.

Wyrażam radość i satysfakcję, że problematyka konferencji spotkała się z tak wielkim zainteresowaniem i zgromadziła ponad 400 uczestników. Aktualność i doniosłość podjętej problematyki potwierdza także udział gości honorowych:

Pani Gro Harlem Brundtland, która do uczestników konferencji skierowała przesłanie;

$\checkmark$ Pana Ministra Adama Hamryszczaka, który do uczestników konferencji skierował pismo w imieniu Ministerstwa Rozwoju - honorowego patrona konferencji;

$\checkmark$ Pana Wiceprezydenta Warszawy Michała Olszewskiego, który w imieniu współorganizatora przemówił do uczestników konferencji;

$\checkmark$ Pana Filipa Kochana, który przedstawił zaangażowanie reprezentowanego przez siebie Banku Światowego na rzecz wdrażania idei zrównoważonego rozwoju. 
Dziękuję także instytucjom, które objęły konferencję patronatem medialnym. W szczególności dziękuję TVP Info, Polskiemu Radiu 24 oraz Klubowi Publicystów Ochrony Środowiska EKOS. Ich relacje z obrad konferencji z pewnością przyczyniły się do upowszechnienia jej problematyki w społeczeństwie.

Szczególne podziękowania składam członkom Rady Programowej konferencji na czele z jej przewodniczącym Panem prof. Andrzej Papuzińskim z Uniwersytetu Kazimierza Wielkiego w Bydgoszczy oraz członkom Komitetu Organizacyjnego z jego przewodniczącym Ks. prof. Zbigniewem Łepką z UKSW.

Wiem, że przygotowania do konferencji trwały ponad rok. Nie zaskakują nas zatem dobre ich efekty. Znalazły one dojrzały wyraz w formie Apelu Warszawskiego o zrównoważony rozwój świata, który wypracowano po szerokiej konsultacji ze wszystkimi uczestnikami konferencji. Wyrażam nadzieję, że upowszechnienie tego apelu przyczyni się do wzrostu zaangażowania szerokich kręgów społeczeństwa polskiego na rzecz urzeczywistnienia idei zrównoważonego rozwoju.

Niejako w podsumowaniu konferencji wyrażam też nadzieję, że rozpoczęta nią współpraca Instytutu Ekologii i Bioetyki UKSW, Instytutu na rzecz Ekorozwoju i Urzędu m.st. Warszawy, a szczególnie Biura Infrastruktury w tym urzędzie, doczeka się kontynuacji w postaci dalszych wspólnych inicjatyw i projektów. 


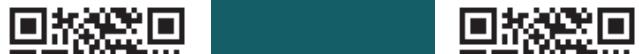 rithy lotyry aritur: Drystin:}

